UNIVERSIDADE DE SÃO PAULO

ESCOLA DE COMUNICAÇÕES E ARTES

Célia Regina Gouvêa Vaneau

Mudra e Galpão:

experiências cênicas interlinguagens 

Célia Regina Gouvêa Vaneau

\section{Mudra e Galpão: experiências cênicas interlinguagens}

\section{Versão Original}

Tese apresentada ao Programa de Pós-Graduação em Artes Cênicas da Escola de Comunicações e Artes da Universidade de São Paulo para obtenção de título de Doutora em Artes.

Orientadora: Profa. Dra. Maria Helena Franco de Araujo Bastos 
Autorizo a reprodução e divulgação total ou parcial deste trabalho, por qualquer meio convencional ou eletrônico, para fins de estudo e pesquisa, desde que citada a fonte.

Catalogação na Publicação

Serviço de Biblioteca e Documentação

Escola de Comunicações e Artes da Universidade de São Paulo Dados fornecidos pelo(a) autor(a)

Gouvêa Vaneau, Célia Regina

Mudra e Galpão: : Experiências Cênicas Interlinguagens /

Célia Regina Gouvêa Vaneau . -- São Paulo: C. R. . Gouvêa

Vaneau , 2017.

307 p.: il.

Tese (Doutorado) - Programa de Pós-Graduação em Artes Cênicas - Escola de Comunicações e Artes / Universidade de São Paulo.

Orientador: Maria Helena Franco de Araujo Bastos

Bibliografia

1. Interlinguagens 2. Dança 3. Anos Setenta 4. Mudra 5. Galpão I. Franco de Araujo Bastos, Maria Helena II. Título.

CDD 21.ed. - 700 
Nome: VANEAU, Célia Regina Gouvêa

Título: Mudra e Galpão: experiências cênicas interlinguagens

Tese apresentada ao Programa de Pós-Graduação em Artes Cênicas da Escola de Comunicações e Artes da Universidade de São Paulo para obtenção do título de Doutora em Artes.

Aprovada em:

\section{Banca Examinadora}

Prof.(a) Dr.(a):

Instituição:

Julgamento:

Prof.(a) Dr.(a):

Instituição:

Julgamento:

Prof.(a) Dr.(a):

Instituição:

Julgamento:

Prof.(a) Dr.(a):

Instituição:

Julgamento:

Prof.(a) Dr.(a):

Instituição:

Julgamento: 



\section{AGRADECIMENTOS}

Agradeço à minha orientadora, Profa. Dra. Helena Bastos, intuitiva artista da dança, bem como às colegas artistas e pesquisadoras do Laboratório de Dramaturgia do Corpo da ECAUSP: Carolina De Nadai, Camila Venturelli, Catarina San Martinho, Fernanda Machado, Flávia Spirópulos, Ilana Elkis, Laura Bruno, Nathália Catarina Alves Oliveira, Tatiana Melitello e, especialmente, Isis Akagi, pelos retornos concedidos ao meu texto.

À minha mãe centenária, Odete, pela paz que sempre distribuiu à sua volta; a minhas filhas Yara e Vânia e aos irmãos Vera, Leila, Herculano e Odete. A todos os professores, colegas, artistas e parceiros citados, pela vitalidade que me trouxeram. A Talita Bretas, sempre. Grata sou ao marido Maurice Vaneau neste 2017, que marca o décimo ano de sua morte. Ele que a mim muito incentivou e por mim torceu. 



\section{RESUMO}

A pesquisa tem o objetivo de registrar e analisar períodos importantes e inovadores das artes cênicas - com ênfase em dança - em que foram desenvolvidas propostas interlinguagens, concentrando-se em duas experiências vivenciadas por mim na década de 1970: o Mudra (Centro Europeu de Aperfeiçoamento e Pesquisa dos Intérpretes do Espetáculo), dirigido pelo coreógrafo Maurice Béjart em Bruxelas, na Bélgica, do qual fui integrante da primeira turma em 1970 e que desembocou na fundação do grupo Chandra (Teatro de Pesquisa de Bruxelas); e o Teatro de Dança Galpão, berço da dança contemporânea em São Paulo e do qual fui responsável pela primeira montagem, Caminhada (1974), e pela última, De pernas para o ar (1981), em parceria com o diretor teatral Maurice Vaneau, nos primórdios da fusão de procedimentos singulares próprios à dança e ao teatro. A linguagem investigativa praticada no Galpão desencadeou um movimento que transformou o modo de se conceber e construir a estrutura de peças coreográficas, e os resultados dessa experiência ecoam até a atualidade. $\mathrm{O}$ ciclo de sete anos de existência desse grupo ocorreu durante o período da ditadura civilmilitar brasileira e também da contracultura, tornando-se refúgio de um público atento e curioso. O período corresponde ao interstício entre as vanguardas modernistas tardias e o pósmodernismo. A hipótese levantada é a de um procedimento específico interlinguagens com foco na dança que aliou investigação estética e participação política. $O$ processo interlinguagens é um derivado coreográfico das visões de Antonin Artaud e tem como protagonista o corpo concebido como um processo em devir. Aliado ao movimento, relaciona tempo e espaço por meio da mutação, instaurando uma dramaturgia poética cinestésica. Pensar a questão do tempo vai remeter às noções de experiência e memória. Elejo o método da descrição associado à análise e problematização, em um procedimento hermenêutico, que inclui explicação e interpretação. Presentificam-se ainda propostas técnicas praticadas, frutos da fusão interlinguagens e de estudos somáticos recentes, resultando na elaboração da Técnica Orgânica, uma opção para o treinamento do performer. O objetivo é o de oferecer uma contribuição pessoal aos estudos e reflexões aos múltiplos praticantes e pensadores da dança no Brasil, cujo número é crescente, bem como fornecer uma referência à constituição de currículos de departamentos de Dança, acadêmicos ou não.

Palavras-chave: Interlinguagens; Dança; Anos setenta; Mudra; Galpão. 



\begin{abstract}
The research aims to record and analyze important and innovative periods of the performing arts - with an emphasis on dance - in which inter-languages proposals were developed, focusing on two experiences that I experienced in the 1970s: the Mudra (European Center for the Improvement and Research of Performing Artists), directed by the choreographer Maurice Béjart in Brussels, Belgium, of which I was a member of the first group in 1970 and which led to the founding of the Chandra Group (Brussels Research Theater); and the Teatro de Dança Galpão, the cradle of contemporary dance in São Paulo, where I was responsible for the first installation, Walk (1974), and the last one, Legs to the Air (1981), in partnership with theatrical director Maurice Vaneau, in the beginnings of the fusion of singular procedures proper to the dance and the theater. The investigative language practiced in the Galpão unleashed a movement that transformed the way of conceiving and constructing the structure of choreographic pieces, and the results of this experience echo until the present time. The cycle of seven years of existence of this group occurred during the period of the Brazilian civil-military dictatorship and lso of the counterculture, becoming a refuge for an attentive and curious public. The period corresponds to the intersection between late modernist vanguards and postmodernism. The hypothesis raised is that of a specific inter-languages procedure focusing on dance that allied aesthetic research and political participation. The inter-languages process is a choreographic derivative of the visions of Antonin Artaud and has as protagonist the body conceived as a process in becoming. Allied to the movement, it relates time and space through mutation, establishing a kinesthetic poetic dramaturgy. Thinking about the question of time will refer to the notions of experience and memory. I choose the description method associated with analysis and questioning, in an hermeneutic procedure, which includes explanation and interpretation. Presented techniques are also practiced, fruits of inter-languages fusion and recent somatic studies, resulting in the elaboration of the Organic Technique, an option for the training of the performer. The objective is to offer a personal contribution to the studies and reflections of the many dance practitioners and thinkers in Brazil, whose number is increasing, as well as provide a reference to the formation of curricula of Dance departments, academic or otherwise.
\end{abstract}

Keywords: Inter-languages; Dance; The Seventies; Mudra; Galpão theater. 



\section{SUMÁRIO}

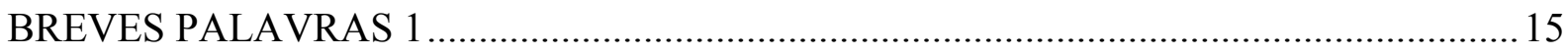

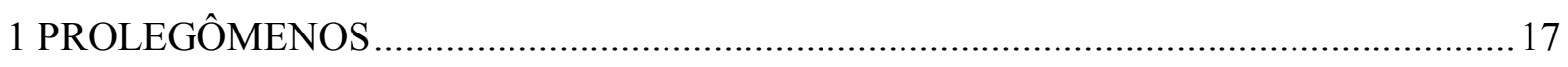

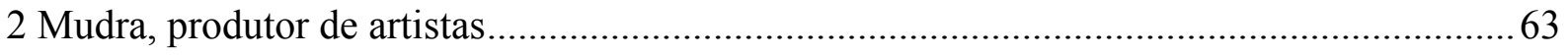

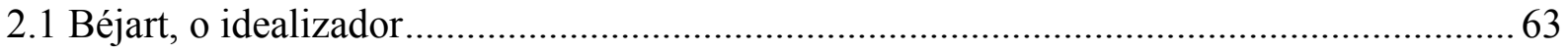

2.2 Mudra, por quê?

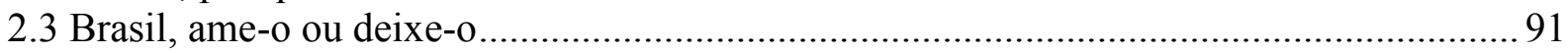

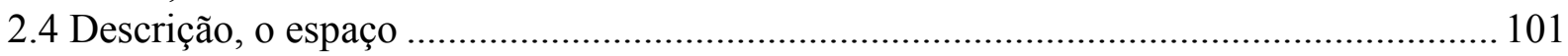

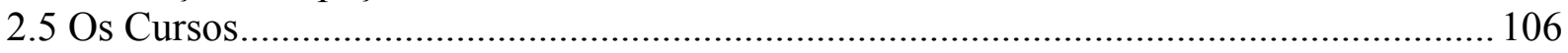

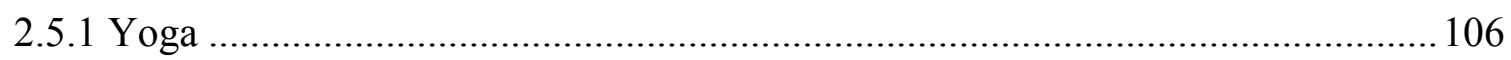

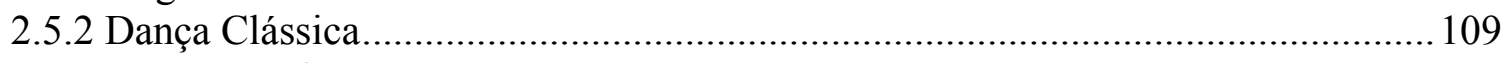

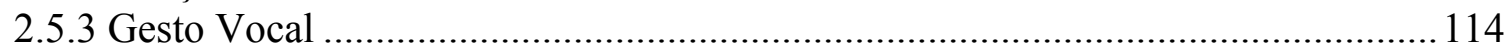

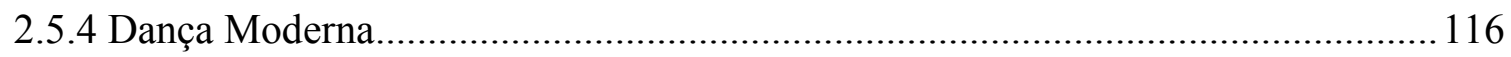

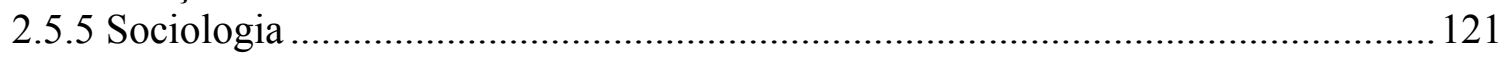

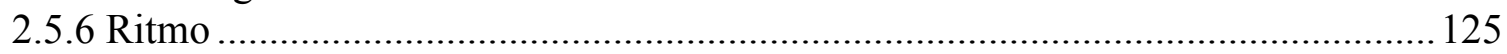

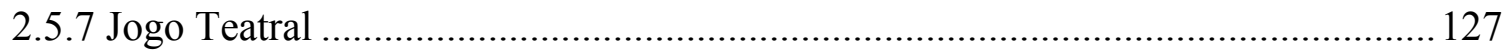

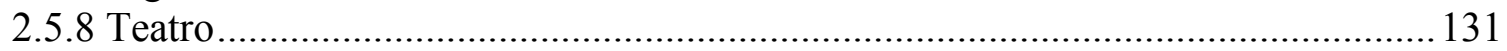

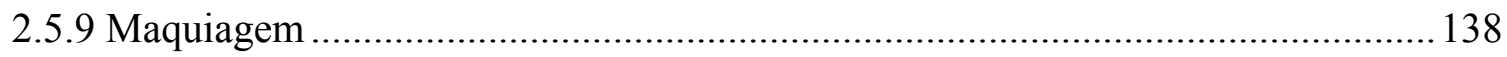

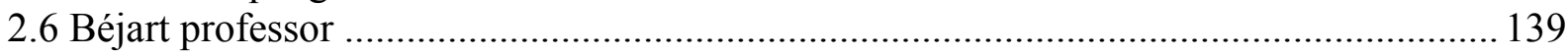

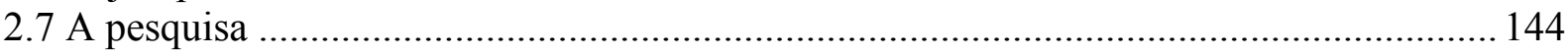

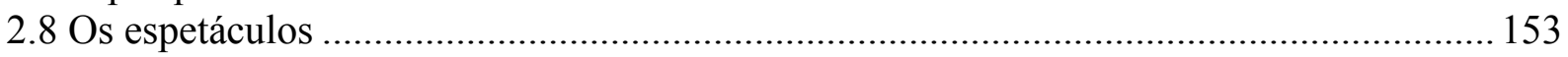

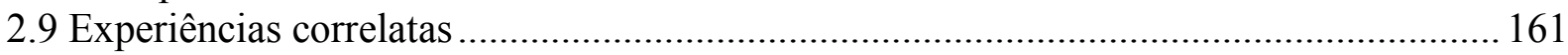

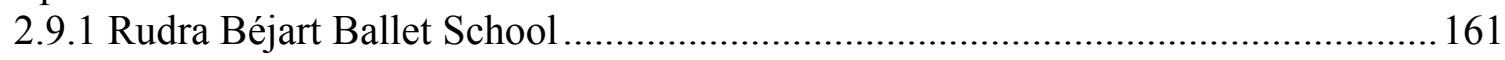

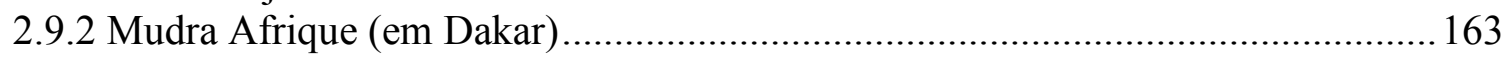

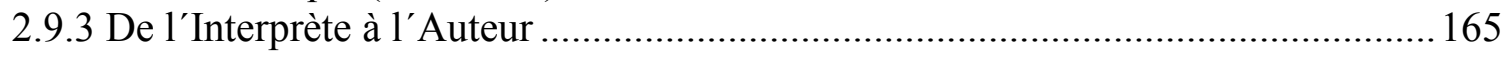

2.9.4 PARTS: Performing Arts Research and Training Studios ..................................174

2.10 O Grupo Chandra (Théâtre de Recherche de Bruxelles) ............................................... 180

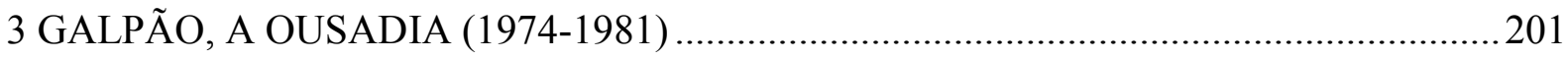

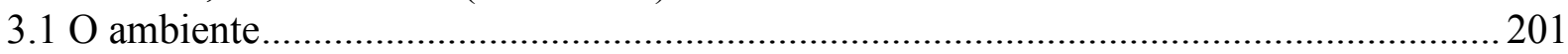

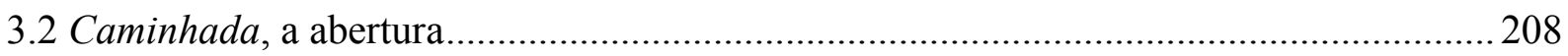

3.3 Funcionamento: aulas, apresentações, palestras, workshops ........................................ 222

3.4 A presença de diretores teatrais em espetáculos de dança..............................................227

3.5 A participação criativa do elenco: a conexão consigo, o início dos processos colaborativos 228

3.6 Nomenclaturas: Dança-teatro, contemporânea, dramaturgias coreográficas ................... 231

3.7 A aliança entre conexão política e investigação estética..............................................233

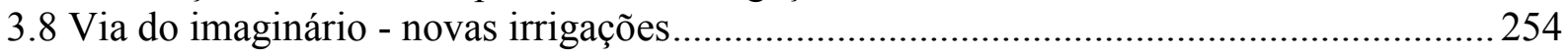

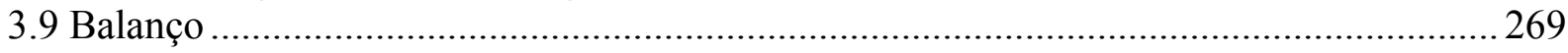

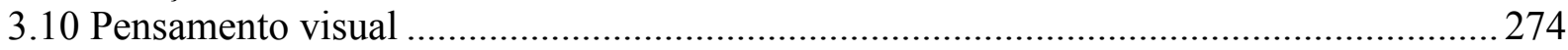

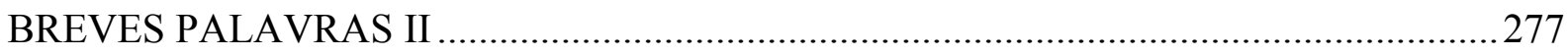

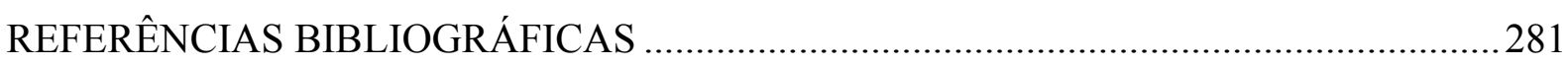

ANEXO A - Depoimento de Cristian Duarte sobre a escola Parts.......................................295

ANEXO B - Depoimento de Carol Paladino sobre o centro De l'Tnterprète à lee Auteur .......297

ANEXO C - Depoimentos de colaboradores do Teatro de Dança Galpão (1974-1981) ........301 



\section{BREVES PALAVRAS 1}

A presente reflexão é composta por três capítulos, além das Breves Palavras I e II, dos anexos e da bibliografia. O primeiro disparo é esta introdução, nomeada de "Breves Palavras I". A seguir, três capítulos: no primeiro, "Prolegômenos", exponho os conceitos-alavancas do trabalho; o segundo é dedicado ao período inaugural do Mudra, abordando a primeira turma da qual fiz parte e seus desdobramentos; o terceiro delineia o movimento do Teatro de Dança Galpão e incursões interlinguagens no Brasil. Por fim, uma conclusão, nomeada de "Breves Palavras II". Breves Palavras I e II, na abertura e fechamento da pesquisa, pontuam o entendimento sintético do trabalho, enquanto alternativa às conhecidas "Introdução" e "Conclusão".

Os prolegômenos plantam os conceitos básicos que conduzirão o entendimento dos capítulos seguintes, tecendo o que será narrado a seguir: interlinguagens, corpo, percepção, tempo, espaço, memória e experiência. Grifo a cognição proprioceptiva e cinestésica. Aparece mais meu pensamento que a minha pessoa. O propósito primeiro é o de sublinhar o reconhecimento da relevância do corpo enquanto produtor de conhecimento desde o pósguerra - a partir da segunda metade do século XX, especificamente. Para tanto, detenho-me no pensamento de René Descartes (1596-1650), que inaugurou a Modernidade no pensamento. Três séculos depois, Maurice Merleau-Ponty (1908-1961) estabeleceu o quiasma ou entrelaçamento entre a pessoa e o mundo.

Os outros dois capítulos são uma autobiografia assumida. Tratam de uma trajetória vivida que corresponde à contribuição que tenho a oferecer. O conceito de "interlinguagens" abrange não apenas múltiplas disciplinas, mas também a gama que vai do olhar muito interno ao muito externo, do mais secreto ao mais objetivo. Espero praticar a singularidade coletiva, que ecoa no alter, no outro. Considero a pessoalidade enquanto parte das interlinguagens, composta por várias disciplinas, pois sei que o componente psíquico é parte inevitável de qualquer produção artística.

O tratamento pela palavra, o verbo. O processo assemelha-se ao de uma montagem coreográfica. Colocar pedra sobre pedra. Ao se tirar uma do lugar, o equilíbrio falha, todas desmoronam e vem o recomeço. Compor textos ou danças é isso: é ir fazendo, acrescentando e retirando coisas, partes, pedaços, atentando-se sempre ao que o processo solicita sem nunca se chegar ao dito resultado final.

Minha avó materna era costureira. Cerzia, cerzia, cerzia, cosendo peças de tecido sem que as costuras pudessem ser notadas, ou quase nada. Unir, reunir, juntar. Interlinguagens 
tudo costura. Ao escrever o presente texto, cerzi, cerzi, cerzi. Claro está que não só cerzia minha avó. Fazia alta-costura para suas freguesas. Minha avó amassava as notas de dinheiro que recebia das freguesas como pagamento das roupas e as colocava em uma xícara guardada na cristaleira. Trabalhadeira, integrou a segunda geração nascida no Brasil da família Faber, vinda de Berlim, cujo nome quer dizer "trabalho". Acrescentei, retirei, modifiquei. Transportei. Excluí. Um processo lento, que requer paciência, faculdade que sempre me foi faltante. O ritmo assemelhou-se ao das ondas do mar: se intenso em um dia, reflui no seguinte. Funciono melhor pela manhã do que à noite, mas posso receber um apelo e escrever à noite, $o$ que compromete a produção na manhã seguinte. Saio do computador com a musculatura do corpo encurtada. Alongamentos são necessários antes e depois de ficar longamente sentada.

Movimento. Interlinguagens. Confluências. Interfaces. Enovelamentos. Entrelaçamentos. Embricamentos. Interações. Hibridismo, do latim “ibrida” (ou "bastardo"), de sangue misturado. Procedimentos polifônicos derivados de Artaud, que preconizou um teatro feito de gestos, movimentos e rumores.

Após quarenta anos dedicados a produções artísticas, tomei um recuo para ocupar-me da reflexão e da escrita sobre o percurso efetuado enquanto testemunho reflexivo. Retomei primeiro, em 2010, os estudos de filosofia iniciados no final da década de 1960, antes de ingressar no doutorado direto da Escola de Comunicações e Artes da Universidade de São Paulo (ECA/USP) em 2013.

A pesquisa envolve questões artísticas mescladas a aspectos políticos, sociológicos, históricos e antropológicos, guiados pelas interlinguagens, com ênfase na dança.

Sugiro, àqueles que se propuserem ao conhecimento detalhado do trabalho cênico realizado, a consulta ao acervo Décadas de Dança - Preservação e Compartilhamento do Acervo Gouvêa-Vaneau em www.acervogouvea-vaneau.com.br 


\section{PROLEGÔMENOS ${ }^{1}$}

Nada morre; tudo fica lá pulsando subterraneamente

Tadeusz Kantor ${ }^{2}$

Interlinguagens. Inter, em vez dos prefixos multi, pluri, extra ou trans, implicando o último em atravessamento, aquilo que não pertence a lugar nenhum, passagem que não se instala. Há ainda o prefixo contra, como no termo "contradisciplinar", ou o deparar-se com um dado contrário que pode ser elucidativo. Aos prefixos citados, segue, invariavelmente, a palavra "disciplinaridade", com suas conotações coercitivas. No sentido foucaultiano, a palavra "disciplina" remete também a organização e estrutura, que correspondem a forma. A palavra "sistema", do latim "systêma", indica "pensar tudo junto", ou seja, designa o conjunto de elementos interconectados, de modo a se formar um todo organizado. A linguagem é um sinal, sonoro ou não. O silêncio pode também ser considerado linguagem. Toda emissão é linguagem, sem necessariamente implicar no emprego do nosso órgão muscular, achatado, oblongo e móvel situado na cavidade bucal.

O "inter" conota reciprocidade e interação, diferentemente do "intra", que designa a interioridade. O "inter" relaciona-se ao que o visionário e vanguardista histórico Antonin Artaud (1896-1948) preconizou ao visualizar um teatro feito de gestos, movimentos e rumores que conheci e pratiquei no Mudra, o Centro Europeu de Aperfeiçoamento e Pesquisa dos Intérpretes do Espetáculo, e que correspondeu a um nascimento artístico.

As experiências cênicas aqui abordadas tiveram lugar nos anos setenta - uma na primeira e a seguinte na segunda metade da década -, no Mudra, dirigido pelo coreógrafo Maurice Béjart (1927-2007) e situado em Bruxelas, na Bélgica, do qual fui integrante da primeira turma em 1970. Dada a internacionalização do Centro, a palavra "Europeu" foi suprimida de seu nome na segunda metade dos anos setenta.

O primeiro Mudra, da fase inicial, desembocou na fundação do Grupo Chandra Teatro de Pesquisa de Bruxelas. Uma das condições de admissão de um candidato ao Mudra

\footnotetext{
${ }^{1}$ Prolegômenos: do grego "prolegómena", ou "coisas que se dizem antes"; "longa introdução"; "conjunto de noções preliminares".

2 Tadeusz Kantor (1915-1990) foi dramaturgo e artista visual polonês. A tradução deste trecho foi feita com base nas versões francesa e estadunidense: KANTOR, Tadeusz. Leçons de Milan. Paris: Actes Sud Papiers, 1990. p. 331. KANTOR, Tadeusz. KOBIALKA, Michal (Ed). A journey through other spaces: Essays and manifestos, 1944-1190 - Tadeusz Kantor. Los Angeles: University of California Press, 1993. p. 208-265.
} 
era o de destinar-se à interpretação artística. Interpretar pode remeter a uma visão filtrada, particularizada, quando forneço minha própria versão dos fatos. Hoje, a palavra "intérprete" esvaziou-se, pois, examinada de perto, remete ao modo pessoal e peculiar de se executar uma partitura, e já não há mais partituras pré-definidas fechadas no fazer coreográfico, mas sim um processo colaborativo entre o propositor e o elenco. Béjart sempre percebeu e valorizou as qualidades de cada bailarino com quem trabalhava. Opto pelo termo "atuante", derivado da ação provocada pelo movimento.

O Mudra foi um centro interdisciplinar renovador, único então em seus propósitos. Por ele, passaram artistas que vieram a consolidar-se, como Maguy Marin, Juliana Carneiro da Cunha, Pierre Droulers e Diane Broman, contemporâneos ao período em que lá estive, e, posteriormente, Anne Teresa De Keersmaeker, José Besprosvany, Michèle Anne De Mey, Nicole Mossoux, Michèle Noiret, Hervé Robbe, Jean Gaudin, François Hifler, Bernardo Montet, Catherine Divèrres, Emmanuelle Huynh, Nacho Duato, o brasileiro Cláudio Bernardo e muitos outros, embora nem todos tenham completado o ciclo de três anos. O incêndio que destruiu o prédio do Mudra em 1992 provoca mais uma motivação para concentrar-me no tempo inicial de sua existência.

A primeira turma principiou com 25 participantes e terminou com apenas oito. $\mathrm{O}$ ano letivo teve início em outubro e, até dezembro, atravessamos um período de éssai (ou "experiência"). Somente três meses depois os nomes foram confirmados. As avaliações ocorriam ao final de cada temporada. Alguns colegas partiam por vontade própria ou por decisão da direção e corpo discente. Entre os oito remanescentes (hesito em empregar a palavra "aluno", uma vez que o termo significa "sem luz", qualidade nada presente entre os selecionados mudristas), apenas a canadense Louise Latreille optou por retornar ao seu país.

Na constituição do grupo Chandra, juntou-se a nós Dominique Bagouet (1951-1992), Então bailarino contratado pelo Ballet du XXème siècle, em 1973, Dominique optou por deixar a companhia de Béjart para aderir à aventura de nosso grupo interdisciplinar nascente, somando-se aos egressos da primeira turma do Mudra. Falecido precocemente em 1992, deixou um legado considerável: o de uma dança com componentes barrocos, bastante recortada, construída na cidade de Montpellier, ao sul da França. Micha Van Hoecke foi o primeiro a tomar a decisão de deixar a companhia para tornar-se diretor da pequena trupe. Alguns anos depois, entre 1979 e 1982, Micha viria a tornar-se diretor do Mudra.

O segundo momento ocorreu no Brasil: o Teatro de Dança Galpão, berço da dança contemporânea em São Paulo e do qual fui responsável pela primeira montagem, Caminhada (1974) e pela última, De pernas para o ar (1981), em parceria com o diretor teatral e 
multiartista Maurice Vaneau (1926-2007). A linguagem investigativa praticada desencadeou um movimento que transformou o modo de conceber e construir a estrutura de peças coreográficas, movimento cujos resultados ecoam até a atualidade. De papel primordial na fusão de procedimentos singulares próprios à dança e ao teatro, o ciclo de sete anos de existência do Galpão ocorreu durante o período duro da ditadura civil-militar brasileira e também da contracultura. Marcado por ambos, mesclando investigação estética e participação política, tornou-se refúgio de um público atento e curioso. O procedimento específico de interlinguagens ali praticado teve como foco a dança. O período corresponde, igualmente, ao interstício entre as vanguardas modernistas tardias, o pós-modernismo e/ou o contemporâneo. O interstício encontra-se prenhe tanto daquilo que está deixando de ser quanto do que virá. Refere-se, aqui, a um corpo sensível em devir, que anuncia uma dança como mu-dança ou trans-formação.

O importante e histórico momento ocorrido no Teatro de Dança Galpão entre 1974 e 1981, bem como a parceria artística Gouvêa-Vaneau vêm sendo estudados em vários departamentos de Dança de universidades brasileiras. Importa fornecer uma base de estudos proveniente da fonte de onde procede a ação. Há, ainda, pouco registro sobre a experiência inédita e pioneira que ocorreu no Teatro de Dança Galpão durante seu ciclo de sete anos de existência. A primeira casa exclusiva às atividades da dança em São Paulo ainda não recebeu uma análise procedente de quem ali atuou e fez.

O processo contemporâneo de produção parte de muito pouco, quase nada, uma ideia talvez, antes de ir delineando seus contornos. Há poucos suportes. A proposta inicial vai ganhando força à medida que o processo avança. A dança contemporânea, dita pós-moderna ou pós-dramática, é atividade porosa, aberta, agregadora, disponível à absorção de outras linguagens. Facilmente, assimilou o vídeo e incluiu as novas mídias por não contar com um arcabouço inicial que a contenha, um material prévio - texto ou música - dos quais independe. Abarcou, também, as artes visuais, a performance e mesmo a história da arte e a filosofia. Relevante é o registro das experiências citadas ocorridas na década de setenta, que ecoaram e escoaram em décadas seguintes, até a atualidade.

A busca interligada permeou a produção contemporânea: tênues tornaram-se as fronteiras entre as artes. Palavras como "mistura", "borrão" ou "embaralhamento" foram absorvidas e mesmo banalizadas, tal seu uso habitual. Melhor é o termo "fluido", ou “fronteiras fluidas", que indicam trânsito fácil, ou, ainda, o lugar movediço do limiar. Outras denominações possíveis são, além da dança-teatro, a coreografia dilatada ou expandida. $\mathrm{O}$ teatro dito pós-dramático, instaurado a partir do final do modernismo, dilatou o papel do 
corpo, aproximando-se de procedimentos próprios à dança, que é, hoje, quase sinônimo de confluência entre as artes, em uma tessitura que envolve imagens, sons e movimentos.

Segundo Hans-Thies Lehmann, "no teatro pós dramático, a respiração, o ritmo, a atualidade da presença física dos corpos predominam sobre o logos [...] o teatro se faz choragrafia - des-construção do discurso orientado pelo sentido e invenção de um espaço que se subtrai à lei do télos e da unidade",3, o que não impede a busca pela coerência dramatúrgica. Lehmann acrescenta:

Poema cênico [...]. Como um poeta o diretor compõe campos de associação entre as palavras, os ruídos, os corpos, os movimentos, a luz e os objetos [...]. Poderíamos falar aqui de teatro "interdisciplinar". Mas o tema propriamente dito é a estreita inter-relação de linguagens teatrais que normalmente se encontram desintegradas entre si: jogo teatral, música, instalação, poesia das luzes, canto, dança..."4

No dizer de Antonin Artaud, trata-se de "ligar o teatro às possibilidades de expressão pelas formas, por meio de gestos, ruídos, cores, plásticas, etc."5, ou, como afirmou reiteradamente, um teatro feito de gestos, movimentos e rumores. A propósito do espaço, Artaud diria:

Eu chamo cultura orgânica uma cultura baseada sobre o espírito em relação aos órgãos, e o espírito banhando-se em todos os órgãos... Há nesta cultura uma idéia do espaço. Cultura no espaço quer dizer cultura de um espírito que não cessa de respirar e de se sentir viver no espaço, e que chama para si os corpos do espaço como os próprios objetos de seu pensamento. ${ }^{6}$

Nesse curto extrato de texto, Artaud emprega três vezes a palavra "espírito". Vale lembrar que o termo vem do latim "spiritus" e do grego "pneuma", derivando daí palavras

\footnotetext{
${ }^{3}$ LEHMANN, Hans Thies. Le Théâtre posdramatique. Paris: L'Arche, 2002. p. 235-236.

${ }^{4}$ Ibid., p. 177-178. Tradução nossa. Texto original: "Poème scénique [...] Comme un poète, le metteur em scène compose les champs d'associations entre les paroles, les bruits, les corps, les mouvements, la lumière et les objets [...] On pourrait parler ici de théâtre interdisciplinaire. Mais le thème proprement dit est la strette de langages théâtraux qui normalement se trouvent désintegrés entre eux: jeu théâtral, prestation musicale, installation, poésie des lumières, chant, danse..." LEHMANN Hans-Thies. Le Théâtre postdramatique.

5 ARTAUD, Antonin. Messages Révolutionnaires. In: THÉVENIN, Paule. Oeuvres complètes d'Antonin Artaud. v. 8. Paris: Gallimard, 1971. p. 266.

${ }^{6}$ Ibid., p. 201-202. Tradução nossa. Texto original: "J'appelle culture organique une culture basée sur l'esprit en relation avec les organes, et l'esprit baignant dans tous les organs... Il y a das cette culture une idée de l'espace...culture dans l'espace veut dire culture d'un esprit qui ne cesse pas de respirer et de se sentir vivre dans l'espace, et qui appelle à lui les corps de l' espace comme les objets mêmes de sa pensée".
} 
como "pneu" ou "pneumático", que remetem ao ar e à respiração. Foi somente a partir do século XIII que a palavra adquiriu algo de especial. ${ }^{7}$

Os pressupostos artaudianos serviram-me como um farol na perspectiva de entrega dos dançatores, ou performadores, no sentido de ultrapassarem-se a si mesmos rumo ao desconhecido. Avesso ao psicologismo e à cultura racional ou supremacia da razão presentes no contexto francês no qual se inseria e que se irradiava por todo o fazer teatral, Artaud propõe um teatro "que se dirija ao organismo"

O autor foi pela primeira vez sacudido pelo teatro asiático em 1931, apresentado durante a Exposição Universal de Paris naquele ano. Em suas palavras, "a revelação do teatro Balinês foi a de fornecer do teatro uma ideia física e não verbal"9. A revelação definitiva ocorreu posteriormente, na América Latina, mais precisamente em uma viagem ao México em 1936, quando foi confrontado aos índios mexicanos tarahumaras, habitados por uma dimensão mítica, orgânica e cósmica.

Figura 1 - Antonin Artaud

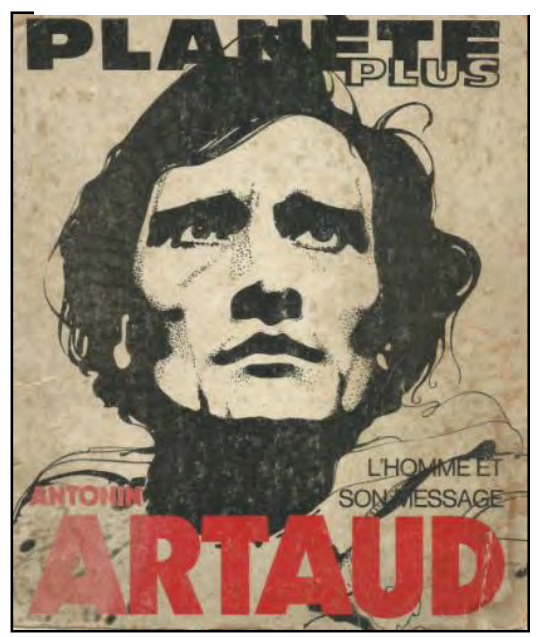

Fonte: Capa da Revista Le Nouveau Planète. Paris, 20 fev. 1971.
Figura 2 - Índios tarahumara

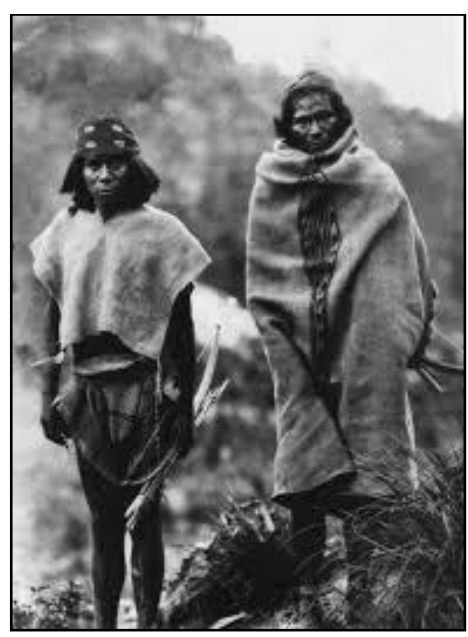

Fonte: Tarahumaras. Disponível em: $<$ https://pt.wikipedia.org/wiki/Tarahu maras $>$.

\footnotetext{
${ }^{7}$ HARRIS, Sam. Despertar: um guia para a espiritualidade sem religião. Tradução de Laura Teixeira Motta. São Paulo: Companhia das Letras, 2014. p. 15.

${ }^{8}$ ARTAUD, Antonin. Le théâtre et son double. Paris: Gallimard, 1964. p. 126. Tradução nossa. Texto original: "Un théâtre qui produise des transes, come les danses de Derviches et d'Aïssaouas produisent des transes, et qui s'adresse à l'organisme".

${ }^{9}$ Ibid., p. 103. Tradução nossa. Texto original: "La revelation du théâtre Balinais a été de nous fournir du théâtre une idée physique et non verbale".
} 
Artaud encontrou, ali, uma alternativa à cultura verbal francesa à qual estava habituado e que o moldara, em direção a uma dramaturgia própria que, se não foi suficientemente encenada, gerou inúmeras transformações no teatro do século XX.

Artaud muito escreveu e pouco encenou, para a sorte de muita gente de teatro que lhe sucedeu e que se inspirou em seus escritos iluminados. Visionário que foi, pressentiu e registrou um novo teatro que não chegou a realizar. Apesar de ter deixado uma vasta obra, insurgiu-se contra a palavra escrita, que se torna cristalizada e imobiliza o fluxo do pensamento. Artaud nunca cessou de defender um teatro dirigido aos nervos do espectador, o que requer a circulação da energia (energeya) ou força em ação: "Do ponto de desgaste ao qual nossa sensibilidade chegou, é certo que necessitamos, antes de mais nada, de um teatro que nos acorde: nervos e coração" ${ }^{\prime 10}$. Certamente, o autor não visualizava os nervos enquanto integrantes do sistema nervoso periférico, mas como distintos da razão. Ele afirmou: "Um espetáculo que não tema ir tão longe quanto necessário na exploração de nossa sensibilidade nervosa, com ritmos, sons, palavras, ressonâncias e ramagens" ${ }^{11}$. Há, portanto, um despregamento da literatura, que conduz à uma composição cênica que mescla elementos visuais, vocais e gestuais. Artaud se opunha ao princípio discursivo do teatro e a toda a tradição teatral francesa, buscando a fonte primitiva, religiosa e metafísica, a imagem, a plástica, a alegoria. Sugeria a leitura dos vedas e do Barde Thodol, o livro dos mortos egípcio.

Capaz de provocar impacto, um tal teatro opera os canais cinestésicos, ligados à sensação em movimento, lembrando que a palavra "sensação" é derivada do grego "soma", ou corpo. Cético quanto ao alcance da razão discursiva e avesso a qualquer psicologismo, Artaud procuraria um modo de comunicação vibratório. Ecoando Artaud, escrevi no programa da peça de dança Trem fantasma e outras danças, de 1979: "gostaríamos que viesse a ser aquilo que consideramos a função primordial do espetáculo: o assombro - o acordar dos sentidos, o abandono do espectador que, desarmado, possa navegar em seu espírito e suas sensações"12.

O logos foi o modo de conhecimento ocidental desde a tradição platônico-aristotélica. Sua acepção mais ampla é sentido. Algumas décadas depois de Artaud, e em outra parte do mundo, o encenador e teórico norte-americano Richard Schechner recorreria também ao

\footnotetext{
${ }^{10}$ ARTAUD, 1964, p. 129. Tradução nossa. Texto original: "Au point d'usure où notre sensibilité est parvenue, il est certain que nous avons besoin avant tout d'un théâtre qui nous réveille: nerfs et coeur".

11 Ibid., p. 133. Tradução nossa. Texto original: "nous envisageons de donner um spectacle où ces moyens d'action directe soient utilisés dans leur totalité; donc un spectacle qui ne criagne pas d'aller aussi loin qu'il faut dans l'exploration de notre sensibilité nerveuse, avec des rythmes, des sons, des mots, des résonances et des ramages".

${ }^{12}$ Programa de Trem fantasma e outras danças, setembro/novembro de 1979.
} 
Oriente, referindo-se ao teatro rásico, derivado da palavra "rasa" - sabor ou paladar, situado no terreno das sensações. A palavra conota reciprocidade, compartilhamento e cocriação entre preparadores e participantes. O modo asiático difere em muito da unidade aristotélica de tempo e lugar, com começo, meio e fim e que propicia a relação ver/ouvir/compreender, resultando em um todo, que se completa e se fecha.

O teatro rásico é sensorial, lúdico e sinestésico. Segue o curso do "syn", ou colocar junto, indicando uma ação combinada, uma cooperação, derivando daí palavras como "simbólico", "signo", "sino" e "sistema", na medida em que promovem uma junção de elementos: "A arte e a ciência do processo relacional interno entre consciência, função biológica e ambiente, todos os três fatores sendo entendidos como um todo sinergético"13, incluindo também a intuição, ou conhecimento direto, que dispensa mediações. No procedimento sinergético, tudo caminha junto, de maneira a promover alianças, podendo-se falar em razemoção (numa junção das palavras "razão" e "emoção"). O termo "fisicalidade" pode ser questionado, pois parece indicar que há algo ao lado, dentro ou atrás do mesmo. Há quem separe o corpo fenomenal do semiótico, emissor de signos, no dizer de Erika FischerLichte $^{14}$.

Derivam-se os rasa dos natyasastra, ou quinto Veda indiano, compilados entre os segundos séculos antes e depois de Cristo. Sua narrativa mítica denota uma rica linguagem de dança-teatro que antecede os dramas sânscritos e cujas apresentações podiam se estender por vários dias. Uma perspectiva sensorial é instaurada, o que nada tem a ver com oba-oba. Se, de fato, a razão predominou no Ocidente, enquanto a ênfase na ambiguidade, indeterminação e acaso predominaram no Oriente, sabe-se que "segundo a fisiologia popular grega e hebraica, se raciocinava e decidia não com a cabeça, mas com o coração (ou diafragma)" ${ }^{\prime 15}$. Artaud e a questão do Oriente serão retomados mais adiante, ao se relevar a presença de Artaud no Mudra enquanto mentor-motor.

A festa foi sempre um "prato cheio", um habitat do processo interlinguagens. Nas festas populares, desde a mais remota Antiguidade, o corpo amplia seus recursos, muitas

\footnotetext{
${ }^{13}$ HANNA, Thomas apud FORTIN, Sylvie. Toward a new generation: somatic dance education in Academia. Montréal: Impulse - Human Kinetics Publishers, 1995. p. 253. Tradução nossa: Texto original: "the art and science of the inner-relational process between awareness biological function and environment all three factors (being understood as a synergistic whole".

${ }^{14}$ FISCHER-LICHTE, Erika. Réalité et ficction dans le théâtre contemporain. Revue d'études théâtrales, Paris, Registres 11/12, p. 7, 2007.

${ }^{15}$ BAKAN, David. Desease pain and sacrifice. Chicago: University of Chiacago Press, 1968. p. 66.
} 
vezes em resposta à música. Artaud mencionou "a poesia que há nas festas e nas multidões"16, capaz de contagiar o teatro. Maurice Béjart referiu-se igualmente à dança que "deve conservar (ou reencontrar?) a saúde graças a seu contato popular, no sentido primeiro do termo"17.

Figura 3 - Traje e máscara de pano de casca

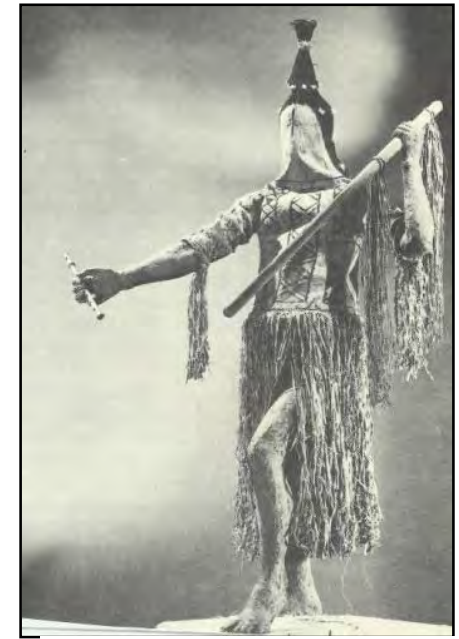

Traje e máscara de pano de casca usado para uma dança de jaguar, da região do Rio Amazonas no Brasil.

Fonte: Cortesia do Museu Americano de História Natural, Nova York.

Festarola (ou "grande festa"), peça de dança de 1988 que integra o corpo de meu fazer coreográfico, foi o título do espetáculo resultante do projeto A Identidade da Dança Nacional, desenvolvido com Bolsa de Pesquisador I, Nível A do CNPq. No elenco, doze dançarinosatores-percussionistas, alguns provenientes do Norte e Nordeste brasileiros e conhecedores das danças populares locais. Destinado a investigar o sentido mítico da festa, empregava máscaras e percussão corporal ou tocada pelos dançarinos-instrumentistas deitados no chão. $\mathrm{O}$ propósito foi desenvolver a aliança entre os conceitos de identidade com o sentido mítico de um povo.

O ator e encenador russo Vsevolod Meyerhold (1874-1940), que também exerceu a atividade de dançarino, partiu do teatro de feira ao processar seu método, ali observando não o elemento popular, mas o artístico. Meyerhold afirmou: “O teatro de máscara sempre foi

\footnotetext{
${ }^{16}$ ARTAUD, 1964, p. 130.

${ }^{17}$ BÉJART, Maurice. Programa da turnê do Béjart Ballet Lausanne ao Brasil. 1989. p. 4.
} 
Teatro de Feira"18, procurando não o elemento popular, mas o artístico. Ainda na Idade Média, nos séculos XII e XIII, outras expressões surgiram, como os trovadores, misto de bardo, compositor e tocador e entoador de cantigas, poetas líricos provençais. O teatro improvisado a partir do esboço de um roteiro (canevas), acrescido ao obrigatório domínio do ofício, a Commedia dell'Arte italiana, eclodiu em meados do século XVI.

O próprio balé - de "balletti", diminutivo de "ballo" (dança) ou, ainda, "balleto" (dancinha, bailinho); termo proveniente do latim "ballare" (dançar, saltitar) e do grego "ballizo" - é fruto do Renascimento italiano no final do século XV, mais especificamente, de celebrações e apresentações de pantomima relacionadas à Commedia dell'Arte. Aclimatou-se, posteriormente, ao solo francês, nas faustosas festas reais, gerando as comédie-ballet. Antes de ser codificado, surgiu nos salões de baile da corte, quando as elites cortesãs, com o intuito de ficar face ao trono do rei, deslocavam-se nos salões em posição frontal ao rei Luis XIV e, para tanto, mantinham os pés voltados para fora, en dehors. O ponto de partida foi fornecido, porém, pelas danças camponesas. Segundo Gründ, "essa foi a vontade de Luis XIV. Depois de mandar repertoriar as danças populares do país, ele proclamou a proibição de sua execução e, edulcorando-as, transformou essas danças em coreografias de corte" ${ }^{\text {,19 }}$, o que atesta um conflito entre elite e povo.

O Rei-Sol apreciava trajes reluzentes que lembravam o radioso astro. Durante seu reinado, de 1643 a 1715, as artes entrelaçavam-se: “As produções teatrais deste período eram frequentemente híbridas: as óperas continham dança, os balés continham récitas e canções. Se a dança ainda não era reconhecida como arte autônoma, a mistura das artes, no entanto, conduziu a trabalhos de grande suntuosidade" ${ }^{20}$. A exemplo do que ocorreu na Europa ocidental, deu-se o mesmo na Rússia durante os séculos XVII e XVIII: "Produções combinando dança com fala e canção brotaram... os russos avidamente imitavam as modas europeias naquele tempo",21, em um período que antecedeu o compartimento em especialidades, que veio a consolidar-se na modernidade, resultando no abandono da ideia de totalidade.

\footnotetext{
${ }^{18}$ MEYERHOLD, Vsevolod Emilevitch Na cena do Dr. Dapertutto. Poética e Pedagogia em V.E.Meyerhold, 1911 a 1916. Terceira Parte. O teatro de feira. São Paulo: Ed. Fapesp, 1912. p. 338.

${ }^{19}$ GRÜND, Françoise. Verbete Dança. In: MARZANO, Michela (Org.). Dicionário do corpo. São Paulo: Edições Loyola, 2012. p. 318.

${ }_{20}$ ANDERSON, Jack. Dance. New York: Newsweek Books, 1979. p. 22. Tradução nossa. Texto original: "Theatrical productions of this period were frequently hybrids: operas contained dancing, ballets contained recitations and songs. If dance still was not recognized as an autonomous art, the mixing of the arts nevertheless led to works of great sumptuousness".

${ }^{21}$ Ibid., p. 63. Tradução nossa. Texto original: "productions combining dance with speech and song arose... Russians were avidly imitating European fashions at that time".
} 
Figura 4 - Figurino do Rei Sol, no Ballet de la nuit, 1953

Estreia de Luis XIV na corte, figurando como o Sol

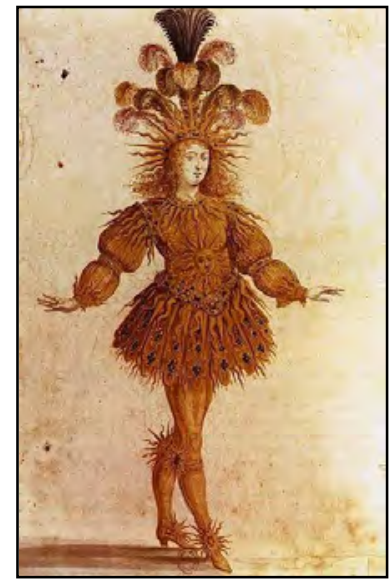

Fonte: Desenho do figurino do Rei Sol, no Ballet de la nuit (1653). <http:// historiainte.blogspot.com.br/2014/02/ima gens-de-luis-xiv-o-rei-sol.html>.

A tragédia grega é tida como condensado da atuação pela palavra, canto e movimento, Tratava-se de soma de elementos ou junção? Como se dava a movimentação? Citada por Maurice Béjart como uma das referências para o paradigma Mudra, a palavra grega "khoreia" significa "dança" e seria derivada de "chara" ("alegria"), enquanto "chore" corresponde a "círculo" e "harmonia". Oscar Gross Brockett fornece uma pista:

Os gregos definiram a dança como qualquer movimento rítmico expressivo; não necessariamente padrões criados pelos pés para gestos ou pantomimas [...]. Em torno do século IV as danças da tragédia foram denominadas emmeleia (termo que significa harmonia, graça e dignidade) [...]. As danças cômicas corais eram denominadas kordax e eram derivadas de várias fontes: movimentos de animais, cerimônias religiosas, celebrações de vitória, e várias outras atividades e ritos. Os atores individuais performavam danças que envolviam chutes nas nádegas, batidas no peito ou coxa, saltos, giros como pião. ${ }^{22}$

É provável que uma influência egípcia e suas formações encadeadas bidimensionais, bem como passos provenientes de outras terras se fizesse notar entre os gregos: "Antigas

\footnotetext{
${ }^{22}$ BROCKETT, Oscar Gross. History of the Theatre. 4 ed. Boston: Allyn and Bacon, 1982. p. 30. Tradução nossa. Texto original: "The Greeks defined dance as any expressive rhythmical movement; thus dance did not necessarily patterns created by the feet, for gestures or pantomime [...] By the fourth century the dances of tragedy had come to be called emmeleia (a term that signifies harmony, grace and dignity). [...] Comic choral dances were derived from many sources: animal movements, religious ceremonies, victory celebrations, and various other activities and rites. The individual actors performed dances that involved kicking the buttocks, slapping the chest or things, leaping, performing high kicks, spinning like a top".
} 
pinturas de dança conhecidas como kolo, horo ou trata em diferentes terras da Europa do leste, revelam uma dança que os camponeses ainda dançam" ${ }^{\text {"23. }}$.

Vasos e esculturas clássicas gregas constituíram objeto de estudos.

Figura 5 - Figuras dançantes que representam pássaros de uma antiga pintura de vaso grego

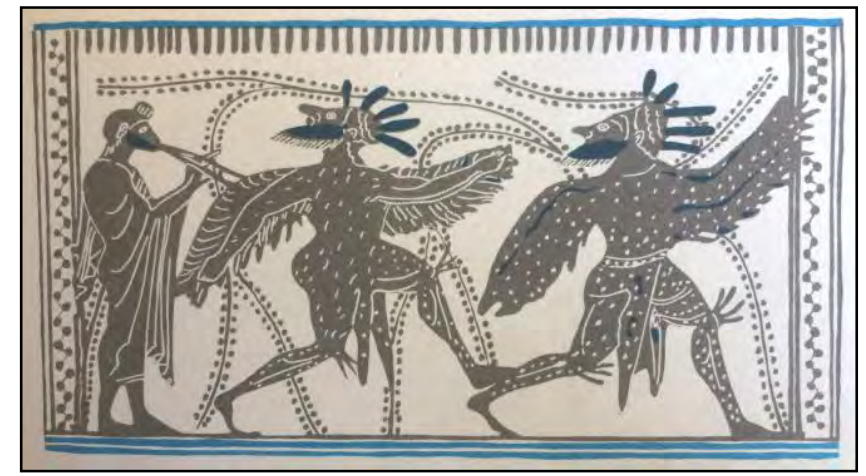

Fonte: HASKELL, A. L., 1969, p. 25.

Há ainda o postulado aristotélico segundo o qual o vigor é causa dos exercícios e estes daquele, apontando para o benefício da atividade corporal. A musa Terpsícore presidia a dança, os coros dramáticos e a poesia lírica e sua figura alegre marcava a cadência dos cantos e da dança ao som da lira. Outros acompanhamentos musicais eram a flauta, o trompete e várias formas de percussão. A Poética de Aristóteles (384-322 a.C.) é pouco esclarecedora quanto à questão, colocando mais em relevo a música, o coro, a cenografia, a trama, o mito. A ação elevada era constituída por fábulas, caracteres, falas ou elocuções, espetáculos e cantos ou melopeias, estruturadas segundo a unidade de tempo, lugar e ação. Há, no entanto, uma referência à dança: "Com o ritmo e sem harmonia, imita a arte dos dançarinos, porque também estes, por ritmos gesticulados, imitam caracteres, afetos e ações" 24 , alternando felicidade e desventura. A palavra tragédia, proveniente do noturno e lunar canto do bode, simboliza a pujança genésica, a força vital, a fecundidade, em suma, a potência que, transmudada em canto, originariamente, acompanhava os ritos do sacrifício de um bode nas festas de Dioniso.

O rito reprodutor das forças da natureza, poderoso impulso de amor pela vida, atraiu Friedrich Nietzsche (1844-1900), que o celebrou em O nascimento da tragédia no espírito da

\footnotetext{
${ }^{23}$ HASKELL, Arnold. The wonderful world of Dance. New York: Doubleday and Company, 1969. p. $24,26$. Tradução nossa. Texto original: "Ancient pictures of the dance known as kolo, horo, or trata, in diferent eastern European lands, reveal a dance that peasants still perform".

${ }^{24}$ ARISTÓTELES. Poética. São Paulo: Ars Poetica, 1993. p. 23, 42-44.
} 
música, de 1871. Herdeiro que foi do romantismo, Nietzsche exaltou a dança e destilou sua ira aos desprezadores do corpo em Assim falou Zaratustra. Em sua elegia do mito trágico, ao referir-se a Dioniso, Nietzsche fez recurso de imagens corporais como dilaceramento, despedaçamento ou destroçamento provocado pelos titãs. Dioniso, porém, insistia em voltar sempre inteiro. O autor alemão combateu o otimista bom senso socratiano, inimigo da tragédia, por ter sepultado o mito, e mencionou a intuição alegórica provocada pela música ${ }^{25}$. Não descreveu, porém, a movimentação cênica presente na tragédia. Antecedendo o laico Aristóteles, Platão (429-347 a.C.) relevaria o papel musical da tragédia, que mergulhava a audiência em lamentações por meio de "palavras, ritmos e modos os mais gemidos"26.

Tragédia e comédia foram classificadas por Platão como próprias ao estilo imitativo, o ditirambo narrativo, enquanto a epopeia - récitos poéticos de aventuras heroicas - mesclava ambos os estilos. Expressão por meio do canto e da dança em louvor a Dioniso, o ditirambo reunia grupos (os komaizen - derivando-se daí a palavra "comédia") que circulavam de uma aldeia a outra durante a festa comemorativa à chegada da primavera na antiga Grécia. Movimentos espontâneos em resposta à música? Desde a Antiguidade e até hoje, nas festas populares, o corpo se manifesta de modo conectado pela voz falada e cantada, do movimento e do som. Não há problema, portanto, lembrando que a palavra "problema" é derivada da grega "probalo", que indica o sentido de lançar para a frente, rumo a uma solução.

Tampouco se relaciona à obra de arte total (Gesamtkunstwerk) wagneriana, imbuída de romantismo, pois, na ópera, as linguagens encontram-se lado a lado, sem que haja fusão, a não ser pelo espetáculo. O que a ópera apresenta é uma somatória, na qual as diferentes linguagens - música, canto e teatro - encontram-se lado a lado, sem que haja fusão: o cantor canta, o bailarino dança, o instrumentista toca, ou seja, as especialidades encontram-se mantidas. Portanto, o sintético conceito cunhado por Richard Wagner está distante de uma conexão entre as linguagens. O mesmo poderá ser dito a propósito de denominações como "multidisciplinar" ou "pluridisciplinar". Gêneros afins como a opereta e mesmo o teatro musical têm essa particularidade. Geralmente colocado na bandeja do entretenimento, o music-hall é uma especialidade norte-americana na qual se pode cantar e dançar ao mesmo tempo. Pode bem aclimatar-se em um país como o Brasil, que já conta em seu passado com a

\footnotetext{
${ }^{25}$ NIETZSCHE, Friedrich. O nascimento da tragédia no espírito da música. São Paulo: Abril Cultural, 1974 (Coleção Os Pensadores). p. 18.

${ }^{26}$ GOLDSCHIMIDT, Victor. Questions platoniciennes. Paris: Urin, 1970. p. 113. Tradução nossa. Texto original: "par les paroles, les rythmes et les modes les plus plaintifs".
} 
herança do teatro de revista português, desde que clichês e estereótipos, poses espetaculosas e formações simétricas sempre ao redor de um eixo central sejam deixadas de lado.

A interligação entre múltiplas linguagens artísticas não é nada recente. Pelo contrário. É fácil entender o porquê: o ser humano fala, canta, gesticula. No nosso carnaval, lá se encontra essa linguagem entrelaçada, que surgiu na Grécia pagã e se expandiu e nos foi trazida pelos europeus, que incorporaram a festa ao calendário cristão. A dança contemporânea é hoje quase sinônimo de interdisciplinaridade ou, como prefiro, interlinguagens. $\mathrm{O}$ assunto voltará a ser tratado no terceiro capítulo.

A mistura, a fusão entre as linguagens flui, pois acompanha o funcionamento do corpo. O Ocidente, particularmente a partir do século XVIII, estabeleceu as especificidades que dividiram e mesmo contiveram as vozes do corpo. Se as artes encontram-se entrelaçadas desde os primórdios da tragédia, qual a especificidade da problemática apresentada? O que se vai tratar é um modo peculiar de entrelaçamento entre as linguagens, bem como o contexto no qual se inserem. É a reflexão, o pensar sobre o amálgama entre as linguagens que é recente e integra o debate atual por meio do recorte de dois momentos inovadores nas artes cênicas: Mudra e Galpão. Ao referir-se à dissolução de fronteiras promovidas pela pós-modernidade, Fredric Jameson registraria notadamente "o desgaste entre cultura erudita e cultura popular (a dita cultura de massa) ${ }^{27}$. A comunicação da primeira é livresca, enquanto que a segunda se dá pela oralidade.

Os contextos investigados foram vividos. Tive a felicidade de dedicar minha vida à interdisciplinaridade. A denominada pluridisciplinaridade do Centro Mudra referia-se, de fato, não à somatória, mas à fusão entre dança, palavra dita ou cantada, ritmo, acrobacia e outras artes performáticas que vieram se somar durante meu processo profissional às ciências da vida - a biologia e as neurociências, como também a física, a filosofia, a antropologia, a arquitetura, a matemática, a sociologia e a psicanálise, com o aporte do inconsciente, entre outras. Tudo tem a ver com tudo. É uma cooperação. Para o neurocientista Antonio Damásio, as neurociências teriam começado com Aristóteles, portanto, desde o século IV, e se desenvolvido a partir do século XIX, embora apenas em 1971 o termo tenha sido cunhado.

\footnotetext{
${ }^{27}$ JAMESON, Fredric. Pós-modernidade e sociedade de consumo. Tradução de Vinícius Dantas. Novos Estudos CEBRAP, São Paulo, n. 12, p. 2, 1985.
} 
Para Damásio, as neurociências nasceram do desejo do ser humano de interrogar-se e perceber-se e já o poeta inglês Wiliam Shakespeare (1564-1616) teria sido um neuropoeta ${ }^{28}$.

O discurso da interação entre arte e ciência pode levar alguns a descartar ou mesmo suprimir dados como emoção e sentimento, mas tais elementos continuam lá, vivos no caldeirão corporal. São muitas as vozes, em uma polifonia borbulhante. Como observou Fredric Jameson a propósito de Michel Foucault (1926-1984), o especialista encontra-se hoje deslocado, pois os saberes encontram-se de tal modo entrelaçados que cabe, antes, o termo "teórico" àquele que transita por e incorpora várias disciplinas, na promoção de uma hermenêutica epistemológica. A especialização separou o que já se encontra interligado, gerando um isolamento de saberes.

$\mathrm{Na}$ atualidade, a interdisciplinaridade vem se difundindo no contexto acadêmico e deve ser ampliada cada vez mais. Em sua edição de 8 a 14 de abril de 2013, o Jornal da USP estampou em sua manchete de primeira página: "A meta é ser interdisciplinar", ao divulgar o evento "Interdisciplinaridade no Ensino, Pesquisa e Extensão", destinado a "discutir o que fazer para que a interdisciplinaridade permeie todas as atividades de ensino, pesquisa e extensão da Universidade", em artigo de Vahan Agopyan, da Escola Politécnica da Universidade. Anteriormente vice-reitor da USP, em 2017 foi eleito reitor da instituição.

No início dos anos 1960, o antropólogo, escritor e educador Darcy Ribeiro (19221997) orientou a fundação da Universidade de Brasília, da qual foi reitor. Em 1962, ocorreu o primeiro vestibular, quando havia apenas um único prédio, o da reitoria. $\mathrm{O}$ escasso número de salas disponíveis teria levado à junção de disciplinas em busca do conhecimento, como Física e Literatura. Por exemplo: a poesia de Fernando Pessoa era analisada à luz da Física Quântica. Exemplo de interdisciplinaridade muito anterior à USP, o projeto buscava, ao mesmo tempo, oferecer ao aluno um chão básico para a escolha de uma profissão, bem como sua inserção no mundo. Durante o governo de João (Jango) Goulart, de 1961 a 1964, o orçamento destinado à Educação era de $11,4 \%$, enquanto que no período seguinte, o da ditadura civil-militar, foi reduzido a $4,7 \%{ }^{29}$.

Até mesmo a mais alta distinção literária, o Prêmio Nobel de Literatura, concedido em 2016 ao compositor musical estadunidense Bob Dylan (nascido em 1941), é fruto do reconhecimento de um trabalho transdisciplinar e expandido presentes na obra do autor, que

\footnotetext{
${ }^{28}$ DAMÁSIO, Antonio [entrevista]. In: Umas Palavras, entrevistado por Bia Corrêa do Lago. [São Paulo]: Canal Futura, 17 jan. 2015.

${ }^{29}$ RIBEIRO, Darcy. TV Brasil, em 28 maio 2016.
} 
reúne prosa, imagens, ritmo e poesia. Um entendimento análogo pode ser atribuído ao Prêmio Nobel de Economia de 2017, concedido ao professor estadunidense Richard H. Thaler, que trouxe componentes psíquicos à análise da economia comportamental, que abrange compras no supermercado a aplicações financeiras, em uma costura interlinguagens que suprime o corte entre racional e irracional.

Segundo Fredric Jameson, esse indecidivel, esse tal "discurso teórico é clara manifestação da pós-modernidade" ${ }^{, 30}$. Esta, para o autor, corresponde à uma estrutura, fruto da globalização. No dizer de Ernst Gombritch, a própria vida interdisciplinar. Há comunicação entre os saberes, decorrente da intersubjetividade e da relação com o ambiente, com o entorno. Posso acrescentar que também o corpo é interdisciplinar. Esses prolegômenos iniciais são igualmente interdisciplinares.

À experiência europeia, sucedeu-se, imediatamente, a brasileira, em um percurso alavancado pela convicção da força, da potência do corpo e do movimento que relaciona tempo e espaço, em um processo de mutação ligado à experiência - práxis, ou empiria - e que equivale ao conjunto de fatores intercambiantes que envolvem a pessoa. Foi, sobretudo, a partir de meados do século XX que o corpo passou a ser reconhecido como produtor de conhecimento, o que gerou o entrelaçamento que é nossa referência. Se tais constatações foram verificadas antes no Hemisfério Norte, em que pese a questão do saber hegemônico, há o fato de os efeitos da Segunda Guerra Mundial lá se fazerem sentir em maior escala.

Maurice Merleau-Ponty afirmou: "eu sou meu corpo"31. Admitiu o entrelaçamento ou quiasma a partir da relação do sujeito com o mundo, conduzindo-me ao entendimento de elementos principais do fazer artístico: espaço e tempo. Eu os afeto e sou por eles afetado. É o que me fez compreender Merleau-Ponty. Nas anotações finais de sua obra póstuma $O$ visível e o invisível, publicada na França em 1964, três anos após sua morte, Merleau-Ponty considerou que, enquanto reflexão, o cogito do cientista e filósofo René Descartes é uma operação sobre significações, enunciando as relações entre as mesmas, com as próprias significações sedimentadas nos atos de expressão, o que pressupõe um contato pré-reflexivo de si consigo mesmo. Diz ainda: "O cartesianismo, querendo ou não, inspirou uma ciência do corpo humano, que também o decompõe num entrelaçamento de processos subjetivos, prolongando essa análise juntamente com a noção de sensação, até o psiquismo"32.

\footnotetext{
${ }^{30}$ JAMESON, 1985, p. 2.

${ }^{31}$ MERLEAU-PONTY, Maurice. Phénomenologie de la perception. Paris: Gallimard, 1945. p. 175.

${ }^{32}$ MERLEAU-PONTY, Maurice. O visível e o invisível. São Paulo: Perspectiva, 1971. p. 33.
} 
"Eu sou, eu existo", ou a identificação do ser ao pensamento, é uma proposição necessariamente verdadeira sempre que pronunciada e constitui a primeira verdade da cadeia de razões. Passada a Idade Média, Descartes inaugurou a modernidade do pensamento, distinguindo radicalmente a substância pensante (res cogitans) da extensa (res extensa). O filósofo conservara a substância proveniente do aristotelismo, tão valorizada durante o período medieval. "Não preciso do meu corpo para pensar", disse, apesar de ser praticante de esgrima. As coisas sensíveis induzem ao erro. Nessa visão, o corpo humano encontrou-se reduzido ao status de máquina, desprovido de interioridade tanto do ponto de vista anatômico quanto fisiológico, de acordo com o modelo da mecânica clássica.

Efetivamente, Descartes depreciou e desconsiderou o corpo, considerando-o um estorvo. Eis o que ele diz em sua segunda Meditação: "Considerava-me, inicialmente, como provido de rosto, mãos, braços e toda essa máquina composta de ossos e carne, tal como ela aparece em um cadáver, a qual eu designava pelo nome de corpo" ${ }^{\text {”3 }}$.

Somente a representação das coisas no pensamento podem conduzir ao conhecimento claro e distinto, formando um arcabouço intelectual que leva ao saber objetivo e universal. Do ponto de vista científico, se na Idade Média predominou a postura de se contemplar a natureza sem nela intervir, pouco antes de René Descartes surge Galileu Galilei (1564-1642), que, ao apontar sua luneta para o céu, elaborou uma nova concepção da Física. O astrônomo era afeito à Matemática tanto quanto Descartes. Este, porém, encontraria em Galileu lacunas em seus fundamentos metodológicos. Perseguindo a consistência do fundamento, Descartes consideraria o Eu pensante o fundamento da ciência: "Verifico aqui que o pensamento é um atributo que me pertence; só ele não pode ser separado de mim"34.

Descartes encontraria apoio na Matemática - tão inerente às questões da dança - como garantia capaz de conduzir ao saber seguro. O método da dúvida, ou a dúvida metódica, permitiria chegar ao conhecimento evidente, apoiado no rigor matemático. Duvidarei de tudo, menos da dúvida. A palavra grega "mathemata" significa "cálculo", e o método cartesiano se apoia na noção de mathesis universalis. Lembrando que método é caminho, segundo os gregos. Descartes fez sua opção com o propósito de encontrar o que procurava. "O conhecimento matemático, sinônimo de razão, foi precisamente aquele que mostrou, no decorrer do exame a que todos foram submetidos, um grau de evidência capaz de resistir

\footnotetext{
${ }^{33}$ DESCARTES, René. Vida e obra. 3. ed. Tradução de J. Guinburg e Bento Prado Júnior. São Paulo: Abril Cultural, 1983. p. 93.

${ }^{34}$ Ibid., p. 94.
} 
naturalmente à dúvida" 35 . O autor acrescenta: "Na matemática não existe o problema da adequação, pois essa ciência é constituída de entidades inteligíveis, e não de coisas materiais que são percebidas”. Assim, as essências matemáticas não necessitam da existência para serem verdadeiras, pois a representação da essência independe dela. Falar em existência implica, forçosamente, na inclusão do corpo, lembrando que o prefixo "ex" designa "fora", “exterior", enquanto "sistere" é "ser o que é".

Já se tornou lugar comum a associação entre René Descartes e a clássica distinção entre alma e corpo, a tal ponto que não se procura investigar e compreender com exatidão o fundador da Filosofia na época moderna, responsável pelo fortalecimento do sujeito e da ideia enquanto representação mental, configurando-se assim como idealista. Deixou marcas em todos os filósofos que o sucederam, tanto em seus conterrâneos quanto no idealismo alemão. Immanuel Kant (1724-1804) iria contestá-lo. Kant criticaria o método de inspecção interna cartesiano e sua perspectiva eminentemente subjetiva. Ao propor o idealismo transcendental, Kant consideraria que Descartes confundiu a averiguação psicológica de si mesmo com a crítica da razão.

Diz Descartes em Discurso do método: "Esse eu, isto é, a alma, pela qual sou o que sou, é inteiramente distinta do corpo e, mesmo, que é mais fácil de conhecer do que ele, e ainda que este não existisse, ela não deixaria de ser o que é". Ele acrescenta: "Por já ter reconhecido em mim mui claramente que a natureza inteligente é distinta da corporal, considerando que toda a composição testemunha dependência, e que a dependência é manifestamente um defeito" ${ }^{\text {36 }}$. Descartes prepara, aí, a terceira verdade na cadeia de razões: "o espírito é mais fácil de conhecer que o corpo"37.

Conforme acima mencionado, Descartes identificou o ser ao pensamento, resíduo último da dúvida metódica: eu penso, eu sou. Conhecer é operação do sujeito, enquanto a coisa independe do conhecimento e do pensamento. Descartes acrescenta "existo" ao "penso". "Para pensar, é preciso existir". A questão ontológica aparece. O que é a existência para Descartes? Esta se encontra submetida a seu ser, constituindo uma explicitação deste. Reduz o existo ao penso. "O próprio corpo, no que tem de essencial, não é conhecido pelos sentidos, nem pela imaginação, mas pelo entendimento" ${ }^{\text {"38. }}$.

\footnotetext{
${ }^{35}$ LEOPOLDO E SILVA, Franklin. Descartes: a metafísica da modernidade. São Paulo: Editora Moderna, 1996. p. 33.

${ }^{36}$ DESCARTES, 1983, p. 47.

${ }^{37}$ Ibid., p. 98.

${ }^{38}$ LEOPOLDO E SILVA, op. cit., p. 57.
} 
O ponto de vista cartesiano compreende a inclusão de outros seres humanos além de si mesmo no processo de acessar o próprio eu, como quando o autor menciona, na sua segunda Meditação, que aqueles que observam de sua janela podem ser nada mais do que autômatos que portam chapéus. Teria Descartes se refugiado no cogito ergo sum para escapar da coerção exercida pela teologia e pela lógica neoaristotélica? Efetivamente, a filosofia e a teologia caminharam juntas até o século XIV.

Tanto era artificial o dualismo cartesiano que este não se sustenta. Em sua sexta Meditação, Descartes vacila. Após reconhecer as faculdades de imaginar e sentir, admite que sente dor, fome e sede, e afirma: "Não somente estou alojado em meu corpo, como um piloto em seu navio, mas que, além disso, lhe estou conjugado muito estreitamente e de tal modo confundido e misturado, que componho com ele um único todo"39. Como o corpo, tão distinto da alma, pode estar tão ligado a ela? Se está no corpo, a alma não pode ser determinada pela sua própria essência. Se o corpo sente fome ou dor, está sendo determinado pelo espírito. A dificuldade para se determinar a separação ou união, ou da consubstanciação, leva àquele que talvez seja o principal impasse do sistema.

René Descartes estabeleceu a divisão entre a res cogitans, a substância pensante, e a res extensa, que designa a qualidade dos objetos materiais, conhecidos por meio da sensação e que conduzem a um conhecimento "obscuro e confuso"40 acerca do mundo empírico. Considerado um idealista radical, não ignorou a segunda. Para ele, há a necessidade de demonstrar que o mundo material existe. Propõe-se a demonstrá-lo com muita segurança, indo ao encontro das representações claras e distintas das coisas materiais. Sem a sensação e a percepção, não há como determinar a materialidade.

Em seu Tratado sobre as paixões da alma, o filósofo francês procede a um inventário, sobretudo anatômico e psicofisiológico sobre as afecções da alma, ou, antes, da junção entre esta e o corpo. É quando se refere à glândula pineal, situada na nuca, como sede da alma. O postulado foi criticado e mesmo ridicularizado por aqueles que o sucederam, como Baruch Spinosa. Henri Bergson (1859-1941), ao referir-se ao espírito, afirma haver este lugar nenhum, não localizado. Mais recentemente, o psicanalista inglês Donald Woods Winnicott (1896-1971), ao ser indagado sobre a posição da mente no corpo, teria respondido: "Ela está por aí" ("She is out there"), ou seja, não se encontra contida em parte alguma, o que aponta para o fato de sermos uma linha em reticência de criação poética.

\footnotetext{
${ }^{39}$ DESCARTES, 1983, p. 136.

${ }^{40}$ GRANGER, Gilles-Gaston. Descartes. São Paulo: Ed. Abril, 1983. p. 16.
} 
Demorando-se em seu estudo sobre a percepção, Descartes concluiria que é pensando, e não percebendo, que o objeto é constituído. Ao referir-se ao corpo próprio, o filósofo diria: “Algumas sensações estão intimamente ligadas ao que julgo ser o meu corpo. Órgãos e funções são quase irresistivelmente sentidos como meus e me parece que não poderiam existir se não existisse o meu corpo" 41 .

Três séculos depois, seu conterrâneo Maurice Merleau-Ponty, apesar de reconhecer o avanço produzido por René Descartes ao destacar o sujeito pensante como produtor de conhecimento, discordaria em outros aspectos além do conceito de "percepção", tal como a separação entre sujeito e objeto.

"Perceptio, ônis" é igual a "de percipere", e significa a ação de colher, a colheita. Estudos recentes atribuem à percepção uma função ativa ao invés de apenas receptiva, envolvendo ação e movimento, bem como a interação ao ambiente. Em sua obra mais célebre, A fenomenologia da percepção de 1945, Merleau-Ponty reserva um longo capítulo final ao cogito cartesiano, no qual reconhece como definitivamente verdadeiro o retorno das coisas ou ideias ao eu. Prossegue tomando o exemplo de uma árvore. Há duas hipóteses: ou eu nada sei a seu respeito e não sou capaz de identificá-la; ou, diante desse ser existente perante mim, posso formar ativamente uma noção. Dito de outro modo: "Minhas percepções finitas e determinadas são manifestações parciais de um poder de conhecimento que é coextensivo ao mundo e que o desvela de parte em parte" ${ }^{~} 42$. Para Merleau-Ponty, o cogito cartesiano só tem sentido a partir de seu próprio cogito. Acrescenta que a consciência de si é o ser mesmo do espírito em exercício. "É preciso que o ato pelo qual eu tenho consciência de algo seja apreendido no instante mesmo em que se cumpre, sem o que ele se quebraria" ${ }^{\circ 3}$, o que situa a consciência no momento presente.

A crítica merleaupontyana aos postulados cartesianos pode ser denominada como "cógito encarnado" que assumo como postura na feitura do meu processo interlinguagens. $\mathrm{O}$ ponto mais importante de convergência entre o autor da de Fenomenologia da percepção e as descobertas de René Descartes está contido na primeira parte da afirmação "O movimento profundo de transcendência que é o meu próprio ser, o contato simultâneo entre o meu ser

\footnotetext{
${ }^{41}$ LEOPOLDO E SILVA, 1996, p. 73.

${ }^{42}$ MERLEAU-PONTY, 1945, p. 424. Tradução nossa. Texto original: "mes perceptions finies et determinées sont les manifestations partielles d'un pouvoir de connaissance qui est coextensif au monde et qui le déploie de part en part".

${ }^{43}$ Ibid., p. 426. Tradução nossa. Texto original: "Il faut que l'acte par lequel j'ai conscience de quelque chose soit appréhendé lui-même dans l'instant ou il s'accomplit, sans quoi il se briserait".
} 
com o ser do mundo"44. O contato simultâneo já estabelece uma discordância entre os filósofos. A primeira verdade, eu penso, é válida desde que compreendida como "eu me pertenço". Mas Merleau-Ponty acrescenta que, estando no mundo, sou levado a considerar que o interior e o exterior são inseparáveis, ou seja, o mundo encontra-se dentro de mim e eu dentro do mundo. Ao referir-se expressamente ao corpo, o autor chega ao cerne de sua colocação:

Se, refletindo sobre a essência da subjetividade, eu a encontro ligada à do corpo e à do mundo, é porque minha existência como subjetividade faz uma unidade com minha existência como corpo e com a existência do mundo e o sujeito que eu sou, tomado concretamente, é inseparável deste corpo aqui e deste mundo aqui. $\mathrm{O}$ mundo e o corpo ontológicos que nós reencontramos no coração do sujeito não correspondem ao mundo enquanto idéia ou ao corpo enquanto idéia, mas ao mundo em si mesmo abarcado numa tomada global, é o próprio corpo como corpo-cognoscente ${ }^{45}$.

Em prol das ideias claras e distintas, Descartes inferiorizou a sensação ou conhecimento obtido por meio dos nossos sentidos e que resulta em um grau pobre e insuficiente de cognição. Estabeleceu, assim, uma hierarquia na qual a substância pensante antecede a substância corpórea. Para o filósofo francês, a ideia e a realidade mental vinham em primeiro lugar. Por sua vez, Merleau-Ponty admitiu a convivência íntima entre as duas substâncias. O fenomenólogo credita a Descartes e, sobretudo, a Immanuel Kant o aparecimento do conceito de "consciência", pela afirmação de que eu não poderia atingir coisa alguma como existente se primeiro eu não me provasse como existente no ato de atingilas. Critica, no entanto, a desvalorização por parte do cogito da percepção do outro, considerando que o Eu só é acessível a si mesmo. Releva, ainda, a encarnação em uma natureza e a possibilidade de uma situação histórica, dados ignorados por René Descartes.

Merleau-Ponty considera a percepção como a primeira abertura ao objeto, atribuindolhe a função de fundar ou inaugurar o conhecimento. Para a Fenomenologia, que estabelece a

\footnotetext{
${ }^{44}$ MERLEAU-PONTY, 1945, p. 432. Tradução nossa. Texto original: "le mouvement profond de transcendance qui est mon être même, le contact simultané avec mon être et avec l'être du monde".

${ }^{45}$ Ibid., p. 467. Tradução nossa. Texto original: "Si, réflechissant sur l'essence de la subjectivité je la trouve liée à celle du corps et à celle du monde, c'est que mon existence comme subjectivité ne fait qu'um avec mon existence comme corps et avec l'existence du monde et que finalement le sujet que je suis, concrètement pris, est inséparable de ce corps-ci et de ce monde-ci. Le monde et le corps ontologique que nous retrouvons au coeur du sujet ne sont pas le monde en idée ou le corps en idée, c'est le monde lui même contracté dans une prise globale, c'est le corps lui même comme corps-connaissant".
} 
ontologia: "A percepção antecipa, vai à frente" ${ }^{46}$. Conhecer é, portanto, antecipar. Apoiandose na teoria estruturalista da Gestalt ("forma", em alemão), acredita que nosso campo perceptivo é formado por coisas e vazios ou intervalos entre elas. Hoje pouco difundida, a Gestalt concebe a forma como totalidade e possui estrutura própria, mais que a soma das partes.

Por sua vez, Henri Bergson refere-se a "uma consciência espontânea e reflexiva ao mesmo tempo"47. Considera o estado de consciência um epifenômeno do estado cerebral, aquilo que ultrapassa e vai além do fenômeno considerado, admitindo a solidariedade entre o estado de consciência e o cérebro, dando como exemplo a relação entre um prego na parede e um vestido que será colocado ali. Refere-se ao antigo problema das relações entre alma e corpo e crê que o pensamento é uma função do cérebro. Em Matéria e memória, Bergson constitui o corpo como um centro de ação destinado a mover os objetos. Diz ainda: "Tudo ocorre como se, neste conjunto de imagens que eu chamo o universo, nada poderia se produzir de realmente novo senão por intermédio de certas imagens particulares cujo padrão me é fornecido por meu corpo" ${ }^{48}$. Importa, aqui, a afirmação do corpo.

O sistema nervoso percebe sensorialmente por meio de todos os sentidos e inclui a propriocepção, expressão cunhada em 1906 pelo neurofisiologista inglês Charles Scott Sherrington. A propriocepção corresponde "ao conjunto dos comportamentos perceptivos que concorrem para este sexto sentido que hoje recebe o nome de sentido do movimento ou

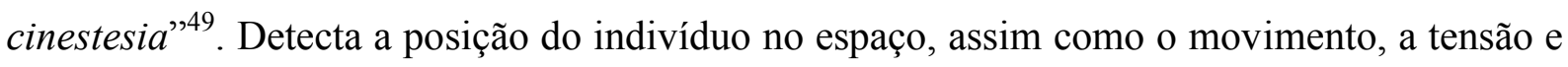
o estiramento musculares. Se me encontro em um lugar em que há um grande trânsito de pessoas e me imobilizo subitamente, como ao descer uma escada rolante, por exemplo, corro o risco de ser atropelado por quem vem atrás de mim. Nesse caso, minha propriocepção encontra-se comprometida. Cientificamente, a percepção não é consciente necessariamente, enquanto o sentimento é o que a torna consciente. Segundo Merleau-Ponty, o visual é o que é atingido pelos olhos e o sensível é o que se atinge pela sensação, que abarca todos os sentidos.

\footnotetext{
${ }^{46}$ MERLEAU-PONTY, 1945, p. 82.

${ }^{47}$ BERGSON, Henri. Matière et mémoire. Paris: Presses Universitaires de France, 1939. p. 10.

48 Ibid., p. 12. Tradução nossa. Texto original: "Tout se passe comme si, dans cet ensemble d'images que j'appelle l'univers, rien ne se pouvait produire de réelement nouveau que par l'intermédiaire de certaines images paticulières dont le type m'est fourni par mon corps".

49 SUQUET, Annie. Cenas: o corpo dançante - um laboratório da percepção. In: COURBIN, Alain; COURTINE, Jean-Jacques; VIGARELlO, George. (Orgs.). História do Corpo. v. 3. Petrópolis: Vozes, 2009. p. 515-516.

A obra em que Sherrington desenvolve a noção de propriocepção se intitula The integrative action of the nervous system (New Haven: Yale University Press, 1906)
} 
$\mathrm{O}$ ato perceptivo depende da ação do movimento: vem a ser, portanto, uma ação do corpo, que inclui a intensidade do tônus muscular. Para Jacques-Dalcroze (1865-1950), “o movimento é uma experiência muscular, e essa experiência é apreciada por um sexto sentido - o sentido muscular" ${ }^{\prime 50}$. A cinestesia trata da percepção do corpo no espaço, visto do interior, orientada por esse "sexto sentido" básico para a ação de improvisar. A palavra "cine" equivale a "movimento" e corresponde à sensação que o indivíduo tem da situação de sua existência, ou seja, compreende as suas funções orgânicas e a corporeidade enquanto cinestesia - do grego "koiné" (comum) e "esthesis" (sensação) - e estabelece junções entre planos sensoriais diversos. Por meio dessa teoria, há o reconhecimento da pessoa como unidade psicossomática. É nesse ponto que queria chegar, pois tal concepção alavanca e ilumina todo o meu fazer corporal artístico, à medida que me situo como uma atuante conectada.

A palavra "coenesthesis" ("cinestésico") foi proferida pela primeira vez em 1794, em Halle, como título de uma tese de doutorado presidida pelo anatomista e fisiólogo Johann Christian Reil e cujo tema versava sobre seu próprio trabalho. Equivale ao termo germânico "Gemeingefühl" - em francês, "sensibilité génerale"; em inglês, "general sensibility" - e nomeia a empatia muscular, definindo o sentido de orientação ótica, gustativa, táctil, olfativa e de coordenação motora, habitando o foro psicológico. Pode criar sinapses (ou conexões) cerebrais que estimulam fluidos energéticos, como dopamina e endorfina.

Os conceitos de propriocepção, cinestesia e intersubjetividade formam o tripé de apoio que alavanca um novo entendimento do corpo e do fazer coreográfico, que me leva a ampliar o entendimento do que foi experienciado tanto no Mudra quanto no Galpão.

Merleau-Ponty credita a Edmund Husserl (1859-1938) o conceito de “intersubjetividade”, quando o sujeito transcendental entra em situação objetiva, e assinala:

[...] a reflexão não se retira do mundo em direção à unidade da consciência como fundamento do mundo, ela toma recuo para ver jorrar as transcendências, ela distende os fios intencionais que nos ligam ao mundo para fazê-los aparecer, ela apenas é consciência do mundo porque ela $\mathrm{o}$ revela como estranho e paradoxal. ${ }^{51}$

\footnotetext{
${ }^{50}$ JAQUES-DALCROZE, Émile. Le rythme, la musique et l'éducation. Lausanne, FRA: Fetisch Frères, 1919. p. 16.

${ }_{51}$ MERLEAU-PONTY, 1945, p. VIII. Tradução nossa. Texto original: "La reflexion ne se retire pas du monde vers l'unité de la conscience come fondement du monde, elle prend recul pour voir jaillir les transcendances, ele distend les fils intentionnels qui nous relient au monde pour les faire paraitre, elle seule est conscience du monde parce qu'elle le révèle come étrange et paradoxal".
} 
A escrita poética do autor francês faz-se presente ao desenvolver seu próprio conceito de "intersubjetividade" em $O$ visível e o invisivel, quando estabelece o elo indissolúvel entre sujeito e objeto, questionando a separação entre ambos. $\mathrm{O}$ ir e vir estabelecem pontes indissociáveis. Merleau-Ponty mostra o quiasma ou entrelaçamento quando principia referindo-se à carne, distinta da matéria:

[...] a carne de que falamos não é matéria. Consiste no enovelamento do visível sobre o corpo vidente, do tangível sobre o corpo tangente, atestado sobretudo, quando o corpo se vê, toca-se vendo e tocando as coisas, de forma que, simultaneamente, como tangivel, desce entre elas, como tangente, domina-as todas, extraindo de si próprio essa relação. ${ }^{52}$

O meu corpo não é coisa nem ideia. Idealidade não estranha à carne fornece eixos, profundidade, dimensões. Segundo o Novíssimo dicionário latino-portuguez, de Santos Saraiva, a palavra "carne" evoca também a gordura, o tronco, a madeira, o pau das árvores. Merleau-Ponty nomearia como visível e invisível os modos de conhecimento, relações idênticas ao direito e avesso de uma mesma peça. A carne evocada por Ponty é quase ontológica e guarda "um estado selvagem como pré-predicativo do ser, comparável aos elementos pré-socráticos" $" 53$.

Os sentidos entendem-se entre si, sem a necessidade de passar por uma ideia ou por uma representação. Para o neurocientista Antonio Damásio (nascido em 1944), em uma perspectiva recente, não existe percepção pura de um objeto em um canal sensorial único, como, por exemplo, a visão. A ocorrência da percepção depende de sinais, do ajustamento do corpo acrescido a sinais sensoriais especializados. Dito de outro modo, não existe percepção pura. "A percepção depende de atividades em várias regiões cerebrais formadoras de imagem e frequentemente envolve também partes do cérebro relacionadas ao movimento" ${ }^{\text {" }}$. Não há, portanto, isolamento. A percepção sinaliza tratar-se de uma faculdade ligada ao presente, ligada ao ambiente.

A intersubjetividade é sustentada por uma intercorporeidade fundamental, por um verdadeiro diálogo intercorpos. Assim como ocorre o contato entre sujeito e objeto, dá-se, também, o elo entre consciência e mundo, gerando-se uma nova proposta de ontologia. $\mathrm{O}$ real

\footnotetext{
${ }^{52}$ MERLEAU-PONTY, 1971, p. 141.

${ }^{53}$ CORRÊA, José de Anchieta. L'évolution de la notion de "corps" à la notion de "chair" chez Maurice MerleauPonty. Tradução nossa. Kriterion: Revista de Filosofia, Belo Horizonte, n. 66, 1971, p. 75.

${ }^{54}$ DAMÁSIO, António. E o cérebro criou o homem. São Paulo: Companhia das Letras, 2011, p. 191.
} 
é sempre o percebido. Essa é uma afirmação axial com referência ao fazer cênico. Não pode haver percepção sem mundo. O corpo habita o espaço ao invés de estar no espaço e no tempo. Para o autor de Fenomenologia da percepção, essa abordagem tem carga arcaica e se ramifica no campo afetivo, o que supõe uma conexão com o psiquismo e a memória da pessoa.

O verdadeiro cogito ergo sum, para Merleau-Ponty, não se restringe ao pensamento sobre o pensamento, mas liga-se ao mundo. A consciência do mundo e a consciência de si encontram-se intrinsecamente ligadas. O postulado remete ao Dasein de Martin Heidegger (1889-1976), igualmente discípulo do teórico da Fenomenologia Edmund Husserl. Para Heidegger, é na existência que corpo e alma se conjugam. A palavra "fenômeno", derivada do grego "phainomenón", significa "mostrar-se". "É o que se mostra, o que se revela, traz à luz do dia, põe no claro aquilo que, em seu mostrar-se, aponta e indica algo que não se mostra"55. Para Merleau-Ponty, o corpo está no mundo como o coração está abrigado dentro do organismo, habitando o Lebenswelt (ou o mundo da vida), que se desvela permanentemente diante de nós. Há a apreensão das qualia, que correspondem às propriedades fenomênicas com as quais um objeto é representado pelo sistema sensório de um organismo com o todo, reiterando mais uma vez o que se oferece, apresenta-se, mostra-se e é apreendido sensualmente.

É o corpo capaz de superar os dilemas decorrentes das filosofias da consciência, que produzem impasses. A capacidade de pensar está necessariamente vinculada ao corpo e à percepção. A constatação leva Merleau-Ponty a admitir a condição corpórea entranhada no mundo, pois não se encontra disposta diante de um espírito desencarnado. O corpo é a parte do mundo que nos permite percebê-lo e pensá-lo. Se a percepção depende da ação do movimento, trata-se, portanto, de uma operação do corpo.

A professora Marilena Chauí observa que o nosso corpo, segundo a Física, é um agregado de átomos; segundo a Química, um composto feito de moléculas de água, oxigênio, carbono, enzimas e proteínas; para a Biologia, um organismo vivo pertencente a uma determinada espécie; e, para a Psicologia, uma aparelhagem receptadora de estímulos externos e internos que respondem e constituem comportamentos observáveis. Imbuída pelo pensamento de Merleau-Ponty e pela ideia de intercorporeidade, Chaú afirma:

\footnotetext{
${ }^{55}$ HEIDEGGER, Martin. Ser e tempo. v. 1. Petrópolis, RJ: Vozes, 1986. p. 58.
} 
Visível-vidente, táctil-tocante, sonoro-ouvinte/falante, meu corpo se vê vendo, se toca tocando, se escuta escutando e falando. Meu corpo não é coisa, não é máquina, não é feixe de ossos, músculos e sangue, não é uma rede de causas e efeitos, não é um receptáculo para uma alma ou para uma consciência: é meu modo fundamental de ser e estar no mundo, de me relacionar com ele e de ele se relacionar comigo. Meu corpo é um sensível que sente e se sente. ${ }^{56}$

Quando Merleau-Ponty refere-se ao tato, no exemplo de uma mão que toca a outra, tornando-se difícil definir qual é a mão que toca ou é tocada, há, aí, uma possível ambiguidade. Em $O$ olho e o espírito, volta a citar Descartes, que afirmou que os cegos "veem com as mãos". Nesse caso, o modelo cartesiano da visão é o tato, primeiro sentido a desenvolver-se no feto segundo a terapia corporal Rolfing, noção reiterada por Annie Suquet ${ }^{57}$.

A visão merleaupontyana foi, na história da filosofia, uma das que mais atribuíram sentido ao corpo: "Se percebemos com o corpo, o corpo é um eu natural e como que o sujeito da percepção" ${ }^{, 58}$. Somos consciência encarnada no corpo. O autor questiona o idealismo transcendental, pois o sujeito da percepção não pode ser um ego transcendente, separado do mundo. Recusa tanto o ponto de vista teológico e a busca do Absoluto quanto as filosofias da consciência que têm como parâmetro o sujeito, do latim "subjectus". Tal concepção, iniciada por René Descartes, teve prosseguimento com os filósofos alemães, de Kant a Husserl, conforme exposto. Merleau-Ponty descarta ainda o cientificismo objetivo e impessoal. No exemplo do tato, citado acima, o corpo que toca não é um objeto que se apresenta diante de uma consciência separada e imaterial. A pessoa que toca percebe entrar em contato físico com o que toca. Nossa corporeidade é fundamento da experiência perceptiva. Os recentes debates contemporâneos entre corpo e ambiente, muito devem às vias abertas por Merleau-Ponty. Em uma confluência de várias disciplinas do conhecimento, as oposições binárias encontram-se excluídas. As dicotomias só têm sentido enquanto análise, quando o que se estuda é destrinchado. A tentativa é a de compreender os contrários, em busca da elucidação.

\footnotetext{
${ }^{56}$ CHAUÍ, Marilena. Convite à Filosofia. São Paulo: Editora Ática, 2004. p. 207.

${ }^{57}$ SUQUET, 2009.

Os órgãos do tato se desenvolvem bastante cedo na maturação do feto. No nascimento, o tato seria um dos primeiros sentidos que é ativado. A reflexão de Steve Paxton sobre a importância do tato e seu papel cultural deve muito ao livro de Ashley Montagu, publicado em 1971 pela Columbia University Press (New York): Touching: the human significance of the skin.

${ }^{58}$ MERLEAU-PONTY, 1945, p. 239.
} 
Em A estrutura do comportamento, uma de suas primeiras obras, o fenomenólogo seguiu os paradigmas da Gestalt. O aspecto estrutural dessa abordagem interessa a MerleauPonty por se situar fora da relação sujeito-objeto e por considerar a estrutura uma dimensão do ser, um sistema de relações e diferenças internas que admite uma organização já dada em um campo de possibilidades. Para o filósofo, estrutura é pregnância, é fecundidade, trazendo nela mesma o seu devir. Heráclito de Éfeso (cerca de 540-470 a.C.) admitiu o movimento em detrimento da estabilidade e afirmou: “Ao vir-a-ser, é necessário tanto o ser quanto o não ser; se eles agem conjuntamente, então resulta um vir-a-ser"59.

O significado das coisas depende de nossa experiência delas enquanto tais. Uma lei física, ainda que concebida enquanto modo para organizar fatos físicos, funda-se não somente nos fatos, mas também em nossa estrutura perceptiva. Merleau-Ponty procura mostrar que uma abordagem objetiva e científica do corpo não permite uma compreensão completa e adequada dos fenômenos. As conexões neurofisiológicas, sustentadas pelo realismo científico, não dão conta de explicar a capacidade do corpo de realizar uma experiência cheia de significado e uma atividade organizada.

Conforme a concepção merleaupontyana, a peculiar unidade do corpo não pode ser explicada nem pelo sensacionismo - que defende que todo o conhecimento provém unicamente das sensações - nem tampouco pelo idealismo. A fenomenologia do corpo pensa que a união entre alma e corpo não pode ser determinada por decreto, mas se realiza a cada momento da existência. A dualidade entre meu corpo e minha subjetividade desaparece logo que se concebe a existência como um ser no mundo.

Merleau-Ponty distingue então o corpo objetivo do corpo fenomenal. O primeiro é encontrado nas ciências naturais, como a Anatomia e a Fisiologia, enquanto que o segundo não é, de modo algum, um objeto, mas nossa capacidade corporal da percepção e da ação significativa. A percepção se atém ao núcleo do nosso ser, constituindo o fenômeno originário que funda a possibilidade da verdade, do conhecimento e da liberdade.

O projeto de Merleau-Ponty distingue-se do husserliano, que afirma a possibilidade de se colocar as próprias coisas "entre parênteses" por meio da redução fenomenológica, e que permite, por exemplo, a partir de uma bananeira, chegar-se à noção de "baneiridade", mas com a particularidade de se devolver ao mundo o eidhos (ou miolo, núcleo, semente). O procedimento é esclarecedor, pois deixa de separar uma suposta essência do fenômeno, o que

\footnotetext{
${ }^{59}$ NIETZSCHE, Friedrich. Crítica Moderna. Tradução de Carlos A. R. de Moura. In: SOUZA, José Cavalcante (Coord.). Os pré-socráticos: Ed. Nova Cultural, 1999 (Os Pensadores, v. 1). p. 129.
} 
implicaria em uma dualidade com a qual meu pensamento integrador não poderia concordar. Se para o pensador francês, a verdadeira filosofia é reaprender a ver o mundo antes de sua apropriação intelectual, a professora Marilena Chaú acrescenta, em ensaio publicado na Revista Cult, $\mathrm{n}^{\circ}$ 123, em 2008, ano do centenário de nascimento do fenomenólogo francês:

Já que a percepção funda nossa idéia de verdade, nosso corpo, enquanto corpo cognoscente, é iniciação ao mistério do mundo e da razão. Graças ao corpo, espaço, tempo, motricidade, sexualidade, linguagem, visão, emoção, pensamento e liberdade surgem na trama dos acontecimentos corporais e destituem a consciência reflexiva de seu papel constitutivo soberano ou do insensato "projeto de posse intelectual do mundo ${ }^{60}$.

Para Chauí, o racionalismo moderno cindiu o corpóreo do pensamento reflexivo ao eleger a consciência, a pura interioridade, enquanto referência máxima do conhecimento, levando às últimas consequências a separação entre o corpóreo e o anímico e afirmando que a subjetividade constitui a realidade ou põe o mundo a partir de si mesma, atitude essa equivalente nas artes à ênfase no sujeito modernista. A herança deixada pelas filosofias reflexivas, fundadas na cisão entre sujeito e objeto, foi "a oposição entre corpo e alma, matéria e espírito, fato e ideia, sensível e inteligível, abandonando o ver e o sentir em nome do pensamento do ver e do sentir" ${ }^{\prime 61}$. Chauí liquidifica, assim, sua avaliação do peso deixado pelo moderno racionalismo, defendendo o pensamento encarnado em um corpo. Este não é uma coisa, nem o mundo pode ser domesticado pelas representações construídas pelo sujeito do conhecimento.

Em sua busca por uma nova ontologia, há a busca pelo espírito selvagem e pelo ser bruto, presentes nas criações filosóficas e artísticas. Estas alcançam expressões ainda inexistentes, construindo linguagens originais, marcadas pela radicalidade e acessando o ser. São polpa carnal do mundo, carne de nosso corpo e carne das coisas. São quiasma ou entrecruzamento "do visível e do invisível, do dizível e do indizível, do pensável e do impensável, cuja diferenciação, comunicação e reversibilidade se fazem por si mesmas como estofo do mundo" ${ }^{, 62}$. A experiência criadora é o emblema da ontologia proposta por MerleauPonty. Ela não necessita ser eficaz, mas sim fecunda.

\footnotetext{
${ }^{60}$ CHAUÍ, Marilena. Merleau-Ponty: a obra fecunda. Revista Cult [online], n. 123, 2008. Disponível em: $<$ http://revistacult.uol.com.br/2010/03/merleau-ponty-a-obra-fecunda $>$. Acesso em: 17 jul. 2015.

${ }^{61}$ Ibid, 2008.

${ }^{62}$ Ibid, 2008.
} 
Tal experiência é guiada pelo ato da pequena palavra "ver". "A visão não é um certo modo do pensamento ou presença a si: é o meio que me é dado de estar ausente de mim mesmo, de assistir por dentro à fissão do Ser, ao término da qual somente me fecho sobre mim"63. É o mesmo que disse Fernando Pessoa sob a pele de Alberto Caeiro em Poemas inconjuntos: "ver podendo dispensar tudo menos o que se vê / É esta a ciência de ver, que é nenhuma"64.

As reflexões empreendidas por Merleau-Ponty permitiram a emergência do corpo como matéria sensível e pensante ao mesmo tempo. A ausência de ruptura, o "ping-pong" processual, liquida o recurso às dualidades ou ao hábito ocidental de dividir tudo em dois. Merleau-Ponty enumerou as antinomias presentes na epistemologia, além de sujeito-objeto. Às dualidades já citadas por Chauí, seguem-se: fato e essência, ser e nada, consciência e mundo, imagem e palavra, corpóreo e incorpóreo. Encontram-se, assim, sepultadas as distorções decorrentes do racionalismo moderno, iniciado com René Descartes. Outras divisões binárias podem ser citadas: interioridade e exterioridade, mente e matéria, significante e significado, forma e conteúdo, unificação e disjunção, verdadeiro e falso, razão e emoção, teoria e prática ou universos reais e ficcionais. Interação, interatividade e intersubjetividade são ideias correlatas. Como foi dito, tal modo de pensar leva ao entendimento de noções como tempo e espaço: eu os afeto e sou por eles afetado. Se coreografo uma música cuja partitura não contém contagens claras, o elenco e eu somos levados a encontrar pontos de referência e a desenvolver a escuta tanto da música quanto entre si, ou seja, a partitura nos conduz e, ao mesmo tempo, nós agimos sobre ela. No procedimento, a música nos provoca ao mesmo tempo em que nós provocamos a música por meio de nossas necessidades cênicas.

Transposto para as artes cênicas, o conceito merleaupontyano conduz à associação com o mundo circundante. Em que pese a referência ao fim da utopia modernista e vanguardista, que tinha como um dos focos a invenção e individualidade do sujeito, a expressão "retorno ao real", cunhada por Hal Foster, e a consequente discussão sobre os "teatros do real" (de "res": "coisa"), é discutível porque enfatiza um dos lados, ainda que justificada pela guinada pós-modernista, que, desde os anos 1960, focou imagens e objetos triviais, deslocando o eixo antes concentrado no sujeito. À herança romântica que proclama o artista enquanto fonte de toda significação, ao consequente discurso da morte da arte

\footnotetext{
${ }^{63}$ MERLEAU-PONTY, Maurice. O olho e o espírito. São Paulo: Cosac \& Naify, 2004. p. 42.

${ }^{64}$ PESSOA, Fernando. Poemas Inconjuntos. Lisboa: Âncora Editora, 2006. p. 16.
} 
sustentado por Marcel Duchamp (1887-1968) e Roland Barthes (1915-1980) e à ideia formalista de que a arte é um sistema fechado de significação própria ao novo criticismo.

Adequado é, também, o conceito foucaultiano de heterotopias, que conjuga o real e o irreal ao mesmo tempo, admitindo o elo indissolúvel entre real e ficção. Com “„Utopias e Heterotopias $^{e e}$ - geografias humanas", palestra proferida em março de 1967 - que deu origem ao artigo intitulado Des espaces autres, publicado na revista Architecture/Mouvement/Continuité em outubro de 1984, último ano de vida do autor Michel Foucault concentra-se integralmente no corpo e na questão corporal.

Se a utopia indica um espaço em um lugar não real, uma vez que a vogal " $u$ " indica negação, a heterotopia situa espaços outros e lugares efetivamente localizáveis, justapostos e simultâneos, com um recorte temporal, em uma conjunção simultânea de real e irreal. A disciplina heterotopologia passa a existir. O hetero, o outro, o diferente, junta-se a topologia ou topografia, referindo-se à descrição anatômica e particularizada de qualquer parte do organismo humano. O topos avizinha-se do território, tão mencionado por Gilles Deleuze no conceito de "desterritorialização". Avizinha-se também da dança e da coreografia, quando corpos são dispostos no espaço. O mesmo entendimento se estende com relação ao tempo. Eu administro o tempo do mesmo modo com que sou administrado por ele. O mesmo ocorre no cinema. É impossível que um documentário não esteja permeado por ficção, devido ao olhar do cineasta, que elege, seleciona, escrutina a ação. Em relação ao espaço, a simbiose entre afetar e ser afetado do mesmo modo acontece. Tal relação foi reconhecida por Gaston Bachelard (1884-1962), que disse: "Parece, então, que é por sua ,imensidão que os dois espaços - o espaço da intimidade e o espaço do mundo - tornam-se consoantes" ${ }^{\text {"65 }}$.

Merleau-Ponty menciona as relações inter-humanas, o entroncamento entre o sujeito e o mundo, o fluxo contínuo e constante que extingue a separação. Pela evidência do outro, o Eu se coloca no plural. Observando o ato de amamentar um bebê, Merleau-Ponty diria: “A mordida tem imediatamente para ele um significado intersubjetivo. Ele percebe as intenções em seu corpo, meu corpo com o seu e então minhas intenções em seu corpo" "66. Posteriormente, outros conceitos análogos foram concebidos, como o de transcorporeidade e a transindividualidade de Felix Guattari, abordada por Nicolas Bourriaud em Estética

\footnotetext{
${ }^{65}$ BACHELARD, Gaston. A poética do espaço. Tradução de Antônio de Pádua Danesi. São Paulo: Martins Fontes, 1996. p. 207.

${ }^{66}$ MERLEAU-PONTY, 1945, p. 404. Tradução nossa.
} 
relacional, que chamarei de singularidades coletivas, assunto que será trabalhado no terceiro capítulo.

Como, então, pensar a singularidade específica de um artista? Bourriaud apoia-se em Guattari para explicar a subjetividade coletiva, uma transubjetividade formada por significantes fluidos com os quais a pessoa pode se identificar, provenientes, primeiramente, do meio cultural dessa pessoa, como a família e até o aparato informacional que recebe e que compõe a corporeidade existencial por meio de alianças com o concreto. Encontra-se, dessa forma, distante a romântica noção de subjetividade. Admitindo a interdependência, Bourriaud reconhece uma "transformação ecológica das subjetividades"67.

As ligações estabelecidas por Ponty liquidam o estanque. As dicotomias não se sustentam, pois os contrários não são antagonistas, nem mesmo complementares, mas encontram-se fusionados. Profissionais das artes cênicas, ao proporem oficinas, por vezes, referem-se ao trabalho corporal $e$ vocal, o que é quase uma aberração, pois a voz encontra-se alojada no corpo.

Merleau-Ponty iluminou a questão ao dizer que a matéria é "grávida" de sua forma ${ }^{68}$, encontrando-se, portanto, aparentada desde a origem, superando a divisão aristotélica entre matéria e forma. A expressão "extremamente feliz" leva à constatação de que, de fato, para o artista, na maior parte das vezes, o conceber artístico com frequência já implica em sua projeção.

Aponta ainda o autor para o papel desempenhado pelo corpo como campo perceptivo e prático. Os tipos de receptores dos sentidos do corpo humano são:

- exteroceptores - respondem a estímulos externos, originados fora do organismo;

- proprioceptores - detectam a posição do indivíduo no espaço, assim como o movimento, a tensão e o estiramento musculares;

- interceptores - respondem a estímulos viscerais ou outras sensações, como sede e fome.

Por meio da percepção, um indivíduo organiza e interpreta as suas impressões sensoriais para atribuir significado a seu meio. A percepção consiste na aquisição, interpretação, seleção e organização das informações obtidas pelos sentidos. Pode ser

\footnotetext{
${ }^{67}$ BOURRIAUD, Nicolas. Estética Relacional. São Paulo: Martins Fontes, 2009. p. 133.

${ }^{68}$ MERLEAU-PONTY, 1945.
} 
entendida do ponto de vista estritamente biológico ou fisiológico, envolvendo estímulos elétricos evocados nos órgãos dos sentidos. Não se trata de habitar, de ter, mas de ser o corpo, ("leib”, em alemão), corpo vivo, que difere do Körper, mera materialidade. Em um corpo, ainda que imóvel, há circulação de energia, transformação, devir, movimento e mudança. Ele não se encontra parado.

O princípio da interação foi também sustentado pelas ciências cognitivas. Um amálgama se forma entre as ciências da vida, como a Biologia, as neurociências e outras. Segundo o médico Gustav Fechner, inventor do termo "psicofísica", em psicologia, neurociência e ciências cognitivas, percepção é a função cerebral que atribui significado a estímulos sensoriais a partir do histórico de vivências passadas.

Reitero que, no decorrer do século XX, a unidade psicofísica da pessoa passou a ser amplamente reconhecida. A fusão entre o psíquico e o somático, o sensório e o motor, o corpo concebido não como um veículo à comunicação, mas ele mesmo comunicante, aos quais vêm se somar os neurônios espelho, provocadores da empatia. A performance - desempenho ou ação - vincula-se à escuta ao próprio corpo. Daí a recorrência da palavra "embodiment", ou "encarnação", o mesmo que "corporeidade".

Corporalidade, do latim "corporalitate", é o mesmo que corporeidade. A noção introduzida por Merleau-Ponty resultou não apenas nos estudos sobre a relação entre corpo e ambiente, mas pode remeter ainda à ancestralidade. É o que Martin Puchner denominou "retorno do corpo" e Harold Segel de "ascensão do corpo". A questão da ancestralidade foi tratada no Mudra no curso Jogo Teatral, ensinado pelo professor Fons Goris, na abordagem acerca das idades da vida.

A convicção da potência corporal sustenta, primeiramente, a formação, o preparo que habilita o fazer cênico e, a seguir, a composição. Diante do que foi exposto, o que pretendo é trabalhar com os registros já realizados para refletir sobre eles na construção de partituras coreográficas. É o que me proponho a fazer.

A percepção não é necessariamente consciente, enquanto o sentimento é o que a torna consciente. $\mathrm{O}$ ato perceptivo depende da ação do movimento: vem a ser, portanto, uma ação do corpo, que inclui a intensidade do tônus muscular. Henri Bergson considera lei: "A 
percepção dispõe do espaço na exata proporção em que a ação dispõe do tempo"69 ${ }^{\text {. Carregada }}$ de lembranças-imagens é que a percepção apreende o presente.

Reportar-se a acontecimentos ocorridos e experiências vividas na década de setenta remete, antes de tudo, à interligação entre tempo, movimento, espaço, memória e experiência, após termos abordado os temas corpo e percepção. "O passado só existe reconstruído, a arqueologia só pode ser feita a partir do presente" ${ }^{, 70}$. Reconhecer o entrelaçamento entre pessoa e mundo por meio de um pensar (cogitare) conectado gerará o entendimento de noções como tempo e espaço. Antecedendo as revelações efetuadas por Merleau-Ponty, houve outros modos de pensar a questão conjugada tempo-espaço.

Em Estética transcendental, Immanuel Kant considera o espaço e o tempo como as duas formas puras da intuição sensível. Ambos existem na razão do sujeito, e não no mundo empírico, segundo a acepção kantiana. Para Kant, espaço e tempo não constituem um conhecimento que tem origem na experiência, mas na subjetividade, em nossa capacidade de conhecer, que produz um dado fornecido a priori. Há fenômenos que nos serão representados pelos sentidos. Há coisas no espaço, mas o próprio espaço não tem existência empírica. Nas palavras de Kant: “O espaço não é mais do que a forma de todos os fenômenos dos sentidos externos, isto é, a condição subjetiva da sensibilidade, única que permite a intuição externa"71. A realidade empírica do tempo ocorre no sujeito antes de qualquer percepção real. Dito de outro modo, somos afetados por tudo o que povoa o espaço e pelas ingerências do tempo, mas é na intuição interna que eles habitam: "O tempo apenas muda algo que está no tempo"72.

O que acontece não é inerente aos próprios objetos, mas unicamente ao sujeito que os intui. Não é o próprio tempo que muda, mas o sujeito. Por sua vez, o movimento contém ambos os elementos - tempo e espaço - e ambos condicionam toda e qualquer experiência, seja externa ou interna. Ora, se abro os braços e corro pela sala em que me encontro, os volumes nela presentes dialogarão com os movimentos de meu percurso, ao mesmo tempo em que eu dialogo com os volumes que me oferecem limites, ou seja, eu me amoldo ao espaço e

\footnotetext{
${ }^{69}$ BERGSON, 1939, p. 29. Tradução nossa. Texto original: "la perception dispose de l'espace dans l'exacte proportion où l'action dispose du temps".

${ }^{70}$ LAURENT, Olivier. Le sombre abîme du temps: mémoire et archéologie. Paris: Seuil, 2008 (La Couleur des Idées). p. 82. Tradução nossa. Texto original: "le passé n'existe que reconstruit, l'arqueologie ne peut se faire qu'à partir du présent".

71 KANT, Immanuel. Estética Transcendental. São Paulo: Editora Nova Cultural, 1987 (Coleção Os pensadores). p. 70,78 .

${ }^{72}$ Ibid., p. 76.
} 
ele se ajusta a mim. Martin Heidegger admite o ver e o ouvir como sentidos da distância ${ }^{73}$ e introduz o conceito de "dimensionalidade", ou "circunvisão", que me permite ocupar o espaço, o mundo circundante, a espacialidade do ser-no-espaço: "O espaço nem está no sujeito nem o mundo está no espaço, mas o espaço está no mundo" ${ }^{\text {,74. }}$.

A palavra "então" designa tanto o que já foi quanto o que virá, o por-vir, o devir. "O hoje sai de ontem", disse Roland Barthes ${ }^{75}$. A memória, reconstruída e permeada pelo imaginário, permite trazer para o presente algo que já passou por meio de um ato de presentificação: "A duração real é o que sempre se chamou tempo, mas o tempo percebido como indivisível" ${ }^{\text {"76 }}$. O tempo, ação do movimento, da transformação, alavanca o devir, conforme admitido desde Heráclito (século IV a.C.), o que Bergson chamará de "elã vital".

Tempo e memória interligam-se. O surgimento da escrita no Egito teria prejudicado o emprego da memória. Em determinado trecho do diálogo Fedro, de Platão, que transcrevo a seguir, encontram-se ressalvas ao texto escrito, em benefício da memória:

Dizem que Tamuz fez a Thoth diversas exposições sobre cada arte, condenações ou louvores cuja menção seria por demais extensa. Quando chegaram à escrita, disse Thoth: "Esta arte, caro rei, tornará os egípcios mais sábios e lhes fortalecerá a memória; portanto, com a escrita inventei um grande auxiliar para a memória e a sabedoria”. Responde Tamuz:”. Grande artista Thoth! Não é a mesma cousa inventar uma arte e julgar da utilidade ou prejuízo que advirá aos que a exercerem. Tu, como pai da escrita, esperas dela com o teu entusiasmo precisamente o contrário do que ela pode fazer. Tal cousa tornará os homens esquecidos, pois deixarão de cultivar a memória; confiando apenas nos livros escritos, só se lembrarão de um assunto exteriormente e por meio de sinais, e não em si mesmos. Logo, tu não inventaste um auxiliar para a memória, mas apenas para a recordação. Transmites aos teus alunos uma aparência de sabedoria, e não a verdade, pois eles recebem muitas informações sem instrução e se consideram homens de grande saber embora sejam ignorantes na maior parte dos assuntos. Em consequência, serão desagradáveis companheiros, tornar-se-ão sábios imaginários ao invés de verdadeiros sábios"77.

A citação acima remete à resistência em aceitar-se a escrita, uma vez que os gregos tinham por hábito exercitar a memória e consideravam que os livros os tornaria preguiçosos. O mito de Tót, ou Theith, considerado o pai da escrita, ainda que sua autoria da invenção seja

\footnotetext{
${ }^{73}$ HEIDEGGER, 1986.

${ }^{74}$ Ibid., p. 166.

75 BARTHES, Roland. O prazer do texto. 5. ed. Tradução de J. Guinsburg. São Paulo: Editora Perspectiva, 2000. p. 30.

${ }^{76}$ BERGSON, Henri. Memória e Vida. São Paulo: Martins Fontes, 2006. p. 16.

${ }^{77}$ PLATÃO. Fedro. São Paulo: Ed. Globo, 1962. p. 256.
} 
questionada, encontra a oposição de Tamuz, ou Thamus. Este alega que o registro não consistirá em um fármaco para a memória, uma vez que desestimula a prática da lembrança, o reter em si informações e ensinamentos recebidos. Antonin Artaud recorreria à afirmação de Platão: "O pensamento se perdeu no dia em que uma palavra foi escrita", uma vez que escrever é fixar, é "impedir o espírito de mover-se como uma vasta respiração". O texto $O$ Teatro e os deuses será citado na íntegra no segundo capítulo, pois, a partir dele, Maurice Béjart coreografou o espetáculo de encerramento do ciclo de três anos do Mudra.

Os gregos prezavam também pela oralidade. Se Sócrates (470-399 a.C.) nada escreveu, Platão recorreu à forma de diálogos em muitas de suas obras, pois a conversa dialética é intensa e dinâmica, enquanto a palavra escrita permanece imóvel. Em Atenas, o processo seletivo educacional era muito rigoroso. No séc. V a.C., os livros, não mais que meia dúzia, eram decorados. Importava o que as pessoas diziam. A língua era constituída por poucos autores de referência. $\mathrm{O}$ que importava era a própria língua.

A metáfora do Rio Lethe (Rio do Hades) ilustra a teoria da reminiscência de Platão: seres imergiam para saciar sua sede nesse rio do esquecimento antes do retorno à terra para uma nova vida. A dimensão da sede determinava a quantidade de água ingerida. Os filósofos tomavam a mais diminuta porção do líquido. O rio pode remeter à invenção da escrita, pois, se na oralidade a lembrança é muito importante, a escrita favorece o esquecimento, tornandose um veneno (ou fármaco) para o pensamento humano. O esquecimento implica perda de si e da vida civilizatória, quando o ego torna-se ausente. Daí a palavra "letargia", proveniente da flor de lótus. Maurice Béjart foi outro defensor da memória, em desfavor à escrita da dança. $\mathrm{O}$ pensador francês Jacques Derrida, em A farmácia de Platão, diz: "Um texto não é mais que um texto" ${ }^{, 78}$, em nada comparável à grandeza do pensamento. A afirmação é próxima de Artaud, quando este se refere à fixidez e consequente asfixia da mobilidade promovida pela palavra escrita, que estendo a qualquer escrita, mesmo a coreográfica. Pode parecer contraditório o muito escrever a um contestador desse ato, mas, em se tratando de Artaud, compreende-se que a escrita lhe era inerente e que o autor dela se servia, inclusive, para questioná-la.

A relativização do kronos, ou do tempo cronológico, também considerado como tempo corrente ou helicoidal (do grego "hélios", ou "sol"), permite concentrar-se na duração bergsoniana, em que aparece o tempo expandido, dilatado - a diástasis grega, chamada pelos

\footnotetext{
${ }^{78}$ DERRIDA, Jacques. A Farmácia de Platão. 3. ed. São Paulo: Iluminuras, 2005. p. 14.
} 
latinos de experiência alargada, que permite um ato de presentificação: "É justamente essa continuidade indivisível de mudança que constitui a verdadeira duração [...] a duração real é o que sempre se chamou tempo, mas o tempo percebido como indivisível"79. A sucessão é admitida por Bergson, que discordou da justaposição aristotélica entre antes e depois. Martin Heidegger reiteraria a dilatação como extensio, o "estar dilatado e estendido na amplidão de si mesmo" $" 80$, propiciando o desvelamento ou desocultação de si, necessários ao ato de se fazer emergir o vivido e que surgem como um manancial. Entre as categorias do tempo, há ainda o kairós, momento seguro e certo segundo os gregos, correspondente ao agora.

Deleuze, a propósito do pensamento bergsoniano, diria: "São as lembranças da memória que ligam os instantes uns aos outros e intercalam o passado no presente" ${ }^{\text {}}$. Mudar ou movimentar é engendrar, isto é, fazer nascer, enquanto a moção é aquilo que se depreende do movimento. "Todo processo de mudança e de movimento é um processo de vida" ${ }^{82}$. A temporalidade, mundo do mutável, na visão de Santo Agostinho (354-430), foi tida como inexistente, uma vez que o presente "voa tão rapidamente do futuro ao passado, que não tem nenhuma duração". O autor acrescenta: “O passado já não existe e o futuro ainda não veio... uma hora compõe-se de fugitivos instantes. Tudo o que dela já debandou é passado" ${ }^{\text {, }}$, havendo apenas expectatio (presente do futuro), contuitus (presente do presente) e expectatio (presente do futuro).

Já Aristóteles, em seu tratado sobre o tempo, no quarto livro da Física, havia indagado quanto à existência ou inexistência do tempo, ou entre aquilo que é e logo deixará de ser, naquilo que não é mais e naquilo que ainda não é mas que logo virá a ser, em um processo de devir, em uma sucessão de instantes entre o antes e o depois. O intervalo é considerado um “não ser”. O espaço é um onde os corpos se movem, enquanto o lugar (topos) é o que contém o corpo, o receptáculo, como por exemplo, as margens de um rio: "Existe um lugar natural para o qual cada elemento parece tender por sua própria natureza: o fogo e o ar (o éter é

\footnotetext{
${ }^{79}$ BERGSON, 2006, p. 16.

${ }^{80}$ HEIDEGGER, Martin apud BRACHTENDORF, Johannes. Confissões de Agostinho. São Paulo: Edições Loyola, 2008, p. 267.

81 DELEUZE, Gilles. Le bergsonisme. Paris: Presses Universitaires de France, 1966. p. 16. Tradução nossa: Texto original: "ce sont les souvenirs de la mémoire, qui relient les instants les uns aux autres et intercalent le passé dans le présent". ${ }^{82}$ LEOPOLDO E SILVA, 1996, p. 47.

${ }^{83}$ SANTO AGOSTINHO. Confissões. Tradução de J. Oliveira Santos e A. Ambrósio de Pina. São Paulo: Nova Cultural, 1999 (Coleção Os Pensadores). p. 322, 324.
} 
circular) tendem para o alto, a terra e a água para baixo" ${ }^{\text {84 }}$. Espaço, lugar e tempo encontramse ligados ao movimento, sendo o tempo sucessivo, enquanto o espaço é simultâneo. O que é simultâneo e sucessivo ao mesmo tempo será o permanente. Tratado pela Física, o tempo, medida do movimento segundo o antes e o depois, tem como atributos: a substância (geração e corrupção); a qualidade (alteração); a quantidade (aumento e diminuição); e o lugar (translação). A mutação se faz presente em todos os casos. Tempo enquanto transformação, ou seja, o que vem a ser atravessado em sua forma. O movimento, passagem da potência ao ato, se dá por três modos segundo Aristóteles: acréscimo e decréscimo; transformação; e deslocamento $^{85}$, e é explicado com exatidão pelos atomistas enquanto encontro fortuito de elementos que provocam novas configurações.

Em De rerum natura (Sobre a natureza das coisas), Tito Lucrécio Caro, no século I a.C (99-55), concebe a natureza enquanto átomos ( $a$ - negação + tomo - divisível) que, ao se encontrarem e se unirem, constituem as coisas no mundo ${ }^{86}$. Nada há que os preceda. As partículas indivisíveis feitas de elétrons e prótons movem-se constantemente de modo dinâmico e assimétrico, podendo eventualmente se desviar, alterando a direção. $\mathrm{O}$ desvio (ou clinamem) da queda vertical a uma determinada altura teria provocado atritos de átomos. Segundo o modelo atomístico, foi o que deu início à constituição das coisas, a exemplo do big bang. Os desvios ocorrem em um infinito vazio. O conjunto de reações químicas é formador da vida e das sinapses, dos interstícios entre uma terminação nervosa e outros neurônios ou células musculares ou glandulares, correspondendo a zonas ativas de contato.

Descartada está a convencional palavra "resgate" no presente estudo, a qual embute um aspecto passadista e apagado. Trata-se de "reviver", viver de novo, encontrando o impulso da physis grega, da natureza, daquilo que brota, que faz jorrar. Corpo e vida encontram-se indissociados, supondo o movimento, a mudança e a transformação, que engendrarão novas visões e contornos. Segundo a visão benjaminiana, a rememoração ocupa seu lugar ao lado da lembrança, captando e transformando o objeto, que constitui aquele sentido recortado da vida.

\footnotetext{
${ }^{84}$ ARISTÓteleS apud REALE, Giovanni. História da Filosofia Antiga. v. 2. Tradução de Marcelo Perine. São Paulo: Edições Loyola, 1993. p. 208.

${ }^{85}$ Informação verbal. Informação fornecida em aula pela Prof. ${ }^{a}$ Dra. Raquel Gazzola na disciplina Tópicos de Filosofia III na Faculdade de São Bento, São Paulo, em 14 de agosto de 2012.

${ }^{86}$ LUCRÉCIO. Da natureza das coisas ("De Rerum Natura"). Tradução portuguesa de Antonio José de Lima Leitão. São Paulo: Edições Cultura, 1941. p. 215. "Resta explicar-te, procedendo em ordem / O nascimento e subversão do mundo;/ Como o choque recíproco dos átomos/ Formado tenha o céu, o térreo globo,/ As estrelas, a lua, o sol, os mares; Que são animais filhos da terra/ Como é que principiou a espécie humana”.
} 
Para Bergson, a lembrança é tida como uma percepção que se enfraqueceu. Por sua vez, a nostalgia, em sua acepção grega, corresponde ao sofrimento do retorno.

Se o fazer ou o produzir dominam o tempo presente, o distanciamento permitirá um relato mais apurado e é o que tenciono atingir, enquanto a consciência é faculdade prática voltada ao presente, fazendo supor que a consciência do passado é memória: "A consciência é a marca característica do presente, ou seja do vivido atualmente, do agente enfim" relacionada ao real, enquanto a lembrança/memória, a Mnémosyne grega, mãe das nove Musas, entre as quais Terpsícore, habita a subjetividade, sendo eminentemente virtual. Estar consciente corresponde a um estado de alerta, estar acordado, atento, em oposição ao estado inconsciente. $\mathrm{O}$ estado de prontidão foi um dos quesitos aprendidos e apreendidos no Mudra.

O tema da memória conduz inevitavelmente às concepções de Henri Bergson, que, juntamente com seu conterrâneo Merleau-Ponty, oferecem o suporte ao pensamento aqui desenvolvido sobre o compartilhamento de questões acerca do corpo, da percepção, do movimento, do espaço, do tempo e da memória: "Que nos interroguemos sobre a liberdade, a inteligência, a percepção, a memória, é sempre a mesma lição que emana, uma lição de energia" ${ }^{\text {"8 }}$. Ambos filósofos-poetas analisaram o corpo em um período anterior ao aparecimento da neurociência e eram denominados, então, fisicalistas. Bergson fez da intuição, ou conhecimento imediato, método, em busca da simplicidade, da clarificação de um problema que, por si só, já conduz à sua solução, admitindo que, quanto mais a inteligência aproxima-se do instinto, mais cumpre sua função. Primitivamente, eram inseparáveis: “A inteligência tem perguntas, o instinto tem respostas" $" 89$.

A percepção, introdutora da questão do corpo, está relacionada a algo invisível, que é a memória. Para Bergson, a memória não se encontra no cérebro, podendo este apenas ocasionar sua funcionalidade. Tratando-se de algo reconhecível, mas imaterial, Bergson consideraria a memória como ação ou presença do espírito, que pode também ser denominado como animus, ou ainda sopro vital ou, segundo a nomenclatura indiana, a praná. Diria o

\footnotetext{
${ }^{87}$ BERGSON, 1939, p. 156. Tradução nossa. Texto original: "la conscience n'est que la marque caractéristique du présent $\mathrm{c}^{\prime}$ est à dire de l'actuellement vécu, c'est à dire enfim de l'agissant".

${ }^{88}$ HEIDSIECK, François. Henri Bergson et la notion d'espace. Paris: Presses Universitaires de France, 1961. p. 127. Tradução nossa. Texto original: "Que nous interrogions la liberte, l'intelligence, la perception, la mémoire, c'est toujours la même leçon qui se dégage, une leçon d"energie".

${ }^{89}$ Informação verbal. Grupo de estudos sobre a obra Os dados imediatos da consciência, de Henri Bergson, orientado pelo Prof. Dr. Franklin Leopoldo e Silva na Faculdade de São Bento, São Paulo, entre agosto e dezembro de 2012.
} 
filósofo francês: "Nós não vemos como a memória se alojaria na matéria" Antonio Damásio afirmaria que a memória é decorrente do que percebo do ambiente, tal como o odor de um perfume, por exemplo. Tudo parece indicar que a memória é o registro que permanece no corpo de modo arraigado. Daí a mestra da dança Renée Gumiel (19132006) ter intitulado “A memória gruda na pele" a um de seus espetáculos ${ }^{91}$.

Apesar de Bergson denominar como psicofísica a fusão entre matéria e espírito, de admitir que a atividade da matéria roça o espírito - "fiz descer o espírito, tão perto quanto pude, da matéria - o espírito se insinua, ou melhor insere-se na matéria, aproximando-se dela por gradações sucessivas" ${ }^{\$ 2}$-, persiste a distinção, a divisão dual entre matéria e memória, tornando-se difícil de ser assimilada por um pensamento que visa à integração do corpo, aqui desenvolvido. Trata-se do corpo sensível, que concebe o ser humano habitado por fluxos energéticos e elimina a dualidade entre corpo e mente. Se Bergson admite, em se tratando de memória, esse lugar nenhum, não localizado, por outro lado, o neurocientista português Antonio Damásio procura localizá-la, munido de ferramentas mais recentes e decidido a propor uma arquitetura para o cérebro. Soando como uma resposta a Bergson, Damásio diz, a propósito do armazenamento dos dispositivos memoriais: "Precisamos descobrir no cérebro os segredos do algum modo e localizar o algum lugar", acrescentando:

Além de criar representações mapeadas que resultem em imagens perceptuais, o cérebro realiza outra proeza: cria registros de memórias dos mapas sensoriais e reproduz uma aproximação de seu conteúdo original. Esse processo é conhecido como recall, ou evocação ${ }^{93}$.

A "chamada" é ativa e pressupõe a inserção em contextos dos quais emana. Bergson conceberia o passado como espaço, e não enquanto simples multiplicidade, entendendo como inversamente relacionadas a extensão da memória e sua força de penetração: “A extensão da memória sugere a imobilidade de uma coisa, enquanto a memória é um movimento" 94 . Autor

\footnotetext{
${ }^{90}$ BERGSON, 1939, p. 198. Tradução nossa. Texto original: "Nous ne voyons pas comment la mémoire se logerait dans la matière".

${ }^{91}$ René Gumiel (1913-2006) foi uma das introdutoras da Dança Moderna no Brasil e uma de minhas principais mestras no final de minha adolescência, em São Paulo. O referido espetáculo, apresentado no Teatro Sérgio Cardoso, em São Paulo, data de 1993.

92 BERGSON, Henri. Três cartas de Henri Bergson para Gilles Deleuze. Apresentação de Elie During. Tradução de Rodrigo Lucheta. Revue Critique, n. 732, maio 2008. Primeira versão lida em Paris, em 2005, no Centro Georges Pompidou, na ocasião de homenagem a Gilles Deleuze.

${ }^{93}$ DAMASIO, 2011, p. 173.

94 HEIDSIECK, 1961, p. 125. Tradução nossa. Texto original: Tradução do Original : "l'étendue de la mémoire » suggère l'immobilité d'une chose, alors que la mémoire est un mouvement".
} 
de Le bergsonisme, Gilles Deleuze reporta-se à noção kantiana do tempo como "autoafecção", ou estofo da subjetividade, para afirmar: "Memória é o verdadeiro nome da relação consigo, ou do afeto por si" 95 . Sem serem convocadas, imagens passadas reaparecem "nos seus antros e cavernas" 96 .

Em entrevista, abordando outra perspectiva, o neurocientista Antonio Damásio explica que, enquanto os processos biológicos referentes aos genomas são organizados de modo a formar um sistema simples, o contexto da regulação social se encontra em processo permanente e estabelece interfaces entre criatividade, imaginação e memória na qualidade de capacidades interligadas ${ }^{97}$. Já o arquivo pressupõe organização. Encontra-se vivo, pois continuará a ser consultado, manipulado. O acervo Décadas de Dança - Preservação e Compartilhamento do Acervo Gouvêa Vaneau, realizado em 2012 por meio do apoio do XII Fomento à dança da cidade de São Paulo, constitui um exemplo do que é a finalidade do arquivo: ele deve ser compartilhado ${ }^{98}$. Michel Foucault se serviria do conceito de "mapa" e de “diagrama", desenvolvidos, igualmente, por Gilles Deleuze, ao referir-se à técnica que separa, isola, reúne e classifica, submetida a leis culturais que se destinam à preservação. Para Foucault, o arquivo é entendido como "o conjunto dos vestígios de uma cultura, a serem analisados, no presente, pelo olhar desmistificador do arquivista" 99 .

As reflexões expressas fornecem o apoio, constituindo as alavancas sobre as quais se assenta a trajetória artística que virá a ser aqui tratada. Entre as categorias do tempo, há ainda o kairós, momento oportuno e certo segundo os gregos, correspondente ao agora. Tal pensamento, relacionado à presente pesquisa, traz a oportunidade de abordar a fértil e irradiante experiência do Galpão, que, em 2014, completou quarenta anos de seu início. O que foi feito ali deslocou os parâmetros da dança, fornecendo as ferramentas da investigação de linguagem e o elo com o entorno e a sociedade. Torna-se imprescindível reviver e registrar essa experiência, antecedida que foi pelo ciclo belga Mudra/Chandra, igualmente irradiadores.

\footnotetext{
${ }^{95}$ DELEUZE, Gilles. Foucault. 6. ed. Tradução de Claudia Sant'Anna. São Paulo: Brasiliense, 2008. p. 115.

${ }^{96}$ SANTO AGOSTINHO, 1999, p. 276.

${ }^{97}$ FRONTEIRAS do pensamento. INSTITUTO CPFL Cultura. Entrevista exclusiva com Antonio Damásio. Portal do Instituto CPFL. Disponível em: http:/www.institutocpfl.org.br/2013/12/05/fronteiras-dopensamento-e-instituto-cpfl-cultura-entrevista-exclusiva-com-antonio-damasio/. Acesso em: 18 mar. 2015.

${ }_{98}^{98}$ www.acervogouvea-vaneau.com.br. Outras informações: www.celiagouvea.com

99 LANÇAMENTO do livro Literatura Expandida. Encontro entre a artista Dominque Gonzalez-Foerster, a pesquisadora Ana Pato e a curadora Daniela Castro, realizado em 7 de março de 2013, no Sesc Bom Retiro (São Paulo), por ocasião do lançamento do livro Literatura Expandida: arquivo e citação na obra de Dominique Gonzalez-Foerster, de Ana Pato. Disponível em: Vimeo.com/64333420. Acesse em: 3 mar. 2016.
} 
Todas as fases descritas e analisadas caracterizaram-se por abrir mão dos parâmetros já existentes, em busca de novos.

Se, como foi dito, as fronteiras entre as artes encontram-se hoje esmaecidas, emergem com frequência termos derivados da multimídia quando se depara com a arte feita hoje. Tal dado, somado à inclusão de tipos, preparos e faixas etárias múltiplos dos atuantes, bem como à solicitação da participação criativa dos elencos por meio dos métodos de improvisação e composição, já se encontravam presentes no período do Galpão.

É ou não necessário ter presenciado, experimentado um acontecimento para discorrer sobre ele? Ter vivido em carne e osso habilita um melhor relato? Almino Affonso, Ministro do Trabalho do governo brasileiro de João Goulart em 1964, ao se referir aos acontecimentos que resultaram no golpe militar naquele ano no país, declarou: "Eu estava lá"100 . O recuo ou distanciamento no tempo permitirá uma avaliação mais apurada, afiada? No sentido kantiano, a palavra "experiência" designa o conjunto de funções organizadas pelo sujeito. Para Kant, todo conhecimento é proveniente da experiência, mas nem sempre ela é a fonte, pois, além da empiria absorvida pelos sentidos, há o conhecimento que advém da razão do sujeito. Para Kant "na ordem do tempo nenhum conhecimento precede em nós a experiência e é com esta que todo o conhecimento tem o seu início. Se, porém, todo o conhecimento se inicia com a experiência, isso não prova que todo ele dela derive""101. Kant diria: "A experiência é, sem dúvida, o primeiro produto que o nosso entendimento obtém ao elaborar a matéria bruta das sensações"102. Hoje a palavra "experiência" substituiu a representação mental e é vizinha da percepção. O pensador hermenêutico alemão Hans-Georg Gadamer (1900-2002) emprega o termo "Erlebnis" ao associar o vivido a um peso particular, carregado de significado ${ }^{103}$, ou seja, algo que não pode ser descartado.

A experiência é distinta da vivência, que guarda um aspecto instantâneo, próxima do kronos. A palavra "experiência", do alemão "erfahrung”, "inclui a partícula fahr de fahren, conduzir, guiar, deslocar-se" $" 104$. É no ato da transmissão que a vivência ganha o estatuto de experiência, e esta é sempre coletiva e derivada de uma temporalidade que opera de modo

\footnotetext{
${ }^{100}$ RODA VIVA. São Paulo: TV Cultura, 31 de março de 2014.

${ }^{101}$ KANT, Immanuel. Crítica da razão pura. Tradução de Alexandre Fradique Morujao. Lisboa: Calouste Guilbenkian, 2013. p. 36.

102 Ibid., p. 56.

103 GADAMER, Hans-Georg. Verité et méthode. Paris: Seuil, 1996. Tradução nossa. Tradução francesa do original alemão (p. 78): "quelque chose devient Erlebnis dans la mesure où il n'a pas été seulement vécu mais où le fait de l'avoir été a eu un poids particulier, qui lui confère une significaion durable".

${ }^{104}$ LANGENSCHEIDT. Langenscheidts Taschenwörterbucher. Berlim: Langenscheidt Worter 2011. p. 795 e 797 apud KEHL, Maria Rita. O tempo e o cão. São Paulo: Boitempo Editorial, 2009. p. 161.
} 
lento, mais próxima do ócio que da atividade, focada no tecido do tempo fluido, contínuo, que supõe a mutação e o movimento. Há, portanto, uma distinção entre a palavra "experiência", que supõe a transmissão de conhecimentos, com "experimento", que remete a tentativa. No dizer de Walter Benjamin (1892-1940), ainda que a palavra, hoje, pareça em desuso, “o conselho, tecido no próprio estofo da vida, é sabedoria [...] o narrador empresta a matéria de seu relato à experiência. E o que ele conta, por sua vez, torna-se experiência naqueles que escutam sua história"105. O propósito, aqui, é transmudar o vivido em legado por meio da transmissão da experiência.

Proveniente do latim "experientia" ("prova", ou "ensaio"), essa palavra pode ser coletiva e é derivada do verbo "experiri”, formado pelo prefixo "ex", que designa a separação do interior. A raiz "peri" do verbo, proveniente do indoeuropeu, indica "intentar", ou “arriscar". O fonograma "péri”, segundo Julia Kristeva, indica a palavra “casa". "Ent" é agente, enquanto "ia" corresponde a "abstração". "Experiência” é, portanto, "a qualidade (ia) de intentar ou provar (per) a partir das coisas (ex). Relaciona-se com o conhecimento empírico, ou heurístico, ou seja, o conhecimento adquirido, analisando os resultados e formulando novas provas à base de erros anteriores"106.

Há a anedota em torno do pintor malaguenho Pablo Picasso (1881-1973), segundo a qual ele, que tanto apreciava pintar guitarras, deixou de fazê-lo quando ganhou uma, tornando-se o objeto presentificado, assinalando que o virtual revelou-se mais potente que o real. A ausência do objeto concreto amplia seu espectro, podendo fazer surgir contornos reais. Amelia Jones, professora de História da Arte na Universidade da Califórnia, escreveu sobre body art e performance, apesar de ter nascido quando essas experiências corporais começaram a ocorrer, no início dos anos 1960. Ainda segundo Benjamin, se um narrador "não viveu pessoalmente os acontecimentos, ao menos ele os obtém diretamente daqueles que foram seus atores"

Reportar-se a temas e épocas não vividos é, evidentemente, legítimo. Caso contrário, ninguém estaria autorizado a mencionar Platão ou Aristóteles, por exemplo. Se razões

\footnotetext{
105 BENJAMIN, Walter. Oeuvres III. Paris: Gallimard, 2000. p. 120 e 121. Tradução nossa. Texto original : "Le conseil, tissé dans l'étoffe même de la vie, est sagesse(...). Le conteur emprunte la matière de son récit à l'expérience: la sienne ou celle qui lui a été rapportée par autrui. Et ce qu'il raconte, à son tour, devient expérience en ceux qui écoutent son histoire".

106 EXPERIENCIA. Portal Etimologias: Diccionario Etimológico español en línea. Disponível em: $<$ http://etimologias.dechile.net/>. Acesse em: 10 out. 2014.

${ }^{107}$ BENJAMIN, op. cit, p. 127. Tradução nossa. Texto original: "s'il n'a pas em personne vécu les événements, du moins les tient-il directement de ceux qui em furent les acteurs".
} 
logísticas podem impedir a presença em um determinado lugar, estudos podem conduzir a abordagens reveladoras, embora o presente trabalho tenha por objeto fatos experimentados, vívidos e vividos.

Adequada é a imagem do palimpsesto. Do grego "palimpsestos" (ou "raspado de novo"): de "palin" (de novo) mais "psestos" (raspado). O termo designa os manuscritos sobre pergaminhos, nos quais se faz desaparecer a escrita para se escrever novamente. Foram os copistas da Idade Média que apagaram, fazendo emergir novos traços sobre o pergaminho, que substituíram os papiros e foram rareando no decorrer do século $\mathrm{XV}$, quando a calibragem das peles dobradas e cosidas em códex passaram a ser deixadas de lado. Modernamente, por meio de processos artísticos, tem sido possível fazer reaparecer em parte os primitivos caracteres: "O primeiro rascunho à força de rasuras [...] acabou por ser para mim próprio o mais impenetrável palimpsesto" ${ }^{108}$. Novas camadas sobrepõem-se a outras. Dito de outro modo, nada procede do nada. Há um sustentáculo anterior sobre, contra ou com o qual um novo pensamento adquire contornos e vem a se estabelecer. $\mathrm{O}$ mesmo processo ocorre nas artes.

Opto, porém, em focar dois momentos fundantes e renovadores das artes cênicas, que tiveram como marca a multidimensionalidade, em uma expressão do crítico teatral Sábato Magaldi (1927-2016): o Mudra e o Galpão. Em ambos, o recorte corresponde ao período inicial, aos primórdios, remontando à primeira promoção, que durou de 1970 a 1973 . No Centro europeu, o ciclo teve a duração de três anos, posteriormente reduzido a dois, e ao seu término alguns egressos formaram o grupo Chandra (Théâtre de Recherche de Bruxelles), que durou um ano. A palavra "chandra", assim como "mudra", é derivada do sânscrito e corresponde a "meia-lua". É imprescindível registrar sua estrutura, entendida como "algum conjunto ou grupo de elementos relacionados entre si segundo certas regras, ou algum conjunto ou grupo de elementos (membros), funcionalmente correlacionados" ${ }^{\text {} 109}$.

Atualmente, no Brasil, cresce o número de departamentos de Dança junto a universidades públicas e privadas. A referência a um centro formador de artistas é relevante. Há experiências análogas e posteriores, como a Performing Arts Research and Training Studios, a PARTS, situada também em Bruxelas e dirigida pela coreógrafa Anne Teresa De Keersmaeker, ex-aluna do Mudra; e o De l'Interprète à l'Auteur, que forneceu uma formação

\footnotetext{
${ }^{108}$ RIBEIRO, Aquilino. Lápides partidas. Lisboa: Bertrand, 1945, p. 120.

${ }^{109}$ MORA, José Ferrater. Dicionário de Filosofia. São Paulo: Martins Fontes, 2001. p. 234.
} 
superior a artistas/dançarinos, situado em Lyon, na França, e foi dirigido pela ex-colega mudrista e chandrista Maguy Marin, cuja radicalidade coreográfica será também abordada.

O segundo momento, imediatamente posterior, foi a abertura do Teatro de Dança Galpão em São Paulo, inaugurado durante o endurecimento da ditadura militar no Brasil, quando o viés político, bem como o estético-investigativo, aliaram-se. O ciclo do primeiro espaço dedicado à dança em São Paulo teve a duração de sete anos e teve seu início, assim como o término, com peças de dança de nossa autoria. A trajetória ocorreu nos interstícios, naqueles estreitos canais, entre o moderno, o pós-moderno e o contemporâneo. Destituído de coxias, o espaço não convencional era um convite aos experimentos. A precariedade serviu como gatilho, pois predispunha à ausência do medo de errar, propiciando elementos altamente estimulantes a novos experimentos e disparos.

Disse o poeta:

$$
\begin{gathered}
\text { Belo porque tem do novo } \\
\text { a surpresa e a alegria. } \\
\text { Belo como a coisa nova } \\
\text { na prateleira até então vazia. } \\
\text { Como qualquer coisa nova } \\
\text { inaugurando o seu dia. } \\
\text { Ou como o caderno novo } \\
\text { quando a gente o principia }{ }^{110} \text {. }
\end{gathered}
$$

Por acaso ou não, participei de uma série de momentos inaugurais, às vezes difíceis e incertos, além dos ciclos Mudra/Chandra e Galpão: a friche (galpão industrial transformado em centro cultural) Anis Gras, na França (2000-2001), na qual formulei, junto a outros artistas, um projeto inicial de atividades para a antiga destilaria de anis situada em Arcueil, na periferia de Paris, que não contava ainda com o apoio do poder público e cujas atividades hoje vão de vento em popa; e o Fomento à Dança da cidade de São Paulo, no qual atuo desde 2002, quando recém-retornada de uma longa estadia na Europa e nutrida pela postura cidadã de artistas como Maguy Marin (nascida em 1951) e Ariane Mnouchkine (nascida em 1939), com quem havia convivido na França.

\footnotetext{
${ }^{110}$ MELLO NETO, João Cabral de. Poesias Completas: 1940-1965. 3. ed. Rio de Janeiro: Livraria José Olympio Editora, 1979. p. 240.
} 
Cheguei em São Paulo no período do lançamento do Programa Municipal de Fomento ao Teatro, no saguão do Theatro Municipal de São Paulo, em 2002. Era período eleitoral e dirigi-me a um comitê para conhecer os programas e propostas a fim de escolher um candidato em quem votar. Deparei-me com o nome de Vicente Cândido, um dos incentivadores responsáveis pela implantação do Programa Municipal de Fomento ao Teatro, antecedido pelas colocações do movimento "Arte contra a barbárie", que buscava alternativas ao teatro de entretenimento, dito digestivo, rumo a um processo lento e longo que permitisse investigações e descobertas de novas linguagens, quer cênicas, quer inseridas no espaço urbano, o que só é possível por meio da implantação de políticas públicas consistentes.

Contatei o então vereador Vicente Cândido, que buscava a reeleição, e solicitei seu apoio para um programa semelhante para a dança: o Fomento à Dança. De sua parte, ele propôs que formasse uma comissão. Visitei entidades como o Centro de Estudos em Dança (CED) coordenado por Helena Katz (nascida em 1950), levando a notícia e buscando nomes ${ }^{111}$.

A comissão formada constituiu o embrião do Mobilização Dança, formado ainda em 2002 e responsável pela conquista de uma política cultural para a dança por parte dos órgãos públicos. Naquele momento, os artistas estavam prontos a tomar uma atitude e a resposta foi intensa e imediata. Quis a história que eu ocupasse esse lugar articulador. A configuração conjetural reservou-me o cumprimento da tarefa descrita. Fizeram também parte daquele embrião as irmãs Eliana e Sofia Cavalcante, Marcos Moraes, Raul Rachou e muitos outros. Se as circunstâncias incumbiram-se que eu desempenhasse a função desencadeadora de um processo, muitos foram os movimentos que antecederam a conquista do Fomento à Dança Municipal, como o Movimento Teatro Dança (MTD), em 1993, que teve como participantes Ana Mondini, Helena Bastos, João Andreazzi, Márcia Bozon, Mariana Muniz, Miriam Druwe, Sandro Borelli, Umberto da Silva e Vera Sala. Formada em 1995, integrei a Cooperativa Paulista dos Dançarinos-Coreógrafos junto a relevantes artistas da dança, da qual Helena Bastos foi a segunda presidente ${ }^{112}$ e que desembocou na atual Cooperativa Paulista dos Trabalhadores em Dança. Éramos onze integrantes. Tentamos realizar uma criação coletiva, mas a junção de tantos caciques fez com que não desse certo. Fui convidada a dirigir

\footnotetext{
111 Crítica de dança do jornal O Estado de São Paulo, Helena Katz é, também, professora da Pontifícia Universidade Católica de São Paulo (PUC-SP).

112 Helena Bastos, artista da dança, pós-graduada e professora da Escola de Comunicações e Artes da Universidade de São Paulo, é orientadora desta pesquisa. O primeiro presidente da CPDC foi Umberto da Silva (1951-2008).
} 
a montagem, em parte, por ser a mais velha do grupo. Propus que partíssemos de Lygia Clark (1920-1988) e Hélio Oiticica, ainda não tratados em montagens de dança até então. A ideia era boa. Entre os egressos do MTD não prosseguiram Borelli e Druwe. Entraram Gabriela Imparato, Susana Yamauchi, Renata Melo e eu. Face aos períodos inciais de iniciativas das quais participei, resta-me esperar que o fato de fazer doutorado na idade madura ganhe novos adeptos.

Referências importantes para o estudo das artes cênicas, tanto o Mudra, que desembocou no Chandra, quanto o Galpão foram momentos que tiveram como marca a interdisciplinaridade, a investigação da linguagem cênica e a integração entre as artes, apontando para uma hipótese de feitura amalgamática peculiar e específica. Iniciativas pioneiras, não seguiam nenhum modelo pré-estabelecido. Ao contrário, instauraram novos modos de conceber e realizar o fazer coreográfico, adotando procedimentos ainda não hegemônicos. A feitura de uma peça de dança não parte de padrões prévios, mas vai se construindo à medida que o processo avança, configurando caminhos. Mudra e Galpão: duas experiências singulares. Ocorreram há cerca de quarenta anos, mas não se pode dizer que foram, pois ainda são. Trata-se de uma autobiografia objetivizada. Uma das vertentes do teatro e da dança atuais encontra-se crivada por relatos autobiográficos e depoimentos pessoais, tendência esta que pode bem se estender aos escritos acadêmicos.

É possível uma apreensão cinesiológica da teoria, alegre e lúdica, que constitui uma possível primeira hipótese resultante da presente pesquisa. Vale lembrar que Nietzsche intitulou de A gaia ciência, ou $O$ alegre saber, sua obra lançada em 1882, na Alemanha (Die Fröhliche Wissenschaft). No texto que apresento, o arcabouço teórico será igualmente concebido como fruto de um conhecimento vivido, propondo uma teoria absorvida de modo perceptivo, pois a palavra "teoria", no sentido grego, corresponde a "visão de conjunto". A primeira sílaba indica o contato com a divindade. Mais do que contemplar, Krishnamurti atribuiu à palavra "teoria" um insight a partir do qual um indivíduo "formula uma ideia, um conceito, e age em concordância com esse conceito"113. A teoria tende a simplificar um problema por meio da elucidação ao invés de complicá-lo e pode ser compreendida de modo cinestésico.

Uma segunda hipótese é pedagógica e concerne ao treinamento adequado por meio da Técnica Orgânica, que conduz ao emprego de pouca energia muscular pelo entendimento da

\footnotetext{
${ }^{113}$ KRISHNAMURTI, Jiddu. A world in challenge times. Boston; London: David Skitt, 2005. p. 8.
} 
estrutura óssea enquanto motor do movimento. Fruto de uma experiência estadunidense que realizei primeiro como bolsista de Alwin Nikolais e anos depois como fellow da John Simon Guggenheim Memorial Foundation. Em um momento em que a prática de técnicas de dança moderna codificadas já não mais atrai os aspirantes a dançarinos, a exemplo do que ocorria nas décadas de 1970 e 1980, repensamos a preparação corporal do performer, mais em contato consigo e seus fluidos e órgãos, empregando um menor esforço muscular e adquirindo um tônus mais justo. Como quis Foucault, hoje, um professor já não mais abre a porta para o aluno: no máximo, concede-lhe a chave. Sílvia Geraldi sugere: "Não faça, explore", sepultando o mimetismo e as velhas práticas de um professor ensinar frente ao espelho, de costas para os alunos ${ }^{114}$.

O vocábulo alemão "Ereignis", ou "acontecimento", contém "o adjetivo eigen, que designa o que é seu; isto é, o acontecimento na medida em que diz respeito e molda a subjetividade, o ,próprio ${ }^{e}$ do sujeito" ${ }^{115}$. O propósito é o de fazer emergir, tratar daquilo que se revela, abre-se, mostra-se. O corpo é a principal referência. "Agon”, que compõe a palavra "protagonisa", refere-se à agonia primeira, aquela que atua como oposição, como força contrária sobre o daimon, que, em grego, designa o conhecimento, a inteligência, o sopro, a divindade, o espírito, palavra esta da qual "demônio" é derivada.

O feixe conjugado de conceitos aqui apresentados - corpo, percepção, espaço, tempo, movimento, memória e experiência - fornece o estofo que nutre a minha trajetória artística. Paul Valéry chamaria de produtos da vida os seguintes conceitos: "memória, pensamento, sentimento, invenção, etc., com todas as qualidades de maravilhoso que atribuímos a eles"116. O corpo é o protagonista.

\footnotetext{
${ }^{114}$ Sílvia Geraldi, artista da dança e professora do Instituto de Artes (IA) da Unicamp, é autora da tese de doutorado Raizes da teatralidade na dança cênica - recortes de uma tendência paulistana, apresentada ao IA em 2009. A tese aborda as coreógrafas Célia Gouvêa e Sônia Mota em seus trabalhos nas décadas de 1970 e 1980 . A tese foi publicada: GERALDI, Sílvia. Raízes da teatralidade na dança paulistana: duas criadoras - Célia Gouvêa e Sônia Mota. Curitiba: Ed. Prismas, 2015.

${ }^{115}$ SCHWERING, Karl-Leo apud MARZANO, Michela (Org.). Dicionário do corpo. São Paulo: Loyola, 2012.. p. 42.

116 VALÉRY, Paul apud STAROBINSKI, Jean. Some Simple Reflections on the Body. In: FEHER, Michel; NADDAFF, Ramona; TAZI, Nadia (Orgs.). Fragments for a history of the human body. New York: Urzone, 1989. p. 397.
} 
2 Mudra, produtor de artistas

Era uma vez, em

1970, ontem, amanhã, neste instante, daqui a pouco, há muito tempo.

Alain Louafi ${ }^{117}$

\subsection{Béjart, o idealizador}

Figura 6 - Maurice Béjart

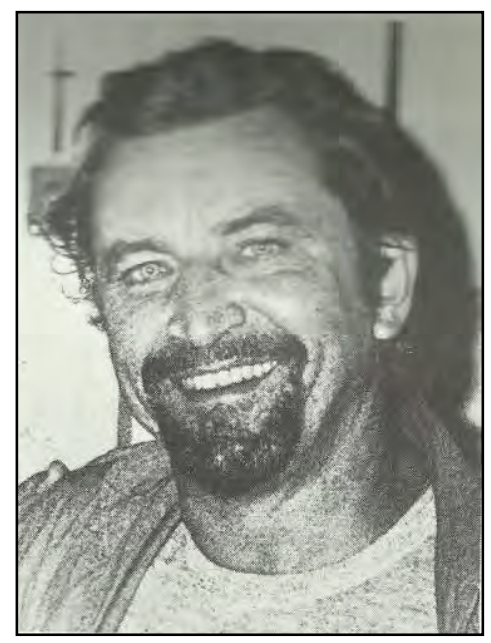

Fonte: Programa da temporada brasileira do Ballet Du XXe Siecle (1979)

Em 1970, ano da fundação do Mudra, Maurice Béjart, então com 43 anos, já havia realizado uma explosão coreográfica considerável. Proveniente de Marselha, situada no sul da França, filho do pequeno industrial e filósofo Gaston Berger, nasceu em 1927, vindo a falecer em 2007, em Lucerna (ou Lausanne), na Suíça, onde estabeleceu sua última companhia, em 1987. Faleceu aos exatos 80 anos de idade, como Sidarta, ou "aquele cujo objetivo é atingido", o Buda, que Béjart tanto admirava.

Instalou-se em Paris no início do pós-guerra, onde fundou o Ballets de 1'Etoile em 1954 em associação com Jean Laurent, posteriormente renomeado, em 1957, de BalletThéâtre de Paris, Ballet-Théâtre de Maurice Béjart ou Ballet-Théâtre de Paris de Maurice Béjart. Constava do repertório uma peça de Heitor Villa-Lobos (1887-1959). Não pretendo

\footnotetext{
${ }^{117}$ Colega franco-marroquino do Mudra e do Chandra.
} 
proceder aqui a um inventário da vasta obra bejartiana, mas deter-me nos aspectos mais inovadores do coreógrafo, dos quais faz parte, certamente, o projeto Mudra.

$\mathrm{Na}$ perspectiva do debate atual, é possível apontar certos aspectos da vasta obra de Maurice Béjart. Destaco o alerta que ele faz sobre o papel preponderante da personalidade do bailarino, tido como parceiro. É possível dançar sem um coreógrafo, mas este não pode trabalhar sem o corpo do bailarino. "O pensamento criador do coreógrafo manifesta-se através da carne viva e pensante de um corpo"118. Aparece, aí, em sentido pleno, a palavra "compor" ou "por com" - com o outro, supondo a alteridade. É provável que Béjart tenha sido o primeiro a dizer que seus balés só tinham existência enquanto estivessem sendo dançados, pouco adiantando lembrá-los.

Outro aspecto é o sentido do ritual: o sagrado existente em todos os continentes, ligado às culturas locais, abrangendo a natureza, o cosmos e os seres, assim como a busca de rituais novos pelos jovens ocidentais por meio do rock ou do pop, como ocorreu em Woodstock, no final da década de 1960:

$\mathrm{O}$ ritual precisa do corpo. Todas as religiões falam do corpo e falam ao corpo. O corpo! É a descoberta primordial deste século. Aliás, o século XX é o século em que se decidiu mostrar o corpo. Veja-se a roupa de banho [...]. Depois de 1900, as mulheres abandonaram os espartilhos, e o esporte irrompeu na vida cotidiana ${ }^{119}$.

Richard Schechner acrescenta: "Rituais são memórias coletivas codificadas em ações" ${ }^{120}$. Corpo, rito e memória encontram-se interligados.

Por fim, a importância do público: "Há que pensar na respiração do público; determinado balé que arrebate todo mundo na primeira parte corre o risco de parecer insignificante quando se sabe que o público lembra mais o que viu por último" ${ }^{\text {"21 }}$. Já uma das pioneiras da dança moderna norte-americana, Doris Humphrey (1895-1958), afirmaria que um bom final garante em $60 \%$ a possibilidade de tornar uma coreografia bem sucedida ${ }^{122}$, muito embora ideias tais como o clímax, sustentadas pela coreógrafa, estejam hoje superadas.

\footnotetext{
118 BÉJART, 1989, p. 4

119 BÉJART, Maurice. Um instante na vida do outro. Tradução de Suzana Martins. Rio de Janeiro: Nova Fronteira, 1981. p. 223.

${ }^{120}$ SCHECHNER, Richard. Performance studies. New York: Routledge, 2002. p. 52. Tradução nossa: Texto original: "Rituals are collective memories encoded into actions".

${ }^{121}$ BÉJART, op. cit., p. 72

${ }^{122}$ Informação verbal. Informação fornecida por Ruth Currier durante curso de Composição Coreográfica em Nova York em janeiro de 1992.
} 
Maurice Béjart já era desde meados dos anos 1950 um coreógrafo febril, pois compunha compulsivamente, sem a necessidade de, após uma montagem exaustiva, retornar ao seu casulo ou recorrer ao ócio para se realimentar, atendendo sempre à voz imperiosa de uma nova obra que batia à porta: "Criar para obter contratos, criar para meus intérpretes, criar para lutar contra a angústia, criar simplesmente para preencher meus dias. Viagem sem volta" ${ }^{23}$. Sua primeira coreografia de ponta que recebeu reconhecimento foi a célebre $L a$ Symphonie pour um home seul (A Sinfonia para um homem só), de 1955, porosa ao pósguerra, à bomba atômica, à miséria dos anos 1950. Béjart era afeito à música concreta e eletroacústica de Pierre Henry (1927-2017) e Pierre Schaeffer (1910-1995), que trabalhavam juntos na rádio estatal francesa. Entre 1949 e 1958, Henry trabalhou no estúdio Club d'Essai, da Rádio e Televisão Francesa, criado por Schaeffer, e ocupou a função de diretor sonoro (e mesmo operador de som) da pequena companhia bejartiana.

A partitura era insólita, colada ao momento presente, imprópria para ser ouvida na posição sentada, pois invadia os nervos e todo o ser, segundo o coreógrafo Béjart. Um dos compositores da partitura, Pierre Schaeffer colocou ressalvas à coreografia. Se, por um lado, ao público era revelada a existência da música concreta, e se, por meio dela, Béjart pôde escapar ao convencionalismo coreográfico em busca de fusos próprios, o músico afirmou: "Se a música concreta marcava uma explosão e uma ruptura, eu teria preferido, ao contrário, menos expressionismo, uma violência mais contida, mas não poderia nunca desgastar o sucesso de Béjart, nem sua generosidade juvenil” ${ }^{124}$, escreveu o músico. O objetivo declarado do coreógrafo era o de promover a dilatação da consciência e a tomada de posição do espectador por meio do choque, cuja provocação agressiva destina-se a suscitar indignação. Em seu citado livro, Béjart diria: "Só nos desenvolvemos e só temos acesso ao sentido da vida através de choques sucessivos. Crescemos à custa de choques. Ficamos inteligentes ou idiotas à custa de choques"125. A questão do choque seria analisada por Walter Benjamin, anteriormente à eclosão da inovação coreográfica bejartiana:

[...] como qualquer outro choque, precisa ser interceptado por uma atenção aguda [...]. Ele corresponde a metamorfoses profundas do aparelho perceptivo, como as que experimenta o passante, numa escala individual,

\footnotetext{
123 BÉJART, 1981, p. 93.

${ }^{124}$ CHRISTOUT, Marie-Françoise. Béjart. Paris: Editions Seghers, 1972. p. 142.

${ }^{125}$ BÉJART, op. cit., p. 184.
} 
quando enfrenta o tráfico, e como as experimenta, numa escala histórica, todo aquele que combate a ordem social vigente ${ }^{126}$.

Por sua vez, o teórico Peter Bürguer diria que o choque não é duradouro, perdendo rapidamente seu efeito "por ser ele, de acordo com sua natureza, uma experiência única"127. O efeito do choc, que torna mais agudos os sentidos e a atenção, é também analisado pelo professor Ricardo Fabbrini. Segundo o professor, provoca "a reestruturação do sistema perceptivo, condição indispensável para a transformação da consciência que poderia transformar-se em modificação da realidade, no sentido da Revolução ou da comunidade dos homens livres de Schiller"128.

Ligado às vanguardas tardias e como bom francês, Béjart guardava os valores humanistas próprios ao modernismo em coreografias que tinham quase sempre a música como ponto de partida. "Tinha a impressão de estar mergulhado na modernidade. Falava para meus botões: Como sou moderno!" ${ }^{29}$. Drama, emoção e sensualidade são parte do ideário modernista. Enquanto isso, na América do Norte, John Cage realizava um evento multimídia no Black Mountain College em 1952 no qual discursava enquanto Merce Cunningham (19192009) improvisava uma dança, um filme era projetado e Robert Rauschenberg (1925-2008) mostrava suas pinturas - que abrangiam do expressionismo abstrato ao pop - e fazia tocar discos de sua escolha em um velho gramofone ${ }^{130}$. No mesmo ano, em 1952, Alwin Nikolais (1910-1993) coreografou Masks, props and mobiles. Desde 1950, Nikolais delineara um conceito de "teatro total" por meio do emprego de máscaras e objetos. O coreógrafo estadunidense estava também convencido de que o ser humano e, principalmente, o dançarino, deveria ultrapassar sua tradicional humanidade, ampliando-se em direção ao cosmos e ao universo

\footnotetext{
${ }^{126}$ BENJAMIN, Walter. Magia e técnica, arte e política: ensaios sobre literatura e história da cultura. São Paulo: Brasiliense (Obras Escolhidas, v. 1), 1986. p. 192.

${ }^{127}$ BÜRGER, Peter. Teoria da vanguarda. Tradução de José Pedro Antunes. São Paulo: Cosacnaify. p. 159.

${ }^{128}$ FABBRINI, Ricardo Nascimento. O fim das vanguardas. 2014. p. 33. Apostila do curso Estética (Pósmodernidade: a crítica da cultura moderna), ministrado pelo Prof. Dr. Ricardo Fabbrini na FFLCH-USP no $1^{\circ}$ semestre de 2014. Disponível em: <https://pt.scribd.com/document/340602869/Ricardo-Fabbrini-O-fim-dasvanguardas-pdf>. Acesso em: 14 set. 2016.

${ }_{129}$ BÉJART, 1981, p. 81.

${ }^{130}$ BANES, Sally. Terpsichore in sneakers: Post-Modern dance. Boston: Houghton Mifflin Company, 1980. p. 9. Tradução nossa. Texto original: "John's Cage multimídia event at Black Mountain College in 1952 (where Merce Cunningham improvised a dance, a film was projected, Cage lectured, David Tudor played the piano, M.C. Richards and Charles Olson read their poetry, Robert Rauschenberg showed his paintings and played recordings of his choice on an old gramophone".
} 
Quando a dança de Béjart começou a emergir em Paris, os franceses, acostumados a frequentar a Ópera de Paris, aceitavam bem Roland Petit ou a companhia do marquês de Cuevas, mas tinham dificuldade em assimilar danças menos dramáticas, como as de Merce Cunningham, que mantinha a parceria com os inovadores artistas Robert Rauschenberg, que concebia cenários, e o músico John Cage, em coreografias que já não mais submetiam a dança à música, enquanto o avanço musical de Béjart consistia na escolha da música concreta. Apenas em meados da década de 1970 passou a existir um intercâmbio entre dançarinos franceses, que iam a Nova York para estudar principalmente a técnica de Cunningham, e a França, que, por meio de seu ministério da cultura, passou a importar coreógrafos norteamericanos como Alwin Nikolais, Viola Faber e outros para ensinarem em centros coreográficos como o de Angers ${ }^{131}$.

Apesar de desconfiar das generalizações, reconheço uma afinidade entre um modo operacional cognitivo francês, racionalista e cartesiano, e um gosto estadunidense pela exploração das leis do movimento nas realizações coreográficas. As aulas de Robert Dunn nutriram as danças inaugurais na icônica Judson Church em 1962.

Ele colocou questões decorrentes dos elementos mais básicos - estrutura, método, material. As avaliações, em termos de bom ou ruim, aceitável ou rejeitável, foram eliminadas da discussão e a análise as substituiu [...]. Não havia nenhuma fórmula a ser seguida [...]. O que ele queria era que a invenção se instaurasse ${ }^{132}$.

A icônica Judson Memorial Church, localizada na região downtown de Manhattan, no bairro do Greenwich Village, a exemplo de muitas outras igrejas protestantes, contava com um espaço destinado a datas festivas, abrigo para muitas experiências cênicas, especialmente em dança, cujos coletivos costumavam reunir compositores musicais e artistas visuais.

Cunningham e outros artistas não foram bem assimilados na Paris da segunda metade dos anos 1950. Em Nova York, a crítica não acolheu Béjart, apreciado tanto pelo público francês quanto pelo estadunidense, que afluía em massa a grandes locais, como o Madison

\footnotetext{
${ }^{131}$ Alwin Nikolais foi o primeiro diretor do Centro Nacional de Dança Contemporânea (CNDC) em Angers, de 1978 a 1981. Escola superior de dança contemporânea, o centro inclúa a criação coreográfica.

${ }^{132}$ DUNN, Judith. My work and Judson's. Ballet review, v. 1, n. 6, p. 24, 1967. Tradução nossa. Texto original: "He posed questions arising out of the most basic elements - structure, method, material... Evaluation, in terms of "good or bad", "acceptable-rejected" were eliminated from discussion and analysis replaced them. (What did you see, what did you do, what took place, how did you go about constructing and ordering. What are the materials, where did you find or how did you form them, etc.) There was no formula to be filled. Initially this caused some anxiety. What he asked was that invention take place and that work continue to be produced economically and practically".
} 
Square Garden, situado na Rua 34, quando o itinerário das turnês passou a incluir a América do Norte. A crítica negativa se deu, em parte, à tradição atlética norte-americana, que moldou um apreço maior à dança focada no movimento e nas leis que o regem. Béjart foi duramente criticado pelo papa da crítica novaiorquina, o respeitado Clive Barnes (1927-2008), do jornal The New York Times. O ressentimento levou o coreógrafo a uma rejeição da cultura estadunidense, comentando comigo, em uma de suas passagens pelo Brasil, que tencionava fazer uma coreografia sobre o dólar. O mesmo Barnes, em um tempo em que o crítico estava mais para juiz do que membro da classe artística, talvez comparável à "durona", polêmica e temida crítica teatral carioca Barbara Heliodora (1923-2015), foi também severo com coreógrafos da dança contemporânea. Acerca de David Gordon, escreveu, em 1966, sobre o solo Walks and digressions, parte de outro emblemático concerto de dança na Judson Church, marco da dança pós-moderna, que teve a participação, entre outros, de Steve Paxton: "Nada exceto exercícios de mentes egocêntricas pueris na procura fútil de chocar o já inchocável [...] penoso, algazarra adolescente" ${ }^{, 133}$.

$\mathrm{O}$ aspecto humanista e literário, próprios à cultura francesa, levava o público a aceitar melhor obras que contivessem narrativa, em detrimento da arte geométrica. Por exemplo: o neoplasticismo do pintor holandês Piet Modrian (1872-1944), que residiu em Paris pouco antes e pouco depois da Primeira Guerra Mundial, não foi bem digerido na capital francesa. Béjart observou que "quando era Martha Graham, no final de dez dias havia, para cada espetáculo, entre vinte e trinta pessoas na sala. Sei porque ia lá. Quando o New York City Ballet vinha a Paris, ficava três noites com a sala longe de estar cheia, as pessoas não moviam um músculo: gelo total. Isso mesmo"134. Observações de Béjart, ele, que almejou atingir grandes públicos e conseguiu seu objetivo.

Béjart tinha autoridade e sua presença podia ser amedrontadora pelos seus olhos azuis de aço, apesar da voz um pouco rouca e macia. Podia, igualmente, ser terno e curioso, como quando em um dos retornos de minhas férias no Brasil levei um berimbau e ele interessou-se em aprender a tocar. O berimbau é um instrumento altamente corporal, no qual o ventre funciona como caixa de ressonância. Em outra ocasião, em uma de nossas apresentações, emprestou-me uma kalimba autenticamente africana que lhe pertencia para que eu tocasse. Deixei-a em uma prateleira do camarim e dali sumiu. Fiz um escândalo até que fosse

\footnotetext{
${ }^{133}$ BANES, 1980, p. 11. Tradução nossa. Texto original: "nothing but the exercise of puerile egocentric minds in the futile quest of shocking the already unshockable...pitiful, adolescent caterwauling".

${ }^{134}$ BÉJART, 1981, p. 103.
} 
devolvida. Béjart sorriu, parecendo dizer: "Ce n'est pas grave" ("Não é grave"). Dos meus estudos de piano na infância, guardei seis ou sete músicas que toquei de cor durante muitos anos. Assim como costurar, tocar piano me acalma. Quando tinha tempo e havia uma sala livre no Mudra, sentava-me ao piano e tocava. Aconteceu de Béjart entrar e eu interromper a atividade imediatamente por vergonha e ele me pedir para prosseguir.

Associava seu rosto ao de uma onça. $\mathrm{O}$ nariz, com a ponta para baixo, não me agradava. Remetia a um determinado ramo da minha família paterna. A palavra "autoridade" é derivada de autor. Embora habitado que era pelas marcas modernistas, questionou, já na introdução de seu livro de 1979, Un instant dans la vie d'autrui, a banalização do termo "genial", que lhe era frequentemente atribuído, protótipo do ideário vanguardista do artista inventor. Kant, a exemplo de tantos filósofos anteriores a meados do século XX, que fizeram pender para o lado do sujeito a balança do processo cognitivo, referiu-se ao conceito de "gênio" como "a originalidade modelar do dom natural de um sujeito no livre uso de suas faculdades de conhecimento" 135 .

O coreógrafo questionou também a própria questão da autoria: "Em resumo, o importante é que as coisas existam, que um espetáculo exista. Bagatelas esses tais who's who?" ${ }^{136}$. Tal afirmação, curiosamente, converge para o redirecionamento do problema da autoria. Em seu artigo A paixão do real, a crítica de arte francesa Catherine Francblin sustenta a tese de que os artistas, ao integrarem o real em suas obras, provocaram o fim da noção de autor e a "consequente consagração do espectador", chegando a afirmar que "a obra mais real é quase sempre, no espírito dos artistas, uma obra não assinada" ${ }^{137}$. Seus argumentos encontram o apoio de Roland Barthes, para quem a morte do autor coincidiu com a disrupção pós-moderna. Para o filósofo, o que conta não é o autor, mas a escrita e, sobretudo, o leitor: “O autor entra em sua própria morte, a escrita começa [...] é a linguagem que fala, não o

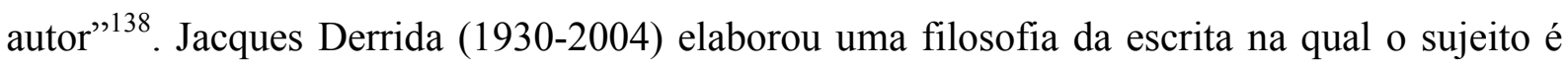
negado e Michel Foucault citou a frase referencial de Samuel Beckett (1906-1989): "Que importa quem fala, alguém disse que importa quem fala", acrescentando que "a partir do

\footnotetext{
${ }^{135}$ KANT, Immanuel. Crítica do juizo, 1790, parágrafo 41 apud HABERMAS, Jürgen. Modernidade - um projeto inacabado. In: ARANTES, O. B. F.; ARANTES, P. E. Um ponto cego no projeto moderno de Jürgen Habermas: arquitetura e dimensão estética depois das vanguardas. São Paulo: Brasiliense, 1992. p. 113.

${ }^{136}$ BÉJART, 1981, p. 83.

${ }^{137}$ FRANCBLIN, Catherine. La passion du réel. Art Press, Paris, Hors Série, n. 13, 1992. Tradução nossa apud PACQUEMENT, Alfred. Prefácio. In: CALLE, Sophie. M'as tu vue. Paris: Éditions du Centre Pompidou; Éditions Xavier Barral, 2003. p. 19.

${ }_{138}$ BARTHES, Roland. La mort de l'auteur. In: BARTHES, Roland. Le Bruissement de la langue: Éssais critiques IV, Paris: Seuil, 1984. p. 61 apud PACQUEMENT, Alfred. In: CALLE, 2003, p. 18. Tradução nossa.
} 
momento em que o sujeito absoluto já não existe mais, o sujeito coletivo deve substituir o sujeito individual" $" 139$.

Maurice Béjart preferiu apequenizar o termo gênio em prol da dedicação ao ofício, à tekné, ao bem fazer. O sociólogo e historiador estadunidense Richard Sennett (nascido em 1943) esmiúça a palavra empregada por Platão: na etimologia de "fazer", há "poien”, da qual se derivam "habilidade" e "poesia". Em seu elogio à perícia artesanal, defende que a obtenção de qualidade em um ato necessita da correlação entre cabeça e mãos. "O artífice explora essas dimensões de habilidade, empenho e avaliação de um jeito específico. Focaliza a relação íntima entre a mão e a cabeça" ${ }^{140}$ para a aquisição de capacidades. Sennett discute se o talento bruto pode substituir o treinamento, pergunta à qual Béjart certamente responderia negativamente, uma vez que foi sempre aliado da disciplina e do rigor.

O pensamento coreográfico de Maurice Béjart fugia, porém, de uma narrativa explícita, ao menos inicialmente. Talvez por isso foi preterido em favor do então mais palatável coreógrafo Roland Petit (1924-2011), em uma Paris conservadora no que concernia à apreciação da dança. Béjart teve a sorte, porém, de ser acolhido em Bruxelas pelo diretor da Ópera Nacional da Bélgica, Maurice Huisman (1912-1993), que lhe propôs uma criação coreográfica de A sagração da primavera, de Igor Stravinski (1882-1960), em 1959. Béjart, a princípio, resistiu, pois a música do compositor russo diferia das experimentações propostas por seus diletos Pierres franceses. Convencido a realizá-la, despiu a coreografia da narrativa original russa, seguida à risca na versão primeira de Vaslav Nijinsky (1890-1950), que teria sido acompanhada de perto pelo compositor. Uma das mais marcantes criações artísticas do século XX, a dissonante Sagração teria antecipado o conflito prenhe que eclodiria com a Primeira Guerra Mundial (1914-1918).

A versão bejartiana não deve ter agradado a Stravinski, o qual teria emitido comentários sarcásticos acerca da coreografia, o que não impediu Béjart de ter considerado o compositor russo como pai do balé contemporâneo, o que de fato foi. Béjart e Stravinski encontraram-se uma única vez, amistosamente e de modo breve em Paris, no final da vida do compositor russo. Para Béjart, "alguns músicos prefeririam ser ouvidos primeiro só pela música e não depender do trampolim que a dança lhes oferecia"141.

\footnotetext{
${ }^{139}$ FOUCAULT, Michel. Conferência "Quest-ce qu'un auteur ?" (1969). In: GROS, Frédéric; BERT, François; DEFERT, Daniel (Org.). Dits et écrits (1954-1988), tome 1. Paris: Gallimard, 2015. p. 789. Tradução nossa.

${ }^{140}$ SENNETT, Richard. O Artífice. Tradução de Clóvis Marques. Rio de Janeiro; São Paulo: Editora Record, 2009. p. 33.

${ }^{141}$ BÉJART, 1981, p. 91.
} 
Sergei Diaghilev (1872-1929) começara como animador do Museu da Arte de Moscou, em parceria com o pintor russo tornado célebre como cenógrafo de balés, Alexandre Benois (1870-1936). Os cenários da época consistiam, geralmente, de telões pintados por grandes artistas que não mais recorriam ao papelão como matéria. Diaghilev exerceu a função de curador de uma mostra de pintores impressionistas franceses em São Petersburgo, o que revela seu trânsito por várias linguagens artísticas. Fundada em 1909 como Ballets de Diaghilev, a companhia foi renomeada no ano seguinte como Ballets Russes.

A estreia do Sacre du printemps (A sagração da primavera) na França do pré-guerra impactou a Paris de 1913, quando de sua apresentação no Théâtre des Champs Elysées, naquela que foi a quinta temporada parisiense da companhia russa, tempo em que eclodia, igualmente, o futurismo russo. A primeira ocorrera em 1909, no Théâtre du Châtelet. Apesar de seu virtuosismo técnico enquanto bailarino, como coreógrafo, Nijinsky levou ainda mais longe a vertente iniciada por Michel Fokine (1880-1942), desembaraçada da nomenclatura do balé. Protagonista de muitos de seus balés como Petruchka, Nijinsky já conhecera uma dança que diferia do vocabulário estritamente clássico, própria ao viés coreográfico proposto por Fokine, que, atraído pela dança libertária de Isadora Duncan (1878-1927) quando de sua visita à Rússia em 1905, buscou soluções coreográficas que escapassem ao balé tradicional, introduzindo novos léxicos coreográficos. Nijinsky deixou o en dehors de lado e virou os pés para dentro, explorando o en dedans, em uma assimilação dos ensinamentos propostos por Émile Jacques-Dalcroze, que exortava à eliminação dos movimentos parasitas.

Na nova versão do Sacre du printemps, como em tantas outras, Béjart imprimiu uma de suas grandes marcas: a de destacar o vigor físico masculino, divergindo da presença masculina tradicional no balé, que funcionava, antes de tudo, como suporte para carregar, elevar e manter no ar as bailarinas, ideais de perfeição, delicadeza, leveza e flutuação, frutos do movimento romântico literário e que desembocou nos célebres balés românticos da primeira metade do século XIX. Pós-classicistas salientavam o individualismo - daí a presença de solistas em contraponto aos corps de ballets. O lirismo, o subjetivismo e a imaginação eram igualmente valorizados. O auge foi atingido em 1841, com a produção de Giselle na Ópera de Paris, apreciada até os dias de hoje. Técnica acadêmica aliada à poesia e narrativa, A Sílfide, ou Giselle, evocava seres irreais e imateriais, apresentando heroínas infelizes no amor e cujo espírito ressurgia após suas mortes, vestindo longos tutus sugeridos pelas saias das camponesas. Uma parceria montada em dois atos com música de Adolphe Adam e texto escrito por Théophile Gautier. Béjart chamaria tal tradição de decadente. Em suas próprias palavras: 
Devolvi aos rapazes o que lhes foi tirado. Fiz tabula rasa de todo um lado efeminado e "mundano". Dei aos cisnes o sexo deles, que Zeus utilizou para seduzir Leda. Abandonei os cisnes do Lago dos Cisnes e fiz um balé intitulado Cygnes (Cisnes), onde três bailarinos, nus da cintura para cima, encarnavam o pássaro mítico ${ }^{142}$.

Ainda que multiplicados, Béjart manteve, porém, a centralização no solista, em torno do qual um grupo de dançarinos se movimenta, enquanto coreógrafos estadunidenses como Alwin Nikolais e Merce Cunningham já não mais estabeleciam hierarquia alguma entre os pontos do espaço, considerando-os todos igualmente importantes, sejam centrais ou periféricos. O coreógrafo francês associou a primavera à irrupção da vida e não seguiu o libreto original, que terminava com a morte da eleita, solução acompanhada por Pina Bausch (1940-2009) e o Tanztheater Wuppertal quase uma década e meia depois. Béjart preferiu celebrar a união macho-fêmea. Ponto comum entre as duas montagens - a de Béjart e a de Pina - foi a associação entre o vigor e sexo masculino e a delicadeza e fragilidade ligadas à mulher, fato mais facilmente identificável na montagem bejartiana. Primeira de uma série de obras capazes de atrair e agradar multidões, em busca do grande espetáculo popular e do direcionamento a grandes plateias por meio de ideias simples e fortes, a Sagração alcançou um imenso sucesso e foi un trou dans le ciel ("um buraco no céu"), segundo o professor de jogo teatral do Mudra, Fons Goris.

Béjart optou, a exemplo das plantas que irrompem sob a terra no início da primavera, por celebrar as forças da natureza por meio do amor, buscando a força vital, o vigor animal pelos elementos masculino e feminino. Fortes encontram-se o sentido da physis grega, aquilo que brota, que equivale ao ser, bem como a pulsão e potência nietzschianas. De sua pequena companhia francesa, Béjart foi autorizado a convidar apenas os solistas Germinal Casado e Tania Bari para acompanhá-lo na nova experiência belga nascente. Os demais bailarinos foram recrutados pelo Théâtre Royal de la Monnaie ${ }^{143}$, que recebeu, mais tarde, a denominação de Opéra National de Belgique. O objetivo de Béjart era contar com vinte bailarinos masculinos e vinte femininos. Apesar de não ser meu objetivo entrar em detalhes, mas contextualizar, apreender e destacar alguns aspectos do poder criativo e inovador de Béjart, importa o modo como se dá uma estrutura inicial e, sobretudo, que o foco desejado é o formador dos primórdios, o período nascente, inicial, tanto do Mudra quanto do Galpão. Daí considerar relevante também esse assentamento da companhia bejartiana em Bruxelas.

\footnotetext{
142 BÉJART, 1981, p. 151.

${ }^{143}$ O Théâtre Royal de la Monnaie foi inaugurado em 1856, seguindo o padrão neoclássico do século XIX.
} 
O Ballet du XXème Siècle, cujo título embute o propósito estético bejartiano, despido de tutus e libretos, foi fundado em Bruxelas em 1960, apesar de, por vezes, ser considerado neoclássico, denominação que melhor se ajusta a George Balanchine (1904-1983), o célebre diretor do New York City Ballet, nascido em São Petesburgo, na Rússia, e falecido em Nova York, nos Estados Unidos da América. Aplicada à dança, a expressão "clássico" não é precisa, por evocar uma proporção entre a harmonia de formas da Antiguidade. Usualmente, o termo remete àquilo que resiste ao passar do tempo, sem envelhecer. Béjart preferiu o termo "acadêmico", de cujo rigor nunca abdicou. A palavra, aqui, relaciona-se à "disciplina", diferentemente do sentido de "força avassaladora e implacável", que atua como um trator que tudo esmaga e tritura, no sentido artaudiano. Disse Béjart: "Detesto linhas retas, é cansativo como autoestrada. Não confundir linha reta com rigor. O rigor me fascina, é nele que encontro surpresa, liberdade e alegria"144.

Ambos os coreógrafos discordavam da expressão "dança abstrata", uma vez que há corpos de carne e osso em cena. Conforme afirmou Béjart: "Não suporto que me falem em dança abstrata. Um triângulo é abstrato, uma fórmula algébrica é abstrata, não dois ombros e duas coxas, que posso tocar, morder"145. Em outros momentos, porém, defendeu a necessidade de produzir coreografias matemáticas. A expressão "abstrata" pode soar inadequada, mas seu emprego é frequente e quer designar a dança que tem como matéria a própria dança; a dança voltada às leis que regem o movimento e a composição coreográfica, tais como dinâmicas, intensidade da força empregada, entre outras; a dança eminentemente não narrativa e que, como na pintura, rejeita a figuração da realidade por meio de um jogo compositivo entre pontos, linhas e formas, como o fez o pintor russo Wassily Kandinsky, marcado pelo geometrismo em consonância com as cores fortes presentes em sua Rússia natal; ou como o fez Kasimir Malevich em Woman with water pails, de 1912; ou mesmo como o abstracionismo peculiar de Tomie Ohtake (1913-2015), definido pelo curador paulista Fábio Magalhães como abstração construtiva e pelo crítico de arte Mário Pedrosa (19001981) como abstracionismo informal, liberto da geometria no auge do abstracionismo, termo frequentemente associado ao cubismo. Há pintores ditos abstratos, como Hans Hartung (19041989), que se atêm a um aspecto orgânico e aos impulsos, ímpetos e ritmos ao se dedicarem às atividades humanas do riscar e rabiscar semelhantes a garatujas, servindo-se de materiais como pincéis vegetais, galhos, vassouras. O vocábulo grego traduzido por “abstrair" era usado

\footnotetext{
${ }^{144}$ BÉJART, 1981, p. 49.

${ }^{145} \mathrm{Ibid}$, , p. 74.
} 
“comumente para designar o ato de extrair algo de algo, separar uma coisa de outra, privar alguém de alguma coisa, por algo à parte ou separar algo de alguma coisa"146. A mais palpável associação da palavra "abstrato" é o não figurativo. Abstração refere-se, ainda, à separação, ao isolamento, à retirada do estrato, da estratosfera - indicados pelo prefixo "ab".

Figura 7 - Kasimir Malevich em Woman with Water Pails, de 1912

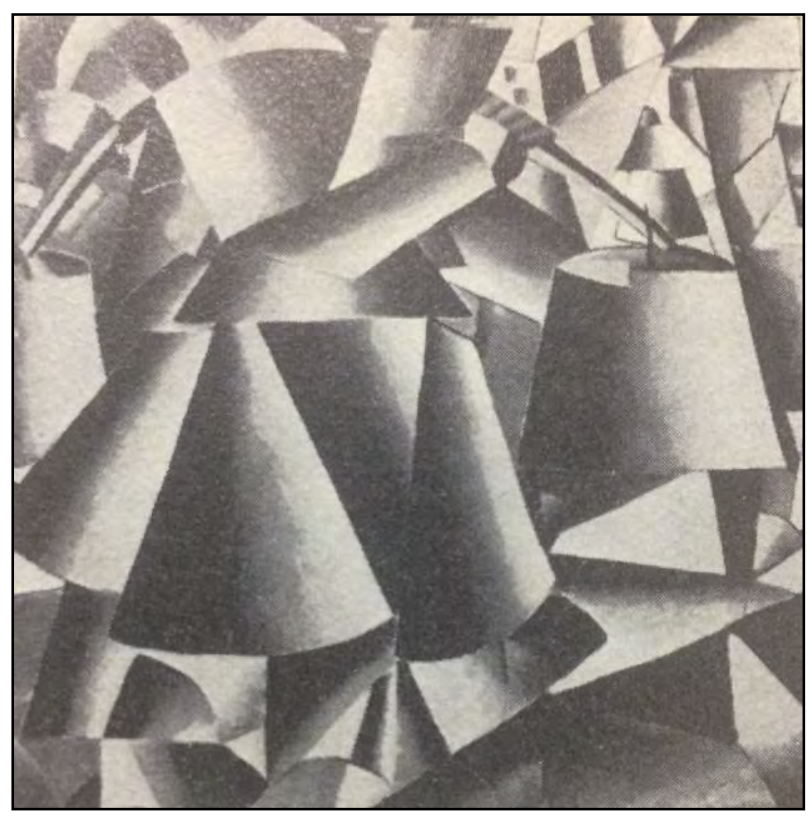

Fonte: READ, Herbert, (1975).

Coreógrafos contemporâneos, ao optarem pela dança dita pura, descrita por Béjart como encadeamento de passos, estendem à roupagem visual (cenários, figurinos) o mesmo conceito. Béjart associava a palavra "concreto" ao espetacular, referindo-se provavelmente, à profusão de objetos visíveis e passíveis de serem tocados. Béjart podia negar-se aos enredos, mas construía peças coreográficas com situações dramáticas definidas e a presença de personagens, seus desejos e afetos básicos como dor, alegria, desejo, temor: "Recusando-me ao enredo, não descobri nada de abstrato: encontrei verdades carnais, o prazer, a angústia, o gozo, o perfil da morte" ${ }^{147}$. Com frequência, uma narrativa linear podia ser encontrada em montagens poluídas ou, no mínimo, carregadas e ecléticas, pelo emprego excessivo de elementos e carga dramática.

\footnotetext{
${ }^{146}$ MORA, 2001, p. 6.

${ }^{147}$ BÉJART, 1981, p 74.
} 
Tal tendência será reconhecida e denominada pelo coreógrafo como barroca, distinta da placidez, do despojamento e da sobriedade. Béjart era, sem dúvida, um homem do espetáculo e do entretenimento, em direção ao grande espetáculo popular, e sempre foi adepto de uma grande arte capaz de misturar sangues, culturas e técnicas. Tais propósitos foram vivamente incentivados pelo então diretor da Opéra National da Bélgica, Maurice Huisman, que incentivou Béjart a dirigir-se "a plateias maiores, com ideias simples e fortes" "148. A referência era, provavelmente, Jean Vilar, diretor do Théâtre National Populaire, o TNP, fundado em 1951 em Paris, que tinha como um de seus objetivos atingir um vasto público. Inicialmente adepto do que veio a ser denominado textocentrismo, Vilar foi, aos poucos, abrindo-se a novas experiências, inclusive às artaudianas. Foi fundador do célebre Festival de Avignon, realizado anualmente a cada verão europeu.

Balanchine e Béjart despiram seus balés do aparato próprio ao intitulado Balé Romântico. Béjart abominava a dança praticada no século XIX, destinada, acima de tudo, a edulcorar. Por seu lado, Balanchine também abriu mão do drama e da teatralidade.

Ambos os coreógrafos mantiveram a relação intrínseca entre dança e música. Béjart chegou a dizer: "Construía meu trabalho unicamente sobre as relações entre a partitura musical e o movimento" ${ }^{149}$; ou, ainda: "A música dá o corpo: a coreografia é a costureira"150, não concebendo que uma pessoa possa viver sem música. Eu mesma gosto de dançar a partir de um estímulo musical, enquanto exercício, mas tal relação, antes considerada intrínseca, tornou-se dissociada nos procedimentos compositivos contemporâneos. Ainda em um passado recente, era frequente ouvir um coreógrafo dizer: "Vou coreografar um Paganini" ou "vou montar um Bartók", centralizando a criação no compositor musical. Por seu lado, desde a infância, Balanchine desenvolveu um conhecimento musical. Ateve-se ao corpo e à música. Ele, que estudou composição e piano no Conservatório de Leningrado desde os dez anos de idade, além de ser filho de um compositor. Coreógrafo desde 1923, foi convidado por Sergei Diaghilev a ingressar na Ballets Russes. Após desertar da União Soviética, foi convidado por Lincoln Kirstein a formar, em 1934, a New York School of City Ballet a partir dos balés clássicos francês, italiano e russo, o que resultou, quatorze anos mais tarde, na fundação do New York City Ballet, para o qual selecionou apenas bailarinas com a mesma estatura: 1,70m.

\footnotetext{
148 BÉJART, 1981, p. 133.

149 Ibid., p. 165.

${ }^{150}$ Ibid., p. 172.
} 
Béjart e Balanchine intercambiaram seus mais relevantes intérpretes: Suzanne Farrell permaneceu anos em Bruxelas na primeira metade da década de 1970, tornando-se, inclusive, a intérprete preferida de Béjart no "Boléro" de Ravel, ou a mais musical, segundo o coreógrafo, imprimindo uma marca aparentemente marmórea. Jorge Donn, por sua vez, deslocou-se a Nova York como bailarino convidado, emprestado ao coreógrafo russo. Se os balés de Béjart eram carregados - por vezes, de modo excessivo - de cenários, figurinos e adereços, uma vez despidos de todo esse aparato restava um vocabulário de movimentos muito inventivo. Béjart foi, sem dúvida, um grande metteur en scène (diretor), haja vista a ópera La traviata, que dirigiu no Théâtre Royal de la Monnaie na primeira metade dos anos 1970, na qual o cenário espelhava o próprio teatro, com sua plateia, frisas, camarotes, etc. O termo "metteur en scène" supõe que quem coloca algo em cena já se encontra em posse daquele algo anteriormente. Grandiosidade é, talvez, a palavra que melhor se adeque às montagens bejartiana, capazes de mobilizar e tocar grandes plateias.

A referência a coreógrafos do calibre de Balanchine ou Béjart leva a refletir sobre a palavra "coreografia" in strictu sensu. Se o vocábulo grego "khoreia" significa "dança" e é derivado de "chara" (alegria), "graphein" corresponde ao ato de grafar, escrever, pintar ou desenhar. "Chore", empregada desde a tragédia grega e da qual provém "orquestra", evoca um conjunto harmônico, processado em círculo, em roda. O entendimento da palavra “coreografia" enquanto "escrita do corpo", levando-se em conta sua raiz grega, conduz à denominação "somagrafia". Levando-se em conta o latim, chegaríamos a "corpuscritura", de "corpus" mais "scriptura".

Em Coreografia, livro de Raoul-Auger Feuillet publicado em 1770, o termo é empregado pela primeira vez, sendo mantido pelo célebre maître de ballet e apreciador da pantomima Jean-Georges Noverre (1727-1810) no século seguinte. A palavra é derivada de “orchéosagraphie", termo que dá título à obra de Thoinot Arbeau, escrita em 1588. "Um inventário e uma descrição precisa das práticas codificadas das danças do século XVI"151. O próprio Balanchine teria introduzido, em 1930, o termo "coreografador" nos Estados Unidos, país que o acolheu, no qual, até então, o termo usual era "dance diretor" para aquele que era incumbido de regrar as sequências de dança nos musicais ou cinema norte-americanos.

Conforme o exposto, ambos os coreógrafos viveram em um tempo em que, quase sempre, o ponto de partida coreográfico se assentava sobre uma partitura musical. Daí

\footnotetext{
${ }^{151}$ BÉJART, 1981, p. 249.
} 
Balanchine referir-se à música enquanto tapete para a dança. A mesma importância que tinha o texto para o teatro, a partir do qual se erigia a peça, tinha a música para a dança. A música fazia desencadear a coreografia. Apesar de não poder viver sem a presença da música e se fazer acompanhar onde quer que fosse por toca-discos e depois por cassetes, alguns compositores musicais prediletos de Béjart teriam preferido que ele seguisse mais acuradamente suas partituras, como no Concerto das ambiguidades para piano e piano, de Pierre Henry, obra de 1950 concebida em movimentos denominados "Tenso", "Esparso", "Difuso", "Conciso", etc.; ou em Stimmung ("humor" ou “estado corporal”, em alemão), de Karlheinz H. Stockhausen, concerto coreografado por Béjart em 1972. No caso, o músico queixou-se do excesso de divindades asiáticas introduzidas pelo coreógrafo. Stockhausen teria preferido o desenvolvimento coreográfico dos sons criados por ele, sem o acréscimo de uma anedota, ou mesmo de uma narrativa ou outro apelo dramático.

No ano seguinte à estreia do Sacre du printemps, em 1960, Béjart coreografou mais uma marcante celebração à vida: o "Boléro" de Ravel, no qual o elo entre ritmo e melodia seguem juntos até atingir o clímax. Frutos de uma mesma fornada, o Sacre e o "Boléro" foram assistidos dezenas de vezes por mim e pelos mudristas, contando ensaios e apresentações com elencos diversos. Os mudristas eram os integrantes do Mudra. Empreguei sempre a palavra no masculino, referindo-me ao Centro Mudra, proveniente do título extensivo: Centro Europeu de Aperfeiçoamento e Pesquisa dos Intérpretes do Espetáculo. Maurice Béjart preferia o feminino, com referência à Escola Mudra.

Em 1961, nova montagem: Béjart realizou, em Veneza, em parceria com o pintor Salvador Dali (1904-1989), uma realização ousada - à qual deu o nome de happening - com um elenco numeroso que executava ações cotidianas, como passar roupas. Havia também uma figura enrolada em ataduras pintando as unhas, um cego diante da TV e um transportador de pratos que, às vezes, deixava cair parte deles, tudo ao som de Scarlatti. Béjart dizia-se atraído por artistas como Yves Klein ou movimentos como a action painting. A montagem alinhavase apenas em parte ao ideário do happening exposto em onze itens pelo estadunidense Allan Kaprow em How to make a happening, que exorta a procura do novo por meio do vínculo com a vida real, cotidiana. Fomentador maior da vertente, o receituário elaborado por Kaprow propôs, na década de 1960, que o happening fosse um acontecimento único, despreocupado com a forma. Sugeriu aos participantes que trouxessem, para o evento, elementos ordinários, não transformados, e sim tal como foram encontrados, ideário que se assemelha à prática dadaísta dos anos 1920 do século XX e cujos procedimentos foram absorvidos, entre outros, pelo pintor e artista cênico polonês Tadeusz Kantor (1915-1990). 
A experiência com Dali acabou mal. Após a apresentação em Veneza, o pintor catalão autorizou Béjart a dar a continuidade que desejasse ao trabalho. Béjart o remontou em Bruxelas, no La Monnaie, com cenários e figurinos elaborados, o que desagradou a Dali. O frescor impactante inicial tinha se esvaído. O prenúncio de uma instalação coreográfica, em uma referência a obras construídas por materiais diversos em um espaço-tempo determinado, podendo incluir a interatividade com o público, provavelmente se adequou melhor em Veneza, embora não houvesse, na cidade italiana, interação com o público, pois a ação ocorria no palco. A repetição transmudou em obra o que se destinava a ser um acontecimento único. Surgida nas artes visuais na década de 1960, com a proposta de relacionar objetos ao ambiente, a instalação vingou e continua se expandindo ainda hoje, enquanto os happenings minguaram ou adquiriram outros contornos.

Em 1965, Béjart propôs para sete bailarinos as Variations pour une porte et un soupir, também de Pierre Henry, de maneira totalmente improvisada e desprovida de um coreógrafo. Pierre Henry se limitou a definir apenas algumas coordenadas. Se Béjart tinha ou não conhecimento das experiências efetuadas pelo músico estadunidense John Cage, não sei, mas houve, na obra, a atuação do acaso, quando cada dançarino sorteava aleatoriamente um tema, tais como sono, balanço, despertar, canto e outros. A peça foi retomada em 1978 e "caiu como uma luva" aos bailarinos egressos do Mudra contratados pelo Ballet du XXème siècle. Tal como Cage e conforme exposto anteriormente, em Béjart, era forte a presença do Oriente e os preceitos de concentração e escuta.

Data igualmente de 1963 a primeira tournée de Béjart e sua então jovem companhia à América Latina, quando ceifou e colheu. Sua passagem pelo Brasil e pela Argentina, em seguida pelo México, foi fulgurante nos meios artísticos, despertando talentos e deixando influências, como Marika Gidali e Décio Otero, no Brasil, e Oscar Araiz, na Argentina, efeito só comparável ao provocado pela primeira visita do Tanztheater Wuppertal Pina Bausch ${ }^{152}$, quase duas décadas depois. Na Argentina, Jorge Donn, então com 16 anos de idade, foi fisgado e partiu de navio, por conta própria, na esperança de obter uma vaga na companhia. Foi esse bailarino pouco conversador e verbal quem me fez entender uma outra modalidade de inteligência: a corporal. Uma inteligência não discursiva. Donn pouco falava, mas seu

\footnotetext{
${ }^{152}$ O Tanztheater Wuppertal, dirigido por Pina Bausch, esteve no Brasil pela primeira vez em 1981, já trazendo alguns de seus carros-chefes, como Café Müller e a Sagração da primavera. A companhia, ainda desconhecida, impactou uma plateia reduzida. A estreia no Teatro Guaíra, de Curitiba, tinha menos de uma dezena de espectadores.
} 
corpo tudo entendia, no que concerne às múltiplas qualidades de movimento que dominava e desenvolvia por meio de um tônus muscular justo. Certa vez, em um tempo próximo à estréia do programa a partir dos escritos do poeta Jean Cocteau, colocaram no andar térreo, perto da entrada do galpão do Mudra, uma corda esticada a um metro de altura. Ele subiu e saiu andando. Beatriz Margenat, apontada como dona de uma presença magnética - a charis (ou graça) - seguiu para Bruxelas pouco depois, já contratada pela companhia.

No final dos anos 1970, início dos 1980 e segunda metade dos anos 1990, Béjart voltou a visitar o Brasil, sempre interessado em acompanhar meus trabalhos coreográficos enquanto sua ex-aluna. Mais de uma vez, esteve em casa para um almoço. Em uma casa repleta de objetos, o coreógrafo fixava-se em alguns, como em uma enorme figa de madeira, em posição vertical. Maurice Vaneau, meu marido, não titubeou em oferecer-lhe. Em 1979, mostrei-lhe fotos de algumas coreografias que fizera, como Pulsações e Isadora. Donn o acompanhava e contou-me que tinha uma irmã gêmea. Ele havia sido o segundo a sair da barriga da mãe. Em uma dessas visitas, disse-me Béjart que havia decidido retirar do repertório a monumental Nona sinfonia de Beethoven (1964), que tinha no "Ode à alegria" o seu clímax. Ícone da grandiosidade e humanismo que por muito tempo alimentaram Béjart, apresentada em grandes salas de espetáculos ou mesmo ginásios para milhares de espectadores, a decisão revelava seu espírito crítico em relação ao próprio trabalho: "Já não me agrada mais. Não posso apresentar ao público algo que não goste”, disse ele. Provavelmente, estaria rejeitando a utopia da paz e fraternidade, o lado romântico presente na obra beethoveeniana, na vizinhança entre o modernismo e o romantismo, ou sua excessiva monumentalidade e mesmo o resvalo na pieguice, embora compositores com lastro eminentemente romântico, como Gustav Mahler, constassem entre suas predileções. A Neuvième symphonie de Beethoven foi a primeira coreografia de Béjart que assisti, poucos dias após minha chegada em Bruxelas. Certo é que foi apropriada por ideologias distintas e mesmo antagônicas, sendo tocada, inclusive, em comemorações oficiais, como na Festa Nacional da Bélgica, em julho de 2017.

Além de ser alimentado pelo sentido do ritual, Béjart manteve sempre uma estreita relação com a música e com a literatura, fruto de sua formação europeia e do fato de ser filho de um estudioso da filosofia, Gaston Berger. Da literatura saltavam personagens, mantendo o esquema da representação. Foram inúmeros os textos literários de apoio, de autores como Charles Baudelaire, Jean Cocteau, Petrarca e muitos outros.

O fato de Nova York ter substituído Paris enquanto capital mundial das artes após a Segunda Guerra Mundial, ou, mais acentuadamente, na década de 1950, torna referencial o 
paralelo. Em Nova York, foi no verão de 1962 que Robert Dunn, que oferecia oficinas de composição no estúdio de Cunningham, organizou o primeiro concerto na Judson Church, com o propósito de apresentar alguns resultados de seus workshops, embora alguns participantes, como David Gordon, já dispusessem de seu próprio material. Reunidos ali estavam Steve Paxton, Deborah Ray, Yvonne Rainer e outros. Embora houvesse a projeção de filmes e adereços tais como patins, conforme informou Lisa Nelson, em palestra proferida no SESC Pinheiros, em São Paulo, em 11 de abril de 2014 (na qual estive presente), havia a junção entre dança, poesia e pintura, embora o legado mais relevante do grupo tenha sido o não à ilusão, conforme manifesto de Rainer de 1965: não à espetacularização e à representação, deslocando a atenção aos movimentos pedestres, tais como andar e promover recursos a jogos corporais - por exemplo: passar sobre ou sob o corpo do outro, focando especificamente a linguagem no movimento do corpo. Os dois últimos aspectos encontravamse situados a quilômetros de distância - não apenas geográfica - da estética bejartiana: espetáculo, representação e maquiagem carregada devido à distância entre público e plateia encontravam-se presentes no Ballet du XXème Siècle. Há de se apontar a rejeição ao imaginário, atendo-se ao concreto, pão-pão, queijo-queijo do estritamente corporal. Por outro lado, se o que se via na Judson Church privilegiava o movimento, o Mudra foi fundado em 1970 com o propósito de reunir, de hibridizar as linguagens artísticas. Se a palavra hibridização conota espetacularidade, aplicando-se o termo às artes do espetáculo, cabia perfeitamente nos propósitos iniciais. Do grego "hybris", indica a miscigenação, a mistura, a mescla, a fusão.

Em 1963, eclodiu a guerra do Vietnã, decretada pelos Estados Unidos, o que levou muitos estadunidenses, especialmente artistas, a uma ferrenha oposição à ofensiva televisionada. A dança norte-americana conhecia grandes transformações. A Contact Improvisation, o contato e o abandono do próprio peso ao corpo do outro surgiu no final da década de 1960 e soou como resposta ao belicismo norte-americano, na esteira do slogan “Faça amor, não faça guerra", presentificado pelo Festival de Woodstock, em 1969. O evento foi mola propulsora para Steve Paxton, abrindo uma nova perspectiva e gerando novas experiências ao sentido de representação mental, cujo sentido foi substituído pelo entendimento dos fluxos de energia que percorrem o corpo.

A prática da improvisação pelo contato é um exemplo claro da abertura da percepção “por meio das opções (focos pré-motores), sensibilidade (sensório), consciência (percepção), 
habilidade para responder (motor) e sentir seu self e comunicação com o parceiro"153. Dois anos antes, no mesmo ano em que Che Guevara foi assassinado na Bolívia, Béjart estreou no Festival de Avignon, na França, a Messe pour le temps présent, mais uma vez em parceria com o compositor Pierre Henry, seu conterrâneo, ambos nascidos no mesmo ano: 1927. Os bailarinos deixavam de lado os tradicionais collants e usavam jeans, espelhando-se no modo de trajar do público, segundo Béjart. Serviam-se de jornais como acessórios cênicos, além de luzes giratórias amarelas que costumam ser colocadas nas pistas para chamar a atenção de motoristas, prevenindo-os de um eminente perigo. O motor daquela criação havia sido a morte recente, em um acidente de automóvel na rota Paris-Bruxelas, aos 24 anos, do jovem, longilíneo e talentoso bailarino Patrick Belda, marido da bailarina brasileira Laura Proença, então integrante do Ballet du XXème Siècle.

Em 1968, dois anos antes do lançamento do Mudra por Béjart, eclodiram as rebeliões que se irradiaram de Paris para o mundo, com fortes reflexos no Brasil e, especialmente, em São Paulo. A reivindicação por dormitórios não separados por sexo na Universidade de Nanterre em março de 1968 foi o estopim que fez eclodir a insatisfação generalizada no governo francês do Marechal Charles De Gaulle. Passou-se a questionar as instituições em geral, incluindo a família. O período de grande transformação nos costumes foi tratado pelos filósofos franceses Gilles Deleuze (1925-1990) e Felix Guattari (1930-1992). Em O AntiÉdipo, publicação muito difundida na época, Deleuze e Guattari apostaram no corpo, considerando-o gatilho na disposição central da política. A referência social passou a ser ocupada pela politização do corpo, tornando-se objeto de reflexão filosófica. Naquele momento, Béjart e cia. encontravam-se em Lisboa, no dia em que Robert Kennedy foi assassinado nos Estados Unidos. Ao término da apresentação, Béjart dirigiu-se ao público, manifestando-se contra a violência e opressão. Portugal achava-se sob a ditadura de Francisco Salazar. A fala de Béjart fez com que o coreógrafo fosse forçado a deixar o País.

Fredric Jameson refere-se aos anos sessenta como uma era feliz, na qual o mundo ainda era jovem:

Os chamados anos sessenta - que se iniciam (vagarosamente) em 1963, com os Beatles e a Guerra do Vietnã, e terminam dramaticamente por volta de 1973-1975 com o choque de Nixon, a crise do petróleo e o que é chamado ironicamente de "a perda" de Saigon - foram entre outras coisas um

\footnotetext{
${ }^{153}$ COHEN, Bonnie Bainbridge. The action in perceiving. Contact Quaterly, Northampton, MA, EUA, n. 2, p. 22-26, outono de 1987.
} 
momento extraordinariamente rico, o mais rico desde os anos 20 , no que diz respeito a novos tipos de montagem dos textos teatrais canônicos herdados do passado da grande literatura mundial: basta mencionar o Hallischer Ufer, o Schiffbaer Damm, Peter Brook ou Grotowski, o Théâtre du Soleil, o TNP ou o National Theatre de Olivier, as produções off-Broadway do teatro novaiorquino, ou as de Beckett e do chamado antiteatro, para invocar todo um universo teatral instigante dentro do qual os chamados happenings necessariamente se situam ${ }^{154}$.

O contexto belga era o de um país monarquista (monarquia constitucional) e jovem, uma vez que a Bélgica só se constituiu como nação em 1830, quando, por meio de uma revolução, separou-se da Holanda. Em 1970, ainda se encontravam ausentes os acirrados conflitos entre dois grupos linguísticos: os valões e os flamengos, conflitos estes que vieram a se agravar na segunda metade do século XX. O idioma falado pela comunidade flamenga aproxima-se do holandês. Segundo observadores, o holandês e o flamengo correspondem às diferenças existentes entre o português falado em Portugal e no Brasil. Hoje, a rica Flandres, situada ao norte da Bélgica, próxima à Holanda, é composta por seis milhões de habitantes e apresenta uma taxa de desemprego menor que a da francófona Valônia, que inclui $41 \%$ dos belgas. $^{155}$

A capital Bruxelas é oficialmente bilíngue, mas a maioria fala francês. A Flandres, a exemplo da Escócia e de Barcelona, é separatista e reinvindica sua independência, gerando conflitos. O nome latino "Bélgica" provém da província romana da Gália. Entre o século XVI e 1830, foi um campo de batalha da Europa. Em guerra contra a Espanha que findou pelo tratado d'Aix-em-Chapelle, o rei Luis XIV, o Grande, anexou a Flandres, em 1668. Entre 2007 e 2011, a região conheceu sua mais longa crise governamental. Distantes estavam ainda os conflitos que agitam, hoje, bairros como, entre outros, Molenbeek, Scharbeek e Anderlecht, este último onde o Mudra se encontrava. Por motivo de casamento, tenho a nacionalidade belga além da brasileira.

\subsection{Mudra, por quê?}

Dois vetores teriam impulsionado Maurice Béjart a dar nascimento ao Mudra: o desejo de retorno a um pequeno núcleo e a busca pelo teatro total, que conduz à conexão com o

\footnotetext{
${ }^{154}$ JAMESON, Fredric. A cultura do dinheiro: ensaios sobre a globalização. Tradução de Maria Elisa Cevasco e Marcos César de Paula Soares. Petrópolis, RJ: Editora Vozes, 2001a. p. 74.

155 BÉLGICA E FLANDERS. Disponível em: <https://www.europeanjobdays.eu/pt-pt/events/workflanders/b\%C3\%A9lgica-e-flanders $>$. Acesso em: 3 out. 2017.
} 
Oriente e ao pensamento fulgurante de Antonin Artaud. A nostalgia de seu tempo de diretor de companhia com reduzido número de integrantes, quando podia manter um estreito contato com cada um, levou-o a dizer:

Hoje trabalho com mais de noventa bailarinos, técnicos de som, figurinistas, ensaiadores, assistentes, etc., e tenho a impressão de que retornarei à fórmula antiga de uma pequena companhia, onde poderei fazer pesquisas pessoais, falar em voz baixa depois de ter falado em voz alta, ter contatos importantes com todo mundo ${ }^{156}$.

O que atraía Béjart, porém, acima de tudo, era a ideia de um teatro total e, consequentemente, do intérprete total. Em Um instante na vida do outro, Béjart afirmou: "Na Mudra queremos reencontrar o ator total, aquele que tem possibilidade de se exprimir pela voz, pelo movimento, pelo corpo inteiro" ${ }^{\prime 157}$, cuja pesquisa retomaria a antiga teoria presente na tragédia grega e no teatro japonês, em que o ator representa, canta e dança. Impressa no programa de Le fils de l'air (1972), colaboração coreográfica entre Béjart e os mudristas das duas primeiras promoções, encontra-se a frase: "A formação de atores-bailarinos-cantorespercussionistas-acrobatas, criadores e intérpretes completos que demanda o espetáculo hoje". Uma das condições da admissão do candidato ao Mudra era o de destinar-se à interpretação artística. A ideia de "completo" associa-se à de "total", ao "intérprete total", ao "espetáculo total”, àquele que integra todas as linguagens.

Em A tentação do espetáculo total, com referência ao próprio Béjart, escreveu MarieFrançoise Christout:

Misturar todas as artes do espetáculo num deslumbramento de formas e cores, operar a síntese, transportar o público num universo onírico onde seus sentidos diversamente solicitados estejam simultaneamente satisfeitos: tal sempre foi a suprema aspiração. Desde o teatro oriental, a tragédia grega, o mistério medieval até o balé de corte, a ópera-ballet ou o oratório coreográfico e certos espetáculos contemporâneos, as tentativas neste domínio foram constantes ${ }^{158}$.

\footnotetext{
${ }^{156}$ BÉJART, 1981, p. 50.

157 Ibid., p. 219.

${ }^{158}$ CHRISTOUT, 1972, p. 41. Tradução nossa. Texto original: "La tentation du spectacle total: Mêler tous les arts du spectacle dans um ébluissement de formes et de couleurs, en opérer la synthèse, transporter le public dans un univers onirique où ses sens diversement sollicités sont simultanément satisfaits: telle a toujours été la suprême aspiration. Depuis le théâtre oriental, la tragédie grecque, le mystère médiéval jusqu'au ballet de cour, à l'opéra-ballet ou à l'oratorio chorégraphique et à certains spectacles contemporain, les tentatives dans ce domaine ont été constantes".
} 
Em meados dos anos 1970, quando eu já havia regressado ao Brasil e iniciado o trabalho no Teatro de Dança Galpão, Béjart deu início à Compagnie Yantra, mais um nome proveniente do sânscrito e que nomeia uma categoria especial de mandala. A palavra significa “apoio” e, também, “mapear", "reger”. Reunindo profissionais e ex-estudantes do Mudra em produções multimídia, contou em seu repertório com uma peça da ex-colega Maguy Marin, que coreografou Yu-ku-ri. Outra peça da coreógrafa, May B, de 1981, pode ser considerada um exemplo de um dos alvos máximos almejados pelo Mudra: a fusão de linguagens. Ainda uma montagem do grupo Yantra que obteve destaque foi Molière imaginaire, recebida em Paris como a primeira comédia musical francesa. Para Béjart, a Yantra certamente abria a possibilidade de se ir mais a fundo na celebrada aliança entre texto, música e dança e nas experiências coletivas inovadoras. Dominique Genevois, que inclui ainda no rol Notre faust, de 1975 e, no ano seguinte Héliogabale ou l'anarchiste couronné, assinala que as duas companhias - a pequena e a grande - uniam-se em certas produções, dizendo que o nome Yantra não vingou e que só aparecia nos programas esporadicamente. "Será para temperar a suscetibilidade dos bailarinos que não faziam parte desta pequena elite?"159.

Segundo o encenador polonês Jerzy Grotowski (1933-1999), interlocutor de Béjart, uma escola que compreendia canto, percussão, yoga, flamenco e arte dramática não era mais que um projeto. Considerava o teatro enquanto "ato que se cumpre aqui e agora no organismo do ator, realizando um ato total, no qual o ser integrado participa da ação. O que ele faz deve fazê-lo com todo o seu ser" 160 . O ato total nasce "da conjunção de opostos, como a espontaneidade e a disciplina"161. Em viagem à Alemanha em 1910, Stanislavski foi a Capri para visitar Maximo Gorki, que ali vivia desde 1906, reunindo um grupo do qual fazia parte Vladimir Lenine (1870-1924), então cassado da Rússia pelo governo czarista. Gorki levou Stanislavski a Nápoles para que o mestre russo conhecesse Scarpeta e a Commedia dell'Arte italiana. Antes de retornar à Rússia, Stanislavski seguiu à Alemanha, onde conheceu a Antroposofia de Rudolf Steiner e, também, Jacques Dalcroze e a Euritmia. Estudou Budismo, a Teoria da Vontade de La Ribot ${ }^{162}$ e as teses de Marcel Mauss (1872-1950) acerca do grande número de seres humanos que passam a vida desatentos à observação da grande ferramenta

\footnotetext{
159 GENEVOIS, Dominique. Mudra, 103 Rue Bara. Bruxelles: Contredanse, 2016. p. 314. Tradução nossa. Texto original: "Est-ce pour ménager la susceptibilité des danseurs ne faisant pas partie de cette 'petite élite'" ?

${ }^{160}$ GROTOWSKI, Jerzy. Vers un théâtre pauvre. Paris: La Cité, 1971. p. 86.

${ }^{161}$ Ibid., p. 86.

162 O SÉCULO de Stanislavski - Parte 1: Os construtores de utopia. Texto e Realização: Peter Hercombe. Produção: Daniel Renouf. Narração: André Dussollier. Paris: System TV; L'Union des gens de Théâtre de Russie; La Sept, 1993. Exibido no Canal Curta em 6 de setembro de 2016.
} 
oferecida pelo corpo humano, com o objetivo de levar à tomada de consciência da importância do corpo na sociedade. Mauss defende que os atos mais corriqueiros são capazes de revelar a complexidade humana e chega à teoria etnológica do "fato social total", atentando ao "homem total"163 e apontando para a concepção interativa.

Na contemporaneidade, a palavra "total" conheceu um grande desgaste, assim como, por exemplo, a dita "totalidade", que deriva da primeira, ou o termo "totalitário". O professor de Estética da Faculdade de Filosofia da Universidade de São Paulo, Ricardo Fabbrini, referese ao "ideário romântico da obra de arte total" enquanto realização da "função utópica de síntese" ${ }^{164}$, que condensa (e provavelmente engessa) o pensamento. Em um mundo fragmentado, que perdeu seu eixo, é possível compreender o esvaziamento do sentido da palavra.

O pós-modernismo veio constatar a pulverização, mais que a fragmentação, dos esquemas totalizantes aguçados pelo colapso da União Soviética em 1991, dois anos após a queda do muro de Berlim, em 1989. Sepultado encontrava-se o ideário da Revolução Francesa de 1780 e sua sigla totalizante de Igualdade, Fraternidade e Liberdade. O movimento situacionista francês, que vigorou entre 1958 e 1972, coloca a contestação como ponta de lança e princípio epistemológico, a começar pela contestação da totalidade. A energia, é força em ação. Jean-François Lyotard, em citação de Josette Féral, com referência ao teatro pósdramático, evoca um teatro energético não mais calcado no significado, mas "teatro de forças, intensidades, pulsões em sua presença" ${ }^{\text {165 }}$.

Os antigos gregos consideravam o círculo, então denominado clicos, como a forma perfeita, pois se completa em si mesmo, diferentemente do infinito imperfeito, pois neste sempre cabe mais um. $\mathrm{O}$ total supõe a estabilidade, que exclui o movimento. $\mathrm{O}$ esquema dialético coloca a tese, que afirma, a antítese, que nega e, por fim, a síntese, que totaliza, harmoniza, identifica os contrários, cessando o conflito quando este, de fato, é permanente. A tradição da totalidade é hegeliana-marxista. Segundo Nicolas Bourriaud, "não foi a modernidade que morreu, e sim sua versão idealista e teleológica" ${ }^{166}$. Fredrich Jameson já

\footnotetext{
163 DIBIE, Pascal. Mauss, Marcel 1872-1950. In: MARZANO, Michela (Org.). Dicionário do Corpo. São Paulo; Loyola, 2012. p. 639.

${ }^{164}$ FABBRINI, Ricardo. A fruição nos novos museus. Especiaria - Cadernos de Ciências Humanas, São Paulo, v. 11, n. 19, p. 262, jan./jun. 2008.

${ }^{165}$ LYOTARD, Jean-François apud FÉRAL, Josette. Théorie et pratique du théâtre: au-délà des limites. Paris: L'Entretemps, 2011. p. 108. Tradução nossa. Texto original: "théâtre des forces, des intensités, des pulsions dans leur présence".

${ }^{166}$ BOURRIAUD, 2009, p. 17.
} 
havia se referido à necessidade de deixar para trás "os velhos fantasmas representados pelos males da totalização ou da teleologia"167. É a visão hegeliana totalizadora e idealizante da História que está sendo posta em cheque. No debate atual, o império da razão, incluindo o Iluminismo, ou Aufklerung kantiano, bem como a crença na razão e a ideia de progresso vão decrescendo em prol das relatividades e incertezas e o conceito de "total" perde terreno.

Em seu artigo Teatralidade e performatividade na cena contemporânea ${ }^{168}$, Silvia Fernandes constata a partilha de indefinição de um estatuto epistemológico no teatro contemporâneo, na dança, nas artes plásticas e no cinema, pois os territórios híbridos e fluidos rejeitam a totalização, ou seja, polifonia sim, totalidade não.

Ao analisar o pensamento de Michel Foucault, Deleuze substitui as estratégias e táticas de conjunto que, ao invés de procederem por totalização, o fazem por "transmissão, concordância, convergência, prolongamento" ${ }^{\text {169 }}$. Deleuze e Guattari, ao emprestarem o conceito de "rizoma" da Biologia, o qual percorre infinitas tramas, admitem: "Falamos exclusivamente disto: multiplicidades, linhas, estratos e segmentações, linhas de fuga e intensidades, agenciamentos maquinais e seus diferentes tipos" ${ }^{\prime 170}$. Esse conceito está bem distante de "totalidade", palavra da qual veio a derivar-se, inclusive, o termo "totalitário", quando os poderes Executivo, Legislativo e Judiciário passam a se concentrar nas mãos de poucos. Há muitos conceitos que viajam de um autor a outro, como a nietzschiana indagação expressa em Ecce homo quanto àquilo que faz um indivíduo tornar-se o que é, retomada posteriormente por Michel Foucualt, que também citou a premissa beckettiana: "Que importa quem fala, alguém disse que importa quem fala", acrescentando que, a partir do momento em que "o sujeito absoluto já não existe mais, o sujeito coletivo deve substituir o sujeito individual" ${ }^{\prime 71}$.

O termo "mapmaking", ou "cartografia", relacionado a um dos conceitos da palavra "Yantra", provém do empirista norte-americano William James. Já "rizoma” é "mapa que deve ser produzido, construído, sempre desconectável, reversível, modificável, com múltiplas entradas e saídas com suas linhas de fuga" ${ }^{\text {172 }}$. Além de múltiplos, são flexíveis:

\footnotetext{
167 JAMESON, Fredric. "Fim da arte" ou "fim da História"?. Petrópolis, RJ: Vozes, 2001b. p. 72.

${ }^{168}$ FERNANDES, Sílvia. Teatralidade e performatividade na cena contemporânea. Revista Camarim, São Paulo, n. 46, p. $20,1^{\circ}$ semestre de 2012.

${ }^{169}$ DELEUZE, 1988, p. 40.

${ }^{170}$ DELEUZE, Gilles; GUATTARI, Félix. Mil platôs: capitalismo e esquizofrenia. v. 1. Rio de Janeiro: Editora 34, 1995. p. 12.

${ }^{171}$ FOUCAULT, Michel. Conférence Queest-ce queuun auteur ? [1969] publiée dans Dits et Écrits, 1954-1988, vol. 1, Paris, Gallimard, 789-820. Tradução nossa.

${ }^{172}$ DELEUZE; GUATTARI, op. cit., p. 32.
} 
As multiplicidades são rizomáticas. São fios, hastes que movem as marionetes, formando uma trama [...]. Princípio de multiplicidade: é somente quando o múltiplo é efetivamente tratado como substantivo, multiplicidade, que ele não tem mais nenhuma relação com o uno como sujeito ou objeto, como realidade natural ou espiritual, como imagem e mundo. As multiplicidades são rizomáticas e denunciam as pseudomultiplicidades arborescentes ${ }^{173}$.

Curiosamente, o conceito é derivado de Antonin Artaud, que escreveu:

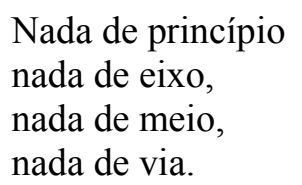

As coisas não começam por estritamente nada, pela boa razão de que elas não existem, e que há somente corpos ou objetos, que não são coisas mas corpos e objetos inqualificáveis, e ainda mais concreto e indeterminados ${ }^{174}$.

Ainda ao analisar o pensamento de Michel Foucault, Gilles Deleuze substitui as estratégias e táticas de conjunto que, ao invés de procederem por totalização, o fazem por "transmissão, concordância, convergência, prolongamento"175.

Palavras como "identidade", "raça", "cultura" e mesmo "história" vêm sendo igualmente questionadas e até rejeitadas por remeterem a conceitos estáticos, sem mobilidade. Até "liberdade", examinada de perto, insere-se no contexto liberal, o que é discutível. A palavra "espetáculo" também parece, hoje, deslocada. Proveniente de "opsis", ou "visão", remete a produções destinadas a "encher os olhos". Prefiro a denominação "peças de dança". O termo "tradição", caro a Béjart, mas muitas vezes execrado, foi salvaguardado por Walter Benjamin, ao reconhecer que a "tradição é uma realidade bem viva e extremamente mutável"176.

No contexto que nutriu o nascimento do Mudra, a ideia de total remetia ao Oriente por meio de um dos nossos mentores-motores principais: Antonin Artaud. O nome Mudra já aponta para uma direção oriental. Béjart citava a dança indiana, não intelectual, antes religiosa

\footnotetext{
${ }^{173}$ DELEUZE; GUATTARI, 1995, p. 32.

174 ARTAUD, Antonin. Suppôts et Suppliciations. In: THÉVENIN, Paule. Oeuvres complètes d'Antonin Artaud. v. 14. Paris: Gallimard, 1978. p. 77. Tradução nossa. Texto original: "Pas de príncipe, pas d'axe, pas de milieu, pas de voie. Les choses ne commençant par rien du tout, pour la bonne raison qu'elles ne sont pas, et qu'il n'y a que des corps ou objets, qui ne sont pas choses mais corps et objets inqualifiables, et d'autant plus concrets qu'ils sont indeterminés".

${ }^{175}$ DELEUZE, 1988, p. 40.

${ }^{176}$ BENJAMIN, Walter. A obra de arte na época de sua reprodutibilidade técnica: In: ADORNO et al. Teoria de cultura de massa. Trad. de Carlos Nelson Coutinho. São Paulo: Paz e Terra, 2000.
} 
e intuitiva. Se o Oriente produz autoconhecimento, o Ocidente produz individualismo, forma de egoísmo. O coreógrafo costumava dizer que a cisão carne-espírito foi criada artificialmente para separar coisas que não são antagônicas e ficar todo o tempo tentando (re)uni-las. Em seu apreço pela dança enquanto ritual, constata no século XX um novo momento:

Tal renascimento da dança, tal desabrochar, deu-se no momento em que a Europa tratou enfim de respeitar a arte e as linguagens dos outros continentes. Pintores e escultores abriram caminho inspirando-se na arte negra. A música virá mais tarde, e será a descoberta das músicas orientais, do Japão, de Bali, da Índia. Será enfim o impulso extraordinário que experimentam há uns vinte anos os grupos de dança vindos de países longínquos, sejam de folclore russo ou do kathakali hindu ${ }^{177}$.

No Ocidente, principalmente em alguns países desenvolvidos da Europa, a cultura é eminentemente literária, livresca. Quem apontou a característica foi Artaud. O texto $O$ teatro e os deuses deixa claro: propõe que o teatro vá ao encontro de outros meios e outras dimensões e sugere que a linguagem do texto volte aos livros, de onde nunca deveria ter saído. Muitos foram os homens de teatro do século XX habitados pelas visões de Artaud. O diretor inglês Peter Brook voltou-se às culturas africana e asiática e incorporou ao seu trabalho temáticas e atores dessas proveniências, inclusive estabelecendo-se com sua trupe no continente africano por vários anos. Brook referiu-se a Artaud:

$\mathrm{Na}$ França um gênio iluminado. Antonin Artaud, escreveu trechos descrevendo a partir de sua imaginação e intuição um outro teatro [...]. Um teatro funcionando como uma praga, pela intoxicação, a infecção, pela analogia, pela mágica; um teatro em que a peça, o próprio evento, ergue-se no lugar do texto [...]. [...] explosões imediatas e poderosas da questão humana, de tal modo que ninguém mais poderia voltar a praticar um teatro da anedota e da conversa. Ele almejou um público que se despojasse de todas as suas defesas, que permitisse a si mesmo ser perfurado, chocado, assustado e violado, de tal modo que pudesse, ao mesmo tempo, ser preenchido por uma poderosa carga nova. Como todos os profetas, devemos separar o homem de seus seguidores. Artaud nunca conseguiu realizar o seu próprio teatro ${ }^{178}$.

\footnotetext{
${ }^{177}$ BÉJART, 1981, p. 103.

${ }^{178}$ BROOK, Peter. The empty space. Middlesex, ING: Penguin, 1968. p. 55-61. Tradução nossa. Texto original: "in France an illuminated genius, Antonin Artaud, wrote tracts describing from his imagination and intuition anoter theatre [...] A theatre working like the plague, by intoxication, by infection, by analogy, by magic; a theatre in which the play, the event itself, stands in pace of a text [...] powerful immediate explosions of human matter that no one would never again revert to a theatre of anecdote and talk [...] he wanted an audience that would drop all its defences, that woul allow itself to be perforated, shoked, startled, and raped, so that at the same time it could be filled with a powerful new charge [...] As with all prophets, we must separate the man from his followers. Artaud never achieved his own theatre".
} 
Indaga ainda Brook: "Existe uma outra linguagem, além das palavras? Existe uma linguagem de ações, uma linguagem de sons, uma linguagem de palavras como parte do movimento" 179 . Genuíno representante do que o encenador inglês intitulou "teatro sagrado", o visionário Artaud deixou marcas inquestionáveis, inclusive na Performance, por sua radicalidade extremada. Para Brook, Jerzy Grotowski foi quem mais se aproximou dos ideais do teatro artaudiano. Grotowski fez do despojamento um ideal. Seus atores se abstiveram de tudo, com exceção de seus próprios corpos, segundo Brook, oferecendo-se como em uma cerimônia, entendida como uma religião sem religião, em que têm lugar tanto a apoteose quanto a derrisão.

Ariane Mnouchkine, a diretora do Théâtre du Soleil, em Paris, que, como Béjart, sempre foi adepta dos elencos multiétnicos, buscou no teatro asiático soluções formais, segundo a ex-colega e amiga Juliana Carneiro da Cunha, dançarina e atriz que, desde o início dos anos 1990, tornou-se atriz da trupe comandada por Ariane, a qual visitou países asiáticos com mochila nas costas na primeira metade dos anos 1960 antes de iniciar sua própria trajetória teatral. $\mathrm{O}$ intuito de ir à China precisou ser modificado devido à dificuldade na obtenção de visto naquele país. Esteve, então, na Índia e no Japão. A encenadora, cujo pai era russo, conhecia até então migalhas do teatro oriental, às quais teve acesso no Théâtre de Nations, em Paris. A máscara, o gesto, a imaginação que é fermentada pelo corpo e, sobretudo, a oposição "ao perigoso realismo ocidental" marcaram definitivamente a estética de Ariane, que, como cidadã participante das questões políticas de nosso tempo, elegeu com frequência temas sociais do presente inseridos em um contexto remoto, o que lhe permitiu atingir uma estética do maravilhoso com toda a grandeza que esse termo comporta no sentido grego, não apenas enquanto indução à curiosidade, mas no sentido mítico profundo que carrega. Tal diretriz foi sempre capaz de acolher e encantar plateias com cerca de seiscentos espectadores por sessão ${ }^{180}$.

Jerzy Grotowski, que, como Ariane e conforme assinalado, integrou o comitê artístico do Mudra em seus primórdios, considerou que, após a era Stanislavski e a era Brecht, o visionário Artaud ocupou a posição de ponta, ainda que tenha sido, por vezes, trivializado e fosse difuso seu pensamento. $\mathrm{O}$ encenador polonês esclareceu que o emprego da palavra

\footnotetext{
${ }^{179}$ BROOK, 1968, p. 55.

${ }^{180}$ Em 1999, Ariane e Juliana hospedaram a mim e minha filha em Paris e cederam-me o estúdio do Théâtre du Soleil para trabalhar. Acompanhei nos bastidores e assisti a muitas sessões de Tambour sur la digue, que estreou naquele momento. Outras informações foram obtidas através da emissão televisa L'aventure du Théâtre du Soleil, exibida pelo Canal Curta em 6 de janeiro de 2015.
} 
“encantação" deriva do poeta e conterrâneo Adam Mickiewicz (1798-1855) e não de Antonin Artaud, que só veio a conhecer em 1964, e sublinhou que Artaud não realizou, mas pressentiu um teatro que transcendesse a razão discursiva e a psicologia, seguindo uma via "a-lógica, quase invisível e intangível"181.

Pode não ter sido o primeiro a fazê-lo, uma vez que Max Reinhardt (1873-1943), na Alemanha, já havia o efetuado, mas Artaud reiterou a necessidade de se suprimir a barreira palco-plateia. Roose-Evans comenta:

\begin{abstract}
Algumas ideias de Artaud não eram, certamente, originais; elas já tinham sido exploradas por Appia, Meyerhold e Reinhardt. Os dois últimos já tinham experimentado quebrar a barreira entre a audiência e os atores, enquanto Meyerhold tinha demonstrado repetidamente que o teatro era um ato criativo em si mesmo, e não simplesmente a ilustração de um texto dramático. O ponto, no entanto, é que Artaud descobriu essas coisas para si mesmo e para o teatro francês ${ }^{182}$.
\end{abstract}

Grotowski evoca, ele mesmo, o teatro sagrado: "Quer falemos do drama medieval europeu, do teatro balinês ou do Kathakali da Índia: este é o conhecimento do fato que a espontaneidade e a disciplina, longe de se enfraquecer uma à outra, se reforçam mutuamente" ${ }^{, 183}$. O ato total nasceria dessa conjunção de opostos.

Em suma, tantos encenadores insurgiram-se contra o logocentrismo ocidental, apesar de o vocábulo "logos" corresponder a "sentido", o que aprofunda a acepção do termo. Os pioneiros da dança moderna americana, nas primeiras décadas do século XX, tiveram o mesmo impulso, o mesmo estímulo. Ted Shawn, "fundador em 1914, com sua esposa Ruth Saint Denis, da primeira escola de dança moderna dos EUA" ${ }^{\text {184 }}$, dizia que todo movimento pode ser um assunto, não apenas o corpo ocidental. Doris Humphrey, que, tal como Martha Graham, foi dançarina da Denishawn, partiu por dois anos em tournée à Ásia, voltando fascinada com o que viu.

\footnotetext{
${ }^{181}$ GROTOWSKI, 1971, p. 86. Tradução nossa.

182 ROOSE-EVANS, James. Experimental Theatre. New York: Avon Books, 1971. p. 197. Tradução nossa. Texto original: "Some of Artaud's ideas were, of course, not original; they had already been pionnered by Appia, Meyerhold and Reinhardt. The last two had experimented with break down the barrier between audience and actors, while Meyerhold had demonstrated again and again that theatre was a creative act in itself, and not simply the illustration of a dramatic text. The point is, however, that Artaud was discovering these things for himself and for the French theatre".

${ }^{183}$ GROTOWSKY, op. cit., p. 89. Tradução nossa. Texto original: "que nous parlions du drame medieval européen, du théâtre balinais ou du Kathakali des Indes : cette connaissance du fait que la spontaneité et la discipline, loin de s'affaiblir l'une l'autre, se renforcent mutuellement".

${ }^{184}$ SUQUET A., 2009, p. 522.
} 
Expressões surgidas no pós-Segunda Guerra, como o Butoh japonês, podem ser consideradas como um diálogo entre oriente e ocidente, uma vez que Kazuo Ohno teve seu insight ao ver dançar La argentinita, embora seu filho Yoshito, também coreógrafo, tenha afirmado que o Butoh, iniciado por seu pai, Min Tanaka e Tatsumi Hijikata, teria nascido de uma orientação de reparar a culpa do Japão enquanto agressor do Ocidente durante a Segunda Guerra Mundial. Outros coreógrafos e artistas orientais mais recentes, como a companhia de Sankai Juku ou Yoko Ono, ocidentalizaram-se, adaptaram-se. Esta, ao promover a aliança entre Ocidente e Oriente, juntou-se ao caldo da contracultura dos anos sessenta, que também trazia no bojo elementos orientais como o budismo e outros. Ainda uma vez, evidenciam-se as "pontes de Ponty", ou o "cozer em caldeirões".

É possível que o "total" para Béjart o tenha levado ao ecletismo, a uma mistura de tendências e estilos. Quando o coreógrafo colocou em cena, explicitamente, divindades hinduistas como Shiva ou Bahkti, comparo-o ao artista engajado cuja arte não é, ou seja, as convicções pessoais mantêm-se na pessoa, e não na obra.

Estaria Béjart buscando uma nova seiva no Oriente ou na diversidade étnica e juventude do pequeno grupo de mudristas, uma vez que reiterava a importância da presença, em Bruxelas, de candidatos provenientes dos cinco continentes? Ou ambos?

\subsection{Brasil, ame-o ou deixe-o}

No final dos anos 1960, enquanto estudante da Faculdade de Filosofia da Universidade de São Paulo entre 1968 e 1970, junto a outros colegas, passei muitas noites guardando o prédio da Rua Maria Antônia das forças da repressão e dos possíveis ataques por parte dos estudantes do Colégio e Universidade Presbiteriana Mackenzie, situado em frente, muitos dos quais integrantes do Comando de Caça aos Comunistas, o CCC. Alguns se colocaram, estrategicamente, no teto da instituição citada para melhor enxergar e atacar a Faculdade de Filosofia da USP, situada em frente. O então presidente da União Estadual dos Estudantes (EEE), José Dirceu, exortava: "Nossa posição será de autodefesa. Não atacaremos jamais", em um conflito que teve início com ovos contra pedras e culminou com a morte do estudante 
secundarista José Guimarães, o que provocou a passeata de 4 de outubro de 1960 pedindo paz e na qual foi erguida a camisa ensanguentada do morto como bandeira ${ }^{185}$.

A própria palavra "comando", presente no título do $\mathrm{CCC}$, é autoritária, pois corresponde a “,mando“e partilhado”. Já havia confrontado alguns de seus membros em 1963, no início da adolescência, em Campinas, em um congresso estudantil durante o governo de João Goulart, com a particularidade de que, naquele momento, os contingentes policiais intervinham para conter as bombas de gás lacrimogênio lançadas pelo CCC em recinto fechado. Optei pelos estudos universitários de filosofia por influência da professora Margot Proença (1933-1970), que diferia em muito do padrão do corpo docente do Colégio Estadual Culto à Ciência, fundado por maçons em 1869 e inaugurado em 1874 com o intuito de fornecer uma educação laica aos estudantes. O nome já estabelece a influência positivista. Tombado em 1983, o estabelecimento encontra-se situado na rua de mesmo nome no bairro do Botafogo, em Campinas, cidade onde nasci e vivi até os 18 anos de idade.

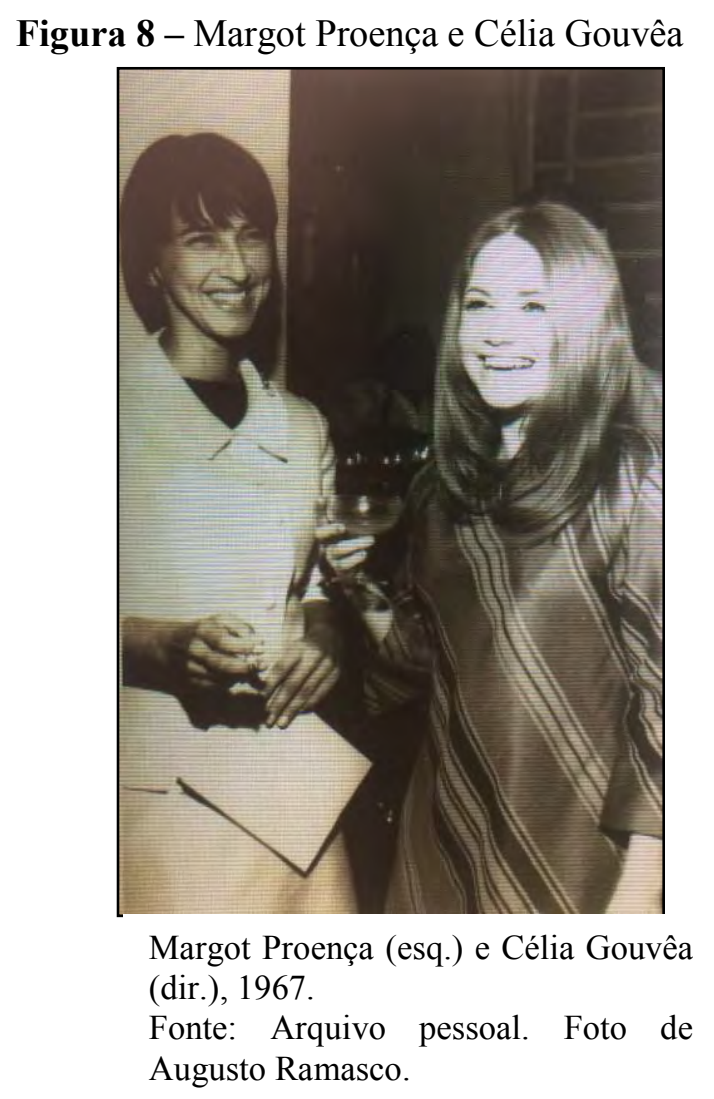

\footnotetext{
${ }^{185}$ Matérias não assinadas do Jornal da Tarde (4 de outubro de 1968) e da Folha de São Paulo (5 de outubro de 1968) expõem os fatos. O então estudante da FAU/USP Hiroto Yoshioka fotografou. As matérias compõem exposição inaugurada no edifício da Rua Maria Antônia em agosto de 2017.
} 
Terceira filha mulher, a do meio entre cinco irmãos, estudei sempre em escolas públicas, com exceção do terceiro ano do colegial, quando deixei o Culto à Ciência por divergências com a professora de Educação Física, matéria que não queria mais cursar para poder melhor me preparar para o vestibular e pelo fato de já praticar dança. As aulas de Educação Física aconteciam em período do dia diverso das demais aulas, obrigando os alunos a um novo deslocamento. Além de já praticar dança, minha estatura baixa nunca combinou com os jogos de vôlei ou basquete. Meus tios paternos eram voltados à música, literatura e filosofia, incentivando-me desde cedo ao cultivo das artes e da literatura. O avô pastor, professor de Grego antigo e Retórica no Seminário Presbiteriano de Campinas, pouco falava em família, embora célebre na prática da homilética, a arte de pregar sermões religiosos. Podia contar piadas ou soltar versos poéticos, mas não admoestava ninguém, enquanto o pai advogado obrigava os filhos a frequentar assiduamente a Escola Dominical da Igreja Presbiteriana, situada entre as ruas Bernardino de Campos 636 (frente) e General Osório 636 (fundos), em um prédio branco ainda existente.

Fizesse chuva ou sol, o pai era pontual na hora de nos conduzir à Igreja, mas não tanto na saída, e minhas irmãs e eu ficávamos muito tempo na esquina esperando, quando todos já tinham ido embora. O quadro postado na parede da instituição com uma estrada estreita e com poucos atrativos e que conduzia ao céu, ao lado da outra pintura, larga, habitada por bêbados e fanfarrões e que conduzia ao inferno, povoou-me por muito tempo. Tratava-se de uma ilustração da passagem bíblica "As duas estradas", do Novo Testamento, no evangelho de Mateus, capítulo 7, versículos 13 e 14, encontrada também em Lucas, 13:22 a 29, com a denominação "A porta estreita", ilustração esta que contém imagens tais como "choro e ranger de dentes", primórdios prováveis da coreografia Assim seja?, de 1984. Em carta escrita de Bruxelas ao meu pai no início dos anos 1970, dizia que a estrada estreita exortava as pessoas a viverem sem intensidade. As imagens devem ter contribuído para deixar um lastro de rigidez de caráter, acrescido à ruivice herdada da avó paterna. No entanto, foi no palco do auditório da Escola Dominical, em uma das comemorações festivas, que me pediram para dançar e, assim, alguns entre o público presente disseram aos meus pais que eu tinha jeito e deveria aprender dança. Aos nove anos, segui aulas de balé com Juary Trondi, que havia trabalhado com Lina Penteado (1928-2016). Ela havia transformado o quarto de empregadas no fundo da sua casa em um pequeno estúdio, munido de barras e espelhos. Na sequência, duas vezes por semana, passei a frequentar o Conservatório Musical Dr. Gomes Cardim, onde ensinava a professora cubana Rosario Martinez, mas as aulas consistiam em ensaios do repertório folclórico mundial para que as alunas se apresentassem em cidades do interior do 
estado de São Paulo. Em minha casa, era chamada de "Rosario estamos perdidos", aludindo ao dia em que o ônibus para a excursão veio buscar-me e demorou a encontrar o endereço. Era o ano de 1959, que marcou a Revolução Cubana. Se a professora de dança era contra ou a favor, nunca soube. Ingredientes de uma educação burguesa, estudava piano e balé.

Na primeira adolescência, visitava favelas aos sábados e, segundo a irmã mais velha, queria salvar o mundo. Ia à Vila Pacaembu (hoje Jardim Pacaembu) acompanhada por amigas que queriam pagar promessa. Em uma das vezes, uma delas vomitou ao entrar em um barraco mal cheiroso. Posteriormente, passei a ir acompanhada por um médico evangélico, ocupandome de preparar as fichas para o atendimento. Um dia, o médico espantou-se ao examinar, lá, uma mulher grávida de seis meses que desconhecia sua gravidez. Certo dia, eu carregava na rua um grande saco de balas para distribuir. Ao cruzar com um amigo, ele me disse: "Isto é paternalismo", o que deve ter mexido comigo. Naquele momento, a intenção era a de cursar Serviço Social ao término do curso colegial. Apesar de não ser católica, frequentava as reuniões da Juventude Estudantil Católica, a JEC, que juntamente com a Juventude Operária Católica, a JOC, e a Juventude Universitária Católica, a JUC, formavam o tripé apoiado pela vertente da Igreja Católica Progressista.

A irupção de Margot foi definitiva. Sua morte trágica aguçou a importância de sua presença, não apenas em mim, mas certamente em muitos colegas. Logo no primeiro dia de aula de filosofia, deu uma frase de Kant para analisarmos. Tirei a nota mais alta da classe. Fiquei achando que poderia fazer algo com aquela matéria. Queria também deixar a família e a cidade natal. Em 1968, ingressei na Faculdade de Filosofia da Universidade de São Paulo (USP) e passei a transitar entre a dança e a filosofia, o que faço até hoje. Passei no vestibular, tendo sido arguida no exame oral pelo temido professor José Arthur Gianotti. Traço de sua geração, era autoritário e tendia a tratar os alunos como ignorantes equivocados, o que conduzia mais à inibição que ao incentivo pelo gosto alegre e curioso do saber, que gera a philos-sofia.

Participei das passeatas organizadas no período, embora nunca tenha mantido uma filiação político-partidária, conservando uma independência de pensamento, extensiva à vida profissional. O edifício da USP da Rua Maria Antônia, $n^{\circ}$ 249, havia sido adquirido do antigo Liceu Rio Branco. Nele, a partir de 1949, passaram a funcionar os cursos História Natural, Química, Letras, Filosofia, Geografia, Ciências Sociais, Pedagogia e Psicologia. No ano seguinte ao meu ingresso, 1969, os cursos deslocaram-se para a Cidade Universitária. O prédio da Maria Antônia ficara extremamente danificado devido à guerra travada com integrantes do Mackenzie. 
As novas dependências da USP eram formadas pelos mesmos edifícios em concreto que se encontram lá hoje, mas o entorno era despido de qualquer árvore. Um campus desprovido de áreas verdes, que custaram a aparecer. Lá estudei, entre outras matérias, Sociologia, Teoria do Conhecimento e Teoria da Literatura, esta com o professor Roberto Schwarz, em 1969. Em dezembro do ano anterior, o regime militar baixara o Ato Institucional $\mathrm{n}^{\circ} 5$ e, entre outras medidas arbitrárias, afastou excelentes professores ainda bastante jovens, que foram proibidos de lecionar por determinação do governo.

Ganhava, então, a vida como professora de rítmica e ginástica feminina em colégios e clubes, com carteira de trabalho assinada. Lecionava Dança também no estúdio de Renée Gumiel. Na placa do prédio de dois andares, lia-se: "Ballet Moderno", para não afugentar possíveis clientes potenciais. Renée considerava expressão mais palatável e atraente do que "Dança Moderna", apesar de ter sido uma das principais introdutoras da dança moderna em São Paulo. O prédio de dois andares no endereço Rua Augusta, $\mathrm{n}^{\circ}$ 877, continha no primeiro andar, o estúdio e, à esquerda, o vestiário, que podia ser acessado por uma escada de cerca de 25 degraus. Logo ao se abrir a porta, via-se uma pequena mesa onde atendia a secretária. À sua frente, de perfil, foi ali que vi, pela primeira vez, Maurice Vaneau, meu companheiro nos 37 anos seguintes. Renée vivia com a família no segundo andar.

Entre 1951 e 1954, Renée teria feito uma primeira estadia no Brasil e voltado em 21 de maio de 1957, quando se deu sua nova entrada no País. Segundo consta do registro de seus documentos, seu nome de nascimento era Annie Amélie Schoeneberg e nascera em Colônia, na Alemanha, filha de Max e Marguerite Schoeneberg. Renée adotou o nome Gumiel de seu marido espanhol Rafael Gumiel Lopez, proveniente de Valença e com quem se casou no Brasil em 1967. Judia, Renée teria tido um número de identificação marcado no braço, impresso por nazistas, removido por meio de uma cirurgia plástica já no Brasil ${ }^{186}$.

Fruto da corrente expressionista, induzia seus alunos a buscarem movimentos que brotassem "de dentro". Comunicava um grande apreço ao espetáculo e ao profissionalismo, como atitude e comportamento. Fui também integrante do grupo de dança dirigido por Renée, o Dança Contemporânea Brasileira. Foi em uma produção da tragédia Fedra, para o II Festival de Dança, organizado por Miroel Silveira (1914-1988), no Theatro São Pedro, em 1969, que conheci meu futuro marido, o diretor teatral Maurice Vaneau, que realizou a direção, figurinos, cenários e iluminação para a montagem.

\footnotetext{
${ }^{186}$ Informações fornecidas pela advogada Dra. Elza Andreazzi, que prestou serviços a Renée por cerca de quarenta anos. A Dra. Elza forneceu-me cópias dos documentos comprobatórios.
} 
Figura 9 - Anúncio do $2^{\circ}$ Festival de Dança, 1969

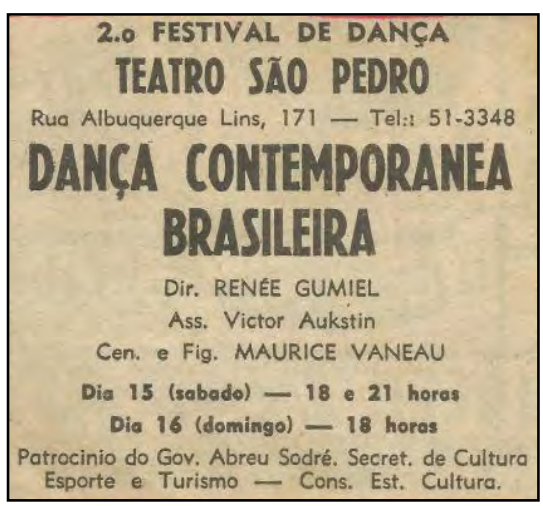

Fonte: arquivo pessoal.
Figura $10-$ Bernadette Figueiredo (primeiro plano) e Célia Gouvêa no Estúdio do Ballet Renée Gumiel, 1969

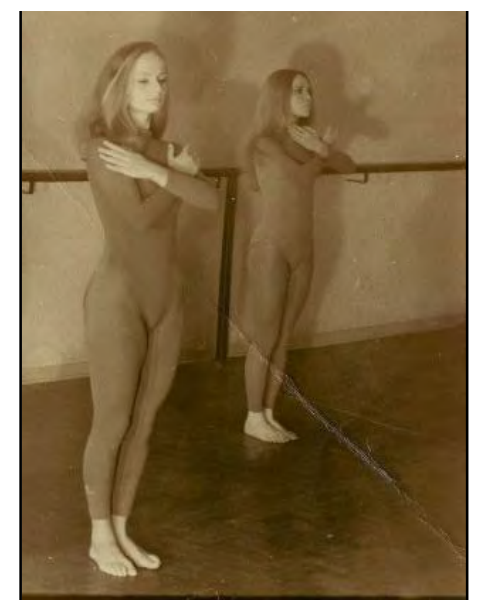

Fonte: arquivo pessoal.

Miroel, o organizador, foi professor de ambas as escolas: a de Arte Dramática e a de Comunicações e Artes da Universidade de São Paulo. Homem de teatro afeito à dança, organizou, no ano anterior, em 1968, uma primeira edição do Festival no Serviço Social do Comércio, o SESC, na unidade Consolação, então denominado SESC Anchieta. Acompanhei a programação, que apresentou, entre outras, duas vertentes distintas da dança. Ambas interessavam-me. Uma foi a Cia. Brasileira de Ballet do Teatro Novo do Rio de Janeiro, que encomendou a Marlos Nobre (nascido em 1939) a composição musical para dez instrumentos de percussão intitulada "Rhythmetron". A coreografia tinha cenário de Gianni Ratto (19162005), milanês radicado em São Paulo desde 1954. O balé empregava sapatilhas de ponta de um modo renovado, antecipando minha convivência que se avizinhava com a companhia de Maurice Béjart.

A outra vertente, arrebatadora e antecessora dos propósitos que alimentaram a arte desenvolvida no Teatro de Dança Galpão (1974-1981), foi o grupo Sonda, dirigido pelo casal Maria Esther Stockler e José Agrippino de Paula, com os atores muito corporais Stênio Garcia e Ariclê Perez no elenco. O grupo propunha uma visão particular da América Latina - cruel e lúdica. No final de $O$ rito do amor selvagem, apresentado no Theatro São Pedro, um dos atores lançava à plateia uma imensa bola, desenhada pela artista Amélia Toledo. Trocada 
entre os espectadores, que a lançavam uns aos outros, a bola provocava uma intensa e contagiante interação lúdica.

A mestra Renée compunha danças nas quais propunha que improvisássemos. Não sabia ao certo se se tratava de um método ou de falta de domínio do fazer coreográfico. Certo é, porém, que com ela comecei a improvisar, porta para a criação em dança. Sua figura exótica tinha sempre às mãos um cigarro que não tragava, a exemplo de Marlene Dietrich, e cujas longas cinzas, curiosamente, nunca caiam no chão, segundo observação da bailarina Patty Brown. Renée encarnava um exemplo modernista clássico. Era personalista e possessiva. Culta e inspirada, estimulava o gosto pela música eletrônica, mais difundida na Alemanha, e pela música concreta, pesquisada, sobretudo, na França, embora o programa da temporada bruxelense de 1960-1961, referente à montagem do drama coreográfico Orphée, com coreografia de Béjart e música concreta de Henry, mencione que "desde 1958 Pierre Henry persegue suas pesquisas puras associando as experimentações eletroacústicas e procedimentos eletrônicos. Sua tendência atual é de misturar essas duas técnicas" ${ }^{\text {"187 }}$. Certo é que, para o compositor francês, ruído e som se equivaliam.

Eu ouvia e apreciava compositores como Olivier Messiaen, Maurice Ohana, Pierre Boulez e, notadamente, Pierre Henry, tão caro a Béjart. Curiosamente sentia-me mais próxima de tais compositores do que dos Beatles, por exemplo, ícones da minha geração. Em comum com meus pares, ouvia muito a Música Popular Brasileira (MPB), que ajudava a temperar a seriedade e preencher vãos afetivos. Quem me introduziu nas técnicas codificadas de dança moderna foi Ruth Rachou. Nascida Ruth Margarido da Silva, a exemplo de Renée, adotou o nome de Gastão, seu marido. Ruth foi minha professora desde a adolescência na Academia de Ballet Lina Penteado, em Campinas. Em 1967, um ano antes de instalar-me em São Paulo, Ruth coreografava e levava o grupo de alunas para dançar na televisão em São Paulo, nos canais Rede Record e TV Tupi, nos programas Jardim Encantado, Ginkana Kibon ou na abertura de $O$ Fino da Bossa, com Elis Regina e Jair Rodrigues. Certa vez, dançamos em um show do Cantor Agnaldo Rayol, que acabara de conquistar o prêmio de "O Rei da Voz". O cantor solicitou ao nosso grupo que a mais valente fosse ao microfone dar sua mensagem, e lá fui eu. A própria Lina Penteado nos acompanhava nas viagens feitas em uma perua kombi e, após as apresentações, nos oferecia um lanche antes de voltarmos a Campinas, sempre na

\footnotetext{
${ }^{187}$ Tradução nossa. Texto original: "Depuis 1958 Pierre Henry poursuit ses recherches pures em y associant les expérimentations électroacoustiques et les procedés électroniques. Sa tendance actuele est le mélange de ces deux techniques".
} 
mesma padaria, a Cisne - que existe até hoje, na esquina das ruas Pedroso de Moraes e Inácio Pereira da Rocha, no bairro de Pinheiros.

Nos anos de 1967, 1969 e 1972 Ruth participou do American Dance Festival, em Connecticut, nos Estados Unidos. Ela nos ensinava em São Paulo, meticulosamente, as técnicas lá aprendidas. Foi Ruth quem me recomendou que procurasse o estúdio de Renée ao chegar em São Paulo, onde ela mesma ensinava antes de ter sua própria escola, que funcionou em vários endereços.

Entre 1968 e 1970, eu rodava a cidade de São Paulo diariamente de ônibus da Faculdade ao trabalho. Uma aula de dança moderna aqui, outra de clássico ali... A prática de muitas técnicas em um só lugar era um sonho. Apesar da maior afinidade com a dança moderna, achava que precisava do balé para o fortalecimento técnico. Queria que minha perna fosse alta, que subisse. Queria saltar, girar. Fazia aulas de balé no pequeno estúdio que Marika Gidali mantinha nos Jardins, na rua Sarandi, em uma travessa de apenas um quarteirão que tinha a Rua Bela Cintra como uma das pontas. Um de meus colegas ali era Ivaldo Bertazzo. Foi lá que, certo dia, Clarisse Abujamra comentou que tinha saído no jornal uma notícia acerca de um novo centro multidisciplinar em Bruxelas, dirigido pelo coreógrafo Maurice Béjart e aberto a candidatos do mundo todo com idade entre 15 e 21 anos. Dirigi-me ao consulado belga para maiores informações e resolvi tentar a sorte. Não sabia que quem trouxera a notícia, publicada nos jornais, fora meu futuro parceiro Maurice Vaneau. Viajei para Bruxelas com apenas uma passagem de ida, o que era possível em 1970, para fazer a audição. Acabei por escolher a dança em detrimento da filosofia, declarando, então, a um amigo, que não queria viver a vida atrás de um livro.

Optei por deixar o País no ano da conquista pelo Brasil do tricampeonato na Copa do Mundo de Futebol, realizada no México em 1970. A vitória foi, aqui, encampada pelo regime militar por meio da canção "Pra frente Brasil", espécie de hino ufanista que exaltava a competência futebolística brasileira. Os militares quiseram apropriar-se daquela vitória e o presidente Médici chegou a enrolar-se em uma bandeira brasileira. Em 1969, assumira o governo do País o terceiro general desde o golpe civil-militar de 1964: o General Emílio Garrastazu Médici, que implantou o período mais violento de toda a ditadura e permaneceu no poder entre 1969 e 1974. Ainda em 1970, nesse país sempre plural, ocorreu a estreia de $O$ corpo é a obra, um exercício experimental de liberdade performado pelo artista plástico Antonio Manuel no Museu de Arte Moderna do Rio de Janeiro no qual o artista pendurava-se $\mathrm{nu}$, em um ato primeiramente recusado na mostra oficial, mas que contou com o apoio do 
crítico de arte Mário Pedrosa, que considerava a arte algo maior que um regulamento e incentivava a imaginação criativa, encorajando os artistas à liberdade.

Face ao slogan "Brasil, ame-o ou deixe-o", resolvi deixá-lo. Corruptela do "love it or leave it" estadunidense durante a Guerra do Vietnã, era mais uma imitação entre tantas do modelo norte-americano. A tríplice opção de vida naquele momento apresentava o caminho da luta armada, do imobilismo ou o da contracultura. Esta, fomentada desde os anos 1940 pelos beatniks estadunidenses, atingiu o ápice nos anos sessenta. Respondendo ao encenador José Celso Martinez Corrêa, a contracultura não era contra a cultura de jeito nenhum, muito ao contrário. Incluiu, sim, o "pé na estrada", ou On the road, celebrado por escritores como Jack Kerouac, que, no filme realizado sobre sua vida, Jack Kerouac: king of the beats ${ }^{188}$, afirmou ter permanecido na estrada por sete anos para escrever seu livro em apenas três. Um dos mentores do movimento beatnik viveu no século XIX: Henry David, ou H. D. Destaca-se, também, Thoreau (1817-1862), que construiu uma cabana com as próprias mãos, na qual viveu às margens do Lago Walden, no Estado de Massachussets, nos Estados Unidos da América, onde nasceu. Em Walden, o autor afirmou: "Minha maior habilidade sempre foi precisar de pouco"189, insuflando uma atitude perante a vida avessa ao consumismo capitalista, que se atinha apenas às coisas que são necessárias à vida.

No final dos anos 1960 e início dos 1970, alguns amigos meus resolveram percorrer o mundo com mochila nas costas, pedindo carona nas estradas. Mencionei as três opções mais frequentes aos jovens naquele período. Não escolhi nenhuma das opções, mas sim o monastério artístico. O pendor monástico foi se confirmando ao longo dos anos, não só ao retomar os estudos de filosofia no Mosteiro de São Bento, em São Paulo, muitos anos depois, mas por ser também espécie de "rato de bibliotecas". Por meio de uma audição em Bruxelas, resolvi participar da aventura mudrista, descrita pelo colega Alain Louafi como "intensa, formadora, rica e inesquecível"190. Naquele momento, em São Paulo, muitas colegas dançarinas ganhavam a vida dançando em shows nas boates ou na televisão e, pela manhã, estavam muito cansadas para fazer aula. Sua reputação avizinhava-se, então, à de prostitutas.

\footnotetext{
${ }^{188}$ Mostra de filmes Geração Beat, Centro Cultural Banco do Brasil, São Paulo, janeiro de 2017. A palavra "beatnik" teria sido grafada pela primeira vez em 1958, por Herbert Caen, que acrescentou o sufixo russo "nik", proveniente de "sputnik", ao termo "beat", referente a um estilo despojado e anticonsumista presente nas décadas de 1950 e 1960.

189 THOREAU, Henry David. Walden. Tradução de Denise Bottmann. Porto Alegre: L\&P Editores, 2010. p. 76.

190 Texto não publicado escrito pelo colega Alain Louafi por ocasião da morte ao nosso mestre yogue André van Lysbeth. No original: "Une aventure intense, formatrice, riche et inoubliable".
} 
Pude pagar a primeira parcela de minha passagem de ida a Bruxelas com um dinheiro ganho em um show da empresa automobilística Ford, destinado a agradar seus clientes.

Parti sozinha do Aeroporto de Viracopos, em Campinas, no dia 30 de setembro de 1970, em um tempo em que viajar de avião para outro continente não era fato corriqueiro. Viajava para participar de um teste. Estava cheia de confiança, auxiliada pelo sentido do risco e coragem de quando se tem quase 21 anos.

Figura 11 - Célia no aeroporto de Viracopos no embarque para a Europa

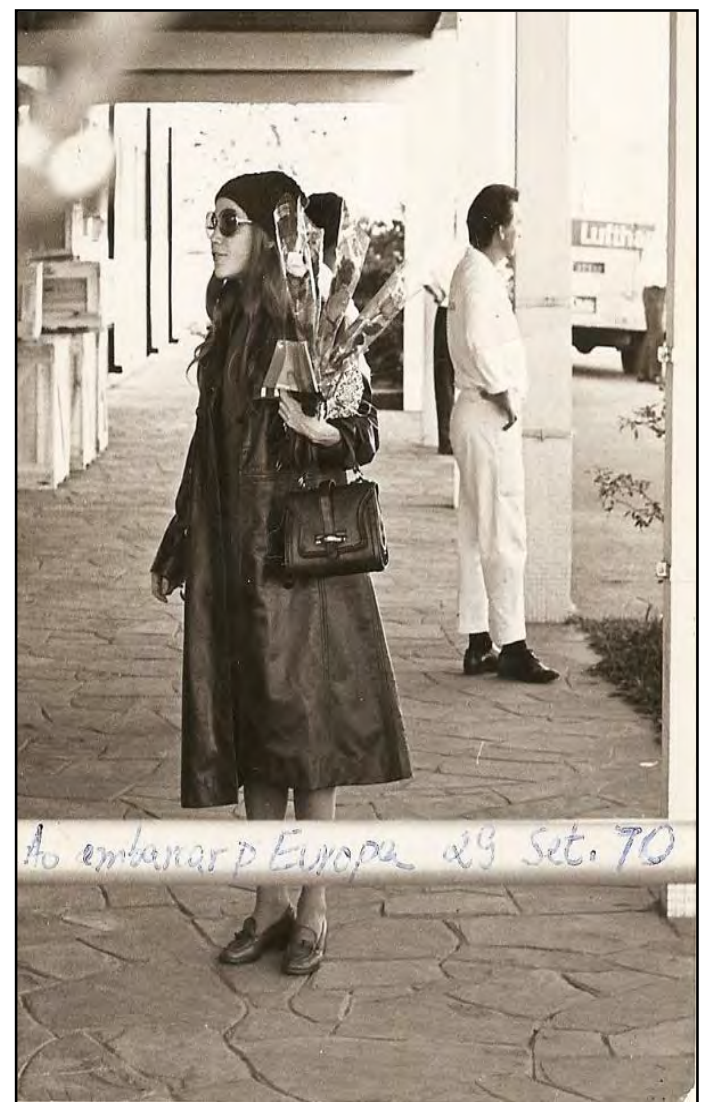

Campinas, SP, 29 set. 1970.

Fonte: arquivo pessoal. Foto de Augusto Ramasco.

Cheguei em Bruxelas no dia $1^{\circ}$ de outubro para passar pelo concorrido teste no Mudra três dias depois. Imaginava que o Mudra seria um edifício, rodeado por um parque, em alguma praça de Bruxelas. Medo não tinha, apenas seguia. Não chegava a articular uma frase inteira em francês, apenas palavras soltas. Ainda no aeroporto, coloquei meus 32 quilos de bagagem no carrinho, o charriot, e fiquei zanzando até encontrar o balcão de câmbio, trocar parte dos travellers checks por francos belgas e pegar um táxi, mostrando ao motorista a lista 
com os três endereços de pensionatos que me havia sido fornecida pelo consulado belga em São Paulo. O primeiro já não existia mais. Vingou a segunda alternativa, um pensionato católico, esse sim uma grande casa em meio a um jardim, onde me informaram sobre os bondes amarelos, os trams, que teria que pegar até chegar à estação ferroviária Gare du Midi, próxima ao Mudra.

\subsection{Descrição, o espaço}

Um espaço habitado e vital. Um lugar de trabalho e convívio. Situava-se em um bairro industrial de Bruxelas, próximo ao mercado, junto à estação Gare du Midi e da mais famosa fábrica de chocolate belga, a Côte d'Or, fundada em 1883, quando a Bélgica era apenas uma senhora quinquagenária. $\mathrm{O}$ antigo depósito de bondes vicinais recebeu um paredão branco na fachada, onde estava escrito em letras azuis: "Opéra National Mudra", no n 103 da Rue Bara, no bairro de Anderlecht, que nomeia também o célebre time de futebol local. Em 1970, no entreposto reformado e recém inaugurado, passou a funcionar, também ali, a companhia dirigida por Maurice Béjart, o Ballet du XXème Siècle, composta por cerca de sessenta bailarinos de múltiplas nacionalidades, como sempre agradou a Béjart.

Tratava-se de um grande galpão funcional, sem nada supérfluo. À esquerda da pesada porta metálica azul da única entrada, havia a sala de repouso, composta por quadrados desnivelados e acarpetados, ao lado da cantina.

Figura 12 - Sala de repouso do Mudra. Bruxelas, 1970

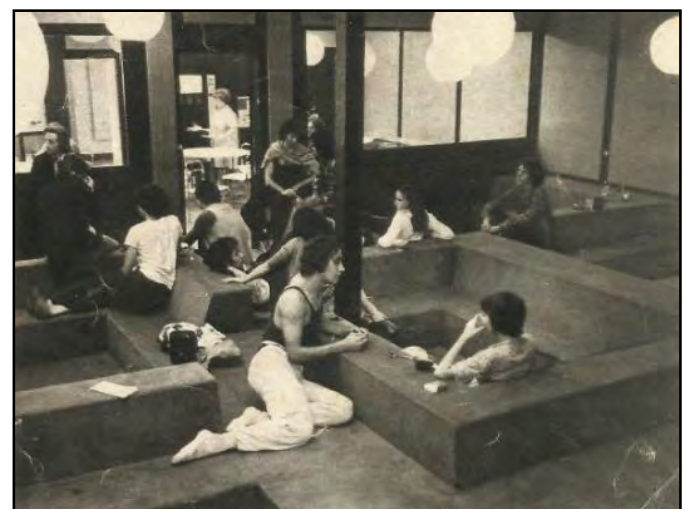

Fonte: Revista Marie Claire, nov. 1971. Fotógrafo não identificado.

Acima, a sala de ritmo e a de meditação, acessada por uma escada azul em formato de caracol. Havia ainda, naquele andar, outras dependências, como o escritório de Béjart, para 
mim inexistente, pois nunca pus meus pés lá, assim como nunca entrei nos vestiários de Béjart, nem tampouco nos destinados aos professores e aos bailarinos da companhia, situados ao lado dos nossos, no lado oposto ao aqui descrito.

Ao fundo, um depósito de cenários. O chão, de cimento. À direita, no andar térreo, os vestiários femininos e masculinos, munidos de duchas. Havia dois para os mudristas, um feminino e outro masculino, dois para a companhia, mais um ocupado por Béjart e os professores. No andar superior, havia quatro grandes salas de ensaio munidas de pianos, gravadores, câmeras magnetoscópicas, magnetofones, barras, cortinas e espelhos, designadas como salas 1, 2, 3 e 4. A última era a maior, geralmente destinada ao Ballet du XXème Siècle e utilizada para as atividades do Mudra quando a companhia se encontrava em turnês, o que ocorria com bastante frequência. Uma das salas tinha o piso inclinado, pois muitos palcos eram, então, construídos em declive, justificando Béjart dizer aos bailarinos: "montes" ("suba", "vá para trás") ou "descends" ("desça", "venha para a frente").

Figura 13 - Capa do catálogo do Mudra (1970)

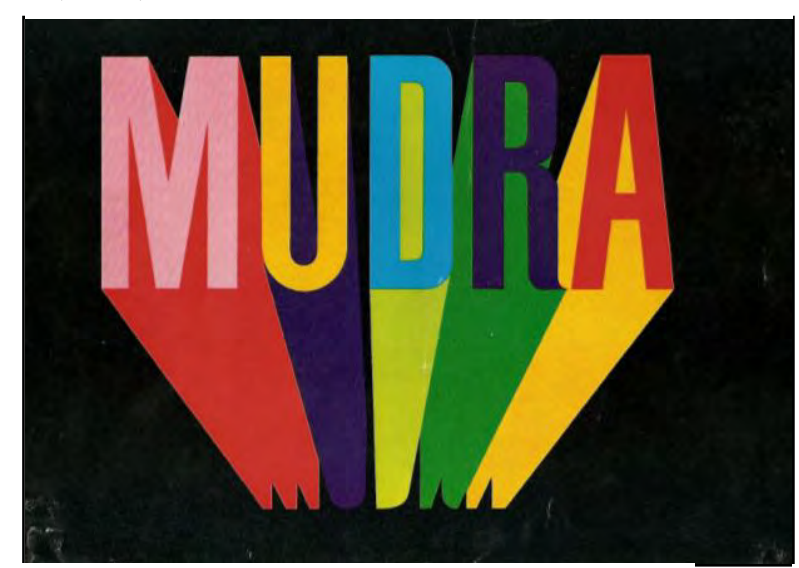

Fonte: Capa do Catálogo do Mudra, 1970.
Figura 14 - Integrantes da primeira turma do Mudra

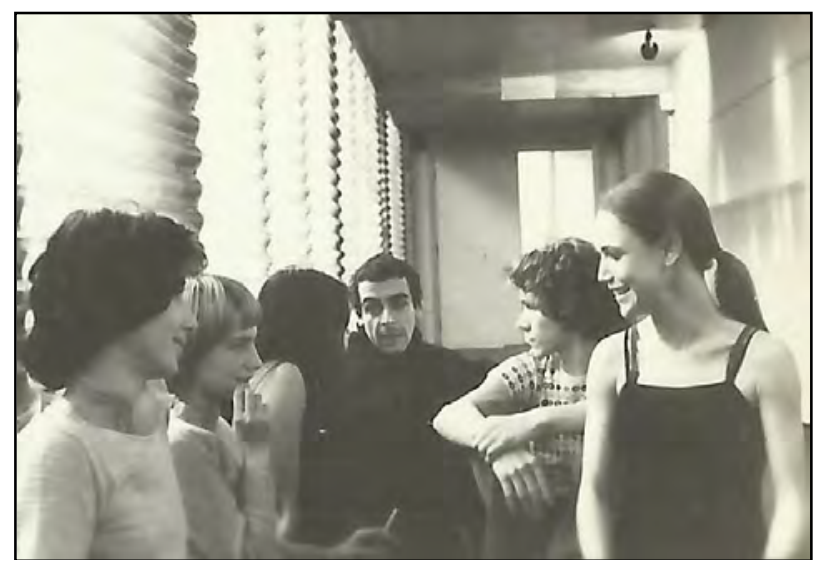

Da esq. para a dir.: Juliana Carneiro da Cunha, Maguy Marin, Christiane Glik, Alain Louafi, Pierre Droulers e Célia Gouvêa, no emblemático corredor do Mudra. Fonte: arquivo pessoal. Foto de Maurice Vaneau (1970).

Havia ainda o escritório, onde se encontrava sempre a postos a diretora administrativa, a excêntrica Madame Monette Vermeulen, que misturava questões artísticas e administrativas às pessoais. Naquele primeiro dia, subi as escadas à procura de seu escritório, pois ela dissera que me esperaria e indicou-me uma sala onde poderia exercitar-me. Já se encontrava, ali, uma moça alemã que, ao me ver, abriu os cinco dedos de uma mão indicando cinco - cinq, apenas 
cinq serão aceitos de toda a Europa. Subitamente, nas vésperas do dia em que passaria pela audição, Mme. Vermeulen irrompeu na sala em que me aquecia junto a outros candidatos e, dirigindo-se a mim, solicitou que fizesse primeiro um grand jeté, depois um grand écart e, por fim, um arabesque. Eu, que não tinha uma sólida técnica clássica mas confiava no meu "algo a mais", argumentei que tudo aquilo fazia parte do repertório clássico, recebendo como resposta a alegação de que um salto é um salto, nem clássico nem moderno. A áspera interferência não a impediu, porém, de, logo após minha aprovação, conduzir-me em seu carro para buscar minha mala no pensionato em que me hospedava e me levar à casa onde uma família alugava quartos e onde eu ficaria alojada. Algumas famílias belgas interessaramse em alugar quartos para mudristas.

Posteriormente, Mme. Vermeulen assumiu a codireção do Grupo Chandra, que fundamos ao término da formação no Mudra. Vermeulen dividiu a direção com Micha Van Hoecke, ocupando-se, especialmente, das questões administrativas. A residência onde fiquei era muito distante do Mudra, o que me levava a permanecer por muito tempo nos trams amarelos. Após um mês, mudei-me para um minúsculo apartamento situado no $\mathrm{n}^{\mathrm{o}} 48$ da Rue Grisar, bem próximo ao Mudra. Naquele bairro industrial, era possível encontrar aluguéis baratos. No subsolo foram morar Juliana e Maguy, em cujo apartamento costumávamos nos reunir para desenhar. Meus desenhos não eram figurativos, o que desagradava a minhas colegas.

No andar acima, morava o bailarino polonês Gérard Wilk. A proprietária do pequeno prédio de quatro andares era uma polonesa corpulenta, sorridente e de olhos azuis, dona da épicerie (quitanda) da esquina, ainda existente quando voltei ali no início dos anos 1990, acompanhada por minhas filhas. O apartamento no qual vivi tinha cerca de 4x6 metros. A cama (de solteiro) era embutida, fechada durante o dia para que tivesse acesso à pia e ao fogão, colocados junto à janela, ao fundo. Certa vez, a reparti com a artista da dança Sônia Mota, que residia e trabalhava em Anvers (Antuérpia) e veio fazer aulas com o balé, em Bruxelas. Não havia banheiro, apenas uma toilette a cada dois andares. Tomava banho no Mudra. Um dia, adoentada, recebi ali a visita de Maurice Vaneau, que afirmou que jamais poderia viver em um lugar tão exíguo. Ele, que, em São Paulo, morava em um apartamento de duzentos metros quadrados no qual vivo até hoje. Durante suas longas estadias em Bruxelas, Maurice residia na casa da família, localizada na Avenue Louise 376, próxima ao parque Bois de la Cambre, que foi meu próximo endereço na cidade até a volta ao Brasil. No entanto, voltei a manter, enquanto um pied à terre e devido ao baixo custo e proximidade com o Mudra, um outro apartamento no último andar do mesmo endereço: $n^{\circ} 48$, Rue Grisar. 
No segundo dia no Mudra, anterior à audição que se realizaria no dia seguinte, após o aquecimento, dirigi-me à cantina. Em uma das mesas, havia uma jovem de cabelos curtos com franja e ar receptivo. Percebendo minha dificuldade em articular frases em francês, perguntou se eu falava espanhol. Tratava-se de Maguy Marin, que contava então 19 anos de idade e tinha passado pelo teste e sido aprovada naquele mesmo dia. Sua formação principal era o balé clássico, enquanto a minha era a dança moderna. Como ainda não dominava o idioma francês, podíamos bem nos comunicar, ela falando em espanhol e eu em português. Nossa primeira afinidade foi política. Aprendi espanhol por meio das músicas cantadas por Atahualpa Yupanqui, que me foram ensinadas por Maguy.

No catálogo de apresentação do Centro, há a afirmação do elo entre teatro e sociedade, a relação com os grupos sociais do qual emana e, sobretudo, em período de transformações sucessivas e rápidas, a permanência de dois elementos: o público e o intérprete. A instituição Mudra, sem fins lucrativos e de caráter internacional recebia subsídios do governo belga e da Fundação Gulbenkian, da UNESCO ${ }^{191}$, que a reconhecia enquanto associação internacional com finalidade científica.

O diretor da Ópera Nacional da Bélgica, Maurice Huisman, era um entusiasta apoiador dos projetos de Maurice Béjart por considerá-lo um criador extraordinário. Ao homem Béjart e sua pouca afeição ao luxo, escreveu Huisman: "Ele não possui nem casa, nem móveis, nem carro"192. Ao chegar em Bruxelas, em 1959, morou em um minúsculo hotel atrás de um dos emblemas da cidade, o Manekin Piss, próximo à Grand-Place de Bruxelas, morando em seguida, durante doze anos, em um apartamento tipo "porta e janela" em uma rua de belo nome - a Rue Pont de la Carpe.

O projeto do Mudra era o de ser um caldeirão cultural sem impor nenhum sistema ou teoria e no qual as barreiras linguísticas seriam superadas. O conselho administrativo era composto por vários integrantes, mesclando a Bélgica flamenga e valona. Entre os integrantes do comitê artístico, constavam os nomes de Rosella Hightower e dos encenadores Ariane Mnouchkine e Jerzy Grotowski. Este dedicou um artigo a Béjart, considerando-o sinônimo de dança e a encarnação da disciplina.

\footnotetext{
${ }^{191}$ Unesco, a Organização das Nações Unidas para a Educação, a Ciência e a Cultura, foi constituída em 1945, ao término da Segunda Guerra Mundial, com o propósito de promover cooperação entre os povos e garantir a paz. Representada no Brasil desde 1964, instalou-se em Brasília em 1972. O reconhecimento formal da Unesco ao Mudra ocorreu em 1977, quando a palavra "Europeu" foi suprimida do até então denominado Centro Europeu de Aperfeiçoamento e Pesquisa dos Intérpretes do Espetáculo.

${ }^{192}$ CHRISTOUT, 1972, p. 140.
} 
A intenção inicial era a de reunir 25 jovens, cinco de cada continente, que contassem entre 15 e 21 anos de idade (posteriormente reduzida para 18 anos), escolhidos por meio de uma seleção rigorosa, para a qual houve cerca de quatrocentos inscritos. A seleção consistiu em exercícios de balé clássico na barra e exercícios de dança moderna no chão, demonstrados pelo próprio Béjart; uma sequência de dança moderna na diagonal, orientada pela professora Dyane Gray-Cullert; e, por fim, na leitura de um texto na língua do candidato. Felizmente, tinha comigo o livro de estreia de João Guimarães Rosa, Sagarana ${ }^{193}$. A contagem de um dos exercícios de chão era em três tempos e Béjart pediu que contássemos em nossa língua materna. Ao emitir "um, dois, três" em português, ouvi a mesma contagem, na mesma língua. Não hesitei, interrompi e virei-me para trás. Era Juliana Carneiro da Cunha, que viria a tornarse não só uma atriz e dançarina com forte presença, mas também uma amiga. Aos 21 anos, já era uma dessas pessoas que emanam conexão consigo e perto de quem se sente bem. $\mathrm{O}$ exercício proposto por Béjart tinha como finalidade fortalecer o centro do tronco. Incorporei-o à minha "sopa" e pratico-o até hoje.

O propósito, naquele momento, era reduzir para vinte o número de alunos efetivos. Assim, houve um período de éssai (experiência) com duração de três meses, ao final dos quais o corpo discente se efetivou. A confirmação veio na época do Natal, quando Béjart se reuniu com os professores e membros da administração, praxe mantida no final de cada ano letivo ao longo de todo o ciclo de três anos (reduzido para dois, a partir de 1981). Perguntado, certa vez, por um aspirante a uma vaga no Mudra sobre quais eram os requisitos para a admissão, o colega e mais tarde coreógrafo Pierre Droulers não titubeou: “Tem que ser bonito".

As aulas, diárias, tinham início às $8 \mathrm{~h} 30$ e se prolongavam até as 19 horas - aos sábados, das 9 horas às 13 horas. Uma média de dez horas diárias. Com frequência, o período noturno era preenchido por pesquisa (recherche). Os cursos oferecidos eram: Yoga, Dança Clássica e Moderna, Canto ou Gesto Vocal, Jogo Teatral, Ritmo e Sociologia - esta somente no primeiro ano. Além dos cursos regulares, houve estágios de dança indiana com Savitry Nair (Bharata Natyam, a mais antiga dança regional da Índia, praticada no sul do país; Baratha's Natya Sastra, ou a ciência da dança - Bharata tem seu nome derivado de expressão externa de um sentimento espiritual, melodia e ritmo ${ }^{194}$ ); houve, também, estágios de dança e ritmos flamencos, com Susana e Antonio Robledo, respectivamente; e de teatro, segundo a concepção do trabalho de ator de Constantin Stanislavski, ministrado por John Blatchley

\footnotetext{
${ }^{194}$ HASKELL, 1969.
} 
(1922-1994). Um mudrista deveria ser curioso o suficiente para interessar-se igualmente por todas as modalidades corporais. Eu mesma desconhecia meu próprio potencial criativo, apesar de ter praticado o método da improvisação ainda em São Paulo, com Renée Gumiel. Tributária do Expressionismo, Renée exortava o movimento nascido “de dentro". No Mudra, estimulada e instada a criar, é que vim a descobrir capacidades dormentes até então, o que confirma a maiêutica socrática, segundo a qual, quando somos instados, provocados, ocorre a projeção de conhecimentos.

\subsection{Os Cursos ${ }^{195}$}

\subsubsection{Yoga}

A manhã começava, três vezes por semana, com um curso de Hatha Yoga, ministrado pelo mestre belga André Van Lysebeth, um dos primeiros a ensinar o yoga no Ocidente e autor de vários livros. O curso não era obrigatório. A longa permanência em cada postura diferia em muito da contagem em oito tempos, habitual na dança. No Brasil, desde 1968, praticava yoga no estúdio Narayama, em São Paulo, conduzida por minha professora de dança moderna, Ruth Rachou, com quem iniciei meus estudos aos dezesseis anos, ainda em Campinas, minha cidade natal. Posteriormente, prossegui no mesmo estúdio outras modalidades do yoga, como Nirvisha, Ayurvédica e Hormonal, acrescentando a prática do Qi Gong com o mestre chinês Cao Yin Ming, já falecido. Essa prática contém exercícios específicos para cada órgão do corpo e segundo ciclos sazonais e respiratórios, que têm o propósito de trazer energia ao corpo, ativando os fluxos vitais e proporcionando evidentes benefícios medicinais ${ }^{196}$.

Ainda no Mudra, Maurice Béjart convidou seu amigo, Mestre Deshimaru, para iniciar os mudristas ao zazen. A recomendação postural era a de manter o contato com o chão. Iniciando pelo calcanhar, sentir o corpo preso ao solo. Sigo praticando meditação no Templo

\footnotetext{
195 A descrição a seguir tem como fonte principal meu caderno de anotações da época, bem como algumas consultas a colegas. A ordem seguida é a do horário dos cursos: Yoga, Ballet e Gesto Vocal no período da manhã; Dança Moderna, Ritmo, Jogo Teatral ou Teatro e estágios (Dança e Ritmo flamencos com Susana e Antônio Robledo, Bharata Natyam com Savitry Nair ou Pas de Deux no período da tarde).

196 SUQUET. A., 2009.

O sueco Per Henrik Ling, teria se interessado, no começo do século XIX, pelos relatórios elaborados por Jean Amiot, jesuíta francês do século XVIII, sobre o aspecto medicinal do Qi Gong, arte chinesa que se dedica ao controle do Qi, isto é, da energia ou do fluxo vital.
} 
Busshinji da Escola Soto Zen da América do Sul, no bairro da Liberdade, em São Paulo. No início do estado meditativo, o foco encontra-se concentrado, primeiro, na respiração e, em seguida, nos sons circundantes. Esse é um modo de estar conectado com o momento presente, afastando as tóxicas poluições mentais. O que me agrada na postura dos monges do templo citado é a sobriedade e o fato de não acenarem com nenhum benefício, quer afetivo, financeiro ou de qualquer outra ordem aos praticantes. A única recomendação é a de ir lá e sentar-se. “A palavra Zen é derivada do sânscrito „Dhyana“e , que significava meditar sobre o verdadeiro aspecto das coisas e discerni-lo, mantendo para isso a máxima tranquilidade de espírito" ${ }^{\prime 197}$.

Um dos significados da palavra "yoga" é "união", "religar" ou "ligar o ser uma nova vez". Na postura da torção sentada, por exemplo, os joelhos voltam-se para a frente, enquanto a cabeça olha para trás. O duplo direcionamento conduz ao discernimento, que amplia o campo de visão.

Figura 15 - Postura yogue da torção

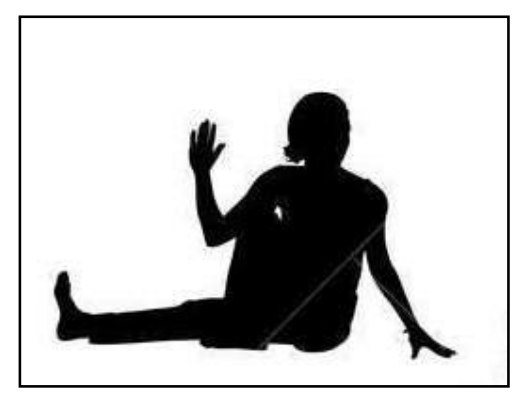

Fonte: Clip Art of Various yoga postures silhouettes.

O professor van Lysebeth costumava lembrar um dos sentidos da palavra Mudra: "selo", ou "selar os corpos", pois, ao fazermos um gesto, estamos selando algo. Outro sentido é "senha" ou, ainda, “destemor". Derivada do sânscrito, a língua sagrada dos brâmanes e dos livros escritos nessa língua, a antiga língua clássica da Índia, a mais velha da família indoeuropeia, encontra o sentido mais conhecido da palavra "mudra", ou "mudrá", que é "gesto". Com a finalidade de promover a união entre as energias cósmica, espiritual e atômica, a prática dos mudras conduz à concentração, à saúde e até mesmo à cura.

\footnotetext{
${ }^{197}$ ESCOLA Sotoshu. Zen. Editado pela Sooshu Nambei Sokan-bu. 2. ed. São Paulo: Superintendência Geral do Sotoshu na América do Sul, 2001. p. 5.
} 
Os gestos, que praticávamos separadamente, à parte dos cursos de yoga, abrangem a posição das mãos, olhos, corpo e a técnica da respiração. Estabelecem a conexão entre o interior do nosso corpo e a energia cósmica, relacionando o micro ao macrocosmo, em um percurso que inclui os nervos e o cérebro, comunicando-se aos órgãos. Proveniente do Yoga Ayurveda, a prática dos mudras constituem um canal para a circulação da energia e da saúde. É nos dedos e nas mãos que o simbolismo será melhor representado. Emitindo as palavras com sons monocórdios enquanto compúnhamos os gestos com as mãos, aprendíamos as correspondências, por exemplo, entre pataka (bandeira), tripataka (três bandeiras), ardapataka (meio estandarte) kartarimuka (tesoura), kapitha (maço de flores), chandrakalá (um quarto de lua), padmakosa (flor de lótus), mrgrachircha (cabeça de animal), sinramuká (cabeça de leão), alapadmá (lótus aberto), kangulá (recipiente), brahma (abelha), hamsasya (cisne de frente), hamsaparaká (cisne de perfil) e assim por diante, sempre com temática relacionada à natureza, aos reinos vegetal e animal. Serão os mudras fixos e estáveis, enquanto o movimento é instável?

O número de mudras é de pelo menos quatro mil: "Um mudra pode imitar um objeto real; um peixe que nada, um pássaro que voa, uma flor de lótus que desabrocha. Mostra também um humor abstrato: amor, ódio, medo, surpresa. Um bailarino hábil pode contar uma história sem palavras" ${ }^{\prime 198}$. Cada dedo da mão tem seu correspondente: o polegar com o fogo ou o sol; o indicador com o ar ou vento; o dedo médio - o mais longo - com o céu ou espaço, o éter ou o etéreo; o anular com a terra; e o dedo mínimo com a água. Além das mãos, os gestos solicitam os olhos e atentam à respiração. Supõem a conexão com o interior de nosso corpo, com a energia universal. Por intermédio dos nervos, os dedos conectam-se ao cérebro, e este aos órgãos. O princípio é o de que os cinco elementos da natureza - terra, água, fogo, ar e espaço - encontram-se alojados em nosso corpo. A terra corresponde ao esqueleto e proporciona as qualidades de força, estabilidade e firmeza.

\footnotetext{
${ }^{198}$ HASKELL, 1969, p. 31. Tradução nossa. Texto original: “A mudra may imitate an actual object; a swimming fish, a flying bird, a lotus flower in boom. It also shows an abstract mood: love, hate, fear, surprise. A skillful dancer can tell a story without words".
} 
Figura 16 - Mudras hindus

Imagens de mudras hindus representando: uma pomba, um pássaro voando, a cabeça de um veado, flor de lótus fechada e aberta

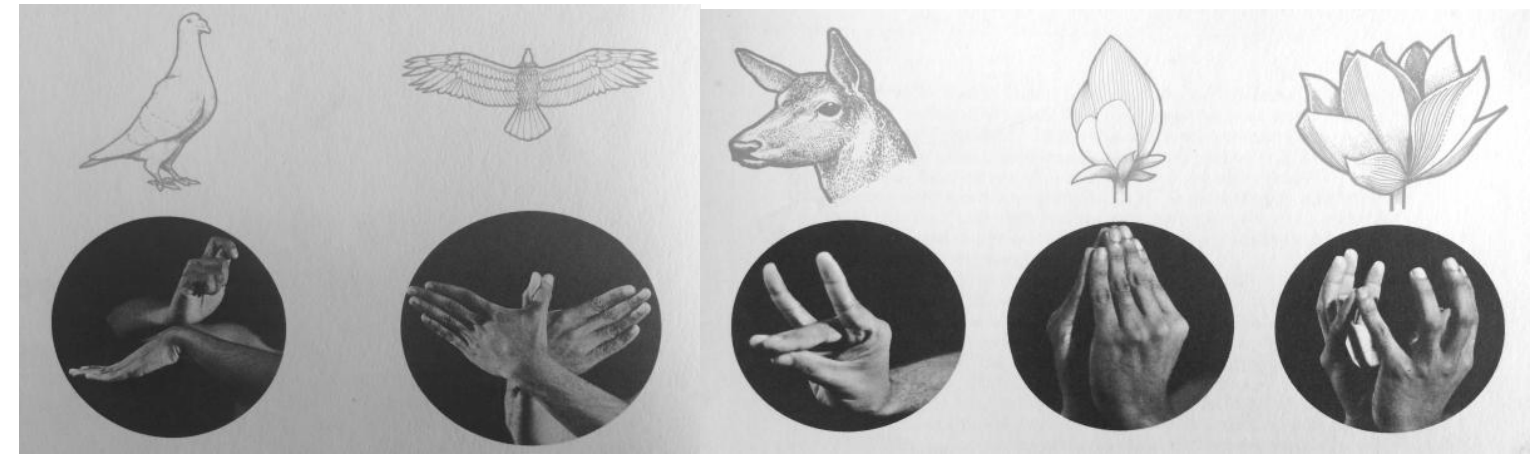

Fonte: HASKELL, Arnold L. (1969).

\subsubsection{Dança Clássica}

Com aulas diárias, de segunda-feira a sábado, um dos objetivos da formação e aperfeiçoamento era o de dotar o mudrista da flexibilidade corporal necessária e melhorar sua base técnica. Béjart tinha a convicção de que o balé clássico é a base do treinamento do bailarino, tornando-o apto a mudar de estilo facilmente. Em um tempo em que a dança a partir de um modelo externo passou a ser questionada, a afirmação seria, também, questionada. Ela era, talvez, derivada do fato de o coreógrafo não ter sido, propriamente, um technicien. Daí a admiração de Béjart pelo domínio técnico, que afirmou: "Não tenho físico de bailarino clássico, não sou o intérprete perfeito para esse gênero de coisa. Então fui obrigado a inventar um estilo, algo que conviesse a meu corpo" ${ }^{\text {199 }}$. O coreógrafo foi levado a encontrar novos gestos, novos passos, ou seja, da limitação, pode nascer a invenção. Béjart defendeu ferrenhamente a tradição: "Todo o meu trabalho baseia-se na tradição. Dupla tradição: a do ensino e da arte. Não sou o revolucionário que apregoam: só fiz tirar o pó das coisas"200.

Por outro lado, outros coreógrafos, como Maguy Marin, que dominava a técnica, podem mais facilmente abrir mão dela e buscar outra linguagem. A prática do balé prepara bem para dançar balé. Tudo depende do propósito: se vou me especializar no butô, por exemplo, por que treinarei o balé? Surpreende-me sempre assistir a trabalhos cênicos de pessoas que nunca praticaram dança moderna, mas que demonstram ter contato com o chão.

\footnotetext{
199 BÉJART, 1981, p. 49.

200 Ibid., p. 124.
} 
No Brasil, Klauss Vianna (1928-1992) defendeu que não é preciso ser formado em balé clássico para dançar. Certa vez, recomendou-me um dançarino para compor um de meus elencos, dizendo-me: "Ele não tem técnica, mas é um bailarino". Entendo que se trata de um corpo dançante, que entendeu o movimento. Tomando como referência meu próprio corpo, pratiquei primeiro a dança moderna, na qual me reconhecia, e a clássica de modo apenas moderado. No Mudra, passei a praticar o balé intensamente, o que tornou meu tronco rígido, necessitando de um novo trabalho de flexibilidade da coluna. O pensamento de Béjart adere à tese de que a técnica liberta, ao invés de prender ou condicionar. O coreógrafo considerava a dança clássica uma arte matemática. E é, de fato. Seu aprendizado se dá por pura mimesis, ou faculdade de imitação, e, durante muito tempo, na dança de espetáculo, o bailarino copiou um modelo exterior a si, o que explica a importância do espelho como referência. No sentido lacaniano, o espelho promove a alteridade, o desejo do outro na construção do eu, constituindo seu imaginário.

Analista de Platão, Victor Goldschmidt diz que “imitar não é um mal, mas imitar mal, sim ${ }^{201}$. Aprendizado como clonagem ou, no dizer do neoevolucionista Richard Dawkins, por meio de memes, ou replicadores de informação. Impossível não colocar em relevo, em se tratando da prática do balé, a relação com o espelho. Se é frequente hoje encontrar salas de dança nas quais há uma cortina diante do espelho, que pode ser aberta ou fechada, com frequência o espelho encontra-se visível em uma aula de balé, embora tal tendência tenha se modificado nas últimas décadas. A autocontemplação caminha na direção oposta à da fantasia e dificulta a interioridade. Um pássaro enxerga-se no vidro espelhado e pensa tratar-se de um semelhante. Vejo-me, auto corrijo-me. Verifico a altura de meus braços, de minhas pernas. Em lugar da diferença, aparece a mesmidade das pernas altas e a limpeza das linhas. Daí os corpos de balé uníssonos e a procura coercitiva da depuração. A pergunta a fazer é: por que o balé se mantém ao longo do tempo?

Considero que a barra molda o ser. Em Utopias e heterotopias, Michel Foucault destaca que o espelho ensina a existência de uma forma, um contorno, uma espessura, um peso, que o corpo ocupa um lugar e é assim que as crianças aprendem que têm um corpo ${ }^{202}$. Por meio da apresentação de uma imagem invertida, o espelho devolve a imagem e leva a um

\footnotetext{
${ }^{201}$ GOLDSCHIMIDT, 1970, p. 104. Tradução nossa. Texto original: "Ce n'est pas d'imiter qui est mal, c'est de al imiter".

${ }^{202}$ FOUCAULT, Michel - Utopias e Heterotopias in LEACH, N. - Rethinking Architecture. Londres: Routledge, 1997, p. 352. Tradução nossa.
} 
reconhecimento no sentido literal do termo: conhecer-se de novo, o que resulta em narcisismo ou autocrítica. Do latim "mirare" ("admirar"), o espelho tem ainda a qualidade de ampliar o espaço. O espelho cumpre a função de testemunha. Observa, concede o veredito implacável referente às imperfeições. Seu emprego na dança dataria do final do século XVIII, tratando-se não ainda de espelhos, propriamente, mas de vidros refratários. São muitos os componentes psíquicos resultantes do ato de mirar-se em um espelho. Um espelho não conversa, confere. Con-fere, fere com.

Um professor de balé, em suas aulas, elabora combinações com múltiplas possibilidades, a partir de um vocabulário codificado há séculos. Adepto da escola russa, o professor principal no Mudra era o porto-riquenho José Parés, que ensinava também no Balé do Século XX e no Balé Nacional de Cuba. Sempre muito lacônico, unia-nos a latinidade. Dada a sua sisudez, surpreendeu-me, certa vez, quando me encontrava no vital corredor do primeiro andar - que unia todas as salas, de 1 a 4 - junto a um radiador, no qual me esfregava para aliviar as dores musculares. Ao passar, ele perguntou, na lata: "Célia, estás se masturbando?" A frase sinaliza que a proximidade cultural latino-americana propicia uma maior intimidade no campo pessoal.

Ainda no primeiro ano, Parés montou uma coreografia onde havia uma alternância de papeis entre mim e a colega Christiane Glik: dois rapazes seguravam e erguiam um pedaço de barra no qual nos pendurávamos. Christiane sempre emanou um forte lastro poético de seus movimentos. Outro professor de balé foi o belga Jacques Sausin. Juntamente com Parés, foram responsáveis pelo notável progresso técnico que efetuei no primeiro ano do Mudra. Quase ao final do primeiro ano letivo, na parte do centro de uma de suas aulas, após a barra, pediu que fizéssemos dezesseis fouettés nas pontas. No final, pediu que todos parassem e me olhassem, dizendo: "Esta é uma moça que antes de entrar no Mudra nunca tinha subido nas pontas!" Cubana, Mênia Martinez dava cursos de pas de deux. Costumamos dizer "dar um curso", que implica em oferenda.

As aulas tinham o acompanhamento musical de Jacques De Lescault ao piano, que, em seus períodos de folga, dedicava-se a fazer nossas cartas astrológicas ou mapas astrais. Sausin costumava encher um cinzeiro inteiro durante a hora e meia de aula, em um tempo em que isso era permitido a um professor enquanto ensinava em uma sala fechada. Ainda ecoam observações como: “É bem perto do chão o jeté na barra, para não afrouxar nem o pé nem o joelho"; "no brisé, bater a parte interna do joelho e não a barriga da perna ou o calcanhar"; "na pirueta, manter o braço na altura do estômago, grudar o pé no passé e o outro pressiona o chão"; "na pirueta arabesque, olhar para a mão"; "não parar no plié, que é passagem"; "para 
saltar, afundar no plié, para receber a força do chão". Sempre me intrigou o mecanismo cerebral que leva à memorização tão rápida pelos bailarinos das sequências mostradas pelo professor. Percebo que há padrões já assimilados no cérebro que tecem configurações às quais as variações apresentadas vêm se aderir. Certo é que a barra molda o ser. Para Maurice Béjart, a disciplina liberta, pois conduz ao domínio de um ofício. Na visão foucaultiana, a disciplina produz seres dóceis, enquanto que, para o budismo, a disciplina é necessária. Eu diria que a disciplina organiza e constitui uma qualidade intrínseca aos profissionais da dança.

Há de se destacar, também, nas aulas de balé, a concentração na barra e as sequências dançantes em diagonal. É verdade que o ser humano foi feito para andar com os pés paralelos, o que exclui a rotação en dehors. Durante muito tempo, considerei o balé um mal necessário. Por outro lado, companhias contemporâneas dirigidas por coreógrafas como Pina Bausch, Maguy Marin e Anne Teresa De Keersmaeker não excluíram a prática de suas rotinas. $\mathrm{O}$ principal argumento é quanto à estrutura, à disposição arquitetônica corporal, além da agilidade. Alain Berthoz estabelece uma relação: "É quando a anatomia leva em conta a geometria"203. Penso que o ensino do balé depende, em grande parte, do bom professor. A colega Sônia Mota, certa vez, comentou que percebe se um corpo compreendeu a dança por meio das mãos. De fato, se há tensão nas mãos e nos dedos a dança não está sendo nem bem ensinada, nem assimilada. É possível, hoje, incorporar princípios somáticos à prática, como atentar ao períneo na execução de um plié.

Elaborei, posteriormente, um trabalho na barra de balé contemporâneo cujo objetivo é o de fornecer flexibilidade e força simultaneamente. Não há apoio musical externo, para que o praticante possa melhor concentrar-se na sua estrutura interna. O trabalho tem início com alongamentos, ampliando o espaço entre vértebras e costelas, com o apoio leve das duas mãos na barra, para facilitar o encontro do eixo, passando em seguida para o toque de uma só mão na barra, principiando pela mão esquerda e acionando o lado direito do corpo. A convenção parte da suposição de que a maioria das pessoas é destra. Mantive a nomenclatura dos passos básicos ao balé, com as particularidades do emprego do metatarso em vez da ponta para evitar o excessivo tônus muscular, articulando calcanhar, metatarso e artelhos, o que permite, também, o alongamento da parte posterior da perna. A preferência é pela terceira posição em vez da quinta, para que o apoio não caia para a borda interna dos pés. Há a alternância entre exercícios com os pés paralelos (en dedans) e o en dehors, aberto. A aliança entre a dança e as

${ }^{203}$ BERTHOZ, Alain. La Simplexité. Paris: Odile Jacob, 2009. p. 109. 
terapias corporais, incrementada nas últimas décadas do século $\mathrm{XX}$, permitiu a execução de um plié pensando no períneo. Por exemplo: não sei se um professor ou um aluno de balé sabem de que lado do corpo fica o estômago e se serão um melhor professor e um melhor aluno se o souberem. Provavelmente, sim.

A colocação do corpo que sintetizei guarda ensinamentos da professora estadunidense Zena Rommet, com os quais tomei contato desde meados da década de 1970 em Nova York na de em São Paulo com a professora italiana Maria Meló (1911-1993) na década de 1980. Adepta do método do virtuoso italiano Enrico Cechetti (1850-1928), com quem estudou no Teatro Scala de Milão, suas aulas eram ministradas em um diminuto estúdio situado em uma galeria entre as ruas Augusta e Haddock Lobo, na capital paulista, e seguiam, invariavelmente, a mesma estrutura. Sentada com sua bengala entre as pernas, a milanesa Meló atentava para dados importantes, como o joelho que "olha" para o dedinho ao flexionar e a pressão do calcanhar contra o chão, ao esticar. Dado importante: o calcanhar deve estar sempre à frente do joelho nos exercícios na barra. Suas aulas pouco se diferenciavam a cada dia, reiterando-se que o princípio da repetição, presente no ensino do balé, é valioso. Muitas mestras de balé idosas ensinam até o último dia de suas vidas. Em sua biografia, Béjart se refere à "Madame", a mestra russa que ensinou não só a ele, mas a outros futuros coreógrafos como Roland Petit. Ao chegar certo dia para a aula, Béjart foi avisado de que não haveria aula, pois a Madame falecera na véspera.

De Marcos Verzani, professor brasileiro de balé hoje radicado em Paris, guardo a repetição de um mesmo exercício na barra, acelerando sua velocidade. Guardo também a numeração dos pontos espaciais, de 1 a 8 (frente, diagonal frontal direita, lado direito, diagonal traseira direita, trás, diagonal traseira esquerda, lado esquerdo e diagonal frontal esquerda). Por seu lado, Maurice Vaneau lembrava sempre o coté cour e o coté jardin, nomenclaturas que trazem a vantagem de não sofrer alterações de acordo com o ângulo em que a pessoa se encontra posicionada. "Lembre-se de Jésus-Christ, Jesus Cristo, ele dizia", ao mencionar a denominação francesa - JC (jardin/cour).

No final do século XVII, as cinco posições básicas da técnica do balé foram codificadas pelo francês Pierre Beauchamp (1639-1705), mestre de dança de Luis XIV e da Académie Royale de la Danse. 
Figura 17 - As cinco posições do balé

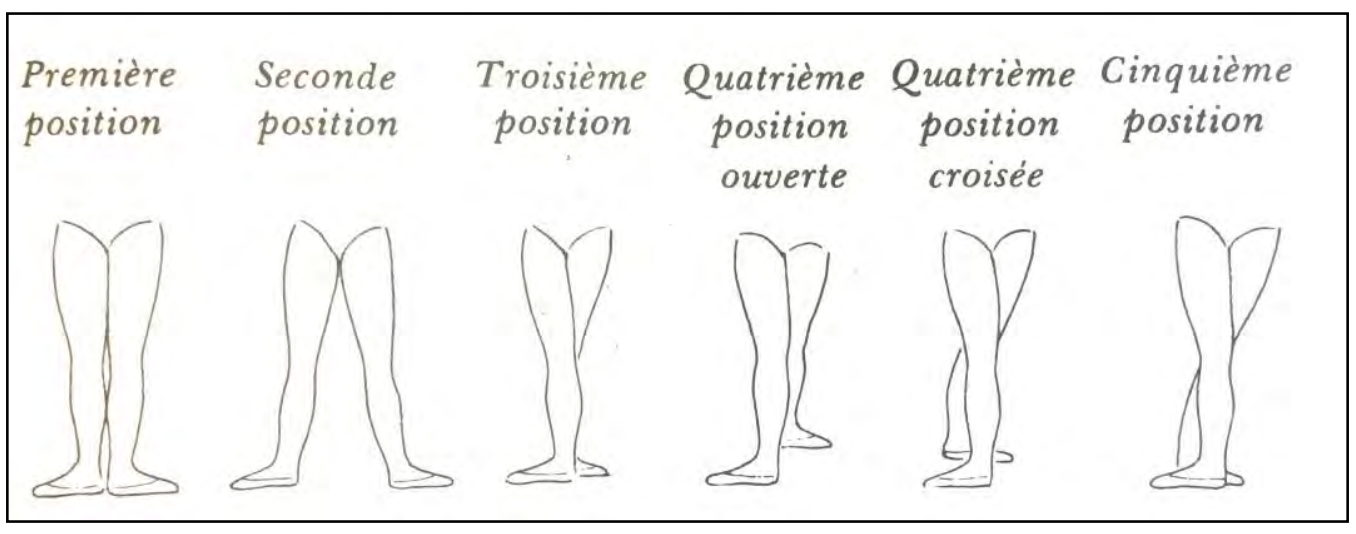

Fonte: MARA, T. (1966).

Relevo o contato com o chão, propulsor da elevação, bem como as oposições baixo e cima ou chão e ar. O colega Marcos Moraes denominaria a mesma relação como "graça" e "gravidade". Os movimentos são acompanhados pelo trabalho do tronco, com o propósito de fortalecer as pernas e flexibilizar a parte superior do corpo. A mesma relação encontra-se, também, presente em danças como o flamenco ou a dança indiana, como voltaremos a observar mais à frente, quando tratarmos de Carmem Miranda.

\subsubsection{Gesto Vocal}

Após a aula de balé, ainda no período da manhã, ministrado por Louis-Jacques Rondeleux e Eljie Bartot, o curso visava à aquisição de uma técnica vocal precisa e flexível, que permitisse tanto a adaptação à pesquisa de timbres dos compositores modernos quanto habilitar à comédia musical ou à ópera, bem como ao teatro clássico ou às criações de amanhã. Tais propósitos, expressos no catálogo da instituição, eram demasiado amplos, sinalizando que as diretrizes do centro recém fundado ainda eram pouco claras e definidas, quando o resultado daquela experiência era ainda desconhecido. Adquiri a compreensão do relacionamento entre voz e respiração.

Os exercícios técnicos vocais focavam a respiração, e não o belo som, e constavam de:

- Exercícios respiratórios: em pé, com a barriga solta, encher o pulmão de ar, emitindo um chiado sonoro, enchendo e afundando a caixa toráxica. Em seguida, soltar, relaxando o ventre. 
- Com o som do metrônomo, efetuar respiração baixa, pela boca: três segundos para inspirar, dois para segurar e quatro para soltar. Quando sentir-se bem, começar a andar. Objetivo do exercício: principiar por meio de uma limpeza pulmonar.

- Respiração em decúbito dorsal: respiração normal (uma vez), sintética (quatro vezes em seis tempos), inversa e lenta, contando de um a seis tempos; passar para a posição de bruços e repetir o exercício. A respiração lenta é controlada e a sintética cada vez mais longa, tanto na inspiração quanto na expiração.

- Na posição sentada, praticar a respiração do ventre, tocando-o com as mãos.

- Em pé, respiração inversa e sintética.

- Emitir as sílabas "mo" e "ma", inspirando e expirando em cada uma delas. A inspiração é curta, a expiração, longa. Na inspiração, deve-se recolher sem subir e é quando a sílaba é pronunciada. Prossegue-se por cinco vezes a emissão dos sons "mo" e "ma", com trabalho da boca e bochechas. A seguir, realizar o mesmo exercício com um parceiro, observando-se.

- De frente e de perfil, emitir as sílabas "ba-be-bi-bo-bu" em uma só nota em vários tons, de acordo com o alcance da voz; interpretar com os sons: a sílaba "mo" e a vogal "o", na seguinte ordem: som/pausa/som que sobe em uma pirâmide/nova pausa.

- Relaxar o ventre e manter as costelas abertas, por meio de três ataques sobre a vogal "o"; sobretudo nos sons staccatos, manter as costelas bem abertas, com o peito ligeiramente elevado. Observar a relação entre costelas e costas.

- Escalas: a partir de três, cinco, seis e nove notas, acalentar o som dentro de si mesmo, sem abrir muito a boca e com os ombros totalmente relaxados. Praticar as terças com as sílabas "mo" ou "po/pa/po" e, em seguida, com a vogal "o". Com a vogal "a", encontrar o próprio timbre e efetuar pequenos ataques, jogando o som para o teto. $\mathrm{Na}$ escala com cinco notas, deter-se na volta sobre a terceira nota e prosseguir a partir dela. Quanto mais agudo o som, maior a descontração do ventre. Na emissão da vogal "a", guardar a garganta totalmente aberta e os maxilares soltos. $\mathrm{O}$ "a" é mais limpo quando sai da garganta. O som grave também pode ser emitido com leveza.

- Emitir as sílabas "bi-ban" repetidas vezes, como se fôssemos "bobos". Para a emissão de sílabas, pensar na abertura oval da boca, projetando, com leveza, o corpo para a frente. 
- Cantar uma berceuse (canção de ninar), empregando sons e movimentos. Buscar imagens vivas e detalhadas, tais como plantas ou animais. A partir de uma música congolesa, por exemplo, repetir um trecho com gestos e sons. A imagem pode ser a de uma pessoa sozinha em uma floresta, que passa a evocar deuses.

Aprendi a sensibilizar a voz, melhorá-la, modelá-la, descobrir os tons graves. O som vocal foi incorporado e emitido sem dificuldades na construção de peças de dança. Introduzi o conceito de "palavra física", que sugere, em vez de narrar. Em $C-E-C-I-L-I-A$, coreografia que compus e estreei na Europa em 2001, ano do centenário de nascimento da poeta Cecilia Meireles, a "serena desesperada", aliava o lirismo puro ao lirismo de guerra, em uma expressão de Mário de Andrade. Do texto, restaram apenas os substantivos, formando um mar de palavras: "madeira", "degrau”, "corda", "arraial", "cadeia”, "sorte” e assim por diante, o que permitia ao espectador compor um painel compreensível e coerente. Do mesmo modo que nada há de errado com relação à dança clássica (ou ballet), nada há de errado com a palavra, importando ampliar seu emprego. Como disse Artaud, são amplas as possibilidades, como a palavra encantatória.

\subsubsection{Dança Moderna}

Principiando o período da tarde, recebíamos a aula de Dyane Gray-Cullert, a única bailarina do Ballet du XXème siècle com sólida formação em dança moderna e igualmente a única afrodescendente do corpo de professores mudrista. Maurice Béjart não seguiu ele mesmo um treinamento em dança moderna. Os movimentos "modernos" presentes em suas coreografias decorriam de experimentos realizados com seu próprio corpo, muitas vezes à frente de um espelho.

Estadunidense, mais precisamente, nova-iorquina, Dyane Gray-Cullert, ou simplesmente Diane Gray, ensinava uma técnica com predominância de exercícios na posição vertical e com deslocamentos nas diagonais em vez de enfatizar o trabalho de chão. Seu método era proveniente dos ensinamentos do estadunidense Lester Horton (1906-1953), cuja ênfase se concentrava mais na verticalidade do que no chão, segundo a aula estruturada por Dyane.

Paralelamente ao trabalho técnico, Dyane Gray costumava solicitar pequenos exercícios de composição. Por exemplo: a partir de quatro movimentos propostos por ela, deveríamos acrescentar outros cinco intermediários; em duplas, desenvolver propostas de 
movimento cujo tema era escolhido pelos próprios alunos, tais como aberto/fechado; explorar o groundbase (ou o chão) como base de apoio; ou ainda improvisação a partir de animais na jaula, que têm fome.

No Brasil, já havia tomado conhecimento da técnica de Martha Graham (1894-1991) por intermédio da minha professora de dança moderna, Ruth Rachou, que aprendeu in loco as técnicas de Graham, Merce Cunningham e outros, como o jazzista Luigi, nos Festivais de Verão que ocorriam no Connecticut College, E.U.A., e as ensinava fielmente aos seus alunos em São Paulo. Além do ensino de uma barre à terre, Graham enfatizava o trabalho de chão, próprios da codificação efetuada pela coreógrafa e pedagoga norte-americana, cuja marca uterina era predominante. Dyane Gray nada trazia dos aspectos dramáticos, míticos ou trágicos, nem tampouco sociais que Graham desenvolvera após a grande depressão ocorrida nos Estados Unidos em 1929.

Acrescido ao expressionismo próprio de Renée Gumiel, minha segunda mestra no Brasil, que considerava o espetáculo algo sagrado, compus o repertório de conhecimentos em dança moderna que tinha ao chegar em Bruxelas. Com referência aos estudos realizados com ambas as mestras, escreveu Sílvia Geraldi:

Ao ingressar no Mudra em 1970, Célia já teria sido introduzida a duas vertentes diferenciadas da dança moderna ocidental que, genericamente, trabalharão em direções opostas, embora complementares: a americana, que enfatizará a apropriação de novos vocabulários por meio de sistemas tecnicamente codificados, para em seguida aplicá-los a fins diversos, sobretudo criativos e expressivos; e a alemã, que criará suas composições a partir de demandas emocionais mais do que padrões pré-fixados, não desconsiderando obviamente o domínio dos aspectos técnico-formais do movimento ${ }^{204}$.

Flora Cushman assumiu, posteriormente, o cargo de diretora do Mudra, em parceria com o bailarino belga Jan Nuyts, entre 1982 e 1988, em substituição a Micha Van Hoecke e Carolyn Carlson. Esta, californiana de origem finlandesa, ex-dançarina da Nikolais Dance Theatre de Nova York, companhia na qual dançou por seis anos. Carlson deu um estágio aos mudristas em 1973, demonstrando domínio pleno das qualidades do movimento, bem como o recorte sobre partes do corpo - peito, bacia, costas e a noção de carregar um suposto volume. Ao instalar-se na Europa, conheceu um sucesso e uma ascensão fulgurantes, que, de algum modo, devem ter doído em Béjart. Logo após a estreia de Carlson no Palácio Papal de

${ }^{204}$ GERALDI, 2015, p. 69-70. 
Avignon, Béjart dizia: "Ela mudou tudo na véspera da estreia, não estava segura do que fazia".

O emprego complexo das dinâmicas e das articulações proposto por Carlson era tal que me levou posteriormente a querer me aprofundar na técnica de Alwin Nikolais, obtendo, por dois semestres, em 1976 e 1978, uma bolsa da Chimera Foundation em Nova York. O prédio, sediado no lado leste da Rua 18, comportava a escola e a companhia de Nikolais e a de seu ex-bailarino Murray Louis. O intuito era dominar as ferramentas coreográficas por meio da técnica, improvisação e composição do método de Nikolais, bem como conhecer a relação movimento-moção e, ainda, o conceito de "descentralização corporal" e "centro fluido" de Nikolais, que resulta no desenraizamento da energia. Em dança, Nikolais qualificava a moção (do latim "motio") mais do que a emoção ou mesmo o movimento. Este pode ser descrever o começo ou o fim de um ato, como em um jogo de damas ou xadrez, por exemplo. A moção "qualifica a natureza de um movimento. Por isso falamos em leis da moção, e não em leis do movimento [...]", afirmou Alwin Nikolais durante sua visita ao Brasil em entrevista exclusiva a Gilberto Braga para o jornal $O$ Globo, na reportagem intitulada "Dança é a arte da moção e não do movimento".

Como arte, a dança é a arte da moção, e não do movimento. Posso qualificar a diferença. Falamos de movimento num jogo de damas ou xadrez. Falando de um modo geral, isto descreve apenas o começo e o fim de um ato; a maneira em que a ação tem lugar é a moção. Em outras palavras, a moção qualifica a natureza de um movimento. Por isso falamos em leis da moção, e não em leis do movimento - e é neste detalhe de qualificação que surge o elemento de mistério. Os bailarinos caem com frequência na armadilha da emoção, antes de entrar na moção. Para mim a moção é primária - é a condição da moção aquilo que culmina em emoção. Em outras palavras, é nosso êxito ou fracasso na ação, no tempo e no espaço aquilo que culmina em emoção. ${ }^{205}$

Uma década e meia depois, de volta a Nova York, na condição de primeira brasileira a obter, no campo da Dança, uma bolsa da John Simon Guggenheim Memorial Foundation, no início da década de 1990, houve a constatação dos resultados do amálgama entre a dança e as terapias corporais, que resultou em uma nova geração de dançarinos, despojados como um ser pedestre e, ao mesmo tempo capazes de executar complexas sequências, demonstrando alta assimilação das leis e qualidades do movimento. Houve, primeiro, o contato com o trabalho

\footnotetext{
${ }^{205}$ BRAGA, Gilberto. Dança é a arte da moção e não do movimento. O Globo, Rio de Janeiro, 23 mar. 1975.
} 
de Susan Klein, discípula de Irmgard Bartenieff, que, por sua vez, estudou com Rudolf Laban e se radicou nos Estados Unidos em 1936. Susan Klein focou a atenção no processo interno e no reconhecimento da ossatura e músculos profundos que sustentam o esqueleto. $\mathrm{O}$ resultado era um menor esforço muscular e uma maior fluidez. A aquisição desses conhecimentos resultou em uma radical modificação em meu modo de me movimentar e compor danças: um modo mais fluido, por meio do emprego de um menor tônus muscular; mais integrado, com base no conhecimento da ossatura e da musculatura profunda que sustenta o esqueleto. $\mathrm{O}$ que nos mantem em pé e nos leva a andar? Certamente é o iliopsoas, o músculo profundo que principia na décima segunda vértebra e ramifica-se para as pernas, estabilizando a coluna vertebral, além de fornecer suporte não só ao abdômen, mas à coluna vertebral, propiciando nossa verticalidade, bem como a possibilidade de se levantar as pernas para andar.

A experiência foi decisiva no preparo corporal que elaborei desde então, denominado Técnica Orgânica, desde o início dos anos 1990. "Orgânico" pode ser "conjunto". Pode ser “conjunto ordenado", "vivo". Para Jerzy Grotowski, o "organismo é o canal através do qual as energias circulam, as energias se transformam e o sutil é tocado"206. A transformação no modo de praticar a linguagem do movimento, mais flexível, ocasionado pela proximidade da dança com as terapias corporais que regulam o tônus muscular, propiciaram um dançarino que se machuca menos.

Guardei o emprego de imagens visuais como a canoa ou a areia, matéria movediça que escorre, que se move à toa na forma imposta pelo acaso e percorre os seis órgãos segundo a concepção da medicina chinesa (coração, pulmão, baço, pâncreas, fígado e rins) e as vísceras (estômago, vesícula biliar, triplo aquecedor, intestino grosso, intestino delgado e bexiga); guardei também a emissão de sons vocais e sua ressonância segundo a região corporal acionada, seguindo-se a progressão dos chakras: o "u" na região pélvica, o "o" em volta do umbigo, o "a" junto ao esterno, o "e" nas costelas e o "i" no topo da cabeça. Esse trabalho é realizado na posição deitada em decúbito dorsal, cujo abandono à gravidade permite um olhar interno mais aguçado. Permite identificar as oposições entre os lados direito e esquerdo do corpo, bem como a parte superior e inferior do tronco. Segue-se o trabalho de reconhecimento da cintura pélvica e da cintura escapular, bem como sobre cada articulação corporal, propiciando sua mobilidade. Já na posição vertical, esse trabalho leva à exploração dos movimentos assimétricos, por meio de qualidades como recolhimento e expansão em planos diversos.

\footnotetext{
${ }^{206}$ GROTOWKY, 1971.
} 
Recorrer a imagens permite o acordar do sensório, em vez de se delinear o desenho do movimento. Atentar à respiração, aos fluxos de inspiração e expiração somados a exercícios com os olhos fechados, conduz igualmente à dissociação relativa ao cotidiano e permite adentrar no interior de si. O tempo alargado, distendido, é, então, experienciado. A abordagem somática (do grego "soma”, ou “corpo”), resulta em uma visão conectada, não fragmentária do corpo. Abrangendo um extenso leque de opções, possibilita chegar à entrega, fundamental ao fazer cênico, bem como a um estado de prontidão, que envolve o sistema nervoso. Tal como um jogador de futebol, ao fazer um gol, encontra-se totalmente envolvido na sua ação, o mesmo estado corporal de prontidão é desejável na investigação cênica.

Outro dado relevante é o reconhecimento dos estados corporais. Lembrando que a palavra "status", em latim, nomeia o ato de ficar em pé. Podem ser incluídos no feixe dos estados corporais a energia e a vitalidade, a expectativa e a tensão, a lentidão e o repouso.

As questões pedagógicas não constituem um fim em si, mas são desenvolvidas enquanto ferramentas que servirão como estrutura a uma prática corporal cênica. Obedecem o ciclo chão/verticalidade/percurso no espaço, com variáveis de tempo. Como complemento ao trabalho técnico, são propostos textos curtos a partir dos quais um exercício cênico é construído, como, por exemplo, a frase de Hilda Hilst: "Como pensar o gozo envolto nestas tralhas?"207. Esse trabalho é voltado ao ensino e dirigido aos interessados em procurar e experimentar vias do conhecimento corporal, bem como da construção cênica.

Após anos de convivência com um Maurice Béjart que, em pleno vigor criativo e como bom europeu, criava obras humanistas que tinham, frequentemente, como ponto de partida, um texto literário, sempre marcadas por intensa espetacularização, tornou-se possível identificar outro modo muito diverso de se proceder. A dança americana nos anos 1970, sempre física e atlética, primava pela busca nada espetacular do movimento pedestre, das ações funcionais, do antiespetáculo. Trisha Brown, por exemplo, despiu a dança da emoção e da expressividade, marcada que foi pelos ensinamentos de outros dois norte-americanos ilustres: Ann Halprin e Robert Dunn, já citados. Tais conhecimentos, somados, levaram-me a desenvolver padrões de movimento próprios.

${ }^{207}$ HILST, Hilda. Cartas de um sedutor. Rio de Janeiro: Ed. UFRJ, 2002. p. 15. 


\subsubsection{Sociologia}

Único curso teórico, o estudo da sociedade integrou o currículo apenas no primeiro ano. Desconheço os motivos que levaram à sua extinção, pois só o fato de incentivar a inserção dos alunos nas questões do mundo, em um direcionamento outro que o progresso técnico e criativo, já o justificava. As aulas, semanais, tinham uma hora e meia de duração e visavam ao grupo multiétnico mudrista, que recebeu abordagens sobre questões culturais, sociais e políticas. O eixo do estudo foi a relação entre indivíduo e sociedade, com suas pontes e fraturas. Os principais teóricos tratados foram o sociólogo e economista inglês Thomas Robert Malthus (1766-1834) e o sociólogo francês Emile Durkheim (1858-1917), considerado o fundador da escola sociológica clássica francesa e que pretendeu elaborar uma teoria científica e sistemática. Teoria é, aqui, entendida como generalização coerente. Teria sido a Mme. Vermeulen quem selecionou os autores tratados? Por que uma das escolhas recaiu no eminentemente conservador Malthus?

O britânico Malthus escreveu Ensaio sobre o princípio da população, onde relacionou o aumento constante da densidade populacional à subsistência mundial. $\mathrm{O}$ autor inglês apresentou a controversa tese de que a população universal aumenta em proporção geométrica, enquanto a produção de alimentos cresceria apenas em proporção aritmética, o que consistiria um perigo. Para solucionar a diferença, Malthus propôs o celibato, a abstenção do casamento. Desconheço os motivos que levaram os programadores do curso a colocar tal autor em questão. A questão do desperdício de alimentos, frequente no mundo industrializado, superior em número àqueles que passam fome, não foi levada em conta.

A sociologia é disciplina surgida na modernidade, contrariamente à filosofia, existente desde a Antiguidade grega. Ocupam-se, os estudos sociológicos, dos indivíduos organizados em sociedade, de um ponto de vista laico. Sucessor de Augusto Comte, Durkheim, na atualidade, é considerado dono de uma perspectiva conservadora. O sociólogo analisou o fato social objetivo de um ponto de vista distante do sujeito referencial cartesiano do qual provém o conhecimento. Para o autor, os fatos sociais tratados devem ser estudados enquanto coisas. O fato social será reconhecível pelo poder de coerção exercido. As ações coercitivas às quais Durkheim faz referência são exercidas sobre a consciência individual. É possível que o pensamento desenvolvido por Michel Foucault acerca do poder coercitivo em Vigiar e punir ecoe as premissas durkheimianas.

A consciência coletiva aparece como interação resultante de relações e influi nas atitudes, ideias e sentimentos, abarcando dados morais que independem da consciência de 
cada um. A estrutura política encontra-se no âmbito das ações coletivas. À cada fato social típico, concerne uma categoria social específica. Constata-se o elo entre corpo político e corpo individual, ou entre história e subjetividade, por meio de segmentos entrecruzados. No mundo ocidental, as coerções exercidas pela Igreja agem sobre o mundo interiorizado dos indivíduos, enquanto as leis, próprias ao mundo exteriorizado, interferem igualmente na vida interior dos indivíduos. A burguesia atesta a divisão da sociedade em classes sociais e age sobre ambas as esferas: interior e exterior. Apesar do reconhecimento das duplas esferas, Durkheim evitaria tanto os fenômenos psíquicos quanto os orgânicos, por escaparem à comprovação científica. Ambos careceriam de objetividade por se situarem no âmbito estritamente individual. $\mathrm{O}$ autor tampouco lançaria seu olhar a outros tipos de sociedade, como a asiática.

O sociólogo francês citou curiosos exemplos, como o dos exploradores ingleses que iam à África para caçar e, à noite, trajavam smoking para jantar. Compete ao Estado funcionar como um cérebro social, um centro organizador que teria a função de libertar a personalidade individual. Tal visão parece, hoje, deslocada, uma vez que o Estado encontra-se submetido ao sistema financeiro.

O indivíduo é considerado um agente ativo e criador e necessita de liberdade para o seu desenvolvimento pessoal: "Não basta que uma sociedade seja ampla, é preciso que o indivíduo possa mover-se com certa liberdade por uma ampla extensão" ${ }^{208}$. A diferenciação entre a individualidade e a subjetividade, que remete à singularidade, cabe ser evocada. Em um contexto libertário, o papel do corpo será transformado, promovendo a inter-relação entre corpo e sociedade. Estes, concebidos como organismo e indivíduo, são inseparáveis, havendo uma relação de interdependência entre indivíduo e sociedade. Compete ao Estado funcionar como um cérebro social, um centro organizador que teria a função de libertar a personalidade individual. O propósito é o de "libertar da coerção dos grupos sociais secundários, relacionados na evolução histórica: a igreja, o feudo, a cidade e a corporação"209.

Considero tal discussão pertinente para o grupo de mudristas que acabava de ser formado e que, necessariamente, iria desenvolver uma convivência para além da própria individuação por meio do ato de interagir. Para Durkheim, a socialização propicia a formação da personalidade e acarreta modificações no comportamento. Ponto-chave para a concepção dinâmica das relações sociais: estas estabelecem ações recíprocas capazes de promover a

\footnotetext{
${ }^{208}$ DURKHEIM, Émile. Lições de Sociologia. Tradução de Mônica Stahel Oliveiros S. Ferreira. São Paulo: Martins Fontes, 1990. p. 11.

${ }^{209}$ Ibid., p. 13.
} 
mutualidade, atuando por meio de interinfluências e interestímulos pelo contato, e provocam reações de cooperação entre seus agentes ou, também, de oposição, como é o caso da competição, que produz conflitos provenientes do entrechoque de interesses. As inter-relações humanas comporão o tecido da estrutura social.

No curso de Sociologia, foi também abordada a sociedade global por intermédio de um critério geográfico ou histórico, quando os interesses comuns prevalecem. O exemplo tomado foi o do Canadá, onde situa-se Quebec, que não constitui uma sociedade. A globalização foi considerada positiva, sem levar em conta a financeirização do mundo que se consolidou posteriormente, prejudicando as populações que vivem em condições econômicas desfavoráveis. O geógrafo brasileiro Milton Santos (1926-2001) trata a globalização como fábula. Esse primeiro período parecia estabelecer pontes entre as nações e foi seguido pelo segundo, o da globalização como ela é, quando o mundo da dignidade humana foi expropriado por empresas que construíram um mundo perverso. É quando o dinheiro, a financeirização toma conta e emergem os excluídos do banquete da globalização, no qual constam, evidentemente, as centenas de milhares que deixam seus países, sobretudo os situados no Oriente Médio e na África, em busca de refúgio nos países europeus.

Há ainda a antevisão de um terceiro período, o da globalização como poderia ser ou globalização solidária, que prevê a convivência com um mundo possível no qual jovens da periferia serão os protagonistas da revanche por meio da ocupação de imóveis abandonados, filmagens realizadas com materiais que não demandam alto investimento ou a prática do rap, gerando formas de solidariedade com aspectos econômicos e políticos ${ }^{210}$. A observação reforça o pensamento segundo o qual uma arte periférica pulsa em territórios outros que teatros e museus, apontando para um movimento artístico nascente que atesta a ligação entre dança e mudança, transformação, o atravessamento das formas.

O aparecimento do rádio permitiu a simultaneidade. Informações passaram a poder ser difundidas mundialmente, tendo como único limite a língua. Estados totalitários podiam controlar as emissões, que hoje se estendem a outros veículos, como a internet. Na Espanha, houve o processo de Burgos. Os fatores que levaram o General Francisco Franco (1892-1975) ao poder foram a Falange, a Opus Dei e o Exército, somados ao Estado católico espanhol, até que o papa João XXIII ordenou à Igreja espanhola que cessasse suas funções dentro do governo político espanhol devido à sanguinária Guerra Civil Espanhola (1936-1939), na qual

\footnotetext{
${ }^{210}$ ENCONTRO com Milton Santos - ou: o mundo global visto pelo lado de cá. Direção: Silvio Tendler. Produção: Ana Rosa Tendler. 2006. Exibido no Canal Curta em 7 de abril de 2016.
} 
Franco apelou ao exército fascita alemão para a destruição de várias cidades - entre as quais Guernica, imortalizada pelo quadro homônimo de Picasso. O conflito civil entre falangistas e republicanos resultou em milhares de mortos, até que os republicanos foram vencidos e Franco, que já havia promovido massacres nas colônias portuguesas da África, instalou o regime totalitário. Foi quando a família Marin, cujo patriarca Antonio integrava os quadros do Partido Comunista Espanhol, atravessou os Pirineus e instalou-se em Toulouse, na França, onde nasceria a filha caçula Marguerite France, conhecida como Maguy Marin.

Houve tribunais de exceção na Espanha, Grécia e França (devido à guerra da Argélia). Hoje, a ideologia teria sido substituída pelo individualismo. A procura pelo bem comum, gatilho para o surgimento da filosofia na Grécia no tempo de Sócrates (470-399 a.C.), e o compromisso com a cidade e seus cidadãos deslocou-se para a esfera da satisfação subjetiva e das preocupações individuais. Fruto do capitalismo exacerbado, o pós-modernismo é globalização, como quer Fredrich Jameson.

$\mathrm{Na}$ sequência foram tratadas questões culturais e referentes a civilizações. Primeiramente, as relações entre magia, religião e ciência. O fogo, utilizado em rituais religiosos, pode ser um resquício da magia. A civilização sumeriana foi abordada. A representação do homem seria uma ofensa a Deus. A medicina foi igualmente descartada, pois nem o corpo nem a morte teriam importância. No Egito, o culto a Horus, o Sol, simbolizava a passagem da vida. Não foram tratadas questões darwinianas, que concedem o peso maior das transformações sociais à Biologia, ou positivistas, comtianas, que subordinam os conceitos aos fatos devido a seu caráter programático, conceitos estes herdeiros do Iluminismo, da Aufklerung kantiana, que evoca um clarão cintilante e cujo peso se encontra na cognição, nos poderes explicativos da razão humana. Os preceitos de Auguste Comte (1798-1857), que cunhou o termo "sociologia", conduziram às palavras inscritas na bandeira nacional brasileira: a "ordem", estática e homogênea, e o "progresso", dinâmico e heterogêneo, como também linear e conservador. Poderiam ter sido discutidas questões referentes ao contexto de onde cada mudrista provinha e o atual, envolvendo a adaptabilidade, bem como a estranheza. Questões referentes à América Latina não foram tratadas. Tão importante na constituição do Departamento de Humanidades da USP, a ponto do pensador Antônio Cândido dizer que, apesar de ser primeiramente voltado à literatura, cursou Ciências Sociais, motivado pela presença de eminentes professores franceses na Universidade, a sociologia veio a ser, para mim, parte de um entendimento interdisciplinar.

Os dois cursos descritos a seguir foram os mais marcantes, devido, em parte, à personalidade de seus professores: Fernand Schirren e Alfons (ou "Fons") Goris. 


\subsubsection{Ritmo}

Um pessimista entusiasta. Assim se autodenominava o nosso professor de ritmo Fernand Schirren.

O que é o ritmo? Variação do tempo. O ritmo, filho da respiração, teria gerado a dança quando caçadores e agricultores sincopavam seus passos contra as folhas secas enquanto se deslocavam, na aurora da pré-história. Na concepção deleuziana, o ritmo é um procedimento, enquanto a dança é processo ${ }^{211}$. Fernand Schirren, percussionista e célebre pianista, acompanhador ao vivo dos filmes mudos no Museu do Cinema de Bruxelas, foi um grande enaltecedor das qualidades bruxelenses, a ponto de considerar a capital belga, onde viveu desde os 3 anos de idade, o centro do mundo. Avesso a viagens, nasceu em Nice, em 1920, filho do pintor Ferdinand Schirren. Era alto e grande, sempre na companhia de sua barba, sua pipa e seus grandes óculos. Apertava os olhos e, com seu olhar perscrutador e sorridente, ia logo definindo: "Você é „„e, você é „bum"er, distinguindo os tensos dos relaxados. Com muito de um filósofo irônico e dono de um humor peculiar, autodefinia-se como um pessimista entusiasta. Não cessava de emitir conceitos, sempre com muita segurança. Segundo ele, seus ensinamentos musicais deveriam ser úteis para a dança e para a vida.

A sala de Ritmo era dotada de pranchas de madeira com cerca de trinta centímetros de largura dispostas sobre cavaletes. Desde o primeiro dia de aulas, os alunos recebiam duas baquetas de madeira, aprendendo a segurá-las, um pouco adiante de suas extremidades: polegares sobre e dedos sob. A pressão dos dedos deveria ser fraca sobre a madeira. A partir dos ombros, braço, antebraço e mão formariam um ângulo reto. A posição das mãos não deveria ser alterada, mas mantida, sem se afastar nem se aproximar as mãos, conservando-se a posição.

A seguir, dois toques seguidos com cada mão, pronunciando-se as palavras "papai” e "mamãe". O acento deveria recair na primeira nota, com o intuito de fornecer um sinal; grandes e pequenos acentos se alternavam. Na sequência, batia-se repetidamente com a mesma mão e acrescentavam-se pausas em determinadas notas. $\mathrm{O}$ toque deveria ser curto, sem se levantar muito as baquetas, ou seja, não se deveria bater muito forte. Tocar com menos força permitia melhorar os acentos, sendo indispensável manter os ombros relaxados. Entre tensão e descontração, o tônus justo era procurado, a fim de se obter batidas enérgicas, precisas, secas.

\footnotetext{
${ }^{211}$ DELEUZE; GUATARI, 1995, Orelha do livro (por Jean-Clet Martin).
} 
Passava-se, em seguida, à composição e escrita de ritmos, principiando por binários e ternários, com recurso a colcheias, semicolcheias, fusas, semifusas, mínimas, semínimas, etc. Introduziam-se pequenas síncopes para variar, o que tornava o ritmo mais agitado. Éramos estimulados a verificar o que era preciso: se já havia sido introduzida comida salgada, agora seria a vez de um doce. É possível colocar um acento na nota anterior à pausa, também denominada de silêncio ou repouso provisório. O curso denominava-se, também, Percussão e Pesquisa Musical. O professor Schirren instruía que, para se construir um ritmo, deve-se, antes, precisá-lo. A partir da célula descoberta, a próxima etapa consiste em dividir o ritmo, pensando por partes, a fim de se encontrar a maneira de se tocar. Por exemplo: posso compor as quatro últimas medidas estabelecendo uma ligação com as quatro primeiras, ou seja, propondo uma reunião (rassemblance) entre curto/curto e longo/longo. Quando os sons são iguais, há menor tensão. Esta aumenta quando diferem. É orgânico porque há um antecedente e um consequente, isto é, semelhança e diferença.

Figura 18 - Curso de ritmo com o professor Schirren, 1971

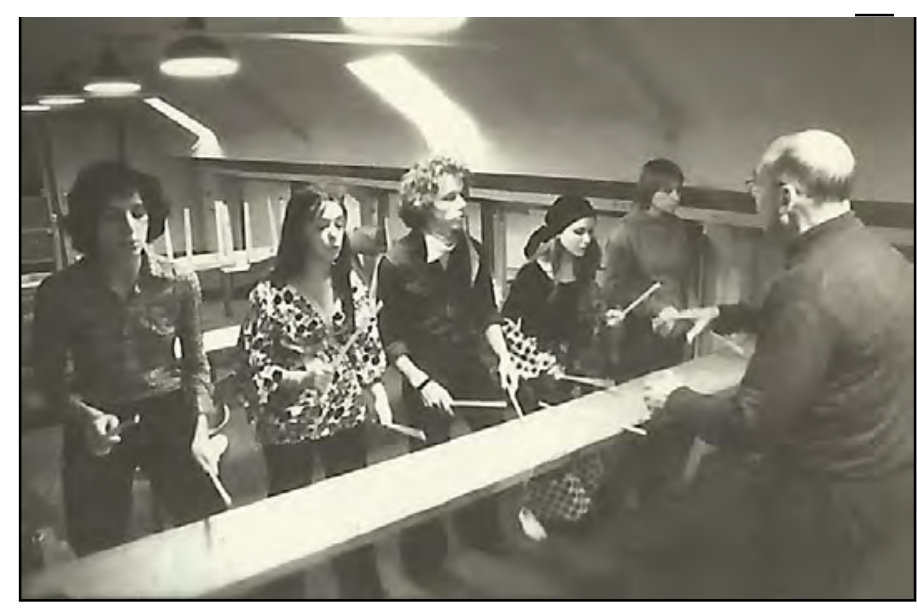

Alunos: Juliana Carneiro da Cunha, Christiane Glik, Pierre Droulers, Célia Gouvêa e Maguy Marim (da esq. para a dir.). Fonte: arquivo pessoal. Fotógrafo não identificado
Figura 19 - Prática e exercício escrito de ritmo realizado em 1971

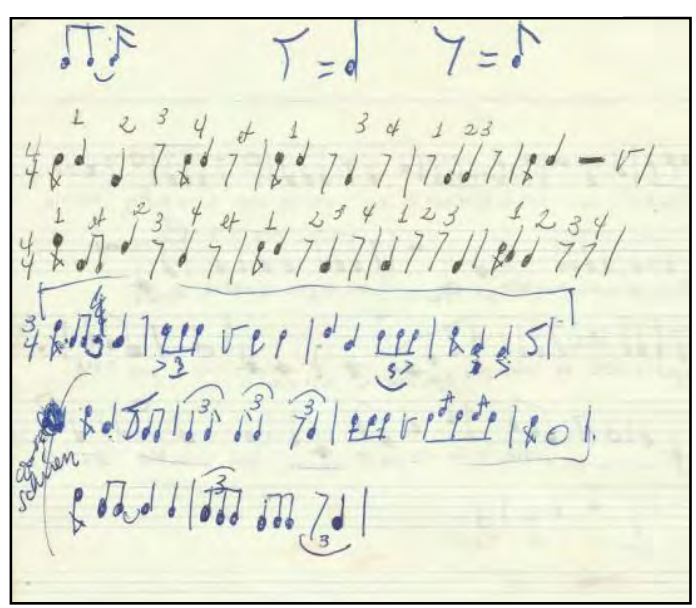

Fonte: arquivo pessoal.

Em livro manuscrito, sem a numeração de páginas, escreveu Schirren: "Uma fase de movimento; uma fase de não movimento. A fase de movimento, eu a chamarei: E; A fase de 
não movimento, eu a chamarei: BUM",212. O "BUM" equivalia ao grau zero do movimento, um abandono à ação do peso e da gravidade. Um terceiro elemento costumava aparecer: o BIM, definido pelo professor como uma parada no meio do caminho durante uma descida.

O ritmo: primordial e soberano, título do livro prefaciado por alunos renomados como Maguy Marin, Anne Teresa de Keersmaeker e Jose Besprosvany, principia por aparentes obviedades, tais como: uma maçã, mais uma maçã, igualam duas maçãs; ou uma cadeira mais uma cadeira formam dois também: duas cadeiras; ou ainda: "As partes do corpo são muito diferenciadas. Tua cabeça não tem coração, teu coração não tem cabeça, e tua mão não tem nem coração nem cabeça" ${ }^{213}$; ou ainda: segurar a força solicita força. Dito de outro modo, consiste em des-complicar, em não buscar o muito nebuloso e difícil. É como pensar por meio de um raciocínio natural, buscando o fundamento das coisas, a arkhé. Na contracapa do livro, há a referência ao Mudra como centro pluridisciplinar (muitas disciplinas), palavra que não aponta para a conversa entre elas.

Seu pensamento, foco de interesse de uma vasta gama de artistas da dança, do teatro, da música e, também, daqueles que refletem sobre essas linguagens, inclui muitas observações sobre o tempo, aliado notório do ritmo. Há ainda observações sobre as ocasiões festivas, quando os batedores do tambor como que penetram a terra e, com seu som, preenchem o ritual e repudiam a morte. Segundo o professor: seria esta a célula inicial da polifonia, que antecedeu em muito as catedrais antigas. A repetição rítmica, retorno ao passado, é recomeço contínuo e adiciona o ritmo presente à força do ritmo passado por meio da insistência encantatória. Segundo o professor, todo espetáculo é um retorno à festa. Aos alunos das artes do jogo, da dança e da música, dizia Fernand Schirren: grande é a distância entre saber e saber fazer. Sem citar Platão, enfatizou a tekné (ou habilidade). Convencer comporta vencer, lembrou o professor.

\subsubsection{Jogo Teatral}

Observação e metamorfose - pilares do curso de jogo teatral. Por meio dessas ferramentas, partíamos do estado mineral para passar em seguida ao vegetal, depois ao

\footnotetext{
${ }^{212}$ SCHIRREN, Fernand. Le rythme primordial et souverain. Bruxelles: Contredanse, 1996. Não paginado. Tradução nossa. Texto original: "Une phase de mouvement; une phase de non mouvement. La phase de mouvement, je l'appellerai: ET; La phase de non-mouvement, je l'appellerai: BOUM".

${ }^{213}$ Ibid. Tradução nossa. Texto original: "Ta tête n'a pas de coeur, ton coeur n'a pas de tête, et ta main n'a ni coeur ni tête".
} 
animal, chegando, por fim, ao humano. Observávamos, de fato, os elementos naturais, incluindo visita ao Jardim Zoológico da Antuérpia para selecionar um animal e incorporá-lo. Selecionei o pinguim. Poderia também ter escolhido um macaco ou um cavalo, animais de minha predileção. Distinguir o vislumbrar do ver. Atentar ao mundo circundante, a ele tornarse poroso, cessar o diálogo interno, foi para mim um grande aprendizado:

... saber ver

Saber ver sem estar a pensar

Saber ver quando se ve... ${ }^{214}$

A abordagem do ser humano principiava com a escolha de um ofício, seguida pela percepção de atmosferas ambientais - hospitais, aeroportos e outros - até chegar ao sonho e a textos poéticos, improvisando-se cenas com diálogos. O ofício escolhido por mim foi um sorveteiro de praia brasileira, menino.

O professor Alfons Goris, corpulento, risonho e bem-humorado, pertencia à Bélgica flamenga e formou muitos atores no estúdio fundado por Herman Terlinck na Antuérpia, sucedendo-o na direção do mesmo. No Mudra, inaugurou uma nova fase, a de professor de jovens cuja formação até então era centrada na dança. Éramos instados a propor e inventar sem cessar, em um desafio constante. É dele a expressão "buracos no céu", ao referir-se a algumas coreografias extraordinárias de Maurice Béjart. Empregada por mim na emissão "Figuras da Dança", em maio de 2011, transformou-se em título do filme-performance de Evaldo Mocarzel gravado em maio de 2013 no terraço situado no alto da Assembléia Legislativa, em São Paulo, a partir de personagens evocados na referida emissão.

Num encontro em Bruxelas com o professor Goris no verão de 2001, combinado por ele em um determinado ponto do Jardim Botânico da capital belga, o professor discorreu sobre a gênese de seu curso denominado Jogo Teatral. Provém de Mikhail (ou Michael) Chekhov (1891-1955), sobrinho do escritor e dramaturgo russo Anton Chekov, nascido em São Petesburgo, na Rússia, e falecido em Beverly Hills, na Califórnia, para onde emigrou em 1938, pouco antes da eclosão da Segunda Guerra Mundial. Formado pelo Teatro de Arte de Moscou segundo o sistema stanislavskiano, partiu do método da análise ativa a partir das ações físicas ou psicofísicas, que incluem tanto o agir quanto o pensar, até introduzir o conceito de "gesto psicológico". Quando o professor Goris mencionou a proveniência do

\footnotetext{
${ }^{214}$ PESSOA, Fernando. Poemas Inconjuntos. Lisboa: Ática, 1979 apud IBRI, Ivo Assad. Kósmos Noetós. São Paulo: Perspectiva, 1992. p. 6.

O mesmo ensinamento (aprender a ver) era frequentemente reiterado pelo diretor Maurice Vaneau.
} 
método que aplicava em seus cursos de jogo teatral da corrente stanislavskiana que migrou para a Inglaterra, estava certamente referindo-se a Dartington Hall.

Michael Chekhov, considerado por Stanislavski um de seus mais brilhantes alunos, um ator prodígio, liderou o segundo estúdio do Teatro de Arte de Moscou, o que Stanislavski considerou uma traição. Deslocou para a imaginação a memória emotiva do mestre. No final da década de 1920, emigrou para a Alemanha, onde trabalhou com Max Reinhardt, um dos primeiros encenadores a alterar a relação palco-plateia. Em 1936, instalou-se em Dartington Hall-Devonshire, localizada ao sul da Inglaterra, para dirigir uma escola de arte dramática, quando realizou experimentos de sua técnica. Foi para lá também que se dirigiu o coreógrafo alemão Kurt Jooss (1901-1979), pressionado pela ascensão nazista ao poder, quando coreografou novas peças. Jooss, coreógrafo da emblemática $A$ mesa verde - um tratado sobre o poder e a guerra.

Foi também para a Escola de Artes de Dartington Hall que a húngara Maria Duschenes, nascida Maria Ranschburg (1922-2014), dirigiu-se na primavera de 1937, onde permaneceu até o fechamento da escola no final do verão de 1939, devido aos bombardeios aéreos durante a Segunda Guerra Mundial. O grande codificador das propriedades e qualidades do movimento Rudolf Laban (1879-1958) foi o grande mentor de Dona Maria, como era chamada a mestra maior dos ensinamentos labinianos em São Paulo e com quem a colega Juliana Carneiro da Cunha iniciou seus estudos de dança ainda na infância. Localizada em Dartington Hall, a Jooss-Leeder School of Dance proporcionava aulas de dança práticas e teóricas e outras disciplinas, que iam da iluminação ao artesanato, promovendo ainda a troca de experiências entre seus participantes ${ }^{215}$. Rudolf Laban teria sido um dos mestres de Dartington Hall, ocupando, porém, uma posição mais ofuscada, devido ao seu envolvimento com o Partido Nacional Socialista alemão.

Anteriormente a Maria Duschenes, Renée Gumiel teria permanecido na escola entre 1933 a 1936. Às disciplinas seguidas por Duschenes, Renée acrescentou Teatro, Anatomia, Música, Artes Plásticas e cursos de coreografia com Rudolf Laban ${ }^{216}$.

O sr. e a sra. Elmhirst e a srta. Beatrice Straight, milionários idealistas, formaram em Dartington Hall uma comunidade utópica, voltada à agricultura e à educação artística e que incluía a prática da euritimia e da antroposofia. Esta foi descoberta por Stanislavski em 1910, quando, após viagem à Itália para visitar Maximo Gorki, seguiu para a Alemanha, antes de

\footnotetext{
${ }^{215}$ COSTA, Carlos (Coord.). Ocupação Maria e Herbert Duschenes. São Paulo: Itaú Cultural, 2016.

${ }^{216}$ BOGEA, Inês. Renée Gumiel: 90 anos. São Paulo: Editora SESC, 2003.
} 
retornar à Rússia. A antroposofia, do grego "anthropos" (ou "homem"), indica a sabedoria do homem, segundo o alemão Rudolf Steiner (1861-1925). Enraizada na natureza humana, a antroposofia é derivada da Euritmia, fundada por E.J. Dalcroze ${ }^{217}$ e que conjuga o olhar objetivo dirigido ao espaço externo com o olhar subjetivo dirigido ao espaço interno e ao universo sensorial. A palavra "Eurritmia" conjuga "eu" ("bem") a "rythmus" ("ritmo").

Mikhail Chekhov iria se debruçar sobre esses conhecimentos a partir de 1917, ano da Revolução Bolchevique soviética. Chekhov diria, a propósito do ator: "Somente um comando indiscutível de seu corpo e de sua psicologia lhe dará a autoconfiança, a liberdade e a harmonia necessárias a sua criatividade" ${ }^{218}$, em um procedimento holístico que alia o nível físico, vital, anímico e espiritual. Os exercícios corporais propostos por Chekhov incluem a amplitude, o emprego de partes determinadas do corpo, o flutuar. O autor não cita Rudolf Laban, apesar da proximidade em alguns conceitos. É na proposta de irradiação de luz ao mover-se que Chekhov atinge seu ponto mais específico.

A técnica desenvolvida por Michael Chekhov foi o ponto de partida para a construção do método do professor de jogo teatral Alfons Goris, embora a própria prática e sua cultura, provenientes da origem flamenga, tenham concedido e acrescentado contornos próprios. Goris dizia que a arte dramática não nasceu da literatura, mas do gesto, concepção esta partilhada por Maurice Béjart e Maurice Vaneau. O professor Goris dirigiu os seguintes exercícios cênicos, apresentados no âmbito do Centro Mudra: Leda et le cygne (Leda e o cisne), de Paul Éluard; Cantate 140 - Reveillez-vous, unde voix vous appelle (Cantata 140 - Acordem, uma voz vos chama), de J.S. Bach; e La celestine (A celestina), de F. De Rojas.

Um dos principais preceitos do professor, no que se refere às qualidades pessoais, era o de que aquilo que se tem, a gente tem (em meu caso, as transições fortes e rápidas). O que não se tem, trabalha-se para adquirir. O professor referia-se também, constantemente, ao premier jet (ou primeiro jato), carregado de frescor, que corresponde também a um insight.

\footnotetext{
${ }^{217}$ SUQUET. In: COURBIN; COURTINE; VIGARELLO (Org.), 2009.

${ }^{218}$ CHEKOV, Michael. Para o ator. São Paulo: Martins Fontes, 1996. p. 6.
} 
Figura 20 - Ensaio dos mudristas com o professor Goris na grande sala de ensaios (A4) em 1971
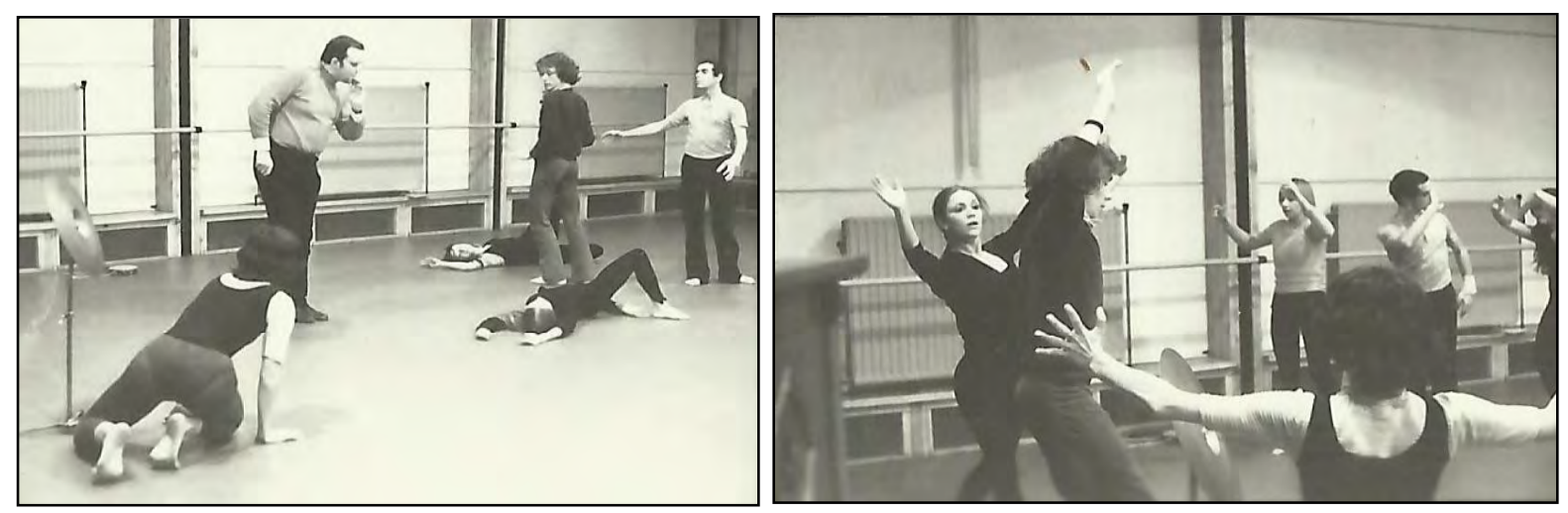

Fonte: arquivo pessoal. Fotógrafo não identificado

Em minha trajetória artística, além do sentido da observação e da metamorfose, guardei muito viva a porosidade às atmosferas emanadas pelos ambientes, conceito chekhoviano que nos foi transmitido pelo professor Goris: a atmosfera é o tom ou espírito dominante e objetivo de um lugar, pessoa, obra ou fenômeno. Captá-las convoca a cognição, o corpo e a imaginação, segundo o professor, em uma alusão à interatividade corporal.

\subsubsection{Teatro}

Em 1972, durante o segundo do ciclo de três anos, o diretor australiano estabelecido na Inglaterra John Blatchley concedeu-nos um curso de teatro, com fundamento no sistema stanislavskiano. Blatchley é cofundador da revolucionária escola de teatro que trouxe consciência do movimento ao teatro inglês desde 1963, a Drama Centre London, originalmente localizada em Chalk Farm e que hoje faz parte da Universidade das Artes de Londres, realocada em Kings Cross. O diretor, cuja produção incluiu a direção de óperas, além da escrita e atuação, esta notadamente do repertório shakespeariano, inclusive no Old Vic Theatre, elegeu de William Skakespeare a peça que trabalharia conosoco: Macbeth.

O grande aprendizado adquirido com o professor Blatchley foi o de encontrar o estado de disponibilidade, adentrar em um universo, viver uma situação dramática, experimentar a metamorfose, entregar-se, estar dentro, em suma, lembrando que a ação é vivida pelo ator, enquanto a situação, pelo personagem. Certa é a implicação da quarta parede, o não direcionamento ao espectador, que diferem da dança e do teatro contemporâneos, nos quais prefiro ser eu mesmo, sem transporte a universos outros. O método (ou sistema) stanislavskiano empregou como ferramentas o conhecimento de si, a sinceridade e a penetração nas emoções mais complexas e profundas para fazer emergir o personagem cênico. 
Constatin Stanislavski, ou Konstantin Sergeevic Stanislavskij (1863-1938), colocou o corpo em relevo. Ao acordar o corpo-pensamento, Stanislavski convoca:

[...] a atenção, a firmeza, a flexibilidade, a concentração, a destreza como psicotécnica; tensão e esforço físico em cena são causados pela violação das leis da natureza (o natural enquanto segunda natureza equivale à organicidade e conduz à qualidade psicotécnica) [...]. O treinamento psicofísico para o corpo relaxado e atento requer exercícios de sensibilização, equilíbrio, força, resistência, agilidade, destreza e consciência do fluxo da energia interna do movimento aperfeiçoando memória, imaginação, atenção, habilidades cênicas especiais e realização concreta de uma ação orgânica, plasticamente expressiva, dirigida a um fim ${ }^{219}$.

De fato, o método stanislavskiano das ações físicas exorta o reconhecimento dos estímulos reais e motivações internas que impulsionam o ator, sem a interferência da consciência. A ação interna corresponde à vivência, assim denominada. O trabalho do ator principia pelas ações físicas, deixando de lado o byt (ou vida ordinária) para alimentar-se da vida interna do ator em direção à personagem, feita de situações, ações, circunstâncias. O si mesmo se assenta não sobre a pessoa, o indivíduo, mas ressoa sua natureza criadora. A vivência implica na participação de todo o organismo. O gesto de abrir uma porta pode remeter a inúmeras intenções e consequentes leituras. Há sempre uma lógica transversal e uma sucessão nesse agir.

A memória foi, primeiramente, denominada afetiva e, mais tarde, emotiva. Quando evocada, os dados que irrompem adequam-se às tarefas físicas e "se realizam no corpo que é bastante mais firme que nossas emoções", escreveu Sergio Jimenez em El Evangelio de Stanislavski $^{220}$. O método da análise ativa, posteriormente denominado de étude, termo derivado da pintura e também presente na música, inclui texto, movimento, corpo-memória e imagem. Contém os "se" hipotéticos.

É nas ações do corpo, é no fazer que a verdade estará presentificada, o que ultrapassa a representação. Mais que a emoção, os nervos é que são acionados. Todos os sentidos participam da ação, aos quais vem se juntar a propriocepção, a que já me referi, reconhecida

\footnotetext{
${ }^{219}$ DAGOSTINI, Nair. O método de análise ativa de Constantin Stanislavski. 2007. 251 f. Tese (Doutorado em Letras), Faculdade de Filosofia, Letras e Ciências Humanas, Universidade de São Paulo, São Paulo, 2007. p. 85.

${ }^{220}$ JIMENEZ, Sergio. El metodo de acciones fisicas. In: . El evangelio de Stanislavski sun sus apostoles, los apócrifos, la reforma, los falsos profetas y Judas Iscariote. México: Editorial Gaceta, 1990. p. 239-287.
} 
na Rússia enquanto um sexto sentido ${ }^{221}$ e responsável pela localização espacial do corpo e o consequente equilíbrio, sem a necessidade da visão, mas interagindo por meio das fibras musculares e do sistema vestibular.

Stanislavski iria admitir a unidade psicofísica - ou união entre a atividade física e psíquica - em sua busca pelo estado criativo, por ele encontrado, por exemplo, em Isadora Duncan, que, após obter sucesso em Paris, em 1904, apresentou-se em Moscou pela primeira vez no ano seguinte. Isadora admitia a necessidade de colocar um motor em funcionamento antes de dançar, motor este perseguido pelo mestre russo antes que um ator entre em cena, conforme relata em Ma vie dans l'art. O encontro entre ambos ocorreu após a estadia de Stanislaviski na Finlândia em 1906, quando questionava o que permite a um ator encontrar um novo sopro a cada apresentação, sem repetir clichês, obtendo a resposta em um estado supra consciente. É quando migra do realismo ao impressionismo, com a montagem de $O$ pássaro azul, de Maurice Maeterlinck, partindo para a abstração. Stanislavski encontra em Isadora Duncan a harmonia com as forças cósmicas, uma intuição, um frescor e energia que o encantam. Para o mestre russo, os atores deveriam ser criadores, auscultando suas motivações interiores e experiências pessoais ${ }^{222}$.

Já o que fez Meyerhold ao afastar-se do mestre e encontrar a biomecânica, distante da profundidade psicológica, o fez ser taxado de excessivamente coreográfico, entendendo-se, aí, coreografia enquanto marcação precisa e mesmo enquanto partitura rígida e fechada de movimentos. Meyerhold que já havia trabalhado com o coreógrafo Michel Fokine na condição de bailarino. Após ter se afastado do mestre Stanislavski, dele se reaproximou em 1902, propondo o teatro laboratório. Apesar do apoio recebido, não obteve o êxito esperado na empreitada.

A procura da eliminação da tensão excessiva do ator, o que proporciona a fluência do corpo-pensamento, levou Stanislavski a observar os movimentos dos gatos, relevando sua desenvoltura. A partir de 1912, introduziu a prática do yoga em seu estúdio, com ênfase no processo respiratório. Foi também adepto de técnicas como a ginástica, a esgrima e, um pouco, da acrobacia na preparação do corpo do ator. $\mathrm{Na}$ efervescência criativa russa do

\footnotetext{
${ }^{221}$ Informação verbal. Informação fornecida em aula pela Prof. Dra. Maria Thais Lima Santos em curso "Da pedagogia à cena, da cena à pedagogia" na Escola de Comunicações e Artes da USP (ECA-USP) em agosto de 2013.

${ }^{222}$ O SÉCULO de Stanislavski - Parte 2: Os anos sísmicos. Texto e Realização: Peter Hercombe. Produção: Daniel Renouf. Narração: André Dussollier. Paris: System TV; L'Union des gens de Théâtre de Russie; La Sept, 1993. Exibido no Canal Curta em 12 de abril de 2016.
} 
princípio do século XX, seu sistema influenciou o Ballets Russes de Sergei Diaghilev quanto à verdade emocional.

Transcrevo a seguir minhas anotações acerca do curso:

O método de Stanislavski parte da observação de que as pessoas que representam são, antes de tudo, seres humanos - e o ser humano mais próximo de si é o si mesmo. Seu estudo parte do si mesmo. Assim, nos primeiros exercícios, o que importa não é comunicar-se com quem nos assiste, mas as sensações que tivemos enquanto representávamos, quando executávamos um exercício. Não se deve ficar pensando, tampouco, nas próprias sensações enquanto estão sendo percebidas, mas simplesmente tentar viver a situação da maneira mais espontânea e simples possível. O reconhecimento das sensações virá depois, durante a análise da ação realizada.

Partir da verdade. Em cena, tudo o que se faz é falso. Não é natural que subamos em cena iluminados por refletores e representemos diante de pessoas que nos olham. Representar é um ato artificial. Porém, devemos tentar ser o mais verdadeiro possível para que o nosso ato possa convencer a pessoa que nos olha. Por exemplo: quando se entra em cena, não se chega dos bastidores. O personagem vem de uma situação que estava vivendo. Se Lady Macbeth está sonâmbula, esfregando as mãos, é porque acaba de sair da cama. Nesse caso, antes de representar a cena, ela estaria deitada em uma cama nos bastidores.

Em cena, a finalidade é comunicar uma verdade, convencer o espectador e mentir ao máximo ao parceiro. Lady Mabeth projeta matar o rei naquela noite, mas dança toda sorridente com ele. Se partirmos da falsidade, não chegaremos nunca a uma verdade, não seremos capazes de convencer. O problema do bailarino é que ele está voltado ao exterior, a gesto que faz, e, dessa maneira esquece-se do que deveria começar no interior. Assim, o gesto viria com uma muito maior grandeza em comparação ao ritmo exterior.

A partir de um ato vivido em cena, vou procurar lembrar do ato, tentando reencontrar e reviver a mesma emoção. Se alguém (Alain), por exemplo, pediu ao outro (Blatchley) para esconder uma folha de papel dentro do livro, é para ele procurar essa folha; ou então alguém (Christiane) que começa a contar seus problemas a outrem (Louise), como se ela fosse sua confidente.

Na verdade, não há Lady Macbeth. Ela não existe senão nas páginas do livro de Shakespeare. Lady Macbeth sou eu. Claro está que não como pessoa, mas sim enquanto natureza criadora, que projeta sua ressonância, conceito este derivado da filosofia hindu. A ação física procederá das motivações internas. O gesto de abrir uma janela, por exemplo, 
requer atenção e tempo, a participação de todo o organismo. A ação física supõe não apenas o movimento realizado, mas a pessoa inteira, em um processo de prospecção. A análise ativa, enquanto método, rastreia o fazer do ator, incluindo seus conflitos. O termo, que surgiu posteriormente a Stanislavski e foi aplicado ao teatro russo moderno, é proveniente da música. Se a tônica do método de Stanislavski foi o processo interno, outros encenadores, como Peter Brook, inverteram a lógica. Disse Brook certa vez a seus atores: "Vá, pegue aquele sapato e faça alguma coisa com ele", focando o objeto, algo externo à pessoa do ator. O termo "byt" aparecerá enquanto execução de ações simples, ordinárias. A palavra "sistema", ou “composto de relacionáveis”, muito empregada quando há referências a Stanislavski, não era empregada pelo professor, que se servia, com frequência, da palavra "método". O sentido de ambas as palavras não é o mesmo. Se um sistema é o conjunto de elementos interconectados, o método indica o caminho que conduz ao alcance de uma meta programada.

\section{Aproximação do personagem:}

Procurar qualidades no seu caráter que são comuns a mim mesmo. Todo mundo tem os sentimentos de: amor/raiva, superioridade/inferioridade, atração/repulsão, cólera, medo, ternura. As manifestações podem ser diferentes. Alguém em estado de cólera pode se tornar frio e imóvel, enquanto outro pode alterar-se. O sentimento, no entanto, é o mesmo. Cabe apropriar-se do texto, tornando-o meu. Devo procurar em mim as qualidades que tem a personagem. Devo imaginar como ela come, como respira. Como eu reagiria diante das situações que ela tem que enfrentar?

Usar o se. Fazer suposições, visualizar situações imagináveis. No fundo, atuar é gostar do jogo, é amar pretender que.

Observar para tomar consciência das atmosferas que nos rodeiam. Por exemplo: observar em um coquetel as pessoas que estão dentro da atmosfera e outras que não estão, que estão ao lado, rejeitando a atmosfera. Melhor é submeter-se às atmosferas, deixar-se influenciar por elas, para, em cena, viver, e não plasticar. Tomando como exemplo o assassinato do presidente norte-americano John Kennedy: procurar captar a voz que ele teria empregado enquanto falava, a atmosfera, o que ele fez, etc.

Experimentar: fechar os olhos, sentir a atmosfera aconchegante, de bem estar, com música, talvez. Depois, movimentar mão e braço de acordo com essa atmosfera. Depois, experimentar o mesmo em uma situação de perigo.

Não se deve passar por cima dos acidentes que se passam em cena. Ao contrário: podemos usá-los de maneira positiva. Se não se tomar conhecimento, se continuar-se como se 
nada houvesse acontecido, é ai que se torna ridículo. Podemos fazer do acidente uma parte dentro do jogo, em lugar de encara-lo como coisas que vêm perturbar a representação.

Como exercício, reproduzir com a própria escrita as palavras do texto que será dito, assim como reescrever com as próprias palavras a maneira como a gente mesma sente o texto.

Análise:

- Enumerar os "eu quero", encontrando, assim os objetivos, a coluna vertebral do texto. Por exemplo: o momento em que Lady Macbeth recebe a carta:

1. Eu quero saber o que contém a carta.

2. Eu quero enumerar, reiterar as qualidades do meu marido.

3. Eu quero que ele venha aqui.

Toda personagem tem um superobjetivo dentro de uma peça, um grande "eu quero”. É preciso dividir o objetivo, ramificando-o em diversos "eu quero" menores, em objetivos secundários.

Proceder à análise, por exemplo, do balé Nijinsky, le clown de Dieu, de Maurice Béjart, que poderia ser dividido em três partes principais: o nascimento de Nijnsky; seu nascimento artístico, pelas mãos de Diaghilev; sua liberdade.

Voltando à Lady Macbeth: esta, inicialmente pequena e muito feminina, pede mais tarde uma força descomunal, extraordinária, para que tenha sentido sua prece demoníaca. Se já começasse muito forte, a ação não poderia progredir.

Outras notas:

- Nunca falar de um personagem abstrato. Quando se menciona alguém que não está em cena, dar uma existência muito precisa a esse personagem. Por exemplo, em Macbeth, podemos pensar em Béjart quando se fala de alguém por quem se tem respeito.

- Dirigir-se não às orelhas, mas aos olhos do espectador.

- O médico não acredita, mas deve convencer.

- Médico e dama de companhia: relação entre duas pessoas que se conhecem, que passaram uma noite inteira juntos, acordados em um quarto de pedra do castelo. A ação começa nessa relação, e não na primeira frase que será dita. 
- A relação entre a ama (ou governanta) e Julieta é entre a mãe de leite e a criança que por ela foi amamentada.

\section{Exercícios:}

1. Executar um desejo - uma ação com três atividades (ou três ações para completar um ciclo de ações), ainda que as duas primeiras não tenham sido suficientes.

2. A: Realizar uma ação em um quarto no qual uma pessoa dorme, com a finalidade de não despertar essa pessoa.

B: A pessoa é muito perigosa e, se por acaso a acordarmos com o nosso ruído, uma pessoa que nos é muito preciosa morrerá.

Por intermédio de três argumentos, convencer uma pessoa, isto é, quero obter alguma coisa e tento convencer:

A: Sou a pessoa que argumenta. Só vou ceder se estiver realmente convencida.

B: Sou a pessoa que quer obter. Vou procurar persuadir.

Vou tentar convencer uma pessoa, para que ela venha salvar a vida de alguém. Dotar de qualidades a pessoa a quem pedimos e por quem pedimos. Ir até o fim desse pedido, permitindo extravasar nossos instintos ferozes. Somente esse último exemplo tem limite de tempo: sete minutos.

- Utilizar, em todos os exercícios, objetos reais, compondo um cenário.

- Acabar uma unidade antes de começar outra. Dar todo o tempo necessário. Não misturar as unidades.

- Importa o jogo e o gosto de pretender ser.

Último exercício:

- Fazer um longo percurso dizendo primeiro uma frase curtíssima e depois toda a carta.

- Fazer um longo percurso lendo toda a carta.

Tal exercício permite conhecer dimensões alteradas de tempo.

A ênfase, ou a tônica de Stanislavski remete ao processo interno. O diretor de teatro Peter Brook (1925) propôs, certa vez, aos seus atores, que fossem pegar um certo sapato e fazer alguma coisa com ele, focando o objeto em um estímulo outro, algo externo à pessoa do ator. Volto ao enovelamento proposto por Merleau-Ponty: importam ambos os processos, 
dependendo das questões suscitadas por cada peça. Um dos principais preceitos do professor Goris era a metamorfose. Do professor Blatchley ficou o transporte para viver uma situação. Hoje, prefiro ater-me ao momento presente, ao aqui e agora, e ser eu mesma.

\subsubsection{Maquiagem}

Para Béjart, os olhos eram uma das mais importantes ferramentas do intérprete. Se não focar, desaparecerá em cena, ficará apagado, deixará de existir enquanto presença. A concepção de uma maquiagem carregada, atributo da teatralidade, presente no teatro oriental, contraria o despojamento presente na cena contemporânea.

Durante um curto período, tivemos aulas de maquiagem com Germinal Casado, bailarino, figurinista e maquiador espanhol, um dos primeiros protagonistas do Ballet du XXème siècle e figura muito próxima a Béjart. Os cursos de Casado nos ensinavam um embelezamento provocado por uma maquiagem carregada, sem espaço entre as sobrancelhas e os olhos, em virtude dos grandes palcos e plateias que abrigavam as produções da companhia.

A maquiagem gera a alteridade. Transforma. Trans-forma. Provoca deslocamentos. No sentido foucaultiano, a máscara, a maquiagem e, ainda, a tatuagem, permitem adquirir uma nova corporeidade, um outro corpo no espaço, dotando-o de poderes secretos e forças invisíveis, remetendo-o a um espaço imaginário no universo da divindade e das linguagens cifradas. É quando o corpo é arrancado de seu espaço próprio e lançado em uma outra dimensão.

Em Dicionário do corpo, Laurence Pfeffer recorre a várias fontes para evocar o jogo de dissimulação, de aparição e desaparição que a maquiagem possibilita enquanto "sinal do efêmero e da renovação" e realça o aspecto antinatural aplicado ao rosto "com a ajuda de produtos aplicados na face, nos olhos, nos cílios, nos supercilhos e nos lábios”. Jogo enganoso de mentiras e ilusões. A autora lembra que, em italiano "o maquiador é chamado de truccatore: ele disfarça o rosto usando beletto (pintura)". Pfeffer lembra ainda que o termo "é recente: apareceu no fim do século XVII, dirigido à falcatrua e à falsificação; conservará esse sentido pejorativo até o século XIX". Retocar, ludibriar, enfeitar. Jogo de sombra e luz, a 
maquiagem é uma miragem: vela e revela ao mesmo tempo, acentua as qualidades ao atenuar defeitos $^{223}$.

\subsection{Béjart professor}

Em conversas informais, Béjart comunicava alguns de seus preceitos:

- Se você tem uma ideia, trabalhe dez horas sobre ela.

- É quando nos encontramos exaustos que surgem as boas ideias

- Todo trabalho deve começar por um planejamento detalhado, ainda que posteriormente seja muito modificado; do contrário, é coisa de amador.

- A improvisação deve projetar a imaginação e não cair no défoulement (ação de se liberar de um complexo psicológico inconsciente).

- A cada vez que, num grupo, alguém diz "todo o mundo”, está se excluindo do mesmo para falar dele objetivamente. No final o meio fica vazio, sem ninguém.

- Vocês pulam de um assunto para outro.

- Solicitar a participação do público em um espetáculo coloca um problema falso. A dança não lhes é familiar e as pessoas se sentiriam numa posição de inferioridade. O que se deve fazer é introduzir a dança na educação das crianças. Não seria o caso de ensinar, mas de preservar o gosto que as crianças têm pela dança e pela música, pois tornam-se sérias quando adultas.

- A coreografia não necessita da escrita. Após o estudo da partitura, os movimentos ficarão gravados na memória.

- A dança é o geral. O balé é o particular.

- O melhor momento é o da visão de um novo trabalho, quando as possibilidades são infinitas. Ao se começar a construção, têm início os problemas.

- Busquem as soluções cênicas em sua própria imaginação.

- Importa ser verdadeiro.

Os três últimos itens - o momento da visão, a imaginação e o que vem a ser verdadeiro - merecem reflexão. A visão (ou miragem) a que se referiu Béjart está menos relacionada à opsis, ou ao foco no olhar, do que à amplitude ou mesmo à infinitude implicadas nas comportas abertas naquele momento singular em que ocorre a apreensão. Corresponde, de

${ }^{223}$ PFEFFER, Laurence. Verbete Maquiagem. In: MARZANO, Michela (Org.). Dicionário do corpo. São Paulo: Edições Loyola, 2012. p. 617. 
fato, àquilo que Marcel Duchamp (1887-1968) denominou de coeficiente artístico, ou a defasagem que há entre o que o artista intencionou fazer e aquilo que conseguiu realizar de fato. Em palestra proferida em 1954 e publicada em 1957, Duchamp trata da concretização de ideias e principia por situar o artista enquanto sujeito: "No ato criador, o artista parte de processos subjetivos e complexos, através de avanços e recuos" 224 que resultam em uma obra. "O autor falha pela inabilidade em expressar sua intenção integralmente"225. O produto resultante distingue-se da intenção inicial, do início nebuloso até a aquisição de contornos nítidos, havendo uma diferença ou distância entre o momento da visão e o da realização antes que se introduza o terceiro elemento que irá conferir valor à obra: o público.

A imaginação, ou a capacidade de produzir imagens constitui marca relevante do meu percurso coreográfico próprio, uma vez que jorrar uma profusão de imagens sempre fez parte intrínseca do meu modo de operar e é, sem dúvida, fruto de um processo psíquico. Do grego “eidolon", designa o espectro, o fantasmático. Predominou o termo "eikon”, do qual provém “ícone”, constituindo-se em um estímulo à opsis, à visão. Diretamente ligada à pessoalidade e à subjetivação ou relação consigo, expressão esta de Gilles Deluze (1924-1990)226, "imaginatio" traduz o árabe "tasawor", derivado de "surat" ("imagem"), que quer dizer, também, "forma", do verbo "sauara" ("formar", “modelar"), assim como “descrever" e “conceber". De fato, uma imagem projetada adquire contorno, é configurada. É fruto da disponibilidade e do devaneio, tais como outras atividade psíquicas improdutivas são "as atividades da imaginação, filhas do ócio e do abandono" ${ }^{, 227}$. O relaxamento e a vagabundagem ativam um estado propício à concepção de imagens projetadas no espaço, cuja concretização poderá ou não ocorrer.

Em A imaginação, Jean-Paul Sartre (1905-1980), considera a imaginação decorrente da liberdade da pessoa. Ato sintético que não se aprende, "ela se dá inteira por aquilo que é, desde sua aparição" ${ }^{228}$. Resultante de um processo introspectivo que requer um olhar interno, a imaginação encontra-se ligada à pessoalidade: é única e intransferível e fruto do tempo vagabundo: "Pessoal e privado, tão inconfundível como a nossa impressão digital, tão

\footnotetext{
${ }^{224}$ DUCHAMP, M. O ato criador. In: BATTCOCK, G. (Org.). A nova arte. São Paulo: Perspectiva, 1986. p. 71.

${ }^{225}$ Ibid., p. 71-74.

${ }^{226}$ DELEUZE, 2008.

${ }^{227}$ KEHL, 2009, p. 161.

228 SARTRE, Jean-Paul. L'imaginaire. Paris: Gallimard, 1940. p. 23. Tradução nossa. Texto original: "Elle se donne tout entière pour ce qu'elle est, dès son apparition".
} 
incomparável como nosso próprio corpo"229. É, também, considerada como "decorrente da exaltação romântica da faculdade da imaginação, que orientou as vanguardas artísticas",230. Artaud, por exemplo, dizia só acreditar naquilo que imaginava, enquanto Tadeusz Kantor (1915-1990) atribuiu a descoberta da imaginação aos surrealistas, descrevendo-a como "região inquietante e herética do psiquismo humano"231. Autor de Fenomenologia da Imaginação, Gaston Bachelard afirmou que as imagens são anteriores às ideias e conceitos. Para mim, a imaginação nasce da necessidade da evasão do mundo real.

Antonio Damásio acrescenta novos esclarecimentos ao examinar o mistério de como as imagens emergem de padrões ou mapas neurais formados por populações de neurônios ou células nervosas. Como resposta, localiza a parte do cérebro em que as imagens ocorrem: “As estruturas cruciais de mapeamento corporal e de formação de imagens estão localizadas abaixo do nível do córtex cerebral, em uma região conhecida como tronco cerebral superior" ${ }^{\text {232 }}$.

No contexto, a palavra "verdade", a alethéia grega, escapa a qualquer conotação platônica, bem como àquilo que foi procurado desde os primórdios da filosofia até a irrupção do pensamento pulsional de Friedrich Nietzsche, quando este afirmou não ser a procura da verdade que move os seres humanos, mas sim a vontade de potência. Nietzsche sustentou "ser verdadeito tudo o que contribui para fomentar a vida da espécie, e falso tudo o que é um obstáculo ao desenvolvimento dessa"233. Não se trata, tampouco, da verdade verificada cientificamente ou da oposição entre falso e verdadeiro. Verdade e mentira, real e ficcional, representar ou ser si mesmo.

É o conceito heideggeriano do velar contraposto ao desvelar-revelar que vai iluminar a questão. Segundo Martin Heidegger, a verdade é a descoberta do encoberto que ocorre no fenômeno de estar no mundo: “A verdade converte-se num elemento da existência, a qual encobre o ser em seu estado de degradação (Verfallen) e descobre-o em seu estado de autenticidade" 234 . A palavra "autêntico" é derivada de "autor" e indica aquilo que é genuíno. A exortação a ser verdadeiro foi tomada por mim ao pé da letra. Somada à formação familiar protestante que recebi, levou-me a uma rigidez de princípios que me fez, inclusive, não levar em conta o público ao fomular um projeto, pois isso soava como cabotinagem, um desvio da

\footnotetext{
${ }^{229}$ JAMESON, 1985, p. 19.

${ }^{230}$ FABBRINI, 2014, p. 31.

${ }^{231}$ KANTOR, Tadeusz. Lições de Milão. Paris: Actes Sud Papiers, 1990. p. 403.

${ }^{232}$ DAMÁSIO, 2011, p. 36.

${ }^{233}$ MORA, 2011, p. 705.

${ }^{234}$ Ibid., p. 704.
} 
verdade. Admitia somente o que de meu cérebro pudesse sair. Em se tratando de intérprete do espetáculo, a verdade corresponde a uma postura despojada, sem impostações falsas, em conexão consigo. Supõe a entrega.

Nos primeiros meses, Béjart deu aulas aos mudristas, confirmando que, no período inicial, ele se achava experimentando conosco, à procura de novos caminhos, de um corpo expandido. Segundo ele, tais aulas serviriam para conhecer as possibilidades de inteligência e criatividade dos alunos. O coreógrafo não costumava empregar o método da improvisação em suas coreografias para o Ballet du XXème siècle. Segundo seu relato, experimentava movimentos com seu próprio corpo diante do espelho, encontrava pequenas células, transmitia-as aos bailarinos e, a partir do contato direto, desenvolvia a coreografia. Conosco era diferente. O propósito era o de realizar experiências que enriquecessem tanto a nós quanto a ele e propiciar um momento no qual as técnicas aprendidas e apreendidas convergissem no corpo de modo expandido:

[...] não tento fazer com que os jovens pensem, ajam e reajam como eu: ao contrário, tento fazer com que ajam e reajam como eles próprios. Para isso é preciso que aprendam. Aquilo que eles são e aquilo que é o mundo do espetáculo que querem abraçar. A base do ensino é a dança. Mas a ideia era abrir a escola ao canto, à percussão, à ioga, ao flamenco, à arte dramática ${ }^{235}$.

Os espelhos da sala eram cobertos, para permitir uma maior concentração. Principiavam por uma barra no chão: deitados, subitamente nos sentávamos com os dois braços no alto, em couronne. O exercício, que pratico até hoje, demanda muita força no centro do corpo quando tenta-se ativar o grande músculo psoas ao invés do reto abdominal. A partir daí, passávamos a executar, aproximadamente, os mesmos passos que na barra, tais como petits batments, passés, developpés, rond des jambes e grands bâtments, com a diferença de empregar também o en dedans, além do en dehors, alternando a posição sentada à deitada e acrescentando a posição da vela, proveniente do yoga.

A seguir, dispostos na sala em posição vertical, Béjart propunha e marcava frases de movimento semelhantes às que empregava em suas coreografias, com a diferença que esses exercícios técnicos no centro, sem barra, acompanhados por movimentos do tronco, tinham o seu sentido analisado: por exemplo, o plié é crescimento, não descida do corpo; o relevé tem muita força. Béjart propunha, também, que experimentássemos “movimentos angulares, em

\footnotetext{
${ }^{235}$ BÉJART, 1981, p. 219.
} 
contraponto aos circulares". Estes, espirais puras, deveriam ser executados como se estivéssemos dentro d'água.

O cuidado de Béjart ao referir-se a uma interioridade na execução dos movimentos apontava para uma possível certeza de que esse terreno era mais familiar aos jovens mudristas. Comparava duas grandes bailarinas, uma clássica e outra moderna, observando que a primeira partia da técnica, algo exterior, enquanto a segunda da interioridade, mas que, para se tornarem completas, deveriam cada uma dominar o oposto de seu ponto de partida. Tal como Schirren, nosso professor de Ritmo, Béjart afirmava a proveniência dos movimentos a partir do ventre, a fim de não produzir formas vazias, exteriores. Isadora Duncan, no primeiro quarto do século XX, atribuiu ao plexo solar, localizado quatro dedos abaixo do umbigo, o centro irradiador dos movimentos, o que já tinha sido questionado pelos estadunidenses Alwin Nikolais e Merce Cunningham, coreógrafos que consideravam qualquer ponto do corpo igualmente potente para dar partida ao movimento, estabelecendo uma relação análoga aos pontos do espaço, conforme já foi dito. Para Béjart, não se deveria planejar um movimento, mas escutar-se o impulso do centro do corpo. Ao contrário dos circulares, os movimentos angulares não teriam nem lógica nem fluxo.

$\mathrm{Na}$ improvisação, ao som do tambor, éramos solicitados a evitar movimentos redondos, pois o ritmo era muito marcado. Em duplas: um batia no tambor, o outro dançava. O primeiro, aquele que tocava, via, comunicava-se por meio dos olhos. O segundo, que dançava, ouvia. Aquele que dançava acrescentava uma pequena série de movimentos, respondida pelo primeiro, até congelar no último movimento. Invertiam-se, então, as posições. No tambor, era preciso alternar frases curtas e longas. O exercício era repetido até se atingir o domínio da proposta. Procurava-se movimentar cada parte do corpo dentro de uma lógica: por exemplo, se faço um ângulo com o braço, em seguida voltarei a cabeça para o lado contrário; agora contraio o ventre e estendo o braço na diagonal; contraio o ombro; dois braços para o alto; em seguida abaixo-os e relaxo. Em duplas ou trios, juntava-se a mão direita com a do colega e compunham-se formas, sempre diferentes. Havia alternância de líderes. A liberdade de movimentos devia ser encontrada dentro de um ritmo.

Ao cabo de uma série de aulas, Béjart anunciou que havia concluído que ele não era um professor, mas um criador, e resolveu que, dali em diante, optava por montar um espetáculo anual com os mudristas em vez de dar aulas. Na década de 1970, ainda pairava a aura do artista-criador-genial, enquanto ser um professor de arte, de qualquer modalidade, correspondia a ser um artista fracassado, questão esta que vem sendo discutida na atualidade 
devido ao fato de haver, hoje, nos estudos acadêmicos formais, inclusive, muitos professores com trabalho artístico reconhecido.

\subsection{A pesquisa}

Nossa pesquisa consistia no entroncamento, na sinergia e na síntese das várias disciplinas cursadas, sem obedecer a nenhum padrão pré-estabelecido. Ao contrário: tinha como alvo buscar novos parâmetros, lançar-se no desconhecido, aventurar-se em uma viagem singular. De tão gasta, a palavra "pesquisa" esvaziou-se. Em francês ou inglês, "recherche" ou "research", respectivamente, remetem a "procurar de novo", dada a insatisfação com as soluções hegemônicas encontradas em um campo circunscrito. Definida como busca, ou investigação, toda pesquisa visa à produção de conhecimento. Jean-François Lyotard considera a pesquisa produção do saber ${ }^{236}$, destinada a desvelar a ordem oculta do mundo, embrenhando-se para além do rotineiro e estabelecido. Pressuposto de acesso a uma suposta verdade, Béjart associou tradição e pesquisa, o que não surpreende, dado o valor que concedeu à técnica clássica. No lugar de respeito, propôs estudo e amor aos predecessores, aos que arriscaram e se rebelaram em seu tempo. O uso da palavra "recherche" para designar nosso trabalho era frequente. Alguns consideram, equivocadamente, que pesquisa é algo que não sai para fora, permanecendo no interior do indivíduo.

Apesar das dez horas diárias de aulas distribuídas entre os períodos da manhã e da tarde, durante o primeiro ano, costumávamos permanecer nas dependências do Mudra até cerca de 22 horas, período da Recherche. É claro que, na manhã seguinte, estávamos cansados, mas o interesse e empenho superavam o cansaço.

Os experimentos visavam entrelaçar as matérias praticadas durante o dia, em busca de uma fusão. Pequenas cenas eram esboçadas, como, por exemplo, emitir um som contínuo deitado em um tapete, totalmente relaxado, enquanto outros se aproximam com movimentos fortes; andar pela sala com os olhos fechados e, dos choques resultantes, desenvolverem-se ações; procurar o conhecimento recíproco por meio do movimento, e não da palavra; entre outros.

O resultado, apresentado no final do primeiro ano letivo, não agradou a Béjart, que considerou o entendimento entre nós mais calcado na palavra que no gesto, uma vez que uma

\footnotetext{
${ }^{236}$ LYOTARD, Jean-François. O pós moderno. Tradução de Ricardo Corrêa Barbosa. Rio de Janeiro: José Olympio, 1986.
} 
das convicções do coreógrafo era a de que a dança atinge uma maior comunicação que as outras artes porque o gesto tem mais força que a palavra. O colega que coordenava os trabalhos, Julien Lévy, pouco tempo depois, foi desligado do Mudra.

No ano seguinte, o grupo iniciante do primeiro ano tentou uma experiência radical: no sábado à tarde, ao fim do expediente, solicitou à espectral figura do bedel de origem flamenga Monsieur Bara que fechasse, ao sair, as portas do estabelecimento, mantendo-os trancados ali até a segunda-feira para testarem uma vivência em comum. Alguns não aguentaram e partiram, escalando o telhado, em algum momento daquele final de semana.

A vida monástica que levávamos tinha como motor o propósito de efetuar descobertas por meio da investigação de linguagem, explorando-nos até às últimas consequências. Tínhamos nossos parceiros em nossas vidas privadas. Frequentávamos assiduamente a cinemateca situada no Palais des Beaux Arts de Bruxelas, chegando a ver três filmes diários, às 18,20 e 22 horas. Foi lá que assisti, aos 21 anos, o filme que, pela primeira vez, provocoume insights: Os palhaços (Les clowns), de Federico Fellini. Não frequentávamos baladas noturnas. Viajávamos a Paris, distante cerca de trezentos quilômetros de Bruxelas, mas os coreógrafos que então se apresentavam, como Felix Blaska, Joseph Rusillo e outros, não nos entusiasmavam. Nem mesmo a companhia de Merce Cunningham, considerada por nós técnica demais quanto ao trabalho do movimento, nos interessou. Apenas Le régard $d u$ sourd (Deafman glance) do texano Robert (Bob) Wilson, então com 27 anos de idade, nos provocou faíscas. Apresentada pela primeira vez na Europa no Festival de Teatro de Nancy, em 1971, a peça, em seguida, rumou a Paris. Com formação em artes plásticas e arquitetura, apreciador das danças de Cunningham e Balanchine, Wilson queria que suas peças fossem absorvidas como dança, e não como teatro, o que equivale a dizer "de modo cinestésico".

Peças que dilatavam e atingiam todos os sentidos requeriam um estado de disponibilidade. Desde que, posteriormente, Wilson transformou-se em um diretor superrequisitado, um star do show business intelectualizado, acabou por elaborar uma fórmula, ainda que de excelente qualidade. Tal fórmula relaciona-se à forma. No programa da versão para ópera da tragédia Macbeth, de William Shakespeare, dirigida por Wilson no Theatro Municipal de São Paulo em 2012, o diretor principiou o texto com as palavras: "Meu Teatro é um Teatro formal". A palavra "formal", aqui, opõe-se a "psicológico". Padrão existente em todas as coisas, a forma pode ser entendida como configuração: “As formas implicam um código, modos de codificação e descodificação [...]. Há, justamente, código e territorialidade para cada articulação 
[...]. A estrutura é o conjunto dessas relações e correlações" ${ }^{\text {237 }}$. A questão voltará a ser tratada no terceiro capítulo, dedicado ao Teatro de Dança Galpão, quanto a Pulsações.

Para nós, mudristas, aquele modo tão peculiar e onírico de desenhar imagens cênicas produzidas em um tempo alargado estimulou, inspirou. Logo depois, um dos colegas compôs um exercício cênico apresentado a Béjart com forte influência da estética paisagística-onírica de Wilson. Foi rechaçado e aconselhado por Béjart a procurar suas ideias em sua própria imaginação. A indução béjartiana ao não copiar foi, por mim, seguida ao pé da letra, imunizando-me, por vezes, de um intercâmbio sadio, só aceitando o que saísse de mim, da própria imaginação, das próprias ideias, inclusive não levando em conta o papel do público.

Nosso radicalismo levou-nos, no decorrer do terceiro e último ano do ciclo, a querermos abandonar o Mudra e formarmos um grupo que se instalaria nas montanhas, no sul da França, perto da residência dos pais do colega Pierre Droulers, situada em 1'Île d'Yeu, na França. Béjart convocou-nos para uma reunião. Sentados em círculo, fomos indagados um a um se queríamos mesmo partir e por quê. Para mim, que antes de seguir para Bruxelas precisava trabalhar para ganhar a vida, estar no Mudra era uma glória. Acabamos abandonando a idéia ingênua e suicida e continuamos onde estávamos. Nosso ato assemelhouse à relação entre Nietzsche e Richard Wagner, compositor tão admirado por Béjart e tão presente na obra coreográfica bejartiana. A admiração e amizade iniciais de Nietzsche por Wagner azedaram-se à medida que o filósofo firmava a própria trajetória. O fascínio expresso em $O$ nascimento da tragédia no espírito da música, tese de Nietzsche de 1871 na qual louva o músico alemão, foi se esgarçando.

Naquele momento de indefinição dos rumos a tomar, disse-me Mme. Vermeulen que Maurice Béjart não tomaria três anos da nossa juventude sem nos oferecer algo em troca no final.

Béjart afirmou que não podia chamar o Mudra de sua escola, uma vez que procurava fazer com que "os jovens pensem, ajam e reajam como eles próprios"238. Aos poucos, porém, foi se delineando em muitos mudristas o desejo de integrar a companhia de Béjart em vez de procurarem vias próprias. Para alguns, os propósitos radicais foram cedendo terreno ao desejo de aprimoramento técnico com o fim de ingressar no Ballet du XXème siècle, comandado por Béjart.

\footnotetext{
${ }^{237}$ DELEUZE; GUATTARI, 1995, p. 55.

${ }^{238}$ BÉJART, 1981, p. 219.
} 
Em 19 de Setembro de 1986, a senhora B. Hassel-Szternfeld, que ocupava, então, o cargo de Diretora Administrativa do Mudra, enviou-me uma carta que finalizava com as palavras: "A sra. Célia Gouvêa foi um de nossos melhores elementos e terminou com sucesso seu ciclo de três anos de estudo"239 . Por quê? Porque encarnava a proposta interlinguagens. Interessavam-me todas as disciplinas e estava aberta a todas, movida por uma curiosidade constante, apesar de não contar com ótima técnica nem vocal nem enquanto bailarina. Fui, portanto, uma mudrista exemplar. De mim, Béjart dizia que tinha uma bela testa, um belo olhar e belas costas.

\footnotetext{
${ }^{239}$ Texto original: "Madame Célia GOUVEA était une de nos meilleurs éléments et a terminé avec succès son cycle de trois années d'etudes. Fait à Bruxelles, le 19 Septembre 1986. B. Hassel-Szternfeld (Mme.) Administrateur-Directeur".
} 
Figura 21 - Carta da diretora administrativa do Mudra dirigida à Célia Gouvêa

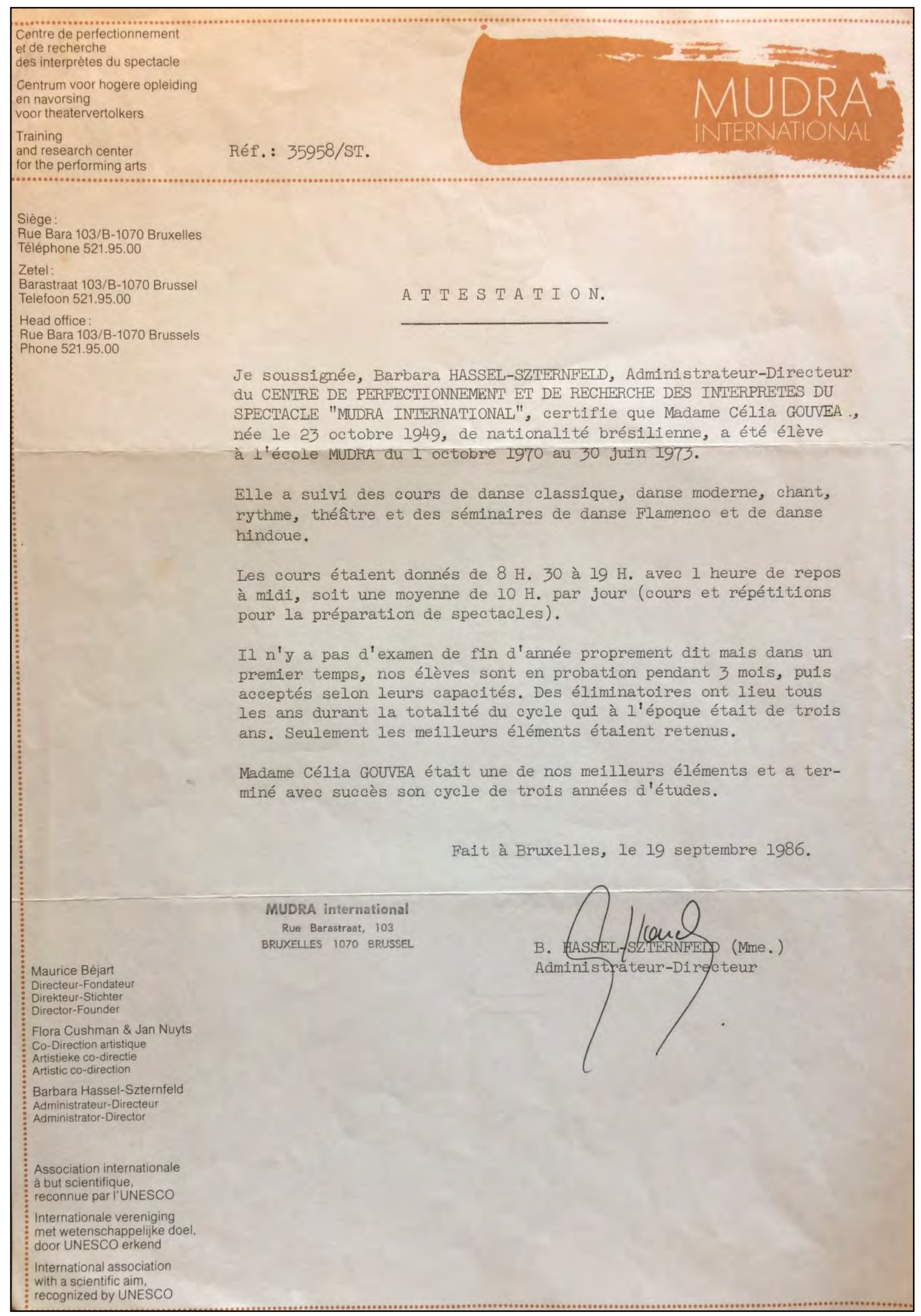

Fonte: arquivo pessoal. 
O aspecto polêmico e contestador levou-me a afixar, no mural da casa, situado no emblemático corredor de passagem utilizado diariamente por todos que circulavam ali e que acessava todas as salas, a seguinte mensagem no mês de maio de 1974, traduzida do francês:

Carta aos mudristas. Mudra, minhas condolências. O que era o Mudra no começo? Mudra sempre foi uma escola para privilegiados, é claro. No entanto, no começo era diferente: sempre houve, é claro, a técnica, mas antes quem ai estava empreendiam uma muito grande aventura no espírito, descobria-se o desconhecido, nos perdíamos também mas no final nos reencontrávamos, mais inteiros e mais livres. O que o Mudra se tornou? Cuidado, mudristas. O Mudra é agora uma escola baseada na competição, na qual as pessoas esperam que o sorriso de Vermeulen (a administradora) e Béjart aumente para si, um sorriso de passagem à Companhia do Balé do Século Vinte. Uma escola que visa, portanto, ao balé, mas onde se trabalha 12 horas por dia, para aprender técnicas que não serão jamais utilizadas, pois o que se quer é integrar uma companhia de dança. Uma escola que já não tem mais razão de existir. $^{240}$

A carta captava o turning point que se acentuaria cada vez mais. O episódio constatava a virada entre o propósito primeiro de entrelaçamento entre as várias disciplinas, com a busca de uma nova linguagem cênica, e esse segundo momento, quando a dança clássica veio a ocupar o topo de uma escala hierárquica.

Cruzando com Béjart frente ao mural, ele apenas olhou-me longamente, sem nada dizer, ciente de que era eu quem escrevera aquelas colocações. Não assinei, por seguir a premissa beckettiana segundo a qual não importa quem disse, mas o que foi dito. Perscrutador, Béjart certamente era. Gostava de gente, também. Perspicaz, batia os olhos em alguém e já o captava, como quando olhou pela primeira vez minha filha caçula Vânia, então com 15 anos de idade, e disse imediatamente: "Vê-se imediatamente que é uma menina que tem talento". Vânia, que praticava balé desde os sete anos e que naquele momento havia

\footnotetext{
${ }^{240}$ Texto original: "Lettre aux mudristes: Mudra, mes condoléances. Quést-ce que c'était Mudra au début? Mudra a toujours été une école pour des priviligiés, bien sûr. Pourtant, au début c'était différent: il y a toujours eu la technique, bien sûr, mais avant les gens qui y étaient entreprenaient une très grande aventure dans l'esprit, on découvrait l'inconnu, mais à la fin on se retrouvait plus entiers et plus libres. Qu'est-ce que Mudra est devenu? Faîtes gaffe, les mudristes. Mudra est maintenant une école basée sur la compétition, où les gens attendent que le sourire de Vermeulen et Béjart se fasse plus grand à leur égard, un sourire de passage à la Compagnie du Xxème Siècle. Une école qui vise le ballet donc, mais où on travaille 12 heures par jour, pour apprendre d'autres techniquesa qu'on utilisera jamais, puisque on veut entrer dans une compagnie de danse. Une école qui n'a plus de raison d'être".
} 
desistido da prática e conservado apenas o treino de circo, reviu sua opção e é hoje uma dançarina-criadora profisssional que vive na França e atua no mundo todo. Seus estudos de dança, iniciados no Brasil, foram completados nos Conservatórios de Dança de Lyon e Paris. Esteve dois anos na escola PARTS (Performing Arts Research and Training Studios) em Bruxelas e dançou com Wim Vandekeybus, sete anos com Maguy Marin, Johann Maheut e Christian Rizzo. Com o núcleo Arrangement Provisoire, em parceria com Jordi Gali, iniciou em 2016 um projeto em Grenoble previsto para durar três anos.

A longilínea bailarina estadunidense Shonach Mirk, mixtu de hippie e pompadour, segundo Béjart, em uma referência à Madame Pompadour, a amante do Rei Luis XV de França, foi protagonista de muitos balés do coreógrafo. Shonach deixou o Mudra para integrar a cia. de Béjart dois anos após sua admissão, em 1972. Segundo ela, o motivo era porque tinha que se sustentar - "support myself", segundo suas palavras. Para Maguy Marin, o argumento não passava de uma desculpa. Veementemente convidada, a própria Maguy acabou por aceitar o contrato de bailarina do Ballet du XXème siècle, afirmando que ali não permaneceria mais de três anos, e foi o que ocorreu. Para nós, o que importava era buscar outra coisa, algo distinto da linguagem bejartiana. Soava como uma captulação o desejo de integrar a companhia de Béjart. Um pensamento equivocado é aquele que considera que, se um dançarino não dominar suficientemente a técnica acadêmica, ele será um ator. Uma coisa nada tem a ver com a outra. Outro equívoco é colocar o ballet no topo de uma pirâmide.

Os mudristas eram, antes de tudo, personalidades. O Mudra, enquanto um projeto inovador, destinado a ser outra coisa, uma nova opção obtida pelo perseguir de uma linguagem original e própria, acenava, dali em diante, a ser um celeiro de dançarinos a nutrir o elenco de uma companhia, a exemplo de muitas escolas acopladas a uma companhia. Nos anos posteriores à minha estada no Centro, minhas impressões confirmaram-se: a idade limite de admissão foi reduzida, passando de 21 para dezoito anos; a duração do ciclo encolheu, passando de três para dois anos. Béjart elegeu, como sua assistente no projeto Mudra-Paris (que não veio a ser concretizado), a então estrela da Ópera de Paris, Jacqueline Rayet, o que indicava a guinada assumidamente acadêmica ou clássica. Ex-mudristas foram, também, convocados para desempenhar outras funções, como a de diretor da instituição. O ex-colega da segunda promoção, Allan Tung, nascido em Connecticut, nos Estados Unidos, foi codiretor do Mudra de 1976 a 1978, precedendo Maurice Béjart e antecedendo Micha Van Hoecke. Juliana Carneiro da Cunha comentou que se surpreendia ao ver o ex-colega percorrer as várias dependências do edifício portando um grosso molho de chaves pendurado na roupa. 
A cantina e a sala de repouso ao lado, com seus cubos desnivelados forrados com carpete de cor mostarda, era o ambiente onde conversávamos, trocávamos ideias e traçávamos planos. Ali, convivíamos também com os bailarinos do Ballet du XXème siècle. A cantina era conduzida por mulheres de origem flamenga, que falavam o francês com os "r" moles e cujo comportamento irradiava sua própria cultura: um modo de ser telúrico, alegre, dinâmico.

Figura 22 - Julien Lévy e Célia em exercício de improvisação

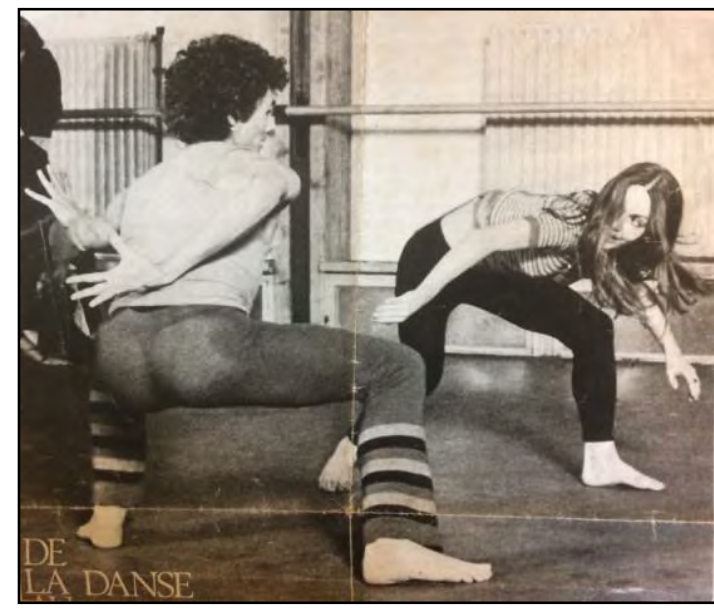

Fonte: Revista Marie Claire, 1971.
Figura 23 - Improvisação em grupo

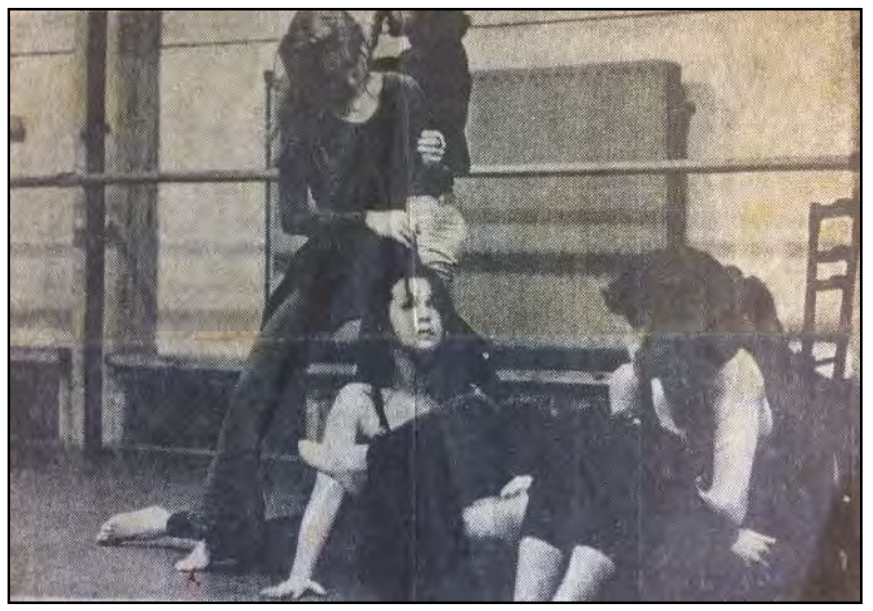

Célia, Christiane Gilk e Juliana Carneiro da Cunha (esq. para a dir.).

Fonte: arquivo pessoal. Foto de Claire Falcy, 1972.

Bruxelas contava, a cada esquina, com uma barraca de venda de batatas fritas com molhos diversos, dos quais o tártaro era um dos mais apreciados, bem como com as pâtisseries, cujas tortas de açúcar, arroz e outras eram, também, oferecidas na cantina. Não raro, as atendentes da cantina portavam uma lista fornecida pela administração com nomes de bailarinas do balé e mudristas a quem não poderiam vender as tortas doces, interdição motivada por motivos de aquisição de peso. Havia, ainda, as épisseries, que expunham invariavelmente, na parte externa, frutas e legumes coloridos em caixas dispostas em diagonal. O lado festivo belga encontra sua mais alta expressão nos Gilles-le-Binche, figuras gigantescas e multicores com seus pequenos óculos escuros, tamancos ou sabots em madeira que surgem no carnaval de Binche, evento reconhecido pela Unesco como obra-prima da herança oral e intangível da humanidade. A música que acompanha a procissão de gigantes e dragões foi incorporada à peça de dança May B, de Maguy Marin, em 1981.

Famosos também são os incontáveis tipos de cerveja, inclusive a gueuze, que, por ser amarga, disse o poeta que teria sido bebida duas vezes. Na cozinha, que costuma empregar 
muita manteiga, destacam-se o pain de veau, o rotie de porc e o waterzooi, mistura de ingredientes cujo nome deu o título a uma das coreografias de Maguy Marin. As batatas fritas, conhecidas como french fries, são, na verdade, belgas, e acompanham bifes e mariscos. Os scargots, puxados das conchas com palitos ou alfinetes e os chocolates Côte d'Or e Godiva são vendidos em porções, principalmente na região central da cidade, próxima à la Bourse. Povos afeitos à dança, à comida e à bebida são tidos por viscerais. "Entre as vísceras, o fígado (algumas vezes hepar, um termo emprestado dos gregos, ou com mais frequência iecur ou iocur), representaram especialmente um importante papel simbólico"241. Desde os períodos renascentista e barroco, a pintura ocupa lugar de destaque no País. Isso por conta da pintura religiosa de Jan van Eyck no século XV; das pinturas paisagísticas de Peter Breughel no século seguinte; do estilo barroco de Peter Paul Rubens no início do século XVII; até a emergência do romantismo, expressionismo e surrealismo, que geraram James Ensor; e, no século XX, expoentes das artes visuais como René Magrite e Paul Delvaux, que atestam a riqueza do imaginário belga.

Não havia, no currículo do Mudra, abordagens somáticas ou estudos anatômicos. Nem tampouco cursos de improvisação e composição. Se é fato que, apesar da lacuna, inúmeros artistas da dança egressos de lá desempenharam importantes funções criativas em suas carreiras, é porque a renomada e inovadora escola atraia gente talentosa, interessada em investigar. À parte o balé, a técnica de dança mais bem aceita por Béjart foi a de Martha Graham, devido, certamente, ao seu alto grau de codificação. Defensor ferrenho do rigor técnico proporcionado pela dança acadêmica, Béjart estabelecia as etapas: submissão à disciplina estrita no aprendizado; contestação; reconstrução própria e alegria do domínio de si. A questão é que o coreógrafo parecia sugerir que outras modalidades de preparo não poderiam formar um bailarino ou que não estivessem construídas com rigor. O que dizer de alguém que deseja ser bailarino, mas não dispõe de um corpo maleável? Foi tal falta de flexibilidade em assimilar ou mesmo admitir a mudança de parâmetros na dança e outras corporeidades que o levaram a exaurir sua própria linguagem coreográfica. Na maturidade, dizia ser um homem da sua geração. Afirmou isso de modo um tanto contrariado, parecendo apenas "tolerar" outros modos de se conceber a dança:

${ }^{241}$ LE GOFF, Jacques. In: FEHER; NADDAFF; TAZI, 1989, p. 14. 
Certas trupes de dança moderna parecem muito fora de moda [...]. As palavras clássico ou acadêmico e moderno não querem dizer nada... a escola acadêmica de um lado, a descontração, a improvisação do outro, eventualmente a flexibilidade oriental, o impulso instintivo do folclore. A dança teatral sob suas diversas formas é a arte do movimento ao mesmo tempo livre e composto, organizado em relação ao tempo posto que ligado à música, ao ritmo bem como ao espaço ${ }^{242}$.

\subsection{Os espetáculos}

À parte Mudra au travail, conjunto de peças de dança compostas pelos mudristas em 1972, apresentado na pequena sala do Théâtre Royal de la Monnaie, em Bruxelas, os outros produtos cênicos tiveram a participação direta de Maurice Béjart.

No pequeno teatro A petite salle de la Monnaie, onde já havia improvisado (e recebido elogios) em dezembro de 1970 a convite do bailarino Daniel Lommel, participei da encenação do poema Escena del Teniente Coronel de la Guardia Civil, de Frederico Garcia Lorca, em uma proposição da colega franco-espanhola Maguy Marin, que, mais tarde, se tornaria um grande nome da dança mundial.

Coube-me o papel do gitano, oprimido e torturado pelo Teniente Coronel, que teria uma alma de tabaco e café com leite, segundo Lorca. A peça coreográfica, que supunha a metamorfose dos personagens, teve a participação de uma colega da segunda turma, a norteamericana Diane Broman, que era muito forte na parte rítmica e vocal. Primeiro, ela entoava um canto religioso terno, plácido e límpido, em uma alusão do apoio da Igreja à ditadura de Francisco Franco, na Espanha. Em outros momentos, Diane emitia um canto de morte como que proveniente de um ancião, com a voz embargada, enquanto o texto referia-se à torre de canela e naranjas en la nieve. A partitura vocal alternava cochichos e gritos. Maguy procurava fugir do movimento ilustrativo: se o texto dizia "he inventado unas alas para volar", a ação era tão somente a de apontar-se a si mesmo e percorrer o espaço com os ombros presos e movimentos sacudidos. A indicação para o personagem era situá-lo entre o santo com olhar fixo e um pequeno diabo, por meio de movimentos trêmulos. Quando abobalhado, se encolhia. Ao final, seus movimentos tornavam-se moles, como se o gitano já não mais tivesse sangue escorrendo em suas veias. Naquele momento, iniciavam-se os golpes, as veinticuatro bofetadas,

\footnotetext{
242 BÉJART apud CHRISTOUT, 1972, p. 98. Tradução nossa. Texto original: "Certaines troupes de danse moderne apparaissent très démodées. Les mots classique ou académique et moderne ne veulent rien dire...l'école académique d'une part, la décontraction, l'improvisation de l'autre, éventuellement la souplesse orientale, l'élan instinctif du folklore. La danse théâtrale sous ses diverses formes est l'art du mouvement à la fois libre et composé, organisé par rapport au temps puisque lié à la musique, au rythme ainsi qu'à l'espace".
} 
com o texto Cancion del Gitano Apaleado, quando o personagem pede que the tragam "agua com peces y barcos". Quanto à minha atuação, Maguy fez um comentário que se confirmaria em minha trajetória futura: agarro, vou a fundo e encontro soluções no primeiro contato com a situação ou personagem, mas, irregular, não consigo manter a mesma qualidade a cada vez.

Foi a partir da pergunta sobre o que leva um ator a encontrar uma nova motivação e, consequentemente, um novo frescor a cada apresentação é que o método stanislavikiano desenvolveu-se. Bem sei que uma boa apresentação depende de sua anterior preparação. Antes de cada apresentação, há muito tempo, pratico dois exercícios de concentração: o primeiro consiste em levantar os dois braços acima da cabeça e descer ambos pelos lados. Enquanto um braço desce pela lateral em um meio círculo, o outro descreverá um círculo e meio. O segundo consiste em fazer, ao mesmo tempo, três movimentos com um dos braços e cinco com o outro. Alternam-se os lados por três vezes. Ambos os exercícios destinam-se a focar a atenção, tornando a dança do dançarino mais potente, segundo a aprendizagem que obtive com o filme Mahabaratha, do diretor Peter Brook. O programa de Jean Cocteau et la danse, apresentado no Cirque Royal de Bruxelas de 14 a 27 de abril de 1972, era composto por três coreografias todas tendo como ponto de partida poemas do escritor Jean Cocteau (1889-1963).

Le Fils de l'Air foi a coreografia que abriu o espetáculo. As duas últimas foram L'Ange heurtebise, com coreografia de Maurice Béjart e participação do ator Jean Marais, companheiro de Cocteau, e Les mariés de la Tour Eiffel, coreografada por Micha Van Hoecke, com a participação de Maurice Vaneau. A primeira foi a estreia profissional dos mudristas - o Centro contava, então, com duas turmas, do primeiro e segundo ano - na cena teatral: Le fils de l'air, a partir do poema e de algumas notas inéditas de Jean Cocteau, entregues a Maurice Béjart pelo filho adotivo de Cocteau, Edouard Dhermit. A trama focava um menino (Pierre Droulers) que brincava com a mãe (Juliana Carneiro da Cunha) em um parque quando foi sorrateiramente roubado pela rainha dos ciganos (Célia Gouvêa) para tornar-se equilibrista de circo. "Os temas, caros a Cocteau, são o Circo, o sonho, a evasão, a

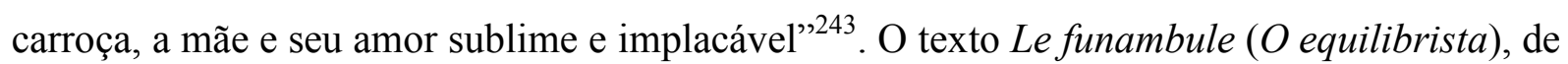
Jean Genet, serviu como texto de apoio e narra a relação entre o fio de ferro e o dançarino, que não pretende divertir o público, mas fasciná-lo. Não se é artista sem que um grande mal não se misture. Só depois da passagem pela floresta escura é que alcançará o domínio de sua

\footnotetext{
243 BÉJART, Maurice. Programa de Jean Cocteau et la danse. Bruxelas, 1972. p. 9. Tradução nossa. Texto original: "Ces thèmes chers à Cocteau qui sont le Cirque, le rêve, l'évasion, la roulotte, la mère et son amour sublime et implacable".
} 
arte. Inapto para a lógica do mundo, o equilibrista se situa entre a pista e o céu, sob a forma de constelação. Um dos mais emocionantes mistérios reside no fato de que o artista, depois de um período brilhante, atravessará um período apertado, em que poderá perder sua razão e seu domínio, mas se sairá vencedor.

O programa impresso atribui a criação como coletiva, com o apoio do corpo de professores, mas a presença de Béjart era constante nos ensaios, orientando para que houvesse uma maior projeção das cenas. Por exemplo: ele propôs que eu fizesse um gesto com o círculo metálico que usaria para pegar e prender o garoto, então eu o mordi; ele pediu que eu desse três voltas em vez de uma, alegando que as boas coisas têm que ser mostradas a todo o público. Para a elaboração dos figurinos, o Théâtre Royal de la Monnaie abriu seus depósitos. Cada um pegou o que achava adequado e confeccionou seu próprio figurino e adereços. Como a quantidade de tecidos era imensa, fato é que levamos também roupas para usar na rua e até para confeccionar cortinas para nossas casas. Dois anos depois, Maurice Vaneau escreveu no programa da estreia de Caminhada, em São Paulo, acerca da estreia mudrista em Bruxelas: "Vivi esse dia a dia [...], até que, finalmente, numa noite no Cirque Royal a grande explosão [...] de jovens com uma maneira nova, diferente, de fazer teatro" 244 .

Figura 24 - Cenas de Le fils de l'air, 1972
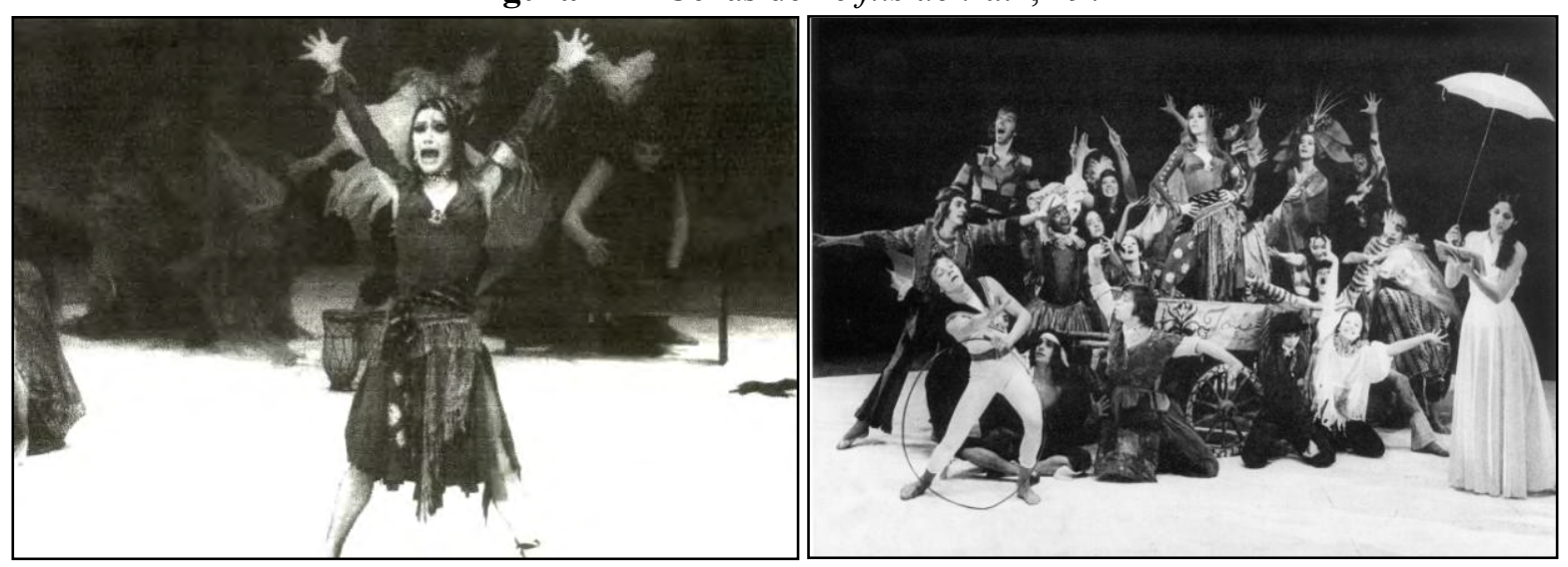

Fonte: arquivo pessoal. Fotos de Claire Falcy.

O elenco contou com todos os participantes das três primeiras_promoções do Mudra.

O espetáculo de encerramento do ciclo de três anos reuniu as três turmas, do primeiro, segundo e terceiro ano e teve a direção assumida de Maurice Béjart. O tom da coreografia foi

${ }^{244}$ VANEAU, Maurice. Programa de Caminhada. São Paulo, 5 de dezembro de 1974. 
dado por um curto solo de Alain Louafi, que o mostrou já pronto a Béjart, no qual havia a simbiótica fusão de palavra, ruídos e movimentos contraídos e ritmados.

A estreia se deu em 12 de maio de 1973 no Teatro Nacional da Bélgica. O ponto de partida do espetáculo, intitulado Le Théâtre et les Dieux, foi o texto-manifesto de Antonin Artaud, escrito logo após sua convivência com os índios mexicanos tarahumaras. O texto foi escolha de Béjart e sintetizava os propósitos mudristas. A coreografia alternava línguas e gêneros diversos, do dramático ao cabaré. Vou reproduzir o trecho selecionado na íntegra, por ter me servido de farol e guia durante toda a trajetória artística.

É porque a cultura não é escrita, e que, como disse Platão: "O pensamento se perdeu no dia em que uma palavra foi escrita". Escrever é impedir o espírito de mover-se, como uma vasta respiração. Pois a escrita fixa o espírito e o cristaliza numa forma, e da forma nasce a idolatria. O verdadeiro teatro, como a cultura, nunca foi escrito. O teatro é uma arte do espaço, e é pesando sobre todos os pontos do espaço que ele se arrisca a tocar a vida. É no espaço assombrado pelo teatro que as coisas encontram suas imagens e, sob as imagens, o rumor da vida. Existe um movimento hoje para separar o teatro de tudo o que não é espaço, e para reenviar a linguagem do texto aos livros, de onde ela nunca deveria ter saído. Esta linguagem do espaço age por sua vez sobre a sensibilidade nervosa, faz amadurecer a paisagem desdobrada sob ele. Eu não pretendo refazer aqui esta teoria do teatro no espaço, que age ao mesmo tempo pelo gesto, pelo movimento e pelo ruído. Ocupando o espaço o teatro acua a vida e a força a sair de seus refúgios. É como a cruz de seis braços, que espalha sobre as muralhas de certos templos mexicanos uma geometria oculta. A cruz do México está sempre cercada, ela se encontra no centro de uma muralha, ela nasce de uma ideia mágica. Para fazer a cruz, o antigo México se coloca no centro de uma espécie de vazio, e a cruz cresce em torno dele ${ }^{245}$.

Pouco depois, Jean-Louis Barrault, que cogitara em instalar em Paris a trupe Chandra, formada por egressos do Mudra, solicitou a Béjart a participação em uma homenagem a

\footnotetext{
${ }^{245}$ ARTAUD. In: THÉVENIN, 1971, p. 203-204. Tradução nossa. Texto original: "C'est pourquoi la culture n'est pas écrite, et que, comme le dit Platon: „La pensée a été perdue du jour où une parole a été écrite“. Écrire c'est empêcher l'esprit de bouger au milieu des formes comme une vaste respiration. Puisque l'écriture fixe l'esprit et le cristallise dans une forme, et, de la forme, naît l'idolâtrie. Le vrai théâtre comme la culture n'a jamais été écrit. Le théâtre est un art de l'espace et c'est en pesant sur les quatre points de l'espace qu'il rique de toucher la vie. Cést dans l'espace hanté par le théâtre que les choses trouvent leurs figures, et sous les figures la ressonance de la vie. Il ya un mouvement aujourd'hui pour séparer le théâtre d' avec tout ce qui n'est pas l'espace, et pour renvoyer le langage du texte aux livres d'où il n'aurait pas dû sortir. Et ce langage de l'espace à son tour agit sur la sensibilité nerveuse, il fait mûrir le paysage deployé au-dessous de lui. Je n'ai pas à refaire ici cette théorie du théâtre dans l'espace, et qui agit à la fois par le geste, par le mouvement et par le bruit. Occupant l'espace il traque la vie et la force à sortir de ses repaires. Il est comme la croix à six branches qui répand sur les murailles de certains temples du Mexique une occulte géometrie. La croix du Mexique est toujours cernée, elle est au centre d'une muraille, elle vient d'une idée magique. Pour faire la croix l'ancien Mexique se met au centre d'une espèce de vide, et la croix pousse autour de lui".
} 
Artaud na qual os bailarinos improvisavam sobre o texto Os tarahumaras dito por Barrault. Béjart voltou ainda a Artaud em 1976, com Héliogabale, o anarquista coroado, protagonizado pelos ex-mudristas Sonach Mirk e Yann Le Gac, que, segundo Béjart, assimilaram qualidades mudristas: "Astutos, vivos, ligeiros, não obedecem a nenhuma ordem acadêmica e ao mesmo tempo submissos à disciplina da barra"246. Considerado por Béjart um personagem irradiante, solar, o imperador Heliogábalo nasceu durante o reinado de Caracala, no ano de 204, na Antioquia. Na montagem, Béjart buscou e atribuiu a Artaud o impulso moderno, sofisticado e, ao mesmo tempo, primitivo, selvagem. Androginia e homossexualidade encontravam-se igualmente presentes. As incursões queer de Béjart foram questionadas, a começar por ele mesmo. Mais uma vez, presente estava a ideia do ritual, estritamente ligada ao corpo, "a descoberta primordial deste século" ${ }^{247}$ e presente em todas as religiões. Já a fornada bejartiana oriental, como Bhakti, de 1968, teve a fraqueza de representar a divindade ao invés de apenas sugeri-la por meio de um estado ou atmosfera.

Termino com um comentário feito pela colega Dominique Genevois, que ingressou no Mudra em 1972, dois anos após a abertura da qual fiz parte. Há alguns anos, sabia que a colega escrevia um livro sobre as questões pedagógicas do Mudra. O livro foi publicado em maio de 2016, quando eu concluía o presente capítulo.

Os estudantes emblemáticos da escola? Podemos citar muitos. Desde os primeiros anos até o fim da atividade da escola em Bruxelas, personalidades marcantes a cruzaram. Mas há um grupo nitidamente simbólico. Precisamente a primeira promoção, que chegou em 1970. Eu me interesso particularmente, pois aquela turma deu o tempo, a cor da escola, uma espécie de ideal, de investimento, de sensibilidade e de capacidade à invenção que inspirou os grupos posteriores ${ }^{248}$.

Registro o fato de eu ter sido protagonista dos dois primeiros ensaios coreográficos de Maguy Marin. Há de se refletir sobre a dificuldade - ou mesmo impossibilidade - de se instalar um projeto semelhante no Brasil ou em outro país da América Latina, devido, entre outras, a razões econômicas e à vontade política para a continuidade de um projeto artístico

\footnotetext{
${ }^{246}$ BÉJART, 1981, p. 221.

247 Ibid., p. 223.

${ }^{248}$ GENEVOIS, 2016, p. 231. Tradução nossa. Texto original: "Des étudiants emblématiques de l'école? Nous pouvons en citer beaucoup. Depuis les premières années jusqu'à la fin de l'activité de l'école à Bruxelles, des personalités marquantes s'y sont croisées. Mais il y a un groupe nettement symbolique. C'est précisement la première promotion, delle arrivée en 1970. Je m'y intéresse particulièrement car cette classe donne le tempo, la couleur de l'école, une sorte d'idéal, d'investissment, de sensibilité et de capacité à inventer qui inspire les grupes postérieures".
} 
sólido, caro e ambicioso. Como vimos, houve iniciativas análogas em outros países, com adaptações estruturais dependendo das condições locais.

Figura 25 - Célia e Maguy Marin, 1973

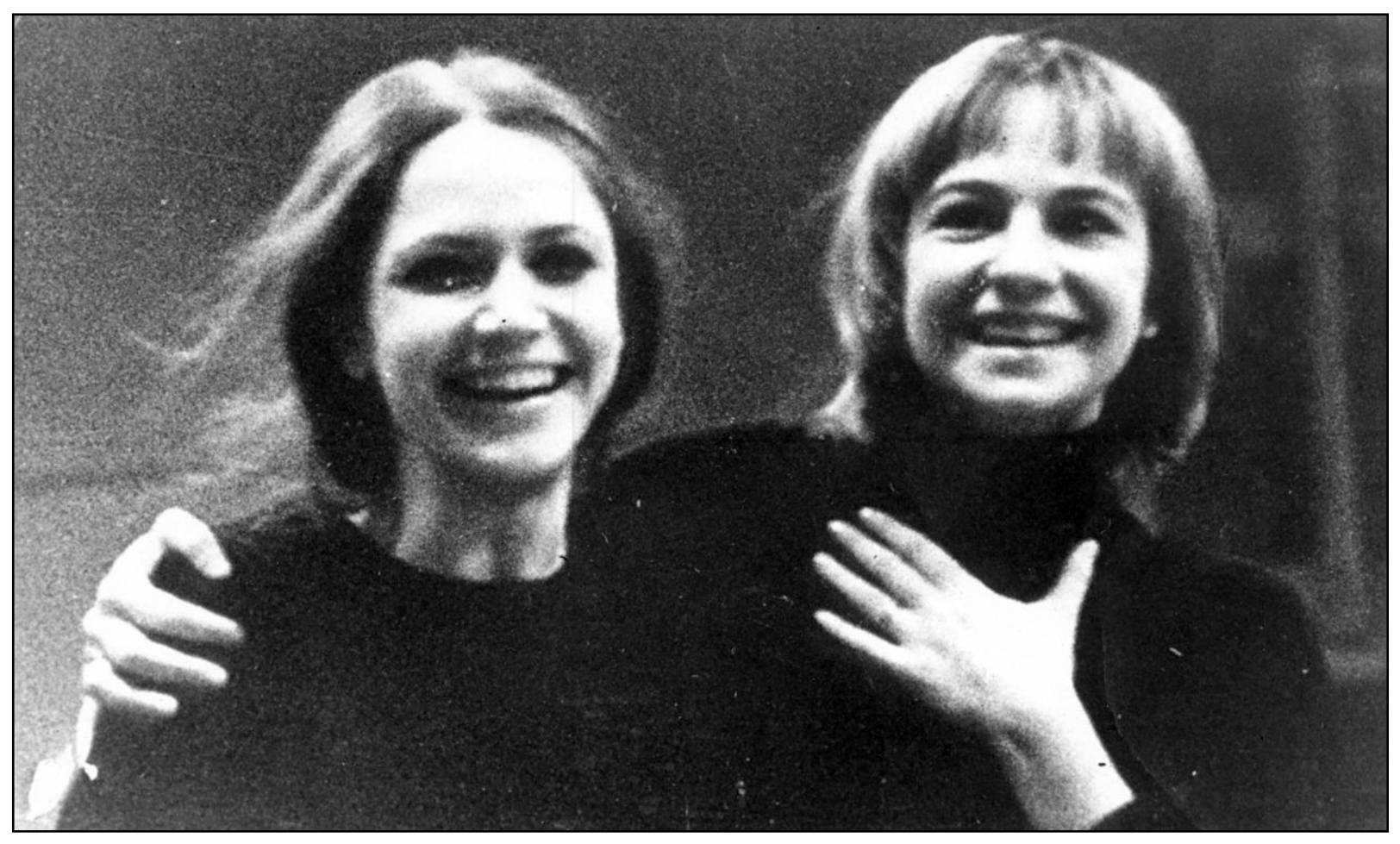

Fonte: arquivo pessoal. Foto de Claire Falcy. 
Figura 26 - Diploma de Célia Gouvêa do Mudra (frente)

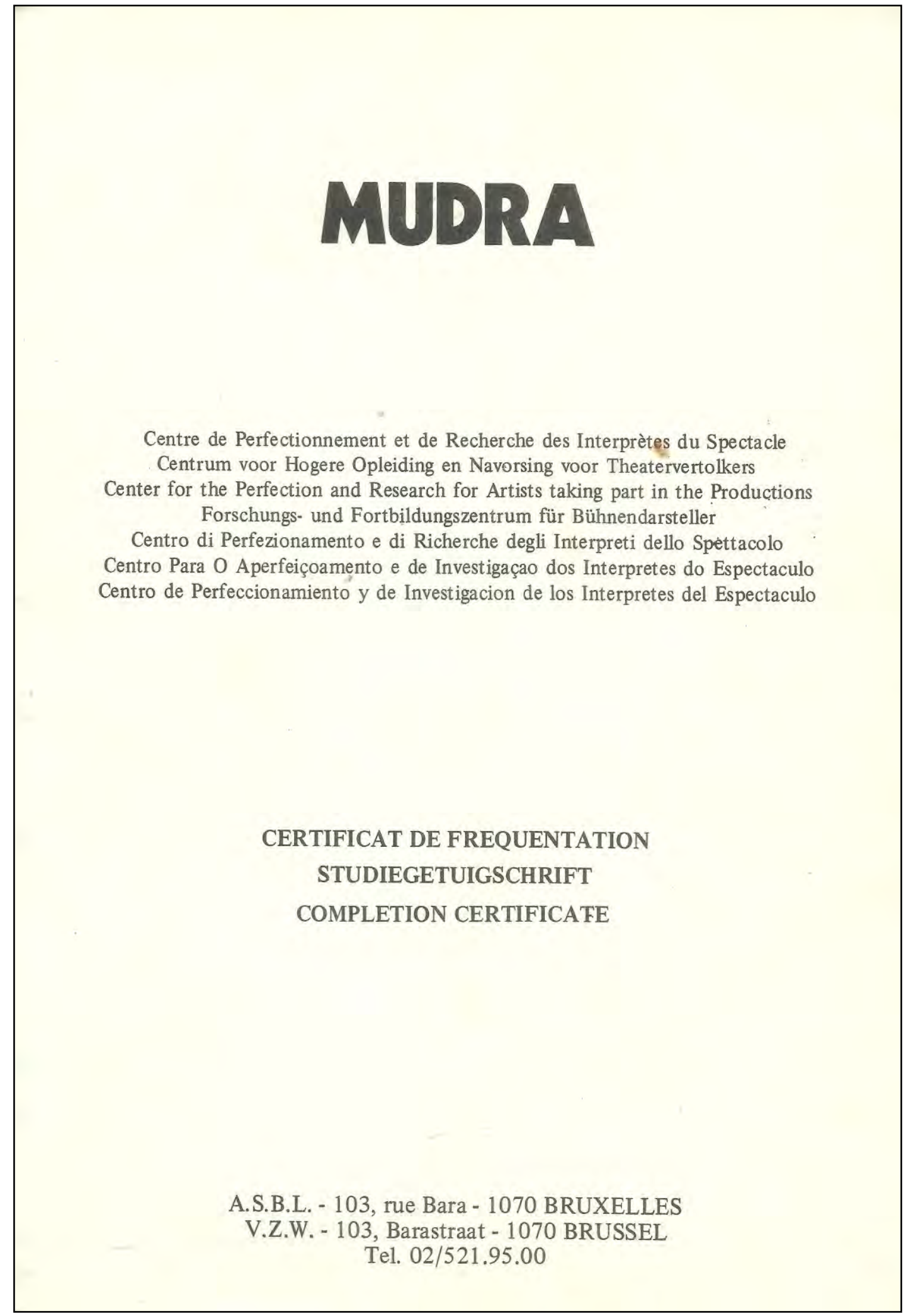

Fonte: arquivo pessoal. 
Figura 27 - Diploma de Célia Gouvêa do Mudra (verso)

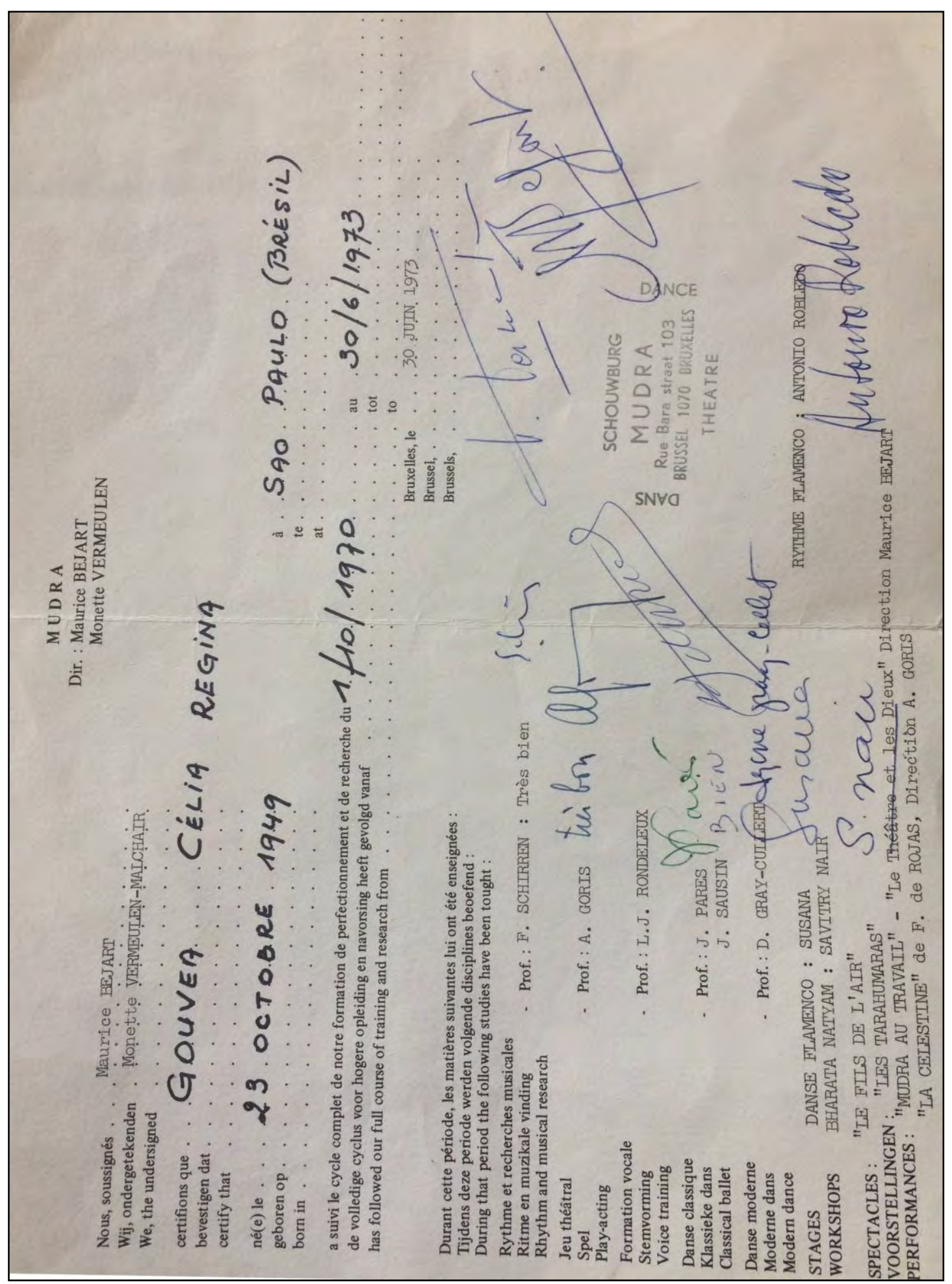

Fonte: arquivo pessoal. 


\subsection{Experiências correlatas}

\subsubsection{Rudra Béjart Ballet School}

Em 1988, o Centro Mudra foi fechado, um ano após a partida de Béjart para a Suíça, após divergências deste com Gérard Mortier, que fora nomeado diretor do Théâtre Royal de la Monnaie (TRM). O Mudra teve, portanto, dezoito anos de existência. A dança contemporânea já havia se firmado e o novo diretor do TRM pretendia uma outra vertente artistica. O coreógrafo norte-americano Mark Morris foi convidado a assumir a direção da companhia belga que substituiu o Ballet du XXème, trazendo consigo seus bailarinos. A companhia passou a se chamar Monnaie Dance Group Mark Morris, que permaneceu em Bruxelas por três anos, de 1988 a 1991.

É extenso o legado deixado por Maurice Béjart. Um deles, certamente, é a leva de novos coreógrafos belgas, como Anne Teresa de Keersmaeker, Wim Vandekeybus, Jan Fabre ou Jan Lawers - todos flamengos, assim como Alain Platel e outros membros da Cie. C. de la B. (Ballets Contemporains de la Belgique). Há ainda os nomes de Luk Perceval, Ivo Van Hocke, Guy Cassiers, Jan Decorte e tantos outros. Tanta ebulição não teria ocorrido não fosse a difusão da dança promovida por Béjart, que deixou um lastro significativo atrás de si. Muitos talentos devem ter se espelhado nos excelentes integrantes masculinos e femininos presentes no Ballet du XXème siècle e, assim, optado pela profissão de bailarinoscoreógrafos. Ainda que as propostas estéticas diferissem, o coreógrafo francês propiciou um ambiente favorável à expansão da linguagem da dança belga. Maurice Vaneau, contemporâneo de Béjart - tinham apenas um ano de diferença de idade -, certa vez comentou que, caso Béjart e companhia já estivessem atuando na Bélgica quando começou a fazer teatro (em 1948), provavelmente teria se tornado bailarino em vez de homem de teatro.

Béjart não acompanhou e mesmo rejeitou as técnicas sinestésicas que visavam a um menor esforço muscular em proveito de uma vida dançante mais longeva, que costumava findar-se por volta dos 35 anos. Dizendo-se um homem de sua geração, manteve-se focado nas suas convicções, ainda que o mundo da dança atravessasse grandes modificações. Isso fez com que, hélas, o grande Béjart se tornasse démodé, désuet.

Béjart partiu para Lucerna, na Suíça, onde fundou, em 1987, o Béjart Ballet Lausanne. Desde a morte do coreógrafo, em 2007, o então diretor adjunto Gil Romain assumiu a direção da companhia. Em 1992, teve início a Rudra Béjart Ballet School, ainda ativa, codirigida pelo ex-mudrista e bailarino do Ballets du XXème siècle Michel Gascard, com um cursus de 
apenas dois anos de duração e ainda mais focado na técnica em comparação ao Mudra. O projeto de uma unidade em Paris não se concretizou, confirmando o ditado de que "santo de casa não faz milagre", pois foi em Bruxelas, e não em Paris, que Béjart encontrou as condições necessárias para erigir o grande projeto ao qual se destinava: uma grande companhia e, posteriormente, uma escola.

A escolha do nome vem também do Oriente: Rudra, o Deus hindu da dança, combatente e vitorioso. Com apenas dois anos de duração, manteve a carga horária mudrista de dez horas diárias seis vezes por semana. O yoga foi substituído pelo kendô, arte marcial proveniente dos samurais japoneses. Não se tem notícia de tantos nomes saídos da escola que tenham se firmado como renovadores da dança, como ocorreu no Mudra, mas, certamente, existem, como Alessio Silvestrin, que coreografou para a São Paulo Companhia de Dança. O currículo do Rudra inclui o aprendizado do repertório coreográfico de Maurice Béjart, fazendo supor que a escola constitui um estágio para a admissão na companhia.

O incêndio que destruiu o prédio do Mudra, basicamente construído com materiais de madeira em maio de 1992, aumenta a relevância do presente relato. Foi considerado criminoso, tendo acontecido em um momento em que Bruxelas estava em vias de tornar-se a capital da comunidade europeia, o que agitou a especulação imobiliária na cidade. Se descrever é historicizar, levo em conta que os fatos narrados não se encontram mortos, mas repercutem. Já Aristóteles considerava a poesia mais importante que a História, pois a primeira trata daquilo que poderia ter ocorrido, enquanto a segunda se atém ao que de fato ocorreu: "Por isso a poesia é algo de mais filosófico e mais sério do que a história, pois refere aquela principalmente o universal, e esta o particular" ${ }^{249}$. Pierre Nora refere-se ao "processo orgânico e lacunar da memória [...]", enquanto a História se atém ao "relato feito através da reconstrução, que ambiciona a objetividade", e completa: "É o sonho da verdade histórica que introduziu o fantasma do efêmero nos discursos sobre as artes vivas" ${ }^{250}$. É bastante discutível o conceito de "efêmero", pois algo fugaz pode habitar a memória inevitavelmente.

\footnotetext{
249 ARISTÓTELES, 1993, p. 54-55.

${ }^{250}$ NORA, Pierre. Les lieux de mémoire. Paris: Gallimard, 1984, p. XXV. Tradução nossa. Texto original: "Mémoire: processus organique et lacunaire...récit fait par la reconstruction, qui ambitionne l'objectivité...C'est le rêve de la verité historique qui a introduit le fantôme de l'éphemère dans les discours sur les arts vivants".
} 


\subsubsection{Mudra Afrique (em Dakar)}

Outras experiências correlatas foram realizadas. Entre 1977 e 1982, Béjart, cujo pai Gaston Berger, filósofo e empresário, nasceu em São Luis do Senegal, empreende um novo projeto: o Mudra Afrique. O coreógrafo modificou o nome paterno, coincidindo com o da esposa de Molière, Armande Béjart, talvez pela sonoridade ou para cunhar uma marca própria em relação ao pai. A cidade, cujo nome homenageia os reis luíses franceses, especialmente Luis XIV, recebeu essa denominação no século XVII, quando os franceses, seguindo a prática inglesa, holandesa e portuguesa, ali plantaram mais um de seus braços colonialistas. Béjart sempre mostrou-se orgulhoso de sua veia negra. Um Mudra sem dinheiro foi estabelecido ali, conforme o depoimento de Alain Louafi, ex-colega do Mudra-Bruxelas e professor no centro africano. Com o apoio do presidente e poeta senegalês Leopold Sedar Senghor, o MudraÁfrica foi fundado em Dakar coordenado por Germaine Acogny, diretora artística conhecida como Mama África que procurou fundir a dança do Ocidente, aprendida em Nova York e Paris, com as danças africanas tradicionais - herdeira que foi dos conhecimentos de sua avó nigeriana, uma sacerdotisa iorubá, cuja procedência é o Benin. Recentemente, Acogny recebeu da república francesa a distinção da Légion d'honneur de Pâques 2016.

Béjart pôde, assim, voltar-se a um dos pilares da dança: a cultura africana. Durante o período de existência do Mudra-África, Acogny publicou o livro African dance, em 1980. Anteriormente, seu pai, Togaun Servais Acogny, escrevera um livro que serviu de apoio à coreógrafa para a realização da coreografia Eau sublime, apresentada na Bienal de Lyon em 1994. O centro africano tinha como objetivo o de estabelecer a dança africana moderna. Acogny encontrava similaridade entre a dança que praticava em seu país e as posições uterinas propostas por Martha Graham.

O currículo incluía as disciplinas dança africana tradicional, teatro, canto, ritmo e improvisação sobre o movimento, tendo como propósito a criação coreográfica. Esse elemento vital constitui o coração do movimento segundo Acogny e recebe modulações de acordo com as circunstâncias, se praticado no trabalho ou na respiração. Na dança africana, predominam as ondulações do torso e a relação com o cosmos, tendo por base os pés na terra, que determinam a posição dos calcanhares, quadris e busto. As contrações e tremores do corpo relacionam céu e terra, considerando a equivalência entre o peito e o sol, o púbis e as estrelas, a face e a lua.

Quando o centro mudrista africano foi fechado, a franco-senegalesa Acogny, que havia fundado seu primeiro estúdio de dança em Dakar em 1968, partiu para Bruxelas, onde 
trabalhou com Maurice Béjart e ofereceu workshops de danças africanas, chegando a formar o Studio-École-Ballet Théâtre du 3e. Monde, em Toulouse, na França, conforme informou Ana Francisca Ponzio $^{251}$. A bailarina e coreógrafa africana trabalhou no Brasil em 1995, a convite de Ivonice Satie, então diretora do Balé da Cidade de São Paulo, quando montou $Z$, a partir de Zumbi dos Palmares, líder quilombola, com música de Gilberto Gil. Acogny retornou ao seu país em 2004, onde abriu a L'École des Sables em Toubab Dialaw, uma vila de pescadores senegalesa. O título completo da escola é L'École des Sables - International Center for Tradicional and Contemporary African Dances in Senegal. A instituição fornece estudos multidisciplinares em amplos estúdios equipados com padrão internacional. Lá, Acogny trabalha sempre em colaboração com seu filho, Philippe Olza.

O propósito de Acogny de codificar uma dança africana contemporânea a partir da premissa de que a dança é a mãe de todas as artes constitui um exemplo de trânsito entre a cultura africana e a ocidental. Desde os anos 1930, o termo "negritude" se contrapõe à colonização francesa, o que levou o poeta Aimé Cesaire (1913-2008) a defender o conceito de "crioulização", derivado do termo "crioulo", língua falada nas Antilhas Francesas, na região caribenha. No Brasil, o termo tem múltiplas conotações, nativos ou procedentes do além-mar, acabando por designar qualquer indivíduo negro. Ao contrário das identidades fixas e enraizadas, a crioulização visa abraçar a instabilidade, as identidades relacionais, móveis e criativas, segundo a estética da reparação proferida por Isaac Julien, nascido no Reino Unido em 1960, cineasta que foca os temas da diáspora e das minorias no mundo pós-colonial e que, ao invés da cultura africana de raiz, propõe a mestiçagem. Esse lugar de resistência, alternativa à publicidade e ao mercado, vem reforçar a assim denominada geopoética, ou poética do político, expressão de Isaac Julien, cuja fala em A coreografia da imagem em movimento: o desejo pós-cinemático foi analisada por Emi Koide ${ }^{252}$. O cinema expandido ou pós-cinema desembocará nas videoinstalações, apresentadas em museus e galerias de arte.

\footnotetext{
${ }^{251}$ PONZIO, Ana. Cia. Jant-Bi Jigeen (Germaine e Patrick Acogny) Afro-Dites / Kaddu Jiggen! Portal Connectdance. Disponível em: < http://www.conectedance.com.br/evento/cia-jant-bi-jigeen-germaine-e-patrickacognyafro-dites-kaddu-jiggen/ > . Acesso em: 14 out. 2014.

252 KOIDE, Emi. Coreografias do cinema expandido: mestiçagem e outras representações. Portal Forum Permanente. Disponível em: <http://www.forumpermanente.org/event_pres/exposicoes/isaac-julien/relatos /coreografias-do-cinema-expandido-mesticagem-e-outras-representacoes>. Acesso em: 15 set. 2015.
} 


\subsubsection{De l'Interprète à l'Auteur}

Não teve vida longa o projeto lançado por Maguy Marin e Companhia em outubro de 2007. Quatro anos após o seu início, De 1'Interprète à 1'Auteur (Do Intérprete ao Autor) foi encerrado no final da temporada de 2011. Durante muitos anos, Maguy afirmou não ter tempo para ocupar-se de uma escola. Nove anos após ter se instalado na cidade de Lyon, na região francesa de Rhône-Alpes, à frente do Centro Coreográfico Nacional (CCN) de Rillieux-LaPape, a coreógrafa e diretora artística associou-se à Universidade Lumière Lyon 2/Faculté des Lettres, Sciences du Langage et Arts - Faculté d'Anthropologie et de Sociologie, situada no campus Porte des Alpes da cidade-satélite de Bron, e formou o curso com duração de um ano letivo com estatuto de Graduação Universitária. Os alunos da formação dirigida por Maguy seguiam cursos com os estudantes da licença profissional Profissões da Mediação Cultural ( $3^{\circ}$ da licença profissional, igualmente ligada à Faculdade de Letras, Ciências da Linguagem e Artes e associada à faculdade de Antropologia e de Sociologia).

Catorze anos (1984-1998) foi o tempo por que Maguy e sua trupe estiveram instalados em Créteil, na periferia de Paris. Outros catorze anos (1998-2002) foi o tempo passado em Lyon à frente do $\mathrm{CCN}$, ao final dos quais Maguy empreendeu uma experiência em Toulouse, sua cidade natal. Em 2015, o grupo voltou a Lyon, instalando-se, dessa vez, no espaço Ramdam, antiga marcenaria adquirida por Maguy com o dinheiro de seus direitos autorais e gerida por um coletivo artístico. Nessa e em outras ações, a coreógrafa franco-espanhola imprime a marca da França cidadã, em uma demonstração de ativismo social. Ao instalar-se em Rillieux, Maguy procurou envolver a comunidade local em um trabalho orientado pelo sentido de associação, antes que o de missão, de maneira a responder à urgente necessidade de inscrever a dança em uma realidade política e social da cidade, escalando seus dançarinos a dar aulas à população local de múltiplas faixas etárias. O projeto de Maguy não nasceu do nada e revelou afinidades com artistas como François Verret - que liderou, por alguns anos, o Les Laboratoires d'Aubervelliers, situado na periferia de Paris - e, também, François Tanguy. $\mathrm{O}$ objetivo era o de implantar canteiros que respondessem às aspirações profundas e necessidades autênticas da população local. Espaços que suscitassem e gerassem trocas e encontros, produzindo expressões. Um experimento de vida social que convidasse as pessoas a tecerem laços e conhecer a gratuidade, revelando suas qualidades umas às outras.

O projeto de implantação concebido por Maguy constitui um quase manifesto que visa retirar o artista de qualquer isolamento e reitera os propósitos de tornar rico o confronto das diferenças por meio da inclusão social, propondo um jogo vivo com novas intervenções 
destinadas a aliar cultura cênica e cultura de rua entre dança contemporânea e dança de rua no território La Villette. Segundo suas próprias palavras, tratava-se de iniciar um confronto de seu trabalho com a população, de assumir um perfil social, colocando-se no espaço público para celebrar a riqueza das diferenças e o prazer do jogo muito vivo da criação. Ela, que já havia aderido em 1995 à greve de fome proposta por Ariane Mnouchkine para pressionar as autoridades francesas a tomarem posição no conflito da Sérvia. Ambas as artistas, com as quais tive o privilégio de conviver ${ }^{253}$, sempre levaram em conta o privilégio de receber verbas estatais, devolvendo o benefício recebido com muito trabalho. Engajamento político e linguagem cênica sofisticada foram sempre suas marcas. Na referida greve de fome, um dos artistas participantes foi François Tanguy, que realiza na cidade francesa de Le Mans um importante trabalho cênico. Foi ele quem proferiu o enunciado de que o teatro que queria fazer relacionava-se ao real, expressão emblemática que designa o teatro contemporâneo.

O título da formação, como usualmente era chamada, substitui a hoje controvertida palavra "intérprete", apontando à transmutação em intérprete-criador. Já na capa do catálogo há a frase: "Interpretar é ser autor de seu gesto"254. O encenador polonês Jerzy Grotowski incentivava ir à cata não do novo, mas de algo que foi esquecido ${ }^{255}$. "Aprender é relembrar-se; mas relembrar-se não é nada mais que aprender - ter um pressentimento, compor com aquilo que nos força a pensar em ato",256.

O procedimento assemelha-se à maiêutica socrática na qual o método visa acordar um conhecimento adormecido, que já se encontra alojado na pessoa. A formação, concebida com aproximadamente 1.100 horas/aula concentradas em dois semestres universitários, tinha como propósito construir uma exploração singular dos campos atuais da arte por meio de uma dimensão crítica e antropológica, historiográfica e filosófica em seus aspectos sensíveis, relacionais e políticos, acolhendo catorze alunos com idade superior a dezoito anos, solicitados a também desenvolver seus dons para a escrita, em uma abordagem reflexiva. Do corpo discente, fez parte a brasileira Carolina Pedalino, cujo depoimento consta dos anexos.

\footnotetext{
${ }^{253}$ Em 1999, deixei Lyon e instalei-me em Paris. Em dezembro daquele ano, 25 anos exatos após a estreia de Caminhada, primeira parceria artística com Maurice Vaneau e que abriu o Teatro de Dança Galpão em São Paulo, estreei Mãe Tzé Tzá nos estúdios do Théâtre du Soleil.

${ }^{254}$ BARTHES, 2000, p. 30.

255 GROTOWSKI, Jerzy. Performer: Conferência de Jerzy Grotowski em "Encontros à volta da performance" Traduzida por Thomas Richards e João Garcia Miguel. Paris: Art-Press, 1987.

${ }^{256}$ Catálogo do curso Do Intérprete ao Autor, criado por Maguy Marin. p. 2. Tradução nossa. Texto original: "Apprendre, c'est se ressouvenir; mais se ressouvenir n'est rien de plus qu'apprendre - avoir un pressentiment, composer avec ce qui nous force à penser en acte".
} 
O currículo, encabeçado pelas linguagens do corpo e técnicas de dança clássica e linguagens contemporâneas, focava os fundamentos do corpo e explorações das linguagens gestuais e técnicas, em um amplo leque de possibilidades que iam desde aspectos do movimento, como peso, apoios, respiração, coordenações e alinhamento, passando por disciplinas tais como taïso, qi gong, yoga, métodos de Moshe Feldenkrais e Mathias Alexander, até a aprendizagem do circo, da dança hip hop e de danças étnicas provenientes de outras culturas. Parte da carga horária era dedicada ao estudo técnico, feito por meio de dispositivos, abordando problemas de gestão e práticas administrativas como contabilidade, direitos autorais, subvenção e logística, e compreendendo, também, o trabalho de iluminação, em um evidente cruzamento entre teoria e prática. Os interventores convidados, em torno de quarenta, incluíam profissionais do ramo artístico e cultural: professores (de dança, interpretação, música, voz, entre outros), praticantes de técnicas específicas, artistas dançarinos, coreógrafos, circenses, comediantes, diretores, compositores, músicos, escritores, cenógrafos, figurinistas, videastas, professores-pesquisadores em Antropologia, Sociologia, História, Filosofia, etc.

O curso de interpretação supunha a interioridade da ação conectada ao entorno por meio do trabalho do ator que promove a interação entre escuta, espaço, movimento, ritmo, musicalidade e voz. O propósito da aprendizagem rítmica era a organização entre tensão e descontração, colocando em ação os músculos, os ossos, o peso e o suor e relacionando-os com as outras artes, de forma a explorar contexto histórico e geográfico da composição. Mesmo as oficinas dedicadas à escrita tinham o ritmo como referência. Consta do catálogo a frase: "O primeiro reflexo do recém-nascido é o de inspirar, o primeiro gesto da vida. Aquele que se opõe a ele é a expiração, o último gesto na hora da morte. Tudo é ritmo". A improvisação, o grito, visavam, igualmente, ampliar o léxico vocal. A língua estrangeira, ou a estranheza em sua própria língua tendiam a convocar novas musicalidades e a encontrar "a corporalidade das palavras e dos sons".

A marca deixada pelo professor de ritmo do Mudra, Fernand Schirren, é clara, tanto em Anne Teresa de Keersmaeker quanto em Maguy Marin. Se a leitura da partitura musical e seus elementos nortearam grande parte das obras de Anne Teresa, em Maguy, a própria construção interdisciplinar, o tratamento do texto, povoado por pausas e respirações, constituiu uma marca do tecido coreográfico, tudo concebido como uma partitura musical. A conclusão é que ambas as coreógrafas não só foram afetadas profundamente pelo prof. Schirren, mas que a música, embora com diferentes abordagens, é básica para ambas, em um sentido novo e diverso ao de Béjart: “Construía meu trabalho unicamente sobre as relações 
entre a partitura musical e o movimento" ${ }^{, 257}$. Além da precisão, da potência e do humor, outro traço forte em Maguy foi sempre seu elo com o entorno, o Unwelt, em um engajamento inteligente, fruto de uma postura imbuída de cidadania que a fez optar por estabelecer sua companhia em uma zona periférica de Lyon, relativamente degradada, habitada, majoritariamente, por imigrantes, e na qual a municipalidade socialista decidiu dar vida aos bairros carentes e criar um polo cultural. Naquele ano de 1998, Maguy e sua companhia deixaram Créteil, na periferia de Paris, para assumir um dos centros coreográficos nacionais de Rillieux-la-Pape, vizinha a Lyon, patrocinados pelo Ministério da Cultura da França.

As propostas pedagógicas de ambas as coreógrafas também diferiam. A formação proposta por Maguy, diferentemente da escola Parts, tinha correspondência universitária e duração de apenas um ano e não perseguia o intuito de acompanhar o que há de mais avançado nas artes cênicas, buscando, antes, um ambiente propício à concentração em um bairro distante da cidade, além de incluir aulas teóricas de antropologia (cultura/olhares/pensamentos/agenciamentos), estética e história da arte na Universidade Lyon 2. A quinzena de estudantes admitidos a cada ano tinha pouco contato com a Cie. Maguy Marin. Para a coordenadora do curso, a portuguesa Teresa Cunha, bailarina da companhia há muitos anos, a integração não seria positiva.

A formação superior para artistas/bailarinos no projeto Do Intérprete ao Autor tinha como responsáveis pedagógicos, além de Maguy Marin, Cláudia Palazzolo - historiadora, professora-pesquisadora da Université Lumière Lyon 2 e responsável pelo grupo de dança Artes do Espetáculo; Denis Cerclet - etnólogo, professor-pesquisador no Centre de Recherces et d'Etudes Anthropologiques (CREA) da Université Lumière Lyon 2 e responsável pelo mestrado "Profissões das Artes e da Cultura"; Axel Guïoux - etólogo, professor-pesquisador no CREA da Université Lumière Lyon 2 e responsável pela licença profissional "Profissões da Mediação Cultural”.

A ex-colega no ciclo Mudra/Chandra, Maguy Marin, conheceu uma explosão mundial com May B, 1981, com base na obra de Samuel Beckett, guardando o elemento absurdo em indivíduos que se descobrem, começando pelo sexo. Afetada que foi pela doença seguida da morte de seu pai, os personagens são toscos, parecendo habitar um asilo. Marin compôs uma coreografia na qual o vocabulário não empregaria passos técnicos conhecidos, imprimindo

\footnotetext{
${ }^{257}$ BÉJART, 1981, p. 165.
} 
uma linguagem renovadora e poderosa. Pouco depois, passou a coreografar grandes montagens, sempre de grande sucesso, tais como Cendrillon, exibida na Ópera de Lyon.

No início dos anos 1990, procedeu a uma grande guinada, com Cortex, estreado no CCN de Créteil em 1991. Se, até aquele momento, a inclusão de palavras funcionava, sobretudo, como ritmo, na fase inaugurada por Cortex as palavras passaram a ser inteligíveis, funcionando em seu sentido literal. Para Maguy, tal recurso implicou em distância, no sentido brechtiano. A tese defendida por Bertolt Brecht (1898-1956) em Aquele que diz sim, aquele que diz não é a de que se o efeito da distanciação torna insólitos e surpreendentes os acontecimentos banais, consequentemente, a identificação torna banais os acontecimentos insólitos. É quando Maguy abdica do contato pelas vísceras e tripas, sua marca anterior. A coreógrafa franco-espanhola foi sepultando seus lastros ibéricos em prol dos franceses. Foi quando deixou procedimentos dramáticos de lado, bem como a atração por montagens com grandes cenários. Passou a procurar manter o tom certo, adequado, bem como formações mais assimétricas. Maguy tornou-se pós-moderna e atraída pelo cotidiano e por fenômenos do consumo. Desde então, sempre em parceria com o músico Denis Mariotte (com quem foi casada por vários anos e tem uma filha, Louise, como a avó materna, e cujo companheiro Charlie Aubry compôs a densa partitura da peça Bit, de 2014), Maguy passou a compor peças praticamente despidas do que se intitula "coreografia" enquanto recurso aos movimentos de dança. Em uma radicalidade crescente, passou a compor puzzles com forte apoio rítmico, uma provável herança dos cursos com o professor Fernand Schirren no Mudra.

Marin passou a não satisfazer um público convencional e seu entendimento daquilo que é ou não dança, o que levou-a à ousadia de apresentar, em 2006, em plena inauguração do novo prédio em madeira da sede do $\mathrm{CCN}$ de Rillieux-la-Pape, dirigido por ela, a estreia de $H a$ ! ha!, partitura sobre o riso executada por bailarinos que, de costas, sentados frente a estantes, só mostram seus rostos ao público no final da peça, no momento dos aplausos. No decorrer da obra, do lado esquerdo, bonecos sentados recebem, paulatinamente, sobre suas cabeças, um peso que os faz cair. A radicalidade da peça tornou "os donos da dança" furiosos e Maguy chegou a ser agredida. Parte da plateia, não só em Lyon, mas também em Paris, onde a peça foi apresentada no Théâtre de la Ville, retirou-se ruidosamente, segundo informações fornecidas pelos bailarinos Jordi Gali e Vania Vaneau. 
Em 1998, por meio de uma Bolsa Virtuose concedida pelo Ministério da Cultura do Brasil (Programa VITAE ${ }^{258}$ ), parti para a França. Convivi com a Cie. Maguy Marin, quando pude acompanhar o processo de criação de três peças estreadas quase ao mesmo tempo: Pour ainsi dire, Vaille que vaille e Quoi qu'il en soit. A companhia, que contava então com doze integrantes, foi dividida em três grupos, procedendo Maguy a coreografar um trio, um quarteto feminino e um quinteto masculino, mantendo assim todos os bailarinos ocupados, o que permitiu que os grupos se formassem por meio de um processo de autoescolha. Diferentemente da tendência adotada desde Cortex (1991), as três peças em questão recorriam a cenários mais carregados.

A primeira se caracterizava pelo humor e absurdo. Única mulher no trio Pour ainsi dire, a bailarina encostava-se no cenário e enumerava suas tarefas e afazeres como compras, ligar para a mamãe, etc., em uma incursão no cotidiano.

A segunda levantava as recorrentes questões: onde me situo? De onde venho e para onde vou? Maguy trabalhou no quarteto primeiro com música de Ludwig von Beethoven, depois no silêncio e, finalmente, com uma música especialmente composta por Denis Mariotte. O sentido poético, sensível e delicado era tratado com minúcia, requinte e sofisticação.

O quinteto masculino Quoi qu'il en soit era um ato político no qual os cinco intérpretes masculinos evocavam seu país de origem: Espanha, Itália e Chile, relevando a atração pela França das letras, das artes, dos direitos do homem, não tão generosa quanto sua imagem, uma vez que esbanja racismo e intolerância. O olhar era antes geopolítico do que geofilosófico, tratando mais da questão das opções de vida, das circunstâncias, das causas, das coincidências, dos fatos ou dos acasos da localização ou deslocalização dos indivíduos, a fim de lançar um olhar sobre a responsabilidade por meio de um banho de pequenos acontecimentos e pequenos encontros entre cinco indivíduos que estão em um lugar e tempo precisos sem, no entanto, terem trilhado o mesmo caminho, sem partilharem as mesmas razões, para construir uma história individual semelhante. Tratando de questões topográficas e territorializadas, Marin revelou ter efetuado atentas leituras deleuzianas.

\footnotetext{
258 VITAE - Apoio à Cultura, Educação e Promoção Social. Associação civil sem fins lucrativos. Sua mantenedora foi a Fundação Ampadia, com sede em Lichtenstein. Operou no Brasil, com sede em São Paulo, de 1985 a 2006. Passou a contemplar a dança em 1988, quando escrevi uma carta solicitando a inclusão e expondo o grau de pesquisa que demanda a realização de uma coreografia. Segundo o relato da crítica teatral Ilka Marinho Zanotto, membro da VITAE, após minha carta ser lida numa reunião do Conselho, a proposta foi aprovada.
} 
Em uma de suas últimas visitas ao Brasil, em 2008, a companhia apresentou Unwelt (Entorno), na qual um impressionante aparato era mostrado, composto por metais espelhados e bobinas anexadas a uma guitarra elétrica. O som era provocado pela passagem de uma bobina a outra até cessar, junto com a peça. À primeira vista, tinha-se a impressão de que o espaço cênico já se encontrava concebido desde o início dos ensaios, enquanto que, de fato, o ponto de partida foi a leitura do livro $A$ ética, de Spinoza, quando a encenação encontrava-se ainda totalmente indefinida. A obra De rerum natura do romano Lucrécio (95-55 a.C.), mencionada no primeiro capítulo desta pesquisa, foi o ponto de partida para Turba (2007), seguida por Description d'un combat (2009), com aportes históricos, mitológicos e filosóficos, e pela bem humorada Salves, de 2010.

Marin tem sido considerada uma "lufada de ar" que vem renovando o teatro europeu. Ela encarnou com maestria os propósitos mudristas, preconizados por Artaud. A coreógrafa elaborou interfaces entre teatro, dança e música por meio de jogos de voz, linguagem e movimento. Na perspectiva interlinguagens, que é a nossa, claro está que a importância ao trabalho vocal concedida por Maguy Marin é mais acentuada, ainda que extratos de textos falados ou mesmo lidos tenham integrado algumas das coreografias de Anne Teresa. No catálogo da formação criada por Marin, há referência à palavra "total", que foi discutida aqui, remetendo à "utilização total do corpo por meio da exploração do movimento, da representação do ator, do ritmo, da voz e da música, mas também por meio de abordagem reflexiva para perguntar a sua relação com o sensível"259.

O ponto principal tange ao tratamento do movimento. Maguy foi uma technicienne exemplar, que podia permanecer vários minutos em um único pé em equilíbrio sobre sapatilhas de ponta. Maguy dava aulas esporádicas de balé, sendo uma professora atenta e minuciosa: "No assemblé sai uma perna, chegam as duas; no sisson sai uma perna, chega uma, depois a outra" ${ }^{260}$. Talvez por isso desembaraçou-se facilmente da técnica e já em May $B$, de 1981, não empregava a nomenclatura de passos técnicos, mas recorria ao cotidiano e a danças étnicas. Tal não foi o caso nem de Anne Teresa nem de Béjart. Nenhum dos dois contou com facilidades físicas, necessitando, por isso, de encarar os desafios, buscando uma superação, um ultrapassar-se. No caso de Béjart, o apego à dança clássica e a procura por uma nova nomenclatura a partir de seu corpo. Anne Teresa atentou aos aspectos somáticos do movimento. A coreógrafa flamenga podia partir de motivos vários, como a pergunta aos

\footnotetext{
${ }^{259}$ Catálogo do curso Do Intérprete ao Autor, criado por Maguy Marin. ${ }^{260}$ Ibid.
} 
bailarinos, na virada do século, quanto às expectativas diante dos anos 2000. Nesse período, predominava

[...] o questionamento do movimento enquanto ponto de partida da criação coreográfica, a integração com a imagem, não apenas através do emprego de vídeos e slides, mas também na presença de elementos plásticos enquanto presença física. Ainda, no contato que mantêm com pensadores, o que leva a uma postura literária e reflexiva ${ }^{261}$.

Figura 28 - Maguy Marin em equilíbrio na ponta de um só pé, 1973

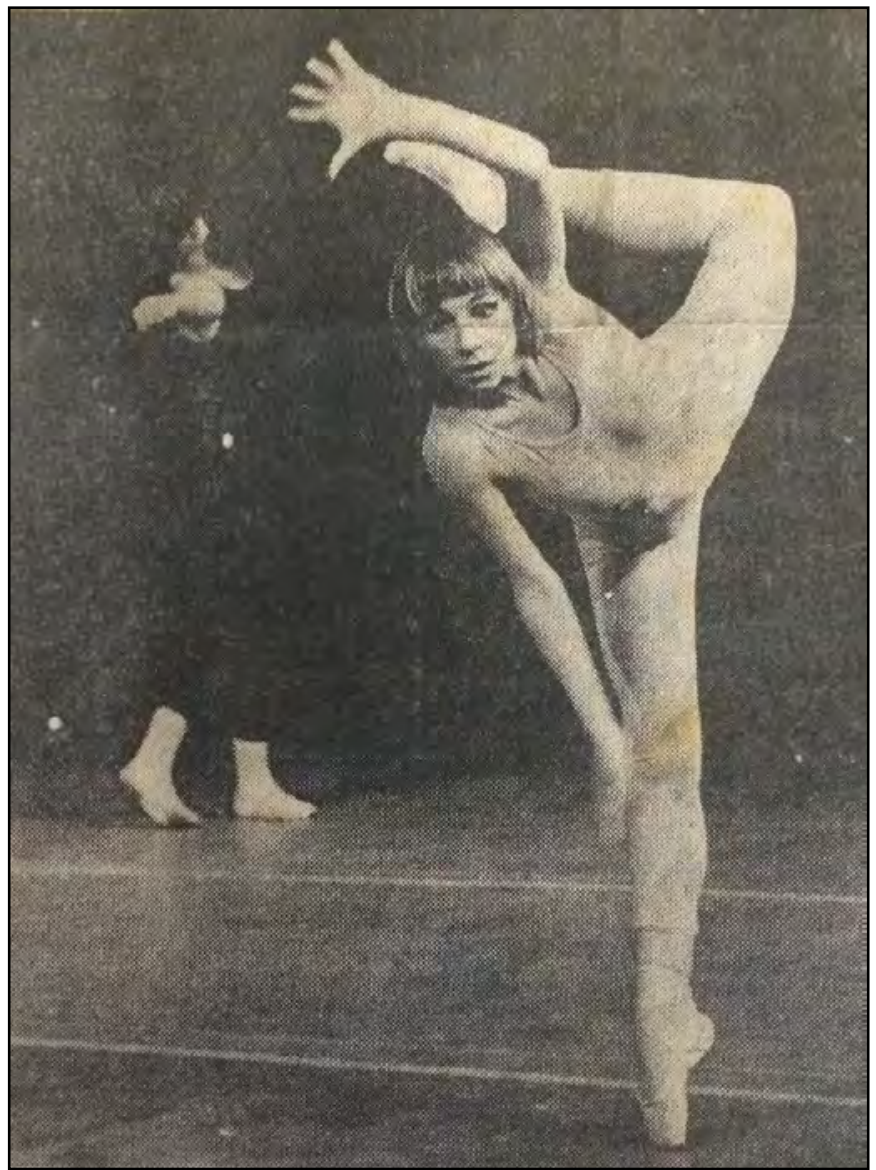

Fonte: arquivo pessoal

O diretor teatral e coreógrafo belga Frédéric Flamand, radicado em Charleroi, referiuse à explosão da representação por meio da inserção de técnicas novas, estabelecendo um diálogo na interface entre as artes visuais, o teatro, a dança, a música e o audiovisual. Já John

261 Informação verbal. Informação fornecida em setembro de 2000 por Marie Thérèse Allier, diretora da Ménagérie de Verre em Paris e organizadora do evento Les Inaccoutumés (“Aquilo que não se parece a nada nem a ninguém”). 
Cage apontou a necessidade da conexão com as máquinas e a tecnologia, superando a desconfiança por meio de uma cumplicidade, ao considerar a dança a melhor arte para promover tal junção, enquanto o teatro é mais lento que a dança no processo devido à narrativa que se faz ainda presente.

Quanto ao modo de trabalho de Maguy, nada havia que a satisfizesse enquanto frase, sequenciamento de movimentos. A denominação "somático" é muito ampla e abrange um largo leque de possibilidades. O ponto comum é, porém, a consciência do que ocorre no corpo no processo de movimentação, a conexão consigo, o sentir importando mais que o fazer. $\mathrm{O}$ processo é longo e desafiador. Susan Klein, nas aulas oferecidas em Nova York a partir dos ensinamentos de Irmgard Bartenieff, dizia que para vislumbrar com clareza qual é o osso que dá início a um determinado movimento são necessários, ao menos, cinco anos de estudos. Se, no ensino tradicional, o foco está no professor, naquele que transmite o conhecimento, no procedimento somático aquele que experimenta é o protagonista.

A questão é como transferir os preceitos somáticos aos procedimentos artísticos, levando à descoberta de corporeidades outras. Intercalar aulas técnicas segundo padrões tradicionais a aulas somáticas, provenientes de Feldenkrais, Bartenieff, da Ideokinesis de Sweigard e do Body-Mind Centering de Bonnie Bainbridge Cohen não é o suficiente. É junto que o procedimento deve andar. Sinergeticamente. A prática e o ensino da dança clássica não se encontram sepultados. Maguy Marin convida, regularmente, o japonês Yoshida Norio, exintegrante do Ballet du XXème siècle de Béjart e adepto do princípio da espiralidade em seus ensinamentos, a dar aulas para sua companhia.

$\mathrm{Na}$ briga da dança com o movimento decorrente da crise da representação, quando executar uma sequência de passos marcados tornou-se o mesmo que representar, houve coreógrafos que procuraram reinventar um vocabulário, um léxico e outro modo de se movimentar, servindo-se, como método, de um processo colaborativo, tal como definir algumas células de movimento e solicitar aos dançarinos que as desenvolvam. Esse é o caso de Anne Teresa De Keersmaeker. Outros preferiram suprimir a nomenclatura própria à dança, como foi o caso de Maguy Marin. Dotada desde o berço, dona de um bom timbre vocal, technicienne exemplar, foi-lhe mais fácil desembaraçar-se dos postulados técnicos, descartando a nomenclatura tradicional da dança clássica. Uma vez que não tinha grandes desafios técnicos a superar, Maguy pôde, com maior facilidade, recorrer a outros códigos, como em May B, quando voltou-se às danças étnicas em vez do balé. Foi profundamente marcada pelos conhecimentos rítmicos adquiridos no Mudra com o professor Schirren, pois suas peças de dança (aliás, curiosamente, durante muito tempo, Maguy referia-se a elas como 
seus "balés") guardaram sempre um sentido rítmico agudo. Em 2016, aos 65 anos de idade, tem preferido o conforto e aconchego de um pequeno núcleo familiar, no sentido literal da palavra, não só colocando em cena os próprios filhos e seus namorados, como conservando alguns de seus antigos dançarinos, como o veterano chileno Ulises Alvarez, o italiano Ennio Grecco e a toulousiana (como Maguy) Cathy Polo.

\subsubsection{PARTS: Performing Arts Research and Training Studios ${ }^{262}$}

Em setembro de 1995, na mesma cidade do Mudra, Bruxelas, a célebre coreógrafa belga Anne Teresa De Keersmaeker, mestre da musicalidade aliada ao gosto pelo movimento, lançou uma nova escola, três anos após a formação de sua companhia Rosas. Balanchine já dissera que uma companhia de dança devia estar respaldada por uma boa escola que, evidentemente, carregasse os paradigmas artísticos de seu diretor. Designada como diretora e responsável pelo currículo artístico e pedagógico, Anne Teresa foi aluna do Mudra e teria dito, segundo rumores, que lá ela teria aprendido a como não fazer as coisas. Duas décadas e meia separam a formação do Mudra (1970) e o lançamento da Parts (1995), tempo suficiente para a alteração dos parâmetros da dança.

A então aluna mudrista Anne Teresa De Keersmaeker teve, como eu, Fons Goris como professor de jogo teatral. Ambos de origem flamenga. O professor Goris disse-me que foi em um de suas aulas que Anne Teresa teria feito pela primeira vez o gesto de puxar o elástico da calcinha, mais tarde multiplicado para quatro bailarinas, com música de Béla Bartók, na bem sucedida coreografia "Mikrokosmos" - Seven pieces for two pianos, de 1989. Sempre mordaz, Goris definiu a hoje diretora da companhia Rosas, como uma camponesa trabalhadora e ambiciosa ${ }^{263}$. Diferentemente de Maguy Marin e como Béjart, a dançarina e coreógrafa não era propriamente uma technicienne, qualidade esta que agradava a Béjart,

\footnotetext{
262 As informações aqui contidas provêm do catálogo impresso da instituição; do site da Parts (http://www.parts.be/en/curriculum-training\#body\%20studies); do meu contato em 2001, quando assisti a aulas e apresentações dos alunos, ensinei e apresentei duas peças de dança $-C-E-C-I-L-I-A$ (primeira versão) e Mãe Tzé Tzá (segunda versão) - durante o evento Summer Studios e dirigi um grupo de alunos em site specific nos saguões do Théâtre Marni, em Bruxelas, no evento LITERARTE; além de entrevista, em 13 de novembro de 2014, com Vânia Vaneau, aluna da Parts de 2000 a 2002 e, posteriormente, bailarina da Cie. Maguy Marin por sete anos (2005-2012), convivendo com o curso de formação De 1'Interprète à l'Auteur. Outros bailarinoscoreógrafos que cursaram a escola são Maria Clara Villa-Lobos (1995) e Cristian Duarte, no segundo ciclo (2000-2002), que me concedeu depoimento por escrito em 10 de fevereiro de 2015, depoimento este que se encontra anexado ao final deste trabalho, enfatizando as palavras "desafio", "rigor", "pressão" e "intercâmbio".

${ }^{263}$ Informação verbal. Informação fornecida por Fons Goris durante encontro com o mesmo no Jardim Botânico de Bruxelas em julho de 2001.
} 
conforme relato de Micha van Hoecke feito em minha casa em São Paulo quando de sua visita ao Brasil, em 1989. Micha era o diretor do Mudra quando Anne Teresa seguiu as aulas sem, no entanto, concluir os estudos.

Acompanhando a tendência atual, Anne Teresa abriu-se a um preparo múltiplo e contemporâneo. Como Béjart, procurou um vocabulário singular a partir de seu próprio corpo. Ao regressar da temporada de estudos de dois anos nos Estados Unidos e criar o duo Fase, em parceria com Michèle Anne De Mey, igualmente uma ex-mudrista, Anne Teresa já era apontada como promotora da junção entre o movimento minimalista e a dança humana e visceral de Pina Bausch.

Se o Mudra foi um galpão adaptado, o prédio branco da Parts que continua em atividade é amplo, esparramado, com dois blocos ocupando um grande terreno, embora ambos tenham sido, primeiramente, entrepostos industriais. Algumas disposições seguem o princípio oriental do feng $s h u i^{264}$. Até mesmo a composição do código para abertura da porta de entrada não é aleatória, e o elo com os preceitos asiáticos não param por aí. A atenção à saúde é nítida. A cantina serve diariamente refeições macrobióticas, recomendando-se que se mastigue quarenta vezes antes de se engolir. A noção de energia resulta na prática de Shiatsu, do Zen, do aikido e da yoga, que se somam ao ensino do método Pilates. Como no Mudra, a jornada principia com uma sessão de yoga. Anne Teresa também estudou e pôs em prática, em algumas de suas coreografias, os preceitos dos números de ouro, servindo-se de seus postulados até para indicar que bailarinos se entenderão melhor entre si no processo de trabalho. Com proveniência egípcia, os números de ouro consideram o ser humano habitado por forças cósmicas, desenvolvendo-se de modo holístico. Atêm-se às proporções existentes na natureza, como a espiral. "Se a espiral é associada à vida, é porque ela procede por transformações. Ela transmuta continuamente as polaridades e as dimensões do movimento. $\mathrm{O}$ central e o periférico, o ascendente e o descendente, o anterior e o posterior aí se encadeiam sem cessar" 265 .

Os cursos funcionam em período integral - de segunda a sexta-feira das 8 horas às 18 horas, exigindo um amplo comprometimento por parte de cada aluno. A língua corrente, falada e escrita, não é nem o flamengo nem o francês, mas sim o inglês, tendo em vista a

\footnotetext{
${ }^{264} \mathrm{O}$ feng shui (vento e água) estuda a relação do homem com o meio ambiente. Arte milenar chinesa, observa as energias do céu e da terra, na forma das montanhas, dos vales e no fluxo dos ventos e das águas.

FUNDAMENTOS de Feng Shui. Portal Sociedade Taoísta do Brasil. $1^{\circ}$ maio 2017. Disponível em: http://sociedadetaoista.com.br/sp/fundamentos-de-feng-shui/. Acesso em: 3 ago. 2015.

${ }^{265}$ SUQUET, A. 2009, p. 523.
} 
ampla internacionalidade da instituição. A Parts é patrocinada pelo Ministério da Comunidade Flamenga e pela União Europeia. Diferentemente do Mudra, que era gratuito, essa escola cobra uma taxa de matrícula bastante salgada apenas uma vez, na admissão. Alguns alunos obtêm apoio de seus países de origem. Uma vez iniciados os cursos, alguns alunos poderão obter uma ajuda de custo da instituição para cobrir os custos de vida.

Durante os cinco primeiros anos, houve um ciclo de três anos de estudos. A partir do ano 2000, passou a haver dois ciclos de dois anos cada, o primeiro denominado Training (Treinamento) e o segundo dedicado à Research (Pesquisa), mais voltado à coreografia. Novas modificações curriculares estão previstas para o ano de 2017. O ciclo inicial contém várias disciplinas, cujo foco é a consciência física, as habilidades teatrais e musicais e a reflexão teórica, fundamentada em textos como, por exemplo, Genealogies of modernity (2001), redigido pelos professores Lieven De Cauter e Rudi Laermans a partir de teóricos e pensadores do movimento modernista. A tônica concentra-se na combinação de ballet e Release Technique. A prática do ballet é justificada devido à sua arquitetura e grande consistência. A Release Techinique expandiu-se na dança pós-moderna dos anos 1970, embora já nos anos 1930 tenha principiado pelos estudos em educação somática promovidos por Mabel Elsworth Todd e sistematizados por Barbara Clark e Joan Skinner com a denominação de Skinner Release Technique ${ }^{266}$.

Alternativa de trabalho corporal nos anos 1970, a proposta iniciada na American Contemporary Dance Co. em Seattle (Washington, EUA) expandiu-se por todo o mundo quarenta anos depois, tendo como princípio: o emprego de imagens - como mover-se na água permitindo que a imagem o mova; elementos psicológicos do crescimento do bebê - a posição fetal, o arrastar-se, o engatinhar, o rolar, dados estes também estudados pela Body-Mind Centering, abordagem desenvolvida por Bonnie Bainbridge Cohen; o ser humano habitado por fluxos energéticos em vez da ideia de dualidade entre corpo e mente; o movimento singular de cada um definido pelo inconsciente, importando a percepção e a experiência cinética subjetiva; o aprendizado do movimento segundo as leis físicas e o potencial da

\footnotetext{
${ }^{266}$ Release Technique. Disponível em: <http://www.contemporary-dance.org/release-technique.html>. Acesso em: 2 out. 2015.

Conforme exposto, conheci a nova via de trabalho corporal em Nova York, nos anos de 1991 e 1992, enquanto fellow da Guggenheim Foundation. Com Susan Klein, pratiquei o método a partir de The Bartenieff Fundamentals e Release Technique no Movement Research, especialmente com Vicky Shik. Essas aprendizagens orientaram-me na elaboração de meu trabalho corporal próprio, denominado Técnica Orgânica, que visa, igualmente, ao uso de pouco emprego de força muscular, resultando em uma maior fluência de movimentos.
} 
anatomia humana sem procurar modificações orientadas por critérios estéticos; o reconhecimento do sistema neurológico como tão importante quanto o sistema músculoesquelético na execução do movimento; a procura do alinhamento do corpo a partir do centro dos ossos e dos músculos que os envolvem, re-padronizando os fluxos de energia; a imobilidade na simétrica "posição de descanso construtivo", que alavanca novas experiências cinéticas e estimula o trabalho da improvisação e da criatividade.

A dança é concebida como uma experiência dinâmica e processual na qual aspectos inconscientes podem ocorrer. "Escuta" e "disponibilidade" são palavras-chave. Os dançarinos ficarão relaxados e os movimentos se tornarão flexíveis e de execução fácil. Essa direção de trabalho corporal poderá conduzir à consciência cinética ou foco na sensação física, a técnicas de meditação, às artes marciais, bem como a terapias corporais como a de Moshe Feldenkrais, ao Body-Mind Centering ou à Alexander Technique, entre outras. Alguns consideram que o aiki-dō teria servido de base à codificação da Release Technique.

A denominação "Release Technique" pode parecer incongruente, uma vez que a palavra "dança" - "tanz", em alemão - é tensão. Martha Graham erigiu sua técnica de dança moderna servindo-se do par contração/relaxamento. Após o longo período em que o aprendizado da dança deu-se por meio de um processo mimético, no qual o praticante apreendia e copiava padrões demonstrados pelo professor e, muitas vezes, machucava-se pelo emprego de um excessivo tônus muscular, a transferência de foco, dessa vez na soltura, foi uma decorrência coerente.

Improvisação e composição, com abordagens diversas, são praticadas, para que o aluno descubra o próprio corpo e seu potencial de movimentos. No segundo ano, a Contact Improvisation é ensinada, com o objetivo de promover a abertura ao parceiro. A composição promove a interface entre arte, ciência e filosofia e tem como pilares dois grandes coreógrafos norte-americanos. O primeiro, William Forsythe, estabelecido na Alemanha, cujo método de desconstrução e recombinação contém alguns dos objetivos visados pela Parts: uma dança conceitual, inteligente, filosófica. A coreógrafa Trisha Brown é a segunda referência, são assimilados extratos da coreografia Set and reset, de Trisha Brown, que agrega noções de estrutura, sistema, lógica, forma e diálogo com elementos plásticos.

Os ótimos professores da Parts procedem de países diversos. Um deles, o venezuelano David Zambrano, ensina uma técnica de dança contemporânea mais orgânica, referindo-se frequentemente em suas aulas à Mãe Terra. Tal técnica é denominada Flying-Low Dance Technique Improvisation. O título reitera a relação com o chão, a soltura da energia e as conexões do corpo, focado no esqueleto, com o ar, o ambiente e o outro gerando 
interconexões que atentam às leis físicas da coesão e expansão. As aulas de Chrysa Parkinson, dos EUA, são também notáveis de se destacar. A professora desenvolve um fino trabalho sobre a percepção, o tempo e tarefas físicas, podendo, às vezes, incluir textos às suas aulas. Chrysa se concentra também em questões como a gravidade, a tonicidade muscular e o olhar, um modo de olhar científico, mas sensível ao mesmo tempo.

O corpo docente não é fixo: nem todos permanecem durante todo o ano letivo e alguns poderão retornar ou não no ano seguinte. A grande diversidade de professores, todos de alto nível, nem sempre pode ser facilmente digerida pelos jovens alunos, pois esses não recebem um acompanhamento pessoal. Levando em conta os critérios seletivos rigorosos acrescidos a um alto grau de exigência, é requerida uma estrutura emocional forte de cada aluno, que deve estar igualmente apto à dinâmica de grupo, ao entrosamento, à adaptação. Há a presença de um coordenador. A escola tem, como um de seus objetivos, ajudar a desenvolver seus alunos como artistas independentes, ativos e criativos. Nada pode ser aleatório ou instintivo. Cada um tem que saber explicar o que faz, conceitualizar, o que nem sempre é fácil para os procedentes do Hemisfério Sul, geralmente mais espontâneos. Tal é o entendimento de Vânia Vaneau, admitida no ano 2000, quando contava com dezoito anos recém-completos, enquanto Cristian Duarte iniciou seus estudos no segundo ciclo da instituição, no mesmo ano, aos 27 anos de idade. Cristian enfatizou os aspectos de rigor, pressão, desafio e intercâmbio que encontrou na Parts. Inicialmente, apenas 25 estudantes eram aceitos, enquanto que, a partir do ano 2000, o número elevou-se a 45.

O reconhecimento da dança como uma arte não isolada, como produção de conhecimento, promove um diálogo curricular com outras disciplinas: o professor de ritmo do Mudra, Fernand Schirren, flamengo como Anne Teresa, concedeu-lhe um forte apoio institucional para que a escola fosse implantada e, ali, seguiu com seus cursos de ritmo até o final de sua vida, promovendo o elo entre o ritmo e a voz. Thierry De Mey, colaborador musical de Anne Teresa, oferece workshops acerca do diálogo entre dança e música. O conhecimento musical de Anne Teresa a faz desejar que os alunos possam decifrar uma partitura musical. Ela, que já foi adepta entusiasta do minimalismo quando, após uma estadia na New York University, coreografou, com a colega e ex-mudrista Michèle Anne De May, a coreografia Fase, com música de Steve Reich, que, juntamente com Philip Glass, foi um dos expoentes dessa vertente surgida na década de 1960 que partia de poucas notas musicais e empregava o princípio da repetição. Em Cesena, por exemplo, a coreógrafa alia tecidos 
polifônicos provenientes do século XIV ao "grande amor pelas potencialidades retóricas do corpo" ${ }^{267}$. Quanto ao teatro, seguindo a tendência contemporânea, aquele que é ensinado não é dramático. Os cursos de teoria são focados em sociologia e filosofia e têm o intuito de prover um aprofundamento nos estudos pessoais.

O fato de ter a Bélgica menos de duzentos anos faz com que o país esteja aberto a estrangeiros, acolhendo-os sem muita dificuldade, o que permite certa noção de pertencimento para quem vem de fora. Claro está que me refiro a artistas, e não aos imigrantes africanos, cujos países foram tão explorados pelos europeus no período neocolonial - no caso da Bélgica, a exploração se deu no território que foi chamado de Congo Belga, posteriormente Zaire e atual República Democrática do Congo. Certo é, porém, que o controle policial é menos rígido e reforçado que em outros países, como a vizinha França, face aos atentados que vêm ocorrendo nos últimos anos.

Coreógrafos renomados, provenientes da Bélgica ou não, são convidados a dar palestras, workshops ou coreografar para o grupo do segundo ciclo, como Meg Stuart, Wim Vandekeybus, Thomas Hauert ou integrantes da cia. Ballets C. de la B.

O estímulo à produção pessoal leva à organização dos student showings, apresentados nos estúdios da Parts duas vezes ao ano, quando a comunidade externa é convidada a assistir. Alguns trabalhos são selecionados e programados para apresentações na Bélgica e no exterior, em condições profissionais.

A palavra que melhor parece se ajustar ao trabalho de Anne Teresa De Keersmaeker é “estrutura", termo relacionado à ordem, disposição, organização. Da perspectiva filosófica, é “o conjunto de procedimentos de investigação, de descoberta, de exposição e de demonstração" 268 que assegura à obra sua coerência e lhe confere inteligibilidade. Para Aristóteles, “organon" significa "instrumento". Em De Keersmaeker, um conjunto orgânico que envolve o corpo mutativo, o movimento. Torna-se possível observar o modo como as coisas se constroem, o modo como se encontram arranjadas, arrumadas ou como as partes se articulam e se inter-relacionam. O método Forsythe aparece antes como desconstrução,

\footnotetext{
${ }^{267}$ Programa de Cesena, estreada em 2011, apresentada no Théâtre de la Ville de Paris de 10 a 19 de maio de 2012.

268 GOLDSCHMIDT, Victor. Remarques sur la Méthode Structurale en histoire de la Philosophie. In: LIBRAIRIE PHILOSOPHIQUE J. VRIN. Écrits. v. 2. Paris: Vrin, 1984. p. 246 apud MOURA, Carlos Alberto Ribeiro. História Stultitiae e História Sapientiae. p. 167. Disponível em: http://www.jcrisostomodesouza.ufba.br/Historia_Stultitiae_historia_Sapientiae.pdf. Acesso em: 22 set. 2016.
} 
estrutura que se compartimenta, desfazendo-se e refazendo-se, pensamento próximo do neoestruturalismo e da noção de fragmento.

\subsection{O Grupo Chandra (Théâtre de Recherche de Bruxelles)}

"Toda expressão artística verdadeira é uma manifestação de independência. Uma aspiração livre, uma recusa de compactuar, uma vontade vital,"269

Para marcar a diferença em relação à dança coreografada por Béjart, o novo grupo, egresso do Mudra, optou pela denominação "teatro", em vez de "dança": Teatro de Pesquisa de Bruxelas. Dos 25 alunos selecionados no primeiro ano, apenas oito chegaram até o final do terceiro ano. Destes, somente a colega canadense Louise Latreille preferiu regressar imediatamente ao seu país, onde fundou em Montréal a cia. Pointes et Pieds Nus, cujo título foi-me informado por Béjart com terna ironia. Os que aderiram foram: Alain Louafi, já mencionado e que reside em Lausane, na Suíça, onde é professor de Teatro no Conservatório local e atua especialmente em peças de K. Stockhausen; Christiane Glik, belga, já falecida, braço direito de Maguy Marin - foi sua assistente e bailarina; o malgache com nome interminável Mamy Raomeriarimanana, sempre energético e alto-astral; Pierre Droulers, que segue como coreógrafo em Bruxelas; Maguy Marin; e as duas brasileiras: Juliana Carneiro da Cunha e eu, Célia Gouvêa. Deixaram a cia. de Béjart para trabalhar conosco: Dominique Bagouet e Micha Van Hoecke. Este último era, então, marido de Maguy, e tornou-se o diretor do grupo. Micha, nascido Michel, tinha 28 anos à época, alguns anos a menos que nós.

A estreia do grupo Chandra ocorreu na cidade de Carpentras, localizada no sul da França, na região do Midi, nas proximidades de Avignon, onde foi apresentada, naquele ano, na Cour d'honneur du Palais des Papes, a peça $O$ cavaleiro solitário, de Jacques Audiberti, dirigida por Marcel Maréchal, um cruzamento entre as terras francesas de Languedoc com Bizâncio e Jerusalém. Constamos na programação do Festivals en Provence, no quadro do festival de Vaison-la-Romaine-Carpentras, um dos muitos festivais de verão da França. A primeira apresentação ocorreu no dia 14 de Julho de 1973, data emblemática da França em que se comemora a tomada e a queda da Bastilha na Revolução Francesa de 1789. O local era o pátio do antigo colégio Jean-Henri Fabre, dotado de arcadas ao fundo, renovado e adaptado

\footnotetext{
${ }^{269}$ DELEUZE, Gilles. A imagem-tempo. Tradução de Eloísa de Araújo Ribeiro. São Paulo: Brasiliense, 1990.
} p. 33 . 
como espaço cênico por Henri Soubeyran e Emile Noël e do qual se avistava a cúpula da velha capela da cidade.

O programa, composto por três coreografias, foi muito bem acolhido pelo público, formado por muitos estrangeiros ou visitantes ( $90 \%$ dos presentes) e pela crítica. O carro chefe do nosso repertório era $O$ teatro e os deuses, coreografia de Béjart, o que nos ajudou a vender espetáculos. A versão original, que reuniu as três primeiras promoções do Mudra, foi compactada para oito dançarinos. O texto continuou a ser dito em várias línguas. Além das maternas, formei com Maguy uma dupla inspirada no cabaré alemão, minuciosamente coreografada por Béjart, no qual dizíamos um extrato do texto de Artaud em alemão.

Béjart não nos cobrava direitos autorais, além de permitir que continuássemos a ensaiar nas dependências do Mudra. O programa impresso trazia pouca informação escrita e muitas fotos, de Claire Falcy. Vestíamos colants inteiriços pretos e os rapazes malhas bege. O texto-base era Os tarahumaras, de Antonin Artaud, citado como "o poeta incandescente, que marcou a primeira metade do século com suas estrelas de ossos fraturados" ${ }^{, 270}$. Sete cenas compunham o programa: Prólogo; "Ideia mágica"; "Gesto, movimento, ruído" (solo); "O vazio" (4 pessoas); “Teoria” (6 pessoas); "Idolatria” (2 pessoas); Epílogo (3 pessoas).

Completava o programa duas outras coreografias, ambas de Micha: o dueto com Maguy Marin Sequenza III, com música de Luciano Berio e voz de Cathy Berberian; e Discours, ou La vallée des songes, uma sucessão de imagens poéticas ligadas à infância de Micha Van Hoecke, nascido na Bélgica, mas cuja mãe era russa. Motivada pela poesia de Balmont e Tchitchipaef, construída em quadros curtos, a coreografia só perdia qualidade quando Micha permitia que seu humor resvalasse na anedota ou mesmo na paródia, ou quando sentimentos como tristeza, angústia e alegria tornavam-se explícitos, levando-me a conjecturar que não era por aí que se construía uma peça de dança. Kitsch e brega não se equivalem. O segundo pode ser um deleite emanado do autêntico popular. Quando feito por quem recebeu uma formação erudita, escorrega. O mesmo não ocorria em Sequenza III, no qual Maguy, vestindo collant inteiriço e sapatilhas de ponta, equilibrava-se em um só pé durante longos sete minutos, naquele dueto de um casal entediado. A escolha musical de Luciano Berio apontava para uma direção não psicológica, mas cirúrgica. Nos programas impressos, Micha e Béjart constavam não como coreógrafos, mas realizadores. Éramos acompanhados pela fotógrafa Claire Falcy.

\footnotetext{
${ }^{270}$ Programa da apresentação de estreia do grupo Chandra. Tradução nossa. Texto original: "Antonin Artaud, le poète incandescente, qui a marqué la première moitié du siècle de ses étoiles d'os brisés".
} 
Figura 29 - Grupo Chandra no espetáculo Le théâtre et les dieux, 1973

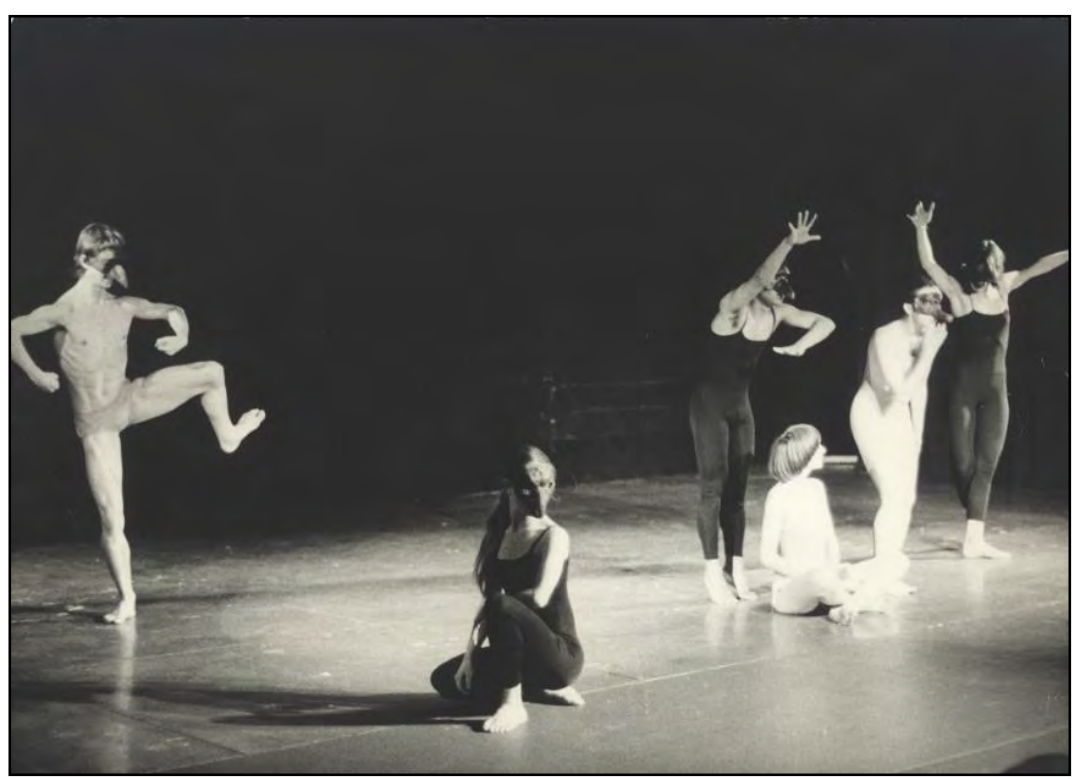

Dominique Bagouet, Célia Gouvêa, Mamy Raomeriarimanana, Maguy Marin, Christiane Glik e Juliana Carneiro da Cunha (da esq. p/ dir.). Théâtre de Recherche de Bruxelles, Bruxelas, Bélgica.

Fonte: arquivo pessoal. Fotógrafo não identificado.

Figura 30 - Cena de La vallée des songes, 1973
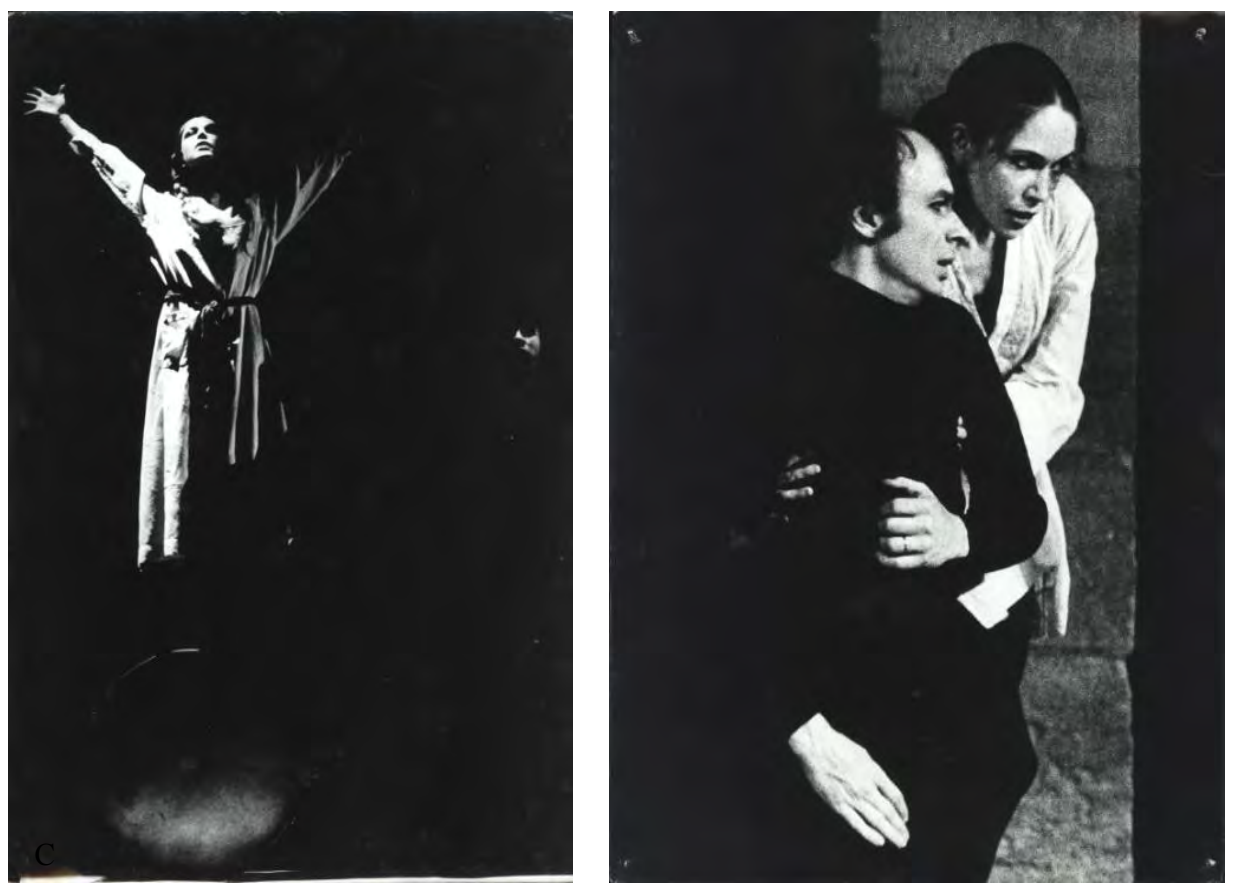

Célia Gouvêa e Micha Van Hoecke (imagem da direita).

Fonte: arquivo pessoal (ambas). Fotógrafo não identificado (foto da esquerda). Foto de Claire Falcy (foto da direita). 
O espetáculo foi recebido pelo crítico J. B. Grand, do jornal Le Provençal, como “de excepcional qualidade [...] uma surpreendente simbiose da voz, do gesto e do ritmo [...] que une a arte dramática e a arte coreográfica [...]. Músicos, cantores, atores, coreógrafos de imenso talento" ${ }^{271}$. De fato, eu tocava ao piano o repertório de Bach e Chopin, aprendido na infância e adolescência, "corretamente", segundo os críticos. Fomos levados a oferecer duas récitas suplementares. A simbiose entre voz, gesto e ritmo foi apontada, bem como a aliança entre música, palavra, canto e silêncio, com o sentido ritual e sagrado, em uma celebração mágica recheada pelo humor. Outro crítico do mesmo jornal, com as iniciais M. G., observou que aqueles corpos, sabiamente treinados na disciplina da dança, não apresentavam uma dança propriamente dita, pois "tudo o que é ruído é retomado, disciplinado, integrado e organizado, um pouco como na música concreta, mas com uma outra finalidade, a da expressão através do corpo" ${ }^{272}$. Original em sua concepção do balé, inteligente, atraente, sugestivo, potente, cativante, intenso, soberbo, de qualidade excepcional - que atores e que bailarinos! Outros consideraram estranho, insólito ou mesmo hermético, em uma referência às mensagens indecifráveis do deus Hermes. A plasticidade e beleza formal foram igualmente comentadas. Na linha de frente, o reconfortante humor.

No retorno a Bruxelas, um misto de alegria pela estreia do grupo e de contas a regrar. A contabilidade entre receitas e despesas de um grupo inovador, jovem e pobre. A proposta de Maguy para que aqueles que contavam com outra fonte de renda recebessem uma remuneração menor foi mal recebida por alguns, o que a aborreceu.

Na sequência, fomos a Londres. No dia 14 de outubro de 1973, no então maior palco da cidade, o Coliseum, para um público de cerca de 2 mil pessoas, apresentamos o mesmo programa da nossa estreia em Carpentras. A crítica impressa, saída no dia seguinte à estreia, foi a única que não conservei. O colega malgache Mamy Raomeriarimanana disse-me então que não tinha gostado do crítico dizer que Maguy era nossa star, pois o star system não fazia parte de nossos planos. No mês seguinte, em novembro, fizemos uma pequena temporada com cinco apresentações na pequena sala do Théâtre Royal de la Monnaie, em horário alternativo, às 18 horas. O programa era composto pelas coreografias Simurgh, de Alain

\footnotetext{
${ }^{271}$ GRAND, J. B. Carpentras: un extraorinaire spetacle avec le Théâtre de la Recherche de Bruxelles. Le Provençal, Carpentras, 17 jul. 1973. Tradução nossa. Texto original: "Ce spectacle fut d'une exceptionnelle qualité. [...] une étonnante symbiose de la voix, du geste et du rythme [...] qui unit l'art dramatique et l'art chorégraphique [...]. Musiciens, chanteurs, comédiens, chorégraphes à l'immense talent".

${ }^{272}$ GRAND, 1973. Tradução nossa. Texto original: "Tout ce qui est bruit est repris, discipliné, integré et organisé un peu comme dans la musique concrète, mais pour une finalité autre, cele de l'expression par le corps".
} 
Louafi (nascido em 1945) e, novamente, Discours, ou La vallée des songes, de Micha Van Hoecke. Nascido igualmente em 1945, Micha estabeleceu-se na Itália, tornando-se diretor do corpo de baile do Teatro da Ópera de Roma. Assemelhando-se a um clown triste, Micha foi um genuíno atuante e um grande salteador.

Adepto rigoroso do Islamismo, o colega franco-marroquino Alain, no período do Ramadan, jejuava durante todo o dia e somente às 18 horas principiava a alimentar-se, primeiro com castanhas. Na irrupção da primavera, a cada ano, Alain convocava todo o grupo a fazer, juntos, no andar térreo do Mudra, uma lavagem intestinal. Tomávamos um copo de água salgada com sal grosso, fazíamos uma série de exercícios, alguns dos quais, abaixados, pressionávamos cada joelho contra os órgãos do sistema digestivo. Íamos ao banheiro, descansávamos um pouco e repetíamos as séries, até a de número nove. Totalmente esvaziados, o único alimento propício naquele dia era um prato de arroz branco com muita manteiga, para lubrificar as paredes do estômago. Nos dias seguintes, experimentávamos um estado pleno de renovação. Alain era um professor nato, um aglutinador, pois the agradava partilhar seus saberes e suas experiências com os outros. O que poderia ser praticado individualmente, ele estendia aos demais.

Descrito por Béjart como "sombrio e áspero", Alain Louafi não dominava o balé clássico, mas ia muito a fundo em suas pesquisas vocais e de movimento. Béjart concedeu-lhe muitos papeis em seus balés, como o do Viajante em Golestan, cuja estreia ocorreu em Persépolis, também em 1973. Alain seguiu Béjart na Suíça, foi professor em Dakar, no Mudra-África, e ensinou Jogo Teatral na escola Rudra de 1992 a 1997. Professor no Conservatório de Teatro em Lausanne, na Suíça, Alain prossegue ensinando no Conservatório de Genebra. Sempre muito determinado, chegou no Mudra com a idade de 25 anos, quatro a mais da idade máxima exigida, 21 anos, posteriormente reduzida para 18. Ao chegar, afirmou à administração, segundo suas próprias palavras: “Agora já estou aqui, vocês terão que me admitir".

Ainda nos anos 1970, Alain certa vez apresentou-se ao compositor Karlheinz Stockhausen no final de um concerto afirmando querer trabalhar com ele. A parceria foi longeva, duradoura. Até hoje, mesmo após a morte do inovador músico alemão, Alain atua em Inori (Adoração), de Stockhausen, aquele que revolucionou a percepção do ritmo, da melodia, da harmonia e da polifonia por meio de uma aguçada escuta musical, que o levou à captação das ondas sinoidais. Em japonês, a palavra "inori” remete a "prece". No concerto para piano e orquestra, estreado em 1975, Alain serviu-se da mímica e da dança ao tratar signos religiosos. Participou também de Licht (ou Luz), igualmente de Stockhausen, de 1980. 
Alain dirigiu nossa colega Juliana Carneiro da Cunha no solo Possessión, estreado na Bélgica e apresentado no Brasil, quando a presença cênica da atriz-dançarina foi, como sempre, realçada, evidenciada.

A proposta de Alain, naquela segunda metade do ano de 1973, foi Simurgh, ou $A$ Conferência dos pássaros, de Fariduddine Attar. Conto sufi, a montagem buscava, antes, um estado de espírito, um clima, uma atmosfera, do que narrar a lenda, despregando-se da obra literária. A montagem era composta por sete estudos, próprios a toda civilização: a energia, o ritmo, o espaço que nos cerca, o encontro entre o Eu e o outro, a nostalgia, a luta e o voo, em uma viagem de imagens. Preferi as cenas iniciais, acerca dos vales que se atravessa na busca pelo conhecimento e da procura de se atingir um estado superior à estória do sábio muçulmano seduzido por uma moça cristã, quando há lastros de maniqueísmo. Imagens que se sucediam acalentadas por ritmos percussivos por meio da voz e de instrumentos, mais o tamborilar das mãos e dos pés.

A temporada belga com os oito dançatores de quatro nacionalidades recebeu comentários de críticos de vários jornais, tais como La Libre Belgique, La Cité, La Dernière Heure e Le Soir. Ao primeiro, Micha declarou, em 13 de novembro de 1973, a J. F., o propósito de ultrapassar o experimental, a pesquisa (termo esbanjado por nós), que associou ao intelectual, para que a escrita mudrista adquirida na formação pudesse atingir o público por meio dessa "realidade de comunicação" que é o teatro. A palavra "intelectual" era bastante demonizada no Mudra e no Chandra, e Béjart não tolerava tal postura. Meus estudos anteriores de filosofia fizeram com que certo comentário fosse assim tachado, quase equivalendo a uma condenação ao degredo. Na mesma entrevista, Micha alega não ser um teórico ao associar a busca de um teatro total aos japoneses $N \bar{o}$ e Kabuki, ao arrebentamento de todos os elementos que compõem um espetáculo: o canto, a dança, o teatro, mirando sempre o corpo como base de toda expressão e a dança como o meio mais adequado na promoção sagrada da união entre as artes. Quando fomos nos apresentar na Universidade de Louvain, Alain duvidou que os estudantes universitários pudessem apreender nossa proposta, por serem intelectuais. Nos tempos do Mudra, certa vez, Béjart chamou-me pejorativamente de "intelectual", como um xingamento, por um aparte dado durante uma conversa. Eu, que era então uma ex-estudante de filosofia. Apesar do pai professor de filosofia, um dos traços de Béjart era a valorização do instinto. Tenho hoje a convicção de que a teoria pode ser concebida e vivida de modo cinestésico, tendo por função aprofundar o conhecimento.

O papel de Micha enquanto diretor do Grupo Chandra era respeitado, embora não fôssemos muito obedientes e as demarcações hierárquicas fossem fluidas. Muitas outras 
avaliações impressas vieram a se somar acerca do grupo Chandra. O crítico P. Sajnau do jornal Le Soir fez uma observação importante: "Não se trata mais de representar, mas de viver e de exprimir, com todas as fibras de seu corpo" ${ }^{273}$. A fuga do discurso verbal explícito em prol de onomatopeias, gritos e ruídos desarticulados era igualmente notada, ora com estranheza, ora com aprovação, justificada pela busca de uma nova linguagem. Albert Burnet, do mesmo conservador jornal Le Soir, comparou os multidisciplinares criptogramas cênicos do Chandra - nos quais a dança ocupava o lugar principal, aliada, porém, a outras competências vocais, musicais e gestuais - a movimentos artísticos como Pop ${ }^{e c}$ art, Tachismo, Abstrato e Surrealismo. A limpidez e a harmonia seriam evitadas em favor do irreal e irracional, do en dedans, dos descadeiramentos, ainda que praticados por excelentes bailarinos convictos e que se levavam muito a sério. Há de se salientar o aspecto bem acabado, concebido e trabalhado e questionamentos sobre o lugar do verbo, do som, do silêncio.

Percorremos, ainda, países como a Suíça (Berna), França (Angoulème e Bordeaux) e Bélgica (Antuérpia e Bruxelas). Ao término das temporadas, no restante do tempo, permanecíamos em Bruxelas realizando novas pesquisas. Nem todas se transformaram em realizações cênicas, entre as quais Michaux, proposto por Micha Van Hoecke a partir do pintor e escritor belga Henri Michaux (1899-1945), cuja pintura feita de pingos e traços curtos sugeriu-me uma movimentação igualmente ágil e aguda com deslocamentos por todo o espaço da sala, desenvolvendo as qualidades que o professor de jogo teatral Fons Goris incentivava no meu trabalho coreográfico: as transições fortes e rápidas. Michaux, nascido na Bélgica, em Namur, faleceu em Paris. Em sua vida, transitou incessavelmente por inúmeros continentes. Esteve na Argentina, onde conheceu Jorge Luis Borges e, também, por seis meses no Brasil, no final dos anos 1930, especialmente em Minas Gerais e no Rio de Janeiro, onde se encontrou com intelectuais como Aníbal Machado e Murilo Mendes. Almejava o arrebatamento violento, uma espécie de fúria construtiva. $\mathrm{O}$ artista pluridisciplinar buscava, no texto, a sonoridade das palavras. Seus desenhos em nanquim foram fruto, em parte, de suas experiências com psicoativos como a mescalina. Ao longo de minha trajetória coreográfica, sempre quis retomar a temática Michaux.

\footnotetext{
${ }^{273}$ SAJNAU, P. Le Soir. Mudra a accouché de Chandra une troupe confiée a Micha Van Hoecke. 23 ago. 1973. Tradução nossa. Texto original: "Il ne s'agi plus de jouer. Il s'agit de vivre et d'exprimer, avec toutes les fibres de son corps". P. Sajnau. Le Soir, 23/08/1973.
} 
Figura 31 - Desenho de Henri Michaux

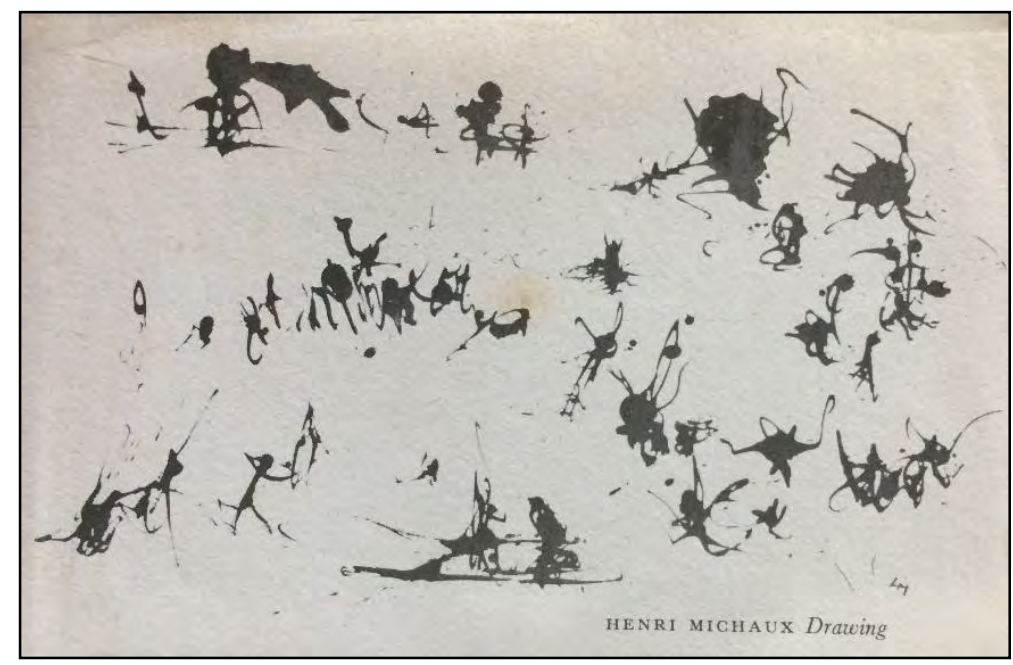

Fonte: READ, H. (1975)

Para a televisão, participamos da emissão Palavras em Liberdade (Les Mots em Liberté) para a Rádio e Televisão francesa (ORTF, na sigla em francês).

O colega Dominique Bagouet ainda não havia iniciado seu bem-sucedido percurso coreográfico. Propôs que eu fosse protagonista de uma dança cujo vocabulário era povoado por movimentos articulares e rápidos, que o coreógrafo tão bem desenvolveria em coreografias como Déserts d'amour (1984), Le crawl de Lucien (1985), Assaï (1986), Le Saut de l'ange (1987), So schnell (1990) e tantas outras. Foi após a realização de Déserts d'amour que Dominique passou a ser considerado, para Chantal Aubry, enquanto propositor de um estilo "barroco contemporâneo". O vocábulo lhe teria sido atribuído devido à junção de um lirismo imagético à pura abstração e devido ao diálogo estabelecido com outros artistas, plásticos ou compositores ${ }^{274}$.

Tratava-se de um pas de quatre a proposta chandrista, dirigida às quatro dançarinas do grupo. Considerada pela maioria de nós, chandristas, como demasiado calcada na dança e pouco dramatúrgica, a coreografia iniciada por Dominique não vingou. Não foi transposta à cena. Dominique era concernido pelas questões formais, o que o distanciava dos parâmetros chandristas. É claro que havia fricções entre os participantes do grupo Chandra, como a proposta coreográfica de um ser aceita e a de outro não, ou quando um encontrava movimentos ricos em uma improvisação e, ao menos naquele dia, o outro não. Segundo seu próprio relato, que me foi concedido quando de sua vinda ao Brasil, Dominique penou até ser

\footnotetext{
${ }^{274}$ AUBRY, Chantal. Les saisons de la danse, n. 326, p. 43, mar. 2000.
} 
aceito e reconhecido na França. Ao morrer precocemente, era tido na dança como um monsieur (um senhor), segundo as palavras de Maguy Marin. Como Maguy, Dominique foi propiciado e propulsionado pelo prêmio do concurso na cidade de Bagnolet, até estabelecer-se em Montpellier.

Com Maguy Marin, trabalhei um exercício cênico que teve como ponto de partida Ato sem palavras, de Samuel Beckett. Ainda uma vez, o texto funcionava como um motor, a propiciar jogos e atmosferas. Pode ter sido um passo para a explosão alcançada por Maguy sete anos depois, com May B, quando, no período de criação, encontrou-se com o escritor irlandês Beckett. Intitulada Caminhada I, a iniciativa foi retomada no programa de abertura do Teatro de Dança Galpão, quando prossegui na atuação da mulher e fui, então, dirigida por Maurice Vaneau. O vínculo com Micha foi o provável responsável pelo mergulho de Maguy na literatura russa. Gogol, por exemplo, inspirou-lhe a coreografia com a música "Contrastes para Três", do húngaro Béla Bartók, composição igualmente coreografada por mim em 1980, sem saber que Maguy a tinha escolhido para uma montagem na Hungria. Vaneau e Micha tornaram-se próximos. Havia afinidades pessoais e artísticas entre ambos. Micha foi convidado pela Ópera de Lyon para uma criação e realizou Eh, Johnny regarde! - mais uma incursão no gênero da comédia musical com narrativa bastante explícita. Convidou, para o papel do protagonista, Maurice Vaneau, de fato um excelente ator. Maguy e eu comparecemos à estreia em Lyon. Ela ainda não poderia supor que a cidade e seus arredores viriam a ser a sede de sua companhia e outros projetos artísticos durante muitos anos. Conduzi o jeep de Micha de Bruxelas a Paris. Uma distância de aproximadamente trezentos quilômetros percorridos em 5 horas.

Os colegas propunham uma ideia ou roteiro cujo desenvolvimento tinha a participação de todos. Os ensaios eram imediatamente práticos, isto é, não dispensávamos um tempo anterior para leituras ou maturações teóricas. Íamos direto ao ponto, ao assunto. Quanto aos figurinos, vestíamos, geralmente, collants inteiriços, que marcam o contorno do corpo, sem fantasia.

Naquele mesmo ano, o de 1973, na Alemanha, país fronteiriço à Bélgica, Pina Bausch acabava de assumir a direção do Wuppertaler Tanztheater, posteriormente renomeado Tanztheater Wuppertal, termo cunhado por seu mestre Kurt Jooss. Pina logo coreografaria sua versão de $A$ sagração da primavera, a emblemática partitura de Igor Stravinski que recebera, catorze anos antes, a versão igualmente arrebatadora de Maurice Béjart. Ao invés da celebração do amor bejartiana, Pina ateve-se ao libreto original acerca do sacrifício da eleita na irrupção da primavera. Pina iniciava seu processo de perscrutar a experiência de vida dos 
bailarinos e criar coreografias conjuntamente com o elenco, o que resultava em peças de dança tocantes por seu humanismo sutil, que se diferenciava do expressionismo dos predecessores alemães e que marcaria profundamente toda a dança mundial no último quartel do século XX, com propostas nas quais o singular era tornado coletivo, provocado pelo método de perguntar. Esse processo, a partir da interioridade, foi aos poucos se esgotando, quando Pina optou por fazer das cidades visitadas pela companhia a matéria de seus balés. É inquestionável que suas danças afetaram profundamente o psíquico-sensório de muita gente, motivo pelo qual ela foi sempre mais "querida" que Maguy.

Jean-Louis Barrault (1910-1994) cogitou convidar todo o grupo Chandra para trabalhar com ele em Paris. Barrault estava interessado em encenar Antonin Artaud. Segundo Béjart, Barrault queria que o coreógrafo remontasse La tentation de Saint-Antoine, realização conjunta entre Barrault e Béjart com texto de Gustave Flaubert e música do velho camarada de Béjart, Pierre Henry. Béjart, no entanto, não estava propenso a aceitar o convite. Em carta escrita aos meus pais, Herculano e Odete, em 20 de fevereiro 1974, após bem-sucedidas apresentações em Berna, na Suíça, quando retornamos seis vezes ao palco para recebermos os aplausos, narro a parada em Paris e o encontro com Barrault:

[...] apresentamos ao meio dia, num estúdio do Teatro dos Champs Elysés, o nosso espetáculo ao Jean-Louis Barrault, que ficou encantado, e tudo está em pé para irmos trabalhar com ele a partir de maio e apresentarmos nosso espetáculo ao mesmo tempo no teatro que ele está construindo frente ao Sena, na ex-Gare d'Orsay, que fomos conhecer. É um lugar extraordinário. O homem é incrível: tá com 63 anos e tem aquela vitalidade. Talvez vocês saibam: em 1968 ele abriu o teatro oficial que dirigia (o Odeon) para os estudantes ocuparem. Foi despedido. Partiu do zero: passou a fazer teatro num ringue de box e agora está emprestando dinheiro aqui e ali para construir um novo teatro na Gare d'Orsay, onde vamos trabalhar. Ele contou, ainda, que foi ele que lançou o frevo no Rio de Janeiro, em 1950, pois, até então, segundo ele, a modalidade só era dançada na Bahia (!). Até que a Bahia fica pertinho de Pernambuco, mas é como se eu dissesse que aprendi e lancei na cidade de Lyon, situada na região de Rhônes-Alpes, a farandola, proveniente da região da Provence, mais ao sul.

A possibilidade de sermos acolhidos por Barrault acabou se esvanecendo, em um momento em que o grupo necessitava de aportes fortes para prosseguir. Foi então que Béjart disse ao grupo que, considerando a forte personalidade de cada um, melhor faríamos em irmos cada um para o seu lado e formarmos nossos próprios grupos. Béjart estava também interessado em contratar Maguy Marin para o Ballet du XXème Siècle. Maguy relutou, pois era partidária ardorosa da tese da procura por uma via própria, mas acabou por entender que 
três anos passados na companhia de Béjart iriam consolidar sua carreira enquanto bailarina e que teria a possibilidade de amadurecer suas visualizações criativas. Estes foram os colegas que propuseram trabalhos cênicos a todos ou a alguns membros do grupo, montados ou não, além do diretor Micha Van Hoecke: Alain Louafi, Dominique Bagouet e Maguy Marin.

Pierre Droulers não fez nenhuma proposta criativa ao grupo, apesar de ter sido o colega mais acalentado pela direção e a maioria dos professores como talento criador promissor. Muitos anos depois da dissolução do grupo, um diálogo que me foi narrado por Maguy trouxe à tona componentes sociológicos da palavra "sucesso". Proveniente de família abastada, com o pai pintor, Pierre sustentou que, segundo seu pai, o sucesso era vulgar. Maguy discordou. Para ela, o sucesso era uma afirmação de si, o que é compreensível, sobretudo, para quem emerge de camadas pouco providas financeiramente. O fato, aparentemente corriqueiro, revela não só um conflito de classes sociais, como mostra que a competição comparecia, dava o ar de sua graça. Maguy, que, no ano de 2016, recebeu o relevante prêmio Lion d'Or em Veneza, alegou que, talvez devido à sua proveniência familiar operária, perseguia sim o sucesso.

Outro aspecto de Maguy foi a de nunca ter escrúpulos em se autocriticar. Quando vinha em turnês a São Paulo, invariavelmente reuníamo-nos uma noite em minha casa para longas conversas que podiam emendar-se até o horário do próximo embarque. Na primeira vez, já detentora de um sucesso mundial, ela disse, a propósito de May B: "Ao menos eu consegui uma” (“Au moins, j'ai réussi une!"). A segunda turnê paulistana, em 1994, foi ofuscada pela morte do piloto de Fórmula 1 Ayrton Senna (1960-1994), que teria levado o potencial público a um recolhimento. Enquanto a trupe Chandra durou, seguíamos praticando aulas nos estúdios do Mudra. Revezávamos no ensino. Ora um, ora outro de nós ensinava. Sempre muito disciplinada, Maguy guardava, em meu inseparável caderno, as anotações de uma barra no chão que havia aprendido ainda no Brasil, com Ruth Rachou, ótimo trabalho para a colocação e encaixe do corpo no chão, quando não há o conflito com a gravidade e a concentração dos processos internos intensifica-se. O colega Mamy era entusiasta daquela proposta de colocação do corpo na posição deitada, quando não é preciso lutar com a gravidade. Tal trabalho poderia ter sido benéfico a outros bailarinos, principalmente àqueles que, até ingressarem no Mudra, só tinham praticado o balé.

Antes de cada apresentação, costumávamos nos assoprar uma motivação. A proposta partiu de Juliana Carneiro da Cunha. "Hoje vou oferecer para uma determinada pessoa que se encontrará na plateia", costumava dizer-me: "Pensar na respiração, ou em ouvir a música, ou na relação com os parceiros”. No último dia de apresentação de uma peça, o mote costumava 
ser o de aproveitar, fazer a fundo cada movimento. Certo dia, o colega Alain disse querer fazer tudo mal feito, errar.

Figura 32 - Integrantes do grupo Chandra em Bruxelas, 1974

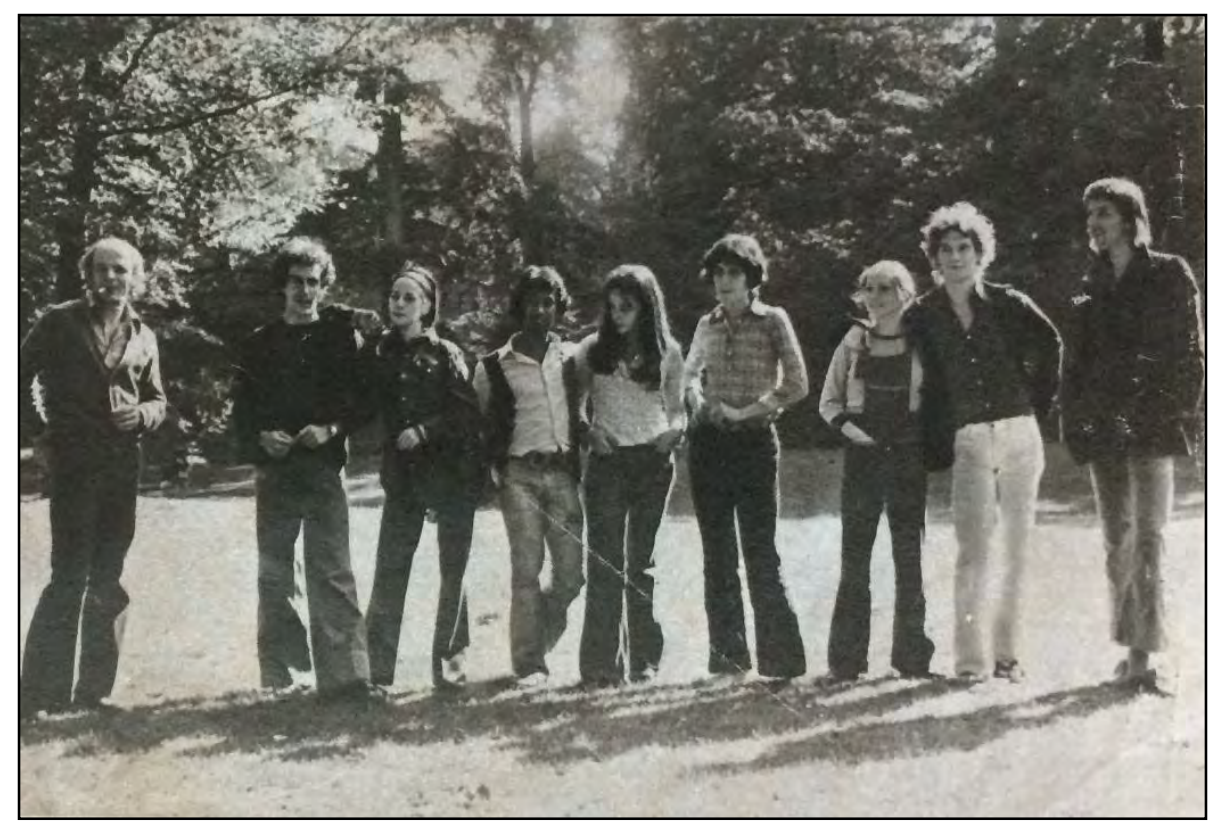

Fonte: Revista Beneluscope, 1974. Fotógrafo não identificado.

\section{Tempo de passagem: a "abaporização" da experiência europeia}

A palavra "abaporu" designa o homem que come gente, antropófago ou canibal. Provém do tupi-guarani e junta "aba" (homem), a "porá" (gente), mais "u" (comer). A icônica tela homônima de Tarsila do Amaral integra hoje o acervo do Museu de Arte Latino-Americana de Buenos Aires (ALBA). Marco do modernismo brasileiro, foi pintada em 1928. Oswald de Andrade, então marido de Tarsila, havia fomentado a ideia do movimento antropofágico, correspondente à deglutição da cultura estrangeira, incorporada à brasileira. O diretor teatral José Celso Martinez Corrêa afirmou ter comido o homem do Norte para alimentar o do Sul. Recentemente, em outubro de 2017 o Cirque Mondain, da Nova Guiné se apresentou em Paris. Sua proposta é a de pegar o circo feito pelos brancos e juntar com a África. O resultado não é nem o branco nem o africano, mas o "circo mundano" - traduzindo o nome do grupo - que impede muitos jovens de se lançar ao mar em direção à Europa ou de se matar.

Um acontecimento marcante para mim, naquele mesmo ano de 1973, foi o golpe de estado no Chile, que levou à morte não só do presidente socialista Salvador Allende, mas de milhares de chilenos. Extensão do golpe militar no Brasil em 1964, que implantou uma ditadura civil-militar que duraria 21 anos, o golpe chileno contou, igualmente, com a 
determinante interferência estadunidense na América Latina. Na França, naquele mesmo ano, por muito pouco o socialista François Mitterrand não venceu as eleições presidenciais. Conservei os resultados que anotei em 20 de maio de 1974: Mitterrand, 49,28\%; Valéry Giscard d'Estaing, 50,71 \%. Em Marseille, cidade com grande afluxo de imigrantes provenientes da África, Mitterrand ocupou a dianteira, com 56\%, enquanto Giscard d'Estaing obteve 43\% dos votos. Acompanhei os resultados das eleições em Paris, na Residence Maydieu, onde residia minha irmã, a jornalista e escritora Leila V. B. Gouvêa, que se encontrava, então, em Paris, realizando um estágio no jornal Le Monde.

A distância do país natal costuma aguçar uma visão mais lúcida e objetiva. O recuo proporciona reflexão, enquanto que a proximidade, entremeada por questões cotidianas, tende a normalizar questões anormais, conduzindo ao acostumar-se. O que é exceção tende a normatizar-se, delineando um estado bem diverso daquele quando se está fora. A nostalgia embute um sofrimento traumático, bem diferente daquele que se instala quando da proximidade, que tende a tornar tudo normal. Aos poucos, fui clareando um projeto de regresso ao País, após quatro anos na Bélgica, com o propósito de realizar um projeto cênico poético e político ao mesmo tempo. Comecei a escrever um roteiro intitulado "Procura-se", embrião de Caminhada. Conservo uma versão datilografada, datada de 13 de maio de 1974, Paris, com correções feitas à mão por minha irmã, Leila. Essa primeira versão confrontava a burguesia por meio dos seguintes personagens: uma cândida dupla de meninas gêmeas vestindo uniforme de escola primária, com saia pregueada escura, blusa branca com brasão da escola, meias soquetes, sapatinho e fitas brancas engomadas no cabelo; yogues; uma moça hippie; e um negro, inspirado pelo texto El asesinato de Malcom X, do dramaturgo uruguaio Hiber Conteris. Esse último personagem, recém-saído de uma penitenciária, considerada cultivo maior da criminalidade, encontra dificuldades para obter trabalho, observando que será melhor aceito e tratado com menor hostilidade pelas autoridades se optar por persistir no crime do que se quiser tornar-se alguém respeitável e ter uma vida digna, o que faz referência à estratificação social, que se opõe à reinserção.

É possível constatar que, em uma longa passagem de tempo, de quatro décadas ou mais, pouco ou nada mudou para melhor. O evidente conflito de classes, as observações quanto às revoluções - quer francesa, russa, chinesa ou africana -, sempre motivadas pela posse da terra, não vingaram, possivelmente por não constituírem matéria para dança. $\mathrm{O}$ propósito muito amplo, abarcando quase que toda a historia da humanidade, foi se afunilando, restaram referências ao cotidiano, como frases ditas por cobradores de ônibus, como "Um passinho à frente", por exemplo; obsessões rítmicas formadas por articulações, ditos e 
provérbios: "A boca fala do que o coração está cheio; rico ri à toa; comer e coçar é só começar; cara de quem comeu e não gostou"; palavras sem sentido semântico mas com boa sonoridade como "Tamararuadassu"; bem como ações que entediam, nauseiam, aborrecem.

Aproximei-me também, naquela primeira metade do ano de 1974, de um grupo de teatro na cidade de Antuérpia que tinha propósitos políticos e encenava, naquele momento, Mistero buffo, do poeta russo Vladimir Maïkovski (1893-1930). Entre as canções inseridas na peça, a mais relevante, no meu, entendimento foi a cantada por mulheres, "Au travail à la chaîne", referência ao trabalho em série, repetitivo, na fábrica, cuja compensação é a expectativa do encontro à noite com a pessoa amada. Quando o patrão oferece uma festa em homenagem à padroeira dos padeiros, a surpresa é encontrar, sob o prato, a fatura da belle fête $^{275}$. Entre os estímulos para a criação que se avizinhava, havia a atração pelo circo. Fui com Vaneau a uma apresentação dessa modalidade em Liège. Ele disse, então, que se era aquilo que eu queria fazer, ele estaria fora. A atmosfera circense só esteve presente em Trem fantasma, de 1979, confirmando a longa incubação necessária a muitas peças.

Indagada pela colega Juliana sobre o que faria caso o grupo terminasse, disse que queria passar um período lendo. Os principais autores que eu lia, à época, eram: Guimarães Rosa, João Cabral, Manoel Bandeira, Nietzsche, Bertolt Brecht, Pablo Neruda, Julien Beck e Antonin Artaud. O hábito de passar o dia inteiro atuando motivava a necessidade de agir, de fazer. Delineava uma perspectiva estética com base no circo, que pode ser lúdico, crítico, belo e fantástico ao mesmo tempo, e cheguei a redigir um manifesto-convocação dirigido a músicos, atores, dançarinos e produtores. Atraída por um repertório corporal composto por roulades (cambalhotas), saltos, estrelas, risos, considerava que, no circo, podia misturar-se tudo.

A primeira iniciativa concreta e individual foi a participação no evento La fête de mai, organizado pelo jornal Pour, com o propósito de estender as comemorações do dia $1^{\circ}$ de maio por todo o mês, reunindo atores, artistas circenses, cantores, músicos de folclore e do jazz e meu solo de dança, Vibrações, que estreava na ocasião, com música de Jacob do Bandolim.

\footnotetext{
${ }^{275} \mathrm{Au}$ travail à la chaîne/Nous attendons que vienne le soi/ Que le soir vienne/Et nos amours de même/Au travail à la chaîne/Nous attendons que viennent nous voir/ Pourvu qu'ils viènnent/Nos amoureux du soir/ Dans le soir nous ramènent/ En nous contant leurs peines du jour/ Toujours les mêmes/ Au travail à la chaîne/ Dans le soir nous ramènent/ Pour nous conter...mais c'est un détour/ Car ils ne viènnent/ Que pour nous faire 1'amour/ Pour fêter la patronne des boulangers/ notre patron a fait une belle fête/ Où il a invié ous les ouvriers/ Oh la belle fête qu'il a offert/ Fête parfaite, fête complète/ Et pour terminer cette belle fête/ Une cigarette par tête/ Et pour terminer cette belle fête/ Nous avons trouvé sous nore assiete/ La facturette de la bele fête/ Une facturette par tête.
} 
Ambientado em um capitel azul montado em terrenos ou praças equipados com som e luz, o evento foi montado em várias cidades belgas pelos habitantes locais, organizadores e pelos próprios artistas - todos os envolvidos, enfim. Competia, igualmente, à população local emprestar caminhões ou caminhonetes para o transporte. Todos os concernidos auxiliavam na montagem do capitel azul, dotado de 750 lugares sentados e de uma cena com dez metros de diâmetro que abrigaria funâmbulos, teatros de animação, cuspidores de fogo, músicos, cantores, mágicos e meu solo de dança. O solo, segundo minhas próprias anotações, era "simples, bonito e popular", ou seja, tinha uma fácil comunicação com a plateia. Básica era a construção de plataformas outras, a circulação da alegria, a aproximação com a vida, enquanto alternativas ao show business. Nos debates e avaliações posteriores, restaram os questionamentos quanto à participação dos espectadores, à quebra de barreira: o que é um trabalho político, próximo das pessoas? O que é uma festa popular?

Duas apresentações foram programadas em cada cidade, tais como Charleroi, Nivelles, Couvin, Huy, Bruxelas, Ghlin e Liège, às 20 horas. A primeira apresentação, no próprio dia $1^{\circ}$ de maio, foi em Bruxelas, na praça Lemmens, no bairro de Anderlecht, para perto de 2 mil pessoas. O jornal Pour visava ser um instrumento de consciência política e de apoio à luta, acrescentando, às questões políticas, a cultura, que arranca o indivíduo da alienação. Esse quesito contava com minha concordância, pois as restrições que fazia a certos projetos políticos eram quanto ao fato dos mesmos se restringirem às questões econômicas e não abarcarem outros aspectos da pessoa. Da trupe Chandra, o colega Alain Louafi foi o único a estar presente em uma das apresentações - a de Liège. Seu comentário foi o de que nunca tinha me visto envolver-me com tanta intensidade em uma peça de dança. Ele, que, anteriormente, comentara que é possível encontrar tranquilidade durante uma barra de balé, como era o caso de Maguy Marin, mas que esse não era meu caso, que encontrava a paz nas atividades de tocar piano e costurar.

Ainda ecoando os potentes sopros revolucionários ocorridos em maio de 1968 em Paris, o propósito do evento era distinguir-se do que o jornal parisiense Humanité, ou Huma, organizava anualmente em Paris, demasiado burguês segundo os editores de Pour, por contar com o patrocínio de empresas poderosas como a Coca Cola e a Renault. A intenção era a de promover uma festa autêntica, organizada de modo colaborativo por grupos operários, comitês de bairros, casas de cultura da juventude, estudantes e professores, propiciando encontros, apoiando e aliando-se às suas causas. O propósito não era o de oferecer um presente paternalista ou distrair a população pela oferta de um entretenimento embrutecedor, capaz de tornar mais suportável o trabalho nas fábricas, escolas e escritórios. O objetivo do projeto era o de 
incentivar bastiões de luta. Naquele momento, os operários reivindicavam que os trabalhadores imigrantes contassem com os mesmos direitos que os nascidos no lugar, os nativos.

Figura 33 - Evento A Festa de Maio, 1974
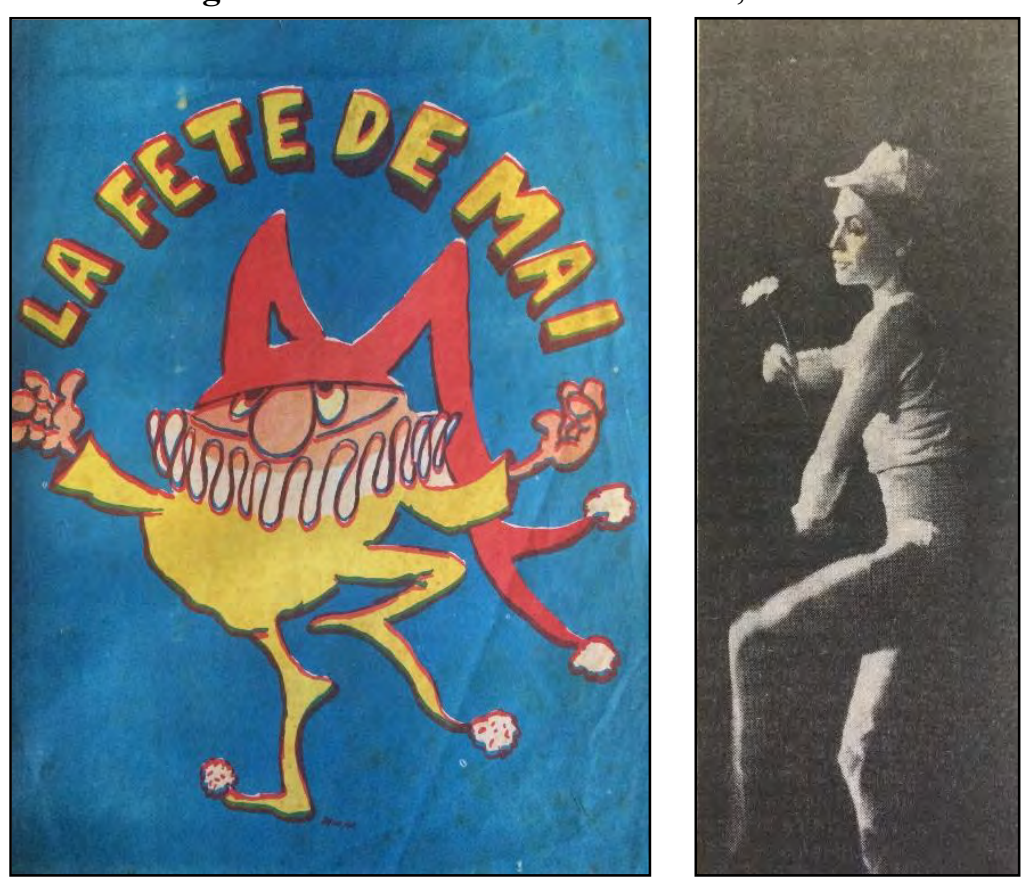

O evento foi realizado em um capitel em várias cidades belgas. Fonte: arquivo pessoal.

Pouco antes de voltar, encontrei-me casualmente com o professor de Ritmo no Mudra Fernand Schirren e fomos a um café no centro de Bruxelas, próximo ao Palais de Beaux-Arts. Tivemos, por vezes, uma relação de maior proximidade, como quando passamos em sua casa uma virada de ano e ele, um bom gourmet, serviu codornas. Naquele último encontro antes da minha volta ao Brasil, após quatro anos passados na Bélgica, disse a ele que o que me alegrava era o fato de não saber o que ia acontecer comigo a partir de então. Sua resposta, com seu forte sotaque flamengo, foi: "Eh bien, il y a des gens qui ont peur de ça" ("Bem, muita gente tem medo disso"). Sem o saber, estava prestes a iniciar um importante trabalho coreográfico, para cuja tarefa ignorava ainda minhas capacidades. Ainda no Mudra, Schirren me havia dito: "Tu cherches trop difficile" ("Você busca difícil demais"). O professor de Ritmo, que seguiu ensinando anos a fio no Mudra e, posteriormente na Parts, conservava uma rotina estrita, guardando o vigor pedagógico.

Lembrei-me de quando Stanislavski fechou-se em uma cabana em suas férias de verão para escrever seu método acerca do trabalho do ator, buscando a resposta à pergunta sobre como é possível o ator, a cada apresentação, encontrar o frescor criador, impressionado que ficara pela performance de Isadora Duncan. Penso que a questão se estende tanto ao trabalho 
do performer quanto ao do professor. O processo que ocorre é o mesmo. Voltei a encontrar (pela última vez) o professor Schirren somente no ano 2000, na escola Parts, quando lhe ofereci um agogô made in Brazil. Ainda em Bruxelas, na cantina do Mudra, disse a Béjart que regressaria ao Brasil. Ele perguntou-me o que iria fazer. Respondi que uma das possibilidades seria a de procurar, em São Paulo, grupos de teatro que estivessem experimentando novas linguagens. De fato, ao chegar, procurei o diretor Márcio Aurélio. Béjart levantou-se e saiu, sem nada dizer.

A volta ao Brasil foi adquirindo contornos mais precisos. Em São Paulo, meu companheiro Maurice Vaneau tinha um apartamento. Como havíamos acumulado muitas coisas naqueles anos bruxelenses e a casa da família Van den Bossche, onde vivíamos, havia sido vendida, optamos por pegar o navio que nos conduziria ao Brasil em Lisboa. Antes, fizemos, juntos, de carro, uma viagem de despedida a vários países europeus. $\mathrm{O}$ último e mais marcante destino foi Praga, na Tchecoslováquia. Minha volta ao Brasil foi precipitada, pois, no retorno a Bruxelas, recebi a notícia da morte inesperada de meu pai, o que ocasionou o meu retorno imediato ao Brasil, de avião, no início do mês de setembro de 1974. Maurice chegou no porto de Santos no final do mês, quando o esquema para a montagem já se encontrava parcialmente delineado.

Para engatar as atividades cênicas, pensei em procurar grupos já estabelecidos que investigassem novas linguagens teatrais e cheguei a contatar o então jovem diretor Márcio Aurélio, em início de carreira. O roteiro próprio foi adquirindo contornos mais nítidos, impondo-se o desejo de montá-lo. Ao desembarcar de navio no porto de Santos em outubro, quase um mês depois da minha volta, Maurice já tinha tomado várias providências para a montagem de Caminhada, projeto ao qual ele imediatamente aderiu. Tudo pronto para dar início à abaporização da longa experiência europeia. Estava a principiar o processo de realização de procedimentos próprios, em um viés político articulado a padrões artísticos investigativos cujos desdobramentos viriam a seguir. Esse pode ser considerado um tempo de liminaridade, de passagem, transição, nem cá nem lá. O concurso de circunstâncias favoráveis contribuiu para dar início a um fértil período à dança contemporânea brasileira.

Viríamos contribuir, dar o nosso recado a um caldo já existente e muito rico da cultura brasileira, da qual extrairíamos dois importantes contributos: o do ritual e o da festa.

\section{Antecedentes interlinguagens no Brasil}

Não foram poucos os antecedentes interlinguagens brasileiros, a começar pelo Carnaval, a festa por excelência, quando há canto, dança e ritmo conjugados. 
No Brasil, um dos maiores ícones culturais é a nascida portuguesa Carmem Miranda (1909-1955). Farei dela uma referência, por considerar tratar-se de alguém que compreendeu e trouxe um traço comum a muitas danças étnicas e eruditas também: a parte inferior do corpo conectada ao chão e a superior ao ar. Tornada mercadoria para atender à política de boavizinhança dos Estados Unidos para o seu quintal-Brasil, parece-me que Carmem teria se inspirado nas danças indianas em seus movimentos articulares dos braços e na movimentação contínua dos olhos, embora o fato nunca tenha sido investigado, muito menos confirmado, podendo tratar-se de coincidência. De fato, as danças indianas tornaram-se conhecidas no Ocidente apenas após a independência da Índia e a retirada do poder inglês do país asiático em 1967. O que foi próprio a Carmem Miranda também o foi na dança flamenca: os pés bem plantados no chão, com torso e braços flexíveis. A longeva ocupação árabe na península ibérica durou setecentos anos, entre os anos 700 e 1.400, quando, por exemplo, firmou-se o cante hondo. A dança árabe mantém, igualmente, os braços flexíveis, mas enfatiza os movimentos circulares da bacia. Há, porém, familiaridades entre todas - dança indiana, flamenca e árabe - na relação entre o chão e o ar. Os povos nômades, como os ciganos procedentes da Índia, ramificaram-se na Península Ibérica, especialmente na Adaluzia, que se evadiram desde o século IX. O fato de Carmem Miranda ter nascido em Portugal e vindo ainda criança ao Brasil talvez justifique a relação.

Por sua vez, o music-hall é especialidade norte-americana, embora oriundo da Inglaterra, modalidade na qual canto e dança são simultâneos. O gênero pode bem aclimatarse ao Brasil. Quando se fala em musical, imediatamente vem a imagem de um conjunto agrupado no centro do palco, sorridente e com os braços para cima, mas não é impossível pensar em possibilidades outras, que fujam aos clichês. Usualmente, as produções de musicais são caras e os ingressos idem. Em 1983, fui assistente, durante a fase das audições, do musical A chorus line, que reuniu um ótimo elenco egresso da dança, mesclando profissionais tarimbados e outros então principiantes, como Cláudia Raia. Ainda no lastro da fusão norteamericana, há o vaudeville: “Tendo surgido por volta de 1880 , o vaudeville designa, nos EUA, um gênero de espetáculo de variedades que mistura números heterogêneos: matracas, canto, dança clássica, teatro, mas também ventriloquismo, cães amestrados, etc." ${ }^{276}$.

Já outro gênero aparentado, o teatro de revista, proveniente de Portugal, havia se afirmado entre nós, com a tônica da ingênua malícia nacional e seu teatro do rebolado, com

\footnotetext{
${ }^{276}$ SUQUET, A., 2009. p. 509.
} 
nomes como Marly Marley e Virgínia Lane. O nome mais emblemático da vertente foi o da carioca Eros Volúsia, que buscava movimentos livres, apesar de ter estudado balé. A proveniência primeira do teatro de revista localiza-se na França, de onde se expandiu no final do século XIX. Como o nome diz, o teatro de revista juntava assuntos variados, retirados "da atualidade imediata (é frequente o seu texto ser quotidianamente alterado, para torná-lo mais aderente a essa actualidade)", estando presentes "a graça, a emoção, a jovialidade, a filosofia, o comentário oportuno, a fantasia transbordante, a espetaculosidade cênica"277.

O gênero, que se expandiu no Brasil desde 1957, era muito apreciado pelo presidente Getúlio Vargas (1882-1954) quando a sede do governo federal estava localizada no Palácio do Catete, na cidade do Rio de Janeiro, sede de shows e cassinos, especialmente o da Urca. Cenógrafos renomados interessavam-se pelo gênero, como Gianni Rato, que, em 1957, participou de É de Xurupito!, teatro de revista de Walter Pinto. A palavra "xurupito" remete a charme, atração. Não raro, as revistas eram machistas e reacionárias, com a figura da mulher cumprindo o estereotipado papel de objeto sedutor, enquanto as coreografias, destinadas a enfeitar as cenas, eram extremamente pobres. A dança enquanto enfeite vigorou, aliás, por muito tempo. Gêneros dedicados ao entretenimento são organizados por cenas destinadas a agradar ao público, e a maior parte delas é regrada em posição frontal, face à plateia.

Inseridos no tempo de guerra, imersos nas questões sociais, os cabarés alemães possuíam outras qualidades, bem diversas. Surgidos em tempos de crise com a finalidade de aliviar a tensão e rir em tempos de guerra por meio do comentário de fatos reais, resultaram em movimentos artísticos como o dadaísmo. Este, surgido em Zurique, na Suíça, em 1916, em pleno período de Primeira Guerra mundial, teve Tristan Tzara como um de seus expoentes e recolhia materiais ordinários do cotidiano para desenvolver suas propostas, podendo ser colocado no rol do teatro total.

No Brasil, nos anos 1970 o grupo Dzi Croquetes, liderado pelo bailarino e coreógrafo norte-americano Lennie Dale, apresentou uma proposta debochada, despudorada e inovadora, em pleno período de ditadura. Neste ano de 2017, voltaram a se apresentar com uma nova versão, confirmando a tendência atual ao chamado movimento de re-enactement (reatualização) de uma peça, expressão hoje muito difundida, tornando a obra em questão

\footnotetext{
${ }^{277}$ REBELLO, Luiz Francisco. História do Teatro de Revista em Portugal. v. 1. Lisboa: Publicações Dom Quixote, 1984.p. 37, 121.
} 
volátil e porosa ao tempo presente. A referida versão, no entanto, não obteve o mesmo impacto que a anterior.

Chacrinha e outras figuras sarcásticas podem dar margem a uma investigação kitsch, mas, invariavelmente, a composição cênica dos musicais costuma ser simétrica e pouco inovadora. Investigar novos modelos de musical no século XXI pode promover um rico filão. São inúmeros os ancestrais das interlinguagens artísticas. O circo pode ser considerado o seu tataravô. O termo "circo" surgiu em Roma, designando os teatros ovais. Entre os séculos VIII e IV a.C., já há o registro, na China, de hábeis malabaristasguerreiros. Entre o Egito e a China, houve domesticação de animais, acrobacia, malabarismo e jogos inseridos em rituais. Os bufões e bobos da corte resultaram nos palhaços. O circo é organizado em números distintos. Não se pode dizer que há fusão de linguagens, mas sim o sentido do risco e do maravilhoso, atendendo às necessidades humanas de viver emoções fortes, perigosas, e imergir na fantasia, escape para a mesmice do dia a dia. Destaca-se, também, a importância do circo-teatro, surgido no início do século XX, que se manteve até os anos 1960 enquanto modalidade corrente. O circo atual, contemporâneo, é poético e visual, mas antes tecnológico que popular. Lembrando que, para Renato Ortiz, popular é aquilo que se vende, não o que é feito ou dirigido pelo e para o povo. Ortiz dirá que "no caso da moderna sociedade brasileira, popular se reveste de um outro significado, e se identifica ao que é mais consumido" 278 .

Cacá Rosset, o diretor do Teatro do Ornitorrinco, que iniciou seus trabalhos em um porão do Teatro Ruth Escobar, apontou a emergência de grupos de teatro na segunda metade da década de 1970, caracterizados por ideias e pensamentos e pela busca de uma linguagem "underground como resposta a um teatro opaco"279. Posso citar ainda: Elke Maravilha kitsch, extroversão, brega é brilho, membro do júri no programa do Chacrinha; Hamilton Vaz Pereira e o grupo Asdrúbal trouxe o Trombone - que reuniu nomes expressivos de modernos comediantes, como Regina Casé e Luiz Fernando Guimarães -, conhecidos como desconstrutores da dramaturgia tradicional; e outros grupos axiais: o dirigido por Naum Alves de Souza e Pod Minoga e o já citado Grupo Sonda, de Maria Esther Stokler e José Agripino de Paula. O que teria provocado tão significativa passagem?

Entre outras afinidades interlinguagens mais recentes, há os nomes de Fernando Lee e o núcleo Omstrab; e de Sérgio Rocha e a quase totalidade dos construtores da dança

\footnotetext{
278 ORTIZ, Renato. A moderna tradição brasileira. São Paulo: Brasiliense, 1988. p. 164.

${ }^{279}$ METRÓPOLIS. São Paulo: Rádio Cultura FM. Apresentado por Cacá Rosset. 8 ago. 2017.
} 
contemporânea brasileira. É aí onde me situo, acrescentando o "estar atento à respiração". Trata-se ainda de um logos, um cogito encarnado.

Esse foi nosso sopro, nossa brisa, nossa aragem, nossa vibração, nosso legado, somado ao que já tinha sido plantado no campo da Dança por personalidades como Renée Gumiel, Maria Duschenes, Ruth Rachou, Marika Gidali e tantos outros. 


\section{GALPÃO, A OUSADIA (1974-1981)}

Tendo em vista um tal procurar, todo criar é um haurir, como procurar a água da fonte. Martin Heidegger ${ }^{280}$

\subsection{O ambiente}

Meados dos anos 1970: tempo de passagem. Novas imbricações entre arte e vida. Coreografias expandidas. Qual foi o eixo dos anos setenta? Tempo de interstícios, de imbricação entre o modernismo, que vigorou desde os anos 1870, aproximadamente, até a transmutação em contemporâneo ou pós-modernismo, cerca de cem anos depois. Se o primeiro caracterizou-se pela ênfase no sujeito, foi atravessado por variadas colorações. Entre os muitos "ismos" que comportou, houve interações com o entorno - como no dadaísmo dos anos 1920 -, em parte devido aos lastros provocados pela Primeira Guerra Mundial (19141918). Ainda que guardássemos preceitos modernistas como o da invenção estética, encontrávamos, igualmente, imbuídos pelo propósito de tornarmo-nos partícipes da realidade apresentada. "Pré-pós-modernismo". Agonia das vanguardas tardias. O olhar para fora é aguçado, marca da arte contemporânea.

Minha chegada ao Brasil, em 1974, marcava uma outra fase, distinta da europeia: a de conexão com o real. Era chegado o momento de dar início ao procedimento interlinguagens, de promover o entrelaçamento polifônico. A hora do deslocamento, do desembarque, da aclimatação, do carregamento e da colocação de questões que conduziriam a outro modo de se pensar e organizar a dança, no qual há perpassamentos, com o livre trânsito entre dança, palavra, música e elementos visuais, ainda que a dança predominasse, com a particularidade de estar permeada por outras linguagens. Não sabia que o processo que iria iniciar seria histórico. Não estava consciente, tampouco, que aquele era um tempo de entroncamento entre as vanguardas modernistas tardias e o pós-modernismo e/ou o contemporâneo.

O endereço era a Rua dos "Inglezes" (nome inicialmente grafado com "z"), número 209, no predominantemente italiano Bairro do Bixiga. O nome do bairro adveio de uma crise

\footnotetext{
${ }^{280}$ HEIDEGGER, Martin. A origem da obra de arte. Tradução de Idalina Azevedo e Manuel Antônio de Castro. São Paulo: Edições 70, 2010. p. 193.
} 
da doença homônima constatada no princípio do século XX. Oficialmente, o bairro se chama Bela Vista, devido à interdição para construir edifícios elevados nas encostas, com o propósito de tornar possível avistar, ao longe, até os bairros do Brás e da Mooca. O próprio Teatro Galpão foi um "puxadinho", segundo Sérgio Mamberti, habitante da Rua dos Ingleses desde 1967, em uma casa alugada, na qual acolheu atores agredidos pelo Comando de Caça aos Comunistas na peça Roda viva, de 1968. Sérgio mudou-se para uma casa própria na mesma rua, no número 381, em 1970, segundo relato que me foi fornecido pelo ator em 19 de março de 2017.

Foi ali, no $n^{\circ} 209$, que ocorreu uma "borbulhante" guinada nos parâmetros da dança praticada em São Paulo. Lá, iniciei o procedimento interlinguagens, quando dança, palavra, música e elementos visuais encontram-se atravessados, ainda que a dança predomine. Foi um período de confluências, palavra que principia pelo relacional prefixo "con". Ditadura X contracultura. Em ambas, a presença do corpo. O corpo protagonista, lembrando, que onde há agon, há agonia. Período não apenas de passagens, mas de limiares, interstícios. Necessidade de escapes libertários. Do Teatro Galpão, enquanto teatro de dança, emerge o elo entre sociedade e investigação de linguagem (constatação que será desenvolvida em tópico mais adiante: “A aliança entre conexão política e investigação estética”).

Um terreno em declive. À frente, um hospital e a decorrente interdição para atividades ruidosas em seu entorno. Mas a atriz e empresária Ruth Escobar (1936-2017) tudo podia. Nascida em Portugal, na cidade do Porto, veio para o Brasil em 1951. Com a cooperação da comunidade portuguesa e do então governador Adhemar de Barros, pôde construir seu complexo teatral, composto por três salas de espetáculos: muitos degraus abaixo do nível do chão, a Sala Gil Vicente (1470-1536), evocando o poeta e dramaturgo português, um dos fundadores do teatro português; acima, a Sala do Meio. No andar térreo, finalmente, o Galpão, cujas portas davam para a rua.

Foi também ali, na Sala Galpão, que Maurice Vaneau encenou em 1968 sua versão da peça Lisístrata, de Aristófanes (448-388 a. C). É sabido que as mulheres atenienses já não queriam mais ter filhos, pois geravam soldados que, muito provavelmente, iriam morrer na guerra que Atenas travava contra Esparta. Como recurso cênico, Vaneau colocou, no sexo masculino dos atores, uma torneira, que era fechada pelas mulheres atrizes. A concepção de Vaneau, que associava o texto pacifista ao ideário hippie, contou com a aprovação do importante crítico de teatro Décio de Almeida Prado, que escrevia no jornal O Estado de São Paulo. Anatol Rosenfeld (1912-1973), intelectual do teatro, registrou igualmente seu parecer: "Maurice Vaneau, em Lisístrata, não poupou o realce ao elemento fálico da comédia grega, 
frisando-o, aliás, corretamente" ${ }^{, 281}$. Ainda um outro comentário constou do livro de Zuenir Ventura 1968: $O$ ano que não terminou:

Em tradução de Millôr Fernandes e com Ruth Escobar no papel principal, a montagem de São Paulo fora modernizada pelo diretor Maurice Vaneau com alguns toques da estética hippie e pop, o que dava à obra a atualidade de uma ilustração para o slogan pacifista da moda: "Faça amor, não faça guerra" 282 .

Data igualmente de 1968 a montagem, na Sala Galpão, de Roda viva, com texto de Chico Buarque de Holanda, direção de José Celso Martinez Corrêa e atuação, entre outros, de Marília Pêra. Ao final de uma das apresentações, os camarins foram invadidos por membros do Comando de Caça aos Comunistas - que, poucos meses depois, voltariam a marcar presença no acontecimento conhecido como "A Batalha da Maria Antônia", no início do mês de outubro. O CCC, sigla ironizada por alguns como "Co-Ca Cola", era, de fato, uma organização paramilitar. A relativa liberdade artística existente desde o golpe civil-militar de 1964 foi estancada em dezembro de 1968 com a decretação do Ato Institucional $\mathrm{n}^{\circ} 5$ pelo presidente General Costa e Silva.

Um ciclo de sete anos foi o que durou o marco incontestável no desenvolvimento da dança contemporânea de São Paulo, que foi irradiada a todo o Brasil. O Teatro de Dança Galpão foi transferido ao Teatro Brasileiro de Comédia (o TBC) no ano de 1979, por motivos de reforma, segundo alguns, ou pelo término do contrato entre a Secretaria Estadual de Cultura e a atriz-empresária Ruth Escobar, segundo outros. A casa na Rua dos "Inglezes" foi a primeira casa exclusivamente dedicada à dança na cidade de São Paulo e inaugurou um tempo de reivindicações de uma política pública da dança por parte do Estado.

Caminhada (1974) e De pernas para o ar (1981), ambas dirigidas por mim e por Maurice Vaneau, abriram e fecharam a casa, respectivamente. As montagens passaram a ser registradas em vídeo somente a partir de meados de 1981 em diante, o que justifica o relato descritivo que farei de certo número de coreografias. Em 1986, Vaneau, alocado na Secretaria de Estado da Cultura enquanto assessor cultural durante a gestão de Jorge Cunha Lima, então Secretário da Cultura, organizou o Festival Dos Pés à Cabeça, com uma programação que abrangia espetáculos, palestras, debates e projeções de vídeo nas duas salas do Teatro Sérgio Cardoso, além de aulas práticas e teóricas e oficinas no Teatro Galpão. A atividade

\footnotetext{
${ }^{281}$ ROSENFELD, Anatol. A arte do Teatro. São Paulo: Publifolha, 2009. p. 64.

${ }^{282}$ VENTURA, Zuenir. 1968: o ano que não terminou. 16. ed. Rio de Janeiro: Nova Fronteira, 1988. p. 193.
} 
extemporânea constituiu um revival do que havia ocorrido no Galpão na década anterior e atraiu um grande número de artistas de dança com formações diversas - inclusive, muitos dançarinos do Balé da Cidade. O ciclo de sete anos aqui tratado será entremeado pela experiência que realizei nos Estados Unidos, entre 1976 e 1978.

A realização de uma montagem imediata ao voltar ao Brasil depois de uma longa estada europeia era uma urgência, uma necessidade. Precisava de um espaço para realizar a proposta, quando soube que a Comissão de Dança da Secretaria de Estado da Cultura - então denominada Secretaria de Estado da Cultura, Ciência e Tecnologia - alugava, há seis meses, um teatro destinado à dança. Entretanto, até então, grupo nenhum quisera apresentar-se ali. Criticavam a precariedade do local. Contatei Marilena Ansaldi, então à frente da Comissão de Dança, fui visitar o teatro e disse de imediato: "É aqui mesmo que vamos realizar nosso trabalho".

O ano inicial das atividades regulares no Galpão enquanto Teatro de Dança foi 1975 , ano que correspondeu ao assassinato do jornalista Vladimir Herzog (1937-1975) em São Paulo, no mês de Outubro, nas dependências do DOI-CODI ${ }^{283}$, fato que levou o então Secretário de Estado da Cultura, o empresário e bibliófilo José Mindlin (1914-2010), a se demitir. Ele, que desenvolvera um bom entendimento com Maurice Vaneau nos assuntos ligados à dança. Mindlin foi substituído por outro empresário, Max Feffer, na então Secretaria de Estado da Cultura, Ciência e Tecnologia. Em uma escalada demolidora, Mindlin afirmou que o objetivo dos responsáveis pelas forças de repressão era o de atingir Herzog para chegar a ele, Mindlin, para, em seguida, derrubar o governador Paulo Egydio Martins ${ }^{284}$.

O ano de 1975 trouxe também lastros em um outro viés, pois a Organização das Nações Unidas (ONU) o elegeu como o Ano Internacional da Mulher, quando muitas deixaram de depilar-se e queimaram seus sutiãs. Surgiram slogans como "Quem ama não mata", que ecoou no Brasil em resposta ao assassinato da socialite Ângela Diniz, muito difundido pela mídia. Estive em Nova York pela primeira vez no ano seguinte, em 1976, e o slogan que mais ouvi foi: "A mulher precisa do homem como o peixe da bicicleta".

O contexto político incluiu, ainda naquele ano, o fim da guerra do Vietnã (1963-1975), já televisionada. No mesmo ano, Angola e Moçambique tornaram-se independentes de

\footnotetext{
${ }^{283}$ DOI-CODI, ou Departamento de Operação de Informações do Centro de Operações de Defesa Interna, era o órgão repressor subordinado ao Exército brasileiro destinado a prender e torturar os oponentes ao regime militar durante a ditadura (1964-1985).

${ }^{284}$ VLADO: 30 anos depois. Direção: João Batista de Andrade. São Paulo: Oeste Filmes Brasileiros; Tao Produções Artísticas, 2006. Exibido no Canal Curta em 18 de setembro de 2017.
} 
Portugal. No Brasil, em 1974, o general Ernesto Geisel assumira a presidência, apoiado por outro general, Golbery do Couto e Silva, em substituição a Emílio Garrastazu Médici, que instaurara o mais sombrio tempo de endurecimento da ditadura civil-militar. Geisel prometia uma abertura lenta e gradual.

A minha volta ao Brasil coincidiu com a Operação Condor, que envolveu o Brasil, a Argentina, a Bolívia e o Uruguai - este, com seus militantes, os montoneros. Houve 300 mil mortos na Argentina, o que equivaleria a uma quantia duas vezes superior à do Brasil. Guardadas as proporções, chegaríamos, aqui, a 150 mil pessoas mortas, segundo o jornalista Franklin Marins.

Década de 1970: recrudescimento em relação à libertária década anterior? Interstício entre o aparecimento da pílula anticoncepcional nos anos 1960, nos EUA, e o surgimento da Aids no início da década de 1980? Certamente, imbricação entre impulsos libertários e amordaçamentos. A euforia vinha se esparramando desde os anos 1950. O ambiente no Brasil era o dos chamados "anos dourados", dos quais a Bossa Nova (1958-1963) é um exemplo. Com Vinícius de Moraes e Tom Jobim, “a BN era um modo de dizer o que o país tinha de melhor e a confirmação de sua viabilidade um Brasil moderno, cosmopolita, sofisticado, belo, livre"285. Intimista, com toques do jazz estadunidense, naquele tempo de tomada de posições, a bossa nova foi suplantada ou ao menos contestada pela música popular brasileira, a MPB, que desviava o olhar interno aos morros e à realidade social do País. Seus apoiadores protestaram face à introdução de instrumentos eletrônicos nos festivais de música da TV Record. Se Caetano Veloso, atento ao pop norte-americano, muito contribuiu para o surgimento do tropicalismo na música - termo que provém do título de uma obra de Hélio Oiticica e que designa o movimento que, em 2017, completou cinquenta anos de existência -, "Domingo no parque", de Gilberto Gil, apesar de incluir em sua música instrumentos eletrônicos tocados pelo conjunto Os Mutantes, manteve uma narrativa linear no que se refere à letra da canção. Havia ainda uma terceira vertente: a música da Jovem Guarda, com Roberto Carlos e o "Tremendão", Erasmo Carlos, revivida em 2017 pela cantora Wanderléa no musical que tem o sugestivo título de 60! Década de arromba.

Juscelino Kubitschek, cujo governo, de 1955 a 1960, estabeleceu o plano de metas e o desenvolvimentismo, propôs realizar "cinquenta anos em cinco". A inauguração de Brasília em 21 de abril de 1960, três anos após o início das obras da nova capital do Brasil, foi um

${ }^{285}$ SCHWARCZ, Lilia; STARLING, Heloisa. Brasil: uma biografia. São Paulo: Cia. das letras, 2015. p. 422. 
marco daquele período, ainda que o deslocamento da capital federal rumo ao oeste e a construção da cidade planejada não tenham sido unânimes, restando controversa a ousada iniciativa do sorridente presidente $\mathrm{JK}$, pois o centro do poder isolava-se, tornando-se quase imune ao contato cidadão possível no Rio de Janeiro. JK teve a sorte de comemorar a conquista, pelo Brasil, da Copa do Mundo de Futebol de 1958, na Suécia, primeira Copa conquistada pela seleção nacional. Coube a João Goulart festejar a segunda conquista, quatro anos depois, no Chile.

A aura em torno da década de 1960 compreendeu o modelo comportamental e estilo de vida estadunidense, o American way of life, que acendeu o desejo e o acesso aos bens de consumo. Inerente ao capitalismo, esse estilo nada carregava da proposta de uma melhor qualidade de vida, a não ser para quem entende que uma boa qualidade de vida implica no usufruto de mercadorias. Estabelecia-se, assim, a ligação entre consumo e felicidade, naquela que foi a era de ouro do marketing e da publicidade e que marcou a ascensão plena do capitalismo. Qualidade de vida carrega, no bojo, um movimento em direção à polis, ao público, à alteridade, ao coletivo, diferentemente da satisfação individual.

A década de 1950 teve, logo em seu início, acontecimentos como a inauguração da primeira Bienal de Artes em São Paulo, em 1951. Findou com a vitória da Revolução Cubana em 1959, ápice do marco utópico modernista capaz de mudar o mundo. As vanguardas, políticas e artísticas, herdeiras do romantismo, tinham como preceito o novo, o original, o pessoal, o genial, a invenção, o fervor. À contracultura iniciada com os beatniks, seguiram-se os Black Powers e os hippies e a oposição "flor contra fuzil". A reação de embate e oposição ao poder constituído principiou logo após a Segunda Guerra Mundial, em 1945, e durou até 1989, com a queda do muro de Berlim, tendo atravessado a Guerra Fria com obras como On the road (ou Pé na estrada) e Hearts \& minds: babyboom, sobre a Guerra do Vietnã, contestada nesse título pelos "fillhos da guerra". Nos anos sessenta, proliferou-se, de fato, o que veio a ser denominado como "arte contemporânea".

No Brasil, o modernismo (ou os modernismos?), que tem, no País, sua inauguração atribuída à Semana de Arte Moderna de 1922, realizada no Theatro Municipal de São Paulo, teria contado com manifestações similares anteriores, ocorridas na cidade do Rio de Janeiro. A vertente alcançou a dança trinta anos depois, com o Balé do IV Centenário, em cuja curta existência - de 1952 a 1954 - o modernismo fez-se presente. Ainda que dirigido pelo coreógrafo húngaro Aurel Von Milloss (1906-1988), conterrâneo de Marika Gidali, mais conhecido entre nós como Aurélio Milloss, estiveram presentes temas ligados à floresta amazônica, com música de Heitor Villa-Lobos, em uma aclimatação do balé a esse país. 
Participaram, igualmente, músicos como Francisco Mignone e Camargo Guarnieri e pintores tornados cenógrafos como Cândido Portinari, Clóvis Graciano e Flávio de Carvalho, que recorriam a telões pintados, a exemplo do que havia sido realizado pela companhia Ballets Russes de Sergei Diaghilev, que esteve no Brasil em 1917. Diaghilev convidou libretistas, músicos e artistas plásticos de sua Rússia para compor obras coreográficas mais de quatro décadas antes do Balé do IV Centenário emergir em São Paulo.

Após a eclosão dos movimentos do concretismo e neoconcretismo na década de $1950^{286}$, que trouxeram a predominância de elementos geométricos, as artes visuais continuaram potentes, com Hélio Oiticica e Lygia Clark - esta, já praticante de experiências táteis e instalações orgânicas e corporais. Para o pensador Andreas Huyssen, o pósmodernismo foi um fenômeno tipicamente norte-americano e analisa o que se passou durante os anos 1960 no Hemisfério Norte:

Caracterizado por uma imaginação temporal que mostrava um forte sentido do futuro e de novas fronteiras, de ruptura e de descontinuidade, de crise e de conflito de gerações, uma imaginação tributária mais de anteriores movimentos europeus de vanguarda, como o Dadá e o surrealismo, do que do alto modernismo. Assim, o ressurgimento de Marcel Duchamp como padrinho do pós-modernismo dos anos sessenta não é um acidente histórico. No entanto, a constelação histórica em que o pós-modernismo dos anos sessenta se lançou em campo (da Baía dos Porcos e do movimento pelos direitos civis às revoltas universitárias, ao movimento pacifista e à contracultura), torna essa vanguarda especificamente norte-americana, mesmo onde seu vocabulário de formas e técnicas estéticas não era radicalmente novo ${ }^{287}$.

Para o professor, teórico e crítico estadunidense Fredric Jameson, a partição em décadas ou períodos históricos é anacrônica e recomenda não se debruçar sobre as glórias e fracassos da década de $1960^{288}$. Jameson distinguirá o pós-modernismo - estilo artístico e cultural - da pós-modernidade - estrutura que concerne à globalização proliferada no

\footnotetext{
${ }^{286}$ Segundo o poeta e ensaísta Ferreira Gullar (1930-2016), ele esteve, juntamente com os irmãos Campos (Haroldo - 1929/2003 - e Augusto), na Exposição Nacional de Arte Concreta em 1956, que marcou, no Brasil, o início da Arte Conceitual, um dos movimentos de expressão poética mais importantes no século XX. No ano seguinte, em 1957, em um artigo publicado na edição de domingo do Jornal do Brasil, Gullar questionou as teses e introduziu a disputa entre concretos e neoconcretos.

Emissão radiofônica no programa "na vertigem do dia" na Rádio Cultura FM, 21 out. 2015.

${ }^{287}$ HUYSSEN, Andreas. Mapeando o Pós-Moderno. In: HOLANDA, Heloísa Buarque de (Org.). PósModernismo e política. Rio de Janeiro: Rocco, 1991. p. 36.

${ }^{288}$ JAMESON, Fredric. Periodizando os anos sessenta. In: SAYRES, Sohny et al. (Org.). The 60's without apology. Minneapolis, MN: University of Minnesota Press, 1985.
} 
capitalismo tardio ${ }^{289}$. No Brasil, o crítico de arte Mário Pedrosa antecipou a denominação “pós-moderna”, conforme já assinalado. Pedrosa empregou o termo em 1966, com referência à arte ambiental de Hélio Oiticica no artigo Arte ambiental, arte pós-moderna, Hélio Oiticica, ao referir-se ao esgotamento da linguagem moderna:

Agora que chegamos ao fim da chamada "arte moderna", inaugurada por [Pablo Picasso] Les Demoiselles d'Avignon, e inspirados pela [então] recente descoberta da arte Africana, os critérios para apreciação não são mais os mesmos que os estabelecidos desde então, baseados que eram nos experimentos Cubistas. Agora, nós entramos num outro ciclo, não mais puramente artístico, mas cultural, radicalmente diferente dos precedentes que começaram (deveremos dizer?) pela arte Pop. Eu chamaria este novo ciclo de antiarte "arte pós moderna".

(De passagem, deixe-nos dizer que, atualmente, o Brasil participa não como um modesto seguidor, mas como líder. Em muitos aspectos, a jovem expoente do velho Concretismo e especialmente do Neoconcretismo, como conduzido por Lygia Clark, prenunciaram os movimentos da $O p$ e mesmo da arte Pop. Hélio Oiticica foi o mais jovem do grupo $)^{290}$.

Reitero a proximidade entre a dança e as artes visuais por sua comunicação eminentemente sensorial, cinestésica, o que justifica a corriqueira fala "de arrepiar" a propósito daquilo que toca.

\subsection{Caminhada, a abertura}

O pré-roteiro de uma peça de dança constituía um ponto de partida e foi melhor se delineando e sendo construído à medida que os ensaios avançavam. Caminhada marcou a passagem do aprender ao apreender. Foi a adaptação ao contexto brasileiro da experiência europeia.

289 FRONTEIRAS do Pensamento. Fredric Jameson. Portal Fronteiras do Pensamento. Disponível em: https://www.fronteiras.com/videos/conferencistas/fredric-jameson. Acesso em: 8 fev. 2017.

${ }^{290}$ OITICICA, Hélio. Environmental art, postmodern art. In: FERREIRA, Glória; HERKENHOFF, Paulo (Ed.). Mário Pedrosa: primary documents. Tradução para o inglês de Stephen Berg. New York: Museum of Modern Art (MoMA), 2015. p. 314. Tradução nossa. Texto original: "Now that we have arrived at the end of what has been called "modern art", inaugurated by [Pablo Picasso's] Les Demoiselles d'Avignon, and inspired by the (then) recent discovery of African art, criteria for appreciation are no longer the same as the ones established since then, based as they were on the Cubist experiment. By now, we have entered another cycle, one that is no longer purely artistic, but cultural, radically different from the preceding one and begun (shall we say?) by Pop art. I would call this new cycle of antiart "postmodern art." (In passing, let us say that, this time around, Brazil participates not as a modest follower, but as a leader. In many regards, the young exponents of the old Concretism and especially of Neo-Concretism (as led by Lygia Clark) have foreshadowed the Op and even Pop art movements. Hélio Oiticica was the youngest of the group.)". 
Contava com a adesão ao projeto do experiente homem de teatro total Maurice Vaneau, disposto a arriscar-se em uma nova experiência e a ela conceder todo seu know-how. Vaneau, até então um sólido diretor de teatro no Brasil e na Europa, que já havia dirigido renomados atores, topou a aventura. Diretor teatral que respeitava o autor dos textos das peças que encenava, ex-diretor artístico e geral por duas vezes do Teatro Brasileiro de Comédia, Vaneau era, na verdade, um homem de teatro completo, que dominava todas as ferramentas do ofício. No TBC, já programara apresentações cênicas de dança às segundas-feiras. Encenações suas nas décadas de 1950 e 1960, como Casa de chá do luar de agosto e Quem tem medo de Virginia Woolf? com Cacilda Becker e Walmor Chagas, passaram a fazer parte do passado. Estava delineado o quadro de ocupação daquele espaço para a realização do projeto. Conforme declaração de Vaneau à Coleção Aplauso, é quando é lembrada sua origem flamenga, povo cuja produção artística é associada à visceralidade:

Nessa volta ao Brasil, de fato preferi me introduzir com Célia nessas novas experiências de linguagem, numa fusão de diferentes técnicas. Considerava que o teatro de texto estava gasto. Pensava então que, voltando às suas origens, à dança, o teatro poderia encontrar uma fonte renovada de criatividade, aproveitando também a vertente tão enraizada na Bélgica flamenga de trazer à tona o inconsciente, certa libertação da lógica e do realismo estreito ${ }^{291}$.

Após o mergulho na dança-teatro realizado em parceria comigo, quando voltou a produzir teatro, escolheu As malandragens de Escapino, de Molière, realizada em 1982, e $A$ tigresa e outras histórias, de Dario Fo, cuja montagem ocorreu em 1985, empregando a linguagem física da Commedia dell'Arte, à qual bastava, antes de tudo, um tablado e o corpo do ator - o que Vaneau denominava de "teatro em estado puro".

Minhas antigas mestras Renée Gumiel e Ruth Rachou cederam generosamente seus estúdios para os ensaios de Caminhada: a primeira, no horário de almoço, do meio-dia às 14 horas, em seu estúdio situado no Baixo Augusta, na região central de São Paulo; e a segunda, à noite, das 20 às 23 horas, e aos finais de semana, em sua escola que funcionava no bairro de Pinheiros, na Rua Capote Valente, antes que pudéssemos ocupar o palco do teatro. No processo dos ensaios, geralmente, eu ia montando sequências e cenas com o elenco, atentamente observadas por Vaneau, que demorava a intervir. As imagens que propunha ao elenco eram frutos de visões nem sempre precisas, que adquiriam contornos mais nítidos

${ }^{291}$ GOUVÊA, Leila. Maurice Vaneau: artista múltiplo. São Paulo: Imprensa Oficial, 2006. p. 188-189. 
durante os ensaios. Sempre depositei grande confiança no acaso e na própria intuição. A tecnologia encontra-se altamente embrenhada em todas as nossas atividades nos tempos atuais, mesmo as mais cotidianas. Por exemplo: para estabelecer um percurso ao sair de casa, posso recorrer ao GPS. Eu, no entanto, prefiro escolher um caminho aleatoriamente se disponho de certo tempo, atraída pela particularidade daquele trajeto. Se me encontro na biblioteca da faculdade, em vez de procurar por um livro preciso, prefiro atentar àqueles que se encontram em uma das mesas móveis junto à placa onde se lê "Não recolocar os materiais nas estantes" ou "Reservado para docentes"; no carro, prefiro ouvir músicas no rádio, que serão menos previsíveis, do que aquelas gravadas por mim e cujo som e série já conheço.

Os ensaios aos finais de semana, sobretudo aos domingos, provocaram conflitos. O pai de uma das dançarinas alegou que a filha não ensaiaria aos domingos por motivo de almoço em família, o que considerava inconcebível em um esquema profissional. Argumentei que sua filha era uma burguesa e sua resposta foi chamar-me de prostituta, o que enfureceu Maurice. Os dois travaram uma briga corporal que os levou ao chão e os óculos de ambos se quebraram. O fato revela a procedência de uma elite abastada por parte dos aspirantes a dançarinos. Ainda que a escola de Ruth Rachou fornecesse muitas bolsas de estudo, não deixava de ser particular, tornando legítima a necessidade de entidades públicas que oferecessem aulas gratuitas, ampliando o acesso a outros segmentos menos privilegiados.

Pintor e cenógrafo nascido na Itália, Tullio Costa, juntamente com a figurinista belga Ninette Van Vuchelen, colaboraram a pedido de Vaneau. Ambos artistas tarimbados, além de extremamente talentosos, já tinham desenvolvido com o diretor outras parcerias artísticas. Como os recursos financeiros eram escassos, os artistas visuais propuseram algo simples e bonito: collants pretos inteiriços, tendo por baixo uma camiseta branca com manchas irregulares em preto pintadas à mão.

O primeiro ensaio ocorreu no dia 14 de outubro de 1974 e a estreia ocorreu no dia 5 de dezembro daquele ano. Não chegamos, portanto, a completar dois meses de ensaios, tempo bastante exíguo em se considerando a linguagem híbrida que praticamos. Era ainda bastante jovem. Completei 25 anos durante a fase dos ensaios, aos quais alguns profissionais vinham assistir, como a bailarina Patty Brown, que previu, então, que aquele espetáculo poderia estourar.

Caminhada abriu a casa, o Teatro de Dança Galpão, com um elenco de doze participantes, e foi a primeira colaboração artística entre eu e Maurice Vaneau. Além de minha antiga mestra Ruth Rachou, que se mostrava satisfeita por surgir alguém disposto a puxar o barco cênico, conforme afirmou à época, desse espetáculo coreográfico, participaram 
muitos de seus então melhores alunos, entre os quais muitos vieram a se tornar profissionais renomados, como Thales Pan Chacon (1956-1997), Daniela Stasi, Mara Borba e Debby Growald, além de Júlio Vilan, que, vindo da Bahia, já era um professor de dança moderna renomado, e Rui Frati, que se tornou assistente de Augusto Boal (1931-2009) ${ }^{292}$. Eva Reska, Heloisa Guimarães, Márcia Bittencourt e Sofia Saruê completavam o elenco. Sofia é filha da artista plástica austríaca Gerty Saruê, que, em uma das apresentações, veio acompanhada pelo físico, matemático e crítico de arte Mário Schenberg (1914-1990), dizendo-me que aquele era um espetáculo de dança que merecia ser visto pelo intelectual. Havia ainda a presença de um percussionista, Nikolaus Stolferfht. O patrocínio (leia-se: o "aluguel do teatro") foi responsabilidade da então Secretaria de Cultura, Esportes e Turismo do Estado de São Paulo e do Conselho Estadual de Cultura.

A trilogia composta por Caminhada I, II e III iniciou um período efervescente e renovador para a dança na cidade de São Paulo. Em dezembro de 1974, ficamos em cartaz durante três semanas, com apresentações de terça-feira a domingo, com duas sessões aos sábados e domingos, acompanhando a prática teatral, perfazendo oito apresentações semanais. Inicialmente, a temporada foi programada para durar dez dias, de 5 a 15 de Dezembro. Devido à repercussão positiva que o espetáculo recebeu, e considerando a disponibilidade do teatro, quisemos prorrogar a temporada por mais uma semana. Para meu espanto, antes de podermos comunicar o fato à imprensa, tivemos que aguardar a volta do marido de uma das dançarinas de um pesqueiro, para que ele autorizasse a esposa a prosseguir. Ao término da penúltima apresentação da primeira temporada, houve uma reunião na casa da fotógrafa Maureen Bisilliat, que era também uma amiga de Vaneau há muito tempo. O diretor Antonio Abujamra também se encontrava presente, bem como o então governador Paulo Egydio Martins. Maurice Vaneau pediu-me que fosse convidá-lo para vir assistir à última apresentação de Caminhada no dia seguinte. Abujamra tentava atrai-lo com o mesmo fim. Não quis, porém, aproximar-me e dirigir-me a um representante nomeado pelo regime militar, preferindo ficar à margem, outsider.

Caminhada já nasceu polêmica. Dança ou teatro? A cada final de ano, havia a campanha de popularização do teatro em dezembro, mês no qual a frequência às casas de espetáculos diminuía devido à proximidade com as festas natalinas. A campanha "Teatro é um Barato" era organizada pela Associação dos Produtores de Espetáculos Teatrais do Estado

\footnotetext{
292 Augusto Boal: diretor, dramaturgo e ensaísta teatral; propositor do Teatro do Oprimido. Voltará a ser mencionado mais adiante.
} 
de São Paulo (APETESP), fundada em 1972. Dois anos depois, em 1974, a atriz Eva Wilma assumiu a presidência da Associação. Vaneau dirigiu a ela uma solicitação para que Caminhada fosse incluída na programação. O pedido foi negado, sob a alegação de que se tratava de dança, e não de teatro, apesar de palavras e frases constarem da montagem, além do fato da atriz ter sido bailarina na juventude e mesmo integrado o elenco do Balé do IV Centenário. O trânsito, o "trans" a atravessar a tanz (“dança" em alemão), propondo uma múltipla linguagem, começava a se afirmar.

No mês de março de 1975, voltamos a nos apresentar, estimulados pela dupla premiação da Associação Paulista de Críticos de Arte, a APCA. Recebemos menção especial e o Prêmio de Melhor Coreografia em Espetáculo Teatral no ano de 1974. Sábato Magaldi considerou Caminhada uma das dez melhores peças teatrais apresentadas na cidade de São Paulo e incluiu-me entre as melhores atrizes da temporada em sua avaliação da atividade teatral do ano de $1974^{293}$.

Novamente, surpreendeu-me que uma das dançarinas dissesse não estar disposta a vestir novamente o mesmo Pierrô (do Carnaval passado), apenas três meses após a estreia. Procedemos a alterações no elenco. Do primeiro, foram mantidos os nomes de Ruth Rachou, Júlio Vilan, Mara Borba, Thales Pan Chacon, Debby Growald, Maurice Vaneau e o meu, acrescidos aos de Jane Ballantyne e José Luis Machado. Retomamos a peça de dança primeiramente no Museu de Arte de São Paulo, o MASP. Fizemos duas apresentações patrocinadas pela Prefeitura do Município de São Paulo, dentro do plano de popularização do teatro, quando houve a concordância de sermos incluídos na programação por parte da classe teatral. Aliás, classe esta que compareceu em grande número no Galpão para assistir nosso trabalho. As cinco apresentações seguintes ocorreram no Teatro Municipal de Santo André, com uma apresentação na sexta-feira, duas no sábado e duas no domingo. Foi quando pudemos contar com a presença, na plateia, da mestra Renée Gumiel, que se encontrava viajando por ocasião da estreia. Renée chancelou: "É ótimo!".

O Teatro de Dança Galpão passou por uma breve reforma e, em 4 de março de 1975, houve a estreia oficial da casa reformada com o Ballet Stagium, que apresentou Entrelinhas (1972) e D. Maria I, a rainha louca (1974). De 13 a 23 de março, uma nova temporada de Caminhada no Teatro Galpão, com sessões de terça a sexta-feira às $21 \mathrm{~h} 15$, aos sábados às 20 e 22 horas e aos domingos às 18 e 21 horas, perfazendo oito sessões. A última apresentação

\footnotetext{
${ }^{293}$ MAGALDI, Sábato. Uma boa temporada teatral. Menos para nossos autores. Jornal da Tarde, São Paulo, sábado, 28 dez. 1974, p. 15.
} 
foi em Campinas, no Teatro Castro Mendes, no dia 18 de abril de 1975, quando se juntou ao elenco Antônio Carlos Cardoso, então diretor do Corpo de Baile Municipal - fundado em 1968 e, a partir de 1979, renomeado de Balé da Cidade de São Paulo -, em uma substituição feita a toque de caixa. Antônio Carlos mantinha uma postura simpática ao meu trabalho e chegou a sugerir que eu procurasse o Governo do Estado para apoiar a linguagem que investigava. Chegou a propor que dirigisse um grupo de estagiários no Corpo de Baile Municipal. Penso que achei pouco. Algum tempo depois, disse-me que também iria inserir texto em sua produção, quando coreografou Nosso tempo, o que sinaliza a influência exercida por Caminhada.

A última apresentação, em Campinas, foi promovida pelo Departamento de Cultura da Secretaria de Educação, Cultura, Esportes e Turismo da Prefeitura Municipal de Campinas, Companhia de Teatro "Sia Santa" e Foguinho. Esteve presente Lina Penteado, diretora da academia onde estudara por quatro anos (1963-1967), mas a apresentação pouco enquadrada não deve ter sido de seu agrado.

Realizamos ao todo cerca de cinquenta apresentações, fato incomum à época, em se tratando de dança.

Os releases de divulgação anunciavam: "Formas diferentes de repressão humana mostradas basicamente em gestos e ruídos, numa experiência nova, distinta da dança ou do teatro comumente entendido". Não nos classificavam, portanto, entre os gêneros convencionais. Já descartávamos as expressões "teatro total" e "balé teatro". Ecoando Antonin Artaud, considerávamos Caminhada a tentativa de realizar um espetáculo que, partindo de um tema inicial, é projetado no espaço através de gestos, palavras, sons e ruídos, em um encontro entre as várias linguagens. Referíamo-nos ainda às experiências recémefetuadas na Bélgica, no Mudra e no Chandra, situando a montagem enquanto aclimatação ou melhor, continuidade. Outra denominação empregada, creditada a Maurice Béjart, era "théâtre éclaté" ou "teatro estourado", "explodido",294.

Muito tempo depois, em 2011, em depoimento gravado na série Figuras da Dança acerca de meu trabalho coreográfico, Ruth Rachou afirmou que, até então, em São Paulo, não havia nada que se assemelhasse ao que realizamos naquele momento. Era muito diferente.

\footnotetext{
${ }^{294}$ O TEATRO fala de repressão. Dançando. Jornal da Tarde, São Paulo, 5 dez. 1974.
} 
De acordo com o ator e crítico Linneu Dias ${ }^{295}$, então integrante da Comissão de Dança juntamente com Marilena Ansaldi, Caminhada iria dar o tom do Galpão como Teatro de Dança, e esse tom era o da investigação e da experimentação. A linguagem dessa trilogia, sua estética, o momento histórico em que se encontra inserida, serão analisados detalhadamente a seguir. Foi o gatilho do processo interlinguagens desenvolvido no Brasil.

O tema da repressão alinhavou as três partes que compunham Caminhada. O tom da primeira coreografia era introspectivo; a segunda continha frases fragmentadas e nela predominava o humor e o absurdo; a última era uma fábula (ou alegoria) sobre um povo oprimido. A primeira foi resultante de um exercício cênico proposto e iniciado com Maguy Marin, colega do Mudra em Bruxelas, a partir da peça Ato sem palavras, de Samuel Beckett. O exercício, situado em uma galeria de arte, não continha qualquer alusão cenográfica ao espaço mencionado (uma galeria). A personagem repetia a mesma frase inúmeras vezes, enunciando sua apreciação sobre uma foto exposta, seguida por três personagens-sombra vestidos de preto que repetiam rigorosamente seus mesmos gestos. A frase dita era: "É verdade, parece um quadro; os fotógrafos de hoje não fazem mais fotos como estas, não é?”. Brandia um lenço branco ao falar. Como imagem correlatada, Maguy lembrou o dia em que uma senhora, ao lado de Béjart, movimentava uma fatia de presunto, bem próxima ao rosto do coreógrafo. A atmosfera, beckettiana, constituiu uma primeira projeção do que Marin viria a realizar alguns anos depois - May B, peça de dança de 1981 e ainda apresentada com muito sucesso no mundo todo até hoje. Sombra, do latim "umbra", refere-se a um espaço pouco iluminado ou obscurecido, onde os corpos, apenas vislumbrados, são opacos, motivo pelo qual são intrigantes. A tentativa de descobrir quem são eles e quais são os seus propósitos é instigada. Em Caminhada I, as sombras cumpriam a função de espectros-espelho. Havia, enquanto recurso sonoro, o som quase inaudível de um jogo de futebol narrado por um radialista.

Caminhada II juntava, em um processo semelhante à colagem: frases, piano tocado ao vivo, jogos com cadeiras que principiavam empilhadas e eram, em seguida, desdobradas. Havia muito humor, o que levava a refletir sobre o que vem a ser uma dramaturgia não linear. O teatro possuía um piano, imediatamente utilizado. Eu tocava uma ciranda de Heitor VillaLobos, justificando os seis anos de estudos em Campinas com a professora Neneca Bicudo de Godoy, assistente de Menininha Lobo, da família do compositor. O modo de fazer era o do

\footnotetext{
${ }^{295}$ NAVAS, Cássia; DIAS, Linneu. Dança Moderna. São Paulo: Secretaria Municipal de Cultura, 1992.
} 
"aqui/agora", "encenando-se" materiais que se encontravam ali, à toa, à disposição. De fato, a criação de um universo ficcional independe da narrativa. Maurice Vaneau entrava em cena com os bigodes pintados de verde, "nadando" em uma cadeira invertida, pondo em relevo sua veia irônica, cômico-satírica.

Caminhada II, inacabada e viva, provavelmente por ser processual, continha muito vigor. Não foi estruturada previamente, tomando-se como material o que havia à mão. A palavra francesa "bribe" é adequada: pode-se até falar em uma estética de bribes, de migalhas. Propus frases soltas que foram incluídas, tais como "Quando menino, queria ser condutor de bonde; quando cresceu, cresceu seu desejo: quis ser condutor du monde!".

A presença supõe o elo com o próprio eixo. Poderá ser atingida na preparação ao ato e será mais facilmente experienciada no silêncio, na lentidão, na quase imobilidade, que conduzem à concentração. A presença requer ainda o abandono da pessoa do atuante, um estado de entrega, um amálgama a uma situação vivida, a entrada no corpo sutil, desmaterializado. A refletir: é a possibilidade de se atingir a presença em meio à agitação externa e/ou interna. A própria palavra "emoção" principia pelo prefixo "e", que conota negação. Portanto, a emoção pode paralisar a moção, o movimento. Segundo Hans-Thies Lehmann, a presença exclui tanto a mimesis quanto a representação. O termo é bem definido por Maryvonne Saison: o reapresentar, a restituição ao presente.

$\mathrm{O}$ procedimento lúdico presente em Caminhada II remete também às já mencionadas heterotopias analisadas por Michel Foucault, como no exemplo das crianças que, na ausência dos pais, brincam sob os lençóis. O lençol é real, mas o que se passa sob ele já não é. Outro exemplo é o jardim, espaço real onde o que ocorre pode estar situado em um outro plano da realidade. Outro ainda é o navio, que, se em certos momentos históricos ocupou uma posição mercantilista, em outros povoa a imaginação. As heterotopias foucaultianas remetem ao primeiro conceito de "teatralidade", formulado pelo teatrólogo russo Nikolai Evreinov em 1922, mesmo ano em que o modernismo eclodia em São Paulo: a teatralnost (ou teatralidade) é um instinto, um gosto em transformar o real que nos rodeia, promovendo ilusões.

Caminhada III era calcada sobre o momento político brasileiro de 1974, apresentando, de modo alegórico e ritualístico, um povo oprimido, que principiava como larvas junto ao chão e que ia, aos poucos, progressivamente, encontrar a posição vertical, passando antes pelo arrastar, rolar e outros modos de movimento em estreito contato com o chão; depois, do plano baixo ao médio, em posições de cócoras ou de quatro, que levam ao engatinhar, ao "V" invertido (que permite a passagem de outro corpo pelo vão formado), bem como à ponte (que permite, igualmente, que outro corpo encolhido possa no vão abrigar-se). Havia uma 
celebração do estar junto, do contato, da cooperação e a consequente rejeição da verticalidade hierárquica, opressiva, evidenciando-se a relação temporal entre os oponentes contracultura/tortura. A organização social agregadora poderia ser considerada simpática, positiva ou até mesmo ingênua, mas não deixa de ser perseguida e mesmo promovida na atualidade, por meio de uma vertente que se mobiliza em direção à alteridade, ao convívio, com o propósito de melhor habitar o mundo.

Em Caminhada III, o grupo era controlado pelo Personagem da Máscara Branca (PMB) portada por Ruth Rachou, que manipulava cada um por meio de garrafas de coca-cola. A cena nos aproximava do artista visual Cildo Meireles, que também recorreu a esse ícone da sociedade de consumo, embora naquele momento a obra de Cildo nos fosse desconhecida, especificamente Inserções em circuitos ideológicos: Projeto Coca-Cola (1970), que apresentava, lado a lado, três garrafas de coca-cola de vidro, com uma cheia, outra pela metade e a terceira vazia. Outras coerções, tais como os concursos de miss e as exigências das medidas exatas (noventa centímetros de busto e quadril e sessenta de cintura) também estiveram presentes. Fazia-se, quase obsessivamente, referências à diversão, em uma alusão à coluna do segundo caderno do Jornal da Tarde intitulada "Divirta-se: estradas, garotas, festas, praias", bem como repetições da frase "O grande conforto", com insistência em se acalcar o impulso consumista: “Comprem salgados, doces, líquidos, pós, pastas, gordurosos; comprem secos, gelados, molhados, granulados, moles, duros, um dois, três, quatro".

Figura 34 - Cena de Caminhada

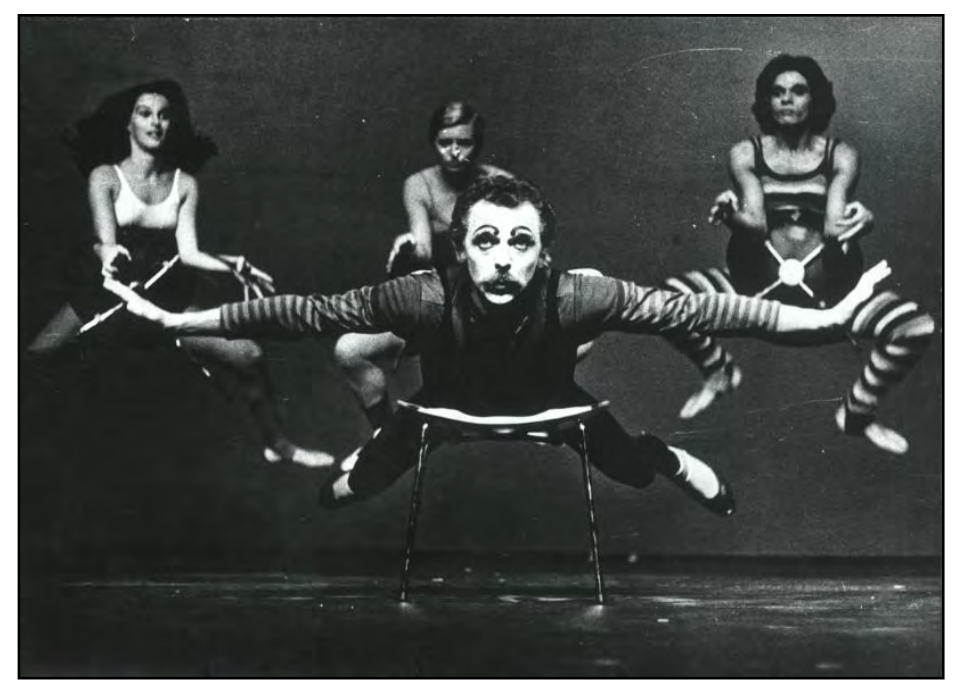

Maurice Vaneau (primeiro plano), Debby Growald, Jane Balantyne e Thales Pan Chacon (segundo plano, esq. p/ dir.). Teatro Galpão, São Paulo, SP, 1975.

Fonte: arquivo pessoal. Foto de Sérgio de Souza. 
Figura 35 - Ruth Rachou no espetáculo Caminhada

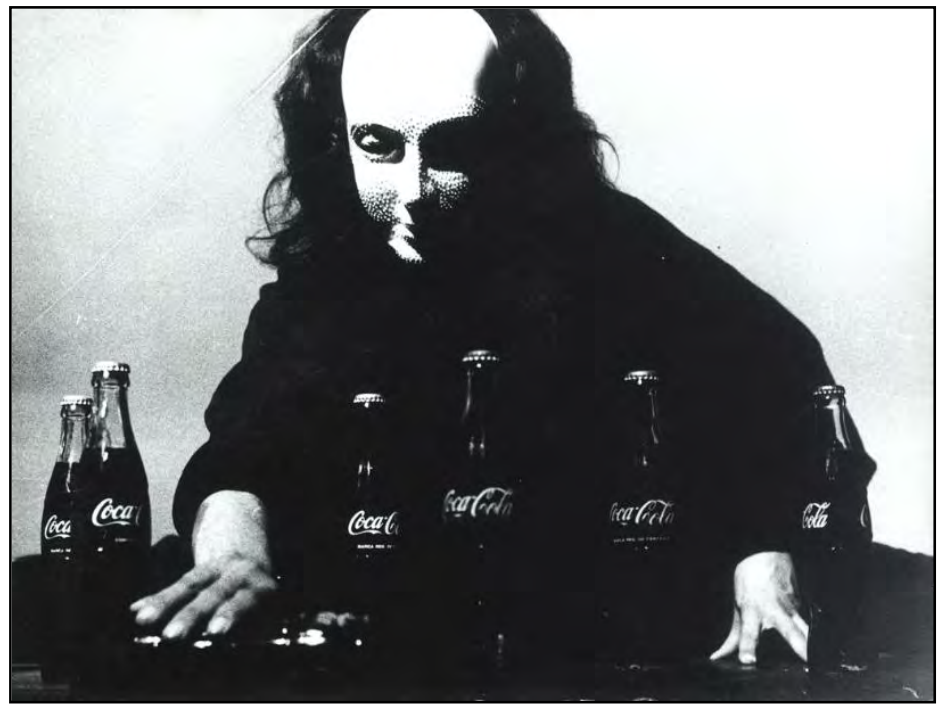

Teatro Galpão, São Paulo, SP, 1975.

Fonte: arquivo pessoal. Foto de Sérgio de Souza.

Figura 36 - Cena de Caminhada

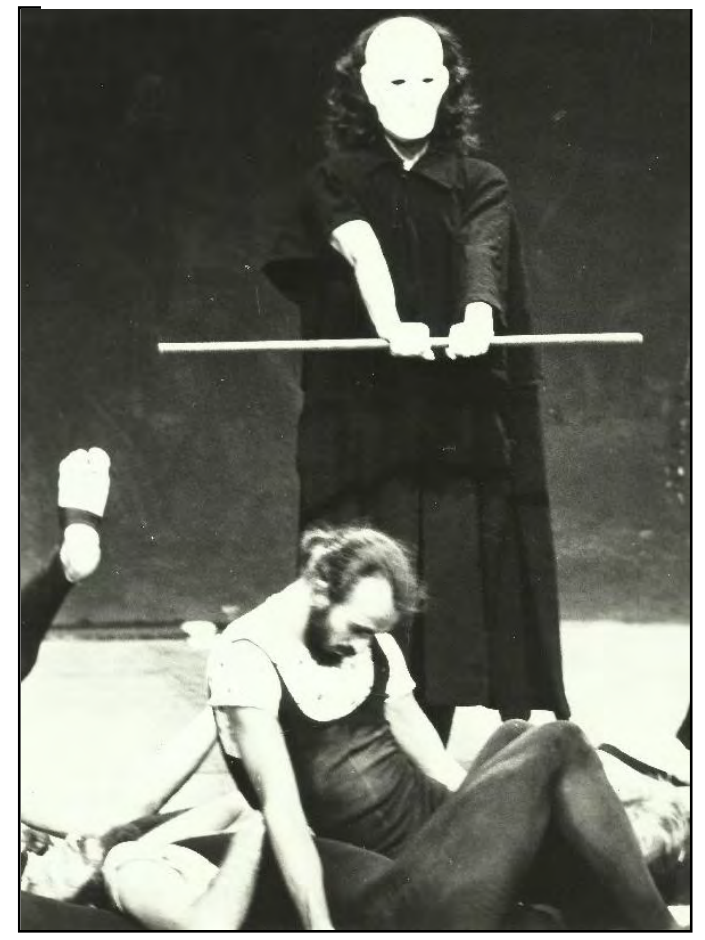

Ruth Rachou e José Luís Machado. Teatro Galpão, São Paulo, SP, 1975.

Fonte: arquivo pessoal. Foto de Marie Hispe Milos.
Figura 37 - Cena de Caminhada

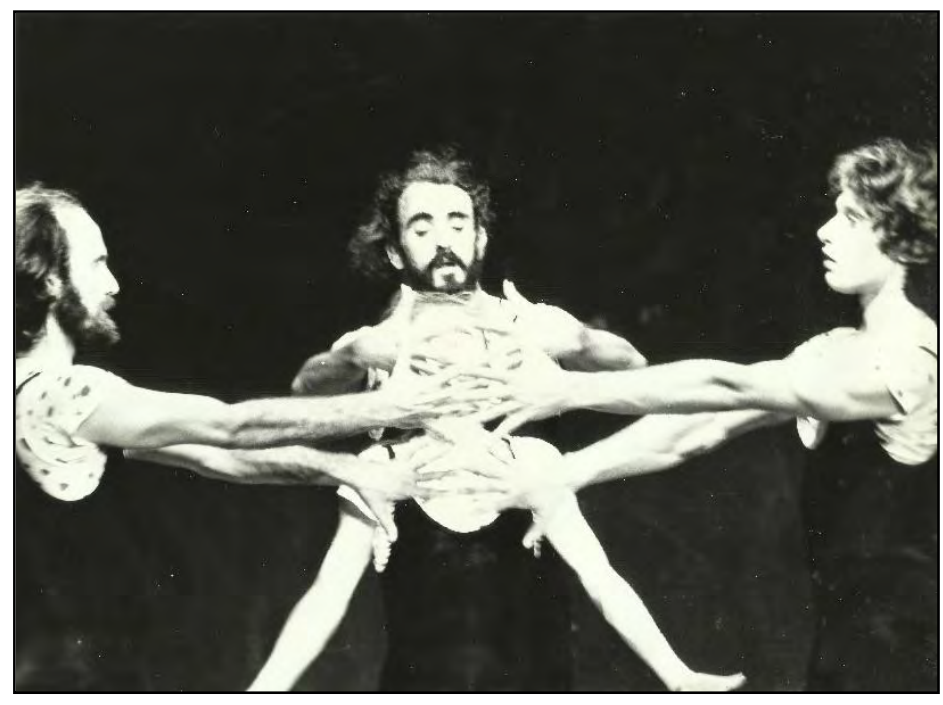

Júlio Vilan, José Luís Machado, Thales Pan Chacon e Célia (ao centro) Teatro Galpão, São Paulo, SP, 1975.

Fonte: arquivo pessoal. Foto de Maria Luisa Schmuziger. 
Constava uma cena de tortura, enquanto o Teatro de Dança Galpão iria firmar-se como um espaço libertador. O professor Franklin Leopoldo e Silva afirmou: “A Liberdade só pode ser vivida como contestação", ou "A verdadeira liberdade é a experiência da libertação", e lembrou Sartre, que, em um período próximo à libertação francesa durante a Segunda Guerra Mundial, afirmara: "Nunca fomos tão livres quanto durante a ocupação", sinalizando que, para se conhecer a liberdade, há que se viver a falta dela ${ }^{296}$. A fala sobre a necessidade de se ter sido escravo para se apreciar a liberdade foi comum a muitos líderes políticos, como a emblemática Dolores Ibárruri, conhecida como La Pasionaria Roja, que proferiu o famoso discurso "No pasarán" em 19 de Julho de 1936, durante a Guerra Civil Espanhola (19361939), e que se situava na linha de frente do projeto "Republica Española Ya!" durante o sangrento conflito entre falangistas e republicanos.

Caminhada III diferia das duas primeiras apresentações. Deleuze e Guattari consideram que não é nem no começo nem no fim, mas sim no meio que as coisas adquirem velocidade. Incluía uma cena de tortura. Tortura é ação direcionada ao corpo, primeiro elemento a ser afetado. Caminhada III era uma alegoria. Continha um começo, meio e fim, razão pela qual se completava em si mesma, não dando ensejo a novos desdobramentos, possibilidade aberta pelas duas primeiras. Constituiu, porém, o embrião de Assim seja? (ou amém), estreada dez anos depois, em 1984, peça de dança escolhida por Sílvia Geraldi como obra de referência em sua Tese de Doutorado acerca de meu trabalho construído nas décadas de 1970 e 1980, apresentada na Universidade Estadual de Campinas (UNICAMP) em 2009, intitulada Raízes da teatralidade na dança cênica - recortes de uma tendência paulistana.

A primeira metade da década de 1980 foi sombria, com o aparecimento da Aids já em seu início. Para a dança, o tempo era igualmente sombrio, dada a ausência de subvenções para se trabalhar. Lembro-me que meu marido Maurice escreveu uma carta a Leona, sua irmã mais velha, na qual dizia: "Célia tem feito muitas coreografias ultimamente. No papel”. Escrevia, então, o roteiro de uma missa dos aflitos, que tinha como epígrafe as palavras bíblicas do livro de Isaias: "Passarão pela terra oprimidos e famintos. Quando tiverem fome, enfurecendo-se, amaldiçoarão ao seu rei e ao seu Deus, olhando para cima. Olharão para a terra, eis aí angústia, escuridão e sombras de ansiedade, e serão lançados para densas trevas". O opressor personagem civil-militar de Caminhada fora deslocado para Deus.

\footnotetext{
${ }^{296}$ Informação verbal. Informação fornecida pelo Prof. Dr. Franklin Leopoldo e Silva no dia 27 de janeiro de 2016 durante o curso "Experiência histórica e subjetividade em Arendt, Marcuse e Sennet", ministrado nos dias 27 e 28 de janeiro de 2016 no Centro Universitáio Maria Antonia, da USP.
} 
Assim Seja? foi realizada ao som da Missa de Liverpool, composta sob encomenda por Pierre Henry em 1967 para a inauguração da Catedral Metropolitana da Igreja do Cristo Rei, em Liverpool, na Inglaterra. Constam da partitura musical as seis partes litúrgicas: Kyrie, Gloria, Credo, Sanctus, Agnus Dei e Comunhão. A coreografia tratou de um povo oprimido que busca em Deus a redenção, assemelhando-se a um rito sacro-profano do final dos tempos. Semelhança presente na temática, mas com resultado estético mais maduro. Aproximava-se de Caminhada III, composta dez anos antes (1974). Sílvia Geraldi bem definiu a peça de dança como uma "missa futurista-primitiva",297. Caminhada e Assim Seja? tinham, em comum, o ritual, o tratamento ritualístico.

O roteiro de Caminhada III foi elaborado quando ainda me encontrava na Europa. Portanto, a situação política do Brasil me era representada, não vivida. Ao iniciar o processo de ensaios, o roteiro foi bastante modificado e mesmo esquecido, pois o processo de construção acaba por conduzir os propósitos. As três peças que compunham o programa completavam-se bem, mas eram muito diferentes umas das outras, revelando-me, desde então, uma tendência a não me repetir, a diversificar e não insistir em uma mesma direção - talvez, para não aborrecer o público, embora este não fosse levado em conta desde o impulso inicial. O que se levava em conta era o mergulho no próprio processo criativo e a busca de soluções para os constantes desafios provocados por uma criação.

É possível afirmar que havia, em Caminhada I, II e III, o contorno de personagens, guardando algumas das características da teatralidade listadas por Josette Féral: a transformação do real, do indivíduo, transgredindo o cotidiano, adentrando na representação e construindo sistemas de sentido. Caminhada II estava próxima da performance, do ser, do fazer e da revelação desse fazer, projetando imagens. Maurice Vaneau surgia "nadando" sobre uma cadeira invertida, com os bigodes pintados de verde. Em artigo para a revista Ballet International escrito na segunda metade da década de 1980, o historiador e crítico de dança alemão Norbert Servos (nascido em 1956), cofundador da revista, afirmou:

Um grande número de coreógrafos trabalhando na atualidade, ancoram firmemente suas peças na realidade: Se o poder dos sentimentos está sendo novamente discutido, ele não se dá num contexto "humano para sempre", atemporal, mas numa visão que atua no presente. Nenhum "poder do

297 GERALDI, 2015. 
Destino" dita os tópicos, mas a concreta e verificável experiência da vida de todos os dias ${ }^{298}$.

Num processo coreográfico, com constância, as imagens surgem antes de haver uma coerência articulada. Para o filósofo Gaston Bachelard, as imagens são anteriores às ideias e conceitos. A experiência do Teatro de Dança Galpão, iniciada em Dezembro de 1974 com Caminhada, foi saudada pelo crítico Sábato Magaldi como "um espetáculo perfeito e, ainda mais do que isso, um novo caminho e uma nova linguagem", frase que encerrava seu artigo $^{299}$. O inteligente dançator integrante do elenco, Thales Pan Chacon, fez uma avaliação que me pareceu acertada: a primeira Caminhada era introspectiva; a terceira, redonda, com começo, meio e fim, naquela alegoria de um povo oprimido que busca libertar-se do opressor. Ambas eram acabadas e, por isso, poderiam ser esquecidas, enquanto a segunda, aberta e permeável, na qual coisas, partes e pedaços poderiam sair e entrar, serem acrescidos ou subtraídos, correspondia a um manancial que muito ainda poderia jorrar, oferecendo uma direção cênica instigante. Alguns anos depois, Thales afirmou que Maurice Vaneau e eu tínhamos aberto um mercado para a dança. Um mercado, ainda que restrito. A seguir, reprodução do texto completo de Sábato Magaldi, que reforça a mesma ideia.

\footnotetext{
298 SERVOS, Norbert. Ballet International. Versão em inglês. Alemanha, jan. 1987, p. 20. Tradução nossa. Texto original: "A large number of the choreographers working today anchor their pieces firmly in reality. If the power of feelings is being discussed again, it is not in a timeless ,forever human context, but with a view to acting in the present. No ,power of Fate ${ }^{e e}$ dictates the topics, but the concrete and verifiable experience of everyday life".

${ }^{299}$ MAGALDI, Sábato. Caminhada, uma fusão perfeita de ideia e forma. Jornal da Tarde, São Paulo, 10 dez. 1974.
} 
Figura 38 - Matéria no Jornal da Tarde sobre Caminhada em 1974

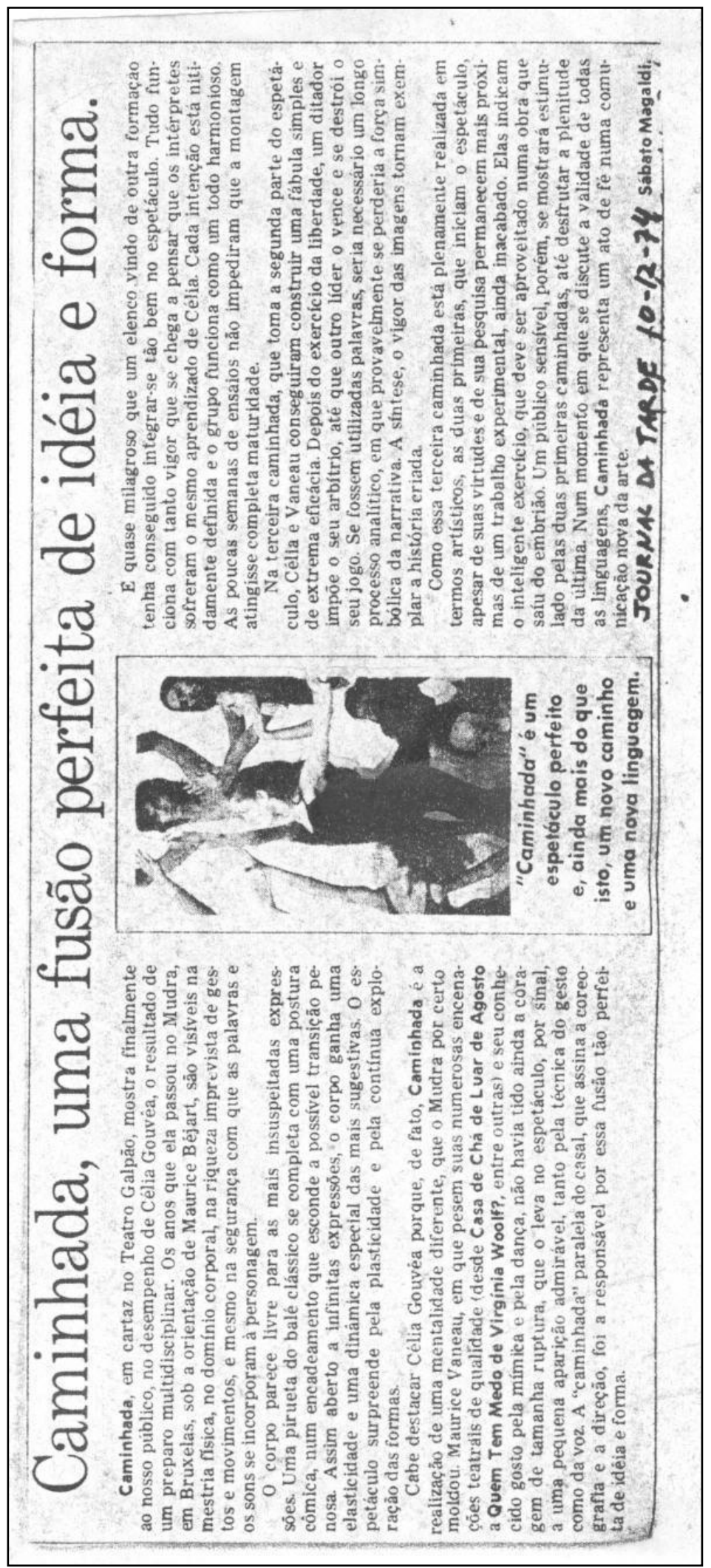

Fonte: arquivo pessoal. 
Duas décadas depois, em 14 de dezembro de 1994, a crítica de dança Helena Katz escreveu na página D2 do Caderno 2 do jornal O Estado de São Paulo:

Era Dezembro de 1974 e o Teatro Galpão inaugurava, em São Paulo, uma nova era para a dança. Célia Gouvêa e Maurice Vaneau, recém-chegados da Europa, estreavam lá Caminhada, espetáculo onde aplicavam as teorias que Célia Gouvêa havia aprendido no Mudra, a escola de Béjart em Bruxelas. A modernidade que traziam assustou muita gente, na época. Mas um elenco de notáveis apostou na proposta. Dançavam em Caminhada, por exemplo, Ruth Rachou, Thales Pan Chacon, Júlio Vilan, Debbie Growald e Daniela Stasi (atual estrela na Martha Graham Dance Company, em Nova York).

\subsection{Funcionamento: aulas, apresentações, palestras, workshops}

As aulas gratuitas oferecidas no Teatro Galpão forneceram a possibilidade de acesso democrático a aulas de dança, que deixou de ser uma atividade exclusivamente acessível a uma elite financeira, embora a presença, no elenco de Caminhada, de Ruth Rachou, que era uma profissional diretora de escola particular de dança moderna, mas que oferecia fartamente bolsas a alunos talentosos, leve a refletir sobre a questão do apoio dos poderes públicos a determinadas iniciativas privadas.

Acertadamente, elaborou-se um projeto pedagógico em paralelo ao artístico. O problema é que havia uma sala única no Galpão. Portanto, não era possível conciliar ambas as atividades ao mesmo tempo. Normalmente, as montagens começavam após o período de aulas, por volta das 17 horas, mas, por vezes, aulas tiveram que ser canceladas para dar lugar a uma montagem com estrutura exigente. Assim, além dos espetáculos, havia aulas oferecidas a atores já estabelecidos e a aspirantes a bailarinos, que tiveram início no mês de março de 1975 e que permitiram o acesso democrático a aulas de dança, que deixaram de ser uma atividade exclusiva das classes abastadas. A procura era tão grande que audições eram organizadas para selecionar o grupo interessado em praticar uma das cinco modalidades de curso oferecidas: Dança Clássica, Dança Moderna, Expressão Corporal, Interpretação e Jazz.

A disciplina Dança Clássica era ensinada por Iracity Cardoso. Dança Moderna, por Antônio Carlos Cardoso - naquele momento, respectivamente, assistente de coreógrafo e diretor artístico do Corpo de Baile Municipal. A Sábato Magaldi, Secretário Municipal da Cultura em 1975 na gestão do empresário Olavo Setúbal como prefeito, a denominação “corpo de baile" agradava por lembrar o título do livro homônimo de Guimarães Rosa. Apesar de poético, o nome não levava em conta a hierarquia nas artes, que relega a dança a um 
complemento auxiliar às montagens operísticas. Aliás, a associação entre música e espírito levou, igualmente, à hierárquica estipulação dos cachês artísticos em montagens convencionais. O maestro ocupa o topo, seguido pelo diretor teatral, cujo cachê será superior se, em vez de dirigir uma peça de teatro, dirigir uma ópera. Abaixo vem a dança, relegada a um patamar inferior pela cultura judaico-cristã, por se ocupar do corpo.

No horário das 9 às 15 horas, Antônio Carlos e Iracity conduziam a aula de balé (horário de trabalho que vigora até os dias de hoje) e só dispunham de tempo para estar no Galpão no final da tarde. No ano seguinte, em 1976, Antônio Carlos foi substituído por Sônia Mota, então bailarina da companhia oficial. Sônia já manifestara sua insatisfação quanto à disciplina do balé e fora aconselhada por Marilena Ansaldi a ir para o Galpão tentar novos experimentos. Sua indisciplina na Rua Monsenhor Passalaqua, ${ }^{\circ}$ 66, sede do Balé, deveria mudar para um novo endereço algumas quadras adiante: Rua dos "Inglezes”, 209.

Sônia tinha conhecido a técnica do estadunidense Louis Falco em Nova York em uma estadia recente na mencionada cidade no início do ano de $1976^{300}$. Falco estruturara um trabalho na barra no qual acrescentara a mobilidade da coluna, do tronco e da bacia, gerando uma descontração na técnica. A sensualidade dessas aulas foi reconhecida por Sônia como própria da cultura dançante brasileira e foi lá no Galpão, a partir de 1976, que a artista elaborou sua própria técnica, consistente trabalho que alia a técnica à respiração e ao reconhecimento de estados corporais. No início das aulas, propõe bocejos que ampliam os espaços vertebrais e permitem o afastamento com o cotidiano. Posteriormente, Sônia intitularia seu trabalho "A arte da presença, transformando seus preceitos em livro ainda inédito, ao qual vem se dedicando há cerca de dezessete anos, quando obteve uma bolsa da hoje extinta Fundação VITAE. Sônia vive há cerca de três décadas na Alemanha majoritariamente. Martin Heidegger desmembrou a palavra "presença” entre o "pré", aquilo que vem antes, e o sein (ou o ser). É o caráter ontológico da presença, enquanto pre-sença, que descobre e se entrega à responsabilidade do pré. É no próprio esquivar-se que o pré se abre em seu ser. "O ente que possui o caráter da pre-sença é o seu pré, no sentido de dispor, implícita ou explicitamente, em seu estar lançado"301. Em alemão, a palavra "presença"

\footnotetext{
${ }^{300}$ Louis Falco (1942-1993), nova-iorquino descendente de italianos, foi dançarino da José Limon Dance Company nos anos 1960 e 1970, retomando os principais papéis dançados por Limón. Proveniente do México, Limon dançou com Doris Humprhrey. Juntamente com sua partner Jennifer Muller, Falco promoveu a passagem entre a Dança Moderna tradicional e a de vanguarda. Os grupos de Limon e Muller apresentaram-se no Brasil em 1981.

${ }^{301}$ HEIDEGGER, 1986, p. 189.
} 
traduz-se como "Anwesenheit". An-wesenheit. Sônia entende o "an", que vem antes e antecede o ser, como o estado corporal anterior à ação.

Até os dias de hoje, a colega segue ensinando o que encontrou naquele ano de 1976. Segundo Sônia, o que a atraía em Falco era um aspecto "solto". Klauss Vianna diria que não existe "o solto". Se um dançarino for solicitado a soltar-se, não saberá como fazê-lo, a não ser que tenha consciência de cada vértebra da coluna vertebral e possa ceder ao arredondamento de cada uma delas. Provavelmente, por ter "achado" com facilidade seus preceitos, a Sônia nunca agradou a palavra "pesquisa", que lhe soa, talvez, como esforço sem resultados, a exemplo da premissa picassiana: "Eu não procuro, eu acho".

Inicialmente, Sônia denominava o trabalho que desenvolvia de "técnica Falco", talvez, por escrúpulos, mas aos poucos foi adquirindo confiança e constatou que o que realizava era próprio, e assumiu o fato. Ainda que, naquele momento, não carregasse com ela questões políticas, não deixou de ser um ato político a inserção de sua técnica de dança no contexto brasileiro.

O cursus era completado pelo Jazz, ensinado por Marilena Silva; Interpretação, com Maurice Vaneau; e Expressão Corporal, ministrada por mim. Inicialmente vinculada à consciência corporal, a designação "expressão corporal" foi aos poucos se desgastando, acabando por ser pejorativamente associada à "ameba com angústia". Minhas aulas constavam de alongamentos, fortalecimento do centro do corpo no chão e exploração de movimentos, como saltos moles, deslizamentos e escorregadas em um e nos dois pés, equilíbrios, empurrões, pequenas vibrações. O material praticado nas aulas já visava levantar vocabulário para a coreografia Pulsações. Aliás, minhas aulas sempre foram mais vibrantes quando desembocavam em um exercício cênico.

Em meados dos anos 1970, o ritual da aula diária era como que sagrado. Posteriormente, firmaram-se as academias e formas menos ortodoxas, tais como nadar, andar e correr foram substituindo o estar concentrados em si mesmo que uma aula proporciona e exige, mais que relacionar o corpo ao entorno. Práticas exotéricas foram substituindo as esotéricas, ou seja, houve um movimento "para fora" que substituiu a concentração proporcionada pelos estúdios, fruto de uma postura igualmente artística que passou a procurar no corpo a corpo com o entorno o fortalecimento de suas propostas.

O ciclo de aulas diárias gratuitas no Teatro Galpão era frequentado por atores como Denise Stoklos, Rosi Campos, Jonas Bloch, Antônio Pitanga e outros. A atividade, como mencionado, permitiu que a dança deixasse de ser uma atividade exercida quase que exclusivamente por jovens burgueses pertencentes a uma elite financeira. Abria-se também a 
atividade a um elevado número de rapazes. Ismael Ivo, por exemplo, começou a praticar aulas de dança ali. O jovem dançarino negro, morador da periferia, era frequentemente convidado por outros colegas para almoçar em suas casas, incentivando-o a prosseguir. Nomeado em 2017 diretor artístico do Balé da Cidade em São Paulo, sua cidade natal, Ismael é um artista da dança reconhecido na Europa, sobretudo na Alemanha. Diretor de festivais. Um dos cursos que Ismael seguia era o de Interpretação. Em suas aulas, Vaneau propunha temas para que os alunos improvisassem. Em depoimento que me foi concedido em 12 de setembro de 2014, disse-me Ismael: "As improvisações propostas por Maurice Vaneau levavam cada um a encontrar a própria criatividade, o encontro consigo, com seu Eu profundo e com as próprias possibilidades de movimento". Muitos ex-alunos do Galpão associavam as aulas de Vaneau às minhas, em uma referência ao exercício da própria criatividade, conforme é possível deduzir dos depoimentos anexos.

Em 7 de Setembro de 1975, o Galpão foi assunto de matéria intitulada "Teatro de Dança: aulas e espetáculo", no jornal City News, a partir de entrevista concedida ao jornalista e crítico de teatro Roberto Trigueirinho, entusiasta de Caminhada, que já apontara a junção entre dança, som, percussão e movimento promovida pela trilogia - o mesmo jornalista escrevera em 15 de dezembro de 1974, no mesmo jornal: "Há uma totipotência. Uma certeza de que se vai para algum lugar. Que não se vai assistir à falência do teatro frente aos agentes asfixiantes que andam por aí”. A entrevista para a reportagem sobre o Galpão ocorreu no "tosco camarim do Teatro de Dança" segundo as palavras do jornalista. Maurice Vaneau esclareceu que, a pedido de Marilena Ansaldi, que ocupava a Câmara de Dança, ele havia elaborado dois projetos: um a longo prazo e outro, urgente-urgentíssimo, destinado a cursos e atividades, colocado em prática desde o mês de março daquele ano, com um orçamento previsto apenas para um período de quatro meses, suficiente para atender e suprir somente o primeiro semestre. Na mesma entrevista, à qual estive presente, Maurice detalhou o processo de seleção aos cursos, quando se perguntava ao aluno qual era o seu objetivo, esperando-se uma resposta clara. Mencionou ainda a postura acomodada da classe teatral, que recusava, em sua maioria, aquela nova experiência, apegando-se a antigos clichês das aulas de dicção. Os bailarinos clássicos também não gostavam de arriscar-se. Maurice concluiu: "Só quem sempre reagiu e tem reagido aberto é o público virgem, aquele que realmente não está condicionado e aceita o novo. A gente já provou que a dança existe, que há quem por ela se interesse e, principalmente, que ela precisa existir”. Nosso trabalho artístico era considerado enquanto um “espetáculo de vanguarda”, embora a palavra já se encontrasse agonizante mundialmente. 
Dando início ao primeiro Festival Internacional de Teatro em São Paulo, realizado no mesmo ano de estreia de Caminhada (1974), Ruth Escobar apresentou, no Theatro Municipal, Life and time of Dave Clark, de Bob Wilson. Problemas com a censura levaram à mudança do nome, intitulado, originalmente, Time and life of Joseph Stalin. Roberto Trigueirinho comparou o impacto nele produzido por ambas as montagens, Caminhada e Life and time of Dave Clark ${ }^{302}$. "Totipotência" era a designação do jornalista ao nosso trabalho, apreciado, sobretudo, por um público jovem.

O Galpão foi se tornando minha segunda casa. Minhas aulas tinham início ao meiodia, e eu por lá ficava até cerca de meia-noite. A ousada e inovadora empresária e atriz Ruth Escobar, proprietária do conjunto que leva seu nome até hoje e que compreendia o Teatro Galpão, foi responsável por montagens teatrais antológicas, algumas das quais pude testemunhar, como Cemitério dos automóveis, de 1968, protagonizada por Stênio Garcia em uma antiga garagem da Rua 13 de Maio.

No ano seguinte, Ruth produziu o Balcão, de Jean Genet, com cenografia do seu então marido Wladimir Pereira Cardoso, a cuja montagem tive a oportunidade de assistir. Ambos não hesitaram em colocar abaixo o complexo teatral Ruth Escobar e montar um imenso balcão do qual os espectadores assistiam a peça que acontecia alguns andares abaixo, no nível do chão. As memoráveis edições do Festival Internacional de Teatro que Ruth realizou inspiraram o diretor contemporâneo Antônio Araujo a realizar a Mostra Internacional de Teatro, já em sua quarta edição em 2017, ainda que em proporções mais modestas devido à crise financeira no País, segundo afirmou o diretor na abertura da primeira mostra.

Ruth, certamente, priorizava as questões artísticas às administrativas, não atentando suficientemente, enquanto locadora, às suas obrigações contratuais com a Secretaria de Estado da Cultura, a locatária. Nesse quesito, enquanto gestora, era negligente. Os banheiros apresentavam problemas de encanamento e cheiravam mal. As privadas encontravam-se frequentemente entupidas. Além disso, como em tantos outros teatros, o local só recebia luz natural quando as portas estavam abertas e, por isso, cheirava a mofo. Os bordereaux fornecidos às geralmente pobres companhias ao final das apresentações eram inexatos. A estrutura das companhias, geralmente precária, impedia escalar alguém designado para o controle da bilheteria. Recentemente, um amigo lembrou ter visto uma de minhas filhas, ainda criança, assumindo a tarefa.

\footnotetext{
302 TRIGUEIRINHO, Roberto. Teatro de dança: aulas e espetáculo. Jornal City News, São Paulo, 15 dez. 1974, p. 35 .
} 
Colado ao teatro, havia um pequeno bar, diminuto, com o pé-direito muito baixo, baixíssimo. Havia umas poucas mesas para fora. Descíamos a escada da porta de serviço junto ao palco, mais alguns degraus e lá estávamos, ao ar livre. Ao lado do bar, uma longa e bela escada ligava a Rua dos "Inglezes" à Rua 13 de Maio, local acalentado por mim para uma edição de Corpo incrustado, que prevê o amoldar dos corpos aos volumes presentes no ambiente, fazendo surgir, do contato, o movimento, em uma incursão da dança no espaço urbano. Recentemente, a Prefeitura Municipal de São Paulo renovou as escadarias, inauguradas em 1929 pelo então prefeito Pires do Rio e tombadas pelo Patrimônio Histórico em 2002. O espaço recebeu seu primeiro restauro em 2006. Conforme dito inicialmente, a menos de duzentos metros do Teatro Galpão, em uma casa construída em um terreno em declive, como as outras da vizinhança, residia o mencionado ator Sérgio Mamberti, que, se não comparecia às aulas para trabalhar o corpo, a exemplo de muitos de seus colegas, estava sempre pronto para uma boa conversa.

\subsection{A presença de diretores teatrais em espetáculos de dança}

Em 1975, no primeiro ano completo de atividades do Teatro de Dança Galpão, o nosso grupo, o Teatro de Dança de São Paulo, produziu três peças de dança: Caminhada, Allegro ma non troppo - a primeira incursão autoral de Maurice - e Pulsações. Houve outras estreias, como Isso ou aquilo? e Auké, além de apresentações do artaudiano ator argentino Benito Gutmacher, com Essências, e das companhias estáveis - o então Corpo de Baile Municipal e o Ballet Stagium e uma aula-espetáculo memorável oferecida por Alwin Nikolais, além de oito conferências com Renée Gumiel e Ismael Guiser e projeções de filmes sobre dança.

Em comum entre as estreias mencionadas, houve a participação criativa de diretores de teatro: Maurice Vaneau, em Caminhada; Iacov Hillel, em Isso ou Aquilo?; e Francisco Medeiros, em Auké, de Ruth Rachou. Outro ponto em comum foi o fato de a dança ter, literalmente, aterrissado no real, quando estabeleceu vínculos com a sociedade, fincou os pés no obscuro entorno de então e eliminou qualquer resquício etéreo. O Galpão passou a ser uma opção para um público curioso, que se sentia atraído pelo que era feito ali. Se as montagens teatrais seguiam uma corrente engajada ou outra voltada a questões estéticas, é possível dizer que as propostas coreográficas do Galpão uniam ambas as tendências, estabelecendo elos efetivos com o real, deixando para trás o bailarino etéreo, idealizado. 


\subsection{A participação criativa do elenco: a conexão consigo, o início dos processos colaborativos}

Antes hierárquicas, verticais, as relações de trabalho na esfera cênica tenderam a tornar-se colaborativas, horizontais. Fato relevante é que passou a existir a participação ativa dos elencos. Instigo os dançarinos a encontrar soluções próprias, assemelhando-se ao processo da maiêutica socrática, quando um saber dormente é solicitado e desperta. Se um participante souber tocar um instrumento, provavelmente vou encaixar o talento em alguma cena. $\mathrm{O}$ foco passa a ser a plenitude de cada participante do elenco. Em francês, há a boa palavra “épanouissement”. Passo a querer ser eu mesmo, sem artificialismos. Importam a presentificação, o habitar, a escuta do corpo, em suma. Quero aproximar-me do si em mim. Principalmente, não representar suprime a mediação.

Esse movimento de interioridade é contrário ao show off da sociedade do espetáculo, que remete à exuberante representação. A sintética expressão de Guy Débord ${ }^{303}$ une política e arte, aponta para o artificialismo e conota o consumismo exuberante inserido no capitalismo tardio no qual proliferou o pós-modernismo, bem como do sentido de espetáculo como palavra proveniente da opsis (ou visão), destinado a encher os olhos do espectador. Aparentemente, o movimento em direção a si mesmo vincula-se à uma postura própria ao modernismo, com a valorização do Eu do artista, pessoal e inventor. Porém, desse movimento em direção a uma pessoalidade despojada, emerge uma postura de alteridade que denominarei singularidades coletivas. Guattari cunharia o termo "transindividual" enquanto nova postura epistemológica perante o mundo ${ }^{304}$, correspondendo à intersubjetividade ou ao diálogo intercorpos.

Félix Guattari, o pensador francês parceiro de Gilles Deleuze em tantos escritos, diria que "a única finalidade aceitável das atividades humanas [...] é a produção de uma subjetividade que auto-enriqueça continuamente sua relação com o mundo"305. Seu conterrâneo Michel Foucault propôs a indagação sobre o que faz de alguém alguém ou como a pessoa se singulariza; o que fez você de você mesmo, admitindo que o contorno que adquire

\footnotetext{
303 Nome maior do Situacionismo francês (1958-1972), a Internacional Situacionista tinha cunho político e artístico e promovia uma crítica radical da vida cotidiana e artística no capitalismo, defendendo a contestação como princípio epistemológico.

${ }^{304}$ GUATTAR, Felix; ROLNIK, Suely. Culture : un concept réactionnaire?, 7 out. 2008. Disponível em: $<$ http://www.cip-idf.org/article.php3?id_article=4025>. Acesso em: 15 mar. 2017.

${ }^{305}$ GUATTARI apud BOURRIAUD, 2009, p. 145.
} 
o corpo individual encontra-se diretamente vinculado ao coletivo apreendido em espaço aberto. Pina Bausch estabeleceu uma distinção entre o pessoal e o privado. Penso que o privado concerne exclusivamente a mim, enquanto o pessoal é ou pode ser abrangente. Desde Jean-Paul Sartre, admitiu-se que a existência constitui o ser, mas, na contemporaneidade, o vínculo da pessoa com o entorno, produzindo o convívio, adquiriu novos contornos, até atingir o conceito de "transindividualidade", que recoloca a subjetividade inevitavelmente aliançada com o mundo.

A revelação pelo despojamento ou o desocultamento de si pode atingir a coletividade, estabelecer alianças com o entorno e promover a relação e o ir e vir do si com o ambiente. Em outras palavras, o ser despojado estará mais apto ao convívio, a trocar com o mundo da vida, e poderá atingir vários seres humanos. $\mathrm{Na}$ dança da atualidade, a avalanche de depoimentos pessoais ou relatos autobiográficos é, em grande parte, devida à transformação de paradigmas resultantes da crise da representação, quando os dançarinos passaram a focar sua estrutura interna - seus ossos, seu esqueleto, a musculatura profunda que os sustenta, seus fluidos, seus órgãos -, conectando-se consigo e verificando como o movimento circula no corpo. Os dançarinos passaram a querer explorar qualidades de movimento próprias, e não mais seguir um modelo externo, o que tornou o ato de coreografar questionado.

A crise da representação política encontra-se na ordem do dia. Construída a partir do Renascimento, que destacou o papel soberano do ser humano, os partidos políticos puderam constituir-se enquanto facções institucionalizadas destinadas à representação parlamentar. Isso se torna evidente no Realismo, quando o pragmatismo dos fatos se sobrepõe a qualquer certeza, consolidando-se no Ocidente no século XIX. No pós-Segunda Guerra, ou, mais especificamente, desde o início da década de 1950, a democracia representativa nas sociedades pós-industriais passou a abranger organizações trabalhistas, movimentos sociais e associações civis. Hoje, no século XXI, o abalo: investidas reacionárias, teocracias, questionamentos e insatisfações generalizadas, bastando lembrar os acontecimentos em Barcelona, na Espanha, em 2011, e os movimentos nas ruas do Brasil em 2013.

Se é verdade que os artistas são dotados de antenas e antecipam acontecimentos, não sei, fato é que a crise da representação, hoje tão evidenciada nas aspirações políticas, manifestou-se e tomou corpo nas artes, o que fez emergir a formação organizacional colaborativa, presente em muitos coletivos. Os modos organizacionais hierárquicos caducaram. Emergem os movimentos sociais e regride a confiança nos modelos de representação política. A diferença entre as criações coletivas, notadamente as do grupo norteamericano Living Theatre, de Julien Back e Judith Malina, cuja montagem de Paradise now, 
de 1968, tornou-se célebre em relação aos coletivos atuais, é que, no período anterior, as funções eram exercidas por todos os integrantes, enquanto, no atual, encontram-se definidas e delimitadas. Antônio Araújo, coordenador do Teatro da Vertigem, chamou o sistema em que vigoravam as criações coletivas de "democratite". Ele explica:

O enunciado é sempre coletivo, mesmo quando parece emitido por uma singularidade solitária... Por mais que haja uma direção artística forte, o grupo não funciona atrelado a uma única vontade autoritária, as funções são compartilhadas e as escolhas estéticas, ideológicas e processuais são debatidas por todo o coletivo de artistas... A concretização do plano estético é vital para a potência da obra oferecida ao espectador... Não se eliminam as especialidades, elas são fomentadas e convivem ${ }^{306}$.

Foi quando houve o desaparecimento do escritor de gabinete, que fora, desde a Antiguidade, a figura mais respeitada em montagens teatrais. A dramaturgia buscada pelos coletivos, que costuram livremente as antes distintas linguagens artísticas, expandindo suas fronteiras, faz com que o dramaturgo acompanhe o processo de ensaios e vá se adaptando ao material gerado pelos experimentos e improvisações. À era do autor literário, seguiu-se a do diretor onipotente, período dos anos 1980 em que o teatro passou a pensar-se a si mesmo, tratando de questões inerentes ao métier, ilhando-se.

Nas artes cênicas, trata-se de presentificar, e não mais representar. Em Diferença e repetição, Gilles Deleuze nos diz:

[...] a representação já é mediação. Ao contrário, trata-se de produzir, na obra, um movimento capaz de comover o espírito fora de toda representação; trata-se de fazer do próprio movimento uma obra, sem interposição; de substituir representações mediatas por signos diretos; de inventar vibrações, rotações, giros, gravitações, danças ou saltos que atinjam diretamente o espírito. Esta é uma ideia de homem de teatro, uma ideia de encenador ${ }^{307}$.

Muitas foram as produções conjuntas entre mim e Maurice Vaneau. Havia, entre nós, a decalagem de uma geração. Sólidos diretores como os dois Maurices - Béjart e Vaneau tinham por hábito o de deter nas próprias mãos as rédeas de todas as marcações cênicas, bem como o controle de todos os elementos constitutivos da mise-en-scène, ao passo que minha

\footnotetext{
306 SILVA, Antônio Carlos de Araújo. A encenação no coletivo: desterritorializações da função do diretor no processo colaborativo. 2008. Tese (Doutorado), Escola de Comunicações e Artes, Universidade de São Paulo, São Paulo, 2008, p. 179.

${ }^{307}$ DELEUZE, Gilles. Diferença e repetição. 2. ed. Tradução Revista de Luiz Orlandi e Roberto Machado. São Paulo: Edições Graal, 2009, p. 29.
} 
geração, nascida em torno dos anos 1950 e que iniciou a atuação artística na primeira metade dos anos 1970, alterou a visão e o procedimento.

\subsection{Nomenclaturas: Dança-teatro, contemporânea, dramaturgias coreográficas}

O grupo que formamos, com Vaneau e eu formando o núcleo estável, recebeu o nome de Teatro de Dança de São Paulo. A escolha foi de Vaneau. Um nome sólido, segundo ele. No final da década de 1990, foi renomeado Célia Gouvêa Grupo de Dança. A palavra "companhia" - tão empregada, que, por vezes, esquece-se de seu sentido etimológico de repartir ou partilhar (“com") o pão ("panne" ou "pannis") - manteve-se, principalmente, por aquelas que contam com uma sólida estrutura financeira, como tantas companhias oficiais. Outros, como o artista da dança João Andreazzi, ficaram apenas com a palavra "cia.”, dita em português. Muitos são os que se serviram do nome do coreógrafo para intitular suas companhias - marca ou fruto de narcisismo? O termo "companhia" transmudou-se em outros, tais como "grupo", "núcleo", "coletivo". Estes se alastraram no início da década de 1990 trazendo como marca, diferentemente das criações coletivas dos anos 1960, o fato de manterem definidas as funções. Não se pode dizer que nossa estrutura de trabalho fosse coletiva: convidávamos artistas para participarem de um projeto dirigido por nós, e o elenco de Pulsações foi formado pelos alunos mais avançados do curso no Teatro de Dança Galpão.

Inúmeras são as denominações: Teatro Coreográfico (Sandro Borelli), Coreodramaturgrafia (João Andreazzi), Coreodramaturgia (Joana Lopes), Coreografia (Daniel Kairós), Teatro e Dança (Mariana Muniz). “Tanztheatre”, a matriz. Termo cunhado por Kurt Jooss ainda na década de vinte, tornou-se colado à linguagem de Pina Bausch. Foi em sua companhia de dança que o termo "dramaturg" (ou dramaturgo) afirmou-se, função que recebeu inúmeras acepções. Mordaz, Maurice Vaneau certamente consideraria o termo "coreodramaturgrafia" tarabiscoté, ou seja, demasiado complicado.

Exponho minha concepção: dramaturgia, em dança, é a ligação, a coerência que se estabelece entre os vários elementos que constituem uma peça. Para Maurice Vaneau, o dramaturgo de nossas peças era ele. Digamos que eu jogava lá diversos elementos e Vaneau os organizava. A linguagem investigativa praticada ali pode ser chamada de dança-teatro: “A dança se converte em dança-teatro quando o ponto de partida para criar uma obra deixa de ser a técnica, o argumento ou o texto, para passar a ser um determinado campo de 
heterogeneidades. Corpos, vozes, palavras, sabores, imagens, cada um povoado pelos outros ${ }^{308}$. Convém acrescentar que o ponto de partida não é composto pelos recursos de que iremos nos servir para construir nosso trabalho. O impulso motor é, antes, constituído pelo tema a ser desenvolvido.

Para Patrice Pavis, a "dança-teatro dos anos setenta marcam o retorno a uma arte mais figurativa, mais engajada e ancorada na história, mais atenta às histórias bem contadas, como reação à radicalidade das vanguardas" ${ }^{309}$, em contraponto à abstração e ao formalismo da dança pós-moderna. Lembro sempre que o fenômeno pós-moderno foi estadunidense. A dança baseada no movimento não implica que possa ser rotulada como a dança do "mexamse, mexam-se", dada a amplitude e profundidade que a matéria movimento oferece. Uma amiga americana disse-me certa vez: "Dance is boring", ou seja, que a dança aborrece, que a dança, sozinha, não faz um espetáculo, necessitando juntar-se a outras linguagens. Tudo depende do modo como se organiza, e nem todos se encontram aptos à apreensão do movimento.

Quanto às funções criativas, nas fichas técnicas dos programas, houve modificações progressivas: em Caminhada, a primeira parceria entre mim e Maurice Vaneau, foi divulgada, pela primeira e única vez, enquanto "argumento, coreografia e direção conjuntos". Posteriormente, meu trabalho passou a ser grafado "concepção e coreografia" e, mais tarde, “criação coreográfica", enquanto Maurice ficou responsável pela "produção", "programação visual" e "direção". Passei a evitar a palavra "criação", que remete a uma atividade exclusiva de Deus. "Invenção" é melhor. Por vezes, havia referência a "roteiro e coreografia". A palavra "roteiro" liga-se a uma trama - ou narrativa - e prevê uma sucessão de cenas ou quadros, enquanto "concepção" conecta um fluxo ou projeção de imagens.

Maguy Marin, simples e direta, empregava apenas "coreografia". Os valores modernistas ainda eram fortes, tais como a utopia de transformação do mundo por meio da arte, bem como o conceito de "originalidade", "do artista inventor, herdeiro da noção romântica de gênio - segundo o imaginário das vanguardas históricas"”310.

Para Helena Bastos,

\footnotetext{
${ }^{308}$ LEPECKI, André. "No estamos listos para el dramaturgo": algunas notas sobre la dramaturgia de la danza. In: Repensar a dramaturgia: errância e transformação. Murcia, ESP: Centro Párraga, 2010. p. 169. Tradução nossa.

${ }^{309}$ PAVIS, Patrice. Dicionário de Teatro. São Paulo: Ed. Perspectiva, 2011. p. 83.

310 FABBRINI, Ricardo. Arte relacional e regime estético: a cultura da atividade dos anos 1990. Revista Científica/FAP, Curitiba, v. 5, p. 11-24, jan./jun. 2010. p. 21.
} 
Coreografia hoje pode ser compreendida também enquanto impulsos de transformações que neste caso, se posiciona nas margens ou periferias enquanto escolhas. Uma concepção como um trabalho arqueológico de escavação nas ruínas da modernidade ocidental em busca de elementos ou tradições suprimidas ou marginalizadas, representações particularmente incompletas porque menos colonizadas pelo cânone hegemônico da modernidade que nos possam guiar na construção de novos paradigmas de emancipação social ${ }^{311}$.

Não se pode dizer que nossa estrutura de trabalho fosse coletiva: convidávamos artistas para participarem de um projeto dirigido por nós. Constato, até os dias atuais, uma disputa pela autoria entre elenco e propositor, quando o resultado do trabalho é bom.

Vingou a expressão "artista da dança" a todos os envolvidos. Do mesmo modo que as matérias ensinadas por um professor universitário passaram a ser ecléticas, reunidas pelo termo "teoria", a prática do amálgama entre as artes resultou na designação, simplesmente, de "artista". O propositor, para o colega carioca João Saldanha, passou a ser "artista coreógrafo". No que ainda tange às nomenclaturas, fato curioso quanto aos títulos que observo, recentemente, em coreografias produzidas e/ou apresentadas em São Paulo é a ênfase no prefixo, tais como "In-saio", "Re-volta", "Entre-tanto", "Vi-vidas" e outros.

\subsection{A aliança entre conexão política e investigação estética}

Ampliaram-se novos entendimentos da relação entre arte e vida, ou arte e política, quando aparece o artista concernido com a polis e as questões que tal relação suscita. Concretizada estava a referência de Maryvonne Saison: "Testemunha da consciência de uma alteridade, da abertura ao mundo e à história"312. Alteridade ou alteridades?

Saison é considerada a provável introdutora do termo "teatros do real". O artista de teatro e dança francês François Tanguy durante a greve de fome promovida em 1995 na Cartoucherie de Vincennes por artistas como Ariane Mnouchkine e Maguy Marin para pressionar o governo francês a tomar posição frente ao conflito, já mencionado, que ocorria então entre a Bósnia e a Sérvia, teria empregado a expressão "teatros do real" para referir-se ao artista envolvido com os conflitos políticos do seu tempo.

\footnotetext{
311 BASTOS, Helena. Dança Corpos Vira Corpos. Trânsitos Compartilhados. Revista Sala Preta, São Paulo, n. 10, p. 155-162, 2010. p. 161.

${ }^{312}$ SAISON, Maryvonne. Les théâtres du réel: pratiques de la représentation dans le théâtre contemporain. Paris: Éditions L'Harmattan, 1998. p. 13.
} 
Desde os anos 1970, contávamos, no Brasil, com o farol guia de investigação estética concedido pelo Cinema Novo brasileiro, não cabendo, aqui, investigar a relação com a nouvelle vague francesa, nem tampouco com outros movimentos tais como o neorrealismo italiano ou a dimensão grandiosa do russo Sergei Eisenstein. O épico filme Deus e o Diabo na Terra do sol, de Glauber Rocha, lançado em 1964, é exemplo nítido da consciência mítica aliada à aridez da terra, fatores estes que produzem seres humanos imersos e debatendo-se em um caldeirão de vida-morte e ao qual o som das Bachianas de Villa-Lobos veio acrescentar uma adequação exemplar. A geração de cineastas brasileiros responsável pelo assim chamado Cinema Novo conjugava uma atitude política, pelo tratamento de temas brasileiros, aliada à renovação artística da linguagem cinematográfica, em uma espécie de junção entre arte e revolução, conforme a divulgação do recente documentário intitulado Cinema Novo, de Eryk Rocha. Além de Glauber, cito Rogério Sganzerla e Júlio Bressane como expoentes.

O ano de 1975, que se seguiu à estreia de Caminhada, foi um período em que o teatro encontrava-se amordaçado devido à ditadura militar. O vigor do Galpão fez com que Vaneau observasse que aquele espaço viera a ocupar o papel antes pertencente a grupos como o Teatro de Arena e o Teatro Oficina. Uma fértil via de escape encontrada pela gente de teatro, denominada "classe teatral", foi a montagem de musicais. Muitos "conta" constaram do repertório do Teatro de Arena: Arena conta Tiradentes, Arena conta Zumbi, Arena conta Bahia. Anatol Rosenfeld comenta:

A partir de nossa "gloriosa revolução" [o golpe militar de 1964], incrementou-se essa modalidade teatral. Muitas peças, transformadas em shows, apresentam cantos de protesto: Liberdade, Liberdade [1965], Opinião [1968], e mesmo Roda Viva [1968]. Os seguidores desse teatro são inspirados pelo cabaré europeu e foram muito conduzidos por Augusto Boal [1931-2009], como autor e diretor, e por Gianfrancesco Guarnieri [19342006]. São engajados politicamente e fazem grande esforço para dar aos espetáculos, também, bom nível técnico ${ }^{313}$.

Egresso do Teatro de Arena, o encenador e teórico Augusto Boal buscou e encontrou o modo brasileiro de representação, a exemplo das diferenças entre os atores ingleses e os norteamericanos - estes, mais descontraídos. Organizou, em 1968, no mesmo Teatro Ruth Escobar no qual o Teatro de Dança Galpão se alojava, a Feira paulista de opinião, espetáculo baseado no diário de Che Guevara. Intelectual consistente, Boal introduziu o método do coringa, que,

${ }^{313}$ ROSENFELD, 2009, p. 390. 
como o nome indica, permite a pluralidade de papéis, eliminando assim a figura do protagonista - no vocabulário do balé, denominado solista. Nas palavras de Paulo Bio Toledo, a encenação

[...] mais do que um espetáculo de teatro, era um ato artístico de enfrentamento, onde diversos artistas foram convidados a responder esteticamente a pergunta: "que pensa você do Brasil de hoje?". No programa do evento, em texto intitulado Que pensa você da arte de esquerda? $?^{314}$.

Tornado partícipe do teatro mundial, Augusto Boal, com seu método denominado Teatro do Oprimido, mesclou arte e vida ao propor agenciamentos teatrais em caixas de supermercado e vagões de metrô, na linhagem das performances. A proposta política de Boal fez com que, durante certo tempo, seu teatro político fosse considerado datado, quando foi um inovador que, a exemplo de muitos outros artistas, tais como Ariane Mnouchkine e Maguy Marin, afirmou ser engajado como cidadão, mas que a arte que produzia não poderia ser considerada engajada, pois a palavra fora deturpada, passando a conotar "panfletaria". Após sua morte, Boal obteve um reconhecimento mais justo e pleno de seu trabalho. O “dionisismo" presente no Teatro Oficina, corporificado por José Celso Martinez Corrêa, fez com que, para muitos, a proposta do Teatro de Arena, que tinha Boal como um de seus expoentes, parecesse "careta", convencional ou demasiado calcada na narrativa, juízo este desfeito pelo atual reconhecimento mundial das inovações promovidas por Boal, principalmente, no que concerne ao cunho performativo presente no Teatro do Oprimido.

Allegro ma non troppo, a primeira incursão autoral de Maurice, abordou o tema da poluição, que, então, já era atual. Em 1975, Maurice comemorava vinte anos de atividades teatrais no Brasil, desde que viera em turnê com o Teatro Nacional da Bélgica, em 1955, e fora convidado pelo empresário Franco Zampari, diretor do Teatro Brasileiro de Comédia, a dirigir aquela casa de teatro, devido à forte impressão provocada no público e na classe de teatro pela direção de Maurice para a peça belga Barabbas, de Michel de Ghelderode. Com Allegro, Maurice penetrava no que, até então, constituía a "minha seara”, e não desejava minha interferência na montagem. Muitos pensaram que a coreografia tinha sido composta por mim, mas quem a realizou foi Maurice. O tom da peça era de humor e sarcasmo, próprios a Vaneau. O elenco era composto por cinco dançatores: Luiz Damasceno, Aron Aron, Dolores Fernandes, Maurice e eu, que atuava vestida de um tutu curto e sapatilhas de ponta.

\footnotetext{
${ }^{314}$ TOLEDO, Paulo Bio. Arte de esquerda no pós-1964. In: CARVALHO, Sérgio; MATSUNAGA, Priscila; BOAL, Julian. Augusto Boal: atos de um percurso. Rio de Janeiro: Centro Cultural Banco do Brasil, 2015. p. 50.
} 
Figura 39 - Cena de Allegro ma non troppo

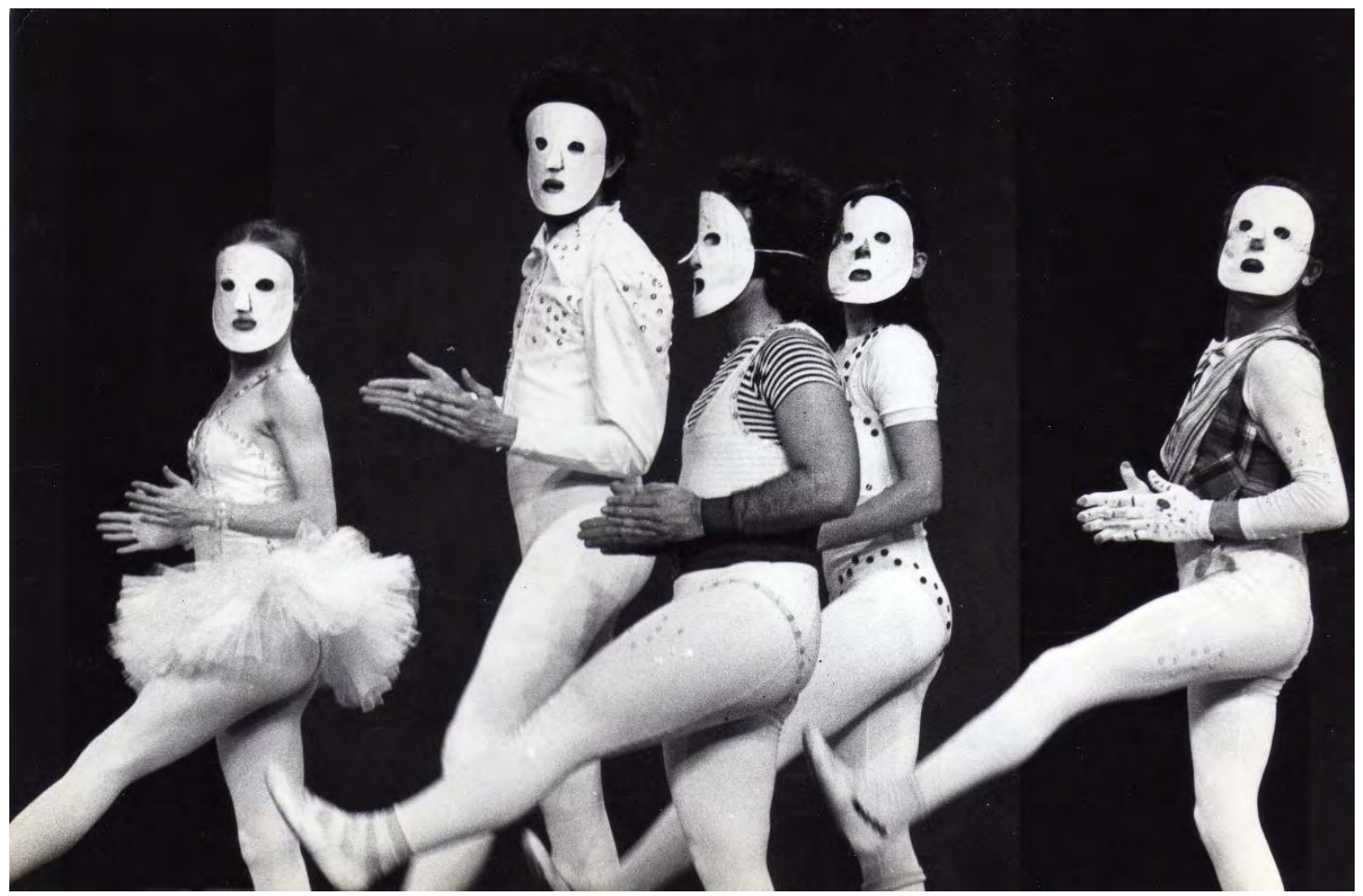

Célia Gouvêa, Luiz Damasceno Aron Aron, Dolores Fernandes e Maurice Vaneau (da esq. p/ dir.). Teatro de Dança de São Paulo, 1975.

Fonte: arquivo pessoal. Foto de Augusto Ramasco.

Figura 40 - Cena de Allegro ma non tropo

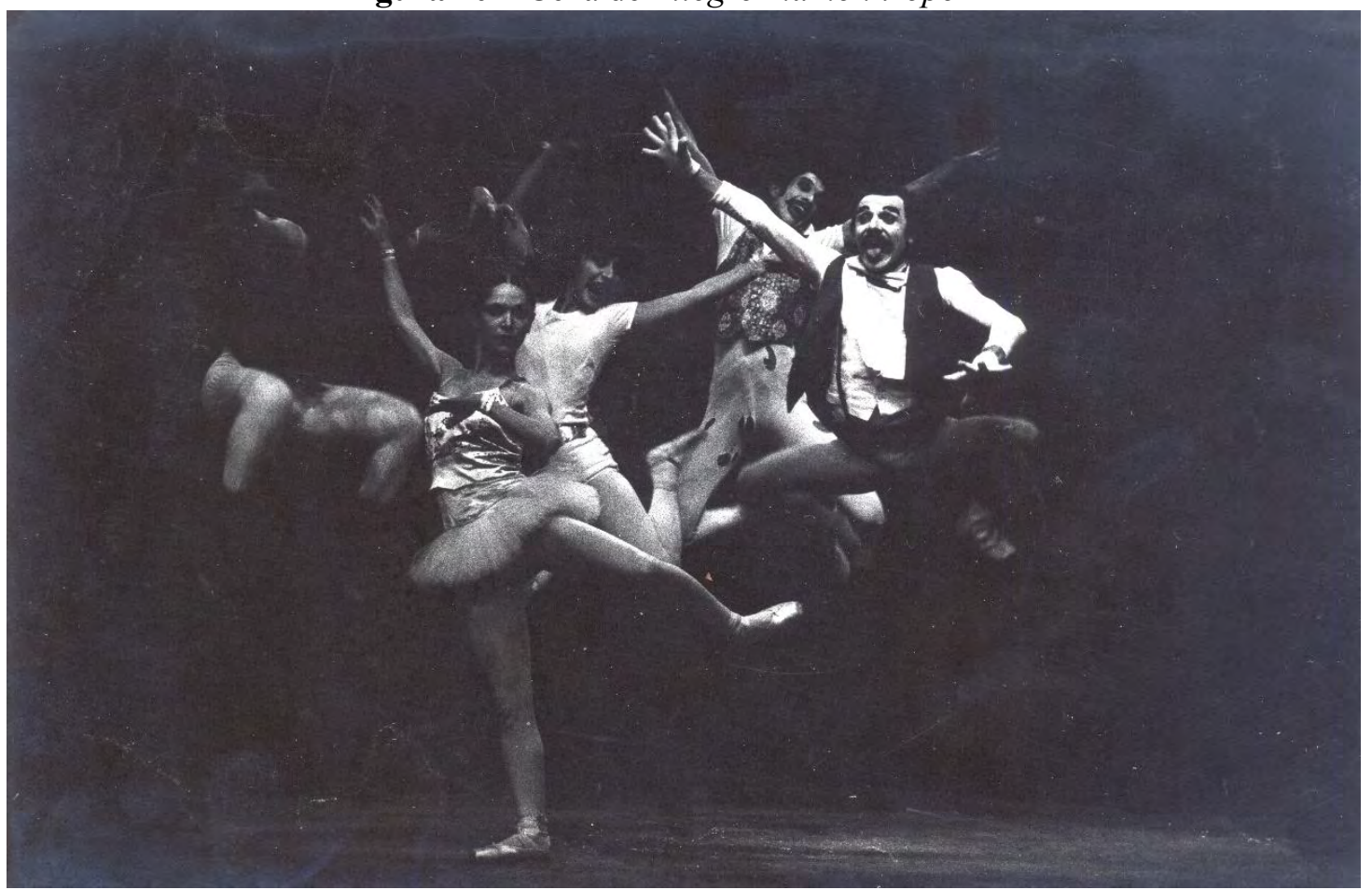

Luiz Damasceno, Célia Gouvêa, Dolores Fernandes, Aron Aron e Maurice Vaneau (da esq. p/ dir.). Teatro de Dança de São Paulo, 1975.

Fonte: arquivo pessoal. Foto de Augusto Ramasco. 
Durante as apresentações da peça no Teatro Galpão no mês de Agosto, Maurice foi convidado pelo então Secretário da Cultura da Prefeitura Municipal de São Paulo, Sábato Magaldi para assumir a direção do Departamento de Teatros, que incluía os teatros de bairro e as escolas de iniciação artística, de música e dança, além do Theatro Municipal, sua orquestra e seu balé. Maurice e Sábato nutriam uma admiração recíproca. O prefeito era o empresário Olavo Setúbal (1923-2008). A nomeação de Maurice foi recebida pela imprensa por manchetes como "nosso teatro nas mãos de um belga"315, apesar de, naquele momento, Maurice já ter se naturalizado brasileiro há cerca de dez anos. A motivação primeira que o levou a aceitar o convite foi a possibilidade de promover o diálogo entre as várias modalidades da arte. A gestão de Maurice foi ousada: não apenas tornou acessíveis os preços dos ingressos, o que permitiu a inclusão de novos frequentadores naquela tradicional casa de espetáculos, mas, entre outras ações, programou o grupo Dzi Croquetes, respondendo ao jornalista que questionou a inclusão do irreverente grupo naquela casa de espetáculos que já contávamos com uma censura, dispensando-se, por essa razão, os jornalistas-censores; acatou à proposta do músico Benjamim Taubkin para a realização de concertos à meia-noite, nos quais tocou, por exemplo, o músico Egberto Gismonti; realizou a Feira de Poesia e Arte, com a participação do nosso grupo de dança improvisando nas escadarias internas e encaixando seus corpos nas cariátides.

Após a temporada de Caminhada, proposta por Marilena Ansaldi, houve uma tentativa de um trio com Marilena, Maurice e eu, mas não deu certo. O insucesso da tentativa provocou a bifurcação entre Isso ou aquilo, o solo que Ansaldi decidiu encenar, em nada relacionado ao poema de Cecília Meireles, e o quinteto Allegro ma non troppo, de Maurice Vaneau. Marilena solicitou a Vaneau que encurtasse um pouco a temporada de Allegro para que ela pudesse estrear, o que não foi complicado, pois nosso público não era muito numeroso. Vou me deter um pouco mais nas produções de Marilena Ansaldi, não só por ter sido ela a fomentadora da existência do local, mas pela troca mais intensa que tivemos com a artista, figura referencial no período e a quem Maurice Vaneau chamava, assim como a Maguy Marin e Cacilda Becker, de bêtes de théâtre (ou animais teatrais). Em conversa com o jornalista, professor e escritor Sábato Magaldi, com quem Marilena se casou, foi elogiada a incursão feita por ela junto aos bailarinos Marilene Silva, Antônio Carlos Cardoso e Iracity Cardoso, denominada Dançaviva, em 1971, que teve a particularidade de entrevistar pessoas na rua, inclusive

\footnotetext{
${ }^{315}$ NOSSO teatro nas mãos de um belga. O Estado de S. Paulo, São Paulo, 3 set. 1975.
} 
motoristas de caminhão, perguntando se já haviam assistido a um espetáculo de dança. Já realizando pesquisas de campo, Marilena revelava-se bastante antenada.

Marilena principiava sua peça com as palavras: "Meu nome é Marilena Ansaldi, tenho 40 anos". Estávamos em 1975 e Marilena prestava um depoimento pessoal, tão presente em nossos dias. O fato atesta que nos encontrávamos em cheio em um limiar - ou, antes, liminar, no sentido literal - daquilo que esparge luz, naquele entrecruzamento entre modernismo, pósmodernismo ou contemporâneo que ofereceu como um de seus frutos a crise da representação, quando sai o personagem e entra "a pessoa".

Os espetáculos de Marilena eram considerados uma espécie que oferecia um pensamento de dança-teatro. Marilena foi sempre movida por pulsões e seus trabalhos cênicos refletiam isso. Uma de suas faces foi a ousadia. Naquele momento histórico, mantinha, porém, o esquema de uma estrela dirigida por um diretor. A exemplo de tantas atrizes de teatro, Marilena manteve o star system. Era o centro em torno do qual orbitavam os demais personagens. Após a estreia do sucesso de público Escuta Zé, a partir do texto de Wilhelm Reich, o não menos ousado Thales Pan Chacon relatou-me que os cachês oferecidos aos atores não era elevado. Marilena e o ator Rodrigo Santiago iriam bancar a produção. Thales, em acordo com os demais atores, propôs que todos cotizassem, com exceção de Zenaide, que optou por ser contratada. O sucesso foi estrondoso e os dançarinos atores, em início de carreira, ganharam bastante dinheiro. No início do período de ensaios, dirigidos por Celso Nunes, segundo Thales, os atores coadjuvantes nos quais ele se incluía, dedicavam-se a muita contrarregragem, como empurrar os grandes painéis sobre rodinhas para cá e para lá. Os painéis tinham sido incluídos na montagem de Allegro ma non troppo, de Maurice Vaneau, quando Marilena criticou o fato de os atores serem vistos por trás dos painéis. A ideia foi reaproveitada no cenário de Márcio Tadeu, que os tornou transparentes. Portanto, o fato de os atores serem vistos tornou-se proposital.

Realmente, os espetáculos de Marilena faziam mais sucesso que qualquer outra produção local apresentada no espaço do Galpão e atingiam um número maior de público. Porém, apesar do respeito e reconhecimento pela extroversão e coragem da coreógrafa, devo dizer que suas montagens mantinham uma estrutura convencional, com os papéis nitidamente distribuídos e separados. Apesar do risco inevitável, da aposta que toda produção sempre faz antes de se expor à resposta do público, as montagens de Marilena conservavam uma receita quase infalível de sucesso, próxima da estrutura teatral narrativa, enquanto o que eu e muitos outros faziam no Galpão advinha do puro gosto à experimentação. Possivelmente, o que fazíamos era dança-teatro, enquanto Marilena propunha um teatro de dança. 
Pulsações foi a última estreia do ano de 1975, completando o trio de nossas estreias pessoais daquele ano. Foi coreografada com alunos selecionados do curso e apresentada no mês de novembro. Pouco antes, no mês de outubro, apresentou-se no Galpão o artaudiano dançarino-ator argentino Benito Gutmacher e seu Teatro da solidão, que levou o crítico Linneu Dias a escrever: “Ao apresentá-lo, o Teatro de Dança dá mais um passo na surpreendente vocação que vem revelando: a de ser um santuário às criatividade e da inteligência, uma ponta de lança vanguardista, em meio à renúncia quase geral às experiências" ${ }^{316}$.

Se os três segmentos que compuseram Caminhada voltaram-se ao humano, Pulsações era calcada nas questões ligadas à forma, embora haja, inevitavelmente, um entrelaçamento entre ambas as questões. Termo muitas vezes rechaçado, desprezado ou diminuído por gente de arte como Klauss Vianna, "forma” remete a configuração, conversa entre elementos, disposição. Pode-se, então, questionar: é o mesmo que dramaturgia? O mesmo que coreografia? Vale pensar a questão. A supressão das dicotomias esteve sempre ligada ao meu modo de pensamento, como o ser humano habitado por fluxos energéticos, ao invés da ideia da dualidade entre corpo e mente.

Retomando Merleau-Ponty: em palestra proferida ainda na década de 1930 e, posteriormente, publicada com o título $O$ primado da percepção e suas conseqüências

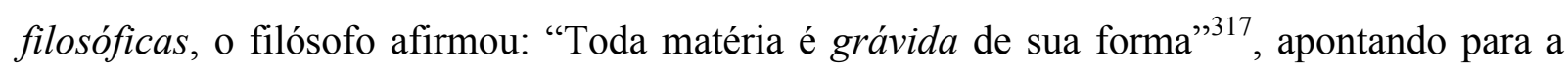
ideia de fecundidade, que lhe foi tão cara e que desenvolveu posteriormente.

A discussão remonta a Aristóteles. Como bem explica Leopoldo e Silva, em Aristóteles, há dois pares de noções que desempenham função estratégica: “[...] forma/matéria e ato/potência. A matéria é o indeterminado que se determina ao receber uma forma. A potência é a possibilidade, em si meramente indeterminada, que se realiza concretamente pela determinação de um ato" 318 .

Dito de outro modo, a forma enforma a matéria. A matéria é despotencializada, passiva. A "matéria prima" contém a forma em potência. Matéria e forma (morphé) constituem uma unidade, bem como potência e ato. A ousía é a substância, forma ou pensamento. As formas encontram-se no mundo das ideias ou na mente de Deus, enquanto a matéria pertence ao mundo da existência. O dualismo platônico torna-se claro: a transcendência é separada da imanência, a essência da existência.

\footnotetext{
${ }^{316}$ DIAS, Linneu. O Estado de São Paulo, São Paulo, 31 out. 1975.

317 MERLEAU-PONTY, Maurice. O primado da percepção e suas consequências filosóficas. Tradução: Constança Marcondes César. Campinas: Papirus, 1990. p. 42.

${ }^{318}$ LEOPOLDO e SILVA, 1996, p. 45-46.
} 
Conforme bem exposto pelo comentador François Stirn: "Aristóteles substitui idéias separadas por formas distintas, mas imanentes às realidades sensíveis mediante relações entre potência e ato"319. A causa formal aristotélica ocorre quando o processo chegou à sua finalidade, como quando a transformação do barro resultou em pote.

Para Hegel, ligado, como Kant, aos poetas do romantismo, o belo era a aparência sensível da ideia. A afirmação supõe que a ideia é anterior. Um artista, em posse de um conteúdo, passaria posteriormente à construção sensível. É bem verdade que existe um momento de concepção - ou visão - que é ilimitado, que antecede a construção, quando aparecem os problemas de como colocar pedra sobre pedra. Um artista pode estar simplesmente habitado, encontrando-se em estado criador, sem ter domínio algum do resultado do seu trabalho. Um vídeo em câmera lenta do pintor francês Henri Matisse (18691954) mostra sua mão hesitando se o traço continuará à esquerda ou à direita. É no fazer que o propósito adquire contornos próprios.

Lembrando a atribuição aristotélica exposta acima, é possível concluir que forma confundiu-se com formato e o que Aristóteles chamou de forma tornou-se conteúdo. É claro que, no século XX, já não se andava atrás da essência. Diz a crítica contemporânea:

As formas implicam um código, modos de codificação e descodificação. As substâncias como matérias formadas se referem a territorialidades, a graus de territorialização e desterritorialização. Mas há, justamente, código e territorialidade para cada articulação, cada uma comportando, por sua conta, forma e substância... A estrutura é o conjunto dessas relações e correlações [...]. Hjelmslev tinha conseguido elaborar uma grade com as noções de matéria, conteúdo e expressão, forma e substância. Esses eram os "strata", dizia Hjelmslev. Ora, essa grade já tinha a vantagem de romper a dualidade forma/conteúdo, pois havia tanto uma forma de conteúdo quanto uma forma de expressão ${ }^{320}$.

Para o filósofo Gaston Bachelard, as imagens são anteriores às ideias e conceitos. A palavra "cinema" tem "cine" (ou "imagem") em sua composição. Em Cinefilia - Invenção de um olhar, Antoine de Baecque constata que "o conteúdo de um filme, sua mensagem, se preferirmos, consiste integralmente na forma cinematográfica desdobrada pela mise en scène, não residindo na tese sugerida por um autor nem em seu roteiro, nem em seus diálogos",321.

\footnotetext{
${ }^{319}$ STIRN, François. Compreender Aristóteles. Trad. Ephraim F. Alves. Petrópolis: Vozes, 2006.

${ }^{320}$ DELEUZE; GUATTARI, 1995, p. 55-57.

${ }^{321}$ LEITE, Alcino. Cinefilia, a Invenção do Olhar. Folha de São Paulo, São Paulo, 6 fev. 2011.
} 
Do mesmo modo, o cineasta Federico Fellini costumava dizer que um filme é para ser visto e ouvido, realçando o papel concedido aos sentidos. Considero discutível a separação entre forma e conteúdo. Nos anos 1960, o comunicólogo canadense Marshall McLuhan (1911-1980) publicou “O meio é a mensagem”, cujo título já explicita o assunto tratado.

A forma não se submete nem é inferior ao conteúdo. A diretora teatral francesa Ariane Mnouchkine, do Théâtre du Soleil, sediado em Paris, afirmou ser no Oriente que essa forma será buscada. Por seu lado, Robert Wilson escreve: "O teatro de Bali, o Katakali indiano, a ópera de Pequim, ou o teatro Nô do Japão são todos formais, ao passo que na cultura ocidental, como disse André Malraux, o teatro foi circunscrito pela literatura" ${ }^{322}$. Há os que sustentam que a cultura veio do Leste para o Oeste, assim como outros consideram que o Oriente foi inventado pelo Ocidente. Há de se refletir se somos ou não parte do Ocidente, por não integrarmos o Hemisfério Norte, ou eixo centro-europeu.

Os últimos meses do ano de 1975 foram dedicados, sobretudo, à montagem de Pulsações. O start - ou gatilho - que deu início à nova coreografia ocorreu em uma noite passada em um camping na cidade de Atibaia, quando, durante toda a noite, escutei o ruído dos grilos, que formavam uma teia eletrizante e carregada da energia pulsante da natureza. Esses sons foram substituídos, posteriormente, pela música eletrônica do estadunidense Richard Maxfield. A intenção era a de promover a conexão com o universo físico, sideral. Cheguei a conversar com um físico, Silvio Vitiello, professor da Unicamp, casado com a bailarina Júlia Ziviani, professora de Dança no Instituto de Artes da mesma instituição. Consultei o professor para obter informações acerca do processamento da energia e das ondas gravitacionais e vibratórias observáveis com os instrumentos então disponíveis. Certo é que o trabalho sobre o movimento a partir das matérias primas da vida orientaria a montagem. Noções referentes às nebulosas, tais como peso, pressão, temperatura e gravidade, adequavam-se perfeitamente aos propósitos coreográficos, bem como a constatação das reações de núcleos de hidrogênio transformados em energia e partículas que, fusionados, produzirão estrelas, que contêm carbono em seu interior. A motivação para a montagem nasceu do contato com o trabalho coreográfico de Alwin Nikolais, em meados de 1975.

\footnotetext{
${ }^{322}$ GONÇALVES FILHO, Antônio. Angústia de ser moderno. O Estado de São Paulo, Caderno Sabático, São Paulo, 23 jun. 2012. p. 5.
} 
Curiosamente, tive a necessidade de ficar fora de casa no início do engendramento. A ruptura com a rotina proporciona, invariavelmente, novas disposições e visualidades. Fiquei em um hotel no bairro do Bexiga e depois na casa de Denise Stoklos, no mesmo bairro, em uma necessidade de romper com a rotina. Conheci as atrizes Elba Ramalho e Tânia Alves em início de carreira e recém-chegadas do Nordeste. Representavam, dançavam e cantavam em Viva o cordão encarnado, com direção de Luiz Marinho.

Primeiro, a vinda da companhia de Alwin Nikolais ao Brasil em 1975 proporcionou a descoberta de uma singularidade no trabalho do corpo e do movimento e abriu uma nova possibilidade. Reconheci o desdobramento, em vários corpos, da fascinante movimentação que havia reconhecido no corpo de Carolyn Carlson, ainda nos tempos do Mudra. Convidado por Maurice Vaneau, o coreógrafo realizou uma aula-espetáculo memorável no Galpão, propondo ao grupo de alunos estímulos que exigiam respostas rápidas e imediatas. A partir da produção de ruídos feitos por ele mesmo, Nikolais solicitou ao grupo ações corporais: andar, correr, parar, rir, chorar, cair no chão, encostar-se na parede, grudar o corpo na parte inferior desta, na superior, saltar, girar, gritar, abaixar-se, deitar-se, andar como se fosse gordo ou magro, etc. Propôs, em seguida, que alguém fizesse uma série de movimentos. O outro (partner) imitava, com uma reação imediata. A seguir, com o grupo colocado em círculo, um se movimentava e os outros o seguiam; depois, outro dava o movimento seguinte, e assim por diante. Finalmente, o grupo corria e cada um juntava uma parte do corpo à de outro. Os exercícios descritos foram, felizmente, por mim conservados em meu caderno de anotações.

O próprio coreógrafo dizia que importava mais a moção do que o movimento, o que implicava a iniciação, o impulso, o motor que nos faz mover (conforme exposto no primeiro capítulo, no item "Dança Moderna”). A moção é que gerava a emoção, para Nikolais. Avesso ao realismo e à narrativa, apesar de admitir a identificação a um herói, como Nureyev, por exemplo, reivindicava a identificação a uma alteridade, que pode ser ecológica ou ambiental. "Comecei a estabelecer minha filosofia do homem como um companheiro de viagem dentro do mecanismo universal total, em lugar do deus do qual emanam todas as coisas" ${ }^{\text {"323. Mais }}$ conhecido por suas peças multimídia - realizadas, segundo o coreógrafo, por curiosidade -, desenvolvia também um rigoroso trabalho sobre as dinâmicas do movimento. As noções de peso, eixo, pulso, volume, fluxo, espaço, tempo e, sobretudo, de energia eram corporalizadas,

${ }^{323}$ BRAGA, Gilberto. Alwin Nikolais. O Globo, Rio de Janeiro, 23 mar. 1975. 
provavelmente provenientes de seus estudos com a educadora alemã Hanya Holm, radicada em Nova York, que praticara os estudos de Émile Jacques Dalcroze e egressa da companhia de Mary Wigman.

A vivência no Mudra, com ênfase no humano, não tinha proporcionado as ferramentas para a construção coreográfica no espaço. A intenção era a de ampliar o conhecimento da matéria da qual a dança é feita, por meio da promoção de um deslocamento de perspectivas, projetando imagens abstratas correspondentes ao universo. Nunca me servi de recursos como o software Life Forms, empregado por Merce Cunningham. Preferi sempre o artesanal ao tecnológico.

Pulsações, um tratado sobre a energia, estreou em 20 de novembro de 1975, com um elenco de doze alunos-dançarinos: Ana Michaela, Bia Luiz, Debby Growald, George Otto, Georges Piette, Manoel Paiva, Henri Michel, Ismael Ivo, Jussara Amaral, Maria Célia, Mirian Giannella e Zina Filler; mais o violonista Saulo Wanderley. O nome do ator Antonio Pitanga consta da primeira convocação. Os ensaios eram feitos "aos pedaços", de acordo com os horários livres do elenco ou parte dele, antes ou depois das aulas e aos finais de semana. Não havia, como se pode supor, nenhuma remuneração extra por parte da Secretaria, e eu paguei do meu bolso os colants em tons pastel vestidos pelos dançarinos. Encontro, em meu caderno de anotações, a tabela de ensaios: "TODOS - sábados das 10 às 14h, domingos das 14 às $18 \mathrm{~h}$; de segunda sexta-feira das 14 às 16:30h e segundas e terças-feiras das 19:30 às 21h”. Sempre tive horror à leitura de descrições escritas de movimentos, indecifráveis. Refiro-me a coisas do tipo: "Raspa calcanhar, pé pela frente, por trás chuta; tombé, pirueta embaixo, em cima corre piqué-detourné, passé abre e fecha"; ou "Homem repouso, duas mãos no joelho, mulher passa uma perna no buraco e chuta outra, balança a cabeça do homem com um pé e outro. Tentar de costas, sacudir pernas em segunda não muito aberta, cabeça diz não" e assim por diante, muitas vezes misturando línguas diversas, colocando em uma só frase as palavras e expressões "chest", "penché torto com suspensão" e "saltos moles", por exemplo. Em Pulsações, "espargir água” (em português) aparece com frequência.

A primeira parte do programa foi uma proposta de Vaneau para que o público elegesse um acessório, um objeto com o qual os dançarinos improvisariam. Por exemplo: em uma noite chuvosa, um guarda-chuva. A proposta já apontava a direção pelo gosto de interagir com o público, tendência esta que foi se firmando nas décadas seguintes.

Na segunda parte, Pulsações, com 35 minutos de duração, era composta por quatro cenas: na primeira, os doze dançarinos dividiam-se em quatro grupos, ocupando o espaço. Em pé, de perfil, de costas ou ainda deitados, quatro grupos formados por três dançarinos 
movimentavam apenas uma determinada parte do corpo: pés, mãos ou ombros, por exemplo. Em seguida, agrupavam-se no centro e realizavam movimentos vibratórios com os calcanhares, provocando o encaixe de uma fila sob outra.

A cena seguinte teve como tema várias modulações de carregamentos, que geraram duetos com encaixes de corpos inusuais e curiosos. Aflorou, então, o interesse em explorar as qualidades do movimento e que regem a construção coreográfica, tais como dinâmica, direções, recorte em determinada parte do corpo que impulsiona o movimento iniciado sempre na ossatura, quantidade de energia empregada, etc. Portanto, ainda em 1975, como acréscimo ao trabalho do corpo interlinguagens, veio a necessidade de trabalhar e dominar a coreografia, a construção, e explorar as propriedades do movimento, como o movimento presente na estabilidade e no repouso e o tempo cinético, aquele no qual existe grande diversidade de dinâmicas empregadas.

Figura 41 - Cena de Pulsações

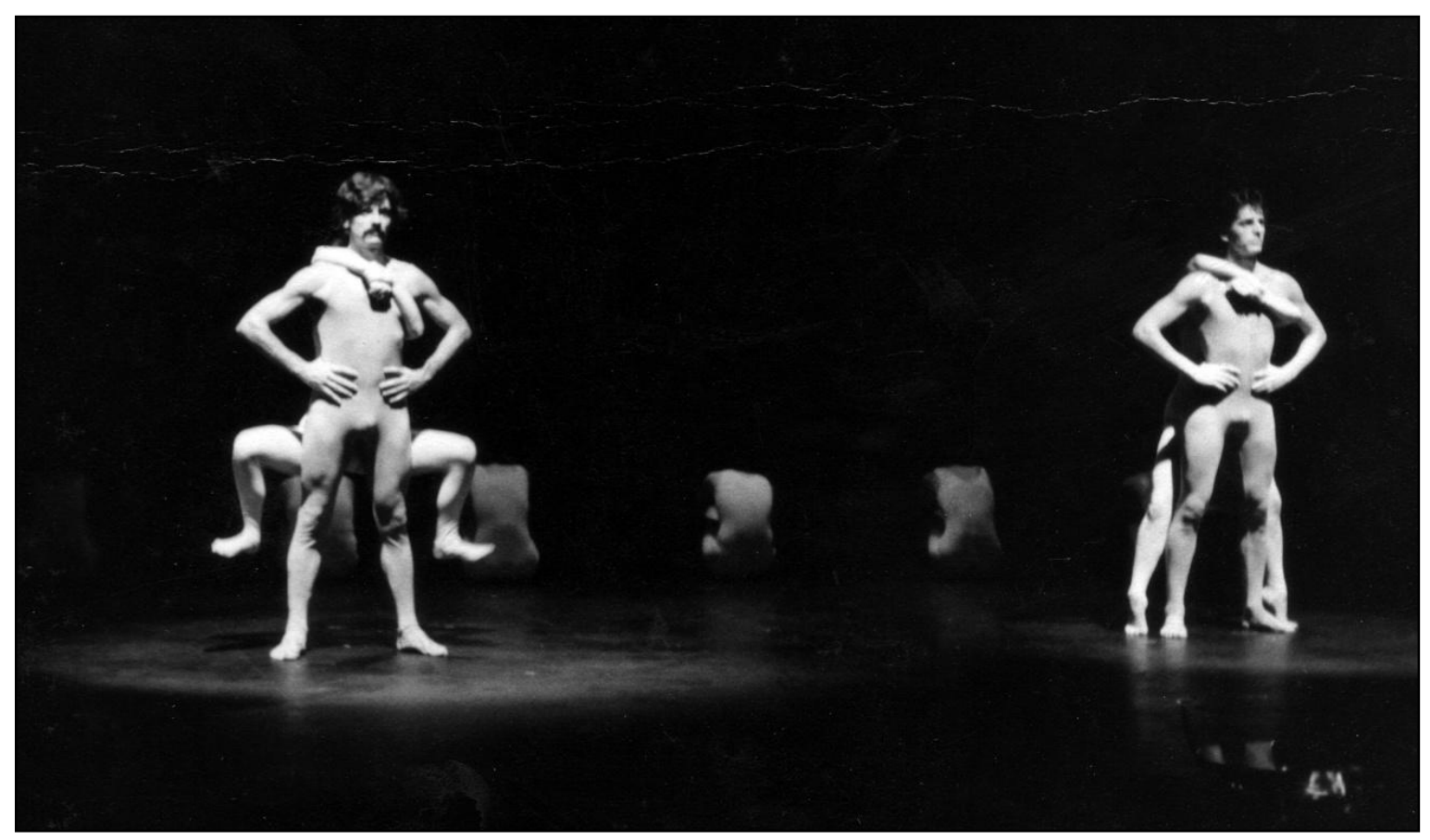

Henri Michel e Georges Piette (da esq. p/ dir.). Teatro Galpão, 1975.

Fonte: arquivo pessoal. Fotógrafo não identificado. 
Figura 42 - Cena de Pulsações

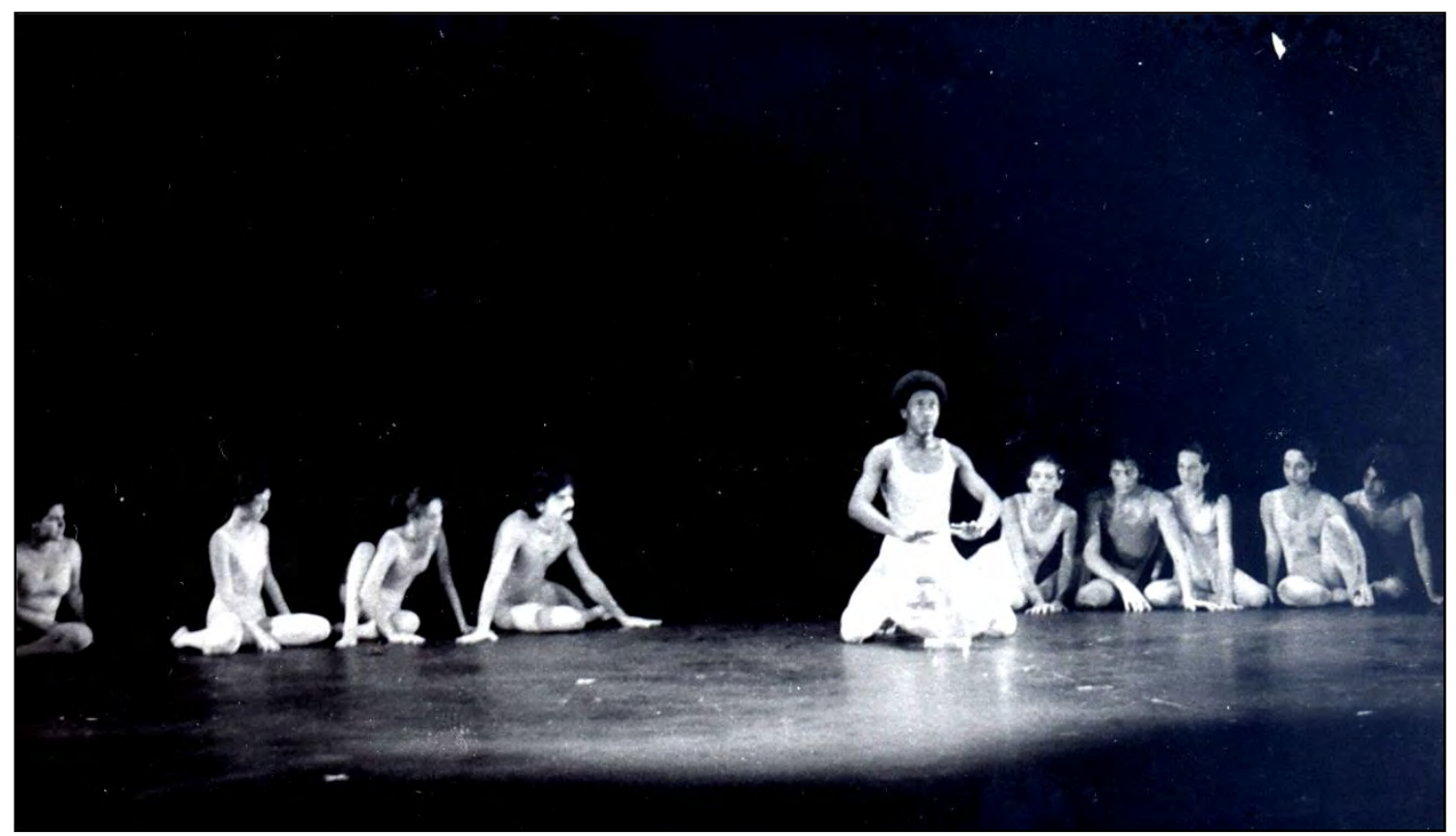

Ismael Ivo (primeiro plano) e elenco (segundo plano). Teatro Galpão. 1975.

Fonte: arquivo pessoal. Fotógrafo não identificado.

O acompanhamento musical era composto por frases sussurradas pelos dançarinos sentados e encolhidos, de costas, no fundo do palco. Foi solicitado, a cada um, escolher uma frase com doze sílabas. Cada um dizia a sua ao mesmo tempo, conservando o tempo métrico, o que gerava um grande enxame sonoro semelhante a um murmúrio. Posteriormente, o grupo reunia-se ao fundo, compondo formações assimétricas verticais que se desmanchavam para que outras surgissem, sucessivamente.

$\mathrm{Na}$ última cena, o estreante Ismael Ivo, situado no centro, à frente do palco, manipulava água em um recipiente transparente em acrílico, enquanto o grupo enfileirado ao fundo dele se aproximava. Encontravam-se bem próximos ao público. A água escorria e a sensação da água no corpo contaminava o público, gerando um clima lúdico e uma comunicação emocional. Havia uma potente entrega por parte dos dançarinos, possuídos por um intenso entusiasmo no sentido literal da palavra: portar, carregar um deus dentro de si, entusiasmo este que caracterizou essa empreitada do jovem elenco do Teatro de Dança Galpão, composto por muitos artistas que experimentavam o palco pela primeira vez.

Pulsações era, porém, despida de qualquer conotação psicológica, dado este que tanto irritou Artaud com relação ao teatro europeu. A maior parte dos movimentos foi minuciosamente marcada por mim e propus exercícios em duplas para encontrar encaixes e carregamentos. 
Uma tendência presente nas peças daquele período no Galpão era um forte envolvimento emocional com componentes políticos. Uma vez que a realidade apresentava-se repressora, abria-se um espaço para a manifestação de si e o contato com o outro. Considerava, porém, que, frequentemente, havia exagero nessa vertente. Resvalava-se, às vezes, para o festivo ou para o sexismo, sobretudo em apresentações efetuadas pelos próprios alunos. Ambas as tendências não me agradavam. Outro fato a registrar em boa parte do elenco era a confiança em si. Logo se sentiam prontos. Eu, que tanto havia ralado antes, no Mudra, até sentir-me razoavelmente pronta, surpreendia-me com tal postura.

Um dos comentários críticos referentes a Pulsações no balanço de final do ano do Suplemento Especial do Jornal O Estado de São Paulo, em dezembro de 1975, menciona “a originalidade e riqueza de concepções”. Curiosamente, Celso Curi intitulou seu comentário no jornal Última Hora de 28 de novembro daquele ano de "Pulsações: a retomada do real", em uma proximidade à expressão de Hal Foster "O retorno do real", tornada referência no teatro contemporâneo. Curi empregou a palavra "abertura" ao mencionar a atração exercida sobre “um público jovem e sedento de informações” pela proposta artística do Galpão e considerou Pulsações "um balé riquíssimo de imagens". Ao descrever o espetáculo em suas "contrações, meios movimentos e passos interrompidos de maneira brusca", apontou "Uma nova proposta, sem ,pernas altase, nem malabarismos”. Houve o reconhecimento de que era possível produzir uma boa dança, inovadora e criativa sem se recorrer, necessariamente, ao código clássico ou ao virtuosismo do corpo.

A ênfase no movimento não agradou a todos. Em uma das seis apresentações realizadas, o mímico Ricardo Bandeira levantou-se durante uma das cenas e bradou: "Mexamse, mexam-se!”. Realizamos ainda uma sétima apresentação na cidade de Votuporanga, no interior do estado de São Paulo. Recebi o convite de Antônio Carlos Cardoso para remontar a coreografia para o Corpo de Baile Municipal no ano seguinte. A coreografia estreou em julho de 1976 no Theatro Municipal de São Paulo, em um programa composto por coreografias do argentino Oscar Araiz, que muito produziu no Brasil. Pulsações não foi dançada pelos bailarinos da companhia oficial com o mesmo entusiasmo da montagem original, mas sua arquitetura, seu arcabouço, estavam lá presentes.

Com Caminhada e Pulsações, estavam plantadas as diretrizes e lançada a proposta estética voltada, de um lado, às questões humanas, à pessoa, à relação com o ambiente, com a sociedade; e, de outro, conjugada à primeira tendência, a exploração das propriedades oferecidas pelo movimento. Este não equivale ao frenesi nem no modernismo nem em 
qualquer outro tempo ou corrente artística, inesgotáveis e diferenciadas que são as qualidades do movimento em velocidade, dinâmica, energia e outros atributos.

\section{Nova York}

Devo abrir, aqui, um hiato em relação à continuidade de minhas atividades no Galpão, pois no início do ano seguinte, em 1976, parti a Nova York, voltando um semestre depois para o trabalho junto à companhia de dança oficial da cidade para com eles fazer Pulsações. Foi quando Sônia Mota pegou o bastão e realizou um trabalho proeminente junto aos alunos, com as ferramentas da dança moderna. O trabalho pedagógico de Sônia desenvolveu-se e alcançou proeminência. Em francês, há uma boa expressão: "Prendre le relais". Uma alusão aos cavalos descansados que irão substituir os fatigados.

Como bolsista, pude estudar, no primeiro semestre de 1976, Técnica, Improvisação e Composição com a Alwin Nikolais Dance Theatre, na Chimera Foundation, situada no lado leste da Rua 18, que abrigava as companhias - a de Nikolais e a de Murray Louis, bem como o trabalho pedagógico de ambos. Tinha 26 anos ao chegar em Nova York pela primeira vez. Após alguns dias no legendário Chelsea Hotel, localizado na Rua 23 Oeste, rumei para um pensionato na Rua 34 Oeste que oferecia quartos individuais, café da manhã e jantar com preços razoáveis, mas era um pouco triste, e acabei repartindo o apartamento da amiga canadense na Christopher Street, no Greenwich Village.

Penei na chegada, pois desconhecia a regra local de nomear as ruas por números, distintos pelos lados leste ou oeste, de acordo com a posição em que cada rua se encontra em relação ao atravessamento pela quinta avenida, que serve como divisor de águas. Após assimilar o fato, tive minha primeira decepção. Os cursos no Nikolais tinham apenas três horas de duração - de segunda a sexta, das 10 às 13 horas. Estava habituada com a rotina mudrista em tempo integral. Não tardou para ter o restante do tempo preenchido. Descobri a New York Public Library no complexo do Lincoln Center, onde podia assistir a vídeos de espetáculos de dança e teatro de todas as partes do mundo e ler livros. À parte a visita a museus, havia o prazer de andar pelas ruas.

Com Alwin Nikolais, aprendi, por exemplo, a andar de costas, que se tornou uma marca em meu trabalho coreográfico. Diziam os bailarinos da companhia: "O que se move no espaço não é a minha pessoa, mas meu corpo. Tudo em mim encontra-se concernido no que faço, portanto não há frieza". Fazia sentido.

Conheci também, no mesmo período, o trabalho com pedras efetuado pela dançarina e coreógrafa japonesa Kei Takei, trabalho que exigia o abandono do corpo no espaço a partir do 
lançamento da pedra e a necessidade de manter todo o corpo, especialmente os ombros, de onde parte o impulso, absolutamente relaxados. Após balanços pendulares, a pedra era lançada e o corpo seguia, percorrendo o trajeto e adquirindo as propriedades da pedra. Nascida no Japão, encorajada por Anna Sokolov, Kei Takei obteve uma bolsa da Fundação Fulbright em 1967 para estudar na Juilliard School em Nova York e com Anna Halprin em São Francisco. Dois anos depois, formou a própria companhia, a Moving Earth, com um elenco multiétnico. Desde então, passou a coreografar sequencialmente a obra Light, que, na segunda metade da década de 1970, atingiu o décimo terceiro estudo, todos eles independentes, embora complementares.

O trabalho com pedras acompanhou-me toda a vida e é quase sinônimo de temporalidade. A obsessão pela matéria pedra levou-me à construção, em 1993, da coreografia Pedra no caminho, a partir do poema de Carlos Drummond de Andrade, com música especialmente composta por Hélio Ziskind e dançada com alta competência pelo trio Ricardo Fornara, Rosa Primo e Francisco Rider.

Em Nova York, logo encontrei ex-colegas do Mudra que haviam entrado no Centro um ano depois de mim. Tinham formado um grupo, o Dramatic Dance Theatre. Participei de um espetáculo deles como artista convidada na Washington Square Methodist Church. Dois deles são muito talentosos: a estadunidense Diane Broman e o holandês Paul Versteeg, que integrou o Chandra na fase final de existência do grupo.

Tive, a seguir, um encontro decisivo. Por indicação da fotógrafa Maureen Bisilliat, procurei sua amiga Ann (Henrietta Michelson-Bagley, hoje Henrietta Mantooth). Artista plástica, ex-atriz de Joseph Chaikin no Open Theater, tinha ascendência indígena e já havia vivido na Venezuela e no Brasil. Houve um entendimento imediato e passamos a compor peças na intersecção entre dança e artes plásticas. Realizamos uma primeira experiência na All Angels Church intitulada Parables. Ela jogava ideias e eu tinha total liberdade para experimentar e criar. Entreguei-me inteiramente ao trabalho e quando, ao fim do semestre, regressei ao Brasil, sabia que tinha apenas começado a explorar uma nova direção. Um disparo havia sido dado rumo a uma nova vertente: a do predomínio da imagem visual e do universo onírico, na interface da dança com as artes visuais. Houve a desterritorialização de objetos comuns e ordinários, transformados em adereços de cena, que ecoaram em várias peças coreográficas que produzi depois, a começar pelo onírico Trem fantasma, de 1979.

De fato, no ano seguinte, em 1977, enquanto Maurice Vaneau fixou-se em Salvador para dirigir o Teatro Castro Alves e ensinar na Universidade Federal da Bahia, eu seguiria em uma nova viagem aos Estados Unidos. Henrietta introduziu-me em estudos sobre a Bauhaus 
alemã, particularmente nas propostas de Oskar Schlemmer e Laszlo Moholy-Nagy. Seu conceito de "teatro", circo e variedades foi marcante na concepção de Trem fantasma.

Voltei ao Brasil para a montagem de Pulsações para o hoje chamado Balé da Cidade em meados de 1976 e segui ensinando no Galpão durante o segundo semestre daquele ano, quando houve uma tentativa frustrada de realização do trio Tchau e bença, com Mara Borba e Thales Pan Chacon, a partir de Os sete pecados capitais, de Bertolt Brecht com música de Kurt Weill (1900-1950). Este, frequente parceiro musical de Brecht, proveniente de família judaica, mudou-se de Dassau, sua cidade natal alemã, para Berlim, antes de instalar-se definitivamente nos Estados Unidos. Após estudar a música moderna de Stravinski, Alban Berg e Paul Hindemith desde 1922, compôs músicas vocais, com sonoridade de forte cunho pungente e visceral. Para além de nomear os órgãos que fecham as cavidades do corpo, como cérebro, pulmões e coração, o termo refere-se àquilo que se encontra profundo e intimamente entranhado. Convoca a anima, o animal.

Curiosamente, Pina Bausch e Maguy Marin montaram a mesma obra, que não consta entre as mais significativas do repertório de ambas. Contratada pela Ópera de Lyon, Maguy disse-me, certa vez, que lhe faltavam ideias durante a montagem e, nesses momentos, ela punha-se a perambular pelo teatro à cata de algum elemento inspirador, tal como um grande pedaço de plástico.

Na sequência, fui à Bahia participar da Oficina de Dança Contemporânea organizada pela professora Dulce Aquino. Participei de um espetáculo em parceria com Clyde Morgan, fiz parte do júri de premiação na Oficina e dei um ateliê com o tema "Infância" que foi muito produtivo. Lia Rodrigues estava entre os alunos. Em São Paulo, apresentei Solos e duos com Mara Borba e parti novamente aos Estados Unidos. Maurice acompanhou-me a São Paulo, de onde parti. Tínhamos alugado o apartamento no qual morávamos para a atriz Ariclê Perez e o diretor Flávio Rangel. Maurice voltou a Salvador e eu, pela segunda vez, segui a Nova York.

Junto com e por meio de Henrietta, tive um contrato de Artist in Residence em Champaign-Urbana, na Universidade de Illinois. A exemplo de outras universidades, cada aluno compõe seu currículo com matérias optativas e, assim, tinha alunos provenientes de vários departamentos, tais como Antropologia, História, Sociologia, etc. Construí, com eles, a peça Tango, baseada no poema homônimo de Jorge Luis Borges. A escolha permitiu projetar um aspecto dramático e emocional a que estavam pouco habituados. Por sua vez, Henrietta optou pelo poema de João Cabral de Melo Neto, Uma das festas da morte, traduzido, em inglês, para $A$ festivity offered by death. Participei da montagem no papel da criança morta. 
De volta a Nova York, retomei os estudos com Nikolais e voltei a assistir a inúmeros espetáculos de teatro experimental e de dança, óperas e musicais da Broadway, bem como, novamente, a vídeos da New York Public Library no Lincoln Center, onde podia, ainda, usufruir da extensa biblioteca.

Henrietta e eu retomamos nosso trabalho conjunto. Passei a ser coreógrafa residente da All Angels Theatre Troupe. Após uma tentativa infrutífera de reunir um grande elenco e experimentar o universo dos insetos por meio da obra de E. E. Cummings, concentramo-nos na construção de uma peça cujo resultado foi extraordinário, denominada Paper pieces, selecionada para a Mostra do Cubículo Theatre, um espaço de vanguarda. Hoje, seria chamado de instalação o que fazíamos então.

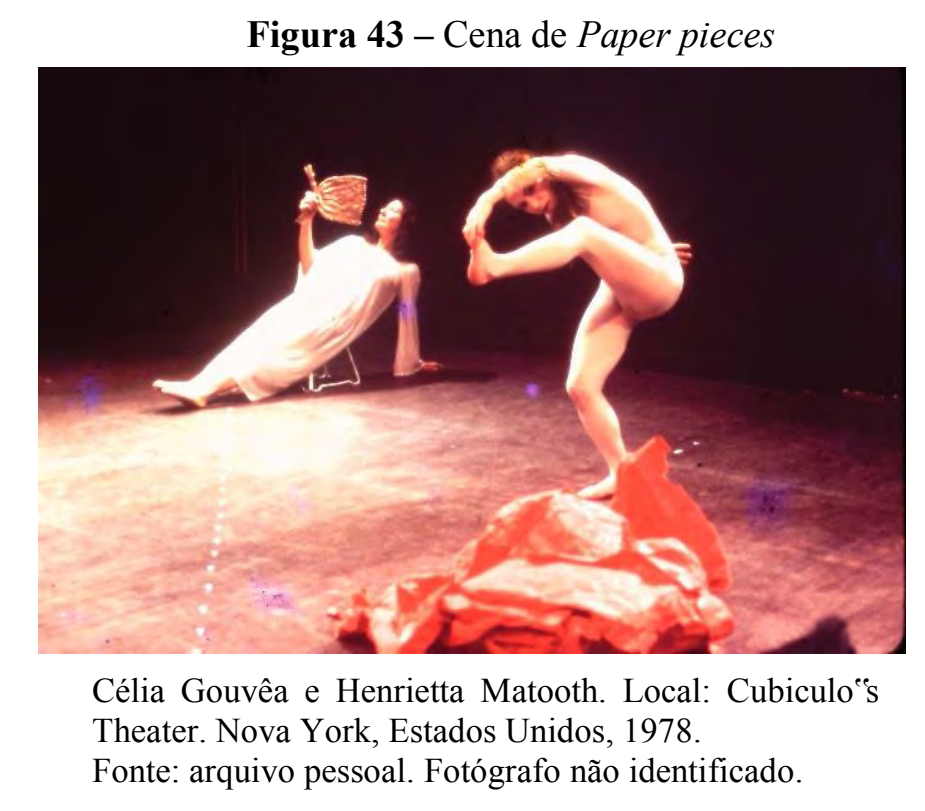

Maurice Vaneau, que tinha ocupado o cargo de diretor do Departamento de Teatros da Prefeitura Municipal de São Paulo e, em seguida, de diretor do Teatro Castro Alves na Bahia, como mencionado, veio ao meu encontro. Realizamos uma série de vídeos a partir de solos meus para o Fundo das Nações Unidas para a Infância (UNICEF), gravados nos estúdios da ONU, com direção de Vaneau. Nós nos casamos nos Estados Unidos e voltei ao Brasil grávida. Maurice tinha, então, a irmã mais velha Leona e o irmão mais novo Raymond vivendo em Miami. Foi naquela cidade que realizou-se a cerimônia, seguida de uma visita ao cemitério no qual a mãe Jeanne, falecida em 1969, encontra-se enterrada.

Naquele novo retorno ao Brasil a intenção era a de agora assentar, ancorar e constituir um núcleo estável de dança contemporânea. 


\section{Nova volta}

Ao chegarmos, fomos convidados a criar um espetáculo em comemoração ao centenário de nascimento da revolucionária Isadora Duncan. O convite partiu de Casimiro Xavier de Mendonça, então à frente da Comissão de Dança da Secretaria de Estado da Cultura. O elenco era exclusivamente feminino, à exceção de um violinista que transitava no palco, tocando.

Casimiro indicou nomes para formar o elenco, que era de primeira: a ex-colega mudrista Juliana Carneiro da Cunha, minha ex-mestra Ruth Rachou, Júlia Ziviani, Marília de Andrade e suas três filhas pequenas e Vivien Buckup, entre outras. Eu dancei grávida até dois dias antes de dar à luz, mostrando minha barriga. A muito talentosa figurinista belga Ninette Van Vuchelen ocupou-se, mais uma vez, dos figurinos, e Vaneau realizou a direção geral.

Figura 44 - Cena de Isadora, ventos \& Vagas

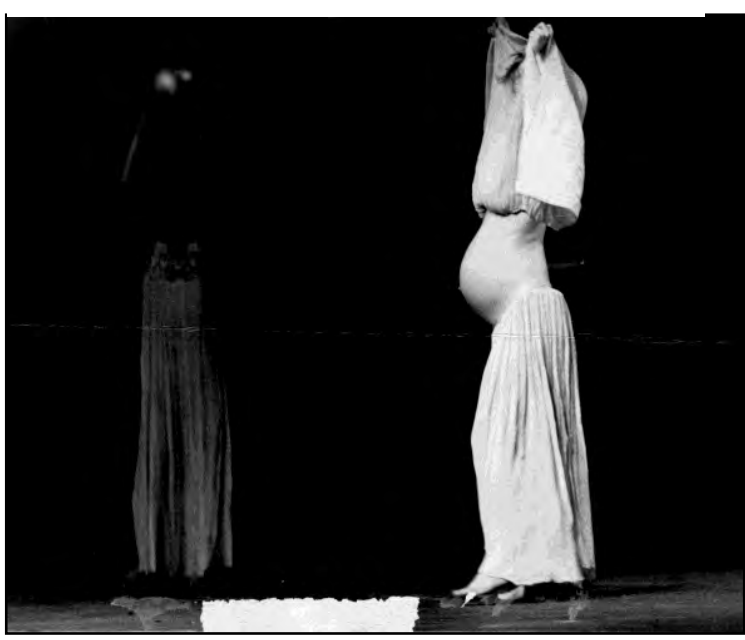

Mara Borba e Célia Gouvêa. Teatro Cultura Artística, São Paulo, 1978.

Fonte: arquivo pessoal. Fotógrafo não identificado.
Figura 45 - Cena de Isadora, ventos \& Vagas

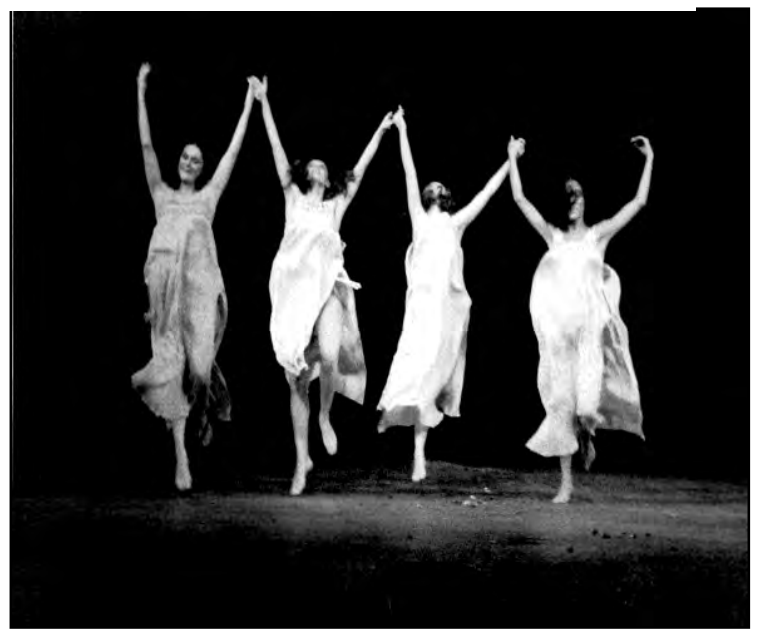

Rutch Rachou, Julia Ziviani, Ana Michaela e Calu Ramos. Teatro Cultura Artística, São Paulo, 1978.

Fonte: arquivo pessoal. Fotógrafo não identificado. 
Figura 46 - Cartaz de Isadora, ventos \& vagas

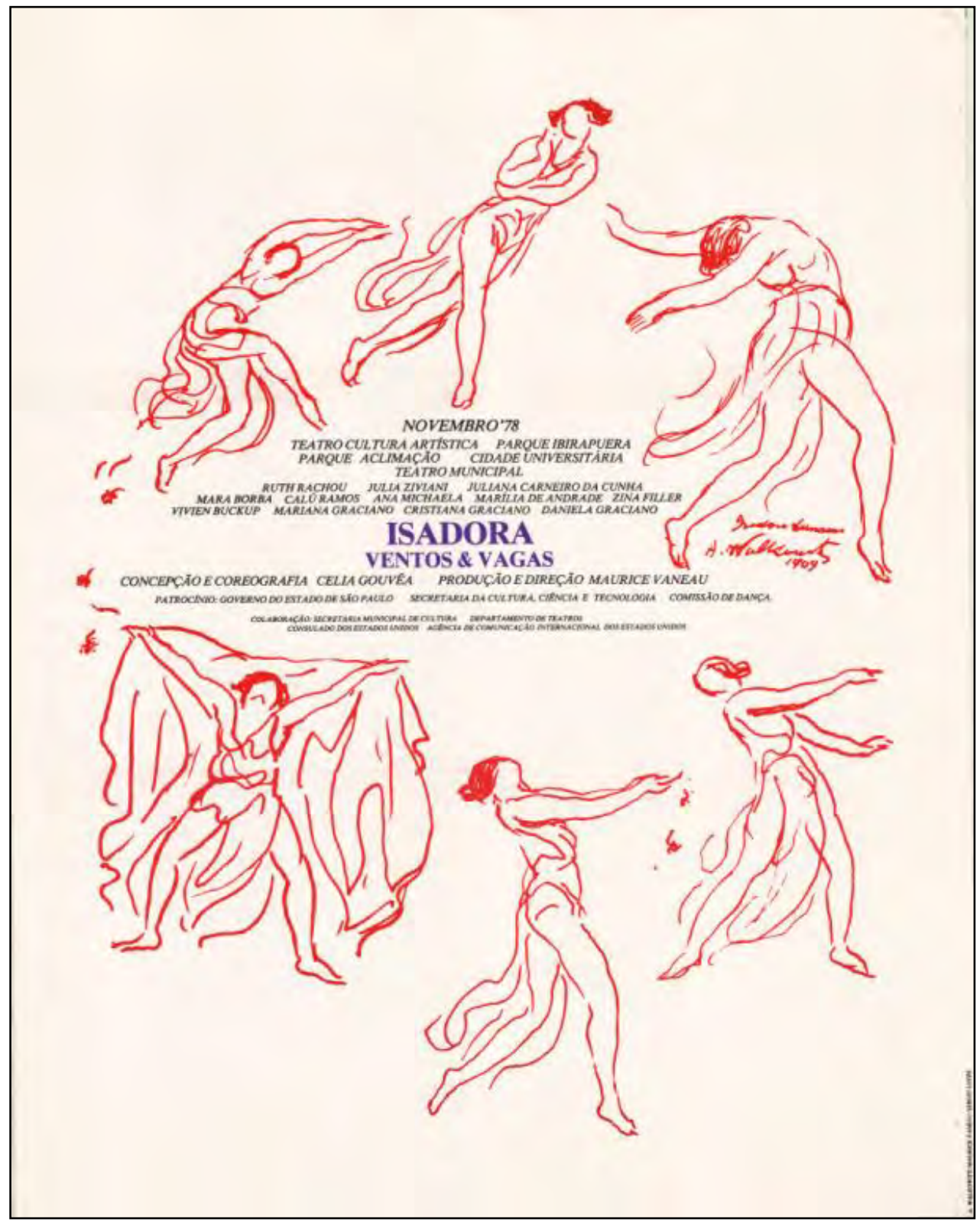

Fonte: arquivo pessoal. 
O ácido jornalista Thelmo Martino comentou que, com tal equipe, Isadora teria finalmente o caviar e o champagne que ela tanto prezava ${ }^{324}$. Cito o jornalista, que marcou aquele período, embora seus escritos pudessem aproximar-se da fofoca. A estreia ocorreu no início de Novembro de 1978 no Teatro Cultura Artística, seguindo temporada em amplos palcos, como o Theatro Municipal de São Paulo, e ambientes outros como o saguão da Fundação Armando Álvares Penteado, a FAAP. Apesar de alguns afirmarem que se tratava de um dos espetáculos mais poéticos e sensíveis que já realizei, o período de dois meses para os ensaios não foi suficiente para burilar cenas e ir mais longe, no meu entender. Conservei as soluções que gostaria de ter tentado na cabeça.

Somente trinta anos depois, em 2008, pude completar minhas intenções no espetáculo em homenagem a Ruth Rachou, no qual coreografei a primeira parte, sobre Isadora. Aliás, há muito considerava Ruth uma espécie de reencarnação de Isadora, pela semelhança física, pelo fato de ter nascido no ano em que Isadora morreu, pela postura emancipada, libertária e autônoma da mulher. Pude, então, colocar a grávida nua e conduzi as dançarinas a procurarem sua própria qualidade de movimento.

Entre outros, a Prof. a Dra. Christine Greiner, da Pontifícia Universidade Católica de São Paulo (PUC-SP), reconhece haver, em meu trabalho, a introdução do método de instigar o intérprete a buscar soluções próprias. Tornou-se corriqueira a expressão "criador-intérprete", já superada pelo entendimento de ambas as palavras, conforme já exposto: nem fazer emergir algo do nada, do zero absoluto, nem fornecer uma visão pessoal a uma partitura já pronta. Trata-se, provavelmente, da maiêutica socrática da procura em despertar no outro um saber já existente, porém ainda adormecido.

Nos anos seguintes, produzi febrilmente, houvesse ou não patrocínios, muito incipientes naquele momento. Creio que o nascimento de Yara, minha primeira filha, abriume canais afetivos que estavam bloqueados e houve uma fecunda projeção de imagens. Gaston Bachelard afirmou que as imagens são anteriores a ideias e conceitos. Meu processo criativo sempre ocorreu exatamente assim, na confluência entre arte e vida.

\footnotetext{
${ }^{324}$ MARTINO, Telmo. Pré-Estreia da Semana. O Estado de São Paulo, São Paulo, 30 out. 1978. "Tudo leva a crer que é a primeira vez, no Brasil, que alguém se lembra de trazer para um aniversário de Isadora Duncan o champagne e o caviar que ela sempre considerou imprescindíveis".
} 


\subsection{Via do imaginário - novas irrigações}

Conservei sempre (e pratiquei) o conselho de Béjart: o de procurar em si mesmo as projeções cênicas - pessoalidade na linguagem que, aliás, foi apontada por muitos acerca de minhas produções. Somaram-se as marcas que o trabalho com elementos visuais propostos por Henrietta Bagley haviam deixado, tais como sacos de frutas colocados no rosto e que se transformam em máscaras. Esses elementos foram acrescidos a pintores surrealistas e a elementos circenses. Como resultado, a minha primeira peça de dança que considero singular e importante: Trem fantasma. Convidei a antiga mestra Renée Gumiel para uma participação especial. Escrevi um texto para ela que principiava com as palavras: "Sou eterna". Nas anotações que constavam do roteiro, Renée era descrita como "uma figura sofisticada e antiquíssima. Milenar. Personagem que considera que ali estará para sempre. Equivale ao instinto de preservação. Evoca o passado, nutre-se de recordações”.

Quando o pano se abria, o palco encontrava-se coberto por um tecido vermelho no qual havia alguns buracos dos quais saiam uma bunda ou vastos cabelos escuros. Da ponta direita aparecia uma mão segurando uma maçã; quando, da ponta à esquerda, surgia um punhal, a maçã abria-se ao meio, partida em duas partes, no lado oposto. Meu personagem calçava altos sapatos com plataforma e tinha na cabeça uma cartola aberta no topo, a qual podia levantar e jogar coisas. Havia duplas fazendo um gesto idêntico, como mascar chicletes. A duplicação reforça, sublinha. Repeti o recurso seguidas vezes, naquela e em outras montagens. Coube a Zina Filler, dona de um senso de ritmo incomum, promover o elo com as lições aprendidas com Fernand Schirren, meu mestre do Ritmo. Executando movimentos de solfejo e saltitando, percorrendo o palco do côté cour ao côté jardin (da direita à esquerda), sempre de frente para o público, Zina enumerava diversas agruras domésticas.

De Béjart, mantive também o gosto para trabalhar com elencos numerosos, guardadas as devidas proporções. Sua companhia era composta por sessenta bailarinos. O meu número era doze. Assim foi em Caminhada, Pulsações e Trem fantasma e outras danças - este era composto por três coreografias: Limites, Raiz e Trem Fantasma.

A estreia ocorreu em 21 de setembro de 1979 no Teatro Brasileiro de Comédia, quando Maurice Vaneau voltava à casa onde iniciara sua jornada brasileira logo ao chegar ao País, no ano de 1955, em turnê do Teatro Nacional da Bélgica. Diretor da peça Barabbas, escrita pelo belga Michel de Ghelderode, Maurice foi convidado pelo produtor italiano Franco Zampari (1898-1966) para dirigir a casa de espetáculos inaugurada em 1948 na rua Major Diogo. Após ausentar-se para o exercício de atividades profissionais na Europa, Maurice 
voltou à direção do TBC em 1963, quando, além da atuação como diretor geral, montou $O s$ ossos do Barão, de Jorge Andrade, que foi o maior sucesso de público daquele teatro.

Por um breve período, o TBC transformou-se em teatro de dança. O programa de Trem fantasma e outras danças estreou pouco antes de eu completar 30 anos de idade. A primeira coreografia, Limites, com música de Erik Satie em leitura da The Camerata Contemporary Chamber Orchestra, era composta por quatro partes: "Muitos", "Um", "Dois" e "Zero". Substâncias elásticas foram o elemento produtor dos movimentos. O ponto de partida era uma ideia visual e plástica, o que permitiu a Maurice Vaneau desenvolver um cenário com panos esticados nos quais havia círculos recortados. A primeira parte era dançada por Luciana Gandolpho, Maria Lúcia Merlino, Márcia Goren, Marina Neves e Sílvia Rosenbaum; a segunda por Zina Filler; a terceira por Mazé Crescenti e Mauro Stávale; e a quarta por mim. Raiz, segunda coreografia da obra, estreou no Teatro Castro Alves em Salvador/Bahia em 13 de julho de 1979, no Festival de Arte Bahia, com música percussiva especialmente composta por Dinho do Nascimento. O som ilustrava as cenas, sem propor uma massa sonora densa.

O elenco de Raiz era composto por Célia Gouvêa, Maria Lúcia Merlino, Luciana Gandolpho, Márcia Goren, Maria Lúcia Merlino, Marina Neves, Mauro Stávale, Mazé Crescenti (1956-1991), Sílvia Rosenbaum e Zina Filler. Dois anos depois, coreografei Urugungo, com música de Naná Vasconcelos, na qual predominava o som do berimbau. Ambas apontavam na direção de uma dança contemporânea brasileira e, por isso mesmo, a crítica as elogiou, mas percebi que aquele não era o meu forte, enquanto o jorrar de imagens descontínuo proposto em Trem fantasma era fértil, com a presença de inúmeros insights. Sérgio Viotti - ator, radialista e crítico, apreciador de meu trabalho coreográfico e que tornouse um incentivador - escreveu no Jornal da Tarde em 02 de novembro de 1979:

Os viajantes são variados. As imagens se confundem. O music-hall, a infância, o circo, o teatro, a dança, a solidão, o presente, o passado, o novo e o velho, tudo isso comandado por uma exata noção rítmica, dispensando música formal, usando palavras isoladas, sílabas e sons (às vezes), pequenas frases (extremamente bem ditas) - também como base para reforçar ritmos [...].

Célia Gouvêa tem um talento coreográfico que agiganta a figura tênue e frágil de mulher e dançarina. O seu mergulho em movimentos é ousado; a sua visão, personalíssima; a sua criação, precisa e coerente com o espírito daquilo a que se propõe em cada um dos trabalhos do espetáculo.

Por seu lado, Corina de Figueiredo escreveu na revista Visão, em 15 de outubro de 1979, com o título "Libertação": 
Célia Gouvêa e Maurice Vaneau conseguiram uma combinação equilibrada entre dança, música, cenografia, figurino e iluminação. Tudo se integra de maneira harmoniosa num espetáculo de raro bom humor e que incorpora à dança, além de outras formas de expressão que lhe são tradicionalmente alheias, vários temas sociais de nosso tempo, sem que se perca com essa incorporação a linguagem abstrata própria ao movimento. Trem Fantasma arrasta a plateia para um mundo de sonho e magia em que as imagens oníricas se sucedem como numa colagem em movimento para a qual colaboram outras formas de expressão artística como a palavra poética, o circo, o teatro.

Em Trem fantasma, o mesmo o elenco de Raiz foi mantido, com o acréscimo de Mingo Martins ao violino e a participação especial de Renée, que entrava em cena deslizando sobre patins, conduzida por dois enfermeiros, um de cada lado. Em seguida, sentava-se, abria um baú e desfiava objetos e memórias. A primeira ideia era que Renée retirasse várias caixinhas de música do baú, colocando-as lado a lado e dando corda em todas, formando uma grande cacofonia sonora. A ideia que vingou, porém, foi a de retirar primeiro uma boneca relativamente grande até uma bem pequena, minúscula, colocando-as sentadas uma a uma, da maior à menor. Dos doze participantes, um terço do elenco, ou seja, quatro integrantes já faleceram: Renée Gumiel, Marina Neves, Mauro Stávale e Mazé Crescenti.

A destacar, há o fato de ter sido, a partir de então, que nossas produções passaram a ser registradas em vídeo.

Figura 47 - Cena da coreografia Limites

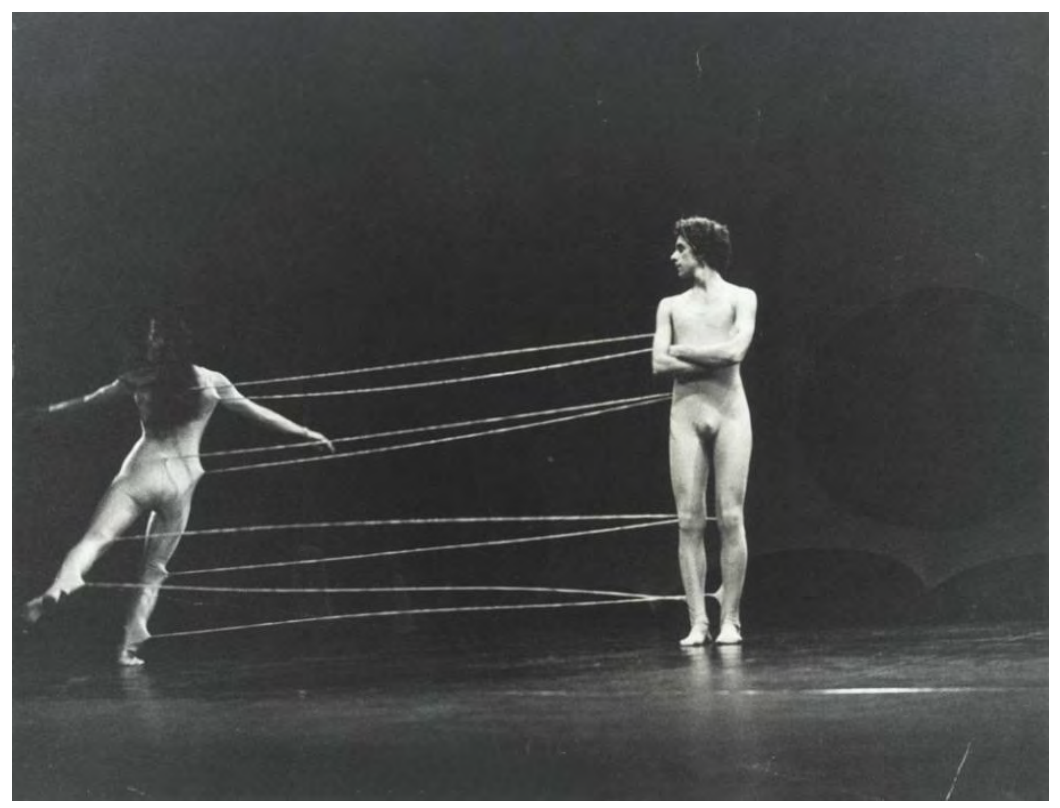

Mazé Crescenti e Mauro Stávali e (da esq. p/ dir.). Teatro de Dança de São Paulo. Teatro Brasileiro de Comédia (TBC), São Paulo, set. 1979. Fonte: arquivo pessoal. Fotógrafo: Leonardo Crescenti. 
Figura 48 - Cena da coreografia Trem Fantasma

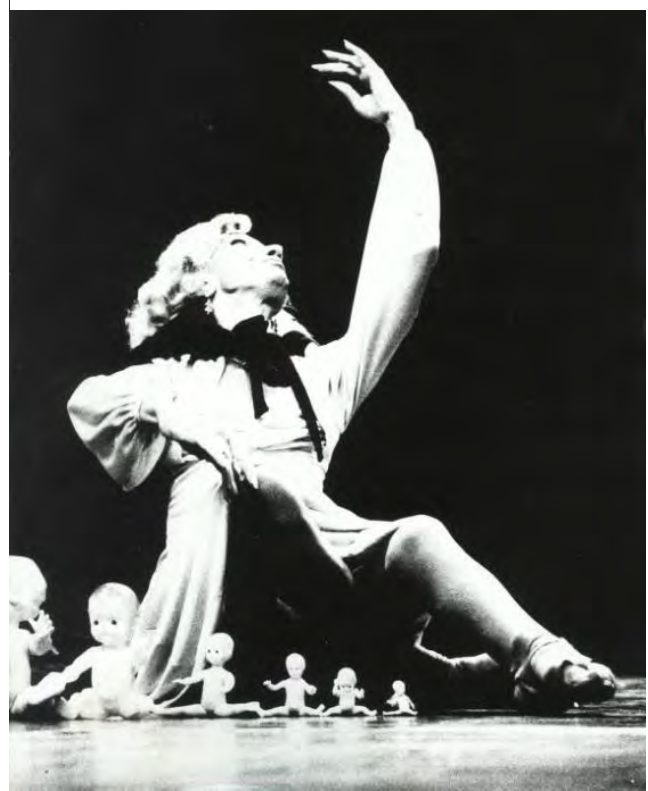

Na foto, Renée Gumiel. Teatro de Dança de São Paulo. Teatro Brasileiro de Comédia (TBC). São Paulo, SP, set. 1979. Fonte: arquivo pessoal. Fotógrafo: Leonardo Crescenti.
Figura 49 - Cena da coreografia Trem Fantasma

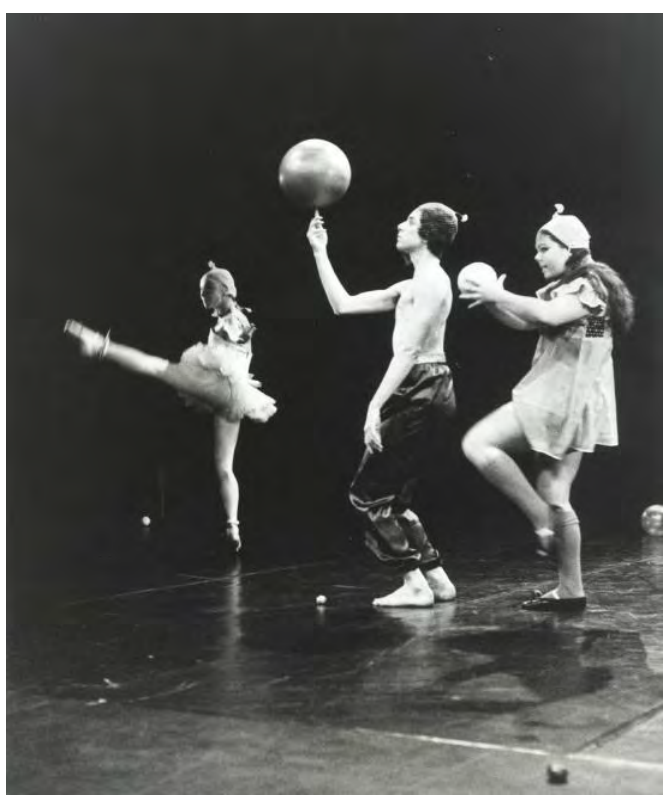

Célia Gouvêa, Mauro Stávale e Zina Filler (da esq. p/ dir.). Teatro de Dança de São Paulo. Teatro Brasileiro de Comédia (TBC). São Paulo, SP, set. 1979.

Fonte: arquivo pessoal. Fotógrafo: Leonardo Crescenti.

Ainda que consideradas as quase quatro décadas que separam a estreia dos dias de hoje, o número de coreografias realizadas é elevado. O processo de ensaios do Trem foi penoso, por falta de verba, gerando atritos e tensões, embora o resultado tenha sido contundente. Imediatamente após o final da temporada, estendida ao Theatro Municipal, estava programada a $1^{\mathrm{a}}$ Mostra de Dança Contemporânea, que reuniu, no TBC, apresentações, palestras e debates, introduzindo a saudável prática de se debater conjuntamente problemas e questões ligados à profissão. Quis realizar um novo trabalho, dessa vez com um elenco diminuto. Meu modo de funcionar sempre foi o de, após um trabalho de grupo, recolher-me e conceber um solo, um duo, no máximo um trio.

A primeira imagem que me veio foi a de uma tampa de privada. Convidei Mazé Crescenti, participante do elenco de Trem fantasma e outras danças. A ideia das latrinas não agradou a Mazé. A ideia ficou embutida e veio à luz anos mais tarde em Festarola (1988), em número de três objetos e, mais ainda, em 2006, com o solo Latrina, com uma série de seis. Quis me abster de música externa, dizendo-me que não precisaria introduzir nenhum elemento para agradar ao público, pois há sempre um público potencial para uma Mostra. Meu estado naquele momento era o de estar interiormente machucada. 
No dueto Promenade, dividi a cena com a iluminada Mazé Crescenti, verdadeira força da natureza que nos deixou aos 35 anos de idade. Ela e eu entrávamos correndo lado a lado; eu me encostava na pilastra lateral e frontal e Mazé dava vários pontapés no meu estômago; voltávamos a correr e a cena se repetia. Em seguida, formávamos encaixes de corpos com desenhos em planos diversos do espaço.

Naquele ano de 1979, realizei quatro coreografias sem subvenção, o que foi, de fato, um tour de force, pois, além das três coreografias que compuseram o programa de Trem Fantasma e outras danças, houve a estreia, no mesmo ano, de Promenade. O então crítico de dança Acácio Ribeiro Vallim Jr., conforme artigo publicado em O Estado de São Paulo em 22 de outubro de 1980, considerou a peça "uma pequena obra prima silenciosa, feita de respiração, voz, batidas no chão e com movimentos que criam harmonia rítmica que é, sobretudo, visual".

Figura 50 - Cena de Promenade

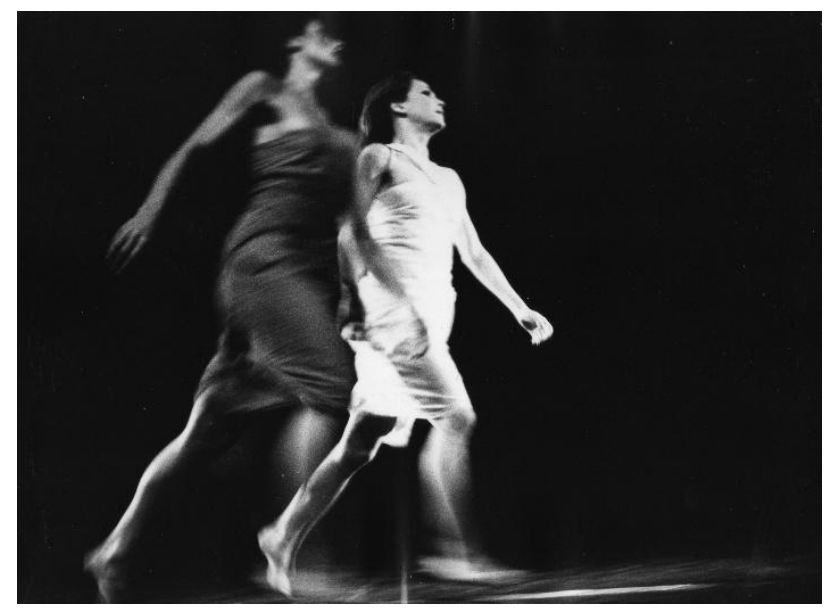

Mazé Crescenti e Célia Gouvêa (da esq. p/ dir.). Teatro de Dança de São Paulo. Teatro Brasileiro de Comédia (TBC). São Paulo, SP, 1979.

Fonte: arquivo pessoal. Fotógrafo: Leonardo Crescenti.
Figura 51 - Cena de Promenade

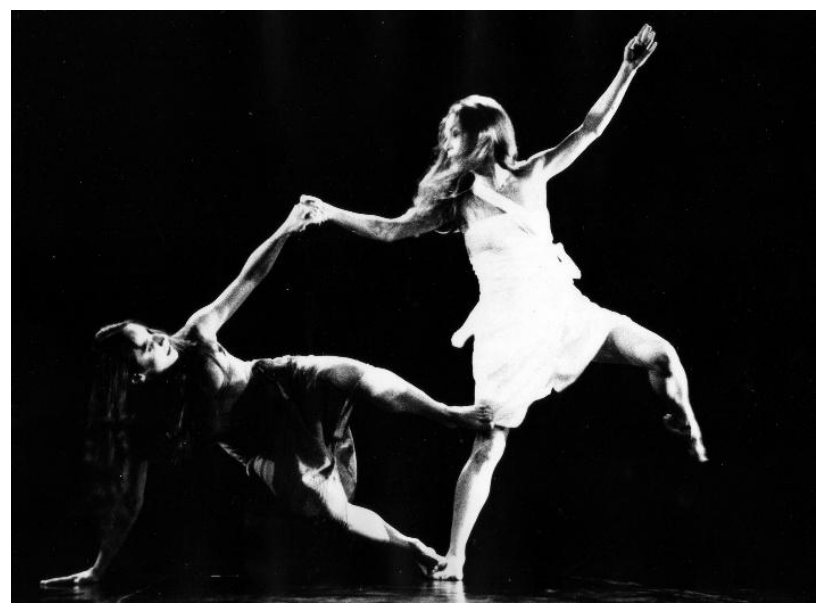

Mazé Crescenti e Célia Gouvêa (da esq. p/ dir.). Teatro de Dança de São Paulo. Teatro Brasileiro de Comédia (TBC). São Paulo, SP, 1979.

Fonte: arquivo pessoal. Fotógrafo: Leonardo Crescenti.

O que chamo de penca de trabalhos significativos não parou por aí. Conheci um período fértil em torno de meus 30 anos. Reconheço este como um tempo muito especial na minha trajetória artística e criativa. Destaco a coreografia Expediente, com música de Luciano Berio, solo que criei para o bailarino J.C. Violla, que trabalhava com o multiartista Naum Alves de Souza. Os dois vieram assistir a Trem fantasma e outras danças. Naum queria que Violla se desenvolvesse mais como bailarino, pois, até então, os trabalhos nos quais atuava primavam pela expressão corporal. Naum achou que eu seria a coreógrafa certa para arrancar 
qualidades já potenciais em Violla. Propus, primeiramente, um texto de Artaud: Van Gogh, o suicidado pela sociedade, mas, para Naum, ele mesmo se ocuparia das atividades especificamente teatrais. Penso ter captado o modo de ser e de se movimentar de J.C. Violla e compus Expediente, o primeiro trabalho em conjunto de uma série. Havia muita fisicalidade, muita complexidade espacial e coreográfica, sem se recorrer a um vocabulário já estabelecido na dança. Foi o início de uma profícua e duradoura colaboração com ambos os artistas, uma relação de afinidades, e creio que sempre pude perceber e evidenciar cenicamente as melhores qualidades de Violla. O então crítico de dança Sérgio Viotti observou em artigo para o Jornal da Tarde em 15 de novembro de 1980: “A proposta de Expediente é aterradora, ela nos mostra o menor dos homens, o homúnculo, prisioneiro de tudo o que devora na rotina inútil do não ser. J.C.Violla nos dá a perfeita visão do herói kafkiano...”

Violla e Naum iriam, também, marcar uma vertente importante no Teatro Galpão: a de uma dança construída com um numeroso elenco formado por cidadãos comuns, urbana e com um visual requintado, especialmente em Valsa para vinte veias, apresentada em 1980.

Figura 52 - J. C. Violla em cena de Expediente

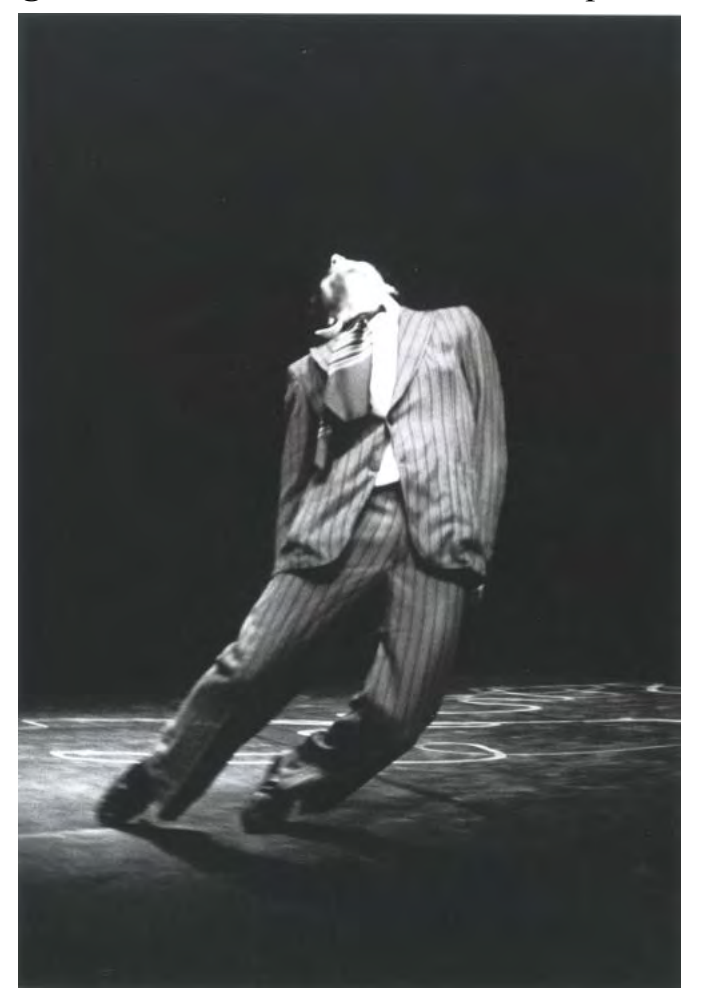

Teatro Galpão, São Paulo, SP, 1980.

Fonte: arquivo pessoal. Fotógrafo: Leonardo Crescenti.

Não vou me deter no trio Contrastes para três, estreado em abril de 1980 no Centro de Convivência Cultural de Campinas, com música do compositor húngaro Béla Bartók, dançado 
inicialmente por mim, Mazé Crescenti e João Maurício, que foram substituídos, posteriormente, por Zélia Monteiro e J. C. Violla, todos nomes altamente capacitados, dançarinos de excelente qualidade. Não me deterei, tampouco, no quinteto Lenda, com música de Hermeto Paschoal, dançado por mim, Zélia Monteiro, J. C. Violla, Rose Akras, João Úbida, cuja estreia ocorreu no Teatro de Dança Galpão em 17 de outubro de 1980. Isso porque considero tais produções obras menores. Fato curioso a ser registrado é que a música altamente elaborada do "mago" Hermeto Paschoal, de qualidade indiscutível, sempre me carregou para uma zona de trabalhos intelectuais, desconectados do meu ser inteiro.

Invariavelmente, a meticulosa profissional Flávia Calabi era responsável pela sonoplastia, que denominávamos então como montagem sonora. Era durante as madrugadas que ela costumava gravar as trilhas, no formato fita de rolo e cassete. As madrugadas passadas em seu estúdio já tinham se tornado um ritual próximo à estreia. Flávia, que tinha vivido alguns anos no Japão, pedia que deixássemos nossos sapatos junto à porta e entrássemos descalços em seu estúdio. Disse-me, um dia, que o único profissional que havia se recusado a isso foi Fauzi Arap, que, apesar de gentil, considerou estar ali para um serviço profissional que, aliás, costumavam ser bem pagos.

No mesmo rol colocarei Quatro corpos, dois estranhos, com acompanhamento musical gravado de flauta shakuhachi, dançada, além de mim, por Ruth Amarante, Yaskara Manzini, Zélia Monteiro, Rose Akras e Soraya Sabino ${ }^{325}$. Outra é Urugungo, com música de Naná Vasconcelos. "Urugungo" é o nome original do berimbau. Em dialeto africano, "uru” é madeira e "gungo", tambor. Ambas estrearam no Theatro Municipal de São Paulo. Não me alongarei em detalhá-las. Quatro corpos leva-me a refletir sobre o que vem a ser uma narrativa não linear, uma vez que, se projeto imagens desconexas, não suficientemente amarradas em uma concepção sólida, caio em um hermetismo (do deus grego Hermes), quando a leitura e a comunicação tropeçam, embora contasse com a concordância de alguns.

Sérgio Viotti escreveu: "Célia Gouvêa lida com imagens, como um poeta, como qualquer criador não-figurativo"326. Além de Ruth, Yaskara, Zélia, Rose, Soraya e eu, compunham o elenco: Alexandre Soares, Olavo Júnior, Cirrus Fernandes e Rogério da Col. Maurice Vaneau voltou a realizar um primoroso trabalho visual. Na véspera da estreia, houve

\footnotetext{
${ }^{325}$ Ruth tornou-se uma das principais bailarinas da cia. de Pina Bausch; Yaskara tem tese de doutorado na Unicamp e participação ativa junto à escola de samba em que atua no carnaval de São Paulo; Soraya e Rose são terapeutas corporais - a última vive na Holanda.

326 VIOTTI, Sérgio. Quatro coreografias. Em todas, inteligência e talento. Jornal da Tarde, Caderno de Programas e Leituras, São Paulo, 15 nov. 1980, p. 12.
} 
a entrega dos prêmios da Associação Paulista de Críticos de Arte (APCA) no mesmo Theatro Municipal, enquanto Vaneau pintava um telão abstrato que serviu de cenário a Quatro corpos. O jornalista Telmo Martino comentou, em sua coluna do Jornal da Tarde, que Maurice não quis estender o braço para apanhar seu prêmio na categoria Melhor Direção Teatral ${ }^{327}$.

Para Maurice, a temporada anual no Theatro Municipal era importante por oferecer recursos técnicos para a feitura tanto da luz quanto do cenário, os quais permitiam o bom acabamento visual, fator relevante para o detalhista esteta que era. Seu trabalho, porém, não se limitava à produção visual - inclusive dos programas. Via de regra, entre duas coreografias, enquanto mudávamos de figurinos nos camarins, Maurice apresentava Intermezzos belos, engraçados, críticos e despudorados, nos quais não hesitava em vestir tutu e calçar sapatilhas de ponta, como fazem as bailarinas clássicas. No programa daquelas apresentações estava escrito: “Assista a um bom espetáculo nacional, prestigie o artista de sua terra".

\section{Parâmetros norteadores:}

Os principais parâmetros que norteavam e ainda orientam minha produção coreográfica podem ser assim considerados:

- A assimetria e descentralização: as disposições assimétricas deixam de eleger o centro como ponto principal e privilegiado. Para o artista visual Alexander Calder (18981976), o que suscita a composição é a disparidade quanto à forma, cor, tamanho, peso, movimento. Simetria e "ordem" não formam uma composição ${ }^{328}$. Elementos díspares produzirão uma conversa melhor articulada, de forma a gerar interesse, instigar. $\mathrm{O}$ olhar do espectador pode selecionar ou apreender a múltipla oferta ao invés de confundir e dificultar a leitura. As ações simultâneas podem ser produto de uma aceleração pós-moderna. Embora meu vocabulário e sintaxe coreográfica pouco se assemelhem ao de Cunningham, com ele concordo inteiramente no que se refere tanto à constatação da presença do tempo na música como na dança, quanto aos "elementos de um trabalho - movimento, som, cenário - entidades independentes que coexistem juntas. A dança não pretende duplicar a frase musical, nem o

\footnotetext{
${ }^{327}$ MARTINO, Telmo. Festa Triste. Jornal da Tarde, São Paulo, 17 jun. 1981. "Ele (Maurice Vaneau) precisava apenas estender o braço para pegar o seu (prêmio) Não estendeu. Enquanto a APCA entregava os prêmios Maurice Vaneau ensaiava, atrás da cortina do palco, o salto e a ponta das coreografias que Célia Gouvêa estréia, hoje, no Teatro Municipal."

${ }^{328}$ CALDER, Alexander. À propos of measuring a mobile. Manuscrito. New York: Calder Foundation, 1943. Tradução nossa. Texto original: "Disparity - in form, colour, size, weight, motion - is what makes a composition. Simmetry and ,order" do not make a composition".
} 
cenário ilustrar. Coreografia, música e cenário simplesmente ocupam juntos o mesmo espaço e tempo" ${ }^{329}$. A música será acrescida depois e não constituirá o ponto de partida, quer seja incidental ou não. Eu considero incidental aquela que, a exemplo do cinema, destina-se a fornecer uma atmosfera, produzir um ambiente em vez de determinar a ação. Merce Cunningham não foi o único, mas relevou "a importância igual de cada área do espaço cênico. Os cantos e lados são tão importantes quanto o centro" ${ }^{\text {330. }}$.

Que se levem em conta as diferenças dos participantes quando o processo solicitar e tornar necessário o emprego do uníssono ou idêntico simultâneo para sublinhar, reforçar ou acalcar uma determinada ação, ao invés da assimetria, que, como acaba de ser dito, é mais rica e recortada que a simetria, quando vêm se somar os ensembles (ou conjuntos), o executar junto, destinados a amplificar e sublinhar uma ação. Desde a dança coral, proposta por Rudolf Laban nos anos 1930 em grandes estádios da Alemanha, entre outros, a multiplicação de corpos executando movimentos idênticos traduz força. Minha mãe dizia ser curioso não haver dois rostos iguais, apesar de termos todos (quase) testa, olhos, nariz, boca. O mesmo se dá com os corpos, desiguais em volume, em velocidade. Solicitar uma mesma execução é possível desde que não haja o propósito de igualar, nivelar, permitindo que sejam benvindas as diferenças, as chamadas corporalidades plurais. O movimento uníssono executado por dois ou mais dançarinos, poderá também ocorrer em múltiplas direções do espaço por cada um, o que subtrairá o aspecto regular e monocórdico.

- A ideia de viagem - a busca do desconhecido, que propicia novas descobertas, explorações improváveis e ainda não tateadas. O processo investigativo era concebido enquanto viagem ao que acessa novas descobertas; um ultrapassar-se penoso, comparado a uma viagem aos infernos.

- A recorrência à infância - Mais que referência ao jogo e ao lúdico, acorda a conexão primeira, sem mediações.

- Resposta ao fluxo de imagens - procurando organizá-las coerentemente no decorrer da montagem.

\section{- Tríade: projeção de imagens, humor, construção do movimento.}

\footnotetext{
329 ANDERSON, 1979, p. 131. Tradução nossa. Texto original: "Cunningham tends to regard the elements of a work - movement, sound, decor - as independent entities which coexist together. The dance does not attempt to duplicate the musical phrase. Nor does the scenery illustrate the choreography. Choreography, music, and scenery simply occupy time and space together".

${ }^{330}$ Ibid., p. 131. Tradução nossa. Texto original: "Cunningham gives equal importance to each area of the stage. The corners and sides can be as important as the center".
} 
- Evidenciar qualidades próprias a cada participante do elenco.

- O emprego de obsessões, marteladas, repetidas.

- O ecletismo dos corpos - baixos, altos, gordos, magros; preparo técnico aprimorado, médio ou seminulo; idades diversas - desde crianças, como em Isadora, ventos e vagas, de 1978, homenagem ao centenário de nascimento de Isadora Duncan, com as três filhas de Marília de Andrade, e mais tarde, em Sapatas fenólicas. Esta, montagem de 1989, tinha no elenco minha filhas Yara e Vânia, que contavam então com 11 e 7 anos de idade respectivamente. Três anos depois, em 1992, Yara foi substituída pela hoje atriz Maria Laura Nogueira, então com 10 anos de idade. Além da presença de crianças, incluí também atuantes maduros, como Ruth Rachou, René Gumiel e Maurice Vaneau. O ecletismo constituiu sempre um ponto de conflito: sempre gostei do movimento e me debrucei sobre as inumeráveis leis que o regem. Inclusive, a mestra Maria Duscheness apreciava o sentido dos desenhos presentes em muitas coreografias. Para o desenvolvimento da vertente, necessitava de corpos aptos e treinados. Por outro lado, a marca de pesquisa que caracterizava meus trabalhos afugentava muitos dançarinos com técnica.

- o gosto do público não era levado em conta o bastante, ou seja, nota-se a ausência de impulso para agradar. Ao modo modernista, importava mais despejar um universo produzido no interior do sujeito.

- viver uma situação (resquícios stanislavikianos) como objetivo, em montagens estruturadas em quadros.

- ritmo: algumas páginas à frente, nos depoimentos de Carol Pedalino e Debby Growald, há a recorrência, por parte de Maguy Marin e Maurice Vaneau, de um mesmo dado: o parceiro maior na construção de um trabalho artístico é o ritmo.

\section{Propósitos:}

O propósito, aqui, não é o de proceder à tarefa jornalística de efetuar um inventário de todas as montagens que no Galpão ocorreram. A cobertura pela imprensa era razoável. A empresa LUX podia ser contratada para reunir todos os artigos publicados nos vários órgãos da imprensa e, mediante pagamento, é claro, fornecia os clippings para que tivéssemos os exemplares originais. Guardo-os preciosamente, mas, infelizmente, neles não constam o número de página dos artigos de jornal. Aquele era um tempo em que as matérias acerca de nosso trabalho publicadas na imprensa eram fartas, abundantes, e a leitura de jornais diários era algo quase obrigatório. Muitos eram os jornais naqueles anos setenta: $O$ Estado de São Paulo/Jornal da Tarde; Folha de São Paulo/Folha da Tarde; Shopping News/City News; 
Diário da Noite; Última Hora; e outros. Em sua retrospectiva das atividades de dança ocorridas no ano de 1980, Acácio Ribeiro Vallim Jr. escreveu no Estadão:

\begin{abstract}
Mas ser original e criativo nessa foi um desafio que poucos souberam vencer. Célia Gouvêa e Graciela Figueroa são nomes sempre associados a trabalhos que procuram, pesquisam e se renovam a cada espetáculo. Impossível dizer sobre "o quê" falaram os trabalhos de Célia e Graciela, já que apenas usaram pessoas, gestos e relações de movimento como matériaprima de criação $^{331}$.
\end{abstract}

Companhias estruturadas, como o Corpo de Baile Municipal, a companhia oficial de balé da cidade de São Paulo e o Ballet de Câmara Stagium apresentavam-se ali naquele teatro, mas era evidente que o Galpão não era sua casa, seu habitat. Para começar, a sala não dispunha de dimensões suficientes para companhias de grande porte, e sim de médio porte. É longa e coerente a trajetória do Ballet Stagium, comandado por seus incansáveis diretores Marika Gidali e Décio Otero. O grupo perseguiu, permanentemente, a temática da brasilidade, propósito que pouco se alterou ao longo de tantos anos. $\mathrm{O}$ foco na literatura e dramaturgia brasileiras não contemplou a inovação de um vocabulário de movimentos, infelizmente.

Desde os primórdios das primeiras companhias de dança estabelecidas em São Paulo, houve a presença de temas brasileiros, haja vista a programação do Balé do IV Centenário, mencionada anteriormente neste capítulo. O Ballet Stagium foi mais longe na proposta, além do fato de a companhia e seus diretores terem mantido uma postura desbravadora, apresentando-se nos mais recônditos rincões do País. A indiscutível coerência do Stagium faz pensar o quão rápidas são as mudanças de parâmetros na dança e o quanto um coreógrafo e/ou um grupo necessitam atentar permanentemente às transformações e mudanças nos modos de se conceber e construir uma peça de dança.

Professores da fase inicial do Galpão, a proposta artística de Antônio Carlos Cardoso e Iracity Cardoso não se adequava de todo ao espaço. Em uma entrevista à revista Veja São Paulo em 22 de janeiro de 2014, Iracity, a atual diretora artística do Balé da Cidade de São Paulo, afirmou pretender, sim, seguir na dança contemporânea, mas sem nada radical. Ora, o Galpão impulsionava e era um convite aos riscos e experimentações, aos excessos, exatamente ao radicalismo. Essa era a marca. Victor Turner esclarece que a palavra “parfourir" (ou "performare") corresponde a "realizar inteiramente”, “completar". Mais ainda:

\footnotetext{
331 VALLIM JUNIOR, Acácio Ribeiro. A tendência dos espetáculos longos no mundo da dança. O Estado de
} São Paulo, São Paulo, dez. 1980. 
Turner esclarece que a palavra é proveniente do indo-europeu e significa "tentar", "aventurarse", "correr riscos".

O Teatro de Dança Galpão ofereceu, também, um incentivo à produção em dança, pois os grupos contavam com um espaço para apresentar seus trabalhos, conforme o reconhecimento expresso por Janice Vieira em seu depoimento ao programa Figuras da $\operatorname{Dança}^{332}$.

O intenso ciclo de atividades que havia iniciado em 1974 no Teatro de Dança Galpão com Caminhada encerrou-se sete anos depois, no final de 1981, também com uma peça de dança de minha autoria: De pernas para o ar, que juntava componentes de uma Alice no país das maravilhas, de Lewis Carrol, com o Fellini 8 e meio, e no qual uma avaliação, dessa vez do universo da dança, era feita, segundo comentário in off do ator, radialista e então crítico de dança Sérgio Viotti, um dos incentivadores do nosso trabalho. A divulgação anunciava "uma aventura gênero Alice, no poço do real”.

\section{De Pernas para o ar, a derradeira}

A peça de dança era dividida por cenas denominadas, em sua maior parte, "casas": "Casa do cotidiano", "Casa das passagens", "A selva", "Casa do vazio", "Casa do tempo", "Casa do amor", "Casa das bailarinas", "Depoimento" e "Tuipakarulla", pelas quais transitava a personagem. Novamente, o elenco de treze intérpretes era composto por nomes de envergadura: Ruth Amarante - que tornou-se uma das principais bailarinas do Tanztheatre de Pina Bausch, Zélia Monteiro -, Rose Akras, Fortunée Drouer - conhecida hoje como Fortuna, a cantora e pesquisadora de música étnica -, Flávio Colatrello, Maria Mommensohn, Soraya Sabino, Yaskara Manzini, Fernando Penteado, Rogério Da Col, João Úbida, Mauro Munhoz e Célia Gouvêa. Era um tempo em que nos apresentávamos de terça a domingo, com duas sessões aos sábados e duas no domingo. Hoje, apesar de haver mais incentivos, na contramão, vem a falta de público para tantas produções.

Segundo a concepção freudiana, a projeção, o jorrar de imagens aproxima-se mais do inconsciente que a semântica palavra verbal. A montagem reunia ambos: derramamento de imagens aliado à grande quantidade de texto. O pensador francês Jean-Pierre Sarrazac

\footnotetext{
${ }^{332}$ FIGURAS da dança, Janice Vieira. Direção: Inês Bogéa. São Paulo: São Paulo Companhia de Dança, 2013. Exibido em 18 de outubro de 2015 pelo Canal Curta.
} 
afirmou: "Nós precisamos de um teatro que realize a fusão do social, do político e da psicanálise - não como vulgato, mas como discurso do inconsciente" ${ }^{\text {,333. }}$.

$\mathrm{O}$ diretor teatral Ulysses Cruz, então crítico do Diário do Grande $A B C$, escreveu em 11 de dezembro de 1981 a matéria "De pernas para o ar, teatro e dança surreais":

De pernas para o ar é o nome do novo espetáculo que o Teatro de Dança de São Paulo - que vive sob a iniciativa particular de Maurice Vaneau e Célia Gouvêa - está apresentando no Teatro Galpão só até domingo. Infelizmente. A inquietante Célia Gouvêa é quem assina o roteiro e coreografia, baseados numa frase de Hilda Hilst: "Minha riqueza? Procura obstinada". Dividido em nove momentos distintos, que se interligam e se inter-relacionam pelo surrealismo de suas propostas. Célia Gouvêa [...] elaborou um roteiro, aparentemente hermético, dividido em várias casas que resultam no final, num inquietante e excitante jogo de climas, de comovedora verdade e profunda identificação.

De Pernas para o ar incluía textos de Hilda Hilst (gravados pela atriz Irene Ravache), Jorge Luis Borges, Henri Michaux, Theon Spanudis e da Bíblia. Havia ainda um texto sobre a estranha tribo dos Umenes de Bonada e outro sobre a usina de Cubatão e a poluição que provoca, dito pelo ator Flávio Colatrello. A peça tinha a duração de noventa minutos, um verdadeiro tour de force, e apresentava uma personagem curiosa (do grego "cur", ou “cuidado"), que percorria as várias casas. Juntava muito texto, muitos objetos, muito tudo. Ali presentes, obsessões como inverter a ordem das palavras: "pera/arep", "fruto/otruf"; rimas pobres mesclando idiomas, como "cebola/bola", "tesoura/vassoura", "asceta/profeta", "belly/jelly", "any/many", "fanhoso/manhoso", "yellow/mellow”, “caroço,/grosso", "fledermaus/ledermaus", “cabo/rabo", "knackt/kracht", "faminto/extinto"; frases curtas, como "Diga cem vezes merda"; ou a protagonista que interpelava insistentemente os inspirados emissores de textos transcendentes com a pergunta cronológica: "Que horas são?”.

Havia comentários cotidianos: "Tenho dentista às quatro"; "Preciso visitar minha avó"; "Comprar grampos na farmácia"; "Costurar minhas sapatilhas". Cito aqui, por exemplo, a cena "Casa das bailarinas", na qual o propósito era o de humanizar tais bailarinas, tornandoas seres de carne e osso. A configuração espacial do Galpão, naquele momento, tornava

\footnotetext{
333 SARRAZAC, Jean-Pierre apud MENEZES, Maria Eugênia. Teórico Jean-Pierre Sarrazac defende sobrevivência do teatro. O Estado de São Paulo, Caderno 2, 14 mar. 2012. Disponível em: http://cultura.estadao.com.br/noticias/geral,teórico-jean-pierre-sarrazac-defende-sobrevivencia-do-teatro,848271. Acesso em: 1 fev. 2015.
} 
possível a ocupação em vários planos: um quadrado superior, de 2x2 metros; a escadaria que unia o plano superior ao inferior (palco).

Após uma conversa sobre assuntos cotidianos, como peso, comida, aborto, desafios recíprocos para executar uma série de fouettés pousando sempre o pé no pliê exatamente no mesmo ponto, as quatro bailarinas, vestidas de longos tutus brancos e sapatilhas de ponta, rolavam nos degraus pretos que formavam a escadaria, ao pé da qual havia uma latrina onde uma das bailarinas, desesperada, vinha chorar, martelando as duas sapatilhas contra o chão para, em seguida, as quatro serem pesadas em um modelo antigo de balança e marcadas, como gado, com uma etiqueta amarrada na primeira saia do tutu, que era levantada a fim de cobrir o rosto de cada uma. Reuniam-se, davam-se as mãos e, assim, com os rostos cobertos, dançavam o pas de quatre dos pequenos cisnes ao som de Lago dos cisnes, de Piotr Ilitch Tchaikovsky (1840-1893), para em seguida procederem a uma sucessão de posturas de agradecimentos as mais variadas ao som de A noite transfigurada, de Schönberg, mixada a aplausos.

O elenco de De pernas para o ar foi um exemplo da heterogeneidade de talentos que sempre me agradou reunir: havia atores (como Flávio Colatrello), dançarinas com técnica (Zélia Monteiro, Yaskara Manzini, Ruth Amarante, Rose Akras, Soraya Sabino), cantora (Fortuna), dançarino iniciante (João Úbida), aspirante a artista (Mauro Munhoz), praticante de movimento consciente (Maria Mommensohn) e outras modalidades mais. Poucos dançarinos com técnica clássica apurada mostram-se abertos e aptos a experimentar outros códigos de movimento e improvisar.

Além de ator, Flávio Colatrello Júnior tornou-se diretor de programas e telenovelas da Rede Globo. Mauro Munhoz é curador da Feira Literária Internacional de Paraty, a FLIP, que acontece anualmente. Fortuna firmou-se como cantora.

No período de $1^{\circ}$ a 31 de Dezembro de 1981, participamos da Campanha de Popularização do Teatro, em meio a 36 peças teatrais e 30 espetáculos infantis. Intitulado Teatro para o Povo, o evento, administrado pela Associação dos Produtores de Espetáculos Teatrais do Estado de São Paulo, contou com o patrocínio do Serviço Nacional de Teatro e da Secretaria da Cultura - órgãos do Ministério da Educação e Cultura. Os dias e horários das apresentações encontram-se estipulados no material de divulgação: quarta quinta-feira: $21 \mathrm{~h} 30$; sexta-feira e sábado: 21 h30 e 24 horas; domingo: 19 horas e 21h30. No ano de 1997, o complexo teatral Ruth Escobar foi comprado pela Apetesp durante a gestão de Sérgio d'Antino. 
A coerência entre as montagens Caminhada, de 1974, que inaugurou o ciclo do Teatro de Dança Galpão, e De pernas para o ar, que, em 1981 encerrou esse ciclo enquanto a casa da dança, pode ser considerada pela via da busca, da investigação, ou da linguagem da procura, como afirmou Sérgio Viotti em artigo no Jornal da Tarde de 15 de novembro de 1980: "Podese até [...] considerá-los trabalhos experimentais. Mas não é a experiência no laboratório (a tentativa que pode redundar em nada). É o resultado de uma experiência que encontrou sua solução, que já nos chega, não como um ato incompleto, mas uma realização definida" ${ }^{334}$.

Figura 53 - Cena de De pernas para ao ar

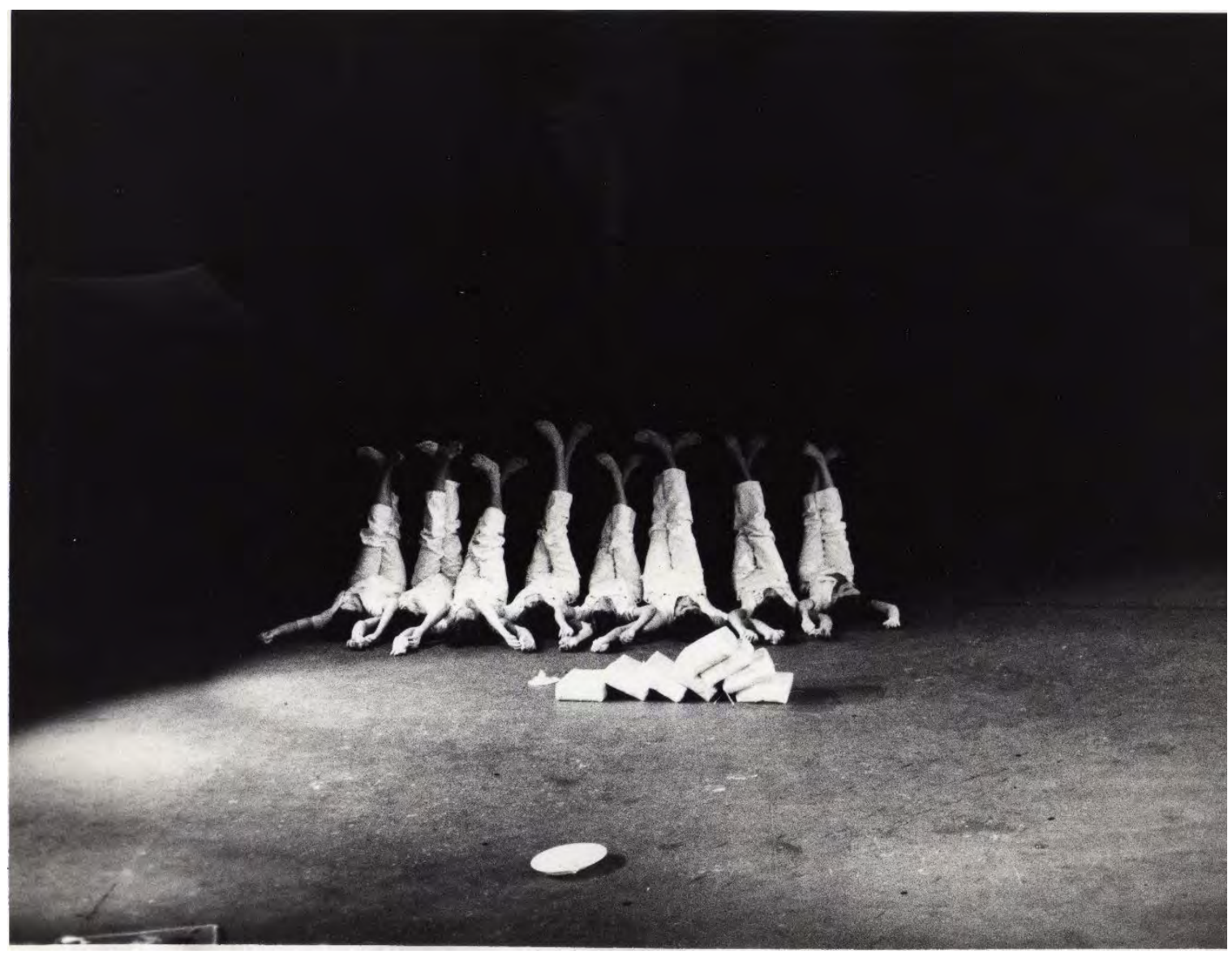

Teatro de Dança de São Paulo. Teatro Galpão. São Paulo, SP, 1981.

Fonte: arquivo pessoal. Fotógrafo: não identificado. 
Figura 54 - Cena de De pernas para o ar

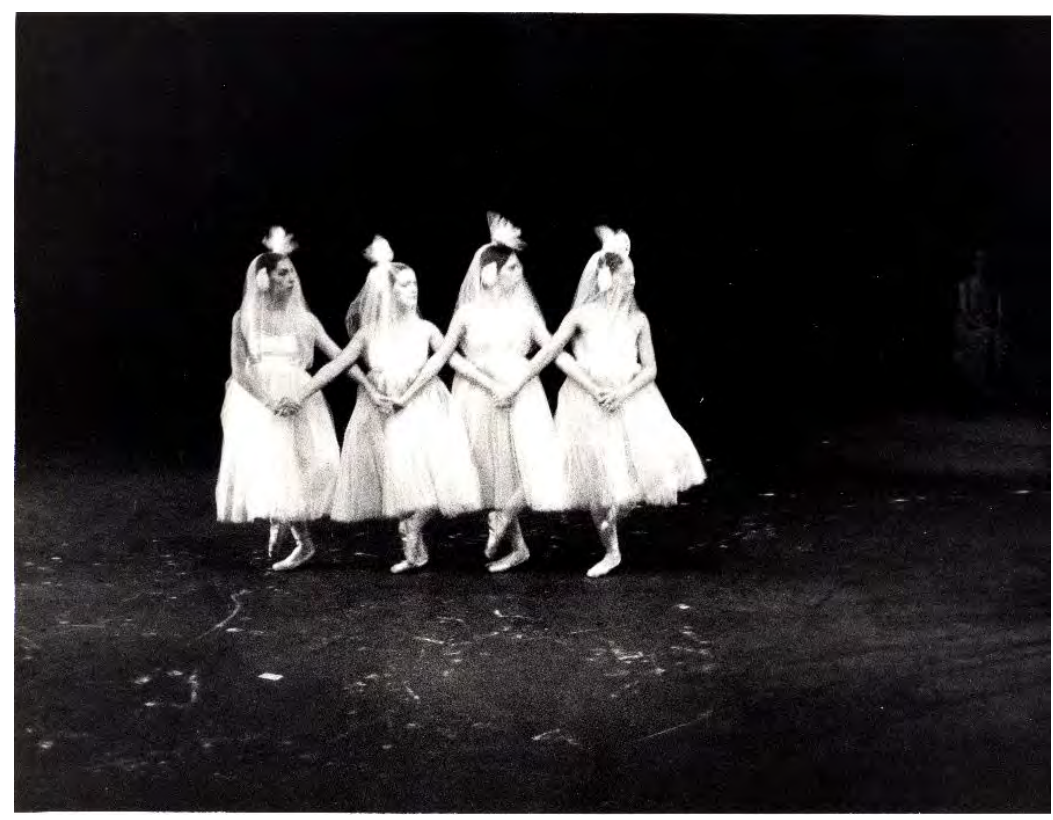

Soraya Sabino, Rose Akras, Ruth Amarante, Yaskara Manzini (da esq. p/ dir.). Teatro de Dança de São Paulo. Teatro Galpão. São Paulo, SP, 1981.

Fonte: arquivo pessoal. Fotógrafo: não identificado
Figura 55 - Cena de $D e$ pernas para o ar

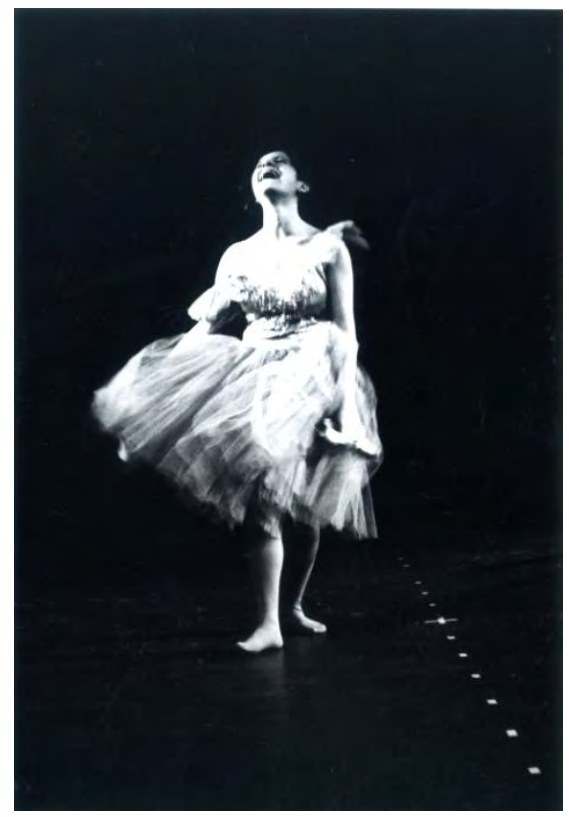

Rose Akras. Teatro de Dança de São Paulo. Teatro de Dança de São Paulo. Teatro Galpão. São Paulo, SP, 1981. Fonte: arquivo pessoal. Fotógrafo: não identificado

\subsection{Balanço}

São favoráveis as palavras de Sílvia Geraldi, pesquisadora e artista da dança já mencionada, publicadas no livreto encartado no DVD Figuras da Dança/2011:

De 1974 (data de Caminhada, a primeira criação) ao presente, somam-se quase quarenta anos de contínua atividade, com aproximadamente sessenta peças produzidas, inúmeras premiações, as mais importantes bolsas nacionais e internacionais, um sem-número de artistas formados no contato com seu trabalho. Todas essas décadas de militância pela consolidação de uma dança contemporânea brasileira demonstram a força de sua inquietação e o poder de sua arte para reinventar-se permanentemente.

Igualmente positivos os comentários retrospectivos da crítica de dança Helena Katz escritos no Caderno 2 do jornal O Estado de São Paulo em 14 de dezembro de 1994:

[...]. Em Assim Seja (1985), de uma beleza impecável, amadureceu sua estética [...] em Sapatas Fenólicas (1992) liquidificava, com alta competência, as marcas da pós-modernidade. Gouvêa e Vaneau marcaram essas duas décadas de carreira com a persistência dos obstinados. Sempre 
protestando contra a orfandade em que as políticas culturais locais mantêm seus artistas, jamais interromperam o fluxo das suas produções. Graças a este empenho pessoal, doaram para a dança brasileira uma coleção de obras importantes. Dois artistas valentes, que merecem condições mais favoráveis para abrigarem suas criações.

Em 18 de Julho de 1998, para o mesmo Caderno, escreveu:

Célia Gouvêa tem um papel muito importante na história recente da nossa dança. Caminhada, o espetáculo que marcou a sua volta ao Brasil, em 1974, inaugurava a companhia que fundou com Maurice Vaneau, o Teatro de Dança de São Paulo. Lá, já se revelava uma criadora inquieta e antenada. Desde então, nunca deu trégua ao comodismo estético, lutando, através das suas mais de 40 coreografias, para que a dança contemporânea conquistasse reconhecimento. E ainda: Pela importância de sua trajetória, pela força da inquietação que sempre temperou o seu percurso, Célia Gouvêa destaca-se como militante na linha de frente de resistência que alguns artistas mantêm em favor da arte brasileira de qualidade.

Houve, no entanto, dificuldades que não foram poucas, e entraves. Talvez um dos problemas fosse o excesso. Excesso de imagens, cuja conversa entre si nem sempre era clara o suficiente para o público, mas poderia, sim, estimulá-lo a múltiplas leituras. As apresentações de De pernas para o ar integraram a campanha das kombis do Serviço Nacional de Teatro e fizemos oito apresentações semanais durante duas semanas: às quartas e quintas, às 21 horas; sextas e sábados às 21 e 24 horas; domingos às 19 horas e 21h30. Pude constatar que, via de regra, a segunda apresentação era melhor, fluía mais, como se a primeira servisse de aquecimento, de treino.

As leis de incentivo foram conquistadas muito tempo depois, em um futuro ainda bastante distante, e não havia uma política pública para a dança em nenhuma instância municipal, estadual ou federal. Via de regra, coreógrafos e dançarinos sustentavam-se dando aulas de dança, com exceção de companhias oficiais e grupos estáveis, como o Stagium e o Grupo Cisne Negro, em São Paulo. Resquícios de uma vanguarda utópica e romântica delinearam a consideração de que a atividade didática correspondia a um desvio, a uma capitulação, um desperdício de energia criativa, quando, na verdade, pode constituir um campo de exploração, desenvolvimento e amadurecimento de muitas questões. Certo é que não é uma atividade solitária. Solicita que se goste de gente, uma abertura para a alteridade.

Infelizmente, não é possível dizer que, paralelamente à maior solidez obtida na estrutura de trabalho dos grupos, tenha havido um acréscimo significativo na frequência de público às montagens cênicas de dança, hoje em número eminentemente maior do que o de 
quatro décadas atrás. Falta público para tantas produções. Em parte pelo fato de vivermos um tempo eminentemente virtual, que parece bastar e satisfazer a um público potencial, que prefira, talvez, inserções curtas, instantâneas. Outra questão é a arte fundada na pesquisa, que não visa fazer-se em mercadoria. Assim como, para se produzir ciência, há necessidade de tempo, sem pressão, o que resulta na necessidade de incentivos. Artistas não empresários, inaptos à produção de riqueza.

Em 29 de dezembro de 2014, Márcia Dessen escreveu na Folha de São Paulo: "Pare de fazer coisas que não ajudam a construir riqueza e bem estar". Fui fruto da geração de 1968, para a qual o consumismo não costumava comparecer na ordem do dia, não constituía moeda de troca. O valor de mercado de nosso produto aproximava-se do nulo. A atitude era a de colocar-se à margem do sistema capitalista.

Considero que há, também, falta de curiosidade, e não entendo como gente de teatro não compareça em número significativo para montagens como as de Sandro Borelli e João Andreazzi, só para citar dois exemplos. No meu entendimento, o artista viveria mergulhado em suas produções. Nos tempos vagos, se dedicaria a flâner para alimentar-se. É recente o fenômeno do talentoso artista professor, que produz boa arte sem descuidar da manutenção de sua sobrevivência, em um pragmatismo saudável. O tempo do professor de artes considerado como artista fracassado parece ter se encerrado. "Mais liberdade, menos segurança; mais segurança, menos liberdade" é uma das premissas do mentor da modernidade líquida, o pensador polonês Zygmunt Bauman (1925-2017), em um de seus achados-chave ${ }^{335}$. Evitei sempre compromissos a longo prazo, pois nunca sabia ao certo onde estaria ou queria estar daí a seis meses.

Um evento realizado em 13 de maio de 2017 no Instituto Polis, em São Paulo, promovido pelo Le Monde Diplomatique Brasil, organizado por Cristiano Navarro, um dos editores do jornal, reuniu artistas de várias áreas - o músico Benjamin Taubkin, a cartunista Laerte, o escritor Ricardo Lísias, a cineasta Eliane Caffé, a atriz Fernanda Azevedo e eu, do campo da Dança, para discutir "Os impactos de um ano de golpe na Cultura". O músico Taubkin afirmou, à ocasião, que a "geração sessenta" não foi criativa para encontrar soluções válidas e viáveis de sobrevivência, mostrando-se desarmada face ao alto capitalismo. Recentemente, no dia 23 de abril de 2017, comemorou-se, em quinhentas cidades do mundo

\footnotetext{
${ }^{335}$ BAUMAN, Zygmunt. Liberdade e segurança: a história inacabada de uma união tempestuosa. In: BAUMAN, Zygmunt. A sociedade individualizada: vidas contadas e histórias vividas. Tradução de José Gradel. Rio de Janeiro: Jorge Zahar, 2008. p. 57-77.
} 
inteiro, o dia mundial dedicado à investigação científica. Em São Paulo, na véspera, houve uma manifestação: a Marcha da Ciência, destinada a reivindicar a possibilidade de se realizarem trabalhos em um tempo largo e sem pressão, dada a necessidade de uma retaguarda com recursos. A pesquisa precisa, invariavelmente, de incentivos, pois os resultados demoram a aparecer. O mesmo vale para a cultura, tantas vezes impregnada de ciências.

Lembro-me bem quando Marilena Ansaldi perguntou-me: "Não é possível encontrar duzentas pessoas que venham ao teatro a cada noite?" Não, infelizmente. O questionamento de Marilena veio no início de seu longo retiro cênico, que duraria doze anos, logo após as apresentações de Clitemnestra, de Marguerite Yourcenar, com direção de Antônio Araújo, em 1991.

Geralmente, as temporadas de espetáculos eram curtas e rapidamente se esgotava o público potencial. Pouco tempo após o término de uma temporada, já começava uma nova coreografia, antes mesmo de se recuperar o fôlego da produção antecedente. Somado à impossibilidade de ensaios remunerados, por vezes, o que se mostrava era imaturo, apressado. Havia uma confiança enorme na intuição, no conhecimento direto, que levava, muitas vezes, a se "fazer o que desse na telha", sem o exercício suficiente da reflexão, o que considero coisa de gente mimada. Ia fazendo, apegando-me a tudo, sem separar suficientemente o joio do trigo, sem peneirar. Vinha a ideia e, imediatamente, "pá-pum", a realização compulsiva. Havia também o apego a detalhes, um querer explorar todas as possibilidades que uma determinada vertente oferecia, tornando-se o fazer maníaco. Concordo com o preceito artaudiano segundo o qual é para fugir ao inferno que todo artista produz. A sempre presente curiosidade leva à postura de eterna aprendiz, desprovida de certezas.

No final de uma das apresentações de De pernas para o ar, um rapaz que parecia seguir a programação de dança, disse: É incrível que há tantas coisas boas e no final há gente que diz: "Não gostei". Ao término da temporada de Trem fantasma e outras danças, uma de nossas melhores produções, quis promover uma turnê no interior do estado de São Paulo, para amadurecer a peça. O então responsável por assuntos da dança na Secretaria de Estado da Cultura, Sr. Henrique Suster, disse-me que eu deveria montar a turnê e apresentar o projeto à Secretaria. Após dezenas de contatos com secretarias e teatros do interior e a pauta montada, recebi o veredicto de que a Secretaria não poderia arcar com as viagens.

Pontualmente, alguma iniciativa governamental esparsa nos socorria, em um tempo de ausência de políticas públicas continuadas para a dança, quando predominava, com chances de vingar, o que se denominava "política de balcão", quando o produtor dirigia-se diretamente aos órgãos públicos para obter apoio unicamente para o seu trabalho. Entre as iniciativas- 
respiro governamentais, houve o projeto Sinfonia nos Parques, que abarcou música e dança, realizado nos parques do Carmo e Ibirapuera em agosto de 1980. O projeto era descrito como uma inclusão de apresentações de orquestras, corais, bandas, conjuntos musicais e grupos de dança, apresentado aos domingos e feriados, alternadamente. A abertura contou com a Orquestra Sinfônica de Campinas, tendo como regente o maestro Benito Juarez, e foi uma promoção conjunta das duas secretarias da Cultura: a Municipal e a Estadual, com o apoio da RTC Rádio e Televisão Cultura, segundo anúncio que conservo em meus arquivos e publicado no Jornal City News de 10 de agosto de 1980. Via de regra, as produções de dança migravam para os teatros de bairro da Prefeitura, além do Galpão. Curiosamente, vingou o termo "independente" para produções que não contavam com patrocínio regular. Sem contar com o apoio do poder público, dependiam da abnegação de seus participantes.

Em 26 de Outubro de 1981, o Jornal da Tarde publicou uma matéria com o título "Pobres bailarinos, cheios de sacrifícios!" que apontava para a ausência de políticas públicas, para a qual, além de mim, foram entrevistados os dançarinos-coreógrafos João Maurício, Sônia Mota e Susana Yamauchi, que, então, apresentavam, no Teatro Galpão, o espetáculo Kiuanka ${ }^{336}$. Mais do que lamúrias, achava-se expresso o protesto quanto às condições de trabalho que dispúnhamos, pois éramos levados a adiantar de nosso bolso os custos que seriam ressarcidos apenas dois meses após a estreia, em um teatro que não contava sequer com uma escada para que o eletricista pudesse subir e afinar os refletores. Aliás, o teatro não dispunha de equipamentos. Os artistas tinham que se encarregar do seu aluguel, bem como do transporte e, ainda, contratar operadores de luz e som, após terem pago pela gravação do som. As perspectivas de lucro eram nulas, mas as migalhas que recebíamos não inibiam a continuidade e o avanço dos nossos trabalhos. Por que manter uma produção incessante? $\mathrm{Na}$ entrevista, afirmei que "a necessidade de criação torna-se quase uma doença entre os artistas". Alwin Nikolais dizia a seus alunos, entre os quais me incluo, que a dança era o gesto sem serventia, não utilitário, sem função prática ou desprovido de valor de mercado.

Funcionava devido à labormania, ou seja, reconheço a presença da necessidade de manter-me permanentemente em processo produtivo. O público era reduzido, como ainda é até os dias de hoje. Rapidamente esgotava-se o número de interessados. Era preciso lidar com o desmotivante e persistente descaso. O acúmulo de funções provocava desgaste, e eu assumia, inevitavelmente, o papel de patroa, ainda que um dos dançarinos, afavelmente,

\footnotetext{
${ }^{336}$ Susana dirigiu até meados de 2017 a Escola de Dança de São Paulo, a antiga Escola Municipal de Bailados. João Maurício partiu para os Estados Unidos, dançou na Companhia de Paul Taylor e é professor.
} 
pusesse a palavra no diminutivo: "patroinha", o que sinalizava a relação afetiva, e não estratificada. Como outros artistas da dança, dava a vida para fabricar produtos pouco vendáveis.

A guinada para os espaços públicos e o abandono das caixas pretas dos teatros se justificam. Há quem credite aos dadaístas a abrangência. O que fazer? Compor novas peças para os eventuais interessados. Muitas vezes, não havia o tempo necessário para uma renovação interna. Não era possível permitir-se a isso. Recorria-se a uma guinada radical na direção seguida na peça anterior, acionando-se canais criativos diversos: se, em determinada peça, eu havia me concentrado em uma exploração de qualidades de movimento, na próxima, trataria de questões humanas, de um modo de ser e estar no mundo, para evitar me repetir. Muitas vezes partia para a sala de ensaios apenas com uma tênue e vaga ideia. Às vezes, adquiria texturas e contextos, às vezes, não. A impossibilidade de conceder o tempo necessário para a maturação e o fato de os ensaios não serem remunerados não ajudavam em nada. Resultava em obras apressadas, sem a devida consistência. Certo é que não podia parar, o que corresponderia a uma morte artística. Quando não havia o tempo necessário para "encher o balde", como costumava dizer, para, em seguida, esvaziá-lo, tendia a recorrer a partituras musicais, geralmente de autores contemporâneos de excelente qualidade.

Outra certeza era a de prosseguir procurando, seguindo o curso de uma pesquisa que nem sempre se apresentava fértil. A recusa em acompanhar padrões estabelecidos era firme. $\mathrm{O}$ termo "dança independente" era frequentemente empregado. Independente equivalia a estar à margem do mainstream, dos financiamentos oficiais. Ter ou ser, eis a questão, segundo o subvertor de provérbios Herculano Villas-Boas. Preferível era quando era possível "deixar que o balde se enchesse", em uma ebulição de ideias, para esvaziá-lo, o que correspondia a produzir por necessidade, algo nada condizente com a produção mercadológica capitalista.

\subsection{Pensamento visual}

No meu entendimento, coreografia é pensamento visual, que opera por imagens. Uma performance pode, é claro, ter a palavra como ignição, mas esta será física, assim como não é possível dissociar o corpo da voz, pois esta integra o corpo. A comunicação performática acontece por meio do aparato sensório-motor. A ênfase do contato se dá pela circulação da energia, pela irradiação do artista-corpo.

A pesquisa empreendida trata de uma trajetória coreográfica que encontra, na potência do corpo, o seu motor. Na dança, como na performance, hoje tão difundida, tanto da parte de 
quem faz quanto de quem vê, busca-se o estado de disponibilidade, quando o território corpo, sua pele, seus músculos, são “des-ocupados” - expressão de Guillermo Gómez Peña. Dá-se, então, a abertura dos canais sensórios para que o mergulho desprovido de resistências possa acontecer. Saberes-sabores. O pensamento corporal é peculiar. É visual. Lygia Clark afirmou que cérebro é também vísceras, que não se opõem ao que é pensante. Referiu-se ainda à "experiência tátil, fantasmática e simbólica da interioridade do corpo" ${ }^{337}$. Ao buscar o estado de invenção, Hélio Oiticica, que já havia constatado junção entre as artes, considera o espectador como ente participante da obra de arte. $\mathrm{O}$ artista surge não mais como criador de objetos, mas como propositor de práticas em aberto"338. Há a incorporação, quando o corpo deixa de ser um mero e eventual suporte, mas o lugar da racionalidade e da invenção. Pelos motivos expostos, há quem diga que a performance, que produz imagens, nasceu das artes plásticas. A afirmação procede. Segundo Marco De Marinis, “uma imagem, ou um grupo de imagens, é, ou pode ser, um texto"339.

Na origem, pensar é pesar, avaliar as coisas. A palavra "peso" é corporal.

\footnotetext{
${ }^{337}$ Clark, Lygia apud ROLNIK, Suely. Lygia Clark, artista contemporânea. São Paulo: Valor Econômico, São Paulo, 12 abr. 2002.

${ }^{338}$ PENNAFORT, Roberta. A busca do estado de invenção. O Estado de São Paulo, Caderno 2, São Paulo, 8 dez. 2012, p. D5.

339 MARINIS, Marco apud SCHECHNER, Richard. Performance Studies: an introduction. New York: Routledge, 2006. p. 227.
} 


\section{BREVES PALAVRAS II}

Pina Bausch estabeleceu uma distinção entre o pessoal e o privado. Penso que o privado concerne exclusivamente a mim, enquanto o pessoal é ou pode ser abrangente. Conforme dito anteriormente, busco o que denomino singularidades coletivas. Desde JeanPaul Sartre, admitiu-se que a existência constitui o ser, contrariando-se a tradição filosófica, que colocou sempre o fiel da balança no sujeito, sede da verdade ou da dita essência. Tento auscultar-me profundamente para atingir o outro.

Na contemporaneidade, o vínculo da pessoa com o entorno, produzindo o convívio, exaustivamente analisado por Nicolas Bourriaud, gerou novos conceitos, como o da transindividualidade, que recoloca a subjetividade inevitavelmente aliançada com o mundo. Felix Guattari, parceiro de Gilles Deleuze em tantos escritos, diria que "a única finalidade aceitável das atividades humanas [...] é a produção de uma subjetividade que autoenriqueça continuamente sua relação com o mundo" 340 .

Outro de meus propósitos é o entendimento cinestésico da teoria, ou a teoria apreendida pelos sentidos. A teoria tende a simplificar um problema por meio da elucidação, ao invés de complicá-lo. A certeza do amálgama entre os saberes, de todos eles conversando. Deixar, permitir que o corpo dirija suas ações, único modo de manter-se produtivo. Viver à toa, ócio criativo. Procuro um entendimento da teoria que não me torne desconectada de meu corpo.

Durante a escrita desta pesquisa, a melhor rotina consistia em escrever todo o dia para, no início da noite, com o corpo "carregado" de pontos de tensão espalhados por todo o corpo, ir fazer meus exercícios por cerca de uma hora e quinze minutos, o que me permitia colocar os ossos no lugar. Disso já falei em "Breves Palavras I", mas reitero. Atividades como varrer a casa ou lavar a louça levam-me a assentar as ideias. Um único compromisso externo, que me leve para fora de casa, altera a rotina e desorganiza. Deixei de ir ver inúmeros acontecimentos artísticos que me interessavam, para não me dispersar. Depois, questionava a decisão. Dizia-me que poderiam ter provocado preciosos estímulos. Quem faz dança costuma ser sempre disciplinado. Impus-me a disciplina de escrever diariamente, nem que fosse uma palavra.

\footnotetext{
${ }^{340}$ GUATTARI apud BOURRIAUD, 2009, p. 145.
} 
Havia, porém, períodos que eram como se eu tivesse brigado com a escrita e que o simples fato de abrir o texto causava-me náuseas. Sonhava em ficar de tal modo ligada que não poderia mais largar a escrita, dia e noite, mas nada desse momento chegar. Acabei por contentar-me em produzir um pouco a cada dia e parar, de vez em quando, para respirar. Tentei muitos métodos, como o de escrever ainda em jejum, antes de me envolver com qualquer questão cotidiana. Quando ligo o computador, devo ir diretamente ao texto. Se for antes verificar e-mails ou, principalmente, o facebook, já a dispersão toma conta.

Considero bastante provável que, logo em seguida ao depósito da tese, surjam muitas ideias não escritas. Com frequência, sentia-me tomada por uma ideia que já havia sido colocada. Perscrutei a razão do fato. Possivelmente, deve-se à tendência de contestar tudo o que já foi feito anteriormente, supondo que o que virá a ser feito será melhor.

Se é verdade, não sei, mas ouvi que Chico Buarque de Holanda não relê seus escritos, pois, ao fazê-lo, já se encontrará em um momento distinto daquele que produziu a escrita e quererá modificá-la, em um processo que lembra o filósofo Heráclito, ao considerar que as águas serão outras ao se atravessar novamente um mesmo rio. Frequentemente, ocorria-me uma ideia e corria ao computador para escrevê-la. Poucos parágrafos à frente, constatava que a mesma já se encontrava lá. Outras vezes, pensava ter encontrado as palavras as mais exatas, as mais adequadas, para um trecho já escrito. Ao conferir o texto, via que as mesmíssimas palavras já haviam sido redigidas. Penso que um trabalho escrito pode ser considerado pronto nesse momento, quando ocorre uma ideia, corro ao computador para registrá-la e constato que a mesma já se encontra lá. A pesquisa é interminável. O momento de considerar o trabalho pronto nunca chega. Percebia-me indo a palestras, filmes e exposições relacionados a minha temática até o dia do depósito do texto. Poderia seguir burilando por, pelo menos, mais um ano, mas chega o momento de dizer "basta".

O fato de o pós-modernismo ter promovido a junção entre a baixa e a alta cultura habilita-me a dispor de fontes díspares, tais como internet, o rádio e a TV, além das referências bibliográficas, que são a praxe. Componente importante é a caminhada, que desobstrui canais cerebrais e permite o percurso e o aflorar das ideias. Caminhantes ilustres o souberam, dos participantes da escola peripatética aristotélica no século IV a.C. a JeanJacques Rousseau (1772-1778). O contumaz andarilho dirá em meio a suas sonherias: “Eu só posso meditar caminhando; assim que paro eu não penso mais e minha cabeça só funciona em 
consonância a meus pés" ${ }^{341}$, em mais uma afirmação do papel do corpo como produtor de conhecimento. A colega artista da dança Angel Vianna aconselhou: "Deixa a vida te levar". Eu diria: "Deixa o corpo te levar, modo de ser mais produtivo".

Em 30 de setembro de 2016, em um encontro do Laboratório de Dramaturgia do Corpo (LADCOR), grupo de estudos que integro, com a coordenação da orientadora Prof. Dra. Helena Bastos, tivemos a presença da professora doutora Maria Silvia Betti, da Faculdade de Filosofia, Letras e Ciências Humanas da USP, a FFLCH. Ela relatou que havia proposto a um grupo de alunos que percorressem um trajeto próximo à antiga Faculdade de Filosofia, na Rua Maria Antônia, marcado pelos conflitos durante a ditadura civil-militar, para que analisassem as próprias sensações.

Segundo a professora, parte dos alunos considerou que não se tratava de uma proposta acadêmica. Que se tratava de um desvio. Ora, mesmo com o avanço da interdisciplinaridade nas universidades, parte dos alunos ainda rechaça a alternativa, apresentando o vício de conceber o intelecto desligado do corpo, em uma superada perspectiva cartesiana. Interlinguagens: amálgama, junção, simbiose. Transmeável é aquilo que se pode atravessar, permeável, transpirável.

Interlinguagens tudo transpassa. Concerne não apenas aos recursos corporais, como também à conversa entre os vários campos do conhecimento. Inter tudo.

Breves palavras, palavras breves.

Pensar é pesar, pesar é pensar.

\footnotetext{
${ }^{341}$ LICHET, Raymond. Jean-Jacques Rousseauu la vie et l'oeuvre. Paris: Librairie Hachette, 1971. p. 32. Tradução nossa. Texto original: "Je ne puis méditer quén marchant; sitôt que je m'arrête e ne pense plus et ma tête e va qu'avec mes pieds".
} 


\section{REFERÊNCIAS BIBLIOGRÁFICAS}

\section{Livros:}

AGAMBEN, Giorgio. O que é o contemporâneo? e outros ensaios. Chapecó: Argos, 2010.

AgOSTINHO, Santo. Confissões. Tradução de J. Oliveira Santos, S.J.; Ambrósio de Pina, S.J. São Paulo: Nova Cultural, 1999.

ANDERSON, Jack. Dance. New York: Newsweek Books, 1979.

ANSALDI, Marilena. Atos: movimento na vida e no palco. São Paulo: Maltese, 1994.

AUGUET, Roland. Histoire et légende du cirque. Paris: Flammarion, 1974.

ARISTÓTELES. Poética. Tradução de Eudoro de Souza. 2. ed. São Paulo: Ars Poética, 1993.

ARTAUD, Antonin. Le théâtre et son double. Paris: Gallimard, 1964.

BACHELARD, Gaston. A poética do espaço. Tradução de Antonio de Pádua Danesi. São Paulo: Martins Fontes, 1996.

BAKAN, David. Desease, Pain and Sacrifice. Chicago, University of Chicago Press, 1968.

BANES, Sally. Terpsichore in Sneakers: post-modern dance. Boston: Houghton Mifflin Company, 1980.

BARTHES, Roland. Le Bruissement de la langue: éssais critiques IV. Paris: Seuil, 1984.

O prazer do texto. Tradução de J. Guinsburg. São Paulo: Perspectiva, 1999.

BATTCOCK, G. (Org.). A nova arte. São Paulo: Perspectiva, 1986.

BAUMAN, Zygmunt. Liberdade e segurança: a história inacabada de uma união tempestuosa. In: A A sociedade individualizada: vidas contadas e histórias vividas. Tradução José Gradel. Rio de Janeiro: Jorge Zahar, 2008, p. 57-77.

BÉJART, Maurice. Um instante na vida do outro. Tradução de Suzana Martins. Rio de Janeiro: Nova Fronteira, 1981.

BENJAMIN, Walter. A obra de arte na época de sua reprodutibilidade técnica: In: ADORNO et al. Teoria de cultura de massa. Trad. de Carlos Nelson Coutinho. São Paulo: Paz e Terra, 2000, p. 221-254.

. Oeuvres III. Paris: Gallimard, 2000.

Magia e técnica, arte e política: ensaios sobre literatura e história da cultura. São Paulo: Brasiliense (Obras Escolhidas, v. 1), 1986. p. 192. 
BERGSON, Henri. Matière et Mémoire. Paris: Presses Universitaires de France, 1946.

. Memória e vida: textos escolhidos. Tradução de Cláudia Berliner. Revisão técnica e

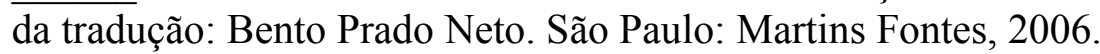

. Cartas, conferências e outros escritos. Seleção de textos de Franklin Leopoldo e Silva. Traduções de Franklin Leopoldo e Silva, e Nathanael Caxeiro. São Paulo: Victor Civita, 1984.

BERTHOZ, Alain. La simplexité. Paris: Odile Jacob, 2009.

BÍBLIA SAGRADA, A. Traduzida em Português por João Ferreira de Almeida. Rio de Janeiro: Sociedade Bíblica do Brasil, 1969.

BOGÉA, Inês. Renée Gumiel 90 anos (catálogo). São Paulo: SESC, 2003.

. Caminhos Cruzados. Teatro de Dança Galpão 1974-1981. São Paulo: SESC, 2014.

BOURRIAUD, Nicolas. Estética relacional. Tradução de Denise Bottmann. São Paulo: Martins Fontes, 2009.

BRACHTENDORF, Johannes. Confissões de Agostinho. São Paulo: Loyola, 2008.

BROCKETT, Oscar G. History of the Theatre. 4. ed. Boston: Allyn and Bacon, 1982.

BROOK, Peter. The Empty Space. Midlesex: Penguin Books, 1968.

BÜRGER, Peter. Teoria da vanguarda. Tradução de José Pedro Antunes. São Paulo: Cosac Naify, 2008.

CALDER, Alexander. À propos of measuring a mobile: manuscrito, arquivo da Calder Foundation, 1943.

CALLE, Sophie. M'as-tu vue. Paris: Centre Pompidou and Éditions Xavier Barral, 2003.

CHAUÍ, Marilena. Convite à Filosofia. São Paulo: Ática, 2004.

CHEKHOV, Michael. Para o ator. Tradução de Álvaro Cabral. São Paulo: Martins Fontes, 1996.

CHRISTOUT, Marie-Françoise. Béjart. Paris:Seghers, 1972.

COHEN, Selma Jeanne. Dance as a Theatre Art. New York: Dodd, Mead \& Company. 1974.

CORBIN, Alain; COURTINE Jean-Jacques; VIGARELLO, Georges. História do corpo, 3 v., Petrópolis: Vozes, 2008.

CORREA, Anchieta José. L'evolution de la notion de «corps» a la notion de «chair» chez Maurice Merleau-Ponty. Louvain: [s.n.], 1971. 
CORETH, Emerich. Questões fundamentais de hermenêutica. São Paulo: E.P.U -Editora Pedagógica e Universitária, 1973.

COSTA, Carlos (Org). Ocupação Maria e Herbert Duschenes. São Paulo: Itaú Cultural, 2016.

CUNNINGHAM, Merce. Notes on Choreography. New York: Something Else Press, 1968.

DALCROZE, Jacques. Le rythme, la musique et l'éducation. Lausanne: Foetisch Frères, 1919.

DAMÁSIO, Antonio. E o cérebro criou o homem. Tradução de Laura Teixeira Motta. São Paulo: Companhia das Letras, 2011.

DELEUZE, Gilles. A imagem-tempo. Tradução de Eloisa de Araujo Ribeiro. São Paulo: Brasiliense, 1990.

. Diferença e repetição. 2. ed. Tradução revista de Luiz Orlandi e Roberto Machado. São Paulo: Graal, 2009. 2008 .

Foucault. Tradução de Cláudia Sant'Anna Martins. 6. ed. São Paulo: Brasiliense, . Le bergsonisme. Paris: Presses Universitaires de France, 1966.

. GUATTARI, Félix. Mil Platôs: capitalismo e esquizofrenia. Tradução de Ana Lúcia

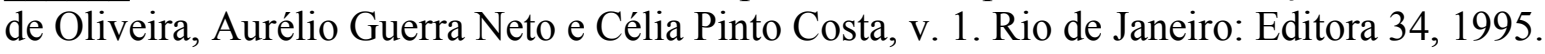

DERRIDA, Jacques. A farmácia de Platão. 3. ed. São Paulo: Iluminuras, 2005.

DESCARTES, René. Descartes: vida e obra. 3. ed. Tradução de J. Guinsburg e Bento Prado Júnior. São Paulo: Abril Cultural, 1983.

DUCHARTRE, Pierre-Louis. La Commedia dell'Arte. Paris: Éditions d'Art et d'Industrie, 1955.

DURKHEIM, Emile. Lições de Sociologia. Tradução de Mônica Stahel Oliveiros S. Ferreira. São Paulo: Martins Fontes, 1990.

FABBRINI, Ricardo. A fruição nos novos museus. São Paulo: Especiaria - Cadernos de Ciências Humanas, v. 11, n. 19, jan./jun.2008.

A arte depois das vanguardas. Campinas: Editora da Unicamp, 2002.

FEHER, Michael; NADDAFF, Ramona; TAZI Nadia, (Orgs.). Fragments for a History of the Human Body, 3 v. New York: Urzone, Inc., 1989.

FÉRAL, Josette. Théorie et pratique du théâtre: au-delà dês limites. Paris: L“entretemps, 2011. 
FISCHER-LICHTE, Erika. The Transformative Power of Performance: a new aesthetics. Chapter 1. Translation: Saskya Iris Jain. London; New York: Routledge - Taylor \& Francis Group, p. 10-37.

FIGUEIREDO, Luciano (Org.). Lygia Clark, Hélio Oiticica: cartas. Rio de Janeiro: Editora UFRJ, 1996.

FISHER LICHTE, Erika. Réalité et ficction dans le théâtre contemporain. Paris: Revue d'études théâtrales, Registres 11/12, 2006/07.

FORTIN, Sylvie. Toward a New Generation: Somatic Dance Education in Academia. Montréal: Impulse - Human Kinetics Publishers, Inc. 1995.

FOUCAULT, Michel. Of Other Spaces: Utopias and Heterotopias In: LEACH, N. Rethinking Architecture. Londres: Routledge, 1997, p. 330-336.

. Vigiar e punir. Tradução de Raquel Ramalhete. Petrópolis: Vozes, 1997.

. Qu est-ce quee un auteur? [1969] (Conférence), Dits et Écrits, 1954-1988, v. 1, Paris : Gallimard, 789-820.

GADAMER, Hans-Geog. L'art de comprendre: herméneutique et tradition philosophique. Traduction de 1'allemand par Marianna Simon. Paris: Aubier Montaigne, 1982.

- O problema da consciência histórica. Tradução de Paulo Cesar Duque. FRUCHON, Pierre (Org.). 2. ed. Rio de Janeiro: Editora FGV, 2003.

GENEVOIS, Dominique. Mudra, 103, rue Bara: l'école de Maurice Béjart 1970-1988. Bruxelles: Contredanse, 2016.

GERALDI, Sílvia. Raízes da teatralidade na dança paulistana: duas criadoras - Célia Gouvêa e Sônia Mota. Curitiba: Ed. Prismas, 2015.

GOFF, Jacques LE. Fragments for a History of the Human Body. New York: Urzone, 1989.

GOLDSCHIMIDT, Victor. Questions Platoniciennes. Paris: Urin, 1970.

GOUVÊA, Leila V. B. Maurice Vaneau: artista múltiplo. São Paulo: Imprensa Oficial, 2006 (Coleção Aplauso Teatro Brasil).

GRANGER, Gilles-Gaston. Descartes. São Paulo: Ed. Abril, 1983. p. 16.

GREINER, Christine. O corpo: pistas para estudos indisciplinares. São Paulo: Annablume, 2005.

GROTOWSKI, Jerzy. Performer: Conferência de Jerzy Grotowski em "Encontros à volta da performance". Traduzida por Thomas Richards e João Garcia Miguel. Paris: Art-Press, 1987.

. Vers un théâtre pauvre. Lausanne: La Cité, 1971. 
HABERMAS, Jürgen. Modernidade - um projeto inacabado. In: ARANTES, O. B. F.; ARANTES, P. E. Um ponto cego no projeto moderno de Jürgen Habermas: arquitetura e dimensão estética depois das vanguardas. São Paulo: Brasiliense, 1992.

HARRIS, Sam. Despertar: um guia para a espiritualidade sem religião. Tradução de Laura Teixeira Motta. São Paulo: Companhia das Letras, 2014.

HASKELl, Arnold L. The Wonderful World of Dance. New York: Doubleday and Company, Inc., 1969.

HEIDSIECK, François. Henri Bergson et la notion d'espace. Paris: Presses Universitaires de France, 1961.

HEIDEGGER, Martin. Ser e Tempo. Parte I. Tradução de Márcia Sá Cavalcante Schubach. Petrópolis: Vozes, 1986.

A origem da obra de arte. Tradução de Idalina Azevedo e Manuel Antônio de Castro. São Paulo: Edições 70, 2010.

HILST, Hilda. Cartas de um sedutor. Rio de Janeiro: Editora UFRJ, 2003.

HOLANDA, Heloísa Buarque de (Org.). Pós-modernismo e política. Rio de Janeiro: Rocco, 1991. p. 36.

HUYSSEN, Andreas. Mapeando o pós-moderno. In: HOLLANDA, Heloísa Buarque (Org.) Pós-modernismo e política. Rio de Janeiro: Rocco, 1991, p. 15-80.

IBRI, Ivo Assad. Kósmos Noetós. São Paulo: Perspectiva, 1992.

JAMESON, Fredric. Pós-modernidade e sociedade de consumo. Tradução de Vinicius Dantas. São Paulo: Novos Estudos CEBRAP, n. 12, 1985.

A cultura do dinheiro: ensaios sobre a globalização. Tradução de Maria Elisa Cevasco e Marcos César de Paula Soares. Petrópolis: Vozes, 2001.

JIMENEZ, Sergio. El metodo de acciones fisicas. In: El evangelio de Stanislavski sun sus apostoles, los apócrifos, la reforma, los falsos profetas y Judas Iscariote. México: Editorial Gaceta, 1990. p. 239-287.

KANT, Immanuel. Estética Transcendental. São Paulo: Editora Nova Cultural, 1987 (Coleção Os pensadores).

KANTOR, Tadeusz. O teatro da morte. BABLET Denis (Org.). São Paulo: Perspectiva, 2008.

Lições de Milão. Paris: Actes Sud Papiers, 1990.

KEHL, Maria Rita. O tempo e o cão. São Paulo: Boitempo Editorial, 2009.

KOBIALKA, Michal. A Journey Through Other Spaces: essays and manifesto, 1944-1990 - Tadeusz Kantor. Los Angeles: University of California Press, 1993. 
KHRISNAURTI, Jiddu. A World in Challenge Times. Boston \& London: David Skitt, 2005.

LAURENT, Olivier. Le sombre abîme du temps: mémoire et archéologie. « La couleur des idées ». Paris: Seuil, 2008.

LEHMANN, Hans-Thies. Le théâtre postdramatique. Traduit de l'allemand par PhilippeHenri Ledru. Paris: L'Arche, 2002.

LEOPOLDO E SILVA, Franklin. Descartes: a metafísica da modernidade. São Paulo: Moderna, 1996.

LICHET, Raymond. Jean Jacques ROUSSEAU la vie et l'oeuvre. Paris: Librairie Hachette, 1971.

LYOTARD, Jean François. O pós moderno. Tradução de Ricardo Corrêa Barbosa. Rio de Janeiro: José Olympio, 1986.

LUCRÉCIO. Da natureza das coisas. Tradução portuguesa de Antonio José de Lima Leitão. São Paulo: Edições Cultura, 1941.

LYOTARD, Jean-François. O pós moderno. Tradução de Ricardo Corrêa Barbosa. Rio de Janeiro: José Olympio, 1986.

MARA, Thalia. The language of ballet. New York: Library of Congress Catalog, 1966.

MELLO NETO, João Cabral de. Poesias Completas: 1940-1965. 3. ed. Rio de Janeiro: José Olympio, 1979.

MERLEAU-PONTY, Maurice. O visível e o invisível. Tradução de José Arthur Giannotti e Armando Mora d'Oliveira. São Paulo: Perspectiva, 1971.

. Phénoménologie de la perception. 4. ed. Paris: Librairie Gallimard, 1945.

. O primado da percepção e suas consequências filosóficas. Tradução: Constança Marcondes César. Campinas: Papirus, 1990.

. O olho e o espírito. Tradução de Paulo Neves e Maria Ermantina Galvão Gomes Pereira. São Paulo: Cosac \& Naify, 2004.

MEYERHOLD, Vsévolod. E. O Teatro de Feira (1912) In: THAIS, Maria. Na cena do Dr. Dapertutto: poética e pedagogia em V. E. Meierhold, 1911 a 1916. São Paulo: Perspectiva/FAPESP, 2009.

NAVAS, Cássia; DIAS, Linneu. Dança Moderna. São Paulo: Secretaria Municipal de Cultura, 1992.

NIETZSCHE, Friedrich. A Filosofia na era trágica dos gregos. Tradução de Gabriel Valladão Silva. Porto Alegre: L\&PM Editores, 2011. 
. Crítica Moderna. Tradução de Carlos A. R. de Moura. In: SOUZA, José Cavalcante (Coord.). Os pré-socráticos: Ed. Nova Cultural, 1999 (Os Pensadores, v. 1). p. 129.

Assim falou Zaratustra. Tradução de Paulo César de Souza. São Paulo: Companhia das Letras, 2011.

ORTIZ, Renato. A moderna tradição brasileira: cultura brasileira e indústria cultural. São Paulo: Brasiliense, 1988.

PAVIS, Patrice. Vers une théorie de la pratique théâtrale: voix et images de la scène. $3^{\circ}$ Chapitre XVIII - La théâtralité en Avignon, pour Josette Féral. 4. ed. Villeneuve d'Ascq: Presses Universitaires du Septentrion, 2007.

Dicionário de Teatro. Tradução para a língua portuguesa sob a direção de Jacob

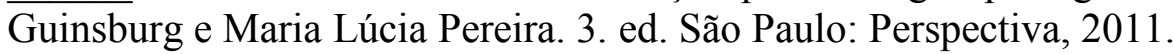

PEDROSA, Mário. Primary Documents. Edited by Glória Ferreira and Paulo Herkenhoff. Translation by Stephen Berg. New York: The Musem of Modern Art (MOMA), 2015.

PESSOA, Fernando. Poemas inconjuntos. Lisboa: Âncora, 2006.

PLATÃO. Fedro. Tradução de Carlos Alberto Nunes. São Paulo: Globo, 1962.

PUCHNER, Martin. Stage Fright: Modernism, Anti-Theatricality, and Drama. Introduction, p. 1-28. Baltimore; London: The Johns Hopkins University Press, 2002.

RANCIÈRE, Jacques. A partilha do sensível: estética e política. Tradução de Mônica Costa Netto. São Paulo: Editora 34, 2005.

READ, Herbert. A Concise history of Modern Painting. New York: Library of Congress Cataloging, 1975.

REALE, Giovani. História da filosofia antiga. Tradução de Marcelo Perine. v. 2. São Paulo: Loyola, 1994.

REBEllo, Luiz Francisco. História do Teatro de Revista em Portugal, 2 v., Lisboa: Publicações Dom Quixote, 1984.

ROOSE-EVANS, James. Experimental Theatre. New York: Avon Books, 1971.

ROSENFELD, Anatol. A arte do teatro. Aulas de 1968 registradas por Neusa Martins. São Paulo: Publifolha, 2009.

SOTOSHU, Escola. Zen. 2. ed. São Paulo: Sotoshu Nambei Sokan-bu. Superintendência Geral do Sotoshu na América do Sul, 2001.

STANISLAVSKI, Constantin. Ma vie dans l'art. Traduction de N. Gourfinkel et Léon Chancerel. Paris: Librairie Théatrale, 1950. 
SAISON, Maryvonne. Les théâtres du réel: pratiques de la représentation dans le théâtre contemporain. Paris: L'Harmattan, 1998.

SARRAZAC, Jean-Pierre. Critique du theater: de l'utopie au désenchantement. Chapitre 3. L'Invention de la Théâtralité, p. 53-70. Belval: Circé, 2000.

SARTRE, Jean Paul. L'Imaginaire. Paris: Gallimard, 1940.

SCHECHNER, Richard. Performance Studies: an Introduction. Second edition. New York; London: Routledge - Taylor \& Francis Group, 2006.

. Performance Theory, rev. and expanded edition. London: Routledge, 1994.

SCHIRREN, Fernand. Le rhytme: primordial et souverain. Bruxelles: Contredanse, 2000.

SCHWARCZ, Lilia M.; STARLING, Heloisa M. Brasil: uma biografia. São Paulo: Companhia das Letras, 2015.

SENNETT, Richard. O artífice. Tradução de Clóvis Marques. Rio de Janeiro; São Paulo: Record, 2009.

SERVOS, Norbert. Revista Ballet International. Versão em Inglês. jan. 1987.

STANISLAVSKI, Constantin. Ma vie dans l'art. Traduction de N. Gourfinkel et Léon Chancerel. Paris: Librairie Théatrale, 1950.

STIRN, François. Compreender Aristóteles. Tradução de Ephraim F. Alves. Petrópolis: Vozes, 2006.

STODELLE, Ernestine. The dance technique of Doris Humphrey and its creative potential. New Jersey: Princeton Book Company, Publishers, 1978.

SUQUET, Annie. Cenas: $o$ corpo dançante - um laboratório da percepção. In: COURBIN, Alain; COURTINE, Jean-Jacques; VIGARELLO, George. (Orgs.). História do Corpo. v. 3. Petrópolis: Vozes, 2009.

TEMKINE, Raymonde. Grotowski. Lausanne: La Cité, 1970.

TOLEDO, Paulo Bio. Arte de esquerda no pós-1964. In: CARVALHO, Sergio; MATSUNAGA, Priscila; BOAL, Julian (Orgs). Augusto Boal: atos de um percurso. Rio de Janeiro: Centro Cultural Banco do Brasil, 2015, p. 48-67.

THÉVENIN, Paule. Oeuvres complètes d'Antonin Artaud. v. 8. Paris: Gallimard, 1971. 266.

. Oeuvres complètes d'Antonin Artaud. v. 14. Paris: Gallimard, 1978.

THOREAU, H.D. Walden. Tradução de Denise Bottmann. Porto Alegre: L\&P, 2010.

VENTURA, Zuenir. 1968: o ano que não terminou. 16. ed. Rio de Janeiro Nova Fronteira, 1988 
VIANNA, Klauss. A dança. 3 ed. São Paulo: Summus, 2005.

\section{Teses:}

ARAÚJO, Antonio. A encenação no coletivo: desterritorializações do diretor no processo colaborativo. 2008. 179f. Tese (Doutorado em Artes Cênicas) - ECA, Universidade de São Paulo, São Paulo, 2008.

DAGOSTINI, Nair. O método de análise ativa de Constantin Stanislavski como base para a leitura do texto e da criação do espetáculo pelo diretor e ator. 2007. 251f. Tese (Doutorado em Literatura e Cultura Russa) - FFLCH, Universidade de São Paulo, São Paulo, 2007.

GERALDI, Silvia. Raízes da teatralidade na dança cênica: recortes de uma tendência paulistana. 2009. 232f. Tese (Doutorado em Artes) - Instituto de Artes, Universidade Estadual de Campinas, Campinas, 2009.

SILVA, Antônio Carlos de Araújo. A encenação no coletivo: desterritorializações da função do diretor no processo colaborativo. 2008. Tese (Doutorado) - Escola de Comunicações e Artes, Universidade de São Paulo, São Paulo, 2008.

\section{Mídia impressa:}

AGOPYAN, Vahan. Interdisciplinaridade, instrumento de qualidade. São Paulo: Jornal da USP, edição de 8 a 14, de abril de 2013.

AUBRY, Chantal. Revista Les saisons de la danse, n. 326, março de 2000.

BASTOS, Helena. Dança corpos vira corpos: trânsitos compartilhados. Revista Sala Preta, n. 10. ECA, Universidade de São Paulo, São Paulo: PPG Artes Cênicas, 2010.

BAINBRIDGE COHEN, Bonnie. The action of perceiving. Revista Contact Quaterly, p. 2226, outono de 1987.

BERGSON, Henri. Três cartas de Henri Bergson para Gilles Deleuze. Revista Critique n. 732, maio de 2008.

BERNARDET, Jean Claude. O processo como obra. Jornal Folha de S. Paulo: 13 jul. 2003.

BRAGA, Gilberto. Alwin Nikolais. Jornal O Globo, Rio de Janeiro, 23 mar. 1975.

CRUZ, Ulysses. De pernas para o ar, teatro e dança surreais. Diário do Grande ABC, Santo André, 11 dez. 1981.

CURI, Celso. Pulsações: a retomada do real. Jornal Última Hora, São Paulo, 28 nov. 1975. FABBRINI, Ricardo. Arte relacional e regime estético: a cultura da atividade dos anos 1990. Revista Científica/FAP, Curitiba, v. 5, p. 11-24, jan./jun. 2010. p. 21. 
FERNANDES, Sílvia. Teatralidade e performatividade na cena contemporânea. Revista Camarim, São Paulo, n. 46, p. 20, $1^{\circ}$ semestre de 2012.

FIGUEIREDO, Corina. Libertação. Revista Visão, São Paulo, 15 out. 1979.

FISCHER-LICHTE, Erika. Réalité et ficction dans le théâtre contemporain. Revue d'études théâtrales, Paris, Registres 11/12, p. 7, 2007.

GONÇALVES FILHO, Antônio. Angústia de ser moderno. Jornal O Estado de São Paulo, Caderno Sabático, p. 5, São Paulo, 23 jun. 2012.

GRAND, J. B. Carpentras: un extraorinaire spetacle avec le Théâtre de la Recherche de Bruxelles. Le Provençal. Carpentras, 17 jul. 1973.

KATZ, Helena. Casal comemora duas décadas de palco. Jornal O Estado de São Paulo, Caderno 2, p. D2, São Paulo, 13 dez. 1994.

. Ladeira da Misericórdia celebra os 50 anos de arte de Maurice Vaneau. Jornal O

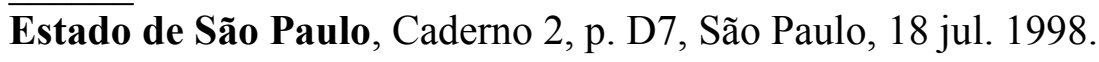

LEITE NETO, Alcino. Da tela para as ruas: apogeu e queda da cinefilia. Jornal Folha de S. Paulo, Caderno Ilustríssima, p. 4, São Paulo, 6 fev. 2011.

MAGALDI, Sábato. Caminhada, uma fusão perfeita de ideia e forma. Jornal da Tarde. São Paulo, 10 dez. 1974.

. Uma boa temporada teatral: menos para nossos autores. Jornal O Estado de São Paulo-Jornal da Tarde. São Paulo, 28 dez. 1974.

. O teatro fala de repressão: dançando. Jornal da Tarde, São Paulo, 5 dez. 1974.

MARTINO, Telmo. Pré-estreia da semana. Jornal O Estado de São Paulo, São Paulo, 30 out. 1978.

. Festa Triste. Jornal da Tarde, São Paulo, 17 jun. 1981.

MUDRA, Bruxelas, 1970. Revista Marie Claire, nov. 1971

PENNAFORT, Roberta. A busca do estado de invenção. Jornal O Estado de São Paulo, Caderno 2, D5, São Paulo, 8 out. 2012.

PROGRAMA DA TEMPORADA BRASILEIRA DO BALLET DU XXE SIECLE. 1979.

RIBEIRO VALLIM JR., Acácio. A tendência dos espetáculos longos no mundo da dança. Jornal O Estado de São Paulo, dez.1980.

ROLNIK, Suely. Lygia Clark, artista contemporânea. São Paulo: Jornal O Valor, 25 . Bienal de São Paulo, São Paulo, 12 abr. 2002. 
SCHEIR, Helmut. What has dance theatre to do with Ausdruckstanz? Ballet International, 10(1), jan. 1987.

SAJNAU, P. Il ne s'agi plus de jouer. Il s'agit de vivre et d'exprimer, avec toutes les fibres de son corps. Le Soir, 23 ago. 1973.

TRIGUEIRINHO, Roberto. Entretanto luto mal rompe a manhã... Jornal City News, Shopping News. São Paulo, 15 dez. 1974.

7 set. 1975 .

. Teatro de dança: aulas e espetáculo. Jornal City News, Shopping News. São Paulo,

VIOTTI, Sérgio. Quatro coreografias: em todas, inteligência e talento. Jornal da Tarde. São Paulo, 15 nov. 1980.

\section{Dicionários:}

AUGÉ, GILlON, HOLLIER-LAROUSSE, MOREAU et CIE.. Petit Larousse. 2. ed. Paris: Librairie Larousse, 1959.

FERRATER MORA, José. Dicionário de Filosofia. 4. ed. Tradução de Roberto Leal Ferreira e Álvaro Cabral. São Paulo: Martins Fontes, 2001.

FERREIRA, Aurélio Buarque de Holanda. Novo dicionário da Língua Portuguesa. 2. ed. Rio de Janeiro: Nova Fronteira, 1986.

GARCIA, Hamilcar; NASCENTES, Antenor. Dicionário Contemporâneo da Língua Portuguesa, v. 4. Rio de Janeiro: Delta, 1958.

MARZANO, Michela (Org.). Dicionário do Corpo. Tradução de Lucia Pereira de Souza, Maria Stela Gonçalves, Mariana Paolozzi Sérvulo da Cunha e Nicolas Nyimi Campanário. São Paulo: Edições Loyola, 2012.

PFEFFER, Laurence. Verbete Maquiagem. In: MARZANO, Michela (Org.). Dicionário do corpo. São Paulo: Edições Loyola, 2012.

\section{Mídia televisiva e radiofônica:}

FOUCAULT, Michel. Utopies et hétérotopies. Palestra gravada. Paris, 1967.

L'AVENTURE du thèâtre du soleil. Direção: Catherine Vilpoux. Exibido pelo Canal Curta, 6 jan. 2015.

METRÓPOLIS. São Paulo: Rádio Cultura FM. Apresentado por Cacá Rosset. 8 ago. 2017.

O SÉCULO de Stanislavski - Parte 1: Os construtores de utopia. Texto e Realização: Peter Hercombe. Produção: Daniel Renouf. Narração: André Dussollier. Paris: System TV; 
L'Union des gens de Théâtre de Russie; La Sept, 1993. Exibido no Canal Curta em 6 de setembro de 2016.

O SÉCULO de Stanislavski - Parte 2: Os anos sísmicos. Texto e Realização: Peter Hercombe. Produção: Daniel Renouf. Narração: André Dussollier. Paris: System TV; L'Union des gens de Théâtre de Russie; La Sept, 1993. Exibido no Canal Curta em 12 de abril de 2016.

RODA VIVA. São Paulo: TV Cultura, 31 de março de 2014.

UMAS PALAVRAS. Entrevista com Antonio Damásio. Entrevistado por Bia Corrêa do Lago. São Paulo: Canal Futura, 17 jan. 2015.

VLADO: 30 anos depois. Direção: João Batista de Andrade. São Paulo: Oeste Filmes Brasileiros; Tao Produções Artísticas, 2006. Exibido no Canal Curta em 18 de setembro de 2017.

\section{Documentos digitais:}

ACERVO Gouvea-Vaneau. Disponível em: <www.acervogouvea-vaneau.com.br>.

BÉLGICA E FLANDERS. Disponível em: https://www.europeanjobdays.eu/ptpt/events/work-flanders/b\%C3\%A9lgica-e-flanders. Acesso em: 3 out. 2017.

CHAUÍ, Marilena. Merleau-Ponty: a obra fecunda. Revista Cult [online], n. 123, 2008. Disponível em: <http://revistacult.uol.com.br/2010/03/merleau-ponty-a-obra-fecunda>.

CLIP ART OF VARIOUS YOGA POSTURES SILHOUETTES. Disponível em: $<$ http://www.fotosearch.com/CSP537/k5372428/>. Acesso em: 8 set. 2016.

EXPERIENCIA. Portal Etimologias: Diccionario Etimológico español en línea. Disponível em: <http://etimologias.dechile.net/>. Acesso em: 10 out. 2014.

FUNDAMENTOS de Feng Shui. Portal Sociedade Taoísta do Brasil. $1^{\circ}$ maio 2017. Disponível em: http://sociedadetaoista.com.br/sp/fundamentos-de-feng-shui/. Acesso em: 22 set. 2015.

FRONTEIRAS DO PENSAMENTO. Instituto CPFL Cultura. Entrevista exclusiva com Antonio Damásio. Portal do Instituto CPFL. Disponível em: http://www.institutocpfl.org.br/2013/12/05/fronteiras-do-pensamento-e-instituto-cpfl-culturaentrevista-exclusiva-com-antonio-damasio/. Acesso em: 18 mar. 2015.

HISTÓRIA INTELIGENTE. Imagens de Luís XIV - o Rei Sol no Ballet de la nuit (1653). Disponível em: <http://historiainte.blogspot.com.br/2014/02/ imagens-de-luis-xiv-o-reisol.html>. Acesso em: 15 set. 2015.

GOLDSCHMIDT, Victor. Remarques sur la Méthode Structurale en histoire de la Philosophie. In: LIBRAIRIE PHILOSOPHIQUE J. VRIN. Écrits. v. 2. Paris: Vrin, 1984. p. 246 apud MOURA, Carlos Alberto Ribeiro. História Stultitiae e História Sapientiae. 


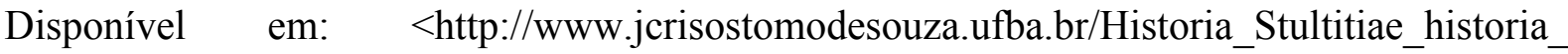
Sapientiae.pdf $>$. Acesso em: 22 set. 2015.

IMERGENCIA. Portal Epipiderme. Disponível em: <http://epipiderme.blogspot.com.br/ p/imergencia-apresentacao-encontro-de_9.html>. Acesso em: 22 set. 2015.

JOHANN Christian Reil. Wikipedia. Disponível em: $<$ https://en.wikipedia.org/wiki/ Johann_Christian_Reil>. Acesso em: 22 set. 2015.

KOIDE, Emi. Coreografias do cinema expandido: mestiçagem e outras representações. Portal Forum Permanente. Disponível em: <http://www.forumpermanente.org/event_pres/ exposicoes/isaac-julien/relatos/coreografias-do-cinema-expandido-mesticagem-e-outrasrepresentacoes $>$. Acesso em: 15 set. 2015.

LANÇAMENTO do livro Literatura Expandida. Encontro entre a artista Dominque Gonzalez-Foerster, a pesquisadora Ana Pato e a curadora Daniela Castro, realizado em 7 de março de 2013, no Sesc Bom Retiro (São Paulo), por ocasião do lançamento do livro Literatura Expandida: arquivo e citação na obra de Dominique Gonzalez-Foerster, de Ana Pato. Disponível em: Vimeo.com/64333420.

MENEZES. Maria Eugênia. Teórico Jean-Pierre Sarrazac defende sobrevivência do teatro. Jornal O Estado de São Paulo, Caderno 2, 14 mar. 2012. Disponível em: $<$ http://cultura.estadao.com.br/noticias/geral,teórico-jean-pierre-sarrazac-defendesobrevivencia-do-teatro,848271>. Acesso em: 22 set. 2015.

PORTAL Connectdance. Disponível em: <www.connectdance.com>. Acesso em: 14 out. 2014.

PORTAL Celia Gouvea. Disponível em: <www.celiagouvea.com>.

RELEASE TECHNIQUE. Disponível em: <http://www.contemporary-dance.org/releasetechnique.html>. Acesso em: 2 out. 2015.

TARAHUMARAS. Disponível em: <https://pt.wikipedia.org/wiki/Tarahumaras $>$. Acesso em: 8 dez. 2014. 
ANEXO A - Depoimento de Cristian Duarte sobre a escola Parts

A PARTS foi um momento especial na minha trajetória. O período em que estive por lá (2000-2002) foi uma possibilidade de imersão para entender meus próprios processos artísticos. Tanto no sentido mais técnico, com a rotina de aulas diárias, quanto na experiência de viver na cidade de Bruxelas e desfrutar da intensidade da produção artística europeia que por ali passa em diversos contextos, teatros, festivais.

Naquela época, eu já estava com uma rotina profissional junto ao Estúdio e Cia. Nova Dança em São Paulo, e a sensação foi a de voltar a ser estudante. Na verdade, não foi "voltar", porque nunca havia feito uma formação em dança. Minha formação se deu informalmente, participando de diversos workshops no Brasil, com vários artistas da dança de São Paulo, e se intensificou no período em que estive junto ao Estúdio e Cia. Nova Dança com Thelma Bonavita, Adriana Grechi, Tica Lemos, Lu Favoreto e Cristiane Paoli-Quito.

Enfim, o período de estudos na Parts me deu ferramentas e condições para que eu pudesse exercitar direção, coreografia e, também, treinamento de dança. Por lá, tive outras visões sobre improvisação, composição, além de aulas técnicas de dança contemporânea e ballet (que não havia feito quase nada antes da Parts).

$\mathrm{Eu}$ estive por lá como bolsista da Capes, programa ApArtes (Aperfeiçoamento e Artes), que me garantiu dois anos de tranquilidade para me dedicar integralmente aos estudos na Escola. Isso foi realmente algo único e maravilhoso. Sabemos que não é fácil conciliar estudos nas artes com a rotina de sobreviver e pagar as contas. Então, foi mesmo um sonho a Capes/ApArtes.

Durante meu período por lá, experienciei um rigor disciplinar muito interessante, que me dava pistas sobre minhas fraquezas e pontos fortes, em meio a bastante "pressão" que nós mesmos gerávamos, por entender a dimensão que uma instituição daquele porte causaria em nossas vidas. Fica até mais fácil identificar isso agora, com distanciamento, com mais maturidade, porque quando estamos no meio da experiência, especialmente nessa faixa etária dos 20-30 anos, ficamos mais frágeis para perceber e lidar com expectativas e frustrações que qualquer processo de aprendizagem revela.

A Parts me desafiou em muitos sentidos e, além de estimular meu trajeto enquanto criador, me convocou a participar de um network daquela Europa do início dos anos 2000, que me deixou em um elo conectivo com artistas e pensadores/produtores de dança na Europa. Essa conectividade me permitiu ir e vir, participar de contextos, viajar, ouvir e ver 
outras formas de pensar e fazer dança. Acho isso muito saudável e estimulante para qualquer pessoa, e mais ainda pra quem se dedica à arte.

Por isso, tenho estado muito comprometido em criar/promover contextos aqui em São Paulo, por meio de projetos que proporcionem cruzamentos com diversos artistas, com outras visões e modos de trabalho, criando pontes e conexões que estão além do prestígio geográfico e que tenham, como motivação maior, o encontro que irradia transformação e outras formas de vida.

Fornecido a Célia Gouvêa em 10 de fevereiro de 2015. 
ANEXO B - Depoimento de Carol Paladino sobre o centro De l'Interprète à leeAuteur

Quando soube da existência e da audição para ingressar na formação De l'Interprète à l'Auteur, do Centro Coreográfico Nacional de Rillieux-la-Pape, minha primeira reação foi pensar que eu nunca seria selecionada para algo tão extraordinário. O programa dirigido pela artista Maguy Marin continha tudo que eu sempre havia imaginado para a formação de um artista completo. Depois de muito hesitar, encarei o desafio de preparar os dois monólogos, a coreografia e participar dos exames técnicos e da entrevista para a seleção dos catorze estudantes do ano 2009/2010. Chegando lá, observando a atmosfera do lugar e das pessoas que me receberam, antes mesmo de passar pela audição, pude perceber que todo meu trabalho dentro da dança havia me levado para aquele lugar e que, por merecimento, eu seria aceita. A resposta positiva veio por meio de um email aproximadamente um mês depois da audição e posso dizer que foi uma das maiores alegrias da minha vida.

Acontece que quando conseguimos algo, depois de um tempo, a conquista se torna banal e, por diversas razões, no dia da primeira reunião, duvidei da minha vontade de estar lá. Teresa, uma das coordenadoras da formação e bailarina de Maguy Marin, mostrou-se, de imediato, uma pessoa severa, que não teria a menor tolerância em termos de faltas, atrasos e, de uma certa forma, assustou-me com seu discurso, que mais me fez pensar em um colégio interno. Junto com a formação, eu deveria finalizar meu Mestrado escrevendo uma dissertação para a Universidade Paris VIII, e o desafio me pareceu grande demais. Ainda não havia encontrado apartamento em Lyon, não conhecia ninguém por lá e, além disso, tinha descoberto, há um mês do início das aulas, que minha mãe estava doente, fato que quase me fez desistir de ingressar no CCN e voltar ao Brasil.

Motivada pela minha família e por amigos, acabei encarando o desafio e lá estava eu para as primeiras aulas de teatro (cours de jeu) com o legendário Jerzy Klesyk. Estas deveriam ser uma das aulas mais importantes de todo o ano e, certamente de toda a minha história na dança e nas artes. Jerzy, assim como Teresa, também tinha algo de bastante rígido no seu posicionamento, e isso criava uma certa tensão entre os estudantes. Aos poucos, fomos entendendo que Jerzy, em sala de aula, era um personagem e para alcançarmos o entendimento de suas propostas, aquela atmosfera era fundamental. Ao longo do ano, entendemos que tudo para Jerzy era um grande jogo e que podíamos, dentro do rigor e da "tensão", nos divertir e relaxar.

Os primeiros meses ainda foram difíceis para articular minha vida com toda aquela demanda. Mas, à medida que o tempo foi passando, a mágica foi acontecendo. Meu entendimento e sentimento de grande gratidão por estar ali veio pela primeira vez na aula de 
Etienne Leman, um senhor de idade avançada, com um corpo e uma disposição de fazer inveja a muitos jovens de 20e anos. Sua aula fazia parte do módulo "Langages du corps et technique dansées fondamentaux du corps". Etienne é um mestre de Aikido e aprendemos em suas aulas o treinamento dessa técnica. Em meio aos exercícios, ele lançava sua filosofia de vida de bem-estar, positividade, disciplina e foco. Esse foi só o começo de uma série de ensinamentos que viriam por meio de professores renomados em diversas áreas do corpo, das artes, da antropologia e filosofia. Importante mencionar que essa formação era vinculada à Faculdade de Antropologia da Universidade Lumière 2 de Lyon, o que conferia ainda um título de bacharelado aos estudantes participantes.

Impossível mencionar todas as aulas e experiências vividas no CCN durante esse ano. Escolho aquelas que, hoje, incorporaram e fazem parte do meu trabalho como intérprete, professora e pesquisadora.

Ainda no âmbito dos fundamentos do corpo, Norio Yoshida e suas aulas de balé clássico foram bastante importantes para uma nova visão dessa técnica. Com uma aula prazerosa e consciente, Norio me transmitiu pensamentos inteligentes sobre a maneira de se trabalhar os movimentos e passos do balé.

Apesar de vir de uma família de músicos e de já ter trabalhado como cantora em diversos contextos, essa formação me abriu para o universo musical de maneira muito sofisticada. Acontece que dança e música, para mim, até então, pareciam duas instâncias separadas. Ou eu atuava em uma coisa, ou em outra. Por meio das aulas de voz, ritmo, musicalidade e, também, de teatro, o ato de performar passou a se tornar uma só coisa. O ritmo corporal, a musicalidade do movimento, a voz como extensão do corpo e tantas outras noções intrínsecas no trabalho artístico de Maguy Marin surgiram por intermédio de professores como Isabelle Dragol, Ulises Alvares, Jean-Noel Siret, Jean-Luc Pacaud e do brasileiro Eduardo Lopes.

No campo teatral, destaco a oficina de máscara com Myriam Azecot, do Théâtre du Soleil. Com refletores de luz e grandes papelões de caixas de geladeira como coxias, Myriam criou um teatro dentro do estúdio de dança e uma atmosfera absolutamente mágica e, também, assustadora. Isso porque Myriam tem um rigor absoluto e uma certa intolerância quando a improvisação não chega no nível de excelência por ela desejado. Foram muitos choros, mas certamente, lições que nenhum de nós se esquecerá jamais.

Com Marie Lamachère, criei um trabalho que considerei um dos mais interessantes que fiz na formação. Marie trabalha com montagens a partir de ações físicas e textos. Na ocasião, trabalhamos Woyzec e, em dupla, compusemos uma minipeça. O objetivo era transitar por estados e deixar emergir emoções a partir dessas ações. 
Diane Broman foi uma das mais (ou a mais) importantes artistas com que tivemos contato. Com Diane, pudemos, depois da formação, fazer duas residências artísticas e nos aprofundar no trabalho que ela intitula Chaotic danse. Trabalhamos sobre os estados, a ação e percepção, sobre a ideia de ser bailarino, músico e ator sem hierarquia ou distinção. Ela e, também, Alexandre Del Perugia (outro professor de jogo teatral), têm a capacidade de instaurar um tempo outro a partir do momento em que entram em sala de aula. É absolutamente formidável. Ambos têm como foco principal o estado de presença e a relação com o público.

Com Dominique Duszinski, ex-bailarina de Pina Bausch, tivemos uma aula de técnica de movimento e cena baseada no processo de criação da coreografa alemã. Criamos por meio de perguntas, e foi extraordinário estar próxima da atmosfera da qual Pina Bausch trabalhava.

Fizemos oficinas de iluminação, figurino, oralidade de língua estrangeira, ferramentas administrativas, ateliê de escrita, filosofia, dissertação de antropologia a partir de entrevistas, contato improvisação, yoga, técnica Alexander e muitas, muitas outras, com coreógrafos diversos.

Muito do que aprendi só pude me dar conta alguns anos depois, colocando em prática como bailarina, transmitindo aos meus alunos ou refletindo com a maturidade. Outras coisas acredito que se perderam na razão, mas se encontram gravadas no meu corpo e no meu inconsciente.

Tive a oportunidade de assistir à última criação de Maguy Marin e me emocionei em ver tudo que aprendi em um só espetáculo. Nesse dia, Maguy me disse: “Arte é uma questão de ritmo". Sim, a formação De l'Interprete à leeAuteur não valorizava nada mais do que o ritmo. A presença, noção a qual tanto evocamos, também se dá por meio da percepção do nosso ritmo interno e do ritmo do outro, das coisas, do espaço.

Posso dizer, hoje, que a experiência que tive nessa formação transformou completamente minha vida, meu entendimento de arte, educação e gestão de um espaço cultural. Hoje, coloco em prática esse conhecimento no Espaço Lua Branca ${ }^{342}$, local de residência do qual eu sou coordenadora, e, também, nos projetos artísticos que desenvolvo. Ainda pretendo desenvolver uma formação prolongada para jovens aqui no Brasil, estando em contato com todos os profissionais que trabalhei na França.

Fornecido a Célia Gouvêa em 24 de abril de 2015.

\footnotetext{
${ }^{342}$ Localizado na Serra da Mantiqueira, no município de Baependi, em Minas Gerais, o Espaço Lua Branca, junto à Ecovila Gamarra, oferece residências artísticas, práticas terapêuticas e comemorações festivas em meio às montanhas e cachoeiras.
} 
ANEXO C - Depoimentos de colaboradores do Teatro de Dança Galpão (1974-1981)

Solicitei a colaboradores do período um pequeno depoimento sobre o Galpão, questionando de que modo aquela experiência marcou suas trajetórias e quais são as questões que carregaram, daquele tempo, em seus percursos.

Ana Michaela (dançarina e terapeuta corporal)

O Galpão foi um espaço de inovação e vitalidade que marcou a todos que tiveram a oportunidade de participar desse momento histórico da dança. A dança era emblemática de uma era onde a palavra foi calada pela ditadura e o medo imperava. Tive o privilégio de participar desse movimento. Digo "movimento" porque era uma manifestação criativa e libertária de um momento de muita violência e perseguições.

O que mais me marca desse período é a riqueza de conhecimentos que nós, alunos, vivenciamos em aulas de várias técnicas, com ótimos profissionais que tinham, como objetivo, formar atores-bailarinos. Nesse sentido, as aulas de Célia Gouvêa e Maurice Vaneau foram marcantes, pois permitiam que explorássemos todo o nosso potencial, isto é, a técnica tinha um fim: a expressão total do artista sem perder a autenticidade de cada um.

Ninguém saiu dessa experiência ileso. Com certeza, todos nós, jovens que participamos disso, levamos para a vida um conhecimento precioso que nos transformou como seres humanos. Trabalhamos a partir do mundo interno. Toda a vivência saía do profundo de nós mesmos. A forma era uma consequência que se transformou em significativos espetáculos concebidos por Célia e Vaneau.

Tenho orgulho de ter feito parte desse início, que tantos frutos trouxe para todos nós. Digo "nós" porque, enquanto durou, éramos um grupo verdadeiro. Pulsações foi um espetáculo onde essa vivência em grupo foi fundamental. Muitas vezes, saíamos dos ensaios vibrantes e cheios de ideias. Nossa criatividade era solicitada a todo momento e o material que trazíamos era aproveitado, o que nos dava muita força para continuar criando. Era muito visceral e havia uma ebulição de ideias e concretizações que nos entusiasmava sempre mais. $\mathrm{Eu}$, como profissional, nunca mais me contentei com uma dança apenas formal. Aprendi a tirar vários coelhos da cartola. 
Daniela Stasi (bailarina, assistente de coreografia e professora de dança)

Caminhada marcou para mim o afortunado começo de uma afortunada carreira na dança.

Foi assim que eu, aos quatorze anos, dei meus primeiros passos no palco do Teatro Galpão, cercada por um grupo de profissionais tarimbados dirigidos por Célia Gouvêa e Maurice Vaneau, recém-chegados do Mudra e cuja generosidade permitiu que eu vivenciasse a dança num grau de profissionalismo que influenciou minha formação de maneira indelével.

Foram, me lembro bem, três semanas de temporada dividindo o borderaux, trazendo à cena a proposta multidisciplinar dos diretores, que maximizaram o potencial de cada indivíduo, incorporando suas habilidades específicas ao todo da obra. Passei de aluna a profissional da dança sem passar pelo amadorismo. Minha opção pela dança veio como consequência natural e inevitável dessa primeira vivência.

Formaram-se, ali, importante vínculos profissionais e pessoais, a serem retomados mais tarde, em situações diversas.

Me orgulho muito de ter feito parte de uma era onde a dança brasileira deu tantos frutos e tenho a certeza de que esse début precoce me deu grande vantagem nas minhas incursões dentro e fora do País.

Obrigada Célia!

Debby Growald (dançarina, coreógrafa, musicista)

Célia e Maurice me marcaram profundamente na experiência do Teatro Galpão.

Eu tinha dezessete anos, e a revelação da arte da dança e do teatro foram fundamentais na minha formação como artista e como pessoa.

$\mathrm{O}$ que mais me marcou foram as personalidades de Célia e Maurice. Aprendi, com eles, a força do trabalho, da busca, o prazer do ensaio e a grandeza dos momentos criativos. $\mathrm{O}$ mundo, para nós, alunos e dançarinos, resumia-se em ir para o Galpão e mergulhar nesse aprendizado.

Aprendi mais com eles que na escola, no ginásio, no colégio e na universidade. Paralelamente às aulas do Teatro Galpão, eu seguia meus estudos pianísticos e as ideias e aprendizados completavam-se e comprovavam-se.

Na prática:

Aprendi com Maurice Vaneau a noção de timing: o que é fazer algo no seu tempo certo, nem mais nem menos; como segurar o público utilizando de um bom timing. Essa ideia 
construiu a minha existência. Ensino essa noção a todos os jovens pianistas e artistas com quem trabalho.

Com Célia, aprendi o valor do trabalho bem feito, a beleza do gesto, a força do movimento bem definido. Também aprendi, com ela, que quando não temos mais força, ainda temos. A força de vontade, a persistência, o fascínio pela realização, aprendi com ela, e essa conduta me segue em todas as minhas realizações artísticas e também cotidianas: não desistir.

Também aprendi com Celinha a exigência da realização. Com ela, aprendi a não aceitar algo que não foi bem feito. Também a experiência europeia de dos dois ajudou-me muito na minha formação como artista e como pessoa. Tudo podia sempre ser melhorado. Quando isso (esse conceito) entrou na cabeça do grupo, tudo sempre melhorou.

A quantidade de artistas, bailarinos, músicos, atores, coreógrafos e artistas plásticos que passaram pelas mãos de Célia e Maurice é a prova de que aquele momento privilegiado foi uma fonte de produção artística para o Brasil.

Denise Stoklos (atriz e diretora), aluna de Célia Gouvêa e Maurice Vaneau no Galpão

No Galpão, eu tive a oportunidade de receber aulas para corpo com grandes conhecedores, como Célia Gouvêa. Muitas questões que se levantaram vieram a me acompanhar na minha vida profissional, principalmente no que diz respeito a relações do corpo com isolamentos (movimentações de partes isoladas do corpo), que facilitariam minha compreensão futura do espasmo (técnica de mímica que pontua o início e fím do movimento) e dos pontos fixos (outra técnica de mímica que marca no espaço onde o gesto situa a criação de ilusões). Como desenvolvi meu trabalho teatral com bases muito na Mímica Contemporânea (advinda de Jean-Louis Barrault e Etienne Decroux), as aulas no Galpão foram fundadoras, posso dizer, desse meu interesse.

\section{Fortuna (cantora)}

Participar dos espetáculos com Célia Gouvêa e Maurice Vaneau era uma tremenda oportunidade e uma vivência única. Tínhamos a abertura de criar cenicamente. Eu ia me colocando com a minha voz, com recursos gestuais, integrando música, dança, canto e teatro! Frequentar o Galpão foi uma vivência única!!!! Aquele palco parece que chamava experiências diferentes, originais... E o ambiente social era muito saudável. Uma época em que tínhamos tempo de compartilhar as experiências no bar ao lado, no restaurante vegetariano... As pessoas se encontravam e se falavam. Era tudo muito curtido! Tive esse 
privilégio numa época de bastante efervescência, tempos que não voltam mais...existia uma coragem de assumir novos caminhos. Sinto saudades das pessoas e dos colegas de trabalho daquela época do Galpão!

\section{Mara Borba (dançarina e coreógrafa)}

Tanto já se falou sobre o Galpão e da sua importância para a Dança...

Quem se beneficiou dessa iniciativa teve um registro especial na sua carreira. No meu caso, foi assim. Sem o projeto Galpão, muitos artistas não teriam alçado voos - sendo reconhecidos pela sua criatividade e linguagem.

Esse foi um dos aspectos contidos nessa iniciativa. Credibilizar outras formas e conteúdos, até então, espalhados em vias alternativas, sem visibilidade ou suporte. Esse fato foi um divisor de águas no conceito mais tradicional inserido na Dança.

\section{Rogério Da Col (dançarino e professor)}

Em 1981, comecei a trabalhar com o Teatro de Dança de São Paulo, com direção de Maurice Vaneau e coreografias de Célia Gouvêa. Foi uma oportunidade única começar a carreira com profissionais desse quilate. De pernas para o ar foi o segundo trabalho que realizei com a Célia e um trabalho muito diferenciado, pois ela explorou as singularidades de todos os participantes. No elenco, havia bailarinos, atores, cantores, pessoas de diversas linguagens da arte. Porém, ela colocou todos para dançar. Lembro que eu fazia um taconeio (sapateado) espanhol com a cantora Fortuna Safdie, o Flávio Colatrello, hoje diretor renomado na televisão, que era apenas um iniciante recém-saído da Escola de Arte Dramática de São Paulo (USP), e a Zélia Monteiro, que naquela época já era uma grande bailarina e, eu, um principiante que recebeu uma oportunidade desta grande profissional. Fazia um pás-dedeux lindo com a Célia com música do Berlioz ("Le nuit d'été"). Durante os ensaios, a Célia descobriu que estava grávida da sua segunda filha e, mesmo sabendo que corria o risco de perder o bebê, continuou ensaiando. Ao longo dos ensaios, eu contraí caxumba. Lembro que a avisei, mas ela nem quis saber: "Hoje você vai ensaiar". Fiquei um tempo afastado e, quando voltei, o meu lugar ainda estava lá, graças à sua generosidade. Muito cedo, entendi que aquilo era um trabalho movido pela paixão. Não tínhamos quase nenhum apoio. Tínhamos o espaço $\mathrm{e}$, às vezes, alguma verbinha muito da mixuruca. A Leda Senise arrumou figurinos e tínhamos alguns figurinos da Fiorucci que ficaram para nós de presente no final da temporada. Eu, como participava de vários quadros, fui um dos mais beneficiados. Aquele ano inteiro trabalhando com a Célia foi um aprendizado que eu carreguei para a vida inteira. $\mathrm{O}$ amor, a 
dedicação, a paixão, um respeito pela profissão que beira o sagrado. Hoje, após 35 anos de carreira, a minha atitude é de gratidão e respeito por esta profissional. Obrigado Célia. A Maurice também, onde ele estiver, a minha gratidão.

\section{Rose Akras (bailarina, coreografa e terapeuta corporal)}

Fico contente e também me orgulho de ter participado de seus trabalhos. Hoje em dia, penso muito no "De pernas para o ar". Você estava muitos anos à frente. Estou finalmente, estudando, fazendo um masters em artes, escrevendo e lendo muito sobre performance art, interdisciplinas, estas coisas que você já fazia. Através do "De pernas para o ar" aprendi que dança era muito mais do que colocar um passo atrás do outro... Obrigada! Celinha sempre à frente, fazendo as pessoas terem novas experiências.

\section{Soraya Sabino (dançarina e terapeuta corporal)}

Recordar da época que trabalhei no Teatro Galpão com Célia Gouvêa e Maurice Vaneau (Cia. Teatro de Dança de São Paulo) me remeteu a um momento de grandes descobertas artísticas e mudanças pessoais, como também a uma das fases mais divertidas!

No final da década de 1970 e início da de 1980, ir ao Teatro Galpão, que era o Teatro de Dança, e assistir aos espetáculos era uma grande experiência pois, tudo que via me provocava profundamente. Eram trabalhos que se tornaram referências no meio da dança e do teatro, também.

Soube da audição que Célia estava fazendo para seu novo espetáculo e, para mim, tentar entrar no trabalho seria um desafio, pois, até então, minha experiência tinha sido com o Ballet Stagium, o Cisne Negro e muitas aulas de ballet clássico.

Quando fui aprovada para o grupo e iniciamos os ensaios, minha sensação era de alegria pelo desconhecido. Sentia um grande alívio por poder dançar, ter técnica e entrar num mundo criativo que não conhecia até então.

Nos primeiros trabalhos de que participei, Urugungo e Quatro corpos e dois estranhos, tateava essa nova experiência e conhecia como Célia coreografava e pensava o movimento.

Quando começamos a ensaiar De pernas para o ar, já estava totalmente integrada ao grupo e à maneira com que Célia criava. Mesmo assim, fui surpreendida pela sensação de ter entrado num quadro surrealista. A cada cena que ensaiávamos, percebia que a ideia me envolvia de tal forma que sempre olhava para a cena e descobria outras ideias por traz e 
olhava, olhava, procurava mais e mais e tentava entender. Algumas entendia, outras não entendi até hoje, mas era genial e delicioso.

De pernas para o ar me fez relaxar em tentar entender a criação. Me divertia, e essa licença que Célia se permitia de dizer tantas coisas ao mesmo tempo e com imagens tão fortes, me surpreendeu!

Hoje penso...

$\mathrm{Na}$ cena das risadas das bundas.

Na conversa dos pés.

Em quatro corpos e dois estranhos.

Nas bailarinas falando dos seus desejos gastronômicos e na Banana Splits gerando um desejo de fazer um spacat (não sei como escreve).

$\mathrm{Na}$ cena das bailarinas sendo pesadas como gado.

$\mathrm{Na}$ Bailarina alcoólatra.

$\mathrm{Na}$ Célia perguntando as horas e cada um respondendo por metáforas.

E em tantas outras cenas...

Nessa época, trabalhar com a Célia e o Maurice me marcou profundamente, me trouxe um outro olhar da arte, da dança, de pensar movimento, e me encanto até hoje quando penso no despojamento deles, na vida deles, totalmente voltados para fazer arte num momento com muito poucos recursos. Sou feliz por ter feito parte desses trabalhos e por ter trabalhado com eles.

Zélia Monteiro (bailarina, coreógrafa, professora)

Comecei a dançar profissionalmente no Teatro Galpão, em 1979, no grupo Teatro de Dança de São Paulo, dirigido por Célia Gouvêa e Maurice Vaneau.

Só isso já seria bastante marcante para mim, mas, para além de ser o teatro em que inaugurei minha trajetória profissional, foi no Galpão que pude conhecer tudo o que havia de mais novo na dança paulistana desse período. Ainda muito jovem, tive a oportunidade de estar próxima de um movimento de artistas que questionavam, transgrediam, reivindicavam liberdade para criar e expor suas ideias e dialogar com o público.

O Galpão era um local não só de apresentações de espetáculos, mas também onde aconteciam oficinas de dança, teatro, voz, ensaios e processos criativos de vários artistas de vanguarda da cidade de São Paulo. Era um local que acolhia esses artistas com suas pesquisas inovadoras, e eu me orgulhava muito - e ainda me orgulho - de também estar trabalhando ali e de ser parte, de alguma forma, daquele movimento. 
Acredito que essa experiência com Célia e o Teatro Galpão tenha me "cativado" definitivamente para a pesquisa em Dança. Eu vinha de uma trajetória de estudos exclusivamente no balé, onde o bailarino não deve questionar nada: a cidade, o indivíduo, o coletivo, as políticas, as ideias de arte, de corpo "não eram assuntos para bailarinos". Foi trabalhando e frequentando esse teatro e "respirando" esse movimento que pude entender o papel de um artista no mundo: suas responsabilidades e a importância de suas experimentações e reivindicações. Comecei a frequentar o sindicato dos artistas e a me inteirar de como os artistas precisam agir no mundo, para além dos palcos.

Algo de que não me esqueço é que, naquela época, precisávamos apresentar o espetáculo antes dele entrar em cartaz para um censor do governo federal, que diria se a obra poderia ou não estrear (estávamos sob o regime de ditadura militar). Mais uma vez, aprendi que, mesmo sob a mais rígida opressão, os artistas encontravam modos de continuar a ocupar espaços e a experimentar seus fazeres.

Também me marcaram muito os espetáculos que assisti ali, que foram de grande impacto para mim: além de Célia Gouvêa, com quem trabalhei, vi os trabalhos de Marilena Ansaldi, Thales Pan Chacon, Sonia Motta, Susana Yamauchi, Mara Borba, Ruth Rachou, Juliana Carneiro, Edson Claro e tantos outros. 